\title{
Evolution of the Late Ordovician Plaesiomyid Brachiopod Lineage in Laurentia
}

Colin D. Sproat, The University of Western Ontario

Supervisor: Dr. Jisuo Jin, The University of Western Ontario

Joint Supervisor: Dr. Rong-yu Li, The University of Western Ontario

A thesis submitted in partial fulfillment of the requirements for the Master of Science degree in Geology

(C) Colin D. Sproat 2012

Follow this and additional works at: https://ir.lib.uwo.ca/etd

Part of the Geology Commons, Paleobiology Commons, and the Paleontology Commons

\section{Recommended Citation}

Sproat, Colin D., "Evolution of the Late Ordovician Plaesiomyid Brachiopod Lineage in Laurentia" (2012). Electronic Thesis and Dissertation Repository. 913.

https://ir.lib.uwo.ca/etd/913

This Dissertation/Thesis is brought to you for free and open access by Scholarship@Western. It has been accepted for inclusion in Electronic Thesis and Dissertation Repository by an authorized administrator of Scholarship@Western. For more information, please contact wlswadmin@uwo.ca. 


\section{EVOLUTION OF THE LATE ORDOVICIAN PLAESIOMYID BRACHIOPOD LINEAGE IN LAURENTIA}

(Spine title: LATE ORDOVICIAN PLAESIOMYID BRACHIOPOD LINEAGE IN LAURENTIA)

Thesis format: Integrated Article

by

Colin Sproat

Graduate Program in Geology

A thesis submitted in partial fulfillment of the requirements for the degree of Master of Science

The School of Graduate and Postdoctoral Studies

The University of Western Ontario

London, Ontario, Canada

(C) Colin Sproat, 2012 
THE UNIVERSITY OF WESTERN ONTARIO

School of Graduate and Postdoctoral Studies

\title{
CERTIFICATE OF EXAMINATION
}

$\underline{\text { Supervisors }}$

Dr. Jisuo Jin

Dr. Rong-yu Li
Examiners

Cam Tsujita

Stephen Hicock

Renbin Zhan

The thesis by

\section{Colin David Sproat}

entitled:

\section{Evolution of the Late Ordovician Plaesiomyid Brachiopod Lineage in Laurentia}

\author{
is accepted in partial fulfillment of the \\ requirements for the degree of \\ Master of Science in Geology
}

\section{Date}

Chair of the Thesis Examination Board 


\begin{abstract}
During the Late Ordovician, a transgression flooded much of Laurentia. The fauna of these intracratonic basins became differentiated from the fauna of the pericratonic shelves and platforms, typically displaying gigantism and coarser shell ornamentation. In this study, 509 specimens from 11 species of the Plaesiomyidae brachiopod family from the Katian and Hirnantian were measured, of which 198 included in principal component analysis to quantify morphological changes over this interval. Three trends were revealed: 1) increasing globosity and dorsal convexity from the early to late Katian, 2) coarser, but fewer ribs on species from the paleoequatorial intracratonic seas compared to species from the mid- to high-tropical pericratonic shelves and platforms, and 3) enlargement of the cardinal process from early to late Katian and predominance of a trilobed cardinal process in the intracratonic species versus bilobed cardinal process in pericratonic species. Two new species were assigned, and two existing species were reassigned.
\end{abstract}

Key Words: brachiopod, Plaesiomyidae, Late Ordovician, Katian, Hirnantian, evolution paleoecology, faunal gradient, paleobiogeography 


\section{Acknowledgements}

I would first like to thank my supervisors, Dr. Jisuo Jin and Dr. Rong-yu Li, without whom I would not have been able to reach this point. Dr. Jin's support made the last two years much easier than they may have otherwise been. I always felt welcomed by stop by for a chat in his office, whether it was paleontology related or not. His professional guidance and personal support are appreciated, and I look forward to continuing to work with him in the future. Dr. Li may not have been as readily available, but was always only an email away, and the coffee and lunches while I was back in Brandon were always appreciated.

Secondly, I would like to thank all my friends I have met here in London. As someone coming from another province, I appreciated being welcomed into the department by so many kind and considerate people. Even when things were getting tough, I could always count on the support of the many friends surrounding me. A special thanks to my roommate Emrah Yenier, not only for moral support, but also for his valuable skills with spreadsheets in Microsoft Excel.

Thirdly, even though they were a province away, I would not have made it through this experience without the support of all my friends from back home in Manitoba. I may not have been able to see them everyday, but when we did get together they made it count. I always enjoyed their messages of support and even simple casual conversations.

Last, but certainly not least, I thank my family. Although they didn't always understand why I was still in school after all these years, they always supported me in my decisions, and were a constant source of encouragement, and for that I will never be able to thank them enough.

This research was funded by a grant from the Natural Science and Engineering Research Council to Dr. Jisuo Jin. I am grateful to Ed Dobrzanski for acting as our field guide in Manitoba. Paul Mayer of the Field Museum in Chicago, Illinois, kindly provided the specimens from the Ohio-Kentucky-Indiana tri-state area. Michelle Coyne of the Geological Survey of Canada kindly provided the Plaesiomys browni type specimens for examination. 


\section{Table of Contents}

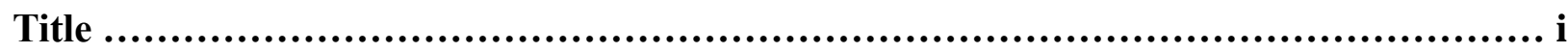

Certificate of Examination .................................................................... ii

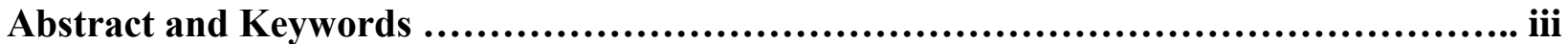

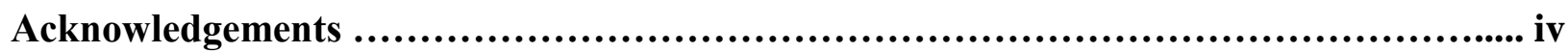

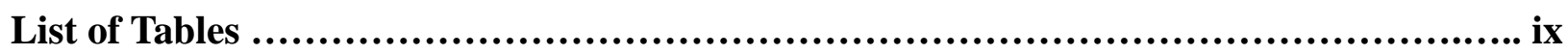

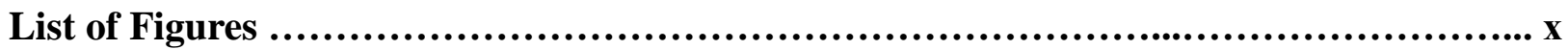

Chapter 1 - Introduction ..................................................................... 1

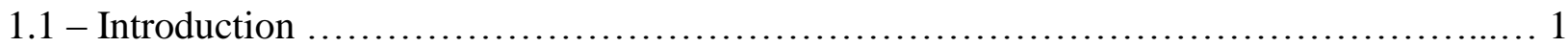

1.2 - The Great Biodiversification Event .................................................... 2

1.2 .1 - Environmental Contributors ................................................ 7

1.2.1.1 - Tectonic activity ............................................... 7

1.2.1.2 - Elevated atmospheric carbon dioxide levels ........................ 8

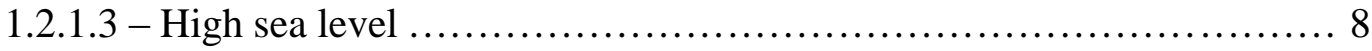

1.2.1.4 - Phytoplankton blooms .......................................... 10

1.2.1.5 - Calcite seas ........................................................ 11

1.2.1.6 - Superplume? ................................................. 13

1.2 .2 - Changes in biodiversity ................................................. 14

1.2.2.1 - The Cambrian fauna .............................................. 14

1.2.2..2 - The Paleozoic fauna .......................................... 15

1.2.2.3 - The Modern fauna ............................................. 18

1.2 .3 - Radiation of articulate brachiopods ................................... 18

1.2.3.1 - Strophomenata ................................................... 19

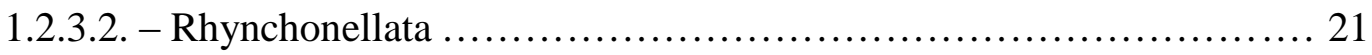

1.2.3.3 - $\alpha, \beta$, and $\gamma$ brachiopod diversity ........................................................ 21

1.2.3.4 - Brachiopod faunal diversity in Laurentia ........................... 22

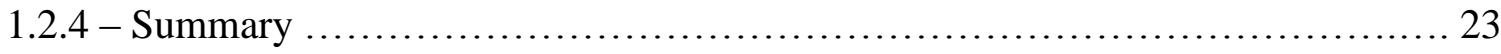

1.3 - Terminal Ordovician mass extinction ............................................. 24

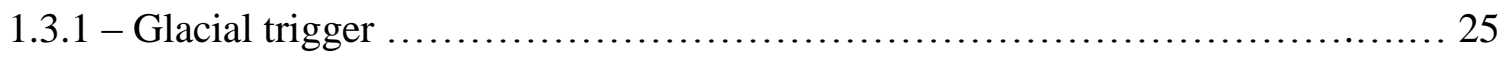

1.3.1.1 - Productivity hypothesis ...................................... 26 
1.3.1.2 - Weathering hypothesis ........................................ 27

1.3.1.3 - Carbonate deposition and weathering hypothesis .................. 28

1.3.1.4 - Volcanism hypothesis ......................................... 28

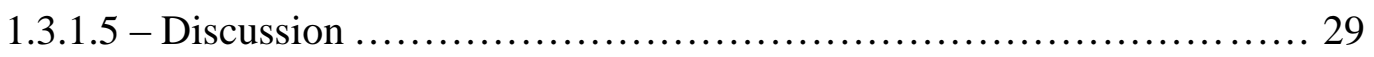

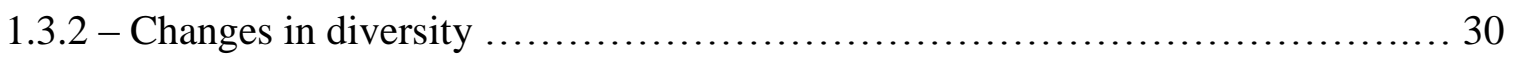

1.3.3 - Change in articulate brachiopod diversity and faunas ........................ 34

1.3.3.1 - Survival faunas ................................................ 33

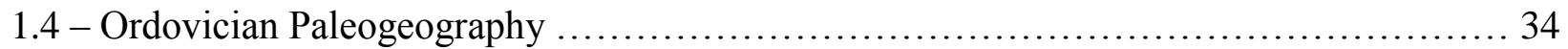

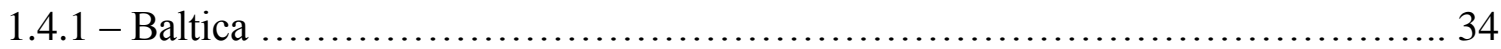

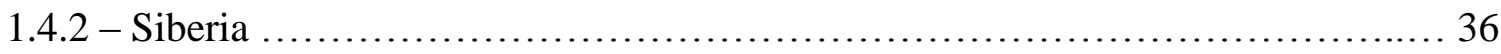

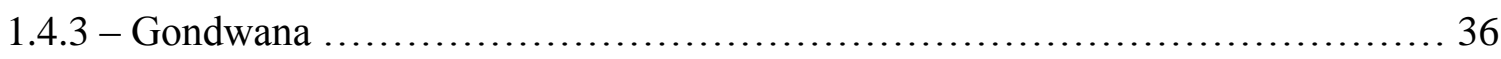

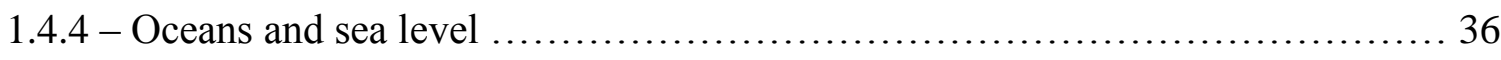

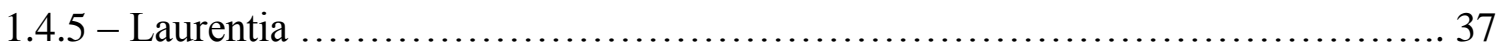

1.4.5.1 - Sea level and Laurentia ........................................ 40

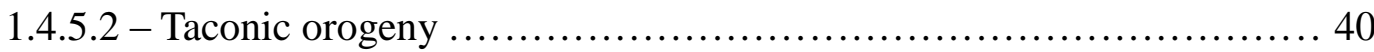

1.5 - Objectives of Current Research and Rationale for the Project .......................... 41

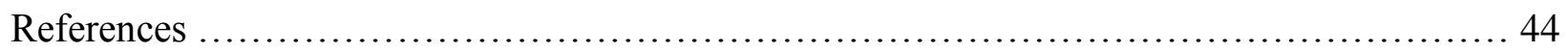

Chapter 2 - Geological and Stratigraphic Setting ..................................... 58

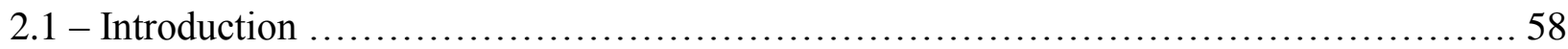

2.2 - Lake Simcoe area, Ontario .................................................. 58

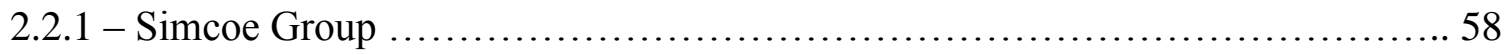

2.2.1.1 - Shadow Lake Formation .......................................... 60

2.2.1.2 - Gull River Formation ............................................ 60

2.2.1.3 - Bobcaygeon Formation .......................................... 61

2.2.1.4 - Verulam Formation ........................................... 62

2.2.1.5 - Lindsay Formation ............................................. 64

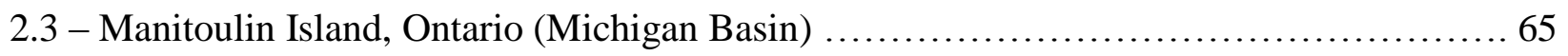

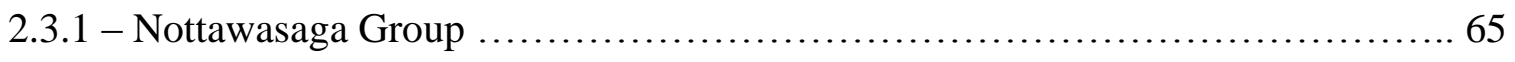

2.3.1.1 - Blue Mountain Formation ........................................ 65

2.3.1.2 - Georgian Bay Formation ........................................ 66

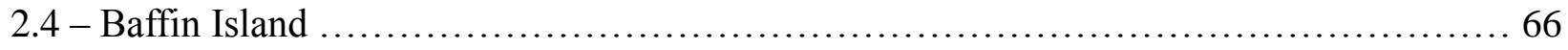

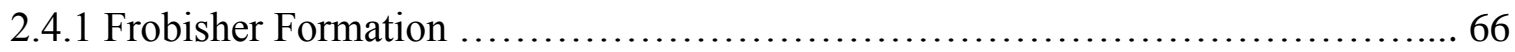


2.4.2 - Amadjuack Formation ................................................. 67

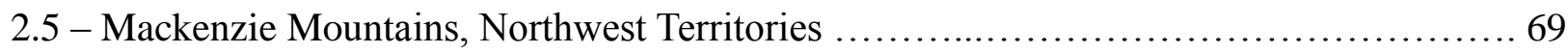

2.5.1 - Sunblood Formation ..................................................... 69

2.5.2 - Esbataottine Formation .................................................. 70

2.5.3 - Whittaker Formation ................................................. 70

2.5.4 - Road River Shale ..................................................... 71

2.6 - Stony Mountain, Manitoba (Williston Basin) .................................... 72

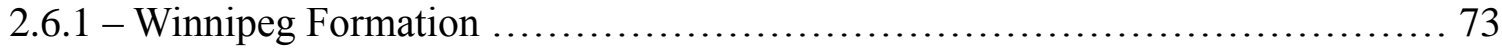

2.6.2 - Red River Formation .................................................. 73

2.6 .3 - Stony Mountain Formation ............................................ 75

2.6.4 - Stonewall Formation ................................................... 76

2.7 - Cincinnati type area, Ohio-Kentucky-Indiana borderland ........................... 77

2.7 .1 - C5 Sequence ........................................................ 77

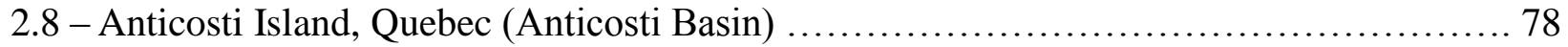

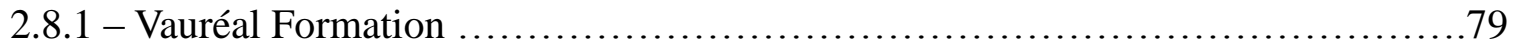

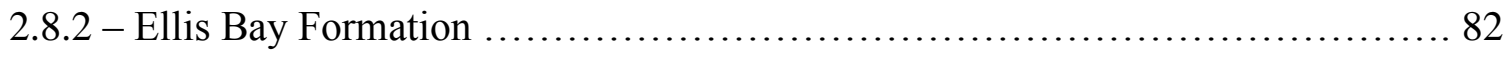

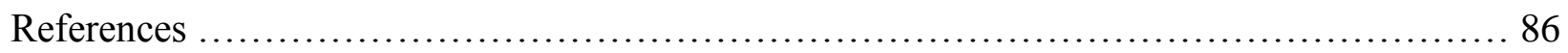

Chapter 3 - Systematic Paleontology ................................................. 94

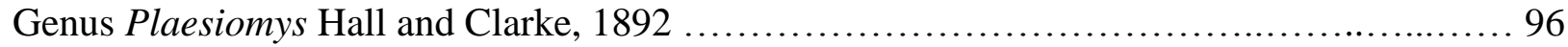

P. browni (Wilson, 1946) .................................................... 115

P. occidentalis (Okulitch, 1943) ............................................... 120

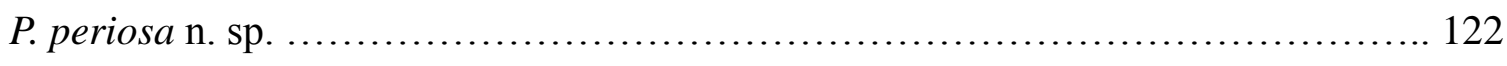

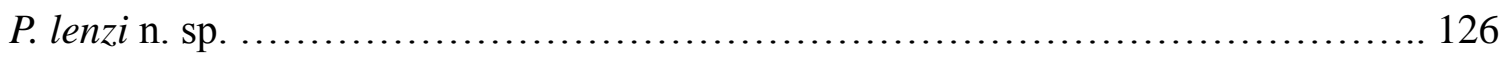

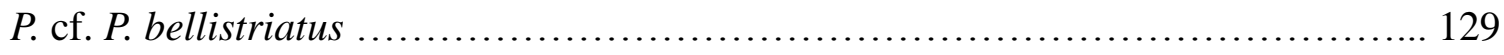

Genus Austinella (Foerste, 1909) .................................................... 131

A. multicostella (Alberstadt 1973) ............................................... 132

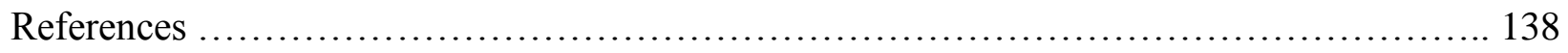

Chapter 4 - Evolution of the plaesiomyid lineage in Laurentia ......................... 143

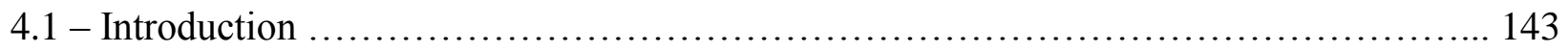

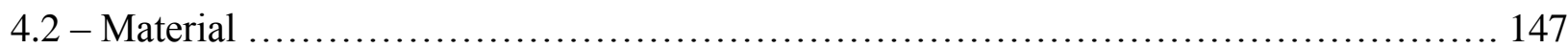

4.2.1 Notes on the Field Museum collection .................................... 155 


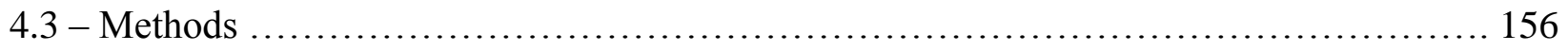

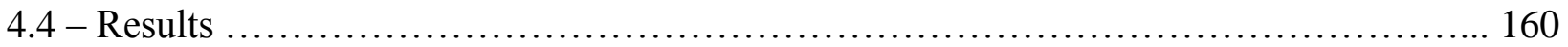

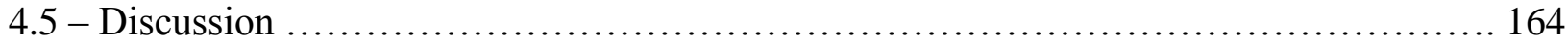

4.5.1 - Dorsal convexity index, globosity index ............................... 168

4.5.2 - Rib bifurcation index ............................................ 172

4.5.3 - Cardinal process: bilobed versus trilobed ............................... 176

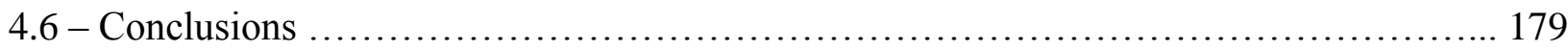

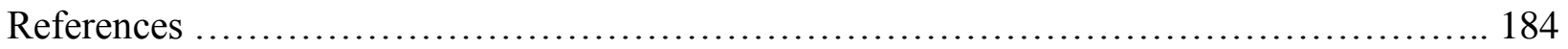

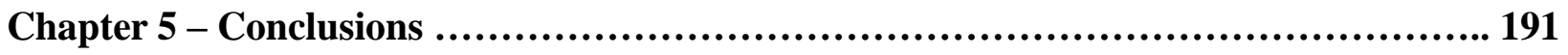

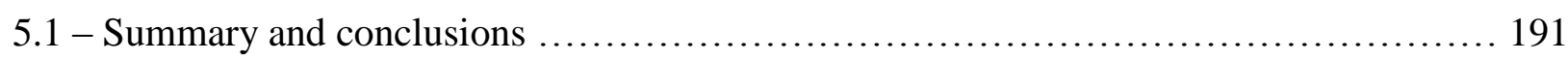

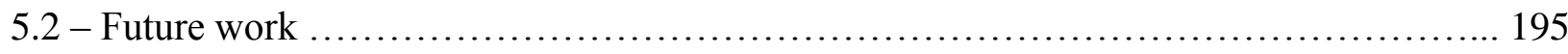

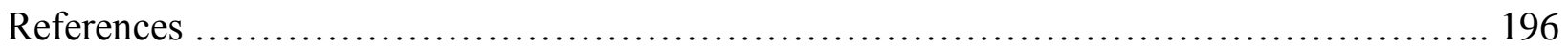

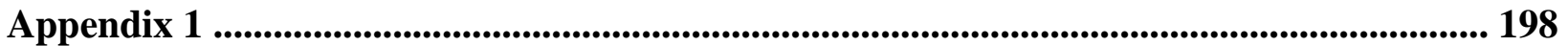

Appendix 2 ........................................................................................................................................ 200

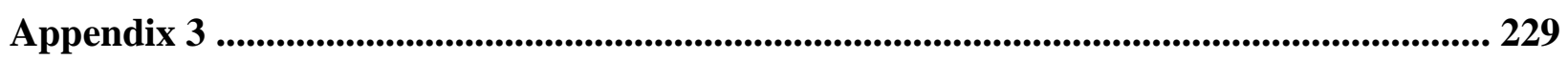

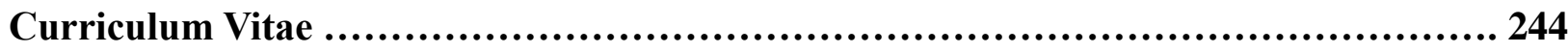




\section{List of Tables}

Table 3.1 - Shell measurements of Plaesiomys browni ............................... 119

Table 3.2 - Statistics of shell measurements for Plaesiomys browni, a sample from Manitoulin Island ....................................................................... 120

Table 3.3 - Plaesiomys periosa type measurements ................................ 123

Table 3.4 - Plaesiomys lenzi measurement statistics ............................... 129

Table 3.5 - Plaesiomys cf. P. bellistriatus measurements ............................ 131

Table 4.1 - Number of specimens measured and used for analysis ........................ 159

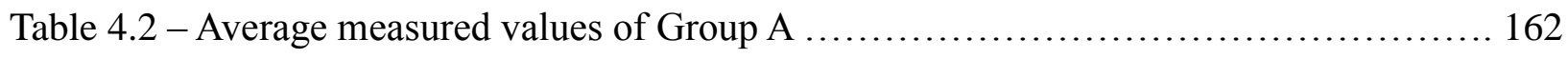

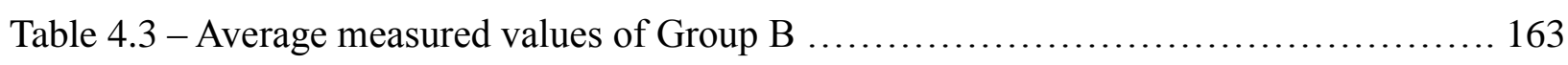

Table 4.4 - Average measured values of Group C . ................................ 164 


\section{List of Figures}

Figure 1.1 - Phanerozoic generic diversity ....................................... 4

Figure 1.2 - Diversity of evolutionary faunas over the Phanerozoic ...................... 6

Figure 1.3 - Estimated sea level over the Phanerozoic $\ldots \ldots \ldots \ldots \ldots \ldots \ldots \ldots \ldots \ldots \ldots \ldots \ldots$

Figure 1.4 - Calcite seas over the Phanerozoic .................................... 12

Figure 1.5 - Generic diversity of brachiopods during the Ordovician .................... 20

Figure 1.6 - Diversity change over the Late Ordovician Mass Extincion ..................... 33

Figure 1.7 - World paleogeography during the Ordovician ............................. 35

Figure 1.8 - Paleogeographic map of Laurentia during the Ordovician with localities ......... 40

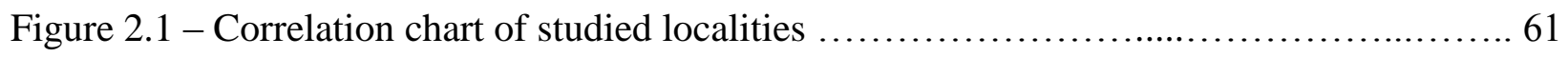

Figure 3.1 - Plaesiomys browni .............................................. 100

Figure 3.2 - Plaesiomys columbia ........................................... 102

Figure 3.3 - Plaesiomys occidentalis ............................................. 104

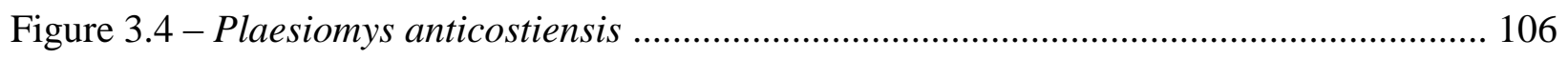

Figure 3.5 - Plaesiomys subcircularis, P. subquadrata ................................. 108

Figure 3.6 - Plaesiomys bellistriatus .......................................... 110

Figure 3.7 - Plaesiomys periosa ............................................ 112

Figure 3.8 - Plaesiomys lenzi, Plaesiomys cf. P. bellistriatus......................... 114

Figure 3.9 - Tracings of serial sections of Plaesiomys browni ......................... 117

Figure 3.10 - Serial sections of the cardinal process of Plaesiomys browni ................. 118

Figure 3.11 - Austinella multicostella ............................................. 135

Figure 4.1 - Range of Dinorthis and Plaesiomys species .............................. 144

Figure 4.2 - Plaesiomys browni, P. subcircularis, P. columbia ......................... 150

Figure 4.3 - Plaesiomys lenzi, P. periosa, P. occidentalis .............................. 152

Figure 4.4 - Plaesiomys subquadrata, P. bellistriatus, P. anticostiensis ..................... 154

Figure 4.5 - Measurements used for PCA ..................................... 157

Figure 4.6 - PCA scattergram .............................................. 161

Figure 4.7 - Increasing globosity over time ..................................... 166 


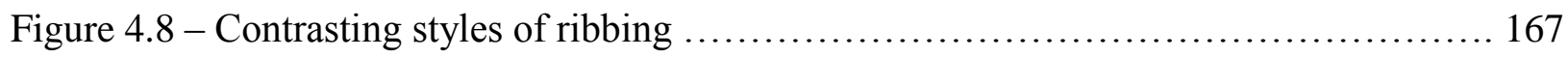

Figure 4.9 - Dorsal convexity index and shell globosity index .......................... 169

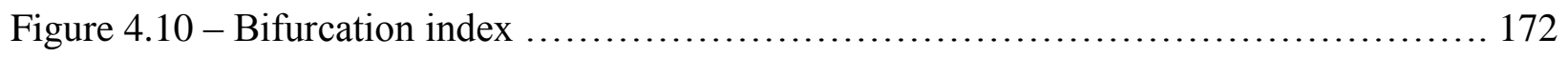

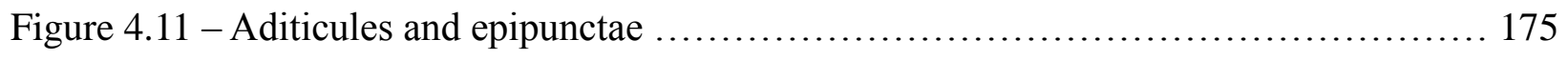

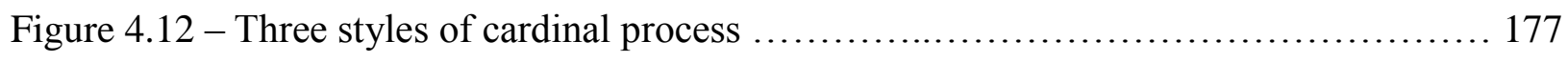

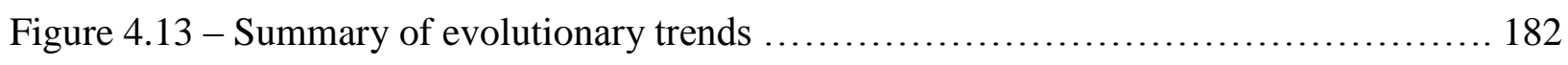

Figure 4.14 - Geographic distribution of plaesiomyids and geographical evolutionary trends 183 


\section{Chapter 1 - Introduction}

\subsection{Introduction}

The Ordovician Earth (488-444 million years ago) was a very different world than it is today. The atmosphere, throughout most of the Ordovician, is thought to have been in a super-greenhouse state (Shields et al. 2003), probably enriched in carbon dioxide (Berner 1994, 2001, 2006) with no polar glaciation until the end of the period. Some have suggested a more protracted cooling interval at the end of the period (Finnegan et al. 2011), and perhaps a cooler Ordovician overall (Trotter et al. 2008). Because of enhanced uplift at mid ocean rifts associated with increased tectonic activity and the configuration of the continents, sea levels were much higher (Hallam 1992; Haq and Schutter 2008), reaching their highest level for the Phanerozoic. The seas flooded much of the continents, creating vast, shallow intracratonic seas (Miller 2005). These intracratonic seas were extensive carbonate factories that formed vast carbonate platforms (e.g. Norford et al. 1994; Cocks and Torsvik 2011).

These environmental conditions were linked to a rapid diversification of organisms living at the time. Throughout most of the Ordovician, life went through rapid pulses of diversification until the Late Ordovician (Webby et al. 2004a). During the Hirnantian a brief glaciation in Gondwana at the South Pole occurred (Brenchley et al. 1994). The glaciation and the associated sea level drop triggered one of the five great mass extinctions of the Phanerozoic Eon (Sheehan 2001). Although the extinction was severe in terms of taxonomic diversity loss, the ecological consequences of this extinction were muted. During the Silurian, surviving taxa repopulated empty ecological niches left behind by those taxa that went extinct, and community structure remained largely similar to that of the earlier Ordovician ecosystems (Brenchley et al. 2001; Sheehan 2001).

The Hirnantian glaciation may have been linked to a preceding warming interval known as the Boda Event based on the migration of low latitude faunas to high latitudes and the presence of warm water carbonates near the poles. (Fortey and Cocks 2005; Cocks 2006). Evidence of any tropical impact is, however, only shown during the 
Hirnantian (Young et al. 2010). Other authors have suggested the Boda event may represent a pre-glacial cooling event. This has mostly been based on a pre-Hirnantian carbon isotope excursion (Saltzman and Young 2005) and dispersal of benthic fauna into basins which had become further oxygenated by enhanced thermohaline circulation that may be explained by cooler oceans (Cherns and Wheeley 2007, 2009). Recently, clumped carbonate paleothermometry has also suggested a longer cooling event with transient ice sheets forming during the late Katian before extensive ice sheets developed during the Hirnantian (Finnegan et al. 2011).

Laurentia (North America and Greenland) straddled the equator during the Ordovician, rotated about $80^{\circ}$ clockwise from its current orientation (Cocks and Torsvik 2011). Much of the continent was covered by a shallow epicontinental sea, growing in area late in the period (Zhang 2011). This large, shallow sea produced large volumes of carbonates, and was inhabited by a variety of invertebrates.

The modern eastern margin (then the southern margin of the continent) was tectonically active. The Taconic orogeny caused both uplift and subsidence along this margin during the Middle Ordovician (van Staal et al. 2007), significantly changing the habitat of the organisms that lived there through relative sea level change.

Brachiopods, being one of the most common constituents of the shelly benthos

during the Ordovician, were significantly impacted by both changing habitats and rapid diversification. This thesis focuses on one brachiopod lineage, the plaesiomyids, of the Laurentian paleocontinent. The evolution of this group over the Late Ordovician following the Great Ordovician Biodiversification Event and into the Hirnantian extinction interval has been studied intensively to understand the effects of the Ordovician climate change on evolution radiation, and extinction.

\subsection{The Great Ordovician Biodiversification Event (GOBE)}

The Great Ordovician Biodiversification Event (GOBE) was one of the two most significant episodes of taxonomic radiation during the Phanerozoic. The other, the Cambrian Explosion, marked the appearance of most of the metazoan phyla and the evolution of widespread biomineralization. The Ordovician radiation, on the other hand, was a radiation at lower taxonomic levels (species, genus, family, and orders) (Webby 
2004a). The only phylum traditionally thought to have originated during the Ordovician radiation was Bryozoa (Servais et al. 2010), but Landing et al. (2010) showed that even the bryozoans originated in the Cambrian.

Until recently, the Cambrian Explosion has been much better documented than the Ordovician radiation event in literature - popularized by the works of Gould (1989) and Conway Morris' Crucible of Creation (2000). It was not until the internationally coordinated IGCP project 410 (Webby et al. 2004) was completed that the significance of the Great Ordovician Biodiversification Event gained worldwide attention.

Webby et al. (2004) provided a thorough review of biodiversity changes across all major groups of organisms and provided an overall summary of biodiversity change. They also provided a brief account of the environment and climate of the Ordovician. Since then, other reviews, including Munnecke et al. (2010) and Servais et al. (2010), have added details focussing on the environmental and ecological dynamics of the Ordovician sea. The biodiversity fluctuations of brachiopods during the GOBE, in particular, were further analyzed by Harper (2006, 2010).

Paleontologists have long noted a marked increase in diversity through the Ordovician. Sepkoski's classic papers that used statistical analyses to uncover diversity trends in invertebrate groups $(1979,1981,1988,1993,1997)$ were the first to quantify the changes in faunal diversity during the radiation. Recent work by Alroy (2010a, b) and Alroy et al. (2008) using data from the Paleobiology Database (http://paleodb.org/) confirmed Sepkoski's findings but the addition of new data to the database and the use of different statistical techniques have shown the increase in diversity may not have been as great as originally shown by Sepkoski (Figure 1.1) 


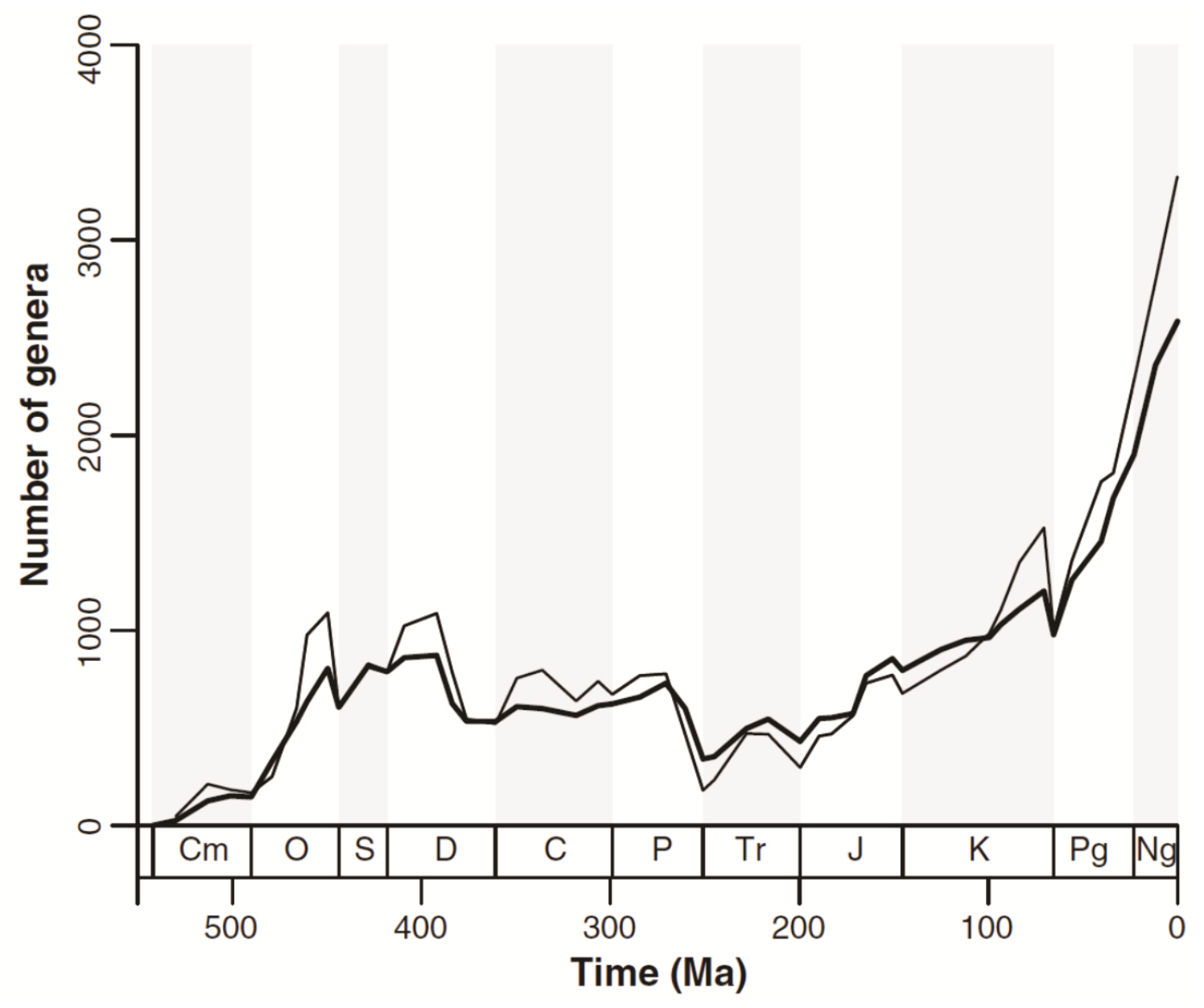

Figure 1.1 - Phanerozoic generic diversity after Alroy et al. (2008). The thicker line shows generic diversity according to the Paleobiology Database while the thin line shows diversity according to Sepkoski's compendium. Generic diversity tripled over the Ordovician period $(\mathrm{O})$. 
Although the diversity of all groups increased during the Ordovician, the Paleozoic fauna diversified much more than the Cambrian and Modern faunas (Figure 1.2). This expansion was concentrated in nearshore and offshore environments, as the Paleozoic fauna already dominated mid-shelf environments by the Early Ordovician (Sepkoski and Sheehan 1983). This Paleozoic fauna consisted mainly of articulated brachiopods, corals, cephalopods, bryozoans, echinoderms, and ostracods (Sepkoski 1984). Most of these groups are filter feeders. Over the course of the Ordovician, they gradually replaced the Cambrian fauna (mostly trilobites and inarticulate brachiopods) in dominance. This replacement reflected a change in feeding styles - the Cambrian fauna was dominated by deposit feeders while the Paleozoic fauna mainly consisted of suspension feeders. Rather than a drastic decline in Cambrian faunal diversity, it was a rapid increase in the diversity and biomass of constituents of the Paleozoic fauna that caused the proportional change in diversity (Finnegan and Droser 2008). The Modern fauna (e.g. bivalves) also increased in diversity but this was mainly confined to nearshore environments (Harper 2006). This radiation established the Paleozoic biodiversity plateau that, although punctuated by extinction events, would continue to the end of the Paleozoic Era.

Besides taxonomic radiation, there was also significant ecological diversification during the GOBE. Enhanced tiering enabled feeding at different heights above and below the seafloor, allowing more organisms to occupy a given area of habitat. This led to increased ecological complexity within Ordovician benthic communities (Ausich and Bottjer 1982; Bottjer and Ausich 1986). At the same time, however, the evolution of infaunal biota impacted the preservation of primary sedimentary features - bioturbation disrupted bedding and lamination commonly preserved in older strata deposited in similar depositional environments. This is particularly evident in the expansion of Thalassinoides galleries during the Ordovician. Worldwide, the simple horizontal forms typical of the Cambrian were supplanted by complex, 3-dimensional structures, penetrating sediment to depths approaching $1 \mathrm{~m}$ to the completely horizontal specimens from the Cambrian (Sheehan and Schieflbein 1984; Jin et al. 2012). 
Cambrian
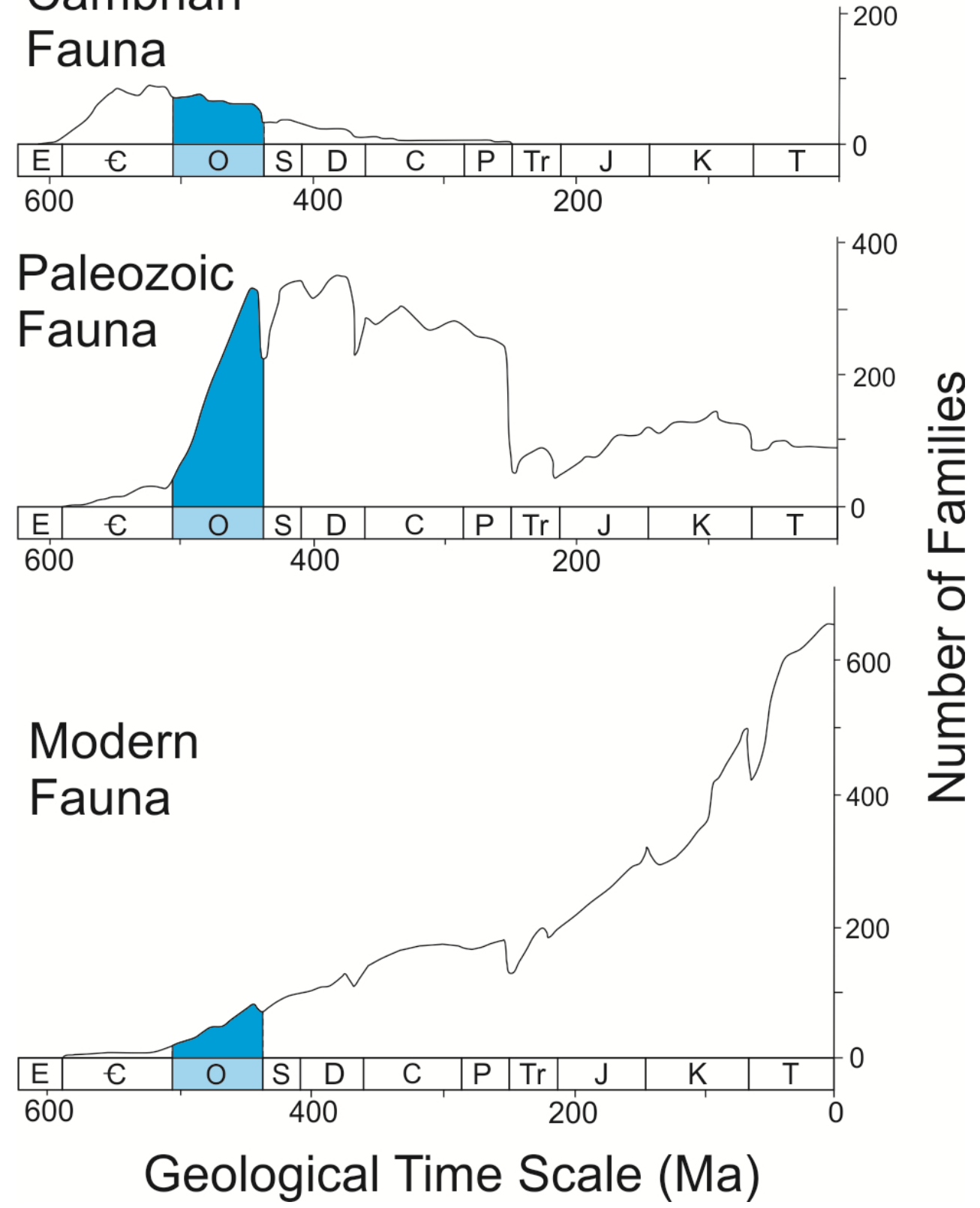

Figure 1.2 - Familial diversity levels of the Cambrian, Paleozoic, and Modern evolutionary faunas over the Phanerozoic, with the Ordovician period highlighted (after Sepkoski 1984). Note the significant increase in diversity of the Paleozoic fauna during the Ordovician period in comparison to the drop in diversity showing the Cambrian fauna and only slight increase in diversity of the Modern fauna. 
It is during this interval that the plaesiomyid brachiopod lineage originated and diversified. The earliest known plaesiomyids were dated to the Darriwilian in Tennessee (Willard 1928, Cooper 1956, Bergstrom et al. 1988), but they did not become abundant until the Richmondian. As such, it is important to understand how the GOBE affected the brachiopod faunas at this time so we can understand the forces contributing to the evolution of the plaesiomyid lineage.

\subsubsection{Environmental contributors}

The unique environmental conditions during the GOBE impacted the evolution of the resident marine fauna. These conditions included high atmospheric carbon dioxide levels, high sea levels, calcium:magnesium ionic ratios in seawater, elevated tectonic activity levels, and a rapid rise in plankton productivity. It is likely that these environmental conditions, at least partially, facilitated the rapid diversification of the Paleozoic fauna.

\subsubsection{Tectonic activity}

Tectonic activity was relatively intense and widespread during the Ordovician in comparison to the rest of the Phanerozoic, including the rifting around the Gondwana margin and the Taconic orogeny along the eastern margin of Laurentia. This episode of enhanced tectonic activity had several consequences. First, the area of the continental shelf increased due to faulting and subsidence as a result of rifting. Miller (2005) concluded that the Ordovician had the most extensive continental shelves of the entire Phanerozoic Eon. Thus, there was an expansion of desirable habitat for the evolving Paleozoic fauna inhabiting the predominantly cool-temperate environments (Sepkoski 1991). Secondly, increased activity at mid ocean ridges would have contributed to a rise in sea level, further expanding marine habitats. It has been shown that rifting, and associated uplift, at mid ocean ridges is one of the most influential factor in sea level rise (Hays and Pitman 1973). Thirdly, the widely dispersed continents during much of the Ordovician would have promoted endemism. Limited faunal exchange between populations on different continents would cause each continent's populations to evolve thereby independently, increasing biodiversity. This is seen in the high abundance of endemic fauna in comparison to cosmopolitan fauna worldwide during the Ordovician 
(Cocks 2001).

\subsubsection{Elevated atmospheric carbon dioxide levels}

Atmospheric modelling studies (Berner 1994, 2001, 2006) have suggested that during the Ordovician carbon dioxide levels were much higher than today - on the order of 8-16 times higher than present-day atmospheric levels (PAL) from atmospheric modelling (Berner 1994, 2001, 2006). Based on delta $\delta^{13} \mathrm{C}$, atmospheric carbon dioxide concentrations steadily rose throughout most of the Ordovician to a maximum during the Katian, before declining from the Katian into the Hirnantian.

Elevated carbon dioxide levels would have influenced the global temperature through enhanced greenhouse effect. Oxygen isotope signatures (a proxy for sea surface temperature) and climate modelling show that elevated carbon dioxide levels drove the Earth's climate into a super-greenhouse state. Climate modelling by Goddéris et al.(2001) shows a global mean annual temperature of $18^{\circ} \mathrm{C}$ while oxygen isotope data indicate a minimum sea surface temperature varying from as high as $27-32^{\circ} \mathrm{C}$ (Shields et al. 2003, derived from calcitic brachiopod shells) or perhaps much lower, down to as little as $22-24^{\circ} \mathrm{C}$ (Trotter et al. 2008), derived from phosphatic chintinozoans which may have been less prone to diagenetic alteration.

\subsubsection{High sea level}

Increased levels of tectonic activity and high carbon dioxide levels both contributed to high sea levels - probably the highest of the entire Phanerozoic Eon. In comparison to modern sea levels, the Ordovician may have had sea levels up to $200 \mathrm{~m}$ above present levels (Hallam 1992; Haq and Schutter 2008). Sea level rose gradually over the Early Ordovician before dropping slightly during the Middle Ordovician. This was followed by a rise during the Late Ordovician before sea levels dropped substantially in the late Katian and Hirnantian (Figure 1.3).

As a result of the drastic rise in sea level and marine transgression, many of the continents were flooded by shallow, but extensive, epicontinental seas for most of the Ordovician (Miller 2005). This greatly expanded the marine habitat for the diversifying Paleozoic fauna. It also would have reduced silicate weathering, which would help to 


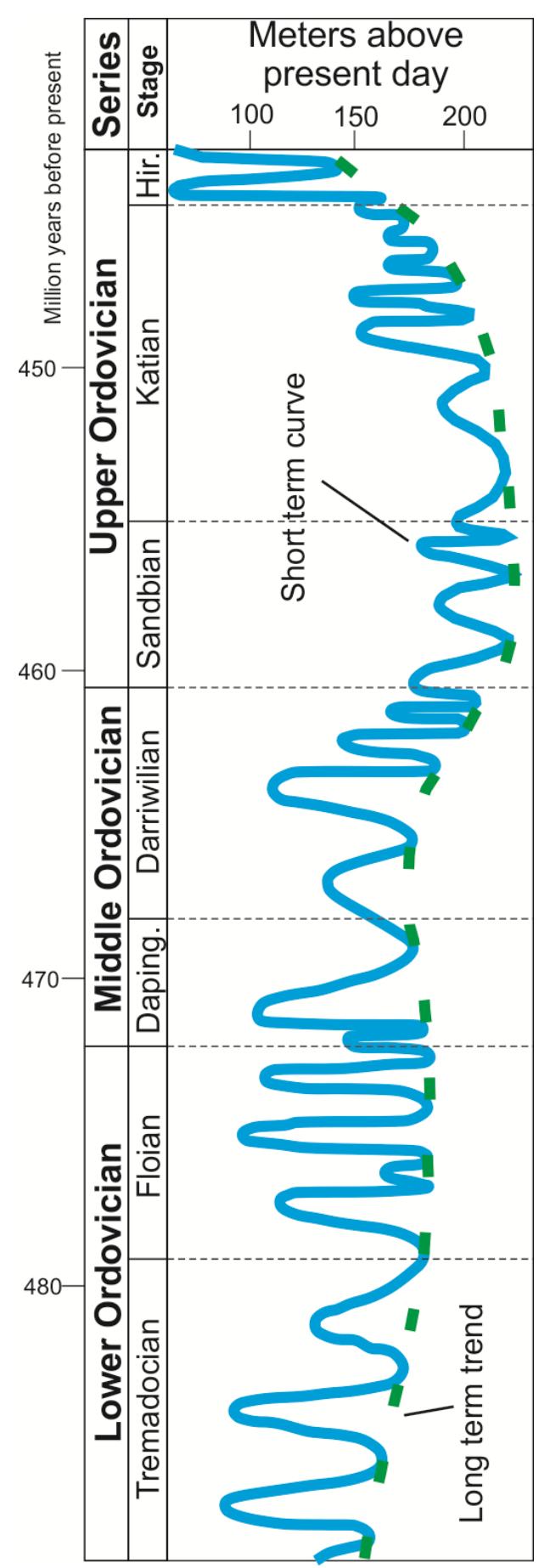

Figure 1.3 - Estimated sea level in meters above present level during the Ordovician after Haq and Schutter 2008 and Servais et al. 2010). Global sea level rose throughout the Ordovician until the Hirnantian, with only a slight drop during the Middle Ordovician. The significant fall at the end of the period has been linked to glaciation on Gondwana. 
maintain the higher carbon dioxide levels (Riding 1993). The higher carbon dioxide levels would have raised atmospheric and sea temperatures, further increasing sea levels, further reducing silicate weathering due to less subaerial silicate exposure, etc., acting as a positive feedback loop in terms of the global climate system.

The high sea levels of the Middle to Late Ordovician are manifested in the sedimentary record. For example, the Red River and Stony Mountain formations in Manitoba, although showing two shallowing upward cycles, show evidence of a relatively deep environment and a rich subtidal continental shelf biota overall (Young et al. 2008). Also, the shale-rich lower Whittaker Formation in the Mackenzie Mountains is substantially finer grained than the underlying Sunblood Formation which contains minor sandy horizons (Ludvigsen 1975). Therefore, the Whittaker Formation may represent a similar, relatively deep environment. Finally, the predominantly carbonate Simcoe Group in Ontario exhibits deeper water facies than the older Ordovician Shadow Lake Formation which was probably deposited in a nearshore to supratidal environment based on its coarse clastic content (Blackriveran in age - upper Middle Ordovician to lower Upper Ordovician; Armstrong 2000).

\subsubsection{Phytoplankton blooms}

The main component of the fossil record of phytoplankton during the Ordovician is acritarchs - small organic-walled microfossils thought to represent algal cysts. As of yet, no global diversity curve of acritarchs has been compiled for the Ordovician. Servais et al. (2004), however, have attempted to compile regional diversity of each of the main paleocontinents during the Ordovician. They note that the study of acritarchs is still in its infancy, such that many gaping holes currently exist in the coverage of their study.

Based on a relatively complete data set from the British Isles, Strother (1996) compiled a diversity curve of acritarchs over the Early Paleozoic. During the Cambrian, acritarch diversity was relatively low with a large increase in the Early to Middle Ordovician. Emerging data from China and North Africa seem to correlate with a Middle Ordovician peak in diversity. Caution should be exercised in extrapolating a regional data set to a global scale; however an increase in diversity seems to be evident.

The North American data set for acritarch diversity, although large, has several 
shortfalls (Servais et al. 2004). There is apparently a large, diverse acritarch fauna in Laurentia during the Ordovician, but the dataset includes numerous synonymies. The descriptions of these taxa are often general, and as such, Laurentian acritarchs are difficult to classify given the current classifications in literature. These synonymies would have to be removed before a true picture of Laurentian acritarch diversity during the Ordovician can be created.

If this increase in diversity is indeed global in nature, a change in the primary production of phytoplankton may have contributed to the increasing diversity of the Paleozoic fauna - composed mainly of filter feeders. Servais et al. (2008) called this a "phytoplankton revolution". The cause of this is not yet certain but may be related to an increase in volcanic input of ions into marine waters (Servais et al. 2008).

With phytoplankton biomass increasing (acritarchs), organisms higher in the food chain, like the filter feeding Paleozoic Evolutionary Fauna, would have become more abundant as well (Signor and Vermeij 1994). Servais et al. (2009; 2010) point out that the exact relationship through this linkage is still unclear, as few studies have examined the relationship between the biomass of producers and biomass of consumers within a food chain. Further study in this area will be needed to determine the strength of the relationship and how it can be analyzed within the fossil record. The difficulty in applying this to paleontology would be the imperfection of the fossil record - not all links in the food chain would be preserved, including both producers (e.g. algae, unicellular protists) and consumers (e.g. soft bodied polychaete worms, hydrozoans, some forms of larvae of benthic invertebrates).

\subsubsection{Calcite seas}

The calcite seas phenomenon manifests changes in seawater chemistry, swinging from a high magnesium:calcium ionic ratio to a low ratio. This was shown to occur in an examination of fluid inclusions within carbonate rocks by Lowenstein et al. (2001) and the development of low magnesium calcite-rich hardgrounds (Palmer and Wilson 2004). These calcite seas occurred over two main intervals during the Phanerozoic - much of the Paleozoic and the Cretaceous (Sandberg 1983; Hardie 1996; Stanley and Hardie 1998; Lowenstein et al. 2001; Porter 2007; see Figure 1.4). 

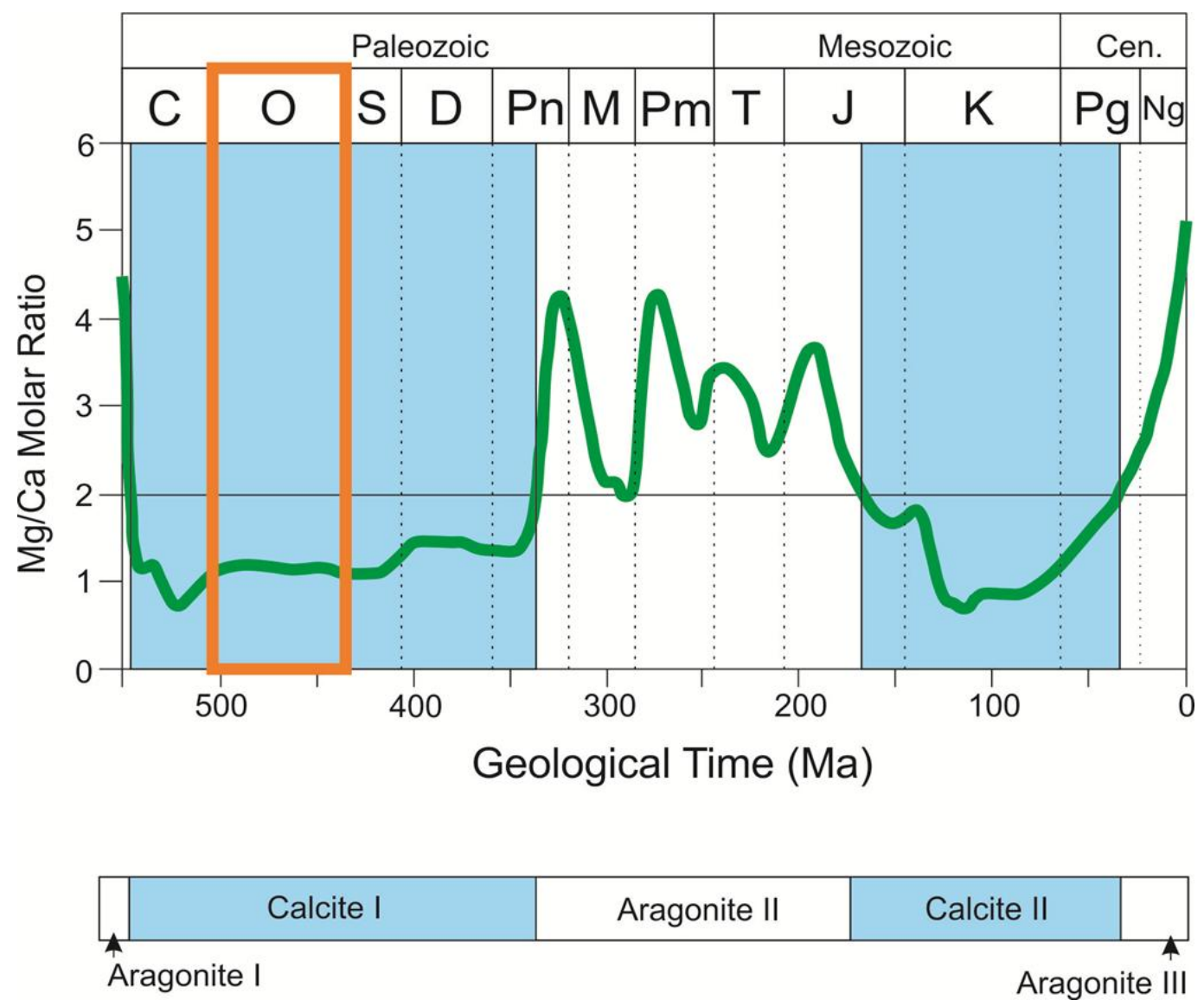

Figure 1.4 - Occurrence of calcite seas versus aragonite seas over the Phanerozoic (after Stanley and Hardie 1998). The oceans were in a calcite sea state during the Ordovician (highlighted). This was probably linked to the simultaneous rise of a number of invertebrate groups possessing calcite skeletons including stromatoporoids, corals, and brachiopods. 
An abundance of calcite secreting organisms rapidly evolved during the GOBE, including tabulate and rugose corals, bryozoans, brachiopods, and stromatoporoids - all contributing to the rise of metazoan reefs (Webby 2002). The enhanced precipitation of calcite from sea water due to greater supersaturation of calcite would have lowered the physiological cost of biomineralization for these calcite secreting organisms (Porter 2007).

Although it has been suggested that the calcite seas contributed to the evolution of these calcite-skeleton organisms, caution should be observed when applying this idea to the rest of the Phanerozoic. Kiessling et al. (2008) have shown that there is very little correlation between seawater chemistry and changing dominance of aragonite versus calcite skeleton organisms. They also note that many invertebrates have the ability to switch between aragonitic biomineralization and calcitic mineralization depending on seawater ionic concentrations. Nonetheless, it is difficult to argue that the rise of the calcitic invertebrate groups in Ordovician calcite seas was a superficial coincidence.

\subsubsection{Superplume?}

The activity of a superplume may have been the common cause for these environmental conditions during the Ordovician. A superplume occurs when hot, molten magma originating from the core-mantle boundary rises up through the cool, denser overlying magma. The superplume may breach the crust, causing increased volcanic activity (Condie 2001). The reversal of Earth's magnetic field may, in some cases, be related to superplume activity (Barnes 2004).

Qing et al. (1998) noted decreasing strontium isotope values in Ordovician and Silurian invertebrate shells beginning in the Middle Ordovician, and they argued that this may be linked to an increase in the hydrothermal flux input into seawater as the result of increased volcanic activity. This increased volcanic activity could, in turn, be linked to a developing superplume.

The problem with the superplume theory is the lack of primary evidence. If there was any record of the trap style volcanism expected from a superplume, it would have long been eroded or obscured by deposition of younger strata and most of the evidence from the Ordovician sea floor would have long since been subducted into the mantle 
(Barnes et al. 1996), other than perhaps a few obducted slabs of Ordovician marine sediments.

A superplume is, however, a plausible explanation for all the above environmental conditions (Qing et al. 1998; Barnes 2004). Spreading at mid ocean ridges would be enhanced, contributing to high sea levels. Volcanism is a significant source of atmospheric carbon dioxide, so that increased volcanism would lead to higher levels of carbon dioxide in the atmosphere. Submarine volcanism would add important ions to the sea water for phytoplankton growth, explaining the phytoplankton revolution. This would also affect the calcium:magnesium ratio of seawater as calcium would be preferentially added by volcanism, contributing to calcite sea conditions. Regardless of primary evidence, it is easy to see how a superplume could connect the causes of the GOBE. Further study in this area will be needed to search for primary evidence of superplume activity.

\subsubsection{Changes in biodiversity}

The Great Ordovician Biodiversification Event was not one single event, but rather a series of smaller biodiversification pulses over the Ordovician period - there was no singular point in time when all taxa began radiation (Webby 2004a; Servais et al. 2010). Each fossil group diversified during different intervals, with many groups going through multiple pulses of radiation. Overall, diversification can be grouped into three main pulses (Webby 2004a): Dapingian to early Darriwilian, late Darriwilian to early Katian, and a diversity peak during the Katian. These peaks, however, may be notably diachronous across different paleogeographic regions, even for the same group of organisms ( for brachiopod examples, see Zhan et al. 2005, 2006, 2007). Following the diversity peak during the Katian, the Hirnantian extinction event reduced diversity levels back down to near Early Ordovician levels (some 25 million years earlier).

\subsubsection{The Cambrian fauna}

The Cambrian fauna, consisting mainly of the trilobites and inarticulate brachiopods, was a relatively minor component of the Ordovician. Trilobite radiation occurred in three pulses (Adrain et al. 2004): the Ibex I fauna radiating during the Tremadocian, the Ibex II fauna radiating during the Floian (Blackhillsian, Rangerian), 
and Whiterockian fauna radiating over the Middle Ordovician and peaking in the early Sandbian (Whiterockian). The Ordovician marked the evolution of the planktonic trilobites, a new life habit for the group (Fortey and Owens 1999). Inarticulate brachiopods became dominantly infaunal and were generally displaced from the continental shelf into deeper or shallower water (Harper and MacNiocaill 2002), although the cementing craniformeans diversified diachronously worldwide (Harper et al. 2004). Overall, however, articulate brachiopods became a far more significant portion of the overall brachiopod diversity during the Ordovician in comparison to the Cambrian period (Harper et al. 2004).

\subsubsection{The Paleozoic fauna}

The most extensive radiation was in the diversification of the Paleozoic fauna. This diversification was centered in nearshore and offshore environments, as the Paleozoic fauna was already dominant in mid-shelf environments by the Early Ordovician (Sepkoski and Sheehan 1983). This Paleozoic fauna consisted mainly of articulated brachiopods, corals, cephalopods, bryozoans, echinoderms, and ostracods (Sepkoski 1984) - dominantly filter feeders.

Corals only had one, but very significant diversity peak during the late Katian (Webby et al. 2004b). The tabulate corals diversified most extensively during the Middle Ordovician while rugose corals didn't diversify until the Late Ordovician (Webby et al. 2004b). The Ordovician radiation of corals had a major ecological consequence as well the Late Ordovician marked the rise of the metazoan reefs (Webby 2002). Previous to this, reefs were dominated by microbial, bryozoan, and sponge communities. The record of these coral reefs is variable, however, depending on the environment. In Manitoba, for example, although there is a highly diverse coral fauna, no large reefs are documented (Young et al. 2008). Closer to the continental margin, however, reefs were more abundant, with Gabrielse et al. (1973) and Wigington (1977) documenting the presence of small reefs within the Whittaker Formation, and Long and Copper (1994) reporting bioherms within the Laframboise Member of the Ellis Bay Formation on Anticosti Island. This could have been related to high water temperatures near the equator being outside the narrow tolerance range for many types of coral, inhibiting reef formation (Kauffman 
and Fagerstrom 1993). This would explain why we don't see significant reef development on Anticosti Island until the Hirnantian (Long and Copper 1994), when global temperatures dropped significantly (Shields et al. 2003; Trotter et al. 2008).

Cephalopods, consisting of the nautiloids during the Ordovician, diversified extensively - going from a single order at the start of the period to at least nine orders during their peak diversity late in the period. Kröger and Zhang (2009), building on the earlier work of Frey et al. (2004), examined cephalopod diversity over the period and determined there was a peak in diversity early in the Tremadocian and during the Katian. Cephalopods grew extremely large during the Ordovician, with some examples from intracratonic seas of Manitoba suspected to represent specimens up to several meters long (Young et al. 2008), likely making them the top predator in the Ordovician seas.

The echinoderms (mostly stemmed filter feeders during the Ordovician) were the first phylum to diversify during the Ordovician. Unlike other groups, they began diversifying during the Early Ordovician, with 21 of 30 clades appearing early in the period, and continued to diversify until the Late Ordovician extinction. The group transitioned from an eocrinoid and stylophoran dominated fauna to a larger crinoid and diplophoran group over the Ordovician (Sprinkle and Guensburg 2004).

Bryozoan taxonomy is still not well established and Ordovician bryozoans are not as well studied as other groups. Nevertheless, overall diversity has still been documented. Taylor and Ernst (2004) show a pattern of gradual diversification over the Ordovician before falling at the end of the period during the Hirnantian. Unlike in the modern seas, where bryozoans are confined to cold water carbonate settings, during the Ordovician bryozoans formed a significant part of the Ordovician tropical ecosystems (Taylor and Allison 1998). For a brief interval from the Mid- to early Late Ordovician (late Darriwilian to Sandbian), bryozoans became dominant reef builders across a wide variety of environments (Webby 2002). This can be seen in the Ordovician strata of Ontario, where fragments of large branching bryozoans can be found (Armstrong 2000).

Stromatoporoids played an important role during the Middle to Late Ordovician as the main reef builders along with coral (Webby 2002). They had two main pulses of origination: one during the late Darriwilian and one during the mid- late Caradoc. They 
reached maximum diversity over the Ordovician during mid- to late Caradoc, before declining during the Ordovician mass extinction (Webby 2004b). Stromatoporoid abundance can be seen in the Selkirk Member of the Red River Formation of Manitoba, where they are commonly associated with tabulate corals (Young et al. 2008).

Graptolites originated during the Early Ordovician. Although earlier Cambrian forms have been described, the first definitely planktonic graptolites evolved in the Early Ordovician (Chen et al. 2006). Diversity trends vary greatly between regions but are generally tied to sea levels. Transgressions and high sea levels are generally associated with graptolite origination events while regression and low sea levels with extinction events, although this is not always the case (Cooper et al. 2004). Graptolite zonation has received recent study on Anticosti Island, where the location of Ordovician-Silurian boundary within, or around the Laframboise Member of the Ellis Bay Formation is still being debated (Melchin 2008).

Chitinozoans are microscopic organic walled microfossils with uncertain biological affinity. These fossils first appeared during the Early Ordovician and became extinct during the Devonian. Chitinozoan microfaunas were generally highly endemic, but a global diversity curve has been published by Paris et al. (2004) showing two origination events during the late Darriwilian and early Katian punctuated by a brief diversity decline. This was followed by a significant decline to the end of the period. Like graptolites, chitinozoans are useful biostratigraphic fossils, and have also been used in an attempt to constrain the Ordovician-Silurian boundary on Anticosti Island (Soufaine and Achab 2000).

Conodont diversity has been examined only over the Early and Middle Ordovician. Globally it appears that, at least at the species level, species were added constantly over the Early Ordovician and Middle Ordovician, with only a slight drop in diversity at the end of the Early Ordovician and slight increase in diversity at the beginning of the Middle Ordovician over relatively constant rates (Albanesi and Bergström 2004). This could be related to the episode of possible cooling as shown by Trotter et al. (2008) - the Middle Ordovician corresponds to a period of cool temperatures in their analysis. 


\subsubsection{The Modern fauna}

The Modern fauna, consisting of mainly the bivalves and gastropods, diversified over the GOBE, but not on the same magnitude as the Paleozoic fauna. Bivalves diversified early in the period, but most extensively over the Late Ordovician with the migration to equatorial regions and adoption of semi-infaunal and infaunal life habits by some groups (Cope 2004). Gastropods diversified over the Floian, Darriwilian, and Sandbian before reaching maximum diversity during the Katian (Frýda and Rohr 2004). Some of the largest gastropods of the Paleozoic are known from this interval, with a specimen of Maclurina manitobensis collected from the Selkirk Member of the Red River Formation, Manitoba, measuring $20 \mathrm{~cm}$ in diameter (Young et al. 2008).

\subsubsection{Radiation of articulate brachiopods}

During the Ordovician, Rhynchonelliformean brachiopod diversity greatly expanded in contrast to the low articulate brachiopod diversity of the Cambrian, during which the inarticulate Linguliformean and Craniiformean brachiopods were dominant. At the end of the Cambrian, there were four Rhynchelliformean superfamilies. At peak diversity during the Ordovician, this number more than quadrupled to 19 superfamilies (Harper et al. 2004). Diversity rose most sharply during the Middle Ordovician with pulses of diversification during the early Dapingian (most significant), mid- to late Darriwilian, and mid Katian. Diversity dropped sharply at the end of the period during the Late Ordovician Mass Extinction (Harper et al. 2004).

Brachiopods from Chinese strata exhibit an exception to this global trend. Zhan et al. (2005) concluded that the brachiopod fauna, along with other benthic groups, diversified earlier than what is shown by global diversity trends. The first peak in generic diversity of brachiopods is shown to have occurred during the Floian in strata of the Upper Yangtze platform (Zhan et al. 2007) rather than the Dapingian as shown globally (Harper et al. 2004). Zhan et al. (2005) proposed that this earlier diversification may have been due to the isolation of the Chinese paleocontinent during the Ordovician - a condition that would have encouraged increased provincialism and diversification. Many brachiopod groups first appeared in China before migrating to other regions of the world, so perhaps this marks the first signs of the GOBE in the brachiopod faunas. 
Diversity elsewhere in the world also varies considerably from the global trend. In Baltica, a difference has been documented between the diversity patterns of deep and shallow marine settings. The shallow North Estonia shows peaks in diversity in the Darriwilian (early and late) and Katian - remaining relatively constant, while the strata of the Livonian Tongue, deposited in a deeper depositional environment, show a large increase in diversity in the Late Darriwilian before dropping in the early Katian and rising again in the late Katian (Harper and Hints 2001; Harper and MacNiocaill 2002; Hints and Harper 2003). Avalonia shows a pattern similar to Northern Estonia with peaks in the early and late Darriwilian as well as the Katian, although the changes in diversity are more significant. Gondwana, unlike all other regions, shows only a single diversity peak during the Sandbian (Harper and MacNiocaill 2002). This shows that although global diversity trends are useful, the full story lies in regional diversity, due to the strong endemism documented during the Ordovician.

Each brachiopod group shows a different pattern of diversification during the GOBE (Harper et al. 2004), and thus it is important to look at the trends within the individual classes and orders.

\subsubsection{Strophomenata}

Two main classes dominated the Ordovician brachiopod fauna (Figure 1.5): the Strophomenata and the Rhynchonellata. Within the Strophomenata, the Strophomenida reached the highest peak diversity and were the most abundant. There are 95 plectambonitoid and 80 strophomenoid genera and subgenera known from the Ordovician (Harper et al. 2004). The Strophomenata, along with the Orthida, expanded deeper into ocean basins, exploiting new niches that were previously under utilized by brachiopods (Harper and MacNiocaill 2002). The generally small-shelled plectamboids originated during the Tremadocian and radiated rapidly during the Dapingian, reaching peak diversity by the late Darriwilian. Diversity then decreased slightly during the Late Ordovician until the terminal extinction. The larger-shelled strophomenoids originated later during the Floian and their most extensive radiation took place from the Dapingian to the Sandbian. This was followed by a brief decline until the mid-Katian when diversity again increased to a secondary maximum. Diversity then fell at the end of the 
A

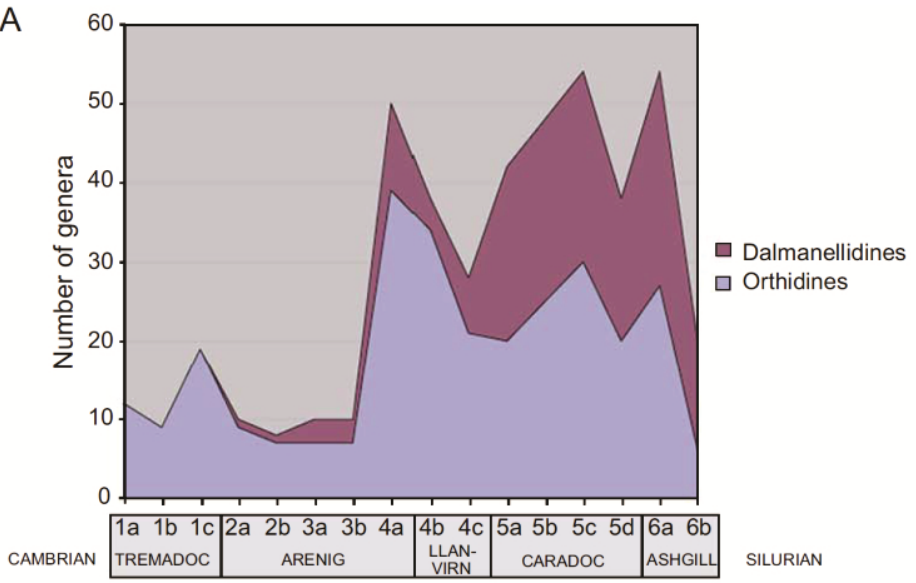

B

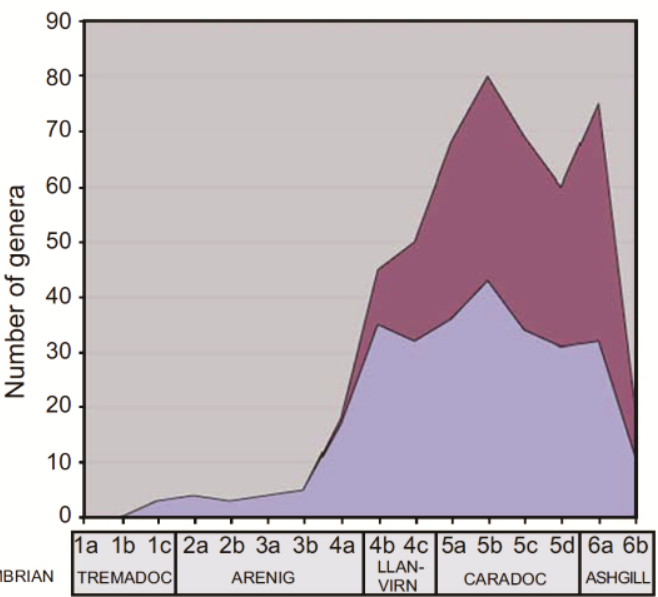

$\square$ Strophomenoideans

口 Plectambonitoideans

C

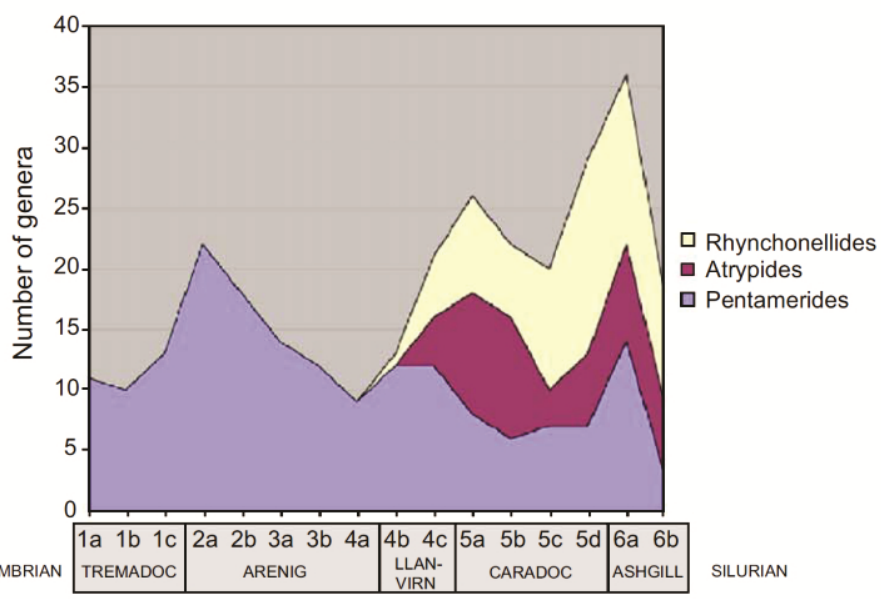

Figure 1.5 - Generic diversity of the main brachiopod orders during the Ordovician (Harper 2006 after Harper et al. 2004). Dalmanellidines and Orthidines (A),

Strophmenoideans and Plectambonitoideans (B), and Rhynchonellides, Atrypides, and Pentamerides (C). 
period. The two groups of strophomenides dominated most Middle and Late Ordovician benthic shelly assemblages (Harper et al. 2004).

\subsubsection{Rhynchonellata}

The most diverse Rhynchonellata were the Orthida - represented by the subgroups Orthidina and Dalmanellidina during the Ordovician (Figure 1.5). The Orthida clade had two diversity peaks during the period - mid-Darriwilian and maximum diversity during the Sandbian-Katian before a gradual decline starting at the end of the Ordovician. Other groups of the Rhynchonellata made up a less significant proportion of the overall brachiopod diversity during the Ordovician (Figure1.5). The Protorthida, although much more significant in terms of relative diversity during the Cambrian (Bassett et al. 2002), were only represented by five taxa during the Ordovician and never became abundant or widespread. Pentamerida went through an early diversification during the Tremadocian, becoming proportionally diverse during the Early Ordovician, especially in carbonate buildups at low latitudes (Harper and MacNiocaill 2002), but lagged in terms of diversity in comparison to other groups later in the period. The Rhynchonellata first appeared during the Darriwilian, peaking in diversity during the Katian and becoming a dominant member of the intracratonic fauna, before declining at the end of the period. Atrypida also first appeared during the Darriwilian and mirrored roughly the diversity patterns of the Rhynchonellata but were largely isolated to the tropical subtidal zone (Harper and MacNiocaill 2002). Spiriferida were only represented by single genus, Eospirifer during the late Katian in East China (Rong et al. 1994). Athyridida is only sparsely documented from the Upper Ordovician, known only from five genera (Harper et al. 2004).

\subsubsection{3 $\alpha, \beta$, and $\gamma$ brachiopod diversity}

Harper (2010) reviewed brachiopod diversity in terms of the $\alpha, \beta$, and $\gamma$ components, building on the earlier work of Sepkoski (1988). The increase in $\gamma$ diversity (inter-province diversity) seems obvious during the Ordovician. The wide geographic dispersal of the continents drove the development of endemic fauna on each continent, especially into the Middle to Late Ordovician. The increase in $\beta$ diversity (inter- 
community diversity) was driven by the expansion of brachiopods into both the nearshore and deeper water environments (Sepkoski and Sheehan 1983). This created new communities in areas that were previously unpopulated by the Paleozoic fauna. Finally, $\alpha$ diversity (intra-community) was driven by the expansion of tiering within communities (Ausich and Bottjer 1982; Bottjer and Ausich 1986) and specialization into specific niches (as shown, for example in Valentine 1969), allowing more organisms to concentrate into a smaller habitat.

\subsubsection{Brachiopod faunal diversity in Laurentia}

Because the brachiopods of the Ordovician were highly endemic, it is important to examine regional trends in diversity. The focus of this study is an orthide lineage within the Late Ordovician brachiopod faunas from various regions of Laurentia. During the earliest Late Ordovician when marine transgressions first started to inundate the Laurentian paleocontinent, diversity was limited. The brachiopods that were part of these faunas were generally small and thin shelled. This can be seen, for example, on Baffin Island within the Frobisher Formation (early Katian, Chatfieldian; Bolton 2000). A collection of strophomenids was made, but none of the characteristic later, more diverse Ordovician brachiopods were noted. This can also be seen in Ontario where plaesiomyids were collected as part of this study from the early Katian (Trentonian, Chatfieldian) Verulam Formation of the Simcoe Group (Plaesiomys subcircularis). This species is significantly smaller than most other congeneric species - far smaller than the large late Katian (Richmondian) examples from elsewhere.

In the Amadjuack Formation of Baffin Island (mid-Katian, Edenian to Maysvillian) and Whittaker Formation of the Mackenzie Mountains (mid- to late Katian, Edenian to Richmondian), a more diverse brachiopod assemblage is found, similar to the Hiscobeccus Fauna of Jin (2001). Bolton (2000) noted at least 18 articulate brachiopod genera from the Amadjuack Formation. Wigington (1977) recorded 13 orthid genera from the lower Whittaker Formation, but made no comments on total brachiopod diversity. Jin and Chatterton (1997) note at least 8 genera from the lower Whittaker Formation in a section different from that examined by Wigington.

Beginning in the mid-Katian (Maysvillian), brachiopods invaded the 
epicontinental seas that formed as sea level began to rise. This can be seen in the evolution of the Hiscobeccus Fauna (Jin 2001). This fauna is dominated by large, globose, thick-shelled brachiopods including Hiscobeccus, Lepidocyclus, and Hypsiptycha, commonly associated with other genera including Oepkinia, Diceromyonia, Plaesiomys,Dinorthis, Platystrophia, Gnamaorhynchos, Strophomena, Tetraphalerella, Rafinesquina, Megamyonia, Kjaerina, and Parastophinella, and stretches across the continent (e.g. Howe 1966; Amsden 1983; Jin and Lenz 1992; Jin and Norford 1996; Jin and Zhan 2001), becoming most abundant in the intracratonic seas during the late Katian (Richmondian). Diversity within these faunas is still relatively high - Jin and Zhan (2001) documented 15 genera from the Selkirk Member of the Red River Formation, Manitoba, and 10 genera from the Gunn and Penitentiary members of the Stony Mountain Formation, Manitoba.

These Laurentian brachiopod fauna prospered until the Hirnantian glaciation (see below) at the end of the period (Jin 2001) when severe environmental changes severely affected the epicontinental ecosystem and disrupted the pericratonic shelf faunas.

\subsubsection{Summary}

The Great Ordovician Biodiversification Event was the second major radiation of fauna during the Phanerozoic and led to the establishment of the Paleozoic fauna and the Paleozoic biodiversity plateau. Several environmental conditions contributed to this event, and all could be linked by a superplume that increased tectonic activity, but no primary evidence of this during the Ordovician has been discovered.

Rather than a single event, the GOBE was a series of events over the period. Different groups diversified during different periods of time, and more than once. The Cambrian fauna became less proportionally significant while the Paleozoic fauna experienced a great diversification. Many of the invertebrate orders and families became established during this period.

Brachiopod diversity increased significantly through the Middle to Late Ordovician. The group transitioned from a fauna made up mostly of protorthids and billingselloids to the diverse Paleozoic fauna that dominated the continental shelf from the Ordovician until the Permian. The orthids, dalmanellids, plectambonitids, and 
atrypids each diversified during the Ordovician, while other groups became more prominent later in the Paleozoic. Brachiopod diversity increased more than four fold over the GOBE, before crashing at the end of the period during the Ordovician mass extinction. Laurentian brachiopods transitioned from a low diversity fauna, relatively small in size and thin shelled, to a diverse fauna dominated by large, globose forms.

\subsection{Terminal Ordovician mass extinction}

The terminal Ordovician mass extinction was the second largest extinction event during the Phanerozoic. The extinction was linked to a glacial period that caused a eustatic drop in sea level, draining the epicontinental seas that covered much of the continents during most of the Ordovician (Brenchley et al. 1994; Sheehan 2001; Brenchley et al. 2003). Brenchley et al. (1994) estimated that the glaciation may have lasted for around 0.5 million years from isotope curves, although an investigation of brachiopod biozones in China by Rong et al. (2002) suggested it may have had a longer duration. Rong et al. (2002) also determined the glaciation was a diachronous event, rather than a simultaneous global event, linked to the gradual deterioration of climate rather than the abrupt event as envisioned by Brenchley et al. (1994). The glaciation was centred in North Africa (part of Gondwana during the Ordovician), with signals of glaciation also being preserved in Arabia, South America, and South and West Africa (Cocks 2001).

Unlike the Cenozoic glaciations, this glaciation occurred during a period of elevated greenhouse gas levels. Carbon dioxide levels have been estimated to be as much as 8-16 times PAL (present atmospheric levels) (Berner 1994, 2001, 2006). This is possible because the sun was $4 \%$ less luminous during the Ordovician (Kasting 1992) compared to the recent - meaning that less solar radiation was being absorbed by the earth during the Ordovician than recent times.

Virtually all marine sections containing sediment deposited above storm wave base recorded a regression at the end of the Ordovician. The associated eustatic sea level drop has been estimated at 50-100 m in magnitude (Brenchley and Newall 1980), with more recent observations suggesting it to be in the upper part of this range (Brenchley et 
al. 2006). Sea levels would still have been higher than today (Haq and Schutter 2008; see Figure 1.3) - around $140 \mathrm{~m}$ above present levels. This would have partly been because intracratonic seas covered the continents - more extensive glaciation would have been required to lower sea level due to the larger areal extent of the oceans than during the recent. The world was also much warmer, and thus an Ordovician glaciation would not have been on the same scale as the more recent Cenozoic glaciations and would have had far less impact on sea levels.

Although the Hirnantian glaciation caused a significant disruption in marine ecology worldwide, the lasting effect of the extinction, at least in ecological terms, is negligible. Although communities in the tropics were devastated by the extinction, ecological structure in temperate zones was only partially disrupted (Harper and Rong 1995). This may have been due to the ability of temperate faunas to migrate towards the equator while tropical fauna had nowhere to flee to escape cooling temperatures. Draining of the once vast epicontinental seas removed an entire environment as a potential marine habitat, but when sea levels again rose during the Early Silurian, ecosystems rebounded (Brenchley et al. 2001; Sheehan 2001). Developing communities during the Silurian were different taxonomically from pre-extinction faunas, but the ecological relationships among their constituents remained similar. As a result, the ecological structure of communities varied little across the Ordovician-Silurian boundary.

The only plaesiomyid known from Hirnantian strata is Plaesiomys anticostiensis (Shaler 1865) from the Ellis Bay Formation of Anticosti Island. This species was adapted to a cool water environment due to a specialized smaller bilobed cardinal process that may have been more efficient during the glacial period than the enlarged forms of cardinal process that developed during the late Katian (Richmondian) in the plaesiomyid lineage (see Chapter 4).

\subsubsection{Glacial trigger?}

Although the Terminal Ordovician Mass Extinction is considered to have occurred because of a drop in eustatic sea level due to the onset of glaciation, the mechanism for initiating this glaciation is still debated. Several hypotheses have been proposed to explain this interval of icehouse climate during an otherwise mostly greenhouse 
Paleozoic Era.

\subsubsection{Productivity hypothesis (Brenchley et al. 1994, 1995)}

The productivity hypothesis argues that increased circulation of the ocean caused the previously oligotrophic seas of the Ordovician to become eutrophic. Upwelling currents brought nutrients previously trapped in deep marine environments due to ocean stratification to the surface.

The increased availability of the nutrients would have triggered large phytoplankton blooms. These blooms would have fed other planktonic and neritic life, and organic activity would have boomed. Increased organic activity would have led to increased draw-down of carbon dioxide from the atmosphere into the oceans as the phytoplankton fixed carbon from dissolved carbon dioxide in seawater. Upon death, these organisms would have sank to the seafloor where they were buried, locking the carbon away in the marine strata.

Isotopic evidence supports this hypothesis. The Ordovician $\delta^{13} \mathrm{C}$ curve compiled by Bergström et al. (2008) shows a large excursion during the latest Katian to early Hirnantian. This indicates a disruption in the normal cycling of carbon - explainable by the burial of large amounts of plankton, eliminating carbon from the short term cycle.

The productivity hypothesis cannot explain some observations. The massive carbon reservoirs predicted by the hypothesis are not observed in Late Ordovician strata, so the sequestration of carbon in rock is yet unproven (Brenchley et al. 1994, 1995). Two more issues were advanced by Sheehan (2001). First, the timing of glaciations with carbon sequestration does not always overlap. Second, the hypothesis requires carbon dioxide levels of 7-10 times PAL (approximately within Berner's (1994, 2001, 2006) suggestion of levels between 8-16 times PAL, but near the bottom of this range). As of yet, there is no evidence that this occurred. Additionally, the hypothesis does not propose a mechanism for the initial oceanic overturn required to trigger this process. Increased oceanic circulation is often linked to global cooling. Perhaps this required global cooling could be the Boda event - an episode of climate instability before the glaciation at the end of the period that has been variously interpreted as either a warming or cooling interval. Cherns and Wheeley (2007, 2009), Finnegan et al. (2011), and Saltzman and 
Young (2005) have interpreted this as a cooling event, but the problem then becomes determining what caused the cooling during the Boda event, if it was indeed a cooling event.

\subsubsection{Weathering hypothesis (Kump et al. 1999)}

The Weathering hypothesis links the draw-down of carbon dioxide from the atmosphere with weathering of silicate minerals. As silicate minerals are chemically weathered subaerially and transformed into carbonate minerals, atmospheric carbon dioxide is consumed. The weathering hypothesis extrapolates this further, proposing that if silicate weathering was enhanced sufficiently (through uplift associated with orogenic events, for example), the decrease in atmospheric carbon dioxide could be enough to cause a drop in global temperatures and trigger a glacial event.

As glaciation advances, the silicate rich rock would be covered by large ice sheets, isolating it from the atmosphere. Chemical weathering would then cease and the draw-down of carbon dioxide would end. Eventually, through volcanic outgassing, atmospheric carbon dioxide levels would begin to rebound contributing to global warming. Glaciers would begin to recede and the planet would re-enter a greenhouse state.

There are a few differences between the weathering and productivity hypotheses. This hypothesis only requires the atmospheric carbon dioxide levels to drop to 10-16 times PAL - a far less significant drop than that proposed by the productivity hypothesis and better fitting with Berner's (1994, 2001, and 2006) 8-16 times PAL estimate. The carbon isotope excursion is explained as enhanced weathering of carbonate platforms during low sea levels due to subaerial exposure, rather than carbon sequestration as suggested by the productivity hypothesis (Young et al. 2010).

Although the weathering hypothesis seems to explain many observations regarding the Late Ordovician events, a single problem remains. Glaciation isn't always associated with mountain building events (Sheehan 2001). This may not be an issue, though, as a variety of factors influence global climate and the weathering hypothesis doesn't necessarily have to explain all glaciations in the Earth's history. Indeed, there is evidence that orogenic episodes associated with supercontinent formation during the 
Precambrian may have triggered glaciations as well (Eyles 2008).

\subsubsection{Carbonate deposition and weathering hypothesis (Villas et al. 2002)}

The carbonate deposition and weathering hypothesis argues that atmospheric carbon dioxide was stored via deposition of carbonates, drawing down atmospheric carbon dioxide levels, and forcing the climate into an icehouse regime. Villas et al. (2002) suggested that the atmospheric carbon dioxide levels are linked to carbonate deposition from seawater. Carbonate deposition is partially controlled by the concentration of the bicarbonate ion in seawater, which is in turn influenced by the concentration of atmospheric carbon dioxide as it diffuses between the atmosphere and seawater.

During glaciation, chemical weathering of carbonates would again release carbon dioxide to the atmosphere, restoring greenhouse gas levels. This would return global temperatures to pre-glaciation levels and return the earth to a greenhouse state.

The main problem with the carbonate weathering and deposition hypothesis is that there were continued glacial pulses that occurred during the Silurian. When the theory was originally advanced, it seemed plausible because there was no record of continued glaciation into the Silurian when oceanic conditions were not as amenable to carbonate precipitation from seawater. Evidence has since emerged suggesting there was several pulses of glaciation during the Silurian (Diaz-Martinez and Grahn 2007), making this theory less feasible.

\subsubsection{Volcanism hypothesis (Buggisch et al. 2010; Lefebvre et al. 2010; Young et al. 2010)}

The volcanism hypothesis is based on evidence of elevated volcanic activity during the Katian (e.g. Huff et al. 1992 - a Middle Ordovician volcanic eruption created one of the largest distributions of bentonite during the entire Phanerozoic), possibly linked to the suggested superplume discussed earlier in this chapter (Qing et al. 1998; Barnes 2004). The hypothesis argues that global cooling was the result of the input of volcanic gasses and dust into the atmosphere. This hypothesis depends on the theory that the Boda Event was a protracted interval of gradual cooling prior to the Hirnantian glaciation (Cherns and Wheeley 2007, 2009; Finnegan et al. 2011; Saltzman and Young 
2005).

There are two main ways that volcanism could have contributed to global cooling. The volcanic dust from widespread volcanic activity could potentially block solar radiation from entering the atmosphere, causing global temperature to drop. Also, aerosols such as sulphur dioxide ejected through volcanic outgassing absorb solar radiation. Because less solar radiation can reach the Earth's surface, cooling would begin.

Rather than cooling, however, volcanism is often used to explain an increase in temperatures due to the input of greenhouse gasses like carbon dioxide into the atmosphere during eruptions. Buggisch et al. (2010) argue that the atmospheric input of carbon dioxide from a single volcanic eruption is miniscule, but considering that the Late Ordovician was a episode of elevated volcanic activity (see Huff et al. 1992), it was likely that the input of carbon dioxide (and other greenhouse gases) from multiple eruptions would have had a more significant effect. Lefebvre et al. (2010) justified this by concluding through modelling that although the outgassing would initially result in heightened greenhouse conditions, after a length of time atmospheric carbon dioxide levels would drop, forcing the climate into a cooling mode. This is due to the effect of basalt weathering - a process that would consume carbon dioxide (similar to the weathering hypothesis above). The ambiguous nature of the climate leading up to the Hirnantian glaciation needs to be clarified before this hypothesis could be accepted. It should be noted, however, that the Middle Ordovician has been linked to the one of the largest ash fall deposits in area known from the Phanerozoic over Laurentia and Baltica (Huff et al. 1992, 1996).

The most significant problem with this hypothesis is the timing of the volcanic activity. Huff et al. (2010) note that caution is needed in correlating the volcanic events with the glaciation and extinction as the bulk of the volcanism occurred almost 10 million years prior to the glaciation. The volcanism may still have had some destabilizing effect the climate in conjunction with other forces, and perhaps may have some connection with the Boda event.

\subsubsection{Discussion}

Given that it is the only hypothesis without any major weaknesses, at this time the 
weathering hypothesis seems to be the most likely scenario for explaining the Hirnantian glaciation. It is true that mountain building has not been documented to have occurred with every major glacial period in the Earth's history, but given the complex nature of the controls on the Earth's climate, it does not seem necessary to invoke a single mechanism to trigger all glaciations.

Thus, it is not necessary to ascribe to a single theory to explain the Ordovician glaciation. Each of the processes described in these theories could have had some influence on the climate. To suspect that only a single mechanism is forcing such a large magnitude of change on a complex system such as the climate would be naive. However, it remains unclear what degree of influence any of these processes may have had on the Ordovician climate.

The weathering hypothesis, although currently seeming to be the most likely explanation, is probably not the final answer. There is not enough evidence at this time to confidently attribute the glacial event to any one hypothesis. Further stratigraphical, geochemical, and modelling studies are needed to clarify the record of the Ordovician climate. Given the vigorous debate regarding the forces controlling the modern climate, it seems unlikely that we can come to any firm conclusions on the Ordovician glaciation in the near future.

\subsubsection{Changes in diversity}

The Ordovician extinction significantly affected biodiversity - an estimated $85 \%$ of species and $61 \%$ of genera were lost (Jablonski 1991), making it the second largest mass extinction of the Phanerozoic. The rapidly changing environment during the Hirnantian detrimentally affected the fauna, which had largely become specialized to the greenhouse conditions and elevated sea levels prior to the extinction that had been in place for tens of millions years.

There were two pulses of extinction during the Hirnantian - one at the beginning of the age and one at its conclusion (Hallam and Wignall 1999; Rong and Harper 1999; Brenchley et al. 2001, 2003; Sheehan 2001; Twitchett 2006; Erwin 2009; Rasmussen and Harper 2011a). These two pulses are linked to the onset and end of the glacial period. The first pulse of extinction correlated with the initial drop in sea level associated with 
the glaciation and increased oceanic circulation. Following the first pulse, a short lived survival fauna developed. The second pulse was associated with the resumption of greenhouse climatic conditions and a return to oceanic stagnation. The second pulse could also have been linked to a methane release related to melting methane hydrates during global warming (Twitchett 2006). Each fossil group was affected to varying degrees by each pulse (Figure 1.6).

\subsubsection{Changes in articulate brachiopod diversity and faunas}

Brachiopod diversity dropped significantly over the Ordovician extinction event. Diversity dropped from 180 genera before the extinction to 70 genera after the first pulse of extinction and down to 55 genera by the Early Silurian (Harper and Rong 1995) - a loss of two thirds of pre-extinction genera. It is only the lower taxonomic ranks, however, that were so significantly affected. Of the brachiopod superfamilies, only two did not survive the extinction (Clitambonitoids and Gonambonitoids; Harper and Rong 1995). Cosmopolitan taxa were less impacted than the endemic taxa (Sheehan and Coorough 1990), probably in part due to the fact that they were widespread at the continental margin whereas the endemic taxa were dominant in intracratonic seas and that they were better able to cope with a wider range of environmental conditions. The extinction would change brachiopod diversity for the remainder of the Paleozoic, with orders other than Orthida and Rhynchonellida becoming increasingly diverse overall in the Silurian (Rong and Harper 1995, 1999).

Brachiopods were affected significantly by both pulses of the terminal Ordovician mass extinction, however more severely by the first pulse. The habitat of the diverse and highly endemic brachiopods that inhabited the shallow intracratonic seas disappeared during the glacially-associated drop in sea level. Robertson et al. (1991) show that most pre-extinction brachiopods occupied the BA 4-5 zone (deep water). During the Hirnantian, most of brachiopods lived in BA 1-3 (shallow), although deeper faunas are known. Some of the early Silurian faunas have been found in shallow water settings on the continental-margins (e.g. Rong and Harper 1999) which suggest that while the entire shallow epicontinental seas were heavily affected, it was only the deeper environments at the continental margin were affected most. 


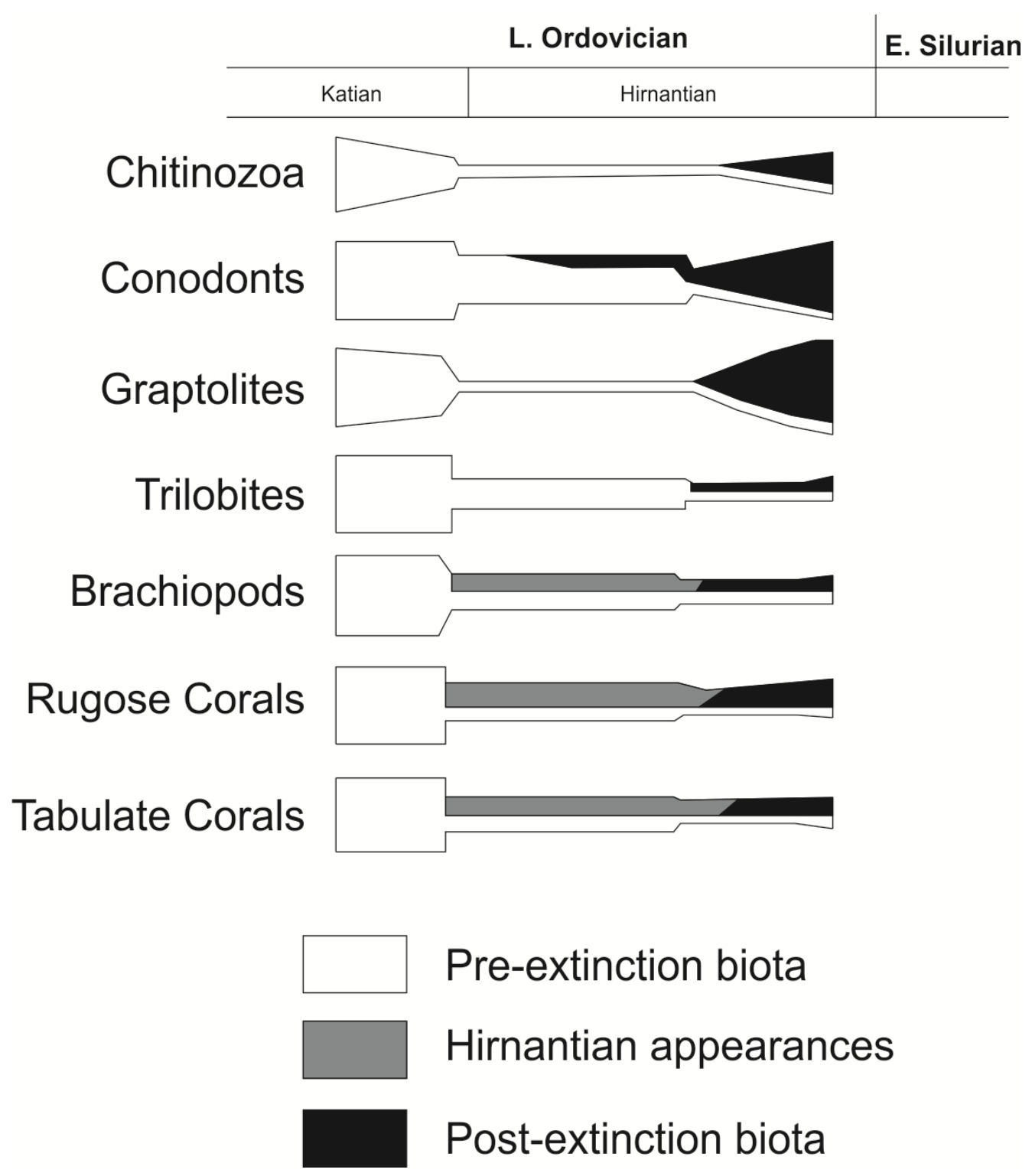

Figure 1.6 - The relative change in generic diversity of several fossil groups over the Hirnantian extinction interval (after Brenchley et al. 2001). Thickness of each bar changes to show approximate changes in standing diversity of group. Pre-extinction faunas decrease in abundance over the extinction interval while post-extinction faunas diversify following the extinction. Some groups, like the brachiopods and corals, have a Hirnantian fauna that developed during the extinction. 
Besides the environmental considerations, explained above, another factor that may have impacted brachiopod diversity was invading fauna from accreting island arc terranes (during Taconian orogeny) and the rapid movement of Baltica towards Laurentia, narrowing the Iapetus Ocean. Rasmussen and Harper (2011b) examined the changing Laurentian faunas over the Ordovician extinction interval and found that many of the new Laurentian brachiopod genera were originated from Baltica and peri-Laurentian island arcs. These invading fauna may have out-competed the incumbent Laurentian for resources during a time of environmental stress, further reducing brachiopod diversity. This could have been the case with other groups as well.

\subsubsection{Survival faunas}

Following this first pulse, diversity somewhat stabilized and a specialized Hirnantia fauna developed (Harper and Rong 1995). This fauna was adapted to live in an icehouse climate and marginal environments that remained relatively intact following sea level fall. When the climate began to change, swinging back to greenhouse conditions, this fauna was not able to adapt to the warmer conditions and much of its constituents largely disappeared (Robertson et al. 2001). Common elements of the fauna included the brachiopod genera Hirnantia, Dalmanella, Leptaena, Hindella, Kinnella, Draborthis, Paromalomena, and Plectothyrella (Sheehan 2001, Rong et al. 2002). Elements of this fauna on Laurentia have been documented within upper Ellis Bay Formation on Anticosti Island, Quebec (E.g. Cocks and Copper 1981; Jin and Copper 2008) and the Mackenzie Mountains, Northwest Territories (Jin and Chatterton 1997). In higher latitudes, an atypical Hirnantian fauna developed known as the Bani Province (Harper and Rong 1995). These brachiopods were probably adapted to low temperature conditions as they are found in association with glacial deposits.

The Edgewood fauna developed in the tropical region of the American Midcontinent, along with Early Silurian faunas (Elias and Young 1998). Deposition was dominated by carbonates in this region (Amsden and Barrick 1988). This, in conjunction with a warmer climate, would have made for a more habitable living environment than regions further from the equator. 
Warming temperatures and rising sea level devastated the Hirnantian and Edgewood faunas, with many taxa not surviving into the Silurian. This was the second pulse of extinction for the brachiopods. Although they disappeared as a single biogeographic unit, some taxa from these fauna did survive to form the basis of the Early Silurian faunas (Robertson et al. 1991), and the wide ranging nature of the Early Silurian faunas may have been a consequence of the influence of the surviving Hirnantian taxa which themselves were generally cosmopolitan (Sheehan 2001).

\subsection{Ordovician Paleogeography}

The continental configuration of the Ordovician was very different from the present (Figure 1.7). The globe was dominated by a vast northern ocean - the Panthalassic Ocean and the large continent of Gondwana stretched from the South Pole to north of the equator (Cocks 2001; Cocks and Torsvik 2002). The remaining continents, mostly isolated from each other, were scattered around the equator and southern midlatitudes. Laurentia, Baltica, and Siberia, along with Gondwana formed the main continents of the Ordovician, with numerous smaller continents and island arcs as well (Cocks 2001; Cocks and Torsvik 2002; MacNiocaill et al. 1997).

\subsubsection{Baltica}

Baltica consisted of most of northern Europe east of the Ural Mountains during the Ordovician (Cocks and Torsvik 2004). Baltica was situated in the high southern latitudes near Gondwana during Early Ordovician, as evidenced by the thin bedded cool water limestones deposited at that time (Cocks and Torsvik 2002, 2005). During the Middle Ordovician, this rapidly began to change. The movement of Baltica accelerated northward rapidly, as shown by the deposition of thicker tropical carbonate deposits. The continent also began to rapidly rotate counter clockwise - although this appears to have had little effect on its fauna (Fortey and Cocks 2003). Both of these movements began to slow, however, during the Late Ordovician (Torsvik 1998; Cocks and Torsvik 2002, 2005). Due to its isolation from the other continents until late in the period, the Ordovician faunas of Baltica were highly endemic (Cocks 2000, 2001). 


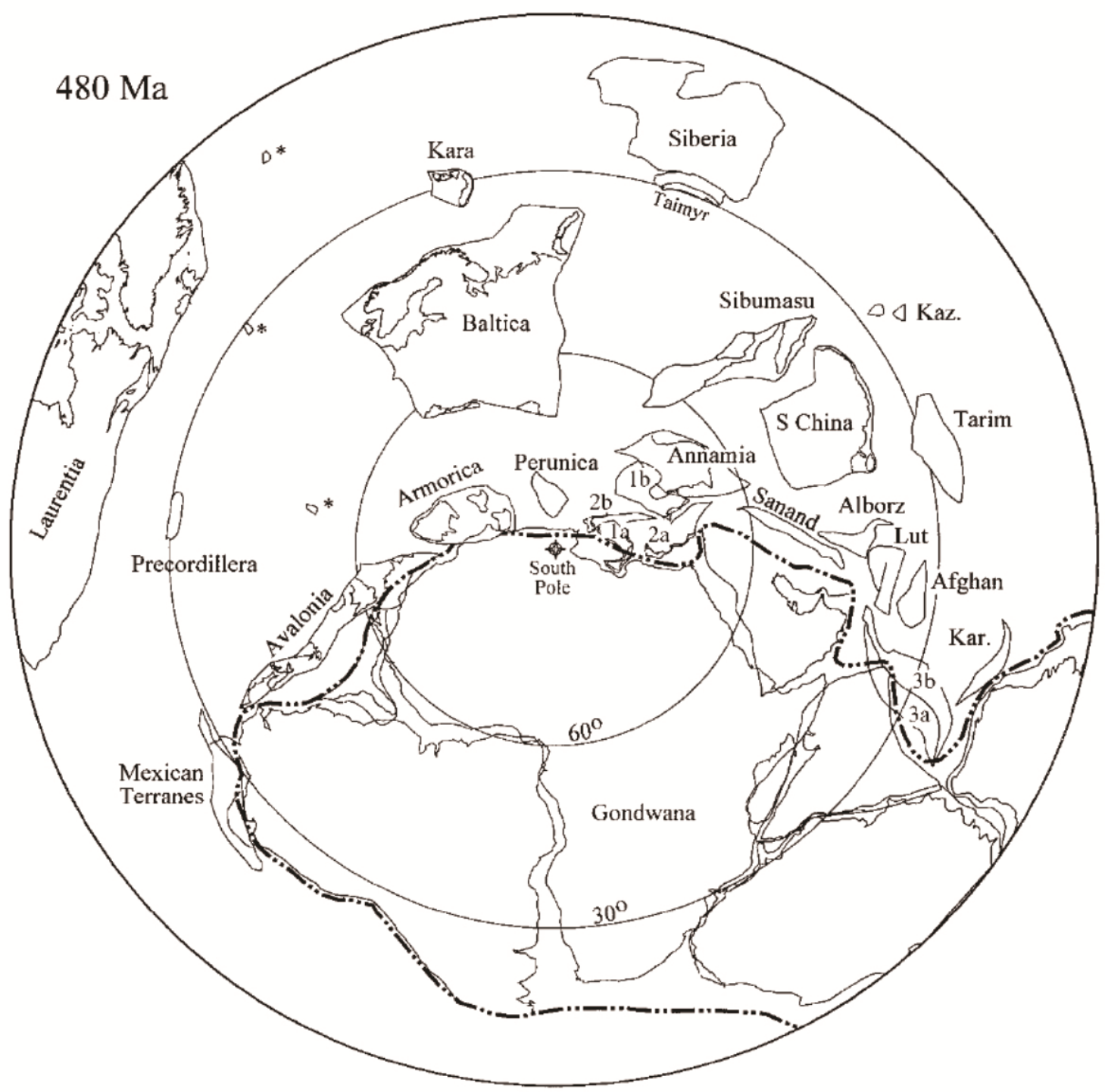

Figure 1.7 - Distribution of the continents as viewed from the South Pole during the Ordovician (480 Ma) (Cocks and Torsvik 2002). The continents were relatively isolated from each other, promoting faunal endemism. The largest continent, Gondwana, stretched from the equator to near the South Pole. 


\subsubsection{Siberia}

In comparison to Siberia's modern orientation, it was inverted during the Ordovician - the current northern margin then formed the southern margin (Torsvik et al. 1995; Torsvik 1998; Cocks and Torsvik 2007). Siberia drifted over the paleoequator northward during the Ordovician, accelerating in its movement later in the period (Cocks and Torsvik 2007). During the Ordovician, Siberia was isolated from the other continents, and did not collide with Baltica until the Late Paleozoic (Cocks and Torsvik 2002). Like Baltica, Siberia's fauna is highly endemic, though it shared some similarity with Laurentia (Cocks 2001).

\subsubsection{Gondwana}

Gondwana was by far the largest continent during the Ordovician, stretching from the equator to the South Pole. It consisted of, early in the period, much of South America, Arabia, Antarctica, Australia, peninsular India, Avalonia, Amorica, Iberia, Perunica, Alpine and Balkan fragments, South China, Sibumasu, New Guinea, New Zealand, and Mexico (Cocks 2001; Fortey and Cocks 2003). During the Middle Ordovician, rifting along the margin of Gondwana split several terranes from the core of the continent, including Avalonia, Amorica, Perunica, Iberia, and the Alpine fragments.

Gondwana is significant in terms of Hirnantian strata as it was on this continent that the glaciation was centred. North Africa, in particular, shows the most widespread evidence for glaciation due to its position near the South Pole during the latest Ordovician (Cocks 2001; Figure 1.7).

\subsubsection{Oceans and sea level}

During the Early Ordovician, the oceans were at their maximum extent following the break-up of the Precambrian supercontinent, Rodinia (Cocks 2001; Cocks and Torsvik 2005). As the period advanced, the smaller oceans began to shrink as tectonic polarity began to shift - eventually leading to the creation of the supercontinent Pangaea during the Permian. The Iapetus Ocean, separating Laurentia from Baltica and Avalonia began to shrink, as shown by the decreasing faunal endemism and increased communication between these continents, especially late in the period during the Katian (Cocks and 
Torsvik 2002). Likewise the Tornquist Sea also began to contract, bringing Avalonia and Baltica into closer and closer contact (Cocks and Fortey 1982).

Eustatic sea level was high during most of the Ordovician - probably at its highest level of the entire Phanerozoic (Figure 1.3). Haq and Schutter's (2008) sea level curve shows a gradual rise in sea level through the Cambrian and Early Ordovician, followed by a more abrupt rise during the Late Ordovician. This was part of the Laurentian Tippecanoe transgression of Sloss (1963) during the Ordovician. Rising sea levels may have contributed to the expansion of the Paleozoic Fauna and its diversification over the period during the GOBE (see above). During the latest Ordovician, eustatic sea level fell in response to Hirnantian glaciation before resuming a rising trend in the Early Silurian, contributing to the terminal Ordovician Extinction.

\subsubsection{Laurentia}

During the Ordovician, the paleocontinent of Laurentia straddled the equator, rotated clockwise from its current orientation (Cocks and Torsvik 2011; Figure 1.8). Laurentia was relatively stable during this time - moving only slightly southward during the Ordovician and Silurian periods (Cocks 2001; Fortey and Cocks 2003). Much of the continent was under a large epicontinental sea during the Middle to Late Ordovician due to elevated eustatic sea level (Cocks and Torsvik 2011; Haq and Schutter 2008). This created a unique environment for the evolution of a specialized intracratonic fauna over the latter half of the period, and contributed to the downfall of this fauna once the terminal Ordovician glaciation began, and drained these seas.

The Laurentian paleocontinent was bordered by two passive margins and an active margin during the Ordovician. Northern North America formed the eastern margin of Laurentia, known as the Franklinian Passive Margin (Cocks 2001; Berry et al. 2002). This margin was made up of blocks from northeastern Siberia to northern Greenland (Cocks 2001). The modern northern margin of North America has not been well mapped, but consists of a number of small intracratonic basins as well as some deeper marginal basins (Cocks and Torsvik 2011). These basins contain mostly carbonate platform facies deposited over the Paleozoic (e.g. Sanford and Grant 2000). The western margin of North America (northern margin of Laurentia during the Ordovician, excluding 


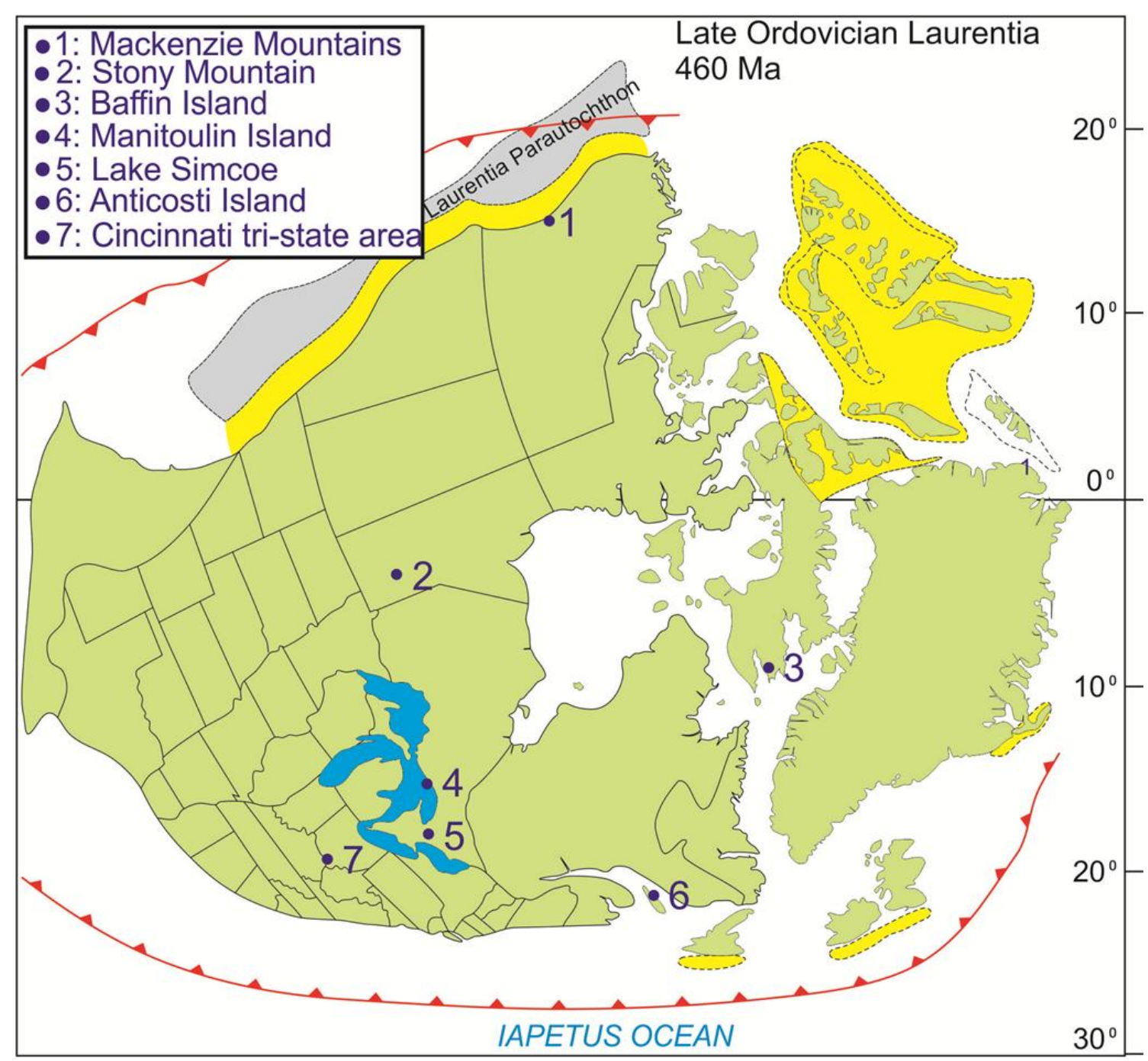

Figure 1.8 - Paleogeographic map of Laurentia during the Late Ordovician (modified from Cocks 2011). Plaesiomyid collection localities being examined in this study are indicated by numbers. The red lines indicate subduction zones while the yellow areas indicate probable continental areas and terrane extensions. 
the Cordilleran regions) was, in general, a passive margin (Cocks and Torsvik 2011). Much of the western part of the continent was covered by a shallow sea through the Ordovician (most extensive during Middle to Late Ordovician), deposited large carbonate platforms and reefs. Subduction was occurring, causing arc volcanism along the edge of the plate. The margin was far farther inland than its current limit - probably between Nevada and California (Cocks 2001). Eastern North America (the southern margin of Ordovician Laurentia) was an active margin starting in the Floian as the Iapetus Ocean began to close (Cocks and Torsvik 2011), eventually causing Laurentia to collide with Avalonia and Baltica during the Silurian during the Caledonian orogeny (Cocks 2001). Volcanism is associated with this region as early as the Early Ordovician, but became more extensive as the subduction zone elongated later in the period (Cocks and Torsvik 2011). The southern Laurentian margin in the Early Ordovician would have been located west of the Appalachian Mountains, but the Taconian orogeny changed this. The southern margin of North America during the Ordovician (then west) was farther north than it is today, marked by the Swannee-Higgins Suture in the east and the Ouachita orogenic belt in the west (Cocks and Torsvik 2011). During most of the Paleozoic until at least the Mississippian, this margin was a passive margin accumulating carbonate sediments (Miall 2008).

The fauna of Laurentia, like most of the other Ordovician paleocontinents, is highly endemic due to the relative isolation of the major land masses from each other (Cocks 2001). Compared to coeval faunas of adjacent tectonic plates, the Laurentian fauna was largely homogenous, although the Transcontinental Arch may have allowed for some minor differentiation on either side, as noted especially in the trilobite fauna (Cocks 2001; Fortey and Cocks 2003). This homogeneity can be seen during the Late Ordovician with regards to the Hiscobeccus brachiopod fauna, which stretched across most of the epicontinental sea covering Laurentia by that time (Jin 2001).

Despite its faunal homogeneity on a global scale, there were still significant differences in the morphology of taxa of different geographic areas, especially between the continental-margin and inland sea settings, and between low and high paleotropical latitudes. In this study, seven localities were selected for detailed study (Figure 1.8). Care was taken to select localities from both equatorial intracratonic environments (e.g. 
Stony Mountain, Manitoba), and subtropical pericratonic environments (e.g. CincinnatiKentucky-Indiana tri-state area, Anticosti Island), to investigate faunal differences along these environmental gradients and to detect evolutionary trends.

\subsubsection{Sea level and Laurentia}

In recent work, Zhang (2011) refined the effects of sea level change on the Laurentian paleocontinent. Estimates of relative sea level in the Appalachians had indicated the maximum transgression occurred during the early Katian (Turinian Chatfieldian) interval (Ettensohn et al. 2004; Ettensohn 2008). Zhang showed that this transgression was diachronous across Laurentia and that conodont data from the Slave Craton in the Northwest Territories indicated a much later maximum transgression during the Richmondian. This rise was shown by the migration of conodonts onto the Slave Craton and much of the Canadian Shield. The difference in the timing of sea level rise was due to the effect of the Taconic orogeny on the present eastern coast of Laurentia tectonic forces were causing a relative sea level rise earlier on the eastern coast than the present north. The subsidence associated with developing foreland basins on the continental side of the orogeny would have resulted in a transgression, regardless of the relatively stable eustatic sea level.

The high sea levels of most of the Ordovician were interrupted by a significant sea level fall during the Hirnantian (Haq and Schutter 2008) related to glaciation on Gondwana. This regression during the latest Ordovician probably caused the extinction of the intracratonic fauna at the end of the period. With the fauna being specialized to the shallow platforms of the intracratonic seas, it would have been difficult for it to adapt to the environment of the continental margin, where it would have faced a different set of environmental conditions and had to displace an already established continental-margin fauna.

\subsubsection{Taconic orogeny}

The Taconic orogeny was a mountain building event that resulted from the accretion of several magmatic arcs onto the Laurentian craton, lasting from the Late Cambrian to Early Ordovician (495-450 million years ago) (van Staal et al. 2007). Van Staal et al. (2007) defined the Taconic orogeny as the entire sequence of orogenic events 
that occured in the peri-Laurentian realm from the Late Cambrian through to the Late Ordovician and dissected the orogeny into three phases: Taconic I, Taconic II, and Taconic III. Van Staal et al. (2009) and van Staal and Hatcher (2010) elaborated further on these stages. Although complex tectonic processes were underway during the Taconic orogeny that could never be explained fully in an abbreviated introduction, a brief summary is here presented.

Taconic I lasted from 500 to 493 million years ago (Late Cambrian). This phase encompasses accretion of infant arc crust of the Lushs Bight westward (present direction) onto the Dashwood microcontinent, located off the margin of Laurentia. The Dashwood microcontinent was a ribbon of land masses derived from Laurentia separated from it as a result of the opening of the Humber Seaway during the Cambrian (Waldron and van Staal 2001).

Taconic II marks the docking of the Dashwood terrane onto the Laurentian craton from 464 to 459 million years ago (Darriwilian to Early Sandbian). Along with the Dashwood microcontinent, a volcanic arc known as the Notre Dame arc in Newfoundland and Ascot Arc of Quebec and the Snooks Arm arc accreted onto the Laurentian margin. This was the main phase of Appalachian orogeny in Laurentia and is recorded in highly metamorphosed rocks that locally reach granulite grade metamorphism.

The final phase, Taconic III, was the accretion of small peri-Gondwanan volcanic arcs outboard of the Dashwood microcontinent, continuing into the Late Ordovician. These rocks formed a narrow belt along the edge of the Laurentian paleocontinent and are of much lower grade metamorphism than those accreted during Taconic II. This is typical of an accretionary complex above a subduction zone.

\subsection{Objectives of Current Research and Rationale for the Project}

Many of the Ordovician faunas of Laurentia have been described, and their environmental controls have been constrained. However, most studies concentrate on a single region. Less often do studies attempt to integrate these individual localities into a continent-wide discussion of the consequences of the environmental conditions and paleogeography of the Ordovician for the rapidly evolving fauna. By investigating the effects of these factors on a larger scale, we can better understand how evolution was 
affected by these different environmental controls.

This thesis examines the Dinorthis-Plaesiomys brachiopod lineage across Laurentia during the Late Ordovician. This Ordovician orthide lineage is known earliest in the Sandbian of the Appalachian Basin and Cincinnati Arch region, and continues into the Hirnantian on Anticosti Island. Plaesiomyids have been found in a variety of depositional settings, from the subtropical pericratonic platforms to the equatorial intracratonic seas.

Because of their wide range across the Laurentian paleocontinent and survival into the Hirnantian glaciation, an investigation of the Dinorthis-Plaesiomys lineage may help provide answers to several questions regarding the Late Ordovician epicontinental fauna:

1. Morphological changes in the lineage must be quantified before any interpretation can be formulated. What morphological changes occurred in the Dinorthis-Plaesiomys lineage over the Late Ordovician?

2. What was the nature of these morphological changes? What were the patterns and processes of such changes in time and space?

3. How were the morphological changes related to the climate fluctuations, ecological and latitudinal gradients?

The following chapter will provide a brief overview of the Upper Ordovician geology of each locality. This will place later chapters in a paleoenvironmental context and enable paleoecological interpretations of brachiopods examined in this thesis.

Chapter 3 will consists of a taxonomic reassessment of the plaesiomyid species discussed in the thesis. Prior to any analysis, the taxonomy of the fossil specimens must be established. Although several studies have examined the genera, there are still questions regarding the validity of Plaesiomys and Dinorthis as separate genera (e.g. Wang 1949, Macomber 1970, Jin and Zhan 2001). This chapter will attempt to address this issue, as well as re-assign two species to the Plaesiomys genus from Lake Simcoe and Manitoulin Island, Ontario, and assign two new species to the genus from the Mackenzie Mountains, Northwest Territories. 
Chapter 4 will investigate the morphology of plaesiomyids from eight localities ranging in age from early Katian (Chatfieldian) to Hirnantian (Gamachian) from both paleoequatorial intracratonic settings and from the subtropical pericratonic shelves. Principal component analysis will reveal any morphological trends in the evolution of this group over the interval. These trends will then be examined in both a temporal and paleoecological context, incorporating information presented in previous chapters. 


\section{References}

Adrain, J.M., Edgecombe, G.D., Fortey, R.A., Hammer, O., Laurie, J.R., McCormick, T., Owen, A.W., Waisfeld, B.G., Webby, B.D., Westrop, S.R., Zhi-yi, Z. 2004.

Trilobites. In The Great Ordovician Biodiversification Event. Edited by B.D.

Webby, F. Paris, M.L. Droser, and I.G. Percival. Columbia University Press, New York. p. 231-254.

Albanesi, G.L. and Bergström, S.M. 2004. Conodonts: Lower to Middle Ordovician Record. In The Great Ordovician Biodiversification Event. Edited by B.D. Webby, F. Paris, M.L. Droser, and I.G. Percival. Columbia University Press, New York. p.312-326.

Aldridge, R.J. 1988. Extinction and survival in the Conodonta. In Extinction and Survival in the Fossil Record, The Systematics Association Special Volume No. 34. Edited by G.P. Larwood. Clarendon Press, Oxford. p. 231-256.

Alroy, J. 2010a. Geographical, Environmental and Intrinsic Biotic Controls on Phanerozoic Marine Diversification. Palaeontology, 53: 1211-1225.

Alroy, J. 2010b. The Shifting Balance of Diversity Among Major Marine Animal Groups. Science, 329: 1191-1194.

Alroy, J., Aberham, M., Bottjer, D.J., Foote, M., Fürsich, F.T., Harries, P.J., Hendy, A.J.W., Holland, S.M., Ivany, L.C., Kiessling, W., Kosnik, M.A., Marshall, C.R., McGowan, A.J., Miller, A.I., Olszewski, T.D., Patzkowsky, M.E., Peters, S.E., Villier, L., Wagner, P.J., Bonuso, N., Borkow, P.S., Brenneis, B., Clapham, M.E., Fall, L.M., Ferguson, C.A., Hanson, V.L., Krug, A.Z., Layou, K.M., Leckey, E.H., Nürnberg, S., Powers, C.M., Sessa, J.A., Simpson, C. Tomašovych, A., and Visaggi, C.C. 2008. Phanerozoic Trends in the Global Diversity of Marine Invertebrates. Science, 321: 97-100.

Amsden, T.W. and Barrick, J.E. 1988. Late Ordovician through Early Devonian annotated correlation chart and brachiopod range charts for the southern midcontinent region, U.S.A., with a discussion of Silurian and Devonian conodont faunas, Oklahoma Geological Survey Bulletin 143. 66 pp.

Amsden, T.W. and Sweet, W.C. 1983. Upper Bromide Formation and Viola Group (Middle and Upper Ordovician) in Eastern Oklahoma. Oklahoma Geological Survey Bulletin 132. 75 pp.

Ausich, W.I. and Bottjer, D.J. 1982. Tiering in Suspension-Feeding Communities on Soft Substrata Throughout the Phanerozoic. Science, 216: 173-174.

Armstrong, D.K. 2000. Paleozoic Geology of the Northern Lake Simcoe Area, SouthCentral Ontario - Ontario Geological Survey Open File Report 6011. 43 pp.

Barnes, C.R. 2004. Was There an Ordovician Superplume Event? In The Great Ordovician Biodiversification Event. Edited by B.D.Webby, F. Paris, M.L. Droser, and I.G. Percival. Columbia University Press, New York. p. 77-80.

Barnes, C.R., Fortey, R.A., and Williams, S.H. 1996. The Pattern of Global Bioevents During the Ordovician Period. In Global Events and Stratigraphy in the 
Phanerozoic. Edited by O.H. Walliser. Springer-Verlag, Berlin; New York. 333 pp.

Bassett, M.G., Popov, L.E., and Holmer, L.E. 2002. Brachiopods: Cambrian-Tremadoc precursors to Ordovician radiation events. In Palaeobiogeography and biodiversity change: The Ordovician and Mesozoic- Cenozoic radiations, Geological Society of London Special Publication Volume 194. Edited by J.A. Crame and A.W. Owen. Geological Society, London. p. 13-23.

Bergström, S., Carnes, J.B. Hall, J.C., Kurapkate, and O'Neil, B.E. 1988. Conodont Biostratigraphy of Some Middle Ordovician in Eastern North American Marginal Sequences with Coeval Successions in Northern China and Oslo, Norway. In The Canadian Paleontology and Biostratigraphy Seminar - Proceddings of Meeting Sepetember 26-29, 1986. Bulletin Number 462, New York State Museum/Geological Association of Canada. Edited by E. Landing. p. 33-42.

Bergström, S.M., Chen, X., Gutiérrez-Marco, J.C., and Dronov, A. 2008. The new chronostratigraphic classification of the Ordovician System and its relations to major regional series and stages and to $\delta 13 \mathrm{C}$ chemostratigraphy. Lethaia, 42 : 97 107.

Berner, R.A. 1994. GEOCARB II: A revised model of atmospheric $\mathrm{CO}_{2}$ over Phanerozoic time. American Journal of Science, 296: 56-91.

Berner, R.A. 2001. Modelling atmospheric $\mathrm{O}_{2}$ over Phanerozoic time. Geochimica et Cosochimica Acta, 65: 685-694.

Berner, R.A. 2006. GEOCARBSULF: A combined model for Phanerozoic atmospheric $\mathrm{O}_{2}$ and $\mathrm{CO}_{2}$. Geochimica and Cosmochimica Acta, 70: 5653-5664.

Berry, W.B.N., Ripperdan, R.L., and Finney, S.C. 2002. Late Ordovician Extinction: A Laurentian View. In Catastrophic Events and Mass Extinctions: Impacts and Beyond, G.S.A. Special Paper 356. Edited by C. Koeberl and K.G. McLeod. Geological Society of America, Boulder, Colorado. p. 463-471.

Bolton, T.E. 2000. Ordovician megafauna, southern Baffin Island, Nunavut. In Geology and paleontology of the southeast Arctic Platform and southern Baffin Island, Nunavut - Geological Survey of Canada Bulletin 557. Edited by A.D. McCracken and T.E. Bolton. Geological Survey of Canada, Ottawa. p. 39-158.

Bottjer, D.J. and Ausich, W.I. 1986. Phanerozoic development of tiering in soft substrata suspension-feeding communities. Paleobiology, 12: 400-420.

Brenchley, P.J. and Newall, G. 1980. A facies analysis of Upper Ordovician regressive sequences in the Oslo region, Norway - a record of glacioeustatic changes. Palaeogeography, Palaeoclimatology, Palaeoecology, 31: 1-38.

Brenchley, P.J., Marshall, J.D., Carden, G.A.F., Robertson, D.B.R., Long, D.G.F., Meidla, T., Hints, L., and Anderson, T.F. 1994. Bathymetric and isotopic evidence for a short-lived Late Ordovician glaciation in a greenhouse period. Geology, 22: 295298.

Brenchley P.J., Carden G.A.F., Marshall JD. 1995. Environmental changes associated with the "first strike" of the late Ordovician mass extinction. Modern Geology, 
20: 69-82.

Brenchley, P.J., Marshall, J.D., and Underwood, C.J. 2001. Do all mass extinction represent an ecological crisis? Evidence from the Late Ordovician. Geological Journal, 36: 329-340.

Brenchley, P.J., Carden, G.A., Hints, L., Kaljo, D., Marshall, J.D., Matma, T., Meidla, T., and Nõlvak, J. 2003. High-resolution stable isotope stratigraphy of Upper Ordovician sequences: Constraints on the timing of bioevents and environmental changes associated with mass extinction and glaciation. GSA Bulletin, 115: 89104.

Brenchley, P.J., Marshall, J.D., Harper, D.A.T., Buttler, C.J., and Underwood, C.J. 2006. A Late Ordovician (Hirnantian) karstic surface in a submarine channel, recording glacio-eustatic sea-level changes: Meifod, central Wales. Geological Journal, 41: $1-22$.

Buggisch, W., Joachimski, M.M., Lehnert, O., Bergström, S.M., Repetski, J.E., and Webers, G.F. 2010. Did intense volcanism trigger the first Late Ordovician icehouse? Geology, 38: 327-330.

Chen, X., Zhang, Y.-D., and Fan, J.-X. 2006. Ordovician graptolite evolutionary radiation: a review. Geological Journal, 41: 289-301.

Cherns, L. and Wheeley, J.R. 2007. A pre-Hirnantian (Late Ordovician) interval of global cooling - The Boda event re-assessed. Palaeogeography, Palaeoclimatology, Palaeoecology, 251: 449-460.

Cherns, L. and Wheeley, J.R. 2009. Early Palaeozoic cooling events: peri-Gondwana and beyond. In Early Palaeozoic Peri-Gondwana Terranes: New Insights from Tectonics and Biogeography, Geological Society Special Publication No. 325. Edited by M.G. Bassett. Geological Society, London, p. 257-278.

Cocks, L.R.M. 2000. The Early Palaeozoic geography of Europe. Journal of the Geological Society of London, 157: 1-10.

Cocks, L.R.M. 2001. Ordovician and Silurian global geography. Journal of the Geological Society, London, 158: 197-210.

Cocks, L.R.M. 2006. Blowing hot and cold during the Palaeozoic. Proceedings of the Geologists' Association, 118: 225-237.

Cocks, L.R.M. and Copper, P. 1981. The Ordovician-Silurian boundary at the eastern end of Anticosti Island. Canadian Journal of Earth Sciences, 18: 1029-1034.

Cocks, L.R.M. and Fortey, R.A. 1982. Faunal evidence for oceanic separations in the Palaeozoic of Britain. Journal of the Geological Society, London, 139: 465-478.

Cocks, L.R.M. and Torsvik, T.H. 2002. Earth's geography from 500 to 400 million years ago: a faunal and palaeomagnetic review. Journal of the Geological Society of London, 159: 631-644.

Cocks, L.R.M. and Torsvik, T.H. 2004. Major Terranes in the Ordovician. In The Great Ordovician Biodiversification Event. Edited by B.D.Webby, F. Paris, M.L. 
Droser, and I.G. Percival. Columbia University Press, New York. p. 157-178.

Cocks, L.R.M. and Torsvik, T.H. 2005. Baltica from the late Precambrian to midPalaeozoic times: the gain and loss of a terrane's identity. Earth Science Reviews, 72: 39-66.

Cocks, L.R.M. and Torsvik, T.H. 2007. Siberia, the wandering northern terrane, and its changing geography through the Palaeozoic. Earth Science Reviews, 82: 29-74.

Cocks, L.R.M. and Torsvik, T.H. 2011. The Palaeozoic geography of Laurentia and western Laurussia: A stable craton with mobile margins. Earth Science Reviews, 106: $1-51$.

Cooper, G.A. 1956. Chazyan and related brachiopods. Smithsonian Miscellaneous Collections, vol. 127, 1245 pp.

Cooper, R.A., Maletz, J., Taylor, L., and Zalasiewicz, J.A. 2004. Graptolites: Patterns of Diversity Across Paleolatitudes. In The Great Ordovician Biodiversification Event. Edited by B.D. Webby, F. Paris, M.L. Droser, and I.G. Percival. Columbia University Press, New York. p. 281-293.

Condie, K.C. 2001. Mantle Plumes and Their Record in Earth History. Cambridge University Press, Cambridge. 306 pp.

Conway Morris, S. 2000. The Crucible of Creation: The Burgess Shale and the Rise of Animals. Oxford University Press, U.S.A. 276 pp.

Cope, J.C.W. 2004. Bivalve and Rostroconch Mollusks. In The Great Ordovician Biodiversification Event. Edited by B.D. Webby, F. Paris, M.L. Droser, and I.G. Percival. Columbia University Press, New York. p. 196-208.

Diaz-Martinez, E. and Grahn, Y. 2007. Early Silurian glaciation along the western margin of Gondwana (Peru, Bolivia, and northern Argentina): Palaeogeographic and geodynamic setting. Palaeogeography, Palaeoclimatology, Palaeoecology, 245: 62-81.

Elias, R.J. 1991. Environmental cycles and bioevents in the Upper Ordovician Red River-Stony Mountain solitary rugose coral province of North America. In Advances in Ordovician Geology, Geological Survey of Canada, Paper 90-9. Edited by C.R. Barnes and S.H. Williams. Geological Survey of Canada, Ottawa. p. 205-212.

Elias, R.J. And Young, G.A. 1998. Coral Diversity, Ecology, and Provincial Structure During a Time of Crisis: The Latest Ordovician to Earliest Silurian Edgewood Province in Laurentia. Palaios, 13: 98-102.

Erwin, D.H. 2009. Climate as a Driver of Evolutionary Change. Current Biology, 19: R575-R583.

Erwin, D.H. and Signor, P.W. 1991. Extinction in an extinction resistant clade: the evolutionary history of the Grastropoda. In The Unity of Evolutionary Biology, Proceedings of the Fourth International Conference of Systematic and Evolutionary Biology, Volume 1. Edited by E.C. Dudley. Dioscoeides Press, Portland, Oregon. p. 152-160. 
Ettensohn, F.R. 2008. The Appalachian Foreland Basin in Eastern United States. In Sedimentary Basins of the United States and Canada, Sedimentary Basins of the World, Vol. 5. Edited by A.D. Miall (K.J. Hsü series editor). Elsevier, Oxford, U.K. and Amsterdam, Netherlands. p. 105-180.

Ettensohn, F.R., Kasl, J.M., and Stewart, A.K. 2004. Structural inversion and origin of a Late Ordovician (Trenton) carbonate buildup: evidence from the Tanglewood and Devils Hollow members, Lexington Limestone, central Kentucky (USA). Palaeogeography, Palaeoclimatology, Palaeoecology, 210: 249-266.

Eyles, N. 2008. Glaci-epochs and the supercontinent cycle after $3.0 \mathrm{Ga}$ : Tectonic boundary conditions for glaciation. Palaeogeography, Palaeoclimatology, Palaeoecology, 258: 89-129.

Finnegan, S. and Droser, M.L. 2008. Body size, energetics, and the Ordovician restructuring of marine ecosystems. Paleobiology, 34: 342-359.

Finnegan, S., Bergmann, K., Eiler, J.M., Jones, D.S., Fike, D.A., Eisenman, I., Hughes, N.C., Tripati, A.K., and Fischer, W.W. 2011. The Magnitude and Duration of Late Ordovician-Early Silurian Glaciation. Science, 331: 903-906.

Fortey, R.A. and Cocks, L.R.M. 2003. Palaeontological evidence bearing on the global Ordovician-Silurian continental reconstructions. Earth Science Reviews, 61:245307.

Fortey, R.A. and Cocks, L.R.M. 2005. Late Ordovician warming - The Boda event. Geology, 33: 405-408.

Fortey, R.A. And Owens, R.M. 1999. Feeding habits in trilobites. Palaeontology, 42:429-465.

Frey, R.C., Bersei, M.S., Evans, D.H., King, A.H., and Percival, I.G. 2004. Nautiloid Cephalopods. In The Great Biodiversification Event. Edited by B.D.Webby, F. Paris, M.L. Droser, and I.G. Percival. Columbia University Press, New York. p. 209-213.

Frýda, J. And Rohr, D.M. 2004. Gastropods. In The Great Ordovician Biodiversification Event. Edited by B.D. Webby, F. Paris, M.L. Droser, and I.G. Percival. Columbia University Press, New York. p. 184-195.

Gabrielse, H. Blusson, S.L., and Roddick, J.A. 1973. Geology of Flat River, Glacier Lake, and Wrigley Lake map-areas, District of Mackenzie and Yukon Territory, Part I: General geology, structural geology, and economic geology - Geological Survey of Canada Memoir 366. Geological Survey of Canada, Ottawa.

Goddéris, Y., François, L.M., Veizer, J. 2001. The Early Paleozoic carbon cycle. Earth and Planetary Science Letters, 190: 181-196.

Gould, S.A. 1989. Wonderful Life. Norton, New York. 347 pp.

Hallam, A. 1992. Phanerozoic Sea Level Changes. New York, Columbia University Press. $266 \mathrm{pp}$.

Hallam, A. and Miller, A.I. 1988. Extinction and Survival in the Bivalvia. In Extinction 
and Survival in the Fossil Record, The Systematic Association Special Volume No. 34. Clarendon Press, Oxford. p. 121-138.

Hallam, A. and Wignall P.B. 1999. Mass extinctions and sea-level changes. EarthScience Reviews, 48: 217-250.

Haq, B.U. and Schutter. 2008. A Chronology of Paleozoic Sea-Level Changes. Science, 322: 64-68.

Hardie, L.A. 1996. Secular variation in seawater chemistry: An explanation for the mineralogies of marine limestones and potash evaporites over the past 600 m.y. Geology, 24: 279-283.

Harper, D.A.T. 2006. The Ordovician biodiversification: setting an agenda for marine life. Palaeogeography, Palaeoclimatology, Palaeoecology, 232: 148-166.

Harper, D.A.T. 2010. The Ordovician brachiopod radiation: Roles of alpha, beta, and gamma diversity. In The Ordovician System, Geological Society of America Special Paper 466. Edited by S.C. Finney and W.B.N. Berry. The Geological Society of America, Boulder, Colorado. p. 69-83.

Harper, D.A.T. and Drachen, A. 2010. The Orthida: the rise and fall of a great Palaeozoic brachiopod clade. In Evolution and Development of the Brachiopod Shell, Special Papers in Palaeontology No. 84. Edited by F. Alvarez and G.B. Curry. The Palaeontological Association, London. p. 107-118.

Harper, D.A.T. and Hints, L. 2001. Distribution and diversity of Ordovician articulated brachiopods in the East Baltic. In Brachiopods Past and Present, The Systematics Association Special Volume Series 63. Edited by C.H.C Brunton, L.R.M. Cocks, and S. L. Long. Taylor and Francis, London and New York. p. 315-326.

Harper, D.A.T. and MacNiocaill, C. 2002. Early Ordovician rhynchonelliformean brachiopod diversity: comparing some platforms, margins and intra-oceanic sites around the Iapetus Ocean. In Palaeobiogeography and Biodiversity Change: the Ordovician and Mesozoic-Cenozoic Radiations, Geological Society of London, Special Publications, 194. Edited by J.A. Crame and A.W. Owen. Geological Society of London, London. p. 25-34.

Harper, D.A.T. and Rong, J.-Y. 1995. Patterns of change in the brachiopod faunas through the Ordovician-Silurian interface. Modern Geology, 20: 83-100.

Harper, D.A.T. and Rong, J.-Y. 2001. Paleozoic brachiopod extinction, survival and recovery: patterns within the rhynchonelligormeans. Geological Journal, 36: 317328.

Harper, D.A.T., Cocks, R.M., Popov, L.E., Sheehan, P.M., Bassett, G., Copper, P., Holmer, L.E., Jin, J., Jia-yu, R. 2004. Brachiopods. In The Great Ordovician Biodiversification Event. Edited by B.D.Webby, F. Paris, M.L. Droser, and I.G. Percival. Columbia University Press, New York. p. 157-178.

Haq, B.U. and Schutter, S.R. 2008. A Chronology of Paleozoic Sea-Level Changes. Science, 322:64-68.

Hays, J.D. and Pitman, W.C. 1973. Lithospheric Plate Motion, Sea Level Changes, and 
Climatic and Ecological Consequences. Nature, 246:18-22.

Hints, L. and Harper, D.A.T. 2003. Review of the Ordovician rhynchonelliformean Brachiopoda of the East Baltic: Their distribution and biofacies. Bulletin of the Geological Society of Denmark, 50: 29-43.

Huff, W.D., Bergström, S.M., and Kolata, D.R. 1992. Gigantic Ordovician volcanic ash fall in North America and Europe: Biological, tectonomagnetic, and event stratigraphic significance. Geology, 20: 875-878.

Huff, W.D., Kolata, D.R., Bergström, S.M., and Y.-S. Zhang. 1996. Large-magnitude Middle Ordovician ash falls in North America and Europe: dimensions, emplacement, and post-emplacement characteristics. Journal of Volcanology and Geothermal Research, 73: 285-301.

Huff, W.D., Bergström, S.M., and Kolata, D.R. 2010. Ordovician explosive volcanism. In The Ordovician System, Geological Society of America Special Paper 466. Edited by S.C. Finney and W.B.N. Berry. The Geological Society of America, Boulder, Colorado. p. 13-28.

Jablonski, D. 1991. Extinctions: A Paleontological Perspective. Science, 253: 754-757.

Jin, J. 2001. Evolution and extinction of the North American Hiscobeccus brachiopod Fauna during the Late Ordovician. Canadian Journal of Earth Sciences, 38:143151.

Jin, J. and Chatterton, B.D.E. 1997. Latest Ordovician-Silurian articulate brachiopods and biostratigraphy of the Avalanche Lake area, southwestern District of Mackenzie, Canada. Palaeontographica Canadiana No. 13, Canadian Society of Petroleum Geologists and the Geological Association of Canada, Calgary, Alberta. $167 \mathrm{pp}$.

Jin, J. and Copper, P. 2008. Response of brachiopod communities to environmental change during the Late Ordovician mass extinction interval, Anticosti Island, eastern Canada. Fossils and Strata, 54:41-51.

Jin, J. and Zhan, R. 2001. Late Ordovician articulate brachiopods from the Red River and Stony Mountain Formations, southern Manitoba. NRC Research Press, Ottawa. 117 pp.

Jin, J., Harper, D.A.T., Rasmussen, J.A., Sheehan, P.M. 2012 (in press). Late Ordovician massive-bedded Thalassinoides ichnofacies along the palaeoequator of Laurentia. Palaeogeography, Palaeoclimatology, Palaeoecology. doi:10.1016/j.palaeo.2011.05.023

Kiessling, W., Aberhan, M., and Villier, L. 2008. Phanerozoic trends in skeletal mineralogy driven by mass extinctions. Nature Geosciences, 1: 527-530.

Kröger, B. and Zhang, Y.-B. 2009. Pulsed cephalopod diversification during the Ordovician. Palaeogeography, Palaeoclimatology, Palaeoecology, 273: 174-183.

Kasting, J.F. 1992. Paradox lost and paradox found. Nature, 355: 676-677.

Kauffman, E.G. and Fagerstrom, J.A. 1993. The Phanerozoic Evolution of Reef 
Diversity. In Species Diversity in Ecological Communities: Historical and Geographic Perspectives. Edited by R.E. Ricklefs and D. Schluter. The University of Chicago Press, Chicago and London. p. 315-329.

Kröger, B. and Zhang, Y.-B. 2009. Pulsed cephalopod diversification during the Ordovician. Palaeogeography, Palaeoclimatology, Palaeogeography, 273: 174183.

Kump, L.R., Arthur, M.A., Patzkowsky, M.E., Gibbs, M.T., Pinkus, D.S., and Sheehan, P.M. 1999. A weathering hypothesis for glaciation at high atmospheric $p \mathrm{CO}_{2}$ during the Late Ordovician. Palaeogeography, Palaeoclimatology, Palaeoecology, 152: 173-187.

Landing, E., English, A., and Keppie, J.D. 2010. Cambrian origin of all skeletonized metazoan phyla - Discovery of Earth's oldest bryozoans (Upper Cambrian, southern Mexico). Geology, 38: 547-550.

Lefebvre, V., Servais, T., François, L., and Averbunch, O. 2010. Did a Katian large igneous province trigger the Late Ordovician glaciation? A hypothesis tested with a carbon cycle model. Palaeogeography, Palaeoclimatology, Palaeoecology, 296: 310-319.

Long, D.G.F. and Copper, P. 1994. The Late Ordovician-Early Silurian Carbonate tract of Anticosti Island, Gulf of St. Lawrence, Eastern Canada. Joint Annual Meeting of the Geological Association of Canada and Mineralogical Association of Canada, Waterloo, Ontario. Field Trip B4 Guidebook. 70 pp.

Lowenstein, T.K., Timofeeff, M.N., Brennan, S.T., Hardie, L.A., and Demicco, R.V. 2001. Oscillations in Phanerozoic Seawater Chemistry: Evidence from Fluid Inclusions. Science, 294: 1086-1088.

Ludvigsen, R. 1975. Ordovician Formations and Faunas, Southern Mackenzie Mountains. Canadian Journal of Earth Science, 12: 663-697.

Macomber, R.W. 1970. Articulate brachiopods from the upper Bighorn Formation (Late Ordovician) of Wyoming. Journal of Paleontology, 44:416-450.

MacNiocaill, C., van der Pluijm, B.A., and van der Voo, R. 1997. Ordovician paleogeography and the evolution of the Iapetus ocean. Geology, 25: 159-162.

Matyska, C. and Yuen, D. 2007. Lower-mantle material properties and convection models of multiscale plumes. Geological Society of America Special Papers, 430: 137-163.

Melchin, M.J. 2008. Restudy of some Ordovician-Silurian boundary graptolites from Anticosti Island, Canada, and their biostratigraphic significance. Lethaia, 41: 155-162.

Miall, A.D. 2008. The Southern Midcontinent, Permian Basin, and the Ouachitas. In Sedimentary Basins of the United States and Canada, Sedimentary Basins of the World, Vol. 5. Edited by A.D. Miall (K.J. Hsüseries editor). Elsevier, Oxford, U.K. and Amsterdam, Netherlands. p. 297-328.

Miller, K.G. 2005. The Phanerozoic Record of Global Sea-Level Change. Science, 310 : 
1293-1298.

Munnecke, A., Calner, M., Harper, D.A.T., Servais, T. 2010. Ordovician and Silurian sea-water chemistry, sea level, and climate: a synopsis. Palaeogeography, Palaeoclimatology, Palaeoecology, 296: 389-413.

Norford, B.S., Haidl, F.M., Bezys, R.K., Cecile, M.P., McCabe, H.R., and Paterson, D.F. 1994. Chapter 9 - Middle Ordovician to Lower Devonian Strata of the Western Canada Sedimentary Basin. In Geological Atlas of the Western Canada Sedimentary Basin. Compiled by G. Mossop and I. Shetsen. Canadian Society of Petroleum Geologists and the Alberta Research Council, Calgary. p. 109-128.

Palmer, T.J. and Wilson, M.A. 2004. Calcite precipitation and dissolution of organic aragonite in shallow Ordovician calcite seas. Lethaia, 37: 417-427.

Paris, F. and Nõlvak, J. 1998. Biological Interpretation and Paleobiodiversity of a Cryptic Fossil Group: The "Chitinozoan Animal". Geobios, 32: 315-324.

Paris, F., Achab, A., Asselin, E., Xiao-hong, C., Grahn, Y., Nolvak, J., Obut, O., Samuelsson, J., Sennikov, N., Vecoli, M., Verniers, J., Xiao-feng, W., and Winchester-Seeto, T. 2004. In The Great Ordovician Biodiversification Event. Edited by B.D. Webby, F. Paris, M.L. Droser, and I.G. Percival. Columbia University Press, New York. p. 294-311.

Porter, S.M. 2007. Seawater Chemistry and Early Carbonate Biomineralization. Science, 316: 1302.

Qing, H., Barnes, C.R., Buhl, D., and Veizer, J. 1998. The strontium isotopic composition of Ordovician and Silurian brachiopods and conodonts: Relationships to geological events and implications for coeval seawater. Geochimica et Cosmochimica, 62: 1721-1733.

Rasmussen, C.M.Ø. and Harper, D.A.T. 2011a. Interrogation of distributional data for the End Ordovician crisis interval: where did disaster strike? Geological Journal, 46: 478-500.

Rasmussen, C.M.Ø. and Harper, D.A.T. 2011b. Did the amalgamation of the continents drive the end Ordovician mass extinctions? Palaeogeography, Palaeoclimatology, Palaeoecology, 311: 48-62.

Riding, R. 1993. Phanerozoic Patterns of Marine $\mathrm{CaCO}_{3}$ Precipitation. Naturwissenschaften, 80: 513-516.

Robertson, D.B.R., Brenchley, P.J., and Owen, A.W. 1991. Ecological disruption close to the Ordovician-Silurian boundary. Historical Biology, 5: 131-144.

Rong, J.-Y. and Harper, D.A.T. 1995. Patterns of change in the brachiopod fauns through the Ordovician-Silurian interface. Modern Geology, 20: 83-100.

Rong, J.-Y. and Harper, D.A.T. 1999. Brachiopod survival and recovery from the latest Ordovician mass extinctions in South China. Geological Journal, 34: 321-348.

Rong, J.-Y., Zhan, R.-B., and Han, N.R. 1994. The oldest known Eospirifer (Brachiopoda) in the Changwu Formation (Late Ordovician) of western Zhejiang, 
east China, with a review of the earliest spriferoids. Journal of Paleontology, 68: 763-776.

Rong, J.-Y., Chen, X., and Harper, D.A.T. 2002. The latest Ordovician Hirnantia Fauna (Brachiopoda) in time and space. Lethaia, 35: 231-249.

Saltzman, M.R. and Young, S.A. 2005. Long-lived glaciation in the Late Ordovician? Isotopic and sequence stratigraphic evidence from western Laurentia. Geology, 33: 109-112.

Sandberg, P.A. 1983. An oscillating trend in Phanerozoic non-skeletal carbonate mineralogy. Nature, 305: 19-22.

Sanford, B.V. and Grant, A.C. 2000. Geological framework of the Ordovician system in the southeast Arctic platform, Nunavut. In Geology and paleontology of the southeast Arctic Platform and southern Baffin Island, Nunavut - Geological Survey of Canada Bulletin 557. Edited by A.D. McCracken and T.E. Bolton. Geological Survey of Canada, Ottawa. p. 13-38.

Sepkoski, J.J. 1979. A kinetic model of Phanerozoic taxonomic diversity II. Early Phanerozoic families and multiple equillibria. Paleobiology, 5: 222-251.

Sepkoski, J.J. 1981. A factor analytic description of the Phanerozoic marine fossil record. Paleobiology, 7: 36-53.

Sepkoski, J.J. 1984. A kinematic model of Phanerozoic diversity. III. Post-Paleozoic families and mass extinctions. Paleobiology, 10: 246-267.

Sepkoski, J.J. 1988. Alpha, beta, or gamma: where did all the diversity go? Paleobiology, 14: 221-234.

Sepkoski, J.J. 1991. A model of onshore-offshore change in faunal diversity. Paleobiology, 17: 58-77.

Sepkoski, J.J. 1993. Ten years in the library: new data confirm paleontological patterns. Paleobiology, 19: 43-51.

Sepkoski, J.J. 1997. Biodiversity: Past, Present, and Future. Journal of Paleontology, 71: 533:539.

Sepkoski, J.J. and Sheehan, P.M. 1983. Diversification, Faunal Change, and Community Replacement during the Ordovician Radiations. In Biotic Interactions in Recent and Fossil Benthic Communities. Edited by M.J.S.Tevesz and P.L. McCall. Plenum Press, New York. p. 673-717.

Servais, T., Li, J., Stricanne, L., Vecoli, M., and Wicander, R. 2004. Acritarchs. In The Great Ordovician Biodiversification Event. Edited by B.D. Webby, F. Paris, M.L. Droser, and I.G. Percival. Columbia University Press, New York. p. 348-360.

Servais, T., Lehnert, O., Li, J., Mullins, G.L., Munnecke, A., Nützel, A., and Vecoli, M. 2008. The Ordovician Biodiversity: revolution in the oceanic trophic chain. Lethaia, 41: 99-109.

Servais, T., Harper, D.A.T., Li, J., Munnecke, A., Owen, A.W., Sheehan, P.M. 2009. Understanding the Great Ordovician Biodiversification Event (GOBE): Influences 
of paleogeography, paleoclimate, or paleoecology? GSA Today, 19: 4-10.

Servais, T., Owen, A.W., Harper, D.A.T., Kröger, B.,Munnecke, A. 2010. The Great Ordovician Biodiversification Event (GOBE): The palaeoecological dimension. Palaeogeography, Palaeoclimatology, and Palaeoecology, 294: 99-119.

Shaler, N.S. 1865. List of the Brachiopoda from the island of Anticosti sent by the Museum of Comparative Zoology to different institutions for exchange for other specimens, with annotations. Bulletin of the Museum of Comparative Zoology at Harvard College, 1:61-70.

Sheehan, P.M. 2001. The Late Ordovician Mass Extinction. Annual Reviews of Earth and Planetary Science, 29: 331-364.

Sheehan, P.M. and Coorough, P.J. 1990. Brachiopod zoogeography across the Ordovician-Silurian extinction event. In Palaeozoic Palaeogeography and Biogeography, The Geological Society Memoir No. 12. Edited by W.S. McKerrow and C.R. Scotese. Geological Society Publishing House, Bath Avon, U.K. p. 181-187.

Sheehan, P.M. and Schiefelbein, D.R.J. 1984. The trace fossil Thalassinoides from the Upper Ordovician of the eastern Great Basin: deep burrowing in the Early Paleozoic. Journal of Paleontology, 58: 440-447.

Shields, G.A., Carden, G.A.F., Veizer, J.F., Meidla, T., Rong, J.-Y., Li, R.-Y. 2003. Sr, C, and $\mathrm{O}$ isotope geochemistry of Ordovician brachiopods: A major isotopic event around the Middle-Late Ordovician transition. Geochimica et Cosmochimica Acta, 67: 2005-2025.

Signor, P.W. and Vermeij, G.J. 1994. The plankton and the benthos: origins and early history of an evolving relationship. Paleobiology, 20: 297-319.

Sloss, L.L. 1963. Sequences in the cratonic interior of North America. Geological Society of America Bulletin, 74: 93-114.

Soufiane, A. and Achab, A. 2000. Chitinozoan zonation of the Late Ordovician and Early Silurian of the island of Anticosti, Quebec, Canada. Review of Palaeobotany and Palynology, 109: 85-111.

Sprinkle, J., and Guensburg, T.E. 2004. Crinozoan, Blastozoan, Echinozoan, Asterozoan, and Homalozoan Echinoderms. In The Great Ordovician Biodiversification Event. Edited by B.D. Webby, F. Paris, M.L. Droser, and I.G. Percival. Columbia University Press, New York. p. 266-280.

Stanley, M.S. and Hardie, L.A. 1998. Secular oscillations in the carbonate mineralogy of reef-building and sediment-producing organisms driven by tectonically forced shifts in seawater chemistry. Palaeogeography, Palaeoclimatology, Palaeoecology, 144: 3-19.

Strother, P.K. 1996. Acritarchs. In Palynology: Principles and Applications, Volume 1. Edited by J. Jansonius and D.C. McGregor. American Association of Stratigraphic Palynologists Foundation. Publishers Press, Salt Lake City, Utah. p. 81-106. 
Taylor, P.D. and Allison, P.A. 1998. Bryozoan carbonates through time and space. Geology, 26: 459-462.

Taylor, P.D. And Ernst, A. 2004. Bryozoans. In The Great Ordovician Biodiversification Event. Edited by B.D. Webby, F. Paris, M.L. Droser, and I.G. Percival. Columbia University Press, New York. p. 147-156.

Torsvik, T.H. 1998. Palaeozoic palaeogeography: A North Atlantic viewpoint. GFF, 120: $109-118$.

Torsvik, T.H., Tait, J., Moralex, V.M., McKerrow, W.S., Sturt, B.A., and Roberts, D. 1995. Ordovician palaeogeography of Siberia and adjacent continents. Journal of the Geological Society, London, 152: 279-287.

Trotter, J.A., Williams, I.S., Barnes, C.R., Lécuyer, C., and Nicoll, R.S. 2008. Did Cooling Oceans Trigger Ordovician Biodiversification? Evidence from Conodont Thermometry. Science, 321: 550-554.

Twitchett, R.J. 2006. The palaeoclimatology, palaeoecology and palaeoenvironmental analysis of mass extinction events. Palaeogeography, Palaeoclimatology, Palaeoecology, 232: 190-213.

Valentine, J.W. 1969. Patterns of taxonomic and ecological structure of the shelf benthos during Phanerozoic time. Palaeontology, 12: 684-709.

van Staal, C.R. and Hatcher, R. Jr. 2010. Global setting of Ordovician orogenesis. In The Ordovician System, Geological Society of America Special Paper 466. Edited by S.C. Finney and W.B.N. Berry. The Geological Society of America, Boulder, Colorado. p. 1-12.

van Staal, C.R., Whalen, J.B., McNicoll, V.J., Pehrsson, S., Lissenberg, C.J., Zagorevski, A., van Breemen, O., and Jenner, G.A. 2007. The Notre Dame arc and the Taconic orogeny in Newfoundland. In 4-D Framework of Continental Crust, GSA Memoir 200. Edited by R.D. Hatcher Jr., M.P. Carlson, J.H. McBride, and J.R. Martínez Catalán. Geological Society of America, Boulder, Colorado. p. 511-552.

van Staal, C.R., Whalen, J.B., Valverde-Vaquero, P., Zagorevski, and Rogers, N. 2009. Pre-Carboniferous, episodic accretion-related, orogenesis along the Laurentian margin of the northern Appalachians. In Ancient Orogens and Modern Analogues. Edited by J.B. Murphy, J.D. Keppie, and A.J. Hynes. Geological Society, London, Special Publications, 327: 271-316.

Vecoli, M. And Le Hérissé, A. 2004. Biostratigraphy, taxonomic diversity and patterns of morphological evolution of Ordovician acritarchs (organic-walled microphytoplankton) from the northern Gondwana margin in relation to palaeoclimatic and palaeogeographic changes. Earth-Science Reviews, 67: 267311.

Villas, E., Vennin, E., Álvaro, J.J., Hammann, W., Herrera, Z.A., and Piovano, E.L. 2002. The late Ordovician carbonate sedimentation as a major triggering factor of the Hirnantian glaciation. Bulletin du Societé de géology du France, 173: 569-578. 
Waldron, J.W.F. and van Staal, C.R. 2001. Taconian orogeny and the accretion of the Dashwoods block: a peri-Laurentian microcontinent in the Iapetus Ocean. Geology, 29: 811-814.

Wang, Y. 1949. Maquoketa Brachiopoda of Iowa. Geological Society of America, Memoir 42. $55 \mathrm{pp}$.

Webby, B.D. 2002. Patterns of Ordovician reef development. In Phanerozoic Reef Patterns, SEPM Special Publication, 72. Edited by W. Kiessling, E. Flügel, J. Golonk. SEPM, Tulsa, Oklahoma. p. 129-179.

Webby, B.D. 2004a. Introduction. In The Great Ordovician Biodiversification Event. Edited by B.D. Webby, F. Paris, M.L. Droser, and I.G. Percival. Columbia University Press, New York. p. 1-40.

Webby, B.D. 2004b. Stromatoporoids. In The Great Ordovician Biodiversification Event. Edited by B.D. Webby, F. Paris, M.L. Droser, and I.G. Percival. Columbia University Press, New York. p. 112-118.

Webby, B.D., Paris, F., Droser, M.L., and Percival, I.G. 2004a. The Great Ordovician Biodiversification Event. Columbia University Press, New York. 484 pp.

Webby, B.D., Elias, R.J., Young, G.A., Neuman, B.E.E., and Kaljo, D. 2004b. Corals. In The Great Ordovician Biodiversification Event. Edited by B.D. Webby, F. Paris, M.L. Droser, and I.G. Percival. Columbia University Press, New York. p. 124146.

Wigington, R.J.S. 1977. The age and orthid fauna of the Lower Whittaker Formation, southern Mackenzie Mountains, Northwest Territories. MSc. Thesis, Department of Geology, University of Western Ontario, London, Ontario. 147 pp.

Willard, B. 1928. No. 6a - The Brachiopods of the Ottosee and Holston Formations of Tennessee and Virginia. Bulletin of the Harvard Museum of Comparative Zoology, 48:255-292, pl. 1-3.

Wilson, A.E. 1946. Brachiopoda of the Ottawa Formation of the Ottawa-St. Lawrence lowland. Canada Department of Mines and Resources - Mines and Geology Branch, Geological Survey Bulletin, No. 8. 147 pp.

Young, G.A., Elias, R.J., Wong, S., and Dobrzanski, E.P. 2008. Upper Ordovician Rocks and Fossils in Southern Manitoba, Canadian Paleontology Conference Field Trip Guidebook No. 13. Geological Association of Canada Publications. 97 pp.

Young, S.A., Saltzman, M.R., Ausich, W.I., Desrochers, A., and Kaljo, D. 2010. Did changes in atmospheric $\mathrm{CO}_{2}$ coincide with latest Ordovician glacial-interglacial cycles? Palaeogeography, Palaeoclimatology, Palaeoecology, 296: 376-388.

Zhan, R., Rong, J., Cheng, J., and Chen, P. 2005. Early-Mid Ordovician brachiopod diversification in South China. Science in China Series D - Earth Sciences, 48: 662-665.

Zhan, R., Jin, J., and Rong, J.-Y. 2006. Beta diversity fluctuations in Early-Middle Ordovician brachiopod communities of South China. Geological Journal, 41: 271-288. 
Zhan, R., Jin, J., and Chen, P. 2007. Brachiopod diversification during the Ordovician: an example from the Dawan Formation, Yichang area, central China. Canadian Journal of Earth Sciences, 44: 9-24.

Zhang, S. 2011. Timing and extent of maximum transgression across Laurentia during Late Ordovician: New evidence from Slave Craton, Canadian Shield. Palaeogeography, Palaeoclimatology, Palaeoecology, 306: 196-204. 


\section{Chapter 2 - Geological and Stratigraphic Setting}

\subsection{Introduction}

Specimens of Plaesiomys species from seven localities (see Figures 1.8 and 2.1) were included in this study, including Lake Simcoe and Manitoulin Island (Ontario), Baffin Island (Nunavut), Mackenzie Mountains (Northwest Territories), Stony Mountain (Manitoba), Cincinnati (Ohio), and Anticosti Island (Quebec). These localities can be broadly grouped into intracratonic (Stony Mountain, Lake Simcoe, and Manitoulin Island) and pericratonic settings (Baffin Island, Mackenzie Mountains, Cincinnati, and Anticosti Island). Stony Mountain was near the equator during this Late Ordovician, while the other localities were subtropical (Cocks and Torsvik 2011).

\subsection{Lake Simcoe area, Ontario}

The Ordovician strata to the east of Lake Simcoe consist of the early Katian (Chatfieldian - Edenian) formations of the Simcoe Group (Melchin 1994; Figure 2.1). The Ordovician deposits in the area accumulated on a shallow carbonate ramp which dipped gently to the southeast towards the Appalachian Basin, bounded by the Frontenac Arch to the North and by the Algonquin Arch to the west (Sanford 1993a).

\subsubsection{Simcoe Group}

The Simcoe Group includes (in order from oldest to youngest) the Shadow Lake, Gull River, Bobcaygeon, Verulam, and Lindsay formations (Liberty 1969; Melchin 1990; 1994; Armstrong 2000) forming a continuous section over the Middle to lower Upper Ordovician, with no significant unconformities (Grimwood et al. 1999). This stratigraphic framework was first proposed by Liberty (1969), and remains mostly unchanged other than a slight modification by Russell and Telford (1983) in the definition of the Lindsay Formation. Overall, the Simcoe Group is predominately limestone and dolostone with varying argillaceous and bioclastic content. Depositional environment interpretation has been debated, with Brookfield (1988) suggesting the group represents a shift to deposition under cool, temperate conditions, with Grimwood et al. (1999) 


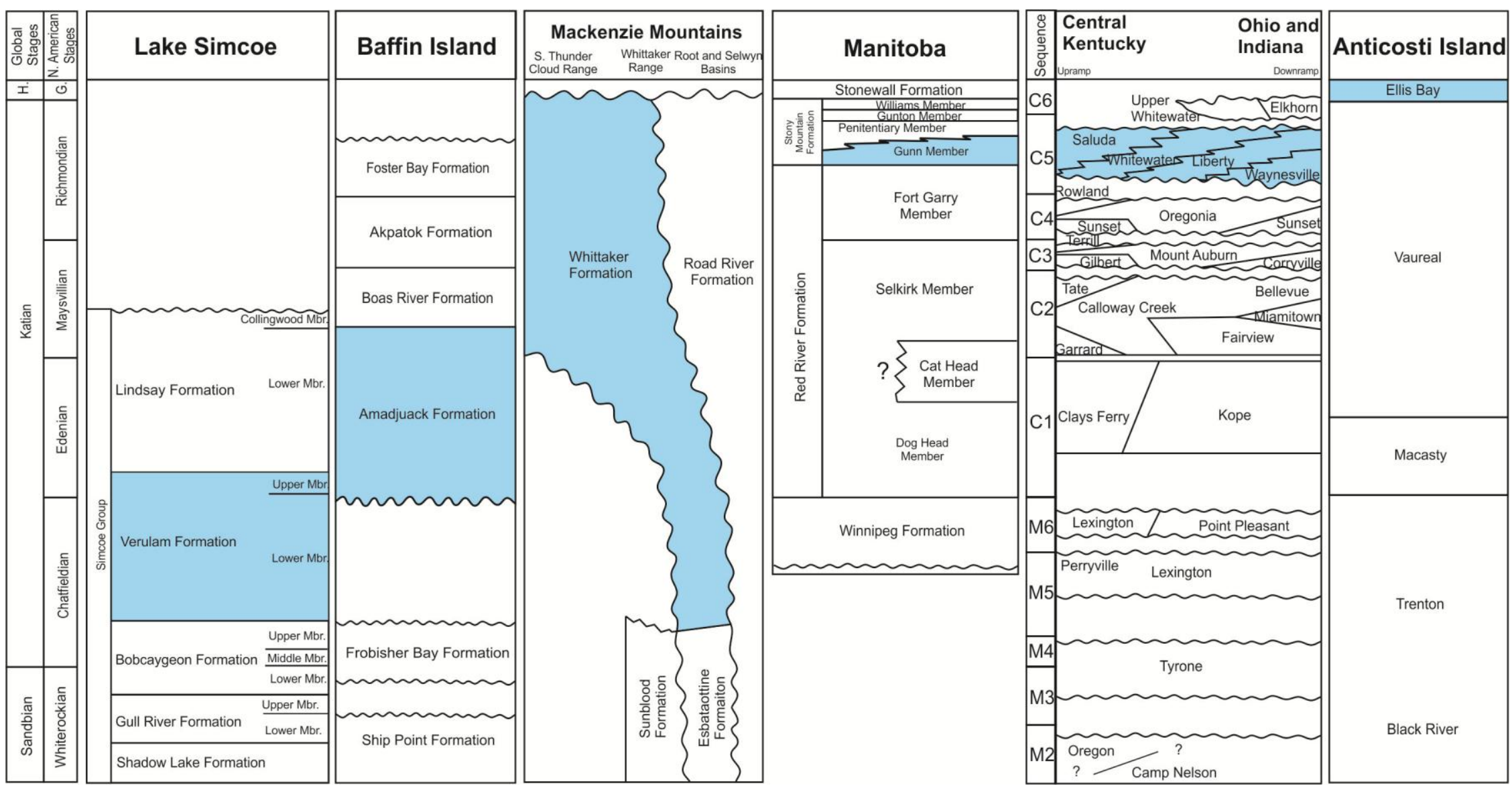

Figure 2.1 - Correlation chart showing the stratigraphy of each locality with studied strata shaded. References are as followed: Lake Simcoe - Armstrong 2001; Baffin Island - Sandford and Grant 2000; Mackenzie Mountains - Mitchell and Sweet 1989; Manitoba Jin and Zhan 2001, modified from Norford et al. 1994 and Longman and Haidl 1996; Cincinnati region (Ohio-Indiana-Kentucky tristate region) - Holland 1996 and Holland and Patzkowsky 2007; Anticosti Island - Sanford 1993b, Desrochers et al. 2010, and Achab et al. 2011. 
favouring the traditional interpretation of warm water carbonates deposited in a deeperwater setting.

\subsubsection{Shadow Lake Formation}

The Shadow Lake Formation is the oldest formation of the Simcoe Group, directly overlying Precambrian basement in the Lake Simcoe area, but commonly absent over Precambrian topographic highs (Melchin 1994). The sharp and irregular nature of its basal contact suggests it represents a significant nonconformity (Armstrong 2000), however it is conformable with the other overlying formations of the Simcoe Group (Grimwood et al. 1999). This formation has far more siliciclastic content than the rest of Simcoe Group (which is predominately carbonate) (Melchin 1990, 1994).

Three facies have been recognized in the Shadow Lake Formation: (1) a red and green argillaceous, arkosic sandstone and conglomerate confined to the basal sections of the unit; (2) arenaceous siliciclastic mudstones and siltstones; and (3) minor argillaceous dolomite and limestones (Armstrong 2000). Because it is bound by a basal nonconformity, the unit shows considerable variation in thickness and lithology (Melchin 1990). Burrowing, ripple marks, and desiccation cracks found within the unit suggest deposition in an alluvial or deltaic setting (Grimwood et al. 1999). Fossils are rare, with conodonts (Barnes et al. 1978), a few brachiopods, ostracods, bivalves (Copper 1978), and fish denticles (Risk and Liberty 1978) being recovered. Brachiopods are either sparse or poorly preserved and are not included in this study.

\subsubsection{Gull River Formation}

The Gull River Formation consists of two members, divided by a distinct marker bed of green dolomitic limestone to dolomite (Armstrong 2000). The lower member is grey, green, and brown fine grained argillaceous limestone to dolostone (Armstrong 2000), with silt- and shale-rich carbonates common towards its base (Melchin 1990). Evaporite casts and nodules, desiccation cracks, and a generally sparse fossil fauna consisting mainly of trilobites and ostracods indicates a restricted intertidal to supratidal depositional environment (Grimwood et al. 1999). This sparse fossil fauna also includes brachiopods, gastropods, and cephalopods (Liberty 1968, 1969; Melchin 1994). A 
gradational contact separates it from the underlying Shadow Lake Formation (Armstrong 2000).

The upper member consists of white to grey-brown, medium bedded, sparsely fossiliferous micrite with thin beds of intraclastic packstones and grainstones (Armstrong 2000) becoming increasingly bioclastic and bioturbated with pellets near the top (Melchin 1994). The upper member was deposited in a somewhat deeper-water setting than the Shadow Lake Member, but still within the shallow subtidal environment (Grimwood et al. 1999). Fossils include low diversity assemblages of corals, bivalves, gastropods, ostracods, trilobites, bryozoans, and brachiopods. Calcareous algae often form stromatolitic structures in this formation (Copper 1978; Melchin 1994).

Neither member contains any plaesiomyids, thus the brachiopods of the Gull River Formation were not included in this study. The lower member is a much shallower environment than the preferred environments of plaesiomyid brachiopods, which may explain its absence in this formation.

\subsubsection{Bobcaygeon Formation}

The Bobcaygeon Formation is also dominantly carbonate in composition and has a gradational contact with the underlying Gull River Formation. It becomes increasingly fossiliferous up section and coarser grained than the underlying Gull River Formation (Armstrong 2000). The Bobcaygeon Formation is divided into a lower, middle, and upper member.

The lower member is grey-brown, thick-bedded, fine to very fine grained bioclastic and peloidal wackestone limestone that is fossiliferous and shows abundant bioturbation (Armstrong 2000). Planar and ripple cross-stratification is common (Melchin 1994). Fossils include corals, trilobites, brachiopods, bryozoans, bivalves, gastropods, stromatolites, echinoderms, and cephalopods - particularly rich in the upper part of this lower member (Armstrong 2000). Relatively large colonies of tabular and prasporid bryozoans may form bafflestones locally. Brachiopod shell beds (usually predominantly the dalmanellid Paucicrura) are found at some horizons, usually in muddrapes on top of skeletal packstone. No plaesiomyid brachiopods have been found. A subtidal depositional environment has been suggested, but less restricted than that of the 
underlying Gull River Formation (Melchin 1994). This unit contains the lower-K bentonite bed - a volcanic ash layer less than $10 \mathrm{~cm}$ in thickness (Armstrong 2000) linked to the increased volcanic activity associated with the eastern coast of North America during the Ordovician (Kolata et al. 1996).

The middle member of the Bobcaygeon Formation is more argillaceous than the lower member and less fossiliferous, consisting of interbedded shale and tabular limestone in its lowermost and uppermost beds surrounding mostly slabby limestone in the middle (Armstrong 2000). The slabby limestone is grey-brown fine to medium grained, peloidal grainstone, and probably represents storm beds in a deeper environment. Melchin (1994) suggested that the basal contact of this member may separate the Blackriveran from the Trentonian, agreeing with the earlier interpretation of Liberty (1968, 1969). Available data suggest that it is restricted in its extent to the Lake Simcoe area only (Melchin 1990).

The upper member consists of light greyish brown, thin- to medium-bedded, fineto coarse-grained fossiliferous limestones with shaly partings or interbeds and is less argillaceous than the middle member (Melchin 1994). The limestone ranges from bioturbated bioclastic wackestones and packstones to tabular-bedded, cross-laminated bioclastic and locally intraclastic grainstones (Armstrong 2000). These deposits have been interpreted to have accumulated as shoal/inter-shoal deposits on a storm influenced continental shelf (Brookfield and Brett 1988) or in a shallower lagoonal environment (Melchin 1994). The fauna is dominated by echinoderms with relatively rare brachiopods, bryozoans, trilobites, and gastropods (Armstrong 2000). Several Precambrian inliers extend into this level, forming what would have been islands in the Ordovician sea with rocky shorelines (Brookfield and Brett 1988). The upper contact with the overlying Verulam Formation is marked by a gradational increase in shale content, forming significant calcareous shale interbeds (Liberty 1969). The upper-K bentonite is located within this upper member (Armstrong 2000).

\subsubsection{Verulam Formation}

The Verulam Formation has been divided into a lower and an upper member (Liberty 1969). The lower is dominated by shale and limestone while the upper is much 
coarser-grained, cross-stratified bioclastic limestone (Armstrong 2000). The unit is intensely bioturbated, and grainstones show ripple and trough cross bedding, planar bedding, graded bedding, and channels (Melchin 1990).

The Verulam Formation is richly fossiliferous, with abundant branching and domal prasporid bryozoans, brachiopods, trilobites, gastropods, and bivalves, and brachiopods, echinoderms, and bryozoans being the dominant constituents (Melchin 1994; Armstrong 2000). Despite the overall fossil abundance, the assemblage is generally low in taxonomic diversity (Brookfield 1988). However, in the Lake Simcoe area a relatively rich and diverse brachiopod fauna occurs in the lower Verulam Formation, although the fauna remains to be described. Plaesiomys subcircularis and $P$. browni make up a minor component of this fauna, and are included in this study. Some fossils in the lower part of the formation are silicified (e.g. P. subcircularis in this study), ensuring good preservation of gross morphology though fine details are destroyed.

The lower member is heterogeneous, consisting of variable amount of micritic and nodular mudstones, bioclastic packstones, and grainstones that form discontinuous lenticular beds within dominantly grey-green calcareous shale (Melchin 1990; Armstrong 2000). The lower member was deposited in an open shelf environment (Brookfield and Brett 1988; Melchin 1994; Grimwood et al. 1999).

The upper member comprises two distinct facies: a shoal facies and an intershoal shelf facies. The shelf facies consists of laminated mudstones, shales, and calcareous siltstones with coarser bioclastic limestones representing storm beds (Melchin 1994; Armstrong 2000). This is shown by the sedimentary structures in the unit - scoured bases, basal shell lags, lenticular bedding, wave ripples, and common trough crossstratification (Armstrong 2000). The upward increase in the frequency and abundance of storm beds may indicate a shallowing upward succession (Melchin 1994) or a shift from distal to proximal storm settings (Brookfield and Brett 1988). The shoal facies consists mainly of crinoidal grainstones and rudstones (Armstrong 2000) and may represent discrete shoal bodies, rather than a continuous unit (Brookfield and Brett 1988). This upper member is restricted to the Lake Simcoe area (Liberty 1969). 


\subsubsection{Lindsay Formation}

The Lindsay Formation can be divided into a lower and upper member - the upper unit being known as the Collingwood Member (formerly Collingwood Shales of the Whitby Formation within Liberty's (1969) classification). The formation contains facies similar to the shoal-intershoal facies of the underlying Verulam Formation (Brookfield and Brett 1988). Dalmanellids and rhynchonellids are similar to those of the Verulam Formation, but no plaesiomyids have yet been collected from this formation despite of the similar facies.

The lower member consists of bluish-grey, nodular, fossiliferous wackestones with high argillaceous content interbedded with coarse bioclastic grainstones, transitioning upward into grey-brown thin and irregularly bedded wackestones and mudstones with shaly interbeds, with less common coarser bioclastic units (Melchin 1994). The fossil assemblage is less diverse than the Verulam, consisting of gastropods, brachiopods, echinoderms, and graptolites (Melchin 1990, 1994). Liberty (1968) proposed that the Trentonian-Edenian boundary should be drawn through the uppermost beds of this unit.

The petroliferous Collingwood (upper) Member is differentiated mainly based on its high organic content in comparison with the lower member (Russell and Telford 1983). It is composed of argillaceous laminated lime mudstones interbedded with coarser thin wackestone to packstone layers. The fauna is much more indicative of a restricted environment in comparison to the lower Lindsay Formation, but still very fossiliferous trilobites, inarticulate and thin shelled articulate brachiopods, ostracods, conularids, nautiloids, and graptolites, and a minor amount of trace fossils have been documented (Melchin 1990). This was the lowest member of Liberty's (1969) Whitby Formation (a formation that also included the Blue Mountain Formation), until the Collingwood Member was separated by Russell and Telford (1983) and placed within the Lindsay Formation based on its calcareous composition and lower organic content in comparison to the overlying Blue Mountain Formation. The Collingwood beds were traditionally interpreted as a shallow environment (Liberty 1969), but is now thought to have been deposited in a rapidly deepening setting (Brookfield and Brett 1988). 


\subsection{Manitoulin Island, Ontario (Michigan Basin)}

Manitoulin Island is located along the northeast margin of the Michigan basin. This oval shaped basin's depocenter lies in the middle of the state of Michigan (Burgess 2008). It contains an up to $4.5 \mathrm{~km}$ thick package of strata, mostly composed of carbonates and evaporites with minor clastics (Fisher et al. 1988) ranging from Cambrian to Jurassic in age. The Michigan Basin was a bull's eye structure before Chatfieldian time. During the Chatfieldian, a far-field tectonic tilting related to the Appalachian orogeny caused the entire basin to tilt eastwards, losing its circular outline to form a continuous carbonate ramp with the Appalachian Basin (Coakley and Gurnis 1995).

On Manitoulin Island, the stratigraphy follows a scheme similar to the Lake Simcoe area, but is extended to include the Nottawasaga Group, which extends the range of Ordovician rocks into the Richmondian (late Katian) (Bergström et al. 2011). Although it is the same age as the Stony Mountain and Cincinnati localities, where plaesiomyids are common, no plaesiomyids have been found in these younger units. The reason for this is not yet clear, especially within the richly fossiliferous Georgian Bay Formation. Plaesiomys browni was collected from a single Verulam Formation locality on Manitoulin Island (same formation as the Lake Simcoe locality) as part of this study.

\subsubsection{Nottawasaga Group}

The Nottawasaga Group is not found in the Lake Simcoe region, but occurs only further west (Liberty 1968). On Manitoulin Island, it is represented by the Blue Mountain Formation and Georgian Bay Formation. The red shales of the Queenston Formation are the youngest Ordovician strata in southwestern Ontario, but are not present in the study area - only in a narrow band extending from the east side of the Bruce Peninsula to the Hamilton area (Sanford 1993b). The stratigraphy shows a transition from noncalcareous shale to a carbonate succession, separated by a gradational contact.

\subsubsection{Blue Mountain Formation}

The Blue Mountain Formation consists of the shales overlying the calcareous shales of the upper Lindsay Formation. These are characterized as blue-grey fissile shales with thin minor dolostone beds (Sanford 1978; Coniglio and Williams-Jones 1992). This unit is sparsely fossiliferous, containing the Blue Mountain Fauna - an 
assemblage of graptolites, brachiopods, and trilobites (Liberty 1968).

\subsubsection{Georgian Bay Formation}

The Georgian Bay Formation is divided into two members: a lower member consists of alternating shale and limestone bands and an upper member that is exclusively limestone (Liberty 1968).

The lower member consists of interbedded calcareous shale and limestone (Liberty 1968). The shale is grey to bluish-grey and greenish-grey, weathering to a buff to yellowish colour. Organic carbon content is very low, but the unit is very fossiliferous. Minor interbeds of dolomite, limestone, and sandstone increase in size and abundance upward in the unit. The top of the unit is an indefinite transition to increased limestone content of the upper Georgian Bay Formation (Sanford 1978).

The upper member is a grey limestone, varying from calcarenite to crystalline in its texture (Liberty 1968) and frequently argillaceous with shaly partings. The unit is richly fossiliferous and occasionally contains coral and stromatoporoid biostromes.

\subsection{Baffin Island}

The study locality on Baffin Island lies approximately $23 \mathrm{~km}$ west of Iqaluit near Frobisher Bay on the southern tip of the Island. It is known in literature as Silliman's Fossil Mount - an isolated Paleozoic outlier resting non-conformably on Precambrian basement. It forms a succession of stable shelf carbonates located southwest of the Foxe Basin (Sanford and Grant 2000; Figure 2.1). The study locality consists mainly of Amadjuack Formation, which is underlain by the Frobisher Formation.

\subsubsection{Frobisher Formation}

The Frobisher Formation was originally defined by Sanford and Grant (1990) to replace an incorrect previous correlation with the Bad Cache Rapids Formation of the Hudson Platform. This formation is the lowest Paleozoic formation of Silliman's Fossil Mount and rests nonconformably on Precambrian basement rock (Sanford and Grant 1990, 2000). The formation is composed of grey, green, and brown (with a mottled weathering light yellow or orange colour) micro to fine crystalline limestone and dolomitic limestone (Sanford and Grant 2000). It forms a sharp contact with the 
overlying Amadjuack Formation, with massive resistant beds at the top of the formation commonly forming an escarpment. Bolton (2000) considered the age to be Turinian (Sandbian) to Chatfieldian (early Katian) based on macro faunal characteristics but McCracken (2000) assigned it to the Chatfieldian based mainly on conodont data.

Bolton (2000) identified a Gonioceras-Labyrinthites fauna typically consisting of the cephalopods Gonioceras wulffi, G. holtedali, G. groenlandicum, and G. sp cf G. angulatum; coral Labyrinthites chidlensis; and sponges Asteriospongia anatrope and Incrassospongia rhipidos. The nautiloids were typically orthocones, with endocerids being most abundant. The receptaculid Fisherites occidentalis is often found associated with these shells. Strophmenids are the dominant brachiopods, but fragments of orthids and hesperorthids were also recovered. No plaesiomyids have been collected. Two species of Strophmena and one of Rafinesquina are recorded from this formation (Bolton 2000). This fauna is far less diverse than the overlying Amadjuack Formation.

\subsubsection{Amadjuack Formation}

The Amadjuack Formation was also originally described by Sanford and Grant (1990). This formation makes up most of exposure at Silliman's Fossil Mount and this is where the formation is most accessible. Elsewhere on the island, the formation is well exposed on the Melville Peninsula and near Amadjuack Lake.

The formation can be divided into three units (Sanford and Grant 2000). The lowermost consists of interbedded shale and shaly limestone. The shale is medium grey to black while the shaly limestone is brown in colour and forms thin, uniform beds. The middle unit has weathering-resistant grey-brown limestone at its base, forming thick massive beds. This changes abruptly upsection into grey, thin and nodular bedded, shaly limestones with interbedded grey shales. The top of the middle unit is a slightly more massive grey, nodular limestone with minor shale partings and interbeds. The upper unit is massive to nodular bedded limestone, light to medium brown with a distinctive yellowish-orange weathering colour. 
A similar stratigraphic scheme was applied elsewhere on Baffin Island (Sanford and Grant 2000). Interbedded limestone and shale in the lower strata grade into a resistant microcrystalline limestone in the upper part of the Amadjuack Formation. Petroliferous shales have been documented in sections of the Amadjuack Formation exposed along the Jordan and Nuvungmiat rivers (Macauley et al. 1990) where up to 9$15 \%$ total organic carbon was reported but deemed to be thermally immature for producing significant amounts of hydrocarbons.

The Amajuack Formation is very fossiliferous, and contains two main fossil faunas (Bolton 2000): the Pseudogygites-Climacograptus fauna found in the lowest Amadjuack and the Kochoceras-Denella fauna that succeeds it through the rest of the formation.

The Pseudogygites-Climacograptus fauna is found in the bituminous beds in the basal part of the formation. Its main components are the trilobites Pseudogygites arcticus, $P$. hudsoni, Triarthus (Triarthus) eatoni, and T. (Danarcus) glaber and the graptolites Amplexograptus and Climacograptus. Based on the graptolites, Bolton (2000) assigned this fauna an early Edenian age. Other components include crinoid stem ossicles, the brachiopods Elliptoglossa(?) sp., Leptobolus(?) sp. and sowerbyellid brachiopods, and molluscs including low spired gastropods, the bivalve Ischyrodonta(?) sp., and the nautiloid Geisonoceras sp.

The Kochoceras-Denella fauna is much more diverse, characterized by a number of orthone nautiloids as well as the trilobite genera Illaenus, Nanillaenus, Anataphrus, and Denella (Bolton 2000). This fauna has been dated as Edenian to early Maysvillian (early to mid Katian). The brachiopods constitute one of the most diverse fossil groups, including Lingula sp., Hesperorthis interplicata, Glyptorthis sp., Plaesiomys subcircularis, Austinella cooperi, Plectorthis inaequiconvexa, Plectorthis sp., Hebertella(?) sp., Platystrophia magnisulcata, Paucicrura rogata, Resserella sillmani, $R$. diminutiva, Sowerbyella sp., Strophomena sp., S. fluctuosa, Rafinesquina(?) pronis, R.(?) declivis subnutans, Rafinesquina sp., Kjaerina sp., Parastrophina minor, Lepidocyclus(?) arctica, L.(?) breve, Idiospira maynei, Cyclospira schucherti, and Cyclospira sp. The 
brachiopod fauna is dominated by the dalmanellid Paucicrura-Plaesiomys subcircularis is relatively uncommon.

\subsection{Mackenzie Mountains, Northwest Territories}

The specimens from the Mackenzie Mountain locality were collected from the lower Whittaker Formation, near the border of the Northwest Territories and Yukon Territory. This formation was deposited on the subtropical pericratonic Mackenzie Platform during the Late Ordovician. The lower Whittaker Formation is underlain by the Sunblood and Esbattaotine formations (and Proterozoic basement to the east of the Mackenzie Mountains) and overlain by the upper Whittaker Formation (Silurian) and Road River shales (Ludvigsen 1975, Mitchell and Sweet 1989; Figure 2.1). These units were deposited in a generally shallow embayment that was sheltered by the broad penninsula of the nearby Redstone Arch. Brachiopod specimens were originally collected as part of Wigington's (1977) master's thesis at the University of Western Ontario and the plaesiomyids from the collection are incorporated into this study.

\subsubsection{Sunblood Formation}

The Sunblood Formation consists of silty dolomites and limestones with a $2 \mathrm{~m}$ thick basal unit of dark grey dolomite containing beds of chert nodules and locally high pyrite content. This grades upward into a light grey to buff weathering with pink mottling, platy limestone (Gabrielse et al. 1973; Ludvigsen 1975). The top of the Sunblood Formation is marked by vividly coloured sandy dolostone, sandstone, and limestone with colour ranging from bright orange, to red, to dark brown, probably due to variable silt content (Douglas and Norris 1961; Gabrielse et al. 1973; Ludvigsen 1975). The uppermost beds of the unit as described by Gabrielse et al. (1973) - well banded buff grey to dark grey interbedded dolostone and limestone - were interpreted to be part of the Esbataottine Formation by Ludvigsen (1975) and subsequent researchers. The base of the Sunblood Formation is conformable with the underlying Broken Skull Formation, and forms a sharp contact (Gabrielse et al. 1973) while the top of the formation is conformable with the overlying Esbataottine Formation where it underlies it (Ludvigsen 1975). In some localities, however, it is overlain unconformably by the Whittaker Formation (Mitchell and Sweet 1989; see Figure 2.1). Fossil content is variable in this 
formation but generally sparse, particularly within the sand-rich strata. Trilobites and ostracods have been collected, with rare gastropod, bryozoan, and brachiopods (Ludvigsen 1975; Tremblay and Westrop 1991).

\subsubsection{Esbataottine Formation}

Prior to the establishment of the Esbataottine Formation by Ludvigsen (1975), this succession was considered part of the Sunblood Formation (see Gabrielse et al. 1973). Ludvigsen redefined it as a distinct unit based on its more recessive weathering pattern and darker colour relative to the rest of the Sunblood Formation. It consists of limestone that is bedded and platy in some localities, containing minor amounts of sandy dolostone. The Esbataottine Formation is richly fossiliferous with a diverse trilobite, brachiopod and ostracod fauna but corals are rare and graptolites are notably absent (Ludvigsen 1975). Despite the rich brachiopod fauna, no plaesiomyids are known from this formation.

\subsubsection{Whittaker Formation}

The Whittaker Formation, first described by Douglas and Norris (1961), is a thick sequence of limestone, dolostone, and shale in the Mackenzie Mountains. It dates from the Late Ordovician (Chatfieldian - early Katian) to the Late Silurian (O'Bertos and Jackson 1963; Ludvigsen 1975; Mitchell and Sweet 1989).

There are two bounding unconformities that define the base and top of the Whittaker Formation. The basal unconformity is related to the start of a marine transgression during the Chatfieldian (early Katian) and separates the Whittaker Formation from the Sunblood and Esbattaotine formations (Mitchell and Sweet 1989). The overlying unconformity is related to a global sea level fall due to Gondwanan glaciation during the Hirnantian (see Haq and Schutter 2008). This upper unconformity separates the Ordovician lower Whittaker from the Silurian upper Whittaker (Wigington 1977). In some localities, the Road River Shale forms a gradational lateral contact the Whittaker Formation (Mitchell and Sweet 1989).

The lower Whittaker Formation is made up of three distinct units (Wigington 1977). The most basal is a grey limestone that transitions to a dark grey dolostone. The top of the Lower Whittaker is mostly a dark argillaceous limestone underlain by 
interbedded dark siltstones.

The Whittaker Formation is richly fossiliferous. In the southern Mackenzie Mountains, the lower Whittaker Formation contains a high diversity trilobite fauna (Gabrielse et al. 1973; Ludvigsen 1975). The brachiopod fauna is less diverse, with Strophomena being common but others such as ?Cyclospira, Diceromyonia, Lepidocyclus,Plaesiomys, Thaerodonta sp., Platystrophia sp., Hesperorthis sp., and Zygospria sp. being recovered (Ludvigsen 1975).

In the more northern localities, the lower Whittaker Formation has a slightly different faunal character. Here, the most common brachiopods are Plaesiomys, Diceromyonia, Rhynchotrema, Lepidocyclus and Thaerodonta (Ludvigsen 1975). This fauna is similar to the Red River fauna found across the interior of Laurentia at this time (Jin and Zhan 2001), including the Stony Mountain Formation. In a narrow wedge near the Whittaker Formation's southern contact with the Road River Formation, a similar fauna missing Plaesiomys, Thaerodonta, Diceromyonia, and Lepidocyclus but including abundant Oepikina and Hesperorthis was thought to have colonized an elongate shallow shoal (Ludvigsen 1975).

In the Avalanche Lake area (west of this study area), a silicified brachiopod fauna of Hirnantian age is known to occur in the transitional interval between the lower and upper Whittaker Formation (Jin and Chatterton 1997). This fauna consists of Brevilamnulella laevis, Dalmanella edgewoodensis, Eospirigerina patilla, Epitomyonia sekwensis, Katastrophomena cf. woodlandensis, and Platystrophia orbiculoidea.

\subsubsection{Road River Shale}

The Road River Shale is the distal facies of the carbonate platform, laterally equivalent with the Whittaker formation limestones (Ludvigsen 1975; Wigington 1977). Deposition occured from the Late Cambrian to Early Devonian (Jackson and Lenz 1962). This unit consists of a thick sequence of graptolitic shales and argillaceous mudstone. No plaesiomyids are known from this unit, and thus it was not studied. 


\subsection{Stony Mountain, Manitoba (Williston Basin)}

The Ordovician strata in Manitoba include the Winnipeg Formation, Red River Formation, Stony Mountain Formation, and Stonewall Formation (Figure 2.1) - spanning the Chatfieldian to Richmondian (Katian). There are two large scale shallowing and brining upward trends observed within these strata, both in the Red River and Stony Mountain Formations (Elias 1991; Kent and Christopher 1994; Young et al. 2008), when bottom waters became increasingly salty until evaporite deposition occurred. There is no evidence of subaerial exposure though, as conodonts have been recovered from all the units (Elias 1981). The specimens being examined in this study were recovered from the Gunn Member of the Stony Mountain Formation.

The Stony Mountain locality is located in the northeastern part of the Williston Basin in the central part of North America. This would have placed it at paleoequatorial latitudes during the Ordovician (Cocks and Torsvik 2011, see Figure 1.8). The Williston Basin has an elliptical shape $-560 \mathrm{~km}$ in diameter with an area of $250000 \mathrm{~km}^{2}$.The sediments of the basin span the Phanerozoic, forming a package up to $4.9 \mathrm{~km}$ thick. The basin later became part of the larger Mesozoic Western Interior Basin - a large foreland basin that developed in conjunction with the Cordilleran orogeny that occupies much of the western half of the North American continent (Kent and Christopher 1994; Burgess 2008).

The Paleozoic strata consist of a basal Cambrian clastic unit topped by a thick package of carbonates with minor evaporites and clastics forming a large carbonate platform bordered by basinal shales and limestones to the west. During the Ordovician the basin would have covered most of the Western part of the continent from Hudson Bay to what is now the west coast of the continent, but erosion has removed much of the outlying deposits (Kent and Christopher 1994; Longman and Haidl 1996). 


\subsubsection{Winnipeg Formation}

The Winnipeg Formation overlies the Middle to Late Cambrian Deadwood Formation, and Precambrian basement where the Deadwood is absent. It varies in thickness across the Williston Basin from less than $10 \mathrm{~m}$ near Lake Winnipeg to $135 \mathrm{~m}$ in the center of the basin (Last and Shum 1991). At its base, it consists of black marine shales which transition to very fine to medium grained bioturbated sandstones (Hendricks et al. 1998). The upper part of the formation includes shales, arenaceous shales, and sandstones (Baillie 1952). Although a varied biota has been reported from the Winnipeg formation, macrofossils are generally rare or absent. The reported fossils may actually have originated from overlying Dog Head Member before it was differentiated from the Winnipeg Formation (Young et al. 2008), as earlier authors did not divide the two formations.

\subsubsection{Red River Formation}

Overlaying the Winnipeg Formation is the Red River Formation. It is predominantly a carbonate succession, which is known to contain both source and reservoir rocks for hydrocarbons in the Williston Basin (Longman and Haidl 1996).

The basal part of the Red River Formation is the Dog Head Member, comprising yellow-brownish grey mottled dolomitic limestone (Bannatyne 1988). The mottled areas are the result of secondary dolomitization while the remaining limestone is primarily fossil fragments in a crystallized calcite matrix (Baillie 1952). This member is Edenian (mid-Katian) in age, corresponding to the beginning of a transgressive phase in the Williston Basin (Elias 1991).

The Cat Head Member conformably overlies the Dog Head Member and consists of bedded light yellow grey to grey-yellow dolostones containing variable amounts of chert (Baillie 1952) that date as early as the early Maysvillian (mid Katian). The member represents the peak of the first Late Ordovician marine transgression in the Williston Basin, lacking both coarser bioclastic packstones and grainstones and intense mottling found in the other Ordovician limestones of Manitoba (Elias 1991). Fossils are relatively rare in this member overall (Young et al. 2008). In the northern exposures, including the type locality, the fauna includes noncalcareous sponges, hydrozoans, graptolites, and 
inarticulate brachiopods as well as corals and rhynchonelliformean brachiopods. The southern localities contain the brachiopod and coral faunas, but lack any soft-body fossils.

The Selkirk Member, Maysvillian (mid-Katian) in age, conformably overlies the Cat Head Member, with a gradational contact. In the Winnipeg area, it consists of dolomitized burrows surrounded by pale yellowish brown to yellowish grey limestone matrix but becomes fully dolomitized northwards (Bailie 1952; Elias 1991). The pervasive Thalassinoides burrows impart a distinctive mottled appearance to the stone (see Jin et al. 2011) and make it desirable as a facing stone for building construction. The Selkirk Member was deposited during regression, and is interpreted as a warm shallow marine shelf below normal wave base (Elias 1991). The biota is highly diverse in the lower Selkirk Member, including stromatoporoids, corals, brachiopods, trilobites, ostracods, receptaculids, cephalopods, gastropods, sponges and bryozoans - with brachiopods and corals being the most abundant (e.g. Elias 1991; Jin and Zhan 2001; Young et al. 2008). The biota is similar in the upper Selkirk, except it has a greater abundance of articulated trilobites and the rugosan colonial coral Palaeophyllum (Young et al. 2008). Despite this high diversity, plaesiomyids are relatively rare in the Selkirk Member (Jin and Zhan 2001).

The Fort Garry Member is the uppermost unit of the Red River Formation - dated to be mid Richmondian (late Katian) in age (Elias et al. 1988). The type section, located at the Mowat Farm Quarry north of Winnipeg, Manitoba, was described by Elias et al. (1988). The lowest $3.5 \mathrm{~m}$ is mainly thin to medium bedded pale greyish-orange sublithographic dolostone, containing a thin pale reddish to purple argillaceous zone. Above is a $0.7 \mathrm{~m}$ interval of red shale with blocks of sublithographic dolostone. Overlying this is an interval of similar thinly bedded pale greyish-orange sublithographic dolostone with minor shale. The upper part of the unit consists of sparsely fossiliferous, pale yellowish-brown to yellowish-grey mottled vuggy dolostone with scattered chert nodules and reddish-brown staining with. Fossils are typically preserved as molds or replacement with silica or dolomite. These beds were deposited in a relatively restricted environment, corresponding to anhydrite beds in the subsurface. The sparse biota consists mainly of corals and stromatoporoids, abundant algae and echinoderm 
columnals, and other groups including trilobites, ostracods, and bryozoans, and brachiopods - though plaesiomyids are absent. This unit represents a shallow environment - the lowest sea level during the first large scale brining upward cycle before a transgression during deposition of the Gunn Member (Young et al. 2008)

\subsubsection{Stony Mountain Formation}

The Richmondian (upper Katian) Stony Mountain Formation overlies the Fort Garry member of the Red River Formation with a gradational contact. The Gunn Member at the base of the formation usually is comprised of red, argillaceous wackestones to packstones, but in some localities it appears green, similar to the overlying Penitentiary Member. This member is highly fossiliferous, containing rich and diverse brachiopods, corals, bryozoans, and gastropods as well as some bivalves. The concentration of fossils is high enough in some layers to form a coquina - possibly representing a storm deposit (Young et al. 2008) that may also be interpreted as winnowed shell beds by fair weather waves. The Gunn member is thoroughly bioturbated, and this may have influenced the prominent red colour of the member by oxygenating the sea floor. It represents the second maximum transgression in the Williston Basin during the Late Ordovician (Elias 1991). Plaesiomyids are very common in this member - all of the studied material from this locality was collected from this member.

The Penitentiary Member is very similar to the Gunn Member, but generally yellowish-green in colour and more extensively dolomitized. The presence of pyrite and somewhat less diverse fauna preserved in this member suggest a more restricted environment than the well oxygenated Gunn Member (Young et al. 2008). Fossils are usually preserved as molds, although occasionally skeletal material can be found. As such, it is difficult to extract and identify fossils from this member, which may contribute to the perceived lower diversity of its fauna. Plaesiomyids are relatively common in this member, but their poor preservation means that accurate biometric measurements are difficult, if not impossible to make. Thus, specimens from this member were not included in this study. In some localities the Gunn and Penitentiary members become 
difficult to distinguish (Bannatyne 1988), particularly to the north, near Fisher Branch, Manitoba (Baillie 1952).

The Gunton Member overlies the Penitentiary Member, forming a sharp contact (Baillie 1952). It is characterized by pale grey, massive-bedded dolostone (Young et al. 2008). The top $3 \mathrm{~m}$ of the Gunton Member, known only from a borehole at Stonewall Quarry, becomes gradually argillaceous and red in colour. This succession is topped by a thin band of yellowish-grey arenaceous dolostone just below the contact with the overlying Stonewall Formation (Baillie 1952). A hypersaline depositional environment has been interpreted based on salt crystal molds within the unit and its low fossil content and diversity, although they are locally abundant (Young et al. 2008). In its northern localities, the Gunton is mottled by Thalassinoides and contains brachiopods, cephalopods, and gastropods, but no plaesiomyids are known.

The Williams Member, at the uppermost part of the Stony Mountain Formation, consists of poorly exposed dolostone deposited during a regression. The member is largely unfossiliferous, except in northern Manitoba where a restricted, shallow water fauna has been documented including eurypterids, xiphosurids, linguloid inarticulate brachiopods, and conodonts (Young et al. 2007; Rudkin et al. 2008). The low fossil abundance and the presence of halite molds within the Williams Member indicate a restricted depositional environment (Young et al. 2008).

\subsubsection{Stonewall Formation}

The Stony Mountain Formation is overlain by the Stonewall Formation (Young et al. 2008), with a probable paraconformity. The Stonewall Formation contains the uppermost Ordovician strata in southern Manitoba, and spans the Ordovician-Silurian boundary, although the boundary's exact position remains unknown (Norford et al. 1994). It consists of a yellowish grey, coarsely crystalline, bedded dolomitic mudstone to wackestone. The burrow mottling of lower units is variably present throughout the formation. The fossil content varies, ranging from rare to abundant locally, but generally are poorly preserved. This is consistent with the other uppermost Ordovician stratarepresenting restricted shallow shelf conditions. Fossils include corals, brachiopods, 
cephalopods, and conodonts (Elias 1991; Elias and Young 2004) but no plaesiomyids are present.

\subsection{Cincinnati type area, Ohio-Kentucky-Indiana borderland}

The Cincinnati locality represents a number of individual localities in the tri-state border area of Ohio, Kentucky, and Indiana. This area was part of a structural feature known as the Cincinnati Arch - an elliptical arch dividing the Appalachian and Illinois basins, covering areas in southwestern Ohio, southeastern Indiana, and central Kentucky. This uplift was the result of tectonic loading during the Taconic orogeny, and formed in conjunction with the adjacent Appalachian foreland basin (Beaumont et al. 1988).

The strata from which specimens were collected all fall within the C5 and C6 sequences of Holland and Patzkowsky (1996; Figure 2.1). These formations represent a return to tropical-style carbonate production after a brief period of temperate-style carbonate sedimentation (M5 to C3 or mid Mohawkian to mid Cincinnatian) (Holland and Patzkowsky 1996).

\subsubsection{C5 Sequence}

Each of the $\mathrm{C} 5$ formations represents a different depositional environment. They are collectively separated from the $\mathrm{C} 4$ sequence below and $\mathrm{C} 6$ above by unconformities. Some plaesiomyid specimens are labelled as originating from the Lorraine Formation now the Maysville Group (after Foerste 1905) and part of Holland and Patzkowsky's C4 sequence. However, their exact stratigraphic position within this group is unknown and they may have been mislabelled. It seems reasonable to assume that they originated from between the upper C4 and the C5 sequence, based on Patzkowsky and Holland's (1997) database of taxa used in faunal turnover analysis. They have included Plaesiomys bellistriatus, $P$. proavita in their C-5 sequence, and P. subquadrata in their C4 and C5 sequences.

These units are composed of a series of interbedded carbonates and shales, with shales making up at least $60 \%$ of the strata within the Ohio Valley (Frey 1987). All of the formations have a similar lithology, consisting of varying amounts of blue-grey argillaceous limestone and soft grey shale (Cumings 1907; Patton et al. 1953) - although 
the Whitewater is commonly brownish and yellowish, and more nodular in appearance than the Waynesville and Liberty (Nickles 1903). The general pattern shows an increase in the proportion of limestone to shale upwards through the Waynesville, Liberty, and Whitewater. This succession represents a gradually shallowing upward succession, with the Waynesville representing an offshore setting, Liberty a deep subtidal setting, and Whitewater a shallow subtidal setting (Holland and Patzkowsky 2007). The Saluda continues this trend, but becomes more dolomitic and contains considerably more argillaceous and arenaceous content. This, combined with observed mud cracks (Cumings 1907), suggests a lagoonal depositional environment.

The biota from the C5 sequence consists dominantly of bryozoans and brachiopods, but is highly diverse, consisting of algae, chitinozoans, sponges, cnidarians, mollusks, hyolithids, annelids, arthropods, echinoderms, and graptolites. The articulate brachiopod fauna consists of Austinella, Cincinnetina, Dalmanella, Glyptorthis, Hebertella, Plaesiomys, Vinlandostrophia (previously Platystrophia), Hiscobeccus, Lepidocyclus, Rhynchotrema, Catazyga, Zygospira, Eochonetes, Holtedahlina, Leptaena, Rafinesquina, Strophomena (Hall 1962; Amsden 1973; Copper 1977; Alberstadt 1979; Howe 1979; Pope 1982; Walker 1982; Davis 1985; Cocks and Rong 1989; Schwimmer and Sandy 1996; Jin 2012).

\subsection{Anticosti Island, Quebec (Anticosti Basin)}

Anticosti Island is known for its well preserved fossil fauna - often with the original calcite skeletons intact without recrystallization. The stratigraphy and fauna have been well-studied and described under a number of different stratigraphic schemes. Long and Copper (1994) provided an extensive summary of the Upper Ordovician stratigraphy of the island, revised recently by Desrochers et al. (2010) and Achab et al. (2011) (Figure 2.1).

This well preserved fauna has been well studied. In the last 25 years, graptolites were discussed by Riva (1988), Melchin (2008), and Achab et al. (2011); conodonts by McCracken and Nowlan (1988); chitinozoans by Soufiane and Achab (2000); reefs by Copper (2001); nautiloids by Holland and Copper (2008); bryozoans in the Hirnantian by Ernst and Munnecke (2009); and stromatoporoids in a monograph by Nestor et al. (2010). 
The Ordovician orthide brachiopods have been monorgraphed recently by Jin and Zhan (2008). Additional monographs describe the strophomenide (Dewing 1999), pentameride (Jin and Copper 2000), and rhynchonellide (Jin 1989) brachiopods.

Anticosti Island is a subaerially exposed section of the Anticosti Basin - a small, crescent-shaped basin, measuring approximately $700 \mathrm{~km}$ in length from the mouth of the St. Lawrence River to western Newfoundland and $250 \mathrm{~km}$ in width - an area of about 50 $000 \mathrm{~km}^{2}$ (Sanford 1993a, b). The basin contains strata from the Lower Ordovician to Lower Silurian deposited as a thick carbonate platform to ramp (Long and Copper 1987, 1994; Long 2007). The only Upper Ordovician strata exposed at the surface on Anticosti Island are the Vauréal Formation and the Ellis Bay Formation, spanning the Richmondian and Hirnantian (latest Katian to Hirnantian).

\subsubsection{Vauréal Formation}

The Vauréal Formation is made up of six members as divided by Long and Copper (1994), with only the two uppermost defined as formal stratigraphic units (Long and Copper 1987): the Lavache, Tower, Homard, Joseph Point, Mill Bay, and Schmitt Creek members. This formation is mostly deeper-water strata, with only upper Homard to Mill Bay showing shallowing in the upper Vauréal Formation (Holland and Copper 2008). Six genera of nautiloids can be found within this formation, with orthocones showing the greatest diversity (Holland and Copper 2008). Brachiopods are not as diverse as those found in the overlying Ellis Bay Formation. Plaesiomys carletona is present in this formation, but was not examined in this study due to the paucity of wellpreserved whole shells for biometric measurements. Plaesiomys anticostiensis is absent and occurs only in the Ellis Bay Formation (Jin and Zhan 2008).

The Lavache Member is the lowermost of the Vauréal Formation, consisting of interbedded micrite and discontinuous bioclastic packstones and wackestones, beds of laminated and nodular argillaceous micrite, with some calcareous mudstone (Long and Copper 1994; Long 2007). Some beds show hummocky cross stratification on the scale of 5 to $10 \mathrm{~cm}$. Firmgrounds are developed locally, as shown by the presence of intraformational conglomerates, infilled burrows, and rare pit and oval shaped sculpted surfaces on the tops of bioclastic beds reflecting destruction of early lithified surfaces 
(Long and Copper 1994). Orthides (Dalmanella, Hebertella, Paucicrura, and Plaesiomys), strophomenides (Archaeochonetes, Eochonetes, Gunnarella, Megamyonia, Mjoesina, Nasutimena, Strophomena, and Tetraphalerella), and spire-bearers (Anazyga and Catazyga) are the most common brachiopods recovered from this member (Dewing 1999; Jin and Zhan 2008). Hiscobeccus gigas is present, but rare (Jin 1989).

Pentamerides are absent (Jin and Copper 2000).

The Tower Member forms steep vertical cliffs of interbedded, laminated micrite and calcareous mudstone with minor bioturbation - described as outer shelf deposits. Occasional rare bioclastic packstone and grainstone beds within the Tower Member are interpreted as distal storm deposits (Long and Copper 1994). A distal shelf depositional environment is suggested by the absence of hummocky cross-stratification and intense bioturbation (Jin and Zhan 2008). The orthides are similar to the Lavache Member (Jin and Zhan 2008), but the strophomenides are slightly different - Nasutimena disappears while Furcitella appears (Dewing 1999).

The Homard Member consists of thin bedded nodular or bioturbated micrites interbedded with calcareous mudstones and bioclastic packstones and grainstones (Long and Copper 1994; Jin and Zhan 2008). The bases of some of the packstones and grainstones are erosional, showing channel scouring. Ball and pillow structures can also be observed (Long and Copper 1994; Long 2007). Brachiopods are very common Plaesiomys carletona, in particular, often forms dense monospecific shell beds (Jin and Zhan 2008). The orthides are the similar to the lower two members (Jin and Zhan 2008) and the strophomenides are similar to those in the Tower Member (Dewing 1999), but two species of the rhychonellide Rhynchotrema can be found in this member (Jin 1989). The Homard member marks the last occurrence of Catazyga, a common spire-bearing brachiopod of the Late Ordovician (Long and Copper 1994).

The Joseph Point Member has been described as mostly calcareous mudstone, with a smaller proportion of laminated and nodular micrites and minor calcarenites. Some of the micrites have been documented in channels probably formed from scouring by storm currents, as shown by the orientation of aulacerid stromatoporoids (Long and Copper 1994; Long 2007). Brachiopods are much rarer in this, and the other upper 
members, in comparison to the lower members and much less diverse. Regardless, the orthides Plaesiomys, Mendacella, Vinlandostrophia (Jin and Zhan 2008) and the strophomenides Eochonetes, Gunnarella, Furcitella, Megamyonia (Dewing 1999) occur sporadically in this member.

The Mill Bay Member is a highly resistant unit, consisting of laminated to medium bedded, commonly cross-bedded, medium- to coarse-grained, bioclastic, feldspar-rich arenites with sparry cement interbedded with laminated carbonate siltstone and minor thin shales - as formally defined by Long and Copper (1987). The thicker beds generally show trough cross-bedding while thinner beds show planar and wavy bedding. The Mill Bay member shows only minor bioturbation. Corals and stromatoporoids are common, forming reefs in this member (Holland and Copper 2008). These reefs are dominated by aulacerid stromatoporoids and the corals Paleophyllum and Ellisites in the western part of the island and the corals Tollina, Ellisites, and Paleofavosites in small rare patch reefs on the southern shore of Mill Bay (Nestor et al. 2010). Hardgrounds and firmgrounds are variable within the unit (Long and Copper 1994), forming foundations for fields of aulacerid stromatoporoids, with some being preserved in vivo (Long 2007). The brachiopods Gunnarella, Furcitella, Eochonetes, Plaesiomys, and Vinlandostrophia are present in this member (Dewing 1999; Jin and Zhan 2008).

The Schmitt Creek Member, as defined by Long and Copper (1987), consists mainly of recessively weathering laminated nodular calcareous mudstones and nodular muddy limestones with minor discontinuous laminated to very thin bedded subfeldsarenite to biosparite sandstones and siltstones. The upper part of the member can be recognized by Hummocky cross-stratification in medium to coarse grained calcarenites. This unit represents a deeper-water setting than the other units of the formation (Nestor et al. 2010). Fossils are sparse, but include brachiopods, corals, nautiloids, gastropods and disarticulated trilobites (Long and Copper 1994). Brachiopods are similar to those of the Mill Bay Member, with the addition of the strophomenide Coolinia (Dewing 1999; Jin and Zhan 2008). 


\subsubsection{Ellis Bay Formation}

The Gamachian (Hirnantian) Ellis Bay Formation consists of variable amounts of carbonate and siliciclastic sandstone. It is divided into 5 members: the Grindstone Member, Velleda Member, Prinsta Member, Lousy Cove Member, and the Laframboise Member (basal to top of section) (Long and Copper 1994). Desrochers et al. (2010) and Achab et al. (2011) have proposed a new stratigraphic correlation between the east and west sides of the island, showing that the siliciclastic-dominated Grindstone-Velleda members of Long and Copper $(1987,1994)$ in the eastern part of the island belong to the Vauréal Formation. The brachiopods used in this study are from the western sections of Anticosti Island and thus not affected by the stratigraphic revision. The following summary, therefore, deals mainly with the western stratigraphic succession of the island.

The fossil fauna is more diverse in the Ellis Bay Formation than the underlying Vauréal formation. Large aulacerids are common throughout this formation, with stromatoporoids being most common in the Prinsta and Laframboise members (Nestor et al. 2010). Nine genera of nautiloids have been documented from this member (Holland and Copper 2008), with most surviving into the Silurian Becscie Formation and beyond (although becoming rare in the lowest Silurian strata). Most of the brachiopods, however, do not cross the Ordovician-Silurian boundary. The orthide Mendacella (Jin and Zhan 2008) and strophomenides Eostrophonella, Coolinia, Leptaena, Aphanomena, and Sowerbyella (Dewing 1999) can be found throughout the formation but most disappear at its top. Plaesiomyids are present in all but the Laframboise Member - perhaps because of its shallower-water reefal setting.

This study includes plaesiomyids of the Grindstone and Prinsta members. Plaesiomys anticostiensis forms a major part of the Hirnantian fauna on Anticosti Island, and form part of a distinct Plaesiomys brachiopod association (Jin and Copper 2008). Other members of this association include Vellamo diversa, Archeochonetes muirwoodae, Hindella umbonata, Thaerodonta glabra, and Mendacella uberis. In the western part of the island, the Grindstone and the Velleda members are composed of micritic mudstone, wackestone, and minor packstone, and yielded nearly all the shells of Plaesiomys anticostiensis used for this study. The member contains a rich and diverse suite of fossils, 
including brachiopods, stromatoporoids, nautiloids, gastropods, and trilobites. In addition to the brachiopods found throughout the formation (above), the orthides Onniella, Ptychopleurella, Vellamo, Barbarorthis, Plaesiomys (Jin and Zhan 2008) are found in this member. Retrorsirostra can be found within the lower part of the member. This is the uppermost range of the strophomenide Furcitella on Anticosti Island (Dewing 1999). Hypsiptycha, a typical Late Ordovician rhynchonellide of North America, has its last appearance datum (LAD) in this member (Jin 1989).

The Velleda Member in the western part of Anticosti Island consists of micritic mudstones, with interbeds of shelly wackestone and packstone. Brachiopods are locally abundant, such as Mendacella, Parastrophinella, Rhynchotrema, and Rostricellula (Jin 1989; Jin and Copper 2000; Jin and Zhan 2008).

The richly fossiliferous Prinsta Member consists mainly of laminated nodular calcareous mudstones, with minor sandstone and limestone beds, and features some oncolitic and biohermal strata (Long and Copper 1987). Corals are most common, forming small patch reefs in the lower part of the member (Nestor et al. 2010), but brachiopods are also abundant. These reefs are typically dominated by domical and laminar tabulate corals along with the rugosans Cyathophyloides lyterion and Paleophyllum, and various sponges (Nestor et al. 2011). Nautiloids are associated with patch reefs and aulacerid stromatoporoid fields (Holland and Copper 2008). The orthides Siljanostrophia, Gnamptorhynchous, and Hesperorthis make their first appearance in this member (Jin and Zhan 2008). Oanduporella, a rare species of Hirnantia, and a species of Dalmanella can be found in this member only on Anticosti Island (Jin and Zhan 2008). The eastern Prinsta member is tentatively correlated to the base of the western Vauréal Formation according to Achab et al. (2011).

The Lousy Cove Member is dominantly micritic mudstone and less fossiliferous than other members of the formation. Well preserved complete crinoid fossils can be found near the top of the member in some sections (Long and Copper 1994). Brachiopods, especially Hindella, are locally abundant with less common corals and stromatoporoids (Long and Copper 1987). This is the uppermost unit Onniella, Vellamo, Barbarorthis, Plaesiomys, Siljanostrphia, Gnamptorhynchous, and Hesperorthis are 
found in, although a new species of Hesperorthis appeared in the Early Silurian on Anticosti Island (Jin and Zhan 2008). Achab et al. (2011) have correlated the eastern Lousy Cove Member to be equivalent to all but the base and uppermost western Ellis Bay Formation.

The Laframboise Member consists of two facies: a biohermal facies and an inter reef facies (Long and Copper 1994; Long 2007). The biohermal facies is dominated by corals, stromatoporoids, and calcimicrobes. Fragments of crinoids, brachiopods, gastropods, and trilobites can also be found within these distinctive reefal clusters. The inter-reefal strata are characterized as being highly bioturbated, nodular to subnodular micritic floatstone with local calcarenite grainstones, intraformational conglomerates, and oncolitic grainstone. The top of the Laframboise Member is unconformable (Long 2007), showing signs of erosion such as hard ground borings and a darkened surface indicating a sea level regression during the Early Silurian. A distinct oncolite bed is known from just below the Ordovician-Silurian boundary (Long and Copper 1987). The brachiopods Hirnantia (Jin and Zhan 2008) and Rhynchotrema (Jin 1989) can both be found in this member. Interestingly, most of the orthide genera that range through the rest of the formation disappear in this member, while the strophomenide genera are generally unchanged. Both, however, disappear at the top of this member. The brachiopod abundance seems inversely proportional to the dominance of species within the bioherms - where bioherms are abundant, fewer brachiopods are found (Jin and Zhan 2008).

The Ordovician-Silurian boundary may be located within the Laframboise Member, but its precise level has not yet been confirmed. The fossil biota supports this notion (e.g. Barnes 1988; McCracken and Nowlan 1988; Soufiane and Achab 2000; Copper 2001; Melchin 2008; Jin and Copper 2008). It has also been suggested, however, that upper Hirnantian strata are missing from the Laframboise Member based on $\delta^{13} \mathrm{C}$ values over the interval (and thus the Ordovician-Silurian boundary) (Underwood 1997; Brenchley et al. 2003), or that there is no hiatus in sedimentation and that the Ordovician-Silurian boundary is located within the lower Fox Point Member that overlies the Laframboise Member (traditionally thought to be Silurian in age) (Jones et al. 2011). Achab et al. (2011), through chitinozoan zonation and a thorough re-examination of isotope evidence, have confirmed that the Ellis Bay Formation is entirely Hirnantian, and 
that the Hirnantian may extend into the uppermost Vauréal Formation. Desrochers et al. (2010) showed that there is the expected multiple pulses of glaciation through the Ellis Bay Formation corresponding to Hirnantian glacial pulses, with one pulse in the uppermost Vauréal Formation. 


\section{References}

Achab, A., Asselin, E., Desrochers, A., Riva, J., and Farley, C. 2011. Chitinozoan biostratigarphy of a new Upper Ordovician stratigraphic framework for Anticosti Island, Canada. GSA Bulletin, 123: 186-205.

Alberstadt, L. P., 1979. The brachiopod genus Platystrophia. United States Geological Survey Professional Paper 1066-B: 1-20.

Amsden, T.W., 1973. Late Ordovician and Early Silurian articulate brachiopods from Oklahoma, southwestern Illinois, and eastern Missouri. Bulletin of the Oklahoma Geological Survey, 19: 1-154.

Armstrong, D.K. 2000. Paleozoic Geology of the Northern Lake Simcoe Area, SouthCentral Ontario - Open File Report 6011, Ontario Geological Survey. 43 pp.

Baillie, A.D. 1952. Ordovician Geology of Lake Winnipeg and Adjacent Areas, Manitoba. Manitoba Department of Mines and Natural Resources, Publication 516, $64 \mathrm{pp}$.

Bannatyne, B.B. 1988. Dolomite Resources of Southern Manitoba. Manitoba Energy and Mines, Geological Services. 38 pp.

Barnes, C.R., 1988. Stratigraphy and palaeontology of the Ordovician - Silurian boundary interval, Anticosti Island, Quebec, Canada. Bulletin of the British Museum, Natural History, Geology, Series 43, 195-219.

Barnes, C.R., Telford, P.G., and Tarrant, G.A. 1978. Ordovician and Silurian conodont biostratigraphy, Manitoulin Island and Bruce Penninsula, Ontario. In Geology of the Manitoulin Area including The Road Log to the Michigan Basin Geological Society Field Trip September 29, 30, and October 1, 1978. Edited by J.T. Sanford and R.E. Mosher. Michigan Basin Geological Society, Lansing, Michigan. p. 6371.

Beaumont, C., Quinlan, G., and Hamilton, J. 1988. Orogeny and stratigraphy: Numerical models of the Paleozoic in the eastern interior of North America. Tectonics, 7: 389416.

Bergström, S.M., Kleffner, M., Schmitz, B., and Cramer, B.D. 2011. Revision of the position of the Ordovician-Silurian boundary in southern Ontario: regional chronostratigraphic implications of $\delta 13 \mathrm{C}$ chemostratigraphy of the Manitoulin Formation and associated strata. Canadian Journal of Earth Science, 48: 14471470 .

Bolton, T.E. 2000. Ordovician megafauna, southern Baffin Island, Nunavut. In Geology and paleontology of the southeast Arctic Platform and southern Baffin Island, Nunavut - Geological Survey of Canada Bulletin 557. Edited by A.D. McCracken and T.E. Bolton. Geological Survey of Canada, Ottawa, Ontario. p. 39-77.

Brenchley, P.J., Carden, G.A., Hints, L., Kaljo, D., Marshall, J.D., Matma, T., Meidla, T., and Nõlvak, J. 2003. High-resolution stable isotope stratigraphy of Upper Ordovician sequences: Constraints on the timing of bioevents and environmental changes associated with mass extinction and glaciation. GSA Bulletin, 115: 89- 
104.

Brookfield, M.E. 1988. A mid-Ordovician temperate carbonate shelf - the Black River and Trenton Limestone Groups of southern Ontario, Canada. Sedimentary Geology, 60: 137-153.

Brookfield, M.E. and Brett, C.E. 1988. Paleoenvironments of the Mid-Ordovician (Upper Caradocian) Trenton limestones of southern Ontario, Canada: Storm sedimentation on a shoal-basin shelf model. Sedimentary Geology, 57: 75-105.

Burgess, P.M. 2008. Phanerozoic Evolution of the Sedimentary Cover of the North American Craton. In Sedimentary Basins of the World: Sedimentary Basins of the United States and Canada. Edited by A.D. Miall (K.J. Hsü series editor). Elsevier, Amsterdam, Netherlands and Oxford U.K. p. 31-64.

Coakley, B. and Gurnis, M. 1995. Far-field tilting of Laurentia during the Ordovician and constraints on the evolution of a slab under an ancient continent. Journal of Geophysical Research, 100: 6313-6327.

Cocks, L.R.M., and J.-Y. Rong, 1989. Classification and review of the brachiopod superfamily Plectambonitacea. Bulletin of the British Museum of Natural History (Geology), 45: 77-163.

Cocks, L.R.M. and Torsvik, T.H. 2011. The Palaeozoic geography of Laurentia and western Laurussia: A stable craton with mobile margins. Earth Science Reviews, 106: $1-51$.

Coniglio, M. and Williams-Jones, A.E. 1992. Diagenesis of Ordovician carbonates from the north-east Michigan Basin, Manitoulin Island area, Ontario: evidence from petrography, stable isotopes and fluid inclusions. Sedimentology, 39: 813-836.

Copper, P., 1977. Zygospira and some related Ordovician and Silurian atrypid brachiopods. Palaeontology 20: 295-335.

Copper, P. 1978. Paleoenvironments and paleocommunities in the Ordovician-Silurian sequence of Manitoulin Island. In Geology of the Manitoulin Area including the Road Log to the Michigan Basin Geological Society Field Trip September 29, 30, and October 1, 1978. Edited by J.T. Sanford and R.E. Mosher. Michigan Basin Geological Society, Lansing, Michigan. p. 47-61.

Copper, P. 2001. Reefs during the multiple crises towards the Ordovician-Silurian boundary: Anticosti Island, eastern Canada, and worldwide. Canadian Journal of Earth Sciences, 38: 153-171.

Cumings, E.R. 1907. The Stratigraphy and Paleontology of the Cincinnati Series of Indiana. In Indian Department of Geology and Natural Resources, Thirty-Second Annual Report. p. 606-1189.

Davis, R.A. 1985. Cincinnati fossils, an elementary guide to the Ordovician rocks and fossils of the Cincinnati, Ohio, region. Cincinnati Museum of Natural History Popular Publications Series, 10. 60 pp.

Desrochers, A., Farley, C., Achab, A., Asselin, E., and Riva, J.F. 2010. A far-field record of the end Ordovician glaciation: The Ellis Bay Formation, Anticosti Island, 
Eastern Canada. Palaeogeography, Palaeoclimatology, Palaeoecology, 296: 248263.

Dewing, K. 1999. Late Ordovician and Early Silurian strophomenid brachiopods of Anticosti Island, Québec, Canada. Palaeontographica Canadiana No 17. Canadian Society of Petroleum Geologists and the Geological Association of Canada. McAra Printing, Calgary. 143 pp.

Douglas, R.J.W., and Norris, D.K. 1961. Camsell Bend and Root River map-areas, District of Mackenzie, Northwest Territories, Geological Survey of Canada Paper 61-13. Geological Survey of Canada, Ottawa, Ontario. 36 pp.

Elias, R.J. 1991. Environmental cycles and bioevents in the Upper Ordovician Red River-Stony Mountain solitary rugose coral province of North America. In Advances in Ordovician Geology, Geological Survey of Canada, Paper 90-9. Edited by C.R. Barnes and S.H. Williams. Geological Survey of Canada, Ottawa, Calgary, and Vancouver. p. 205-212.

Elias, R.J., Nowlan, G.S., and Bolton, T.E. 1988. Paleontology of the type section, Fort Garry Member, Red River Formation (Upper Ordovician) southern Manitoba. New Mexico Bureau of Mines and Mineral Resources Memoir 44, 341-359.

Ernst, A. and Munnecke, A. 2009. A Hirnantian (latest Ordovician) reefal bryozoan fauna from Anticosti Island, eastern Canada: taxonomy and chemostratigraphy. Canadian Journal of Earth Sciences, 46: 207-229.

Fisher, J.H., Barratt, M.W., Droste, J.B., and Shaver, R.H. 1988. Michigan basin. In Sedimentary cover - North American craton. Edited by L.L. Sloss. Geological Society of America, Boulder, Colorado. p. 361-381.

Foerste, A.F. 1905. The classification of the Ordovician Rocks of Ohio and Indiana. Science (New Series), 22: 149-152.

Frey, R.C. 1987. The paleoecology of a Late Ordovician shale unit from southwest Ohio and southeastern Indiana. Journal of Paleontology, 61: 242-267.

Gabrielse, H., Blusson, S.L., and Roddick, J.A. 1973. Geology of Flat River, Glacier Lake, and Wrigley Lake map-areas, District of Mackenzie and Yukon Territory, Part I: General geology, structural geology, and economic geology, Geological Survey of Canada Memoir 366. Geological Survey of Canada, Ottawa, Ontario. 153 pp.

Grimwood, J.L, Coniglio, M., and Armstrong, D.K. 1999. Blackriveran carbonates from the subsurface of the Lake Simcoe area, southern Ontario: stratigraphy and sedimentology of a low energy carbonate ramp. Canadian Journal of Earth Science, 36: $871-889$.

Hall, D. D., 1962. Dalmanellidae of the Cincinnatian. Palaeontographica Americana, 4: 131-165.

Haq, B.U. and Schutter, S.R. 2008. A Chronology of Paleozoic Sea-Level Changes. Science, 322: 64-68.

Hendricks, M.L., Eisel, J.D., and Fischer, W. 1998. Deadwood and Winnipeg sandstone reservoirs, Newporte Field, Renville County, North Dakota. In $8^{\text {th }}$ International 
Williston Basin Symposium Core Workshop Volume. Presented by M.L Hendricks, R.J. Vinopal, W.A. Whiteman, K.L. Canter, R. Inden, D.M. Kent, and K.M.

Bergman. Saskatchewan, North Dakota, and Montana Geological Societies. p. 1-8.

Holland, C.H. and Copper, P. 2008. Ordovician and Silurian nautiloid cephalopods from Anticosti Island: traject across the Ordovician-Silurian (O-S) mass extinction boundary. Canadian Journal of Earth Sciences, 45: 1015-1038.

Holland, S.M and Patzkowsky, M.E. 1996. Sequence Stratigraphy and Long-Term Paleoceanographic Change in the Middle and Upper Ordovician of the Eastern United States. In Paleozoic Sequence Stratigraphy - Geological Society of America Special Paper 306. Edited by B.J. Witzke, G.A. Ludvigson, and J. Day. Geological Society of America, Boulder, Colorado. pp. 117-130.

Holland, S.M. and Patzkowsky, M.E. 2007. Gradient ecology of a biotic invasion: Biofacies of the type Cincinnatian series (Upper Ordovician), Cincinnati, Ohio, region, USA. Palaios, 22: 392-407.

Howe, H. J., 1979. Middle and Upper Ordovician plectambonitacean, rhynchonellacean, syntrophiacean, trimerellacean, and atrypacean brachiopods. United States Geological Survey Professional Paper 1066-C:1-18.

Jackson, D.E. and Lenz, A.C. 1962. Zonation of Ordovician and Silurian graptolites of northern Yukon, Canada. Bulletin of the American Association of Petroleum Geologists, 46: 30-45.

Jin, J. 1989. Late Ordovician - Early Silurian rhynchonellid brachiopods from Anticosti Island, Quebec. Biostratigraphie du Paleozoique no. 10. 127 pp.

Jin, J. 2001. Evolution and extinction of the North American Hiscobeccus brachiopod Fauna during the Late Ordovician. Canadian Journal of Earth Sciences, 38: 143151.

Jin, J. 2012. Cincinnetina, a new Late Ordovician dalmanellid brachiopod from the Cincinnati type area, USA: implications for the evolution and palaeogeography of the epicontinental fauna of Laurentia. Palaeontology, 55: 205-228.

Jin, J. and Chatterton, B.D.E. 1997. Latest Ordovician-Silurian articulate brachiopods and biostratigraphy of the Avalanche Lake area, southwestern District of Mackenzie, Canada. Palaeontographica Canadiana No. 13, Canadian Society of Petroleum Geologists and the Geological Association of Canada. McAra Printing, Calgary, Alberta. 167 pp.

Jin, J. and Copper, P. 2000. Late Ordovician and Early Silurian pentamerid brachiopods from Anticosti Island, Québec, Canada. Palaeontographica Canadiana No. 18. Canadian Society of Petroleum Geologists and the Geological Association of Canada. McAra Printing, Calgary, Alberta. 140 pp.

Jin, J. and Zhan, R. 2001. Late Ordovician articulate brachiopods from the Red River and Stony Mountain Formations, southern Manitoba. NRC Research Press, Ottawa. 117 pp.

Jin, J. and Copper, P. 2008. Response of brachiopod communities to environmental 
change during the Late Ordovician mass extinction interval, Anticosti Island, eastern Canada. Fossils and Strata, 54: 41-51.

Jin, J. and Zhan, R. 2008. Late Ordovician Orthide and Billingsellide Brachiopods from Anticosti Island, Eastern Canada: Diversity Change through Mass Extinction. NRC Research Press, Ottawa. $151 \mathrm{pp}$.

Jin, J., Harper, D.A.T., Rasmussen, J.A. and Sheehan, P.M. 2011. Late Ordovician massive-bedded Thalassinoides ichnofacies along the palaeoequator of Laurentia.

Palaeogeography, Palaeoclimatology, Palaeoecology. doi:10.1016/j.palaeo.2011.05.023.

Jones, D.S., Fike, D.A., Finnegan, S., Fischer, W.W., Schrag, D.P., and McCay, D. 2011. Terminal Ordovician carbon isotope stratigraphy and glacioeustatic sea-level change across Anticosti Island (Quebec, Canada). GSA Bulletin, 123: 1645-1664.

Kent, D.M. and Christopher, J.E. 1994. Chapter 27 - Geological History of the Williston Basin and Sweetgrass Arch. In Geological Atlas of the Western Canada Sedimentary Basin. Compiled by G. Mossop and I. Shetsen. Canadian Society of Petroleum Geologists and the Alberta Research Council, Calgary, Alberta. p. 421430.

Kolata, D.R., Huff, W.D. and Bergström, S.M. 1996. Ordovician K--bentonites of eastern North America, Geological Society of America, Special Paper 313. 84 pp.

Last, W. and Shum, W.W. 1991. Diagenesis of the Winnipeg Formation in Manitoba: A regional petrographic study. In Sixth International Williston Basin Symposium, Special Publication 11, Saskatcheawn Geologcial Society. Edited by J.E. Christopher and F.M. Haidl. Saskatchewan Geological Society, Regina, Saskatchewan. pp.14-20.

Liberty, B.A. 1968. Ordovician and Silurian Stratigraphy of Manitoulin Island, Ontario. Michigan Basin Geological Society Annual Field Conference Guidebook. Michigan Basin Geological Societ, Lansing, Michigan. pp. 25-37.

Liberty, B.A. 1969. Palaeozoic geology of the Lake Simcoe area, Ontario - Geological Survey of Canada Memoir 355. Geological Survey of Canada, Ottawa, Ontario. pp. 1-201.

Long, D.G.F. 2007. Tempestite frequency curves: a key to Late Ordovician and Early Silurian subsidence, sea-level change, and orbital forcing in the Anticosti foreland basin, Canada. Canadian Journal of Earth Sciences, 44: 413-431.

Long, D.G.F. and Copper, P. 1987. Stratigarphy of the Upper Ordovician Vaureal and Ellis Bay formations, eastern Anticosti Island, Quebec. Canadian Journal of Earth Sciences, 24: 1807-1820.

Long, D.G.F. and Copper, P. 1994. The Late Ordovician-Early Silurian Carbonate tract of Anticosti Island, Gulf of St. Lawrence, Eastern Canada. Joint Annual Meeting of the Geological Association of Canada and Mineralogical Association of Canada Field Trip B4 Guidebook. 69 pp.

Longman, M.W. and Haidl, F.M. 1996. Cyclic Deposition and Development of Porous 
Dolomites in the Upper Ordovician Red River Formation, Williston Basin. In Paleozoic Systems of the Rocky Mountain Region. Edited by M.W. Longman and M.D. Sonnenfeld. Rocky Mountain Section - Society for Sedimentary Geology (SEPM), Denver, Colorado. p. 29-46.

Ludvigsen, R. 1975. Ordovician Formations and Faunas, Southern Mackenzie Mountains. Canadian Journal of Earth Science, 12: 663-697.

Macauley, G., Fowler, M.G., Goodarzi, F., Snowdon, L.R., and Stasiuk, L.D. 1990. Ordovician oil-shale source rock sediments in the central and eastern Canada mainland and eastern Arctic areas, and their significance for frontier exploration, Geological Survey of Canada, Paper 90-14. Geological Survey of Canada, Ottawa, Ontario. $51 \mathrm{p}$.

McCracken, A.D., Nowlan, G.S., 1988. The Gamachian stage and Fauna 13. New York State Museum Bulletin 462, 71- 79.

McCracken, A.D. 2000. Middle and Late Ordovician conodonts from the Foxe Lowland of Southern Baffin Isalnd, Nunavut. In Geology and paleontology of the southeast Arctic Platform and southern Baffin Island, Nunavut - Geological Survey of Canada Bulletin 557. Edited by A.D. McCracken and T.E. Bolton. Geological Survey of Canada, Ottawa, Ontario. p. 159-216.

Melchin, M.J. 1990. Lithostratigraphy and biostratigraphy. In Stratigraphy, sedimentology and biostratigraphy of the Ordovician rocks of the PeterboroughLake Simcoe area, southern Ontario. American Association of Petroleum Geologists Eastern Section Meeting, Field Trip No. 3 Guide Book, September, 1990. Edited by M. Coniglio, M.J. Melchin, and M.E. Brookfield. American Association of Petroleum Geologists, Tulsa, Oklahoma. p. 9-33.

Melchin, M.J. 1994. Lithostratigraphy and biostratigraphy. In Stratigraphy, Sedimentology and Biostratigraphy of the Ordovician Rocks of the Lake Simcoe Area, South-Central Ontario. Edited by M.J. Melchin, M.E. Brookfield, D.K. Armstrong, and M. Coniglio. Joint Annual Meeting of the Geological Association of Canada and Mineralogical Association of Canada Field Trip A4 Guidebook. p. 9-33.

Melchin, M.J. 2008. Restudy of some Ordovician-Silurian boundary graptolites from Anticosti Island, Canada, and their biostratigraphic significance. Lethaia, 41: 155162.

Mitchell, C.E. and Sweet, W.C. 1989. Upper Ordovician conodonts, brachiopods, and chronostratigarphy of the Whittaker Formation, southwestern District of Mackenzie, N.W.T., Canada. Canadian Journal of Earth Sciences, 26: 74-87.

Nestor, H., Copper, P. and Stock, C.W. 2010. Late Ordovician and Early Silurian stromatoporoid sponges from Anticosti Island, eastern Canada: crossing the $\mathrm{O} / \mathrm{S}$ mass extinction boundary. NRC Research Press, Ottawa. 163 pp.

Nickles, J.M. 1903. The Richmond Group in Ohio and Indiana and its subdivisions, with a note on the genus Strophomena and its type. The American Geologist, October: 202-218. 
Norford, B.S., Haidl, F.M., Bezys, R.K., Cecile, M.P., McCabe, H.R., and Paterson, D.F. 1994. Chapter 9 - Middle Ordovician to Lower Devonian Strata of the Western Canada Sedimentary Basin. In Geological Atlas of the Western Canada Sedimentary Basin. Compiled by G. Mossop and I. Shetsen. Canadian Society of Petroleum Geologists and the Alberta Research Council, Calgary, Alberta. p. 109128.

O'Bertos, E. and Jackson, D.E. 1963. Age of the Whittaker Formation, Northwest Territories. Bulletin of Canadian Petroleum Geology, 11: 27-32.

Patton, J.B., Perry, T.G., and Wayne, W.J. 1953. Ordovician stratigraphy, and physiography of part of southwestern Indiana - Field Conference Guidebook No. 6. Indiana Department of Conservation, Geological Survey. 36 p.

Patzkowsky, M.E. and Holland, S.M. 1997. Patterns of turnover in Middle and Upper Ordovician brachiopods of eastern United States: a test of coordinated stasis. Paleobiology, 23:420-443.

Pope, J. K., 1982. Some silicified strophomenacean brachiopods from the Ordovician of Kentucky, with comments on the genus Pionomena. United States Geological Survey Professional Paper 1066-L:1-30.

Risk, M.J. and Liberty, B.A. 1978. Paleoecological observations on Manitoulin Island. In Geology of the Manitoulin Area including The Road Log to the Michigan Basin Geological Society Field Trip September 29, 30, and October 1, 1978. Edited by J.T. Sanford and R.E. Mosher. Michigan Basin Geological Society, Lansing, Michigan. p. 29-30.

Riva, J., 1988, Graptolites at and below the Ordovician-Silurian boundary on Anticosti Island, Canada: Bulletin of the British Museum, Natural History, Geology Series, v. 43, p. 221-237.

Rudkin, D.M., Young, G.A., and Nowlan, G.S. 2008. The oldest horseshoe crab: A new xiphosurid from Late Ordovician konservat-lagerstätten deposits, Manitoba, Canada. Palaeontology, 51:1-9.

Russell, D.J. and Telford, P.G. 1983. Revisions to the stratigraphy of the Upper Ordovician Collingwood beds of Ontario - a potential oil shale. Canadian Journal of Earth Science, 20: 1780-1790.

Sanford, J.T. 1978. General Stratigraphy of the Manitoulin Island Area. In Geology of the Manitoulin Area including The Road Log to the Michigan Basin Geological Society Field Trip September 29, 30, and October 1, 1978. Michigan Basin Geological Society, Lansing, Michigan. p. 31-42.

Sanford, B.V. 1993a. St. Lawrence Platform - Introduction; Chapter 10. In Sedimentary Cover of the Craton in Canada - Geology of Canada No. 5 (Geology of North America D-1). Edited by D.F. Stott and J.D. Aitken. Geological Survey of Canada, Ottawa, Ontario. p. 711-722.

Sanford, B.V. 1993b. St. Lawrence Platform - Geology; Chapter 11. In Sedimentary Cover of the Craton in Canada - Geology of Canada No. 5 (Geology of North America D-1). Edited by D.F. Stott and J.D. Aitken. Geological Survey of Canada, 
Ottawa, Ontario. p. 725-786.

Sanford, B.V. and Grant, A.C. 1990. New findings related to the stratigraphy and structure of the Hudson Platform. In Current Research, Part D, Geological Survey of Canada Paper 90-1D. Geological Survey of Canada, Ottawa, Ontario. p. 17-30.

Sanford, B.V. and Grant, A.C. 2000. Geological framework of the Ordovician system in the southeast Arctic platform, Nunavut. In Geology and paleontology of the southeast Arctic Platform and southern Baffin Island, Nunavut - Geological Survey of Canada Bulletin 557. Edited by A.D. McCracken and T.E. Bolton. Geological Survey of Canada, Ottawa, Ontario. p. 13-38.

Schwimmer, B.A., and M.R. Sandy, 1996. Phylum Brachiopoda. In R.M. Feldman and M. Hackathorn (eds.), Fossils of Ohio. Ohio Division of Geological Survey Bulletin 70, p. 210-241.

Soufiane, A. and Achab, A. 2000. Chitinozoan zonation of the Late Ordovician and Early Silurian of the island of Anticosti, Quebec, Canada. Review of Palaeobotany and Palynology, 109: 85-111.

Tremblay, J.V. and Westrop, S.R. 1991. Middle Ordovician (Whiterockian) Trilobites from the Sunblood Formation, District of Mackenzie Canada. Journal of Paleontology, 65: 801-824.

Underwood, C.J., Crowley, S.F., Marshall, J.D., and Brenchley, P.J. 1997. HighResolution carbon isotope stratigraphy of the basal Silurian Stratotype (Dob`s Linn, Scotland) and its global correlation. Journal of the Geological Society, 154: 709718.

Walker, L. G., 1982. The brachiopod genera Hebertella, Dalmanella, and Heterorthina from the Ordovician of Kentucky. United States Geological Survey Professional Paper 1066-M:1-16.

Wigington, R.J.S. 1977. The age and orthid fauna of the Lower Whittaker Formation, southern Mackenzie Mountains, Northwest Territories. MSc. Thesis, Department of Geology, University of Western Ontario, London, Ontario. 147 pp.

Young, G.A., Rudkin, D.M., Dobrzanski, E.P., Robson, S.P., and Nowlan, G.S. 2007. Exceptionally preserved Late Ordovician biotas from Manitoba, Canada. Geology, 35: $883-886$.

Young, G.A., Elias, R.J., Wong, S., and Dobrzanski, E.P. 2008. Upper Ordovician Rocks and Fossils in Southern Manitoba, Canadian Paleontology Conference Field Trip Guidebook No. 13. Geological Association of Canada Publications, 97 pp 


\section{Chapter 3 - Systematic Paleontology}

Note: This chapter follows the standard systematic paleontology format as seen in paleontology journals, as it would be difficult and time consuming to change the chapter to the standard thesis format.

Specimens figured in this study are in the following repositories: Field Museum, Chicago, Illinois (FM); Geological Survey of Canada (GSC); and the Paleontology Laboratory at Western University, London, Ontario (W).

\section{Order ORTHIDA Schuchert and Cooper, 1932 Suborder Orthidina Schuchert and Cooper, 1932 Superfamily Orthoidea Woodward, 1852 Family Plaesiomyidae Schuchert, 1913 Subfamily Plaesiomyinae Schuchert, 1913}

\section{Remarks}

The two most common genera of the Plaesiomyinae are Dinorthis and the type genus, Plaesiomys. Hall and Clarke (1892) were the first to establish the separate genera, with Dinorthis representing simple costate forms and Plaesiomys representing multicostellate forms. This division led to confusion over the 20th century, as it has been found that the forms represent two end members on a morphological gradient. Many of the early works of the 20th century considered Plaesiomys as a subgenus of Dinorthis (e.g. Ladd 1929; Ross 1957). Schuchert and Cooper (1932) treated Dinorthis as a subgenus of Plaesiomys. Wang (1949) suggested that only those specimens that show no rib multiplication should be named Dinorthis, and specimens showing any degree of rib multiplication should be considered Plaesiomys. Since the 1950s, specimens were generally named as either Plaesiomys or Dinorthis, but the names remained somewhat ambiguous. Macomber (1970) attempted to address this taxonomic confusion, 
recognizing that these two genera formed a continuous morphological gradient, suggesting that Dinorthis be confined to species with little to no rib multiplication and Plaesiomys include species that were fully multicostellate, as there were more noticeable morphological differences between those specimens that were both fully multicostellate and partially multicostellate, compared to those that are partially multicostellate and costate.

More recently, Jin and Zhan (2001) separated the genera based on other features. They noted that the late Katian (Richmondian) species commonly assigned to Dinorthis, such as D. occidentalis (Okulitch, 1943), possessed an enlarged trilobed cardinal process while Plaesiomys generally had a bilobed cardinal process. Also, the ventral muscle scars of Dinorthis were prominently bilobed with a strong medial notch at the anterior of the muscle field while Plaesiomys has scalloped ventral muscle scars with inconspicuous anterior bilobation (Jin and Zhan 2001).

This scheme was still not ideal, as Plaesiomys carletona of the Vauréal Formation on Anticosti Island (late Katian, Richmondian) closely resembled Dinorthis occidentalis of the late Katian (Richmondian) intracratonic seas of Laurentia in terms of shell ornamentation, and possessed a similar trilobed cardinal process (Jin and Zhan 2008). A second issue arises when considering the division between the multicostellate forms, and forms which show some rib multiplication but are not truly multicostellate - what degree of rib multiplication makes a shell truly multicostellate, and what if some specimens in a given population are truly multicostellate and some are not?

In this study, the classification of Wang (1949) is followed. All of the late Katian, Dinorthis forms, in the sense of Macomber's (1970) classification (e.g. see Plaesiomys occidentalis below), are morphologically more similar to Plaesiomys than to the earlier Dinorthis forms from the eastern United States (e.g. D. pectinella; see Hall 1847 for illustrations of the type specimens). These earlier species are typically smaller, and show no rib multiplication.

Epipunctae are thought to be a diagnostic feature of the Plaesiomyidae, and have been confirmed thus far in Dinorthis, Plaesiomys, and Retrorsirostra (Jin et al. 2007; Jin and Zhan 2008; Jin and Copper 2010). In this study, their presence in Austinella is 
reported for the first time, further supporting the notion of its synapomorphic nature for the plaesiomyid family. These microscopic perforations are found on the outer surface of the shell connected to long, oblique tubules that penetrate the outer layers of the shell. Unlike true punctae, they do not completely penetrate the shell wall. Much larger and sparser perforations, known as aditicules, are typically found along the crests on the shell surface. Both of these features have contained preserved setae in other well preserved plaesiomyid specimens near the shell margin, which likely had a sensory function (Jin et al. 2007; Jin and Zhan 2008; Jin and Copper 2010). Further study is needed to confirm the presence of epipunctae in the remaining plaesiomyid genera, but it seems likely that epipunctae are diagnostic at least at the subfamily level. The other subfamilies (Evenkininae - Sandbian to Katian, Siberia, and Metorthinae - Floian to Darriwilian, China; Williams and Harper 2000) have yet to be examined.

\section{Genus Plaesiomys Hall and Clarke, 1892}

\section{Type species}

Orthis subquadrata Hall, 1892. Richmond Group, Richmondian, Ohio (see Howe 1966 for discussion on type specimens).

\section{Remarks}

Plaesiomys is found across the Northern Hemisphere, common in rocks of Katian to Hirnantian age (Chatfieldian to Gamachian; Williams and Harper 2000), with several early forms from as early as the Darriwilian (Willard 1926; Cooper 1956). During its peak diversity and abundance in the Richmondian (late Katian), Plaesiomys was most common in subtropical pericratonic shelf settings, sometimes associated with Austinella (below). In Canada, the genus has been found on Anticosti Island of Quebec (Shaler 1865; Twenhofel 1914, 1928; Bolton 1972; Bolton 1981; Jin and Copper 2008; Jin and Zhan 2008), Baffin Island (Roy 1941; Bolton 2000), the Hudson Bay Lowlands (Jin et al. 1997); the Mackenzie Mountains (Ludvigsen 1975; Wigington 1977; Jin and Chatterton 
1997), southern Manitoba (Okulitch 1943; Jin et al. 1997; Jin and Zhan 2001; Young et al. 2008), Ontario (Wilson, 1946; Liberty 1969), and the Rocky Mountains in British Columbia (Wilson 1926; Norford 1962; Jin and Norford 1996). Occurrences in the United States include Illinois (Witzke et al. 1997), Iowa (Ladd 1929; Wang 1949), Minnesota (Bayer 1967), Montana (Ross 1957), Nevada (Ross et al. 1979; Sheehan and Harris 1997), New York (Emmons 1842; Hall 1847; Hall and Clarke 1892), the OhioKentucky-Indiana tri-state area (Shaler 1876; Davis 1985; Holland and Patzkowsky 2007), Oklahoma (Alberstadt 1973), Tennessee (Willard 1926; Cooper 1956; Howe 1988), Texas (Howe 1966), and Wyoming (Macomber 1970). Elsewhere, Plaesiomys has been documented in Ireland (Wright 1964), the Baltic region (Paškevicius 1994; Hints and Harper 2003), Kazakhstan (Popov et al. 2000), and Scotland (Harper 1979). This study focused only on species from North America, where the genus was most abundant and diverse.

Unlike most of the other late Katian brachiopod genera, Plaesiomys survived the first pulse of the Late Ordovician mass extinction event at the beginning of the Hirnantian, as P. anticostiensis was a relatively common component of the Hirnantian fauna on Anticosti Island (Jin and Zhan 2008). This may have been due to several adaptations that allowed this species to survive during the glacial interval (see Chapter 4). Plaesiomys became extinct at the Ordovician-Silurian boundary.

\section{Species examined in this study}

Dinorthis browni Wilson, 1946; Fig. 3.1 A-Q (transferred to Plaesiomys in this study) Southern Ontario; early Katian (Chatfieldian).

Dinorthis columbia Wilson, 1926, Fig. 3.2 A-I

British Columbia (Wilson 1926), Northwest Territories (Wigington 1977); late Katian (Richmondian).

Dinorthis occidentalis (Okulitch, 1943); Figure 3.3 A-P

Manitoba (Okulitch 1943; Jin et al. 1997; Jin and Zhan 2001; Jin et al. 2007), Montana (Ross 1957; Macomber 1970); Richmondian (late Katian). 
Orthis anticostiensis (Shaler, 1865); Figure 3.4 A-O

Quebec (Billings 1862; Shaler 1865, 1876; Twenhofel 1914, 1928; Schchert and Cooper 1932; Bolton 1972, 1981; Jin et al. 2007; Jin and Zhan 2008); Hirnantian (Gamachian).

Orthis subcircularis (Roy, 1941); Figure 3.5 A-K

Ontario (new occurrence), Nunavut (Roy 1941; Bolton 2000); early to mid Katian

(Chatfieldian to Maysvillian).

Orthis subquadrata (Hall, 1847); Figure 3.5 L-T

British Columbia (Jin and Norford 1996), Ohio-Kentucky-Indiana tri-state area (Hall 1847, Meek 1873, Jin et al. 2007), Oklahoma (Alberstadt 1973), Northwest Territories (Wigington 1977); mid to late Katian (Maysvillian to Richmondian).

Plaesiomys bellistriatus Wang, 1949; Figure 3.6 A-J

Ohio, Kentucky, Indiana, Illinois (Wang 1949), Oklahoma (Howe 1966; Alberstadt 1973), Northwest Territories (Wigington 1977), Tennessee (Howe 1988); late Katian (Richmondian).

\section{New species assigned to Plaesiomys in this study}

Plaesiomys periosa n. sp. (also see Wigington, 1977), Figure 3.7 A-I

Northwest Territories (Wigington 1977); late Katian (Richmondian).

Plaesiomys lenzi. n. sp. (also see Wigington, 1977), Figure 3.8 A-J

Northwest Territories (Wigington 1977) late Katian (Richmondian).

Plaesiomys cf. P. bellistriatus, Figure 3.8 K-O

Indiana; late Katian (Richmondian). 


\section{Figure 3.1}

\section{A-Q: Plaesiomys browni (Billings, 1865)}

A: GSC 1620, holotype - ventral view. Trentonian Formation (equivalent to the Simcoe Group) at Belleville, Ontario.

B: GSC 6391, paratype - dorsal view. Hull or Sherman Fall beds (approximately equivalent to the Verulam Formation), north of west red brick house, Ange gardien road, 4 miles $(=6.4 \mathrm{~km})$ west of L'original, Ontario.

C-G: W-MI A - dorsal, ventral, lateral, anterior, and posterior views showing characteristic rib intercalation and bifurcation pattern on the dorsal and ventral valves respectively - ribs multiply close the shell margin. Verulam Formation, Manitoulian Island, Ontario.

H-L: W-MI 1 - dorsal, ventral, lateral, anterior, and posterior views. Same formation and locality.

M-Q: W-MI B - dorsal, ventral, lateral anterior, and posterior views. Same formation and locality. 

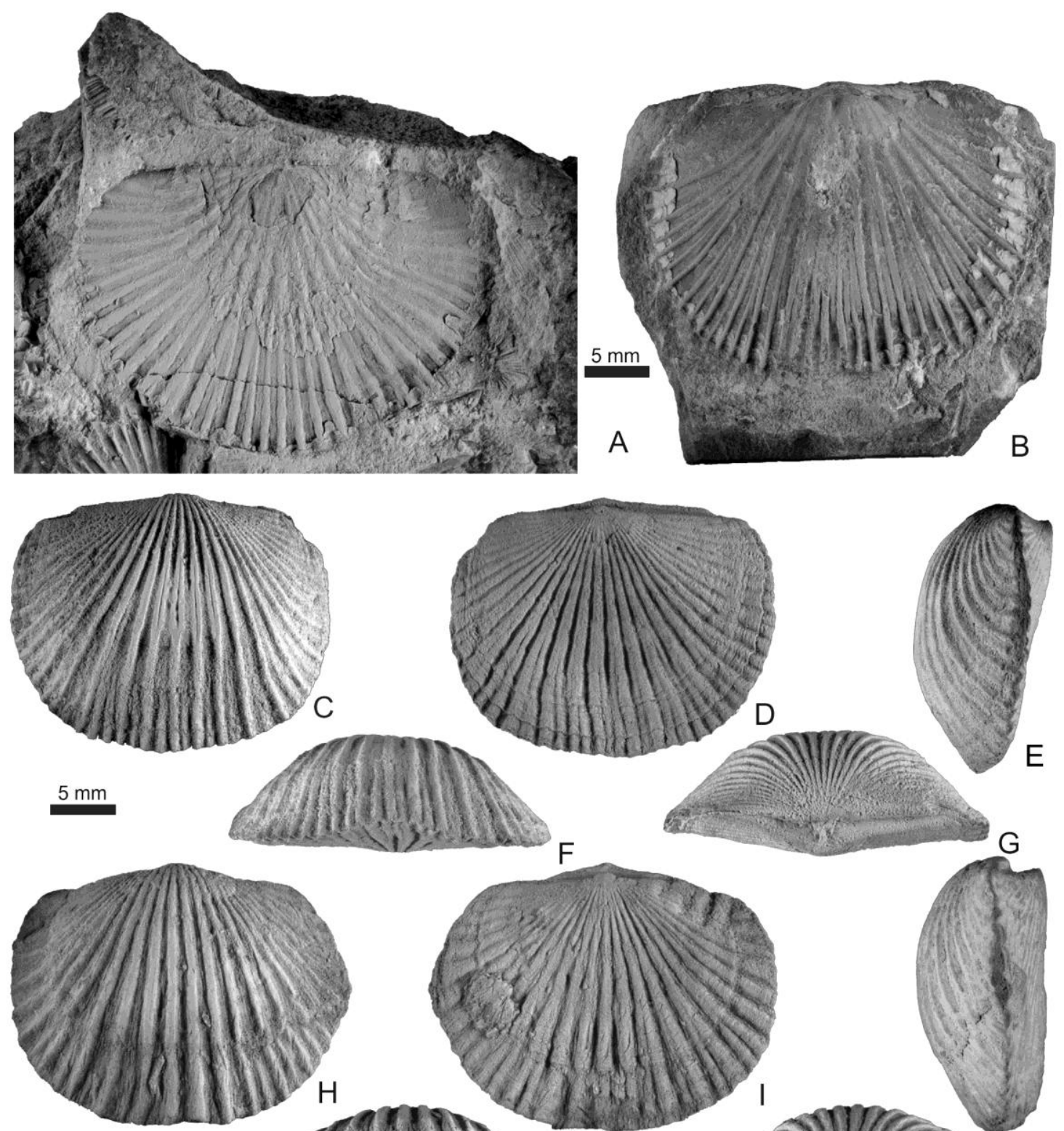

$5 \mathrm{~mm}$
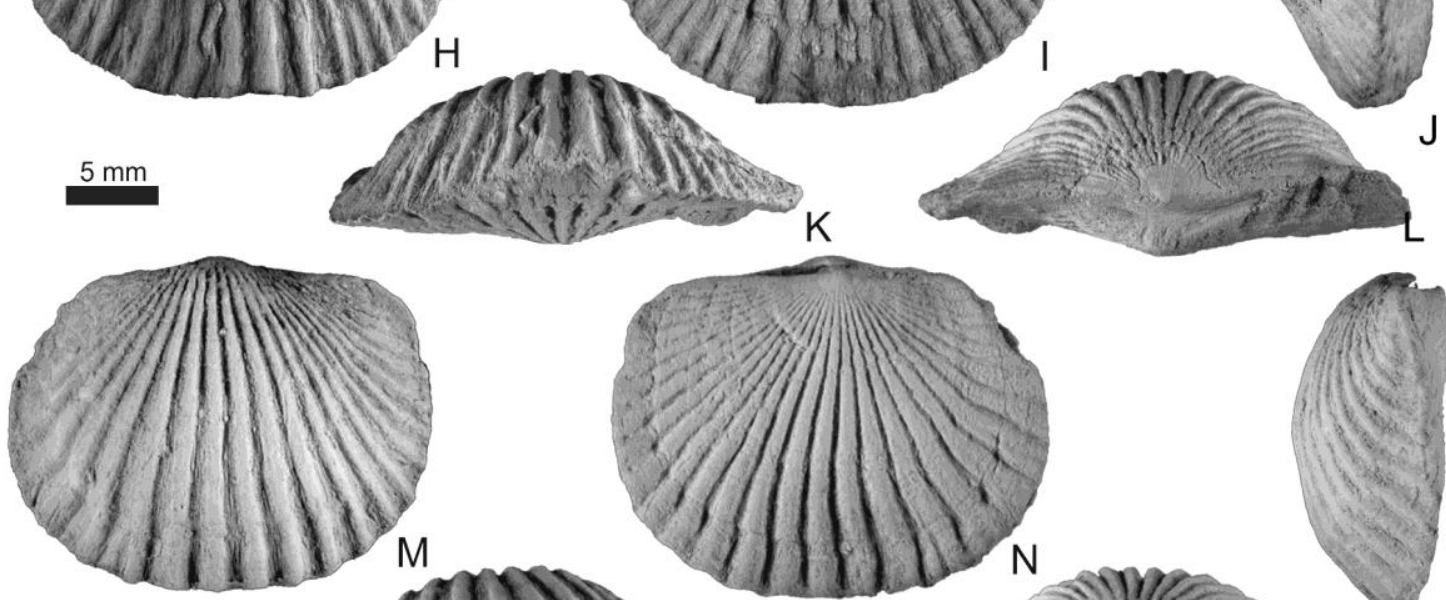

$5 \mathrm{~mm}$
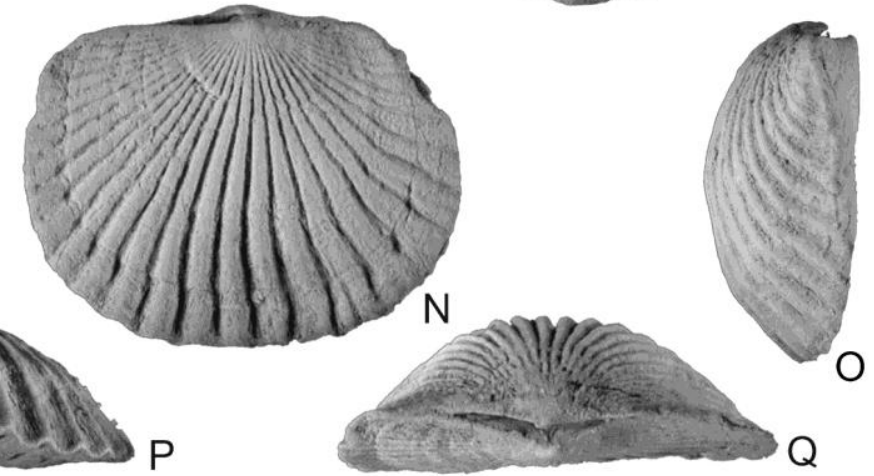


\section{Figure 3.2}

\section{A-I: Plaesiomys columbia (Wilson, 1926)}

A-E: Specimen from Wigington's collection at Western University - dorsal, ventral, anterior, posterior, and lateral views. Note the large size of these specimens in comparison to most other plaesiomyids and characteristic coarse ribs. Locality LZ 26, 245' (=75 m), Whittaker Formation, Mackenzie Mountains, Northwest Territories.

F-I: Specimen from Wigington's collection at Western University - dorsal, ventral, anterior, and lateral views. Locality LZ 26, 245' (=75 m), Whittaker Formation, Mackenzie Mountains, Northwest Territories. 

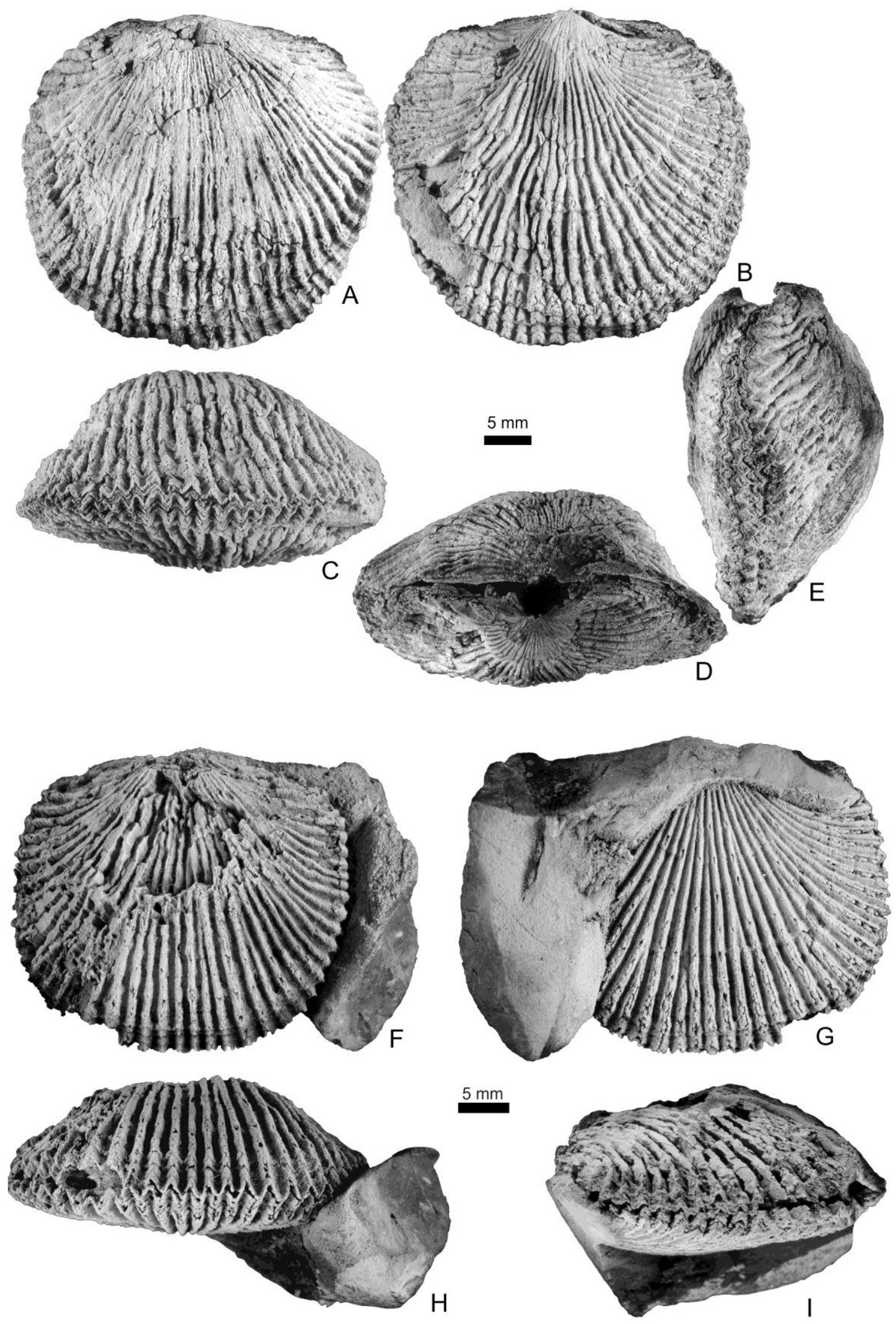


\section{Figure 3.3}

\section{A-P Plaesiomys occidentalis (Okulitch, 1943)}

A-E: GSC 117745, hypotype - dorsal, ventral, lateral, anterior, and posterior views. Gunn Member, Stony Mountain Formation, Stony Mountain, Manitoba.

F-L: GSC 117746, hypotype - dorsal, ventral, lateral, anterior, posterior views, with an enlargement of the posterior showing trilobed cardinal process and open deltrhyrium, and an enlargement of the anterior showing additicules on crests of ribs.

M-N: GSC 108994, hypotype - interior of dorsal valve and enlargement showing trilobed cardinal process with prominent central ridge of the myphore and brachiophores.

O-P: GSC 117747, hypotype - interior of ventral valve showing muscle field with wellpreserved adductor and diductor scars and teeth. 


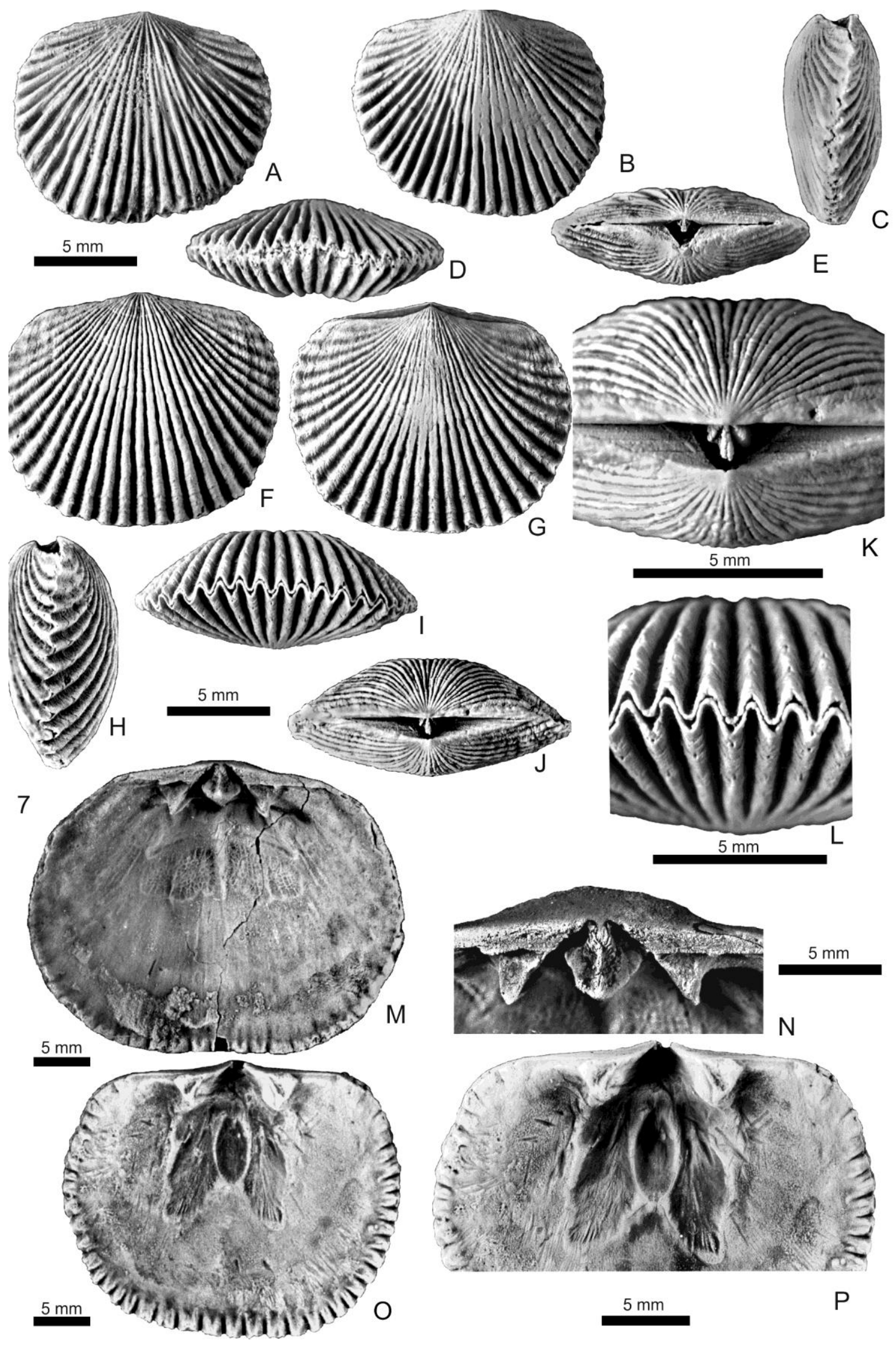




\section{Figure 3.4}

\section{A-O: Plaesiomys anticostiensis (Shaler, 1865)}

A-E: MCZ 147679 - lectotype, dorsal, ventral, lateral, posterior, and anterior views. Likely from Junction Cliff, Grindstone Member, Ellis Bay Formation.

F-L: MCZ 147680 - paralectotype, dorsal, ventral, lateral, posterior, and anterior views; bilobed cardinal process characteristic of the genus. Likely from Junction Cliff, Grindstone Member, Ellis Bay Formation.

M: GSC 117926 - interior of ventral valve; note well-preserved mantle canals, weak grooves and ridges in muscle field, and incipient deltidial plates.

N-O: GSC 131698 - fragment of valve with crenulated, bilobed cardinal process with strongly swollen anterior end. 

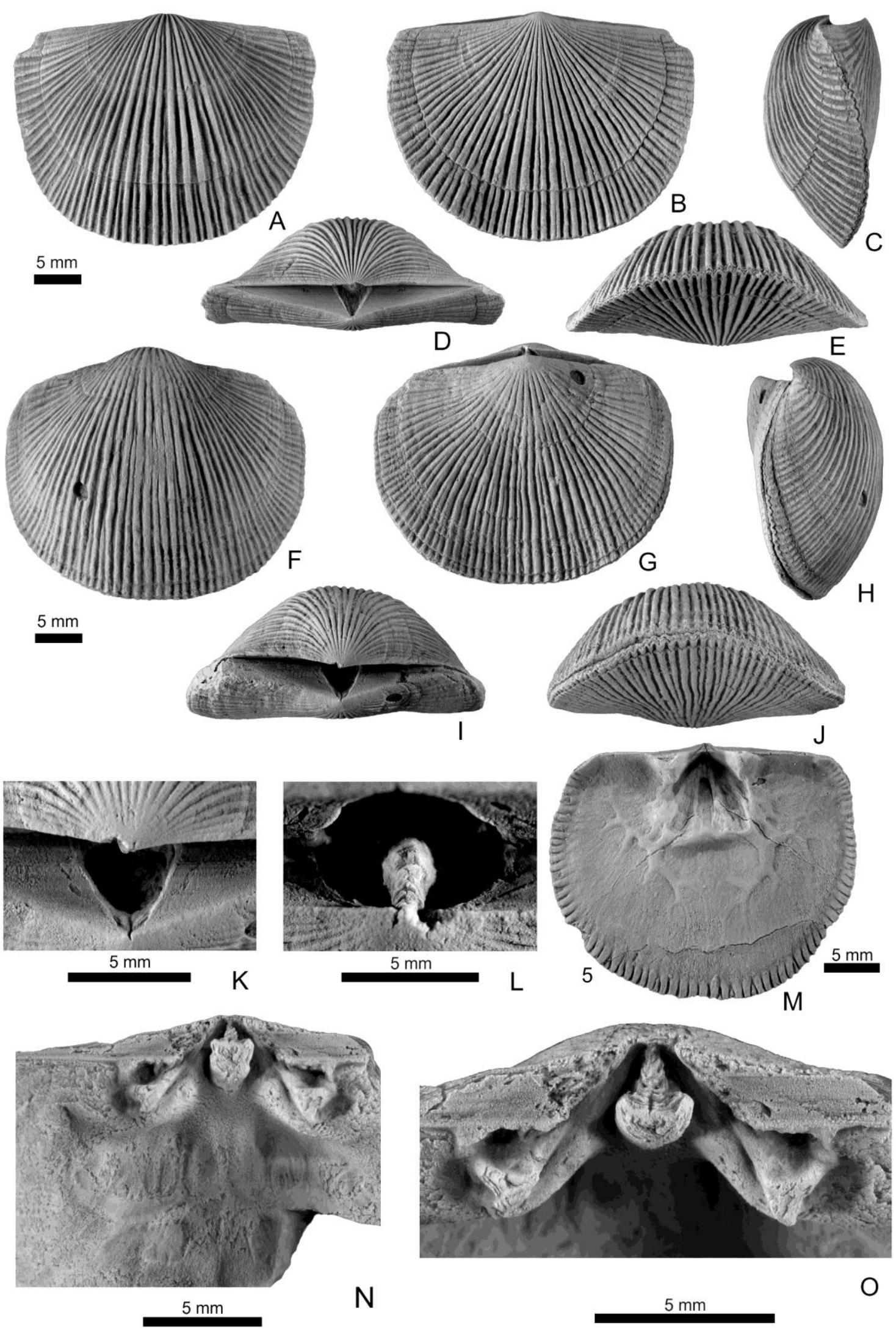


\section{Figure 3.5}

\section{A-K: Plaesiomys subcircularis (Roy, 1941)}

A-E: GSC 113498, holotype - dorsal, ventral, lateral, anterior, posterior, and lateral views showing small size relative to other congeneric species and bilobed cardinal process of the genera. GSC locality O-104526, Amadjuack Formation, Silliman's Fossil Mount, Baffin Island, Nunavut.

F-K: Specimen from Western University - dorsal, ventral, anterior, posterior, and lateral views; enlargement of cardinal process showing typical slender bilobed cardinal process. Verulam Formation, Lake Simcoe area, Ontario (new occurrence).

\section{L-U: Plaesiomys subquadrata (Hall, 1847)}

L-P: W113 - ventral, anterior, posterior, and lateral views; enlargement of the cardinal process. Shows globose profile in comparison to earlier species and globose bilobed cardinal process characteristic of the genus. Upper Katian (Richmondian) strata, Waynesville, Ohio.

Q-U: W2525 - dorsal, ventral, lateral, anterior, and posterior views. Liberty Formation, upper Katian (Richmondian) strata, Germantown, Ohio. 


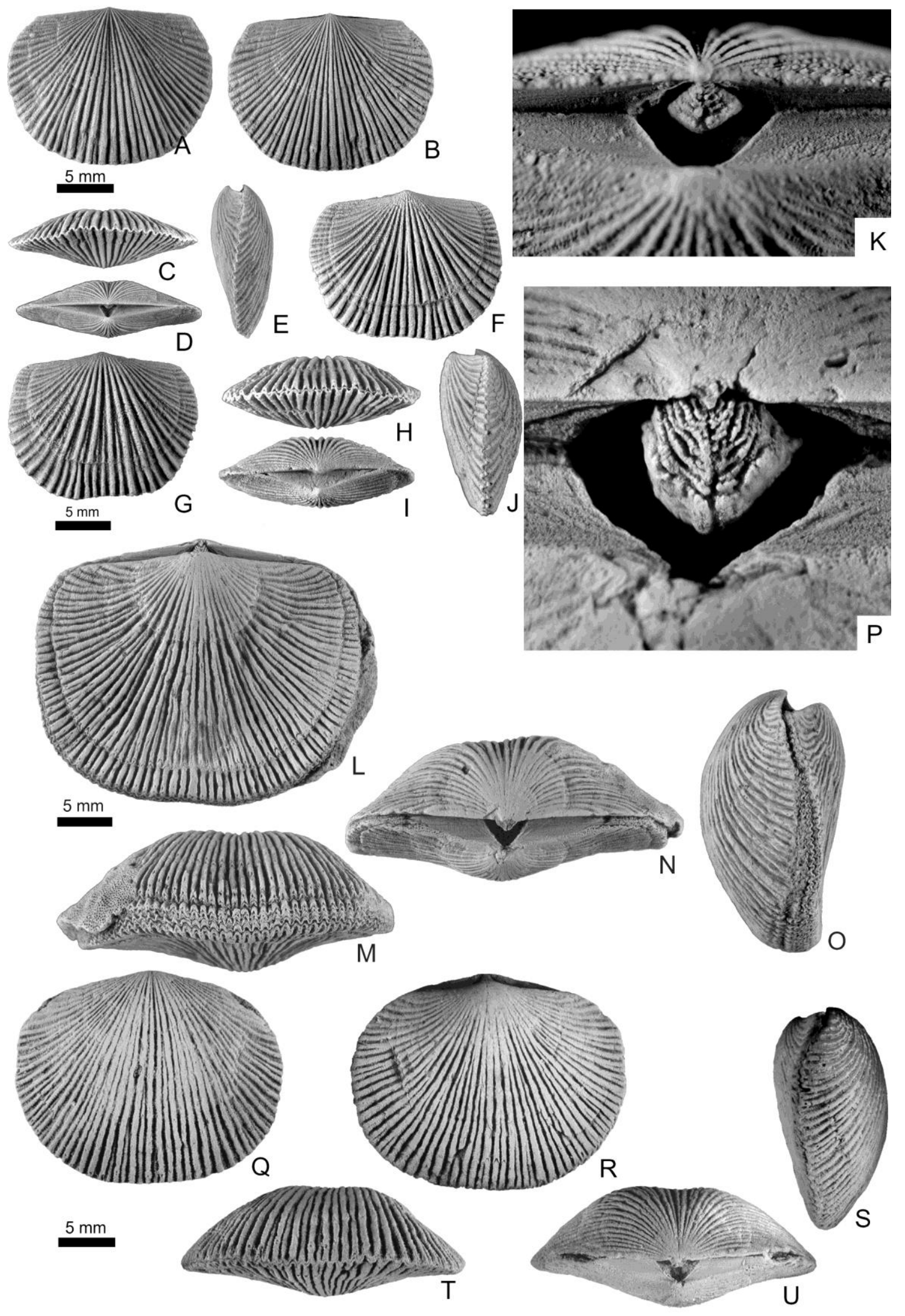




\section{Figure 3.6}

\section{A-J: Plaesiomys bellistriatus Wang, 1949}

A-E: FM-PE2204a - dorsal, ventral, anterior, posterior, and lateral views. Note the fine ribbing pattern and rugae near the commissure. Locality PE 2168, Richmond Group, Madison, Indiana.

F-J: FM-PE2204b - dorsal, ventral, anterior, posterior, and lateral views showing the globose profile of large specimens of this species. Locality PE 2204, Richmond Group, Cincinnati, Ohio. 

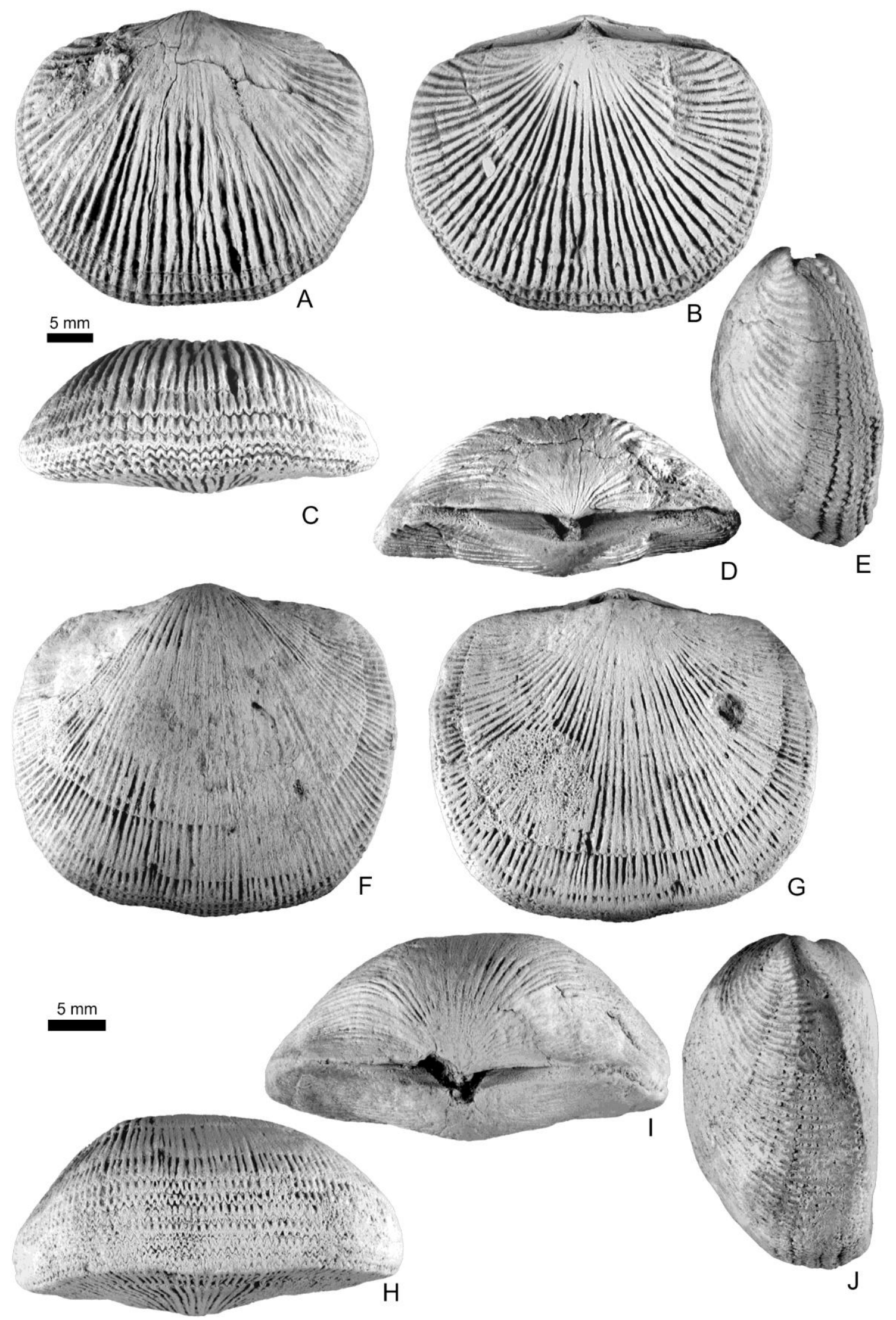


\section{Figure 3.7}

\section{A-I Plaesiomys periosa n. sp.}

A-E: GSC 131793 - dorsal, ventral, anterior, posterior, and lateral views. Note much larger size than other species of the genus. Locality LZ-26, 245' (=75m), Whittaker Formation, Mackenzie Mountains, Northwest Territories.

F-I: GSC 131794 (separate dorsal and ventral valves) - dorsal, dorsal interior, ventral, and ventral interior views. Locality LD-38, 1020' (=311 m), Whittaker Formation, Katian, Mackenzie Mountains, Northwest Territories. 

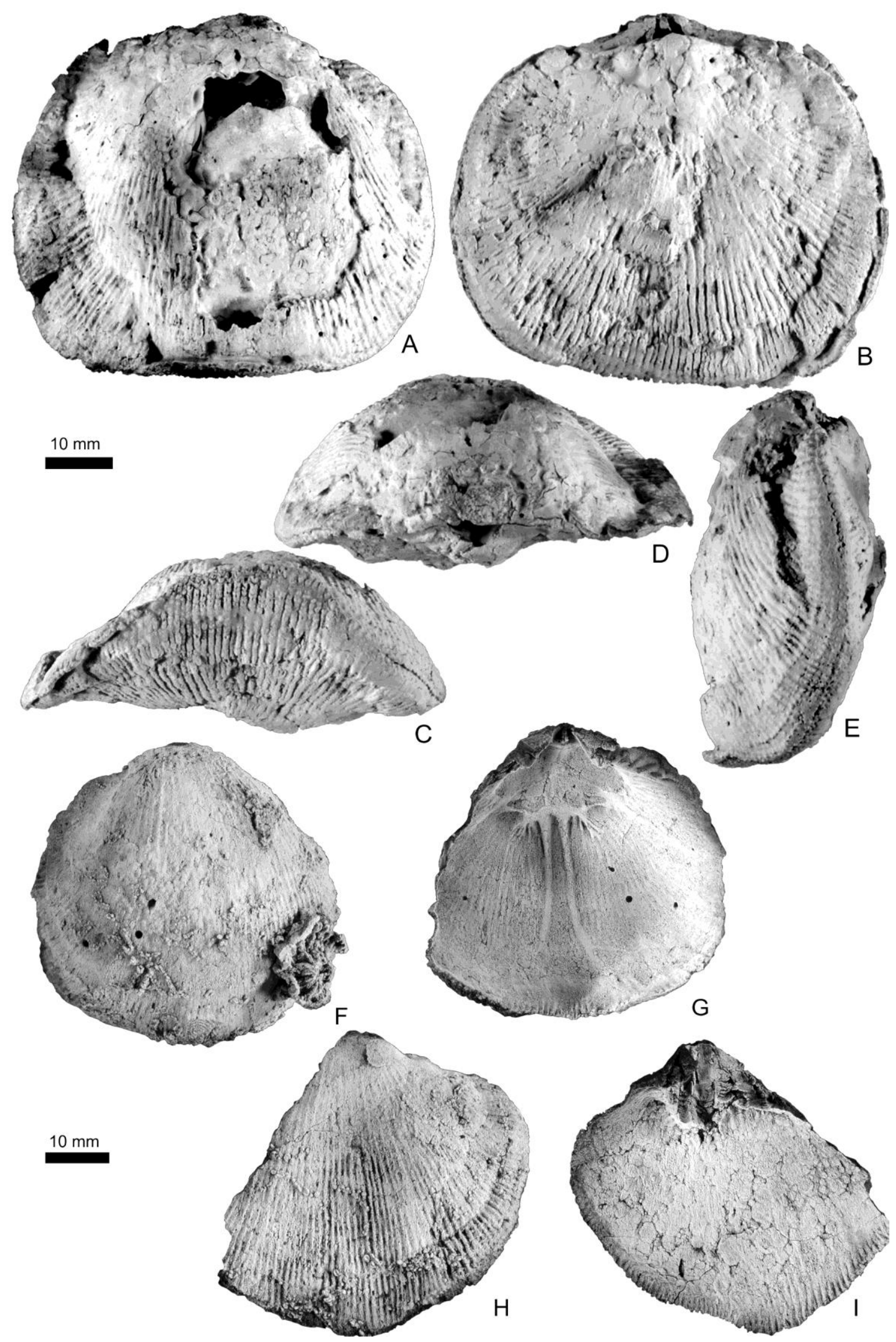


\section{Figure 3.8}

Figures A-J - Plaesiomys lenzi n. sp.

Figures A-E: GSC 131790 - dorsal, ventral, anterior, posterior, and lateral views showing fine ribbing pattern of the species; locality M1730-35' (=527-529 m), Whittaker Formation, Mackenzie Mountains, Northwest Territories.

Figures F and G: GSC 131791 - ventral exterior and interior views. Interior not well preserved. Locality M1730' (=527 m), Whittaker Formation, Mackenzie Mountains, Northwest Territories.

Figures H-J: GSC 131792 - dorsal exterior and interior views, with magnified view of notothyrial platform. Note the bilobed cardinal process and preserved muscle scars. Locality M1730-35' (=527-529 m), Whittaker Formation, Mackenzie Mountains, Northwest Territories.

\section{Figures K-O - Plaesiomys cf. P. bellistriatus}

Figures K-O: FM-P 6827 - dorsal, ventral, anterior, posterior, and lateral views. Note that specimen is probably compressed due to noticeable cracks around the dorsal umbo. Locality PE 2168, Upper Dillsboro Formation, Mount Carmel Quadrangle, Franklin County, Indiana. 


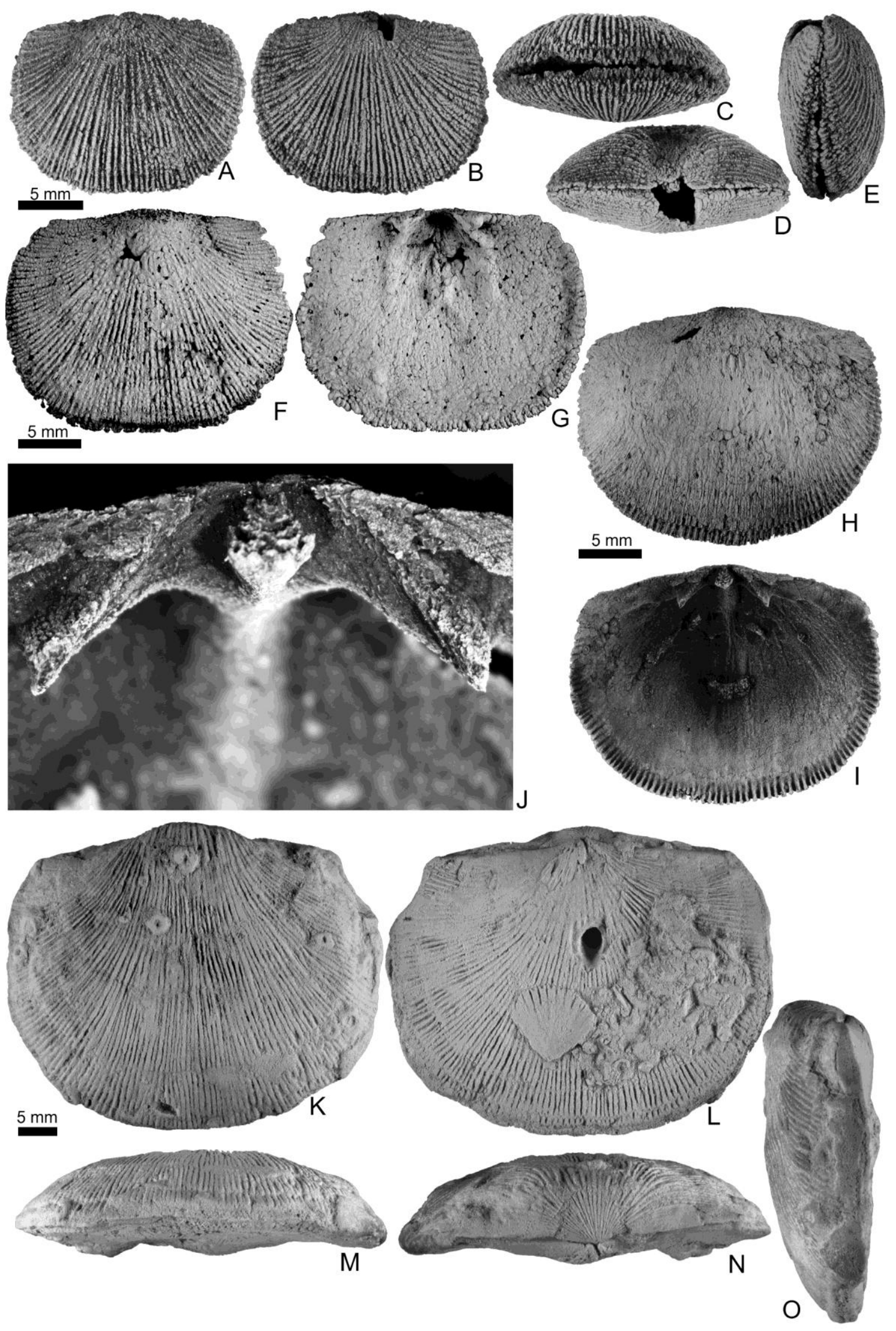




\section{Plaesiomys browni (Wilson, 1946)}

Fig. 3.1A-Q

1946 Dinorthis browni (Billings); Wilson, p. 39-40; pl. 4, figs. 18, 19.

\section{Types}

Holotype GSC 1620 from Trentonian Formation (equivalent to the Simcoe Group) at Belleville, Ontario; paratype GSC 6391 from Hull or Sherman Fall beds (approximately equivalent to the Verulam Formation), north of west red brick house, Ange gardien road, 4 miles $(6.4 \mathrm{~km})$ west of L'Original, Ontario.

\section{Other material examined}

Specimens MI-W 1-25 from lakeshore section, north of Little Current, Manitoulin Island, Ontario, 25 specimens. All were complete shells with conjoined valves.

\section{Description}

Shell small to medium sized, semielliptical; maximum width located near midlength of shell (Figure 3.1E, J, O); shell dorsibiconvex at early growth stage, becoming somewhat convexoplane later in ontogeny; cardinal extremities rounded to obtuse; anterior commissure rectimarginate to weakly uniplicate. Shell ribs moderate to coarse for the genus, covering entire shell, commonly increasing through one order of bifurcation in ventral and intercalation in dorsal valves generally near anterior commissure to reach 2-3 per $5 \mathrm{~mm}$ at anterior margin, rounded crests and troughs (Figure $3.1)$.

Ventral exterior. Valve gently convex at early growth stage, becoming planar to slightly concave anteromedially at later growth stages. Umbo low with minute beak only slightly extending over hingeline; interarea apsacline with planar surface; delthyrium relatively wide, open. Broad and shallow sulcus developed near anterior commissure 
(Figure 3.1F, K, P).

Dorsal exterior. Valve moderately convex, deepest medially at mid-length. Umbo arched over hingeline, higher than ventral umbo in adult forms. Interarea orthocline, notothyrium open (Figure 3.1C, H, M). Fold or sulcus absent (Figure 3.1F, K, P).

Ventral interior. Teeth of moderate size, supported by thick dental plates surrounded by secondary shell growth. Distinct zone of secondary shell thickening near ventral umbo. Muscle scars not apparent in serial sections (Figure 3.9).

Dorsal interior. Sockets subtriangular. Cardinal process with relatively high and strong shaft and bilobed myophore (Figures 3.9, 3.10). Brachiophores of moderate size, relatively thick for shell size, tapering distally, supported by low but clearly defined brachiophore plates. Muscle scars not apparent in serial sections.

\section{Remarks}

This species exhibits some intermediate morphology between Dinorthis and Plaesiomys in terms of its ribbing pattern. Superficially its ribs resemble the generally coarse and simple (unbranching) ribs of Dinorthis, although the ribs are generally finer in P. browni than in typical Dinorthis species. On close inspection of most larger specimens, ribs can be found to multiply within the outermost one third of total shell length from the umbo. Smaller specimens usually lack this distinctive rib bifurcation/intercalation pattern, with rare exceptions, and could easily be mistaken for Dinorthis if large collections were not available for detecting the full range of infraspecific and ontogenetic variations.

The Manitoulin Island specimens closely resemble the type specimens from the Ottawa River valley (Wilson 1946), except that these specimens are somewhat smaller than the type specimens (Figure 3.1; see Table 3.1 and 3.2 below). Specimens from both localities share the same subelliptical outline and dorsibiconvex lateral profile, and also share the same distinctive ribbing pattern. 


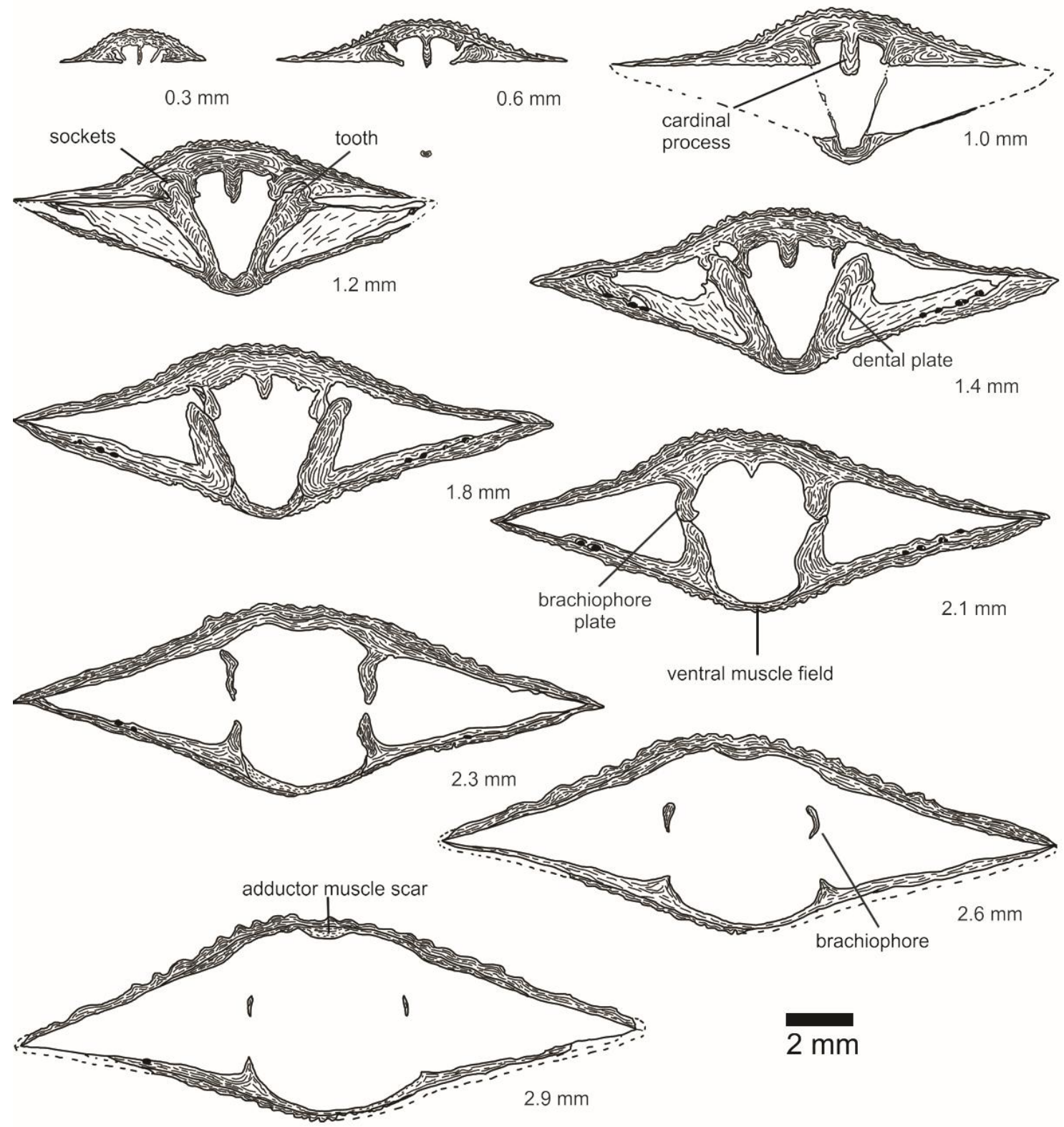

Figure 3.9 - Tracings of serial sections of Plaesiomys browni specimens W-MI5 from the Verulam Formation on Manitoulin Island. Measurements refer to distance from the most posterior point on the dorsal umbo. 


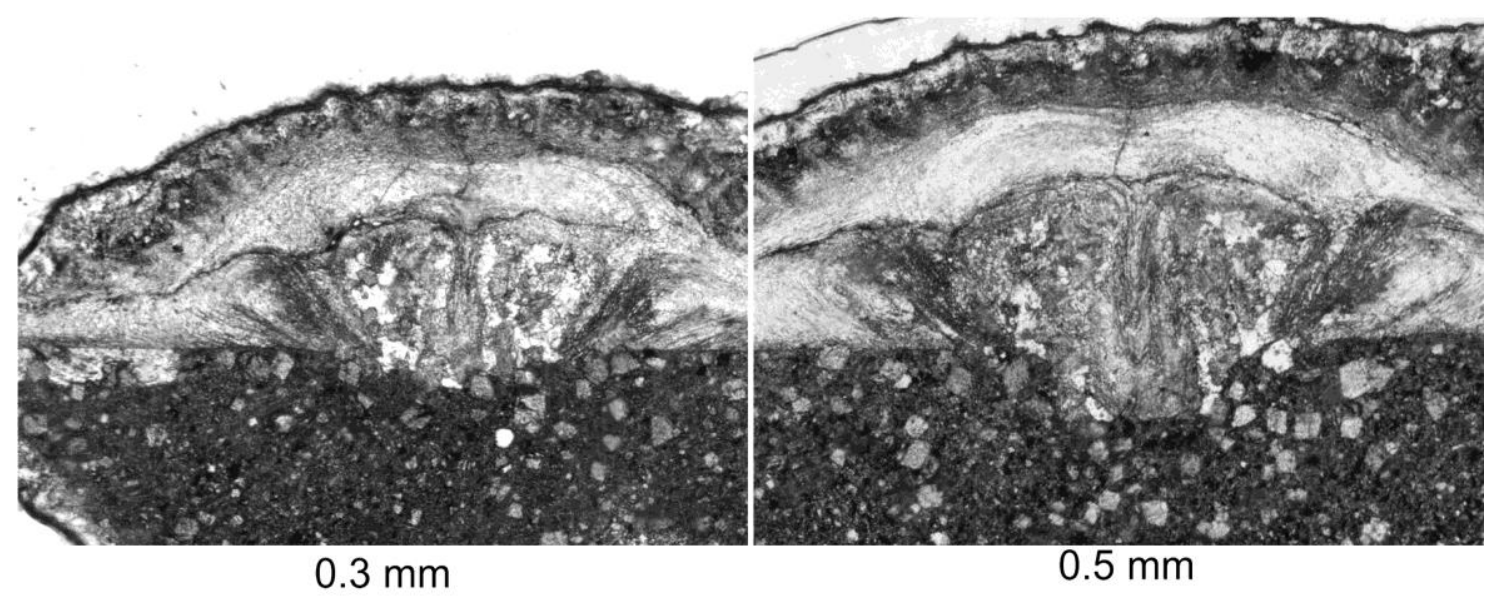

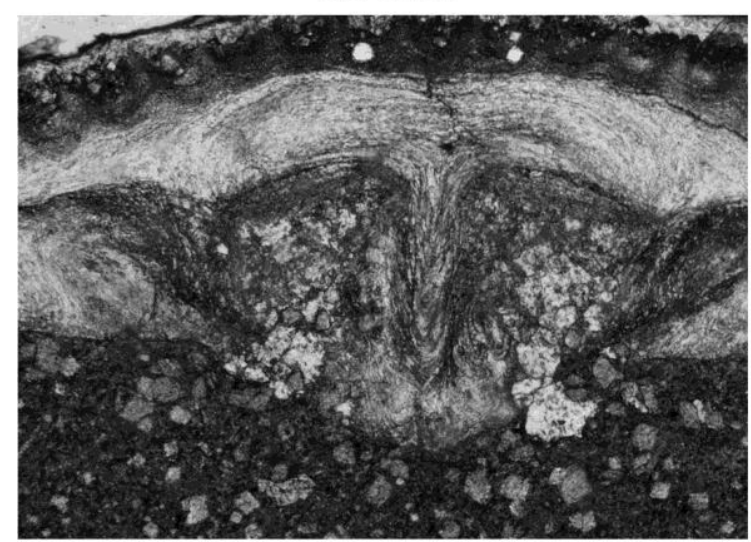

$0.7 \mathrm{~mm}$

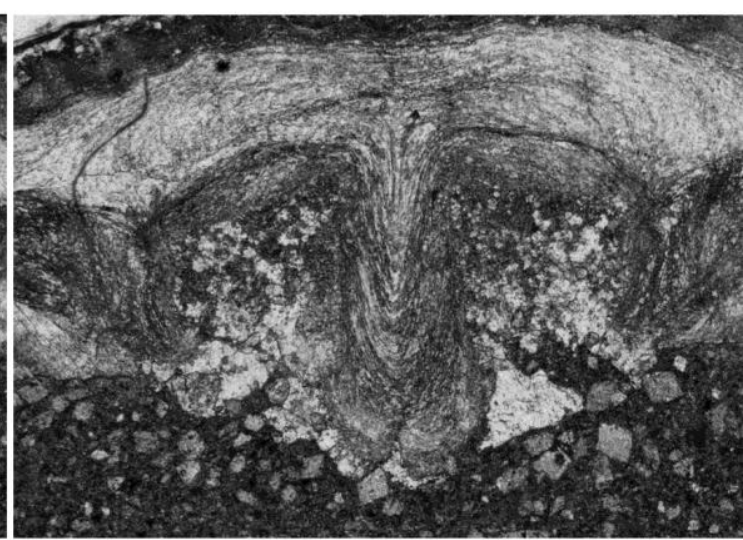

$0.9 \mathrm{~mm}$

$\overline{0.5 \mathrm{~mm}}$

Figure 3.10 - Serial sections of dorsal valve of specimen W-MI5 (Plaesiomys browni) showing the cardinal process of $P$. browni. Shows slender shaft and bilobed myophore. 
In shell outline and profile, this species resembles Plaesiomys subcircularis of Baffin Island (Figure 3.5A-E; Roy 1941; Bolton 2000) and the Lake Simcoe area (Figure $3.5 \mathrm{~F}-\mathrm{K})$, but differs in that this species the ribs do not branch as frequently and generally branch closer to the anterior commissure. This species is also generally larger in both length and width.

This species differs from all other Plaesiomys species in that it is relatively small, especially in comparison to the larger late Katian forms, and possesses the unique ribbing pattern discussed above, whereas most other Plaesiomys species generally have a larger shell, with ribs that multiply multiple times during ontogeny.

Plaesiomys browni, like the other finely ribbed Plaesiomys forms, possesses a bilobed cardinal process, unlike the trilobed cardinal process of coarsely ribbed forms (e.g. P. carletona, P. occidentalis).

\section{Age and distribution}

Early Katian (Chatfieldian) - Verulam Formation, Manitoulin Island, Ontario (new occurrence); Verulam and Lindsay formations, Ottawa River valley and Belleville area, southern Ontario.

Table 3.1. Shell measurements of Plaesiomys browni.

\begin{tabular}{|l|r|l|r|l|l|l|}
\hline & Ld $(\mathbf{m m})$ & Lv (mm) & W (mm) & T (mm) & Td $(\mathbf{m m})$ & Tv (mm) \\
\hline GSC 1620 & 22.19 & & 30.1 & & 6.14 & \\
\hline GSC6391 & & 20.89 & 29.61 & & & \\
\hline
\end{tabular}


Table 3.2. Statistics of shell measurements for Plaesiomys browni, a sample from Manitoulin Island.

\begin{tabular}{|c|c|c|c|c|c|c|}
\hline & $\operatorname{Ld}(\mathrm{mm})$ & $\operatorname{Lv}(\mathrm{mm})$ & $\mathbf{W}(\mathrm{mm})$ & $\mathbf{T}(\mathrm{mm})$ & $\mathrm{Td}(\mathrm{mm})$ & $\mathrm{Tv}(\mathrm{mm})$ \\
\hline Mean & 18.23 & 17.51 & 22.75 & 8.26 & 6.13 & 2.04 \\
\hline Minimum & 14.61 & 14.61 & 17.74 & 6.66 & 4.35 & 1.38 \\
\hline Maximum & 21.33 & 20.15 & 28.08 & 9.81 & 8.65 & 4.72 \\
\hline S.D. & 1.45 & 1.35 & 2.34 & 0.93 & 1.04 & 0.87 \\
\hline
\end{tabular}

Plaesiomys occidentalis (Okulitch, 1943)

Figure 3.3 A-P

1943Pionorthis occidentalis Okulitch, p. 71-72, pl. 1, figs. 8-10.

1943 Pionorthis cf. carletona (Twenhofel); Okulitch, pl. 1, fig. 7.

1957 Dinorthis (Plaesiomys?) cf. D. (P.) occidentalis Ladd; Ross, pl. 37, figs. 16, 19, 20, 23.

1957 Dinorthis (Pionorthis?) cf. D. (P.) occidentalis Okulitch; Ross, pl. 37, figs. 17, 18, $21,22$.

1957 Dinorthis (Pionorthis?) n. sp. Ross, pl. 38, figs. 1, 2, 5, 6.

1957 Dinorthis (?) sp. Ross, pl. 38, figs. 3, 4, 7, 8, 11.

1970 Plaesiomys (Dinorthis) occidentalis (Okulitch); Macomber, pp. 430-433, pl. 75, figs. 12-15; pl. 76, figs 1-27.

1997 Dinorthis occidentalis (Okulitch); Jin et al., p. 21, pl. 1, figs. 13-16; pl. 2, figs. 1-17.

2001 Dinorthis occidentalis (Okulitch); Jin and Zhan, p. 17-20, figs. 6-9; pl. 1, figs. 1-22; pl. 2, figs. 1-13; pl. 3, figs. 1-5; pl. 21, fig. 2.

Types

Holotype GSC 2043 is a dorsal valve that has been broken some time after Okulitch's original study. Paratype GSC 2043a is also a dorsal valve, slightly covered in 
matrix. The type material is in poor condition, and thus not utilized in this study. Both are from the Gunn Member, Stony Mountain Formation, Stony Mountain, Manitoba.

\section{Remarks}

The taxonomic position of Plaesiomys occidentalis has been a matter of debate. Macomber (1970), Jin et al. (1997), and Jin and Zhan (2001) considered the species to be part of the Dinorthis genus, however its ribbing pattern and general morphology suggest its affinity with Plaesiomys.

Dinorthis occidentalis (Okulitch, 1943) is here regarded as a species of Plaesiomys. An examination of specimens from Stony Mountain, Manitoba (see also Jin and Zhan 2001), as well as figured specimens from the Hudson Bay Lowlands (Jin et al. 1997) and Wyoming (Macomber 1970), shows that the rib multiplication pattern of this species is more consistent with Plaesiomys than with Dinorthis (Figure 3.3A-L).

Plaesiomys occidentalis, as examined at a population scale, generally shows some degree of rib multiplication - though individual specimens may be highly variable in the degree of rib multiplication in terms of the number of rib multiplication per order and in the total number of orders of multiplication. These variations are interpreted as intraspecific or ontogenetic in nature. Typical Dinorthis from lower Katian strata of the eastern United States show no rib bifurcation or intercalation (e.g. Hall 1847; Rice 1987).

Plaesiomys occidentalis resembles most closely to P. carletona (Twenhofel, 1928) from the upper Vauréal Formation (upper Katian) of Anticosti Island (see Jin and Zhan 2008). P. occidentalis, like P. carletona, possesses coarse ribs and a trilobed cardinal process, which differentiate them from most other congeneric species. Indeed, these two

species had been assigned to Pionorthis Schuchert and Cooper, 1932, although Pionorthis has been invalidated by Jin et al. (2007) because it is based on a dalmanelloid species, Mendacella sola (Billings, 1866). This suggests that $P$. occidentalis and P. carletona are closely related, and that $P$. occidentalis most suitably assignable to Plaesiomys. $P$. occidentalis differs from $P$. carletona in having fewer rib multiplications, often confined to the shell flanks, compared to multiplications over the entire shell surface in $P$. 
carletona. Also, the umbonal area of $P$. carletona is much more variable than $P$. occidentalis, with the ventral interarea varying from strongly apsacline to moderately apsacline, tilting from approximately 45 to 60 degrees from the commissural plane. Some $P$. carletona specimens show an umbonal area similar to Dalmanella, with a strongly incurved interarea (e.g. plate 1, figure 16 - Jin and Zhan 2008), while other show the more typical flat interarea of other plaesiomyids (e.g. plate 13, figure 12 - Jin and Zhan 2008). P. occidentalis has a more consistently flat interarea with ventral interarea varying very little at approximately 40 degrees from the commissural plane. $P$. carletona also appears have a nearly equibiconvex profile in some specimens (resembling some Austinella species - e.g. see Alberstadt 1973), rather than the dorsibiconvex $P$. occidentalis.

It has been shown that trilobed cardinal process is not diagnostic of the Dinorthis genus (e.g. Plaesiomys carletona - see Jin and Zhan 2008) and is likely an ecophenotypic trait of both Plaesiomys and Dinorthis. The cardinal process of P. occidentalis is definitely trilobate, but the cardinal processes of the early species of Dinorthis are not well studied. Examination of the cardinal process of these earlier forms may further clarify the phylogenetic relationships between Dinorthis and Plaesiomys.

\section{Plaesiomys periosa n. sp.}

Figure 3.7 A-I

1977 ?Family Plaesiomyidae, genus A (unnamed) Wigington, p. 72-74; pl. 6, figs. 27-32; pl. 7, figs. 1-2.

\section{Etymology}

From the Greek periosus, immense, denoting the unusually large size of the shell. 


\section{Types}

The holotype, GSC 131793 (Figure 3.7 A-E), is a conjoined shell from section LZ-26, 245' (=75m) from base, (Pl. 5, figs. 11-15), 63⒌ $58.5^{\prime}-64^{\circ} 00 \mathrm{~N}, 126^{\circ} 38^{\prime}-$ $126^{\circ} 39^{\prime}$ W, Mackenzie Mountains, Whittaker Formation, Richmondian (upper Katian). This specimen appears to be compressed, as shown by fractures around the periphery of the shell, and shell is somewhat damaged, missing large pieces of the dorsal valve. The shell surface of the holotype has previously been treated with an epoxy, presumably to protect it from further damage, but obscures some surface detail. The paratype, GSC 131794(Figure 3.7 F-I), is from section LD-38, 1020' (=311 m) from base, 63 56.5' N, $126^{\circ} 51^{\prime} \mathrm{W}$, Mackenzie Mountains, Whittaker Formation, Richmondian (upper Katian). The paratype is a closely matching pair of ventral and dorsal valves, and probably originally belonged to the same shell. Both holotype and paratype are silicified, and thus somewhat poorly preserved.

\section{Other material examined}

Only the types were available for examination. No other specimens of this species are known.

Table 3.3 - Shell measurements of Plaesiomys periosa type specimens

\begin{tabular}{|r|r|r|r|r|r|r|}
\hline & Ld $(\mathbf{m m})$ & $\mathbf{L v}(\mathbf{m m})$ & $\mathbf{W}(\mathbf{m m})$ & $\mathbf{T}(\mathbf{m m})$ & \multicolumn{1}{|c|}{$\mathbf{T d}(\mathbf{m m})$} & Tv $(\mathbf{m m})$ \\
\hline $\mathbf{1}$ & 51.39 & 49.45 & 59.54 & 24.95 & 19.28 & 5.13 \\
\hline $\mathbf{2}$ & 40.75 & & & & 18.92 & \\
\hline $\mathbf{3}$ & & 44.81 & & & & 11.34 \\
\hline
\end{tabular}

\section{Diagnosis}

Shell unusually large for the genus; dorsibiconvex with highly convex dorsal valve; anterior commissure uniplicate. 


\section{Description}

Shell very large, attaining a maximum length of $51.39 \mathrm{~mm}$, width $59.54 \mathrm{~mm}$, and thickness $24.95 \mathrm{~mm}$ (somewhat compressed; Figure 3.7 E); subcircular to subquadrate (Figure 3.7 A, B); maximum width located near mid-length of shell; dorsibiconvex with very deep dorsal valve; rounded cardinal extremities; anterior commissure uniplicate. Shell ribs of moderate size relative to overall shell size, covering entire shell surface, with 5-6 ribs per $5 \mathrm{~mm}$ at the anterior margin, increasing through bifurcation on the ventral valve and intercalation on the dorsal valve; degree of rib multiplication difficult to determine due to poor preservation of umbonal areas but ribs appear to show 2-3 orders of bifurcation by the anterior margin. Aditicules, epipunctae, or any other microstructures not observed due to silicification of shell, as well as treatment of the surface of the holotype.

Ventral exterior. Valve convex at early stages, becoming flat to slightly concave at later stages. Umbo low with minute and inconspicuous beak; interarea apsacline, with ventral umbo forming a 50 degree angle with the commissural plane (Figure 3.7 E); delthyrium relatively wide, open (Figure 3.7 D); very broad fan-shaped sulcus beginning approximately at one third of the total length from the posterior. (Figure $3.7 \mathrm{C}$ ).

Dorsal exterior. Valve moderately to strongly convex, becoming deepest medially at one third of length from posterior. Umbo arched over hingeline, higher than ventral umbo (Figure 3.7 E). Interarea weakly anacline; notothyrium open (Figure 3.7 D). Valve uniformly convex except for very weak fold near anterior commissure.

Ventral interior. Teeth poorly preserved, small relative to overall shell size (Figure 3.7 I). Dental plates thick and encased by secondary shell thickening. Muscle field faint, obscured by silicification. Narrow peripheral rim of shell marked by crenulations. Ventral vascular media not preserved.

Dorsal interior. Sockets not well preserved, subtriangular. Cardinal process with slender shaft and bilobed, crenulated myophore (Figure 3.7 G). Brachiophores short and thick. Two pairs of adductor scars preserved - posterior pair large and flabellate in 
outline; anterior pair smaller, scalloped in shape; muscle field about one third of shell length and one third of shell width. Dorsal vascular media well preserved (Figure 3.7G), except for anterior portions of valve; lemniscate, with canal branches radiating towards the anterior margin; vasculum medium long and appear to branch near anterior margin; vasculum myaria short and branch into multiple smaller branches toward the shell margin; vasculum cruralium only visible on one side, digitate in outline with little branching; vasculum cardinalia also visible on only one side and only partially preserved.

\section{Remarks}

Wigington's (1977) original description was based on a single complete specimen (specimen 1 below; Figure 3.7 A-E) and one incomplete disarticulated specimen (specimens 2 and 3 below; Figure 3.7 F-I). Neither of these specimens is well preserved overall, although some internal structures are well preserved within the disarticulated valves. The dorsal valve, in particular, shows some details of the configuration of vascular and muscular markings, as described above.

Most notable about these specimens is their difference in size from other plaesiomyids. These are the largest specimens of the family documented to date (see Table 4.3 above), although the thickness of the single whole specimen was probably originally significantly greater as the specimen shows signs of compression). Curiously, there are two complete specimens of Plaesiomys columbia documented by Wigington (1977) from the Mackenzie Mountains that are also unusually large for the family (Figure 3.2), though not as large as these specimens. A third large specimen was found in the Cincinnati collection, but its ribbing style is much finer, suggesting a close affinity with P. bellistriatus (see below; Figure $3.8 \mathrm{~K}-\mathrm{O}$ ). Outside the Mackenzie Mountains, the next largest species of plaesiomyids are P. anticostiensis (Figure 3.4) from the Hirnantian Ellis Bay Formation on Anticosti Island (averaging $20.2 \mathrm{~mm}$ length, $24.8 \mathrm{~mm}$ width, and 10.8 $\mathrm{mm}$ depth), P. occidentalis from the Stony Mountain Formation in Manitoba(averaging $20.2 \mathrm{~mm}$ length, $24.8 \mathrm{~mm}$ width, and $10.7 \mathrm{~mm}$ depth), and $P$. subquadrata from the Cincinnati area (averaging $20.0 \mathrm{~mm}$ length, $25.4 \mathrm{~mm}$ width, and $10.6 \mathrm{~mm}$ depth), but these species are less than half the size of P. periosa. 
This suggests two scenarios: either these large specimens were mostly confined to the Mackenzie Mountains, or more large specimens have not been found elsewhere due to their rarity in comparison to other species, perhaps due to a preservation bias towards smaller specimens. The single large specimen from the Cincinnati region suggests that Plaesiomys gigantism may have been more widespread than are documented thus far. Further collection in the studied localities may reveal additional large specimens.

The ribbing style of $P$. periosa is comparable to Plaesiomys anticostiensis, $P$. subcircularis, and $P$. subquadrata, but is clearly distinct from the more coarsely ribbed species like $P$. carletona or $P$. occidentalis. In the new species, although the ribs are not well preserved, the fine ribs bifurcate frequently, reaching 2-3 orders at the anterior margin. The posterior of specimens 1 and 2 are too heavily abraded to discern any details on the ribs, but an examination of the ventral valve (specimen 3), which isn't as heavily abraded as the other specimens, shows the first order of multiplication starting approximately one third of the total length from the posterior and the second order beginning approximately two thirds of the total length from the posterior, though there is some variation in this pattern.

\section{Age and distribution}

Late Katian (Richmondian); Mackenzie Mountains, Northwest Territories.

\section{Plaesiomys lenzi n. sp.}

Figure 3.8 A-J

1977 Plaesiomys n. sp. 1 (unnamed) Wigington, p. 68-70; pl. 6, figs. 1-26.

\section{Etymology}

Named after the original collector of the specimen, Dr. Alfred Lenz. 


\section{Types}

The holotype, GSC 131790, is from locality M1730-35' (=527-529 m), a whole specimen (Figure 3.8 A-E). Paratypes GSC 131791(Figure 3.8 F-G) and GSC 131792 (Figure $3.8 \mathrm{H}-\mathrm{J}$ ) from locality M1730-35' (=527-529 m) in the same collection are dorsal and ventral valves only. Both holotype and paratypes are silicified, which has destroyed much of the fine structure of the shell. Whittaker Formation, late Katian (Richmondian).

\section{Other material examined}

One dorsal valve and several smaller fragments from locality M1728' (=527 m); one ventral valve, two partial ventral valves, and several smaller fragments from locality M1730' (=527 m); one complete specimen, two complete dorsal valves, one partial ventral valve, and several smaller fragments from locality M1730-1735' (=527-529 m), located at $62^{\circ} 42^{\prime} \mathrm{N}, 127^{\circ} 56^{\prime} \mathrm{W}$, Mackenzie Mountains, Northwest Territories - from Wigington's collection at Western University. Whittaker Formation, late Katian (Richmondian).

\section{Diagnosis}

Shell small to medium sized; ribs finely costellate; ventral interarea catacline, dorsal interarea orthocline to slightly anacline; coarse growth lamellae commonly near shell anterior approximately 3-4 mm apart.

\section{Description}

Shell small for the genus, semi-elliptical in smaller specimens to subquadrate in larger specimens (Figure 3.8A-E); maximum shell width located mid-length between anterior and posterior; shell dorsibiconvex to planoconvex in adult forms (Figure 3.8E); cardinal extremities obtuse; anterior commissure rectimarginate. Shell ribs finely costellate (Figure 3.8 A, B, F, H) - very fine for the genus, increasing in number through bifurcation on both dorsal and ventral valves, reaching 10-12 ribs per $5 \mathrm{~mm}$ near shell 
margin. Growth lamellae commonly developed near shell anterior, approximately 3-4 mm apart.

Ventral exterior. Shell slightly convex to planar in adult specimens, deepest medially in posterior third of shell. Ventral umbo not well preserved in specimens, arched over interarea, but lower than dorsal umbo. Ventral interarea open, catacline (Figure 3.8D-E). Fold and sulcus very weak or absent.

Dorsal exterior. Shell moderately convex, deepest medially at mid-length between anterior and posterior. Dorsal umbo extending slightly over commissure, higher than ventral umbo, but difficult to judge by what extent due to absence of complete specimens. Dorsal interarea open, orthocline to slightly anacline (Figure 3.8D-E). Fold or sulcus absent.

Ventral interior. Teeth small with thick dental plates extending anteriorly to bound muscle field laterally. Adductor scars small, separated by medial ridge and flanked by larger diductor scars, subpentagonal in outline; diductor scars deeply impressed, with strong longitudinal striae, diductor scars fill approximately two fifths of the length and one third of width. Crennulations around peripheral rim of valve (Figure 3.8G).

Dorsal interior. Sockets deep, open anteriolaterally. Brachiophores short, thick. Muscle scars very faint, obscured due to silicification. Cardinal process plate-like and bilobed. Posterior portions of vascular canals preserved, including vasculum medium, vasculum myaria, and vasculum cruralium; lemniscate (Figure 3.8I).

\section{Remarks}

This species differs from all other Plaesiomys species except for P. bellistriatus in that its ribs are numerous and very fine. It resembles the ribbing pattern of $P$. bellistriatus, but $P$. bellistriatus is generally much larger than this species. Also like $P$. bellistriatus, this species often has prominent growth lamellae near the anterior commissure. The fold and sulcus, however, are better developed in P. bellistriatus.

As Wigington (1977) documented, the species possesses a distinctively catacline ventral interarea, in comparison to the apsacline ventral interarea of other species of the 
Plaesiomys genus.

This species, similar to the finely ribbed $P$. bellistriatus, $P$. subquadrata, $P$.

subcircularis, P. anticostiensis, and P. browni, possesses a bilobed cardinal process. This is in contrast to the trilobed cardinal process of coarsely ribbed species like $P$.

occidentalis and P. carletona.

The extremely fine ribbing pattern and unusual orientation of the ventral interarea in P. lenzi are unique among species of Plaesiomys. However, there is variability seen in the interarea of other species of Plaesiomys as well (e.g. P. carletona - see Jin and Zhan 2008). The profile of this species also resembles $P$. bellistriatus in that it is strongly dorsibiconvex with a low ventral convexity.

\section{Age and distribution}

Richmondian (late Katian); Whittaker Formation, Mackenzie Mountains, Northwest Territories.

Table 3.4 - Statistics of shell measurements for Plaesiomys lenzi

\begin{tabular}{|l|r|r|r|r|r|r|}
\hline & Ld $\mathbf{( m m})$ & $\mathbf{L v}(\mathbf{m m})$ & $\mathbf{W}(\mathbf{m m})$ & $\mathbf{T}(\mathbf{m m})$ & \multicolumn{1}{|c|}{$\mathbf{T d}(\mathbf{m m})$} & Tv $\mathbf{( m m})$ \\
\hline Average & 17.06 & 17.71 & 22.92 & 8.25 & 6.43 & 2.03 \\
\hline Min & 14.09 & 13.51 & 18.25 & 8.25 & 5.14 & 1.37 \\
\hline Max & 19.52 & 36.56 & 40.17 & 21.96 & 16.15 & 6.62 \\
\hline S.D. & 2.64 & 7.62 & 6.66 & 5.66 & 4.6 & 2.12 \\
\hline
\end{tabular}

Plaesiomys cf. P. bellistriatus

Figure $3.8 \mathrm{~K}-\mathrm{O}$

\section{Material examined}

One complete specimen (FM-P6827, locality PE2168) - Upper Dillsboro Formation, Mount Carmel Quadrangle, Franklin County, Indiana. 


\section{Description}

Shell very large for genus (see Table 4.5); subquadrate in outline; maximum shell width located mid-length; dorsibiconvex to planoconvex; cardinal extremities obtuse (Figure 3.8K-O). Anterior commissure rectimarginate. Ribs finely costellate, reaching 79 per $5 \mathrm{~mm}$, with rounded crests and troughs. Numerous coarse growth lamellae near shell anterior (Figure 3.8 M), 4-10 mm apart becoming closer nearer the anterior commissure.

Ventral exterior. Shell mostly planar, though slightly convex early in development, deepest medially in posterior third of shell. Ventral umbo arched over hingeline, but slightly lower than dorsal umbo; ventral interarea apsacline, largely obscured by displaced dorsal valve (Figure $3.8 \mathrm{~N}-\mathrm{O}$ ). Broad but shallow sulcus at anterior commissure.

Dorsal exterior. Shell slightly convex, deepest medially over the posterior third of the shell. Dorsal umbo arched high over the hingeline, higher than ventral umbo. Dorsal interarea orthocline, also obscured by displaced dorsal valve (Figure 3.8N-O). No fold or sulcus, except for faint medial depression from umbo to anterior margin.

Interior. Not examined due to lack of available specimens exposing the interior.

\section{Remarks}

This specimen is most similar to Plaesiomys bellistriatus in its fine and numerous ribs and similar growth lamellae near the commissure. The two main differences are its reduced dorsal convexity and significantly larger size. The reduced convexity is probably due to compression, as indicated by fractures in the shell surface near the dorsal umbo.

The unusually large shell size of this specimen compared to typical specimens of Plaesiomys bellistriatus only permits its specific assignment at the comparative level ("cf."). It is similar in size to P. periosa (above), which is still much larger with a length of $51.39 \mathrm{~mm}$ (holotype). As mentioned above, these large forms of Plaesiomys are rare. 


\section{Age and distribution}

Late Katian (Richmondian); Upper Dillsboro Formation, Fairfield, Indiana.

Table 3.5 Plaesiomys cf. P. bellistriatus measurements

\begin{tabular}{|r|r|r|r|r|r|r|}
\hline & Ld $(\mathbf{m m})$ & $\mathbf{L v}(\mathbf{m m})$ & $\mathbf{W}(\mathbf{m m})$ & $\mathbf{T}(\mathbf{m m})$ & Td $(\mathbf{m m})$ & Tv (mm) \\
\hline $\mathbf{1}$ & 38.86 & 36.59 & 47.66 & 13.6 & & 3.39 \\
\hline
\end{tabular}

Genus Austinella (Foerste, 1909)

\section{Type species}

Orthis kankanensis (McChesney, 1861; see McChesney 1868 for figures of specimens). Cincinnatian, Wilmington, Illinois.

\section{Remarks}

Austinella has been found mostly in North America, commonly associated with Plaesiomys in subtropical pericratonic settings. This genus has been found in California (Potter 1990), Iowa (Wang 1949), Northwest Territories (Wigington 1977), Oklahoma (Alberstadt 1973), Tennessee (Howe 1988), and Texas (Howe 1966). Elsewhere, it has also been documented in Kazakhstan (Popov et al. 2002).

Unlike Plaesiomys and Dinorthis, Austinella has a dorsal valve that is typically shallower than the ventral valve, and usually possesses finer ribs. Also, most species of Plaesiomys show a relatively flat ventral interarea (except some specimens of $P$. carletona from Anticosti Island), whereas Austinella often has a much more incurved interarea, with the ventral valve typically arching higher than the dorsal valve. 


\section{Austinella multicostella Alberstadt, 1973}

Figure 3.11A-J

1973 Austinella multicostella Alberstadt, 1973; p. 26-29, pl. 1, figs. 1-9.

\section{Types}

Alberstadt (1973) described and figured several type specimens from his unit 3, subunit 3C of the Viola Formation of the Arbuckle Mountains - none of which were examined as part of this study. Two specimens were selected as holotypes: OU 5814 (ventral valve) and OU 5811 (dorsal valve). Both are from his section A - northeast 1/4 of section 36, township 3 north, range 5 east. Several other figured and unfigured paratypes are also listed.

\section{Material examined}

Three specimens from locality FM PE 5523, Middle Ordovician Simpson Group, Bromide Formation, Ardmore, Carter County, Oklahoma.

\section{Description}

Shell of moderate size for the genus; semielliptical in outline; maximum shell width located near mid-length; slightly ventribiconvex; cardinal extremities obtuse (Figure 3.11A-E). Anterior commissure rectimarginate. Ribs multicostellate, reaching $10-12$ per $5 \mathrm{~mm}$ at the anterior margin, with rounded crests and troughs, multiplying through bifurcation on both valves asymmetrically. Fine growth lines well developed, crinkly, spaced at irregular distances but generally less than $0.1 \mathrm{~mm}$ apart. Coarser growth lamellae sparse, randomly spaced. Epipunctae clearly visible as microscopic tubercles on shell surface (Figure $3.11 \mathrm{H}, \mathrm{J}$ ); commonly forming one row on smaller ribs and two rows on larger ribs, but also less commonly found between ribs; apertures of 
epipunctae generally located on top of tubercles; epipunctae spaced approximately 100 to 200 micrometers apart longitudinally and varying in separation transversally depending on rib size, with a maximum spacing of approximately 120 micrometers; apertures approximately 10-15 micrometers in diameter, rims approximately 50-70 micrometers in diameter. Aditicules are rare, concentrated near shell margin, averaging 60-70 micrometers in diameter (Figure 3.11I). Cardinal process with strong shaft and bilobed myophore (Figure $3.11 \mathrm{G})$.

Ventral exterior. Shell convex, deepest approximately one quarter of total length from ventral umbo. Ventral umbo arched high over hingeline; ventral interarea apsacline (Figure 3.9E); pedicle collar forms a cover over the apex of the delthyrium (Figure 3.11F). Broad, shallow sulcus at anterior commissure beginning approximately one third of total length from the posterior, with broad fan-like shape.

Dorsal exterior. Shell convex, deepest medially at mid-length of shell. Dorsal umbo arched over hingeline, though not as high as ventral umbo (Figure 3.9E). Dorsal interarea orthocline (Figure 3.911). Very broad and shallow fold at anterior commissure, beginning approximately one third of total length from the posterior.

Interior. Not examined due to lack of specimens. 
Figure 3.11

\section{A-J: Austinella multicostella Alberstadt, 1973}

A-J: FM-PE5523 - dorsal, ventral, lateral, anterior, and posterior views showing multicostellate ribbing pattern with fine, asymmetrically branching ribs; enlargement showing pedicle sheath; enlargement showing bilobed cardinal process; enlargements showing the pattern of shell ornamentation $(\mathrm{G})$, aditicules on the rib crests $(\mathrm{H})$, and epipunctae (I) common in other plaesiomyids. Bromide Formation, Ardmore, Carter County, Oklahoma. 

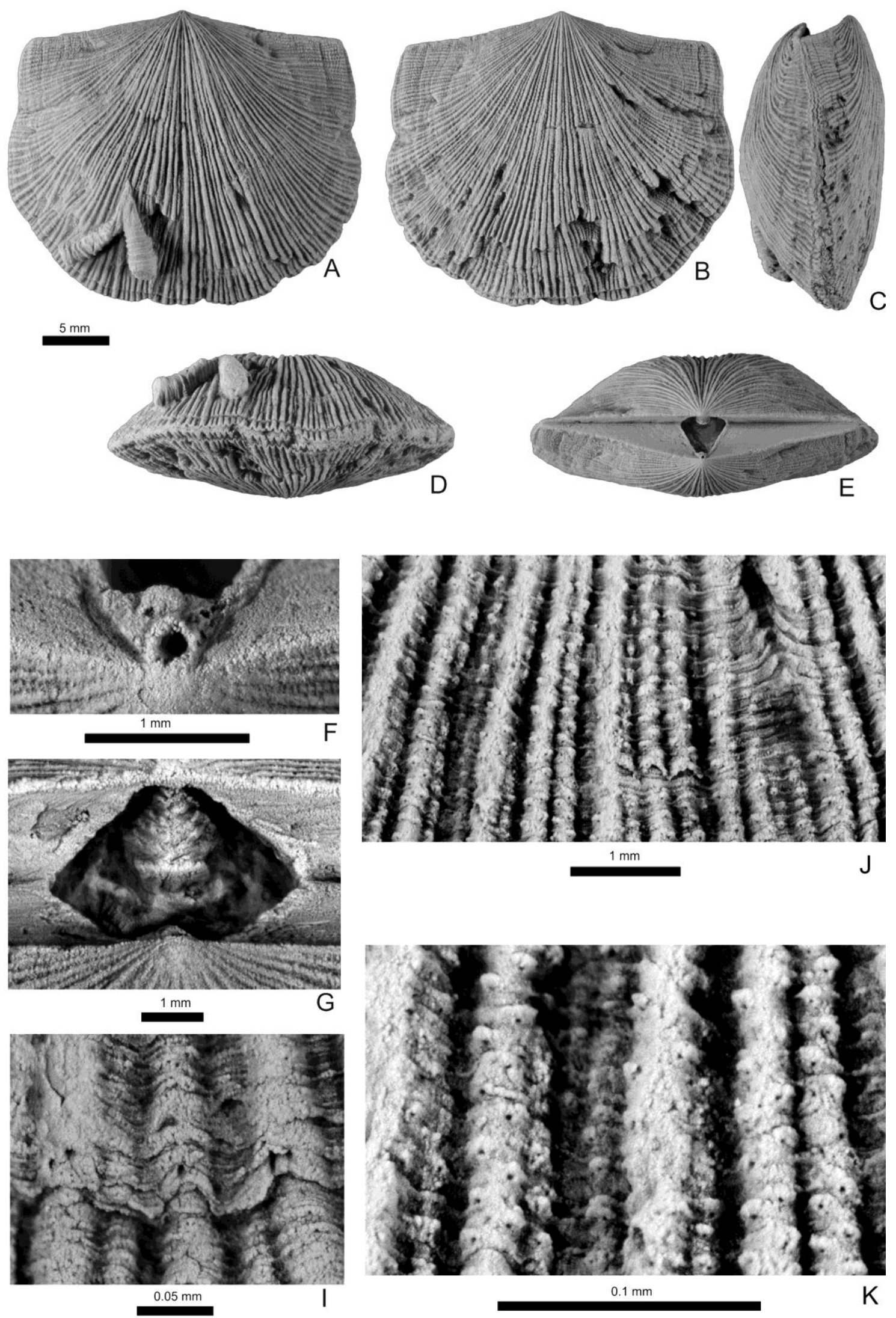


\section{Remarks}

The chief goal of describing Austinella multicostella Alberstadt, 1973 in this study is to report for the first time the presence of epipunctae and aditicules in this genus, as epipunctae have been proposed as a synapomorphic character of the family Plaesiomyidae (Figure 3.11H-J) as seen in Plaesiomys and Retrorsirostra (see Jin et al. 2007; Jin and Zhan 2008; Jin and Copper 2010). In Austinella, the epipunctae are arranged primarily along the ribs, although they are less commonly seen in the interspaces as well. Their limited visibility in the interspaces is most likely a preservation bias because the epipunctae are fairly evenly distributed in longitudinal columns and transversal rows in Plaesiomys. Larger ribs usually bear multiple columns of epipunctae (usually two, but sometimes three). Similar to other plaesiomyids in which epipunctae have been identified, the epipunctae are usually surrounded by distinct tubercles, sometimes forming a hood-like cover over each epipuncta (Figure 3.11J). Less commonly epipunctae are found exposed without tubercular projections.

Interestingly, the aditicules common in other species possessing epipunctae are rare in this species. They are scattered only very sparsely across the surface of the valves and are concentrated near the anterior margin and near growth lamellae (Figure 3.9I). Typically in other species aditicules are also found on ribs away from the margins (e.g. see Jin et al. 2007). In Plaesiomys, there is a broad trend that coarsely ribbed species (e.g. P. occidentalis and P. carletona) tend to have better developed aditicules than finer ribbed species (e.g. P. anticostiensis). The development of aditicules in Austinella multicostella seems to confirm that trend in plaesiomyids

The ribbing in this genus species is very fine, averaging at least two ribs per $\mathrm{mm}$ at the shell margin, compared to the 1-2 ribs per mm of most other species (Figure 3.11AB). Like other plaesiomyids, Austinella multicostella has rounded crests and troughs. The ribs branch asymmetrically - the ribs always are initially much smaller where they branch than closer to the anterior.

Fine growth lines are visible on the shell surface, spaced irregular distances apart but generally less than $0.1 \mathrm{~mm}$ apart. On the figured specimen, the ventral valve shows shell breakage that has healed completely later in development (Figure 3.11B). Given 
that this damage is only around the shell edge, this was likely from a durophagous predator that was peeling the shell edge in an attempt to reach the soft body inside. The dorsal valve of this same specimen is encrusted by two specimens of the problematic fossil Cornulites (Figure 3.11A). 


\section{References}

Alberstadt, L.P. 1973. Articulate Brachiopods of the Viola Formation (Ordovician) in the Arbuckle Mountains, Oklahoma. Oklahoma Geological Survey Bulletin 117. 90 pp.

Bayer, T.N. 1967. Benthonic community in the Maquoketa Formation (Ordovician) of Minnesota. Journal of Paleontology, 41:417-422.

Billings, E. 1865. Palaeozoic Fossils, Volume 1: containing descriptions and figures of new or little known species of organic remains from the Silurian rocks, 1861-1865.

Billings, E. 1866. Catalogues of the Silurian fossils of the island of Anticosti, with descriptions of some new genera and species. Geological Survey of Canada Paper, 71-19. $45 \mathrm{pp}$.

Bolton, T.E. 1972. Geological map and notes on the Ordovician and Silurian litho- and biostratigraphy, Anticosti Island, Quebec. Geological Survey of Canada Paper, 7119. $45 \mathrm{pp}$.

Bolton, T.E. 1981. Ordovician and Silurian biostratigraphy, Anticosti Island, Québec. In IUGS Subcommission on Silurian Stratigraphy, Orodvician - Silurian Working Group, Field Meeting, Antiocsti - Gaspé, Québec, 1981, Vol. 2, Stratigraphy and Paleontology. Edited by P.J. Lespérance. Université de Montréal, Montréal, Québec. p. 41-59.

Bolton, T.E. 2000. Ordovician megafauna, southern Baffin Island, Nunavut. In Geology and paleontology of the southeast Arctic Platform and southern Baffin Island, Nunavut - Geological Survey of Canada Bulletin 557. Edited by A.D. McCracken and T.E. Bolton. Geological Survey of Canada, Ottawa. p. 39-158.

Cooper, G.A. 1956. Chazyan and related brachiopods. Smithsonian Miscellaneous Collections, vol. 127, 1245 pp.

Davis, R.A. 1985. Cincinnati Fossils: An Elementary Guide to the Ordovician Rocks and Fossils of the Cincinnati, Ohio, Region. Cincinnati Museum of Natural History, API, Dayton, Kentucky. 61 pp.

Emmons, E. 1842. Geology of New York, part, comprising the survey of the second geological district. W.A. White and J. Visscher, Albany, New York. 57 pp., 17 pls.

Foerste, A.F. 1909. Preliminary notes on Cincinnatian fossils. Bulletin of the Scientific Laboratories of Denison University, 14: 208-231, pl. 7.

Hall, J. 1847. Descriptions of the organic remains of the lower division of the New York System. New York State Geological Survey, Palaeontology of New York, Vol. 1, $338 \mathrm{p}$.

Hall, J. and Clarke, J.M. 1892. An introduction to the study of the genera of Palaeozic Brachiopoda. New York State Geological Survey, Palaeontology of New York, 8(1): 1-367, pls. 1-20.

Harper, D.A.T. 1979. The environmental significance of some faunal changes in the Upper Ardmillan succession (upper Ordovician), Girvan, Scotland. The 
Caledonides of the British Isles - reviewed, Geological Society of London. p. 439445 .

Hints, L. and Harper, D.A.T. 2003. Review of the Ordovician rhynchonelliformean Brachiopoda of the East Baltic: Their distribution and biofacies. Bulletin of the Geological Society of Denmark, 50-29-43.

Holland, S.M. and Patzkowsky, M.E. 2007. Gradient ecology of a biotic invasion: Biofacies of the type Cincinnatian series (Upper Ordovician), Cincinnati, Ohio, region, USA. Palaios, 22: 392-407.

Howe. H.J. 1966. Orthacea from the Montora Group (Ordovician) of Trans-Pecos Texas. Journal of Paleontology, 40: 241-257.

Howe, H.J. 1988. Articulate brachiopods from the Richmondian of Tennessee. Journal of Paleontology, 62: 204-218.

Jin, J. and Chatterton, B.D.E. 1997. Latest Ordovician-Silurian articulate brachiopods and biostratigraphy of the Avalanche Lake area, southwestern District of Mackenzie, Canada. Palaeontographica Canadiana No. 13, Canadian Society of Petroleum Geologists and the Geological Association of Canada. McAra Printing, Calgary, Alberta. 167 pp.

Jin, J. and Copper, P. 2008. Response of brachiopod communities to environmental change during the Late Ordovician mass extinction interval, Anticosti Island, eastern Canada. Fossils and Strata, 54: 41-51.

Jin, J. and Copper, P. 2010. Microbially induced phophatization of intercrystalline tissue in the Late Ordovician brachiopod Plaesiomys, Anticosti Island, eastern Canada. Special papers in palaeontology, 84: 1-15.

Jin, J. and Norford, B.S. 1996. Upper Middle Ordovician fauna from the Advance Formation, northern Rocky Mountains, British Columbia. In Advance Formation: Stratigraphy and biostratigraphy of a new Ordovician formation in the Rocky Mountains, northeastern British Columbia. Geological Survey of Canada, Bulletin 491, p. 20-77.

Jin, J. and Zhan, R. 2001. Late Ordovician articulate brachiopods from the Red River and Stony Mountain Formations, southern Manitoba. NRC Research Press, Ottawa. 117 pp.

Jin, J. and Zhan, R. 2008. Late Ordovician Orthide and Billingsellide Brachiopods from Anticosti Island, Eastern Canada: Diversity Change through Mass Extinction. NRC Research Press, Ottawa. $151 \mathrm{pp}$.

Jin, J., Caldwell, W.G.E., and Norford, B.S. 1997. Late Ordovician brachiopods and biostratigraphy of the Hudson Bay Lowlands, Northern Manitoba and Ontario. Geological Survey of Canada, Bulletin 513. 115 pp.

Jin, J., Zhan, R., Copper, P., and Caldwell, W.G.E. 2007. Epipunctae and phosphatized setae in Late Ordovician plaesiomyid brachiopods from Anticosti Island, Eastern Canada. Journal of Paleontology, 81: 666-683.

Howe, H.J. 1966. Orthacea from the Montoya Group (Ordovician) of Trans-Pecos Texas. 
Journal of Paleontology, 40: 241-257.

Ladd, H.S. 1929. The stratigraphy and paleontology of the Maquoketa shale of Iowa, pat 1. Iowa Geological Survey Annual Report, 34: 309-448.

Liberty, B.A. 1969. Palaeozoic geology of the Lake Simcoe area, Ontario - Geological Survey of Canada Memoir 355. Geological Survey of Canada, Ottawa. p. 1-201.

Ludvigsen, R. 1975. Ordovician Formations and Faunas, Southern Mackenzie Mountains. Canadian Journal of Earth Science, 12: 663-697.

Macomber, R.W. 1970. Articulate brachiopods from the upper Bighorn Formation (Late Ordovician) of Wyoming. Journal of Paleontology, 44: 416-450.

McChesney, A.M. 1861. Descriptions of new species of fossils from the Paleozoic rocks of the western states. Transactions of the Chicago Academy of Sciences, 1: 5-76.

McChesney, J.H. 1868. Descriptions of fossils from the Paleozoic rocks of the Western States, with illustrations. Chicago Academy of Sciences Transactions, 1: 1-57, Pls. 1-9.

Meek, F.B. 1873. Descriptions of invertebrate fossils of the Silurian and Devonian systems. Ohio Geological Survey, v. 1, pt. 2, Palaeontology, 243 pp.

Norford, B.S. 1962. The Beaverfoot-Brisco Formation in the Stanford Range, British Columbia. Journal of the Alberta Society of Petroleum Geologists, 10: 443-453.

Okulitch, V.J. 1943. The Stony Mountain Formation of Manitoba. Transactions of the Royal Society of Canada, 3rd series, 37: 1-74, 2 pls.

Paškevičius, J. 1994. Baltijos Respubliku geologija. Valstybinis leidybos centras, Vienius. $447 \mathrm{pp}$.

Pickerill, R.K and Brenchley, P.J. 1979. Caradoc marine benthic communities of the South Berwyn Hills, North Wales. Palaeontology, 22: 229-264.

Popov, L.E., Nikitin, I.F., and Cocks, L.R.M. 2000. Late Ordovician brachiopods from the Otar Member of the Chu-Ili Range, south Kazakhstan. Palaeontology, 43: 833870.

Popov, L.E., Cocks, L.R.M., and Nikitin, I.F. 2002. Upper Ordovician brachiopods from the Anderken Formation, Kazakhstan: their ecology and systematic. Bulletin of the Natural History Museum, London (Geology). 58: 13-79.

Potter, A.W. 1990. Middle and Late Ordovician brachiopods from the eastern Klamath Mountains, northern California, Part 1. Palaeontographica Abteilung A, 212(16):31-158.

Raymond, P.E. 1928. No. $6 \mathrm{~b}$ - The Brachiopods of the Lenoir and Athens Formations of Tennessee and Virginia. Bulletin of the Harvard Museum of Comparative Zoology, 292-309, pl. 1-3.

Rice, W.F. 1987. The systematics and biostratigraphy of the brachiopods of the Decorah Shale at St. Paul, Minnesota. Minnesota Geological Survey Report of Investigations, 35: 136-231. 
Ross, R.J., Jr. 1957. Ordovician fossils from wells in the Williston Basin, eastern Montana. United States Geological Survey, Bulletin 1021-M:439-506.

Ross, R.J. Jr., Nolan, T.B., and Harris, A.G. 1979. The Upper Ordovician and Silurian Hanson Creek Formation of Central Nevada. Shorter Contributions to Stratigraphy and Structural Geology, USGS Professional Paper 1126-A-J, C1-C-22.

Roy, S.K. 1941. The Upper Ordovician fauna of Frobisher Bay, Baffin Island. Field Museum of Natural History, Geology, Memoirs 2: 1-212.

Schuchert, C. 1913. In Text-book of Palaeontology, Volume 1, 2nd edition. By K.A. von Zittel. Translated and edited by C.R. Eastman. Macmillan, London. p. 355-420.

Schuchert, C. and Cooper, G.A. 1932. Brachiopod Genera of the Suborders Orthoidea and Pentameroidea. Memoirs of the Peabody Museum of Natural History, 4(1). $270 \mathrm{pp}$.

Shaler, N.S. 1865. List of the Brachiopoda from the island of Anticosti sent by the Museum of Comparative Zoology to different institutions for exchange for other specimens, with annotations. Bulletin of the Museum of Comparative Zoology at Harvard College, 1: 61-70.

Shaler, N.S. 1876. On the fossil brachiopods of the Ohio valley. Kentucky Geological Survey Memoir, 1(3). 44 pp.

Sheehan, P.M. and Harris, M.T. 1997. Upper Ordovician-Silurian Macrofossil Biostratigraphy of the Eastern Great Basin, Utah and Nevada. USGS Professional Paper 1579, C1-115.

Twenhofel, W.H. 1914. The Anticosti Island Faunas. Canada Department of Mines, Geological Survey, Museum Billetin No. 3, Geological Series, No. 19. 35 pp., 1 pl.

Twenhofel, W.H. 1928. Geology of Anticosti Island. Geological Survey of Canada, Memoir 154, $481 \mathrm{pp}$.

Williams, A. and Harper, D.A.T. 2000. Orthida, suborder Orthidina. In Treatise on Invertebrate Paleontology, Part $\mathrm{H}$ - Brachiopoda, Volume 3 - Rhynchonelliformea (part). Edited by R.L. Kaesler. p. 714-782.

Wang, Y. 1949. Maquoketa Brachiopods of Iowa. Geological Society of America Memoir 42. 55 pp.

Wigington, R.J.S. 1977. The age and orthid fauna of the Lower Whittaker Formation, southern Mackenzie Mountains, Northwest Territories. MSc. Thesis, Department of Geology, University of Western Ontario, London, Ontario. 147 pp.

Willard, B. 1928. No. 6a - The Brachiopods of the Ottosee and Holston Formations of Tennessee and Virginia. Bulletin of the Harvard Museum of Comparative Zoology, 48:255-292, pl. 1-3.

Wilson, A.E. 1926. An Upper Ordovician fauna from the Rocky Mountains, British Columbia. Canada Department of Mines, Geological Survey, Bulletin 44 (Geological Series No. 46), p. 1-34, Pl. 1-8.

Wilson, A.E. 1946. Brachiopoda of the Ottawa Formation of the Ottawa-St. Lawrence 
lowland. Canada Department of Mines and Resources - Mines and Geology Branch, Geological Survey Bulletin, No. 8. 147 pp.

Witzke, B.J., Anderson, R.R., and Heathcote, R.C. 1997. Upper Ordovician Brainard Shale (Maquoketa Formation); Stop 4: Highway 20, Dubuque County. In Geology in the Dubuque area. Geological Society of Iowa Guidebook 63. pp. 15-24.

Woodward, S.P. 1852. A manual of the Mollusca; or rudimentary treatise of recent and fossil shells. John Weale, London, $486 \mathrm{pp}$.

Wright, A.D. 1964. The fauna of the Protrane Limestone, II. Bulletin of the British Museum (Natural History), Geology. Vol. 9, No. 6. London, United Kingdom. 304 pp.

Young, G.A., Elias, R.J., Wong, S., and Dobrzanski, E.P. 2008. Upper Ordovician Rocks and Fossils in Southern Manitoba, Canadian Paleontology Conference Field Trip Guidebook No. 13. Geological Association of Canada Publications, 97 pp. 


\section{Chapter 4 - Evolution of the plaesiomyid lineage in Laurentia}

\subsection{Introduction}

The subfamily Plaesiomyinae Schuchert, 1913 is the largest group within the family Plaesiomyidae Schuchert, 1913 that ranges from the Darriwilian to Hirnantian (Whiterockian to Cincinnatian, Llanvirn to Ashgill; see Figure 4.1). The species of Plaesiomyinae are characterized by large, costate to costellate, and subequally biconvex to partially convexoconcave shells. These brachiopods are found globally, but are most abundant in North America.

Some plaesiomyid shells have been shown to possess distinctive epipunctae, a newly recognized type of shell micro-perforations first found in Plaesiomys anticostiensis (Shaler, 1865), that housed setae. These setae within the epipunctae must have enhanced sensory capability of the brachiopod (Jin et al. 2007; Jin and Zhan 2008; Jin and Copper 2010). Since the nature of shell punctation is an important diagnostic character in brachiopod taxonomy, the discovery of epipunctae has changed the long-held view that plaesiomyids had impunctate shells as in all other members of the superfamily Orthoidea. Genera of the Plaesiomyinae include Austinella, Campylorthis, Chaulistomella, Dinorthis, Multicostella, Pionorthis, Plaesiomys, Retrorsirostra, and Valcourea, among which Austinella, Plaesiomys, and Retrorsirostra have been confirmed to have epipunctae. Larger perforations known as aditicules have been confirmed in these species as well, but are much less diagnostic of the family, and have also been found in well preserved specimens of other groups (e.g. dalmanellids - see Jin 2012).

Dinorthis Hall and Clarke, 1892 and Plaesiomys Hall and Clarke, 1892 are very similar in appearance. The main differentiating feature between the genera is the style of shell ribbing. In Plaesiomys, the ribs generally branch towards the commissure whereas specimens assigned to Dinorthis lack significant branching of ribs over the length of the shell. This has led to debate regarding their diagnosis as separate genera, with Macomber (1970) suggesting that each genus represented an end member on a gradational continuum. Macomber tentatively proposed that the division be based on the degree of 


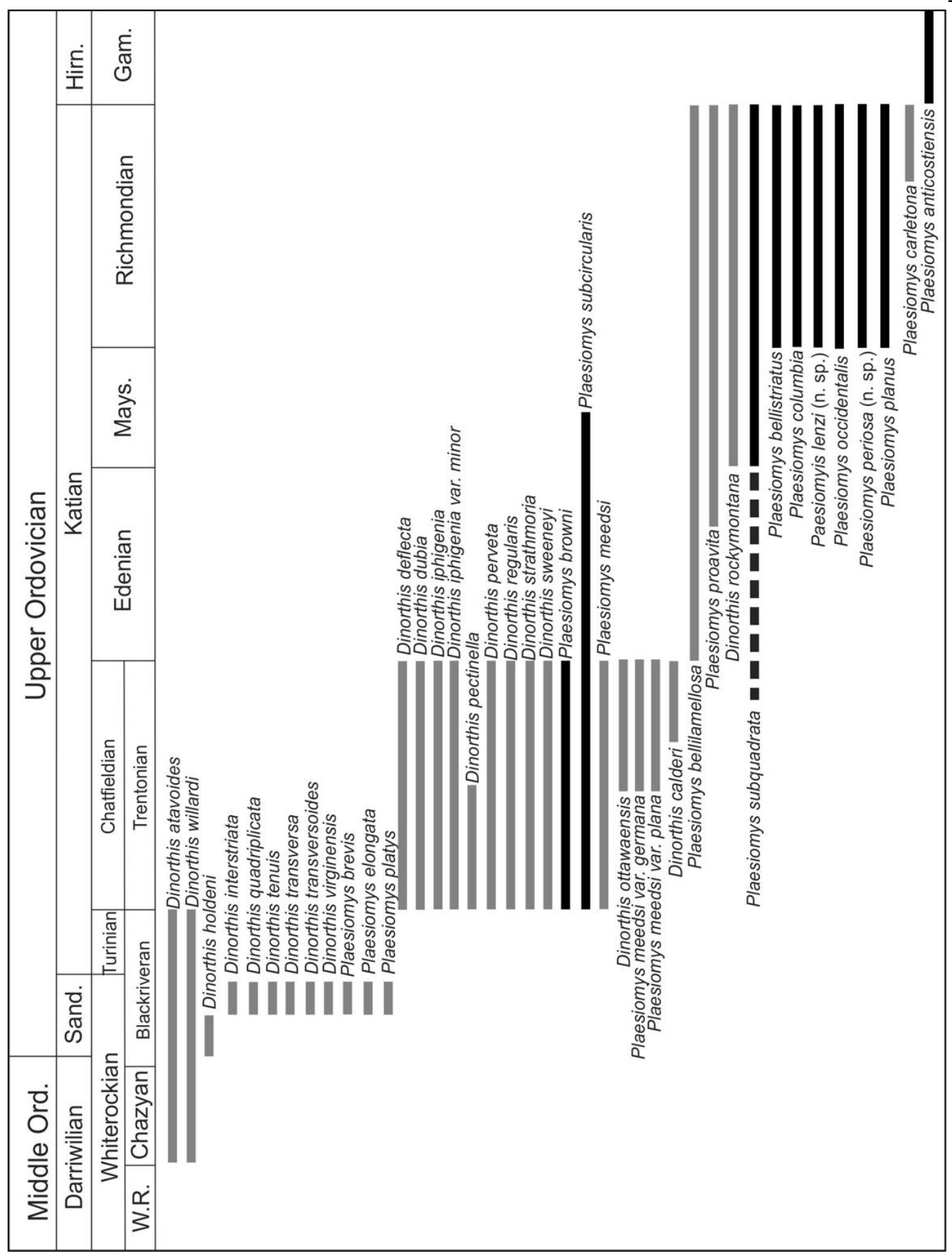

Figure 4.1 - Range of Dinorthis and Plaesiomys species. Black bars indicate species studied herein. The apparently diverse early and middle Late Ordovician faunas are likely due to outdated taxonomy, and are in need of revision. Compiled mainly from the following references: Wilson 1926, Wang 1949, Wilson 1946, Cooper 1956, Howe 1966, Macomber 1970, Alberstadt 1973, Wigington 1977, Roy et al. 1979, Titus 1982, 1986, Davis 1985, Rice 1987, Howe 1988, Jin and Norford 1997, Jin et al. 1997, Bolton 2000, Jin and Zhan 2001, Holland and Patzkowsky 2007, and Jin and Zhan 2008. 
rib bifurcation, with Plaesiomys applying only to those specimens where nearly all ribs multiply at least once. Jin and Zhan (2001) studied Dinorthis occidentalis from Stony Mountain, Manitoba, and followed the scheme of Macomber (1970). They also added that Dinorthis generally has a rectimarginate anterior commissure while Plaesiomys generally shows a uniplicate anterior and that the muscle scars in Dinorthis are more bilobate than the scalloped muscle scars of Plaesiomys. Part of the confusion between the two genera has stems from the lack of detailed study of the internal morphology of the typical Dinorthis. For example, the cardinalia and muscle fields of D. pectinella (Emmons, 1842), the type species, remains poorly studied in comparison to those structures of Plaesiomys. The differentiation between the genera, however, remains to be studied because the material for the type species of Dinorthis, D. pectinella from the Cincinnati type area, tends to be silicified or poorly preserved, and there has been little information about the true nature of its cardinalia.

The affinities of Dinorthis occidentalis (Okulitch, 1943), one of the species being examined here, have likewise been debated by many workers. The species was originally assigned to Pionorthis by Okulitch (1943), however this genus was rendered invalid by Jin et al. (2007) as it was based on a type specimen (Orthis sola Billings, 1866) belonging to the dalmanelloid genus Mendacella. Ross (1957) designated two species from eastern Montana with close affinities to D. occidentalis as Dinorthis (Pionorthis) and one species as Dinorthis (Plaesiomys?). Macomber (1970), in his study of specimens from the Bighorn Dolomite of Wyoming classified D. occidentalis for the first time as a species of Plaesiomys (Dinorthis) as it showed very little or no multiplication of ribs. Jin et al. (1997), studying material from the Caution Creek and Chasm Creek formations of the Hudson Bay lowlands, and Jin and Zhan (2001) studying material from the Stony Mountain Formation of Manitoba (as in this study), placed the species under Dinorthis using the same classification scheme.

Here, the species is reassigned to Plaesiomys, based on its similarity to $P$. carletona of Anticosti Island. Although P. occidentalis shows less rib bifurcation than a typical Plaesiomys, more closely resembles Plaesiomys morphologically and in size than the early Dinorthis from the lower Upper Ordovician Cininnati type area which are 
typically much smaller. Here it is suggested that forms which show any rib multiplication be considered Plaesiomys and only forms which show no multiplication at all be classified as Dinorthis based on similarities seen between P. occidentalis and other Richmondian plaesiomyids (see Chapter 3 for further discussion). Further study is needed on the early Dinorthis forms to determine their affinities.

Brachiopods of the Plaesiomys-Dinorthis lineage are common in the Upper Ordovician carbonate deposits of North America. Canadian localities include Anticosti Island (Quebec) (Shaler 1865; Twenhofel 1928; Bolton 1972; Bolton 1981; Jin and Copper 2008; Jin and Zhan 2008), Baffin Island (Nunavut) (Schuchert 1900; Roy 1941; Bolton 2000), the Mackenzie Mountains in the Northwest Territories (Ludvigsen 1975; Wigington 1977; Jin and Chatterton 1997), southern Manitoba (Okulitch 1943; Jin et al. 1997; Jin and Zhan 2001; Young et al. 2008) and the Hudson Bay lowlands (Jin et al. 1997), Ontario (Wilson 1946; Liberty 1969), and the Rocky Mountains of British Columbia (Wilson 1926; Norford 1962; Jin and Norford 1996). Localities in the U.S. include Illinois (Witzke et al. 1997), Iowa (Ladd 1929; Wang 1949), Minnesota (Winchell and Schuchert 1893; Bayer 1967; Rice 1987), Montana (Ross 1957), Nevada (Ross et al. 1979; Sheehan and Harris 1997), New York (Emmons 1842; Hall 1847; Hall and Clark 1892; Titus 1982, 1986), the Ohio-Kentucky-Indiana tri-state area (Shaler 1865; Davis 1985; Schwimmer and Sandy, 1996; Holland and Patzkowsky 2007), Oklahoma (Alberstadt 1973), Tennessee (Willard 1928, Cooper 1956; Howe 1988), Utah (Ross et al. 1979), Virginia (Cooper 1956), Wyoming (Macomber 1970), and Texas (Howe 1966). Globally, these genera have been found in the Argentina (Benedetto 1998, 2003), Baltic region (Paškevičius 1994; Hints and Harper 2003), Kazakhstan (Popov et al. 2000; Nikitin et al. 2003), Northern Ireland, and Scotland (Harper 1979; Pickerill and Brenchley 1979), the latter two representing parts of Laurentia during much of the Paleozoic.

The Plaesiomys-Dinorthis stock appeared during the Darriwilian with two species from Tennessee in the eastern United States (Willard 1928; Cooper 1956). The lineage underwent a radiation in the earliest Katian time (Trentonian, Chatfieldian), becoming widespread across the United States and eastern Canada, with species originating such as 
D. pectinella (Hall 1847) from the Curdsville Formation of Kentucky, P. meedsi

(Winchell and Schuchert, 1892) from the Decorah Shale of Minnesota and the Advance Formation of the Canadian Rocky Mountains (Jin and Norford 1996), and Plaesiomys subcircularis (Roy, 1941) from the Verulam Formation of Ontario. By middle and late Katian time (Maysvillian - Richmondian), Plaesiomys became abundant in both pericratonic and intracratonic basins of North America, with P. occidentalis forming a major component of the brachiopod fauna that invaded the broad, shallow epicontinental seas, while Dinorthis had disappeared.

Despite the broad pattern of plaesiomyid evolution and paleogeography hinted in previous studies, there has been no detailed, let alone quantitative, analysis of the evolutionary trends, paleoecological niche partitioning, and paleogeographical gradient among various forms of Plaesiomys in North America. This study aims to investigate species niche partitioning of the genus by examining their morphological variations across Laurentia during the Late Ordovician and quantifying the morphological changes in the lineage over time. The implications of such morphological changes in time and space will be explored in terms of paleoecology and paleogeography.

\subsection{Material}

In this study, plaesiomyid brachiopod samples from seven localities across North America were examined (see Figure 1.8). Nine species were studied in detail from the following formations and localities (in approximately oldest to youngest chronological order):

- Verulam Formation (early Katian, Chatfieldian), lakeshore section, north of Little Current, Manitoulin Island, Ontario (UTM 17 429039E 5093089N - WGS 1984 datum). Plaesiomys browni (Wilson, 1946), from a thin calcareous mudstone parting between storm-generated, strophomenide-dominated brachiopod shellbeds and bryzoan-brachiopod wackestones and packstones; scoured bases and prominent wave ripples (decimetre-scale wave length) are present. Specimens in Western University Collection.

- Verulam Formation (early Katian, Chatfieldian), Lake Simcoe area, Ontario 
(UTM 17 644080E 4929611N - WGS 1984 datum). Plaesiomys subcircularis (Roy, 1941), from calcareous mudstone interbeds between thin- to mediumbedded brachiopod-bryozoan wackestones to packstones. Specimens in Western University Collection.

- Amadjuack Formation, GSC locality O-104526 - Silliman's Fossil Mount, Baffin Island, Nunavut, 634'00" N, 6856'45"W. Plaesiomys subcircularis (Roy, 1941). Specimens in Geological Survey of Canada Collection.

- Whittaker Formation (mid Katian, Edenian to Maysvillian), Mackenzie Mountains, Northwest Territories (Wigington's (1977) study area - approximately

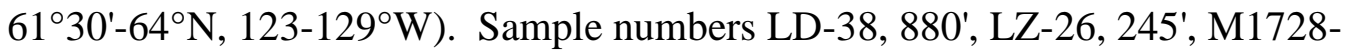
35', and YC-2:F7. Plaesiomys columbia (Wilson, 1926), Plaesiomys lenzi n. sp. (see also Wigington 1977), Plaesiomys periosa n. sp. (see also Wigington, 1977). Specimens in Western University Collection.

- Gunn Member, Stony Mountain Formation (late Katian, Richmondian), Mariash Quarry, Stony Mountain, Manitoba, UTM 14 628152E 5550764N. Plaesiomys occidentalis (Okulitch, 1943). Specimens in Western University Collection.

- Cincinnati Group (late Katian, Richmondian), Ohio-Kentucky-Indiana tri-state area. Field Museum collections (Chicago, Illinois). Plaesiomys subquadrata (Hall, 1847), Plaesiomys bellistriatus Wang, 1949. Specimens in Field Museum Collection.

- Ellis Bay Formation (Hirnantian, Gamachian), localities A425 (UTM 17 408290E 5520150N), A647 (408230E 5520150N), and A1334 (UTM 17 440070E 5511420N), Anticosti Island, Quebec. Plaesiomys anticostiensis (Shaler, 1865). Specimens in Western University Collection. 


\section{Figure 4.2}

\section{A-E: Plaesiomys browni (Wilson, 1946)}

A-E: W-MI A - dorsal, ventral, lateral, anterior, and posterior views showing characteristic rib intercalation and bifurcation pattern on the dorsal and ventral valves respectively - ribs multiply close the shell margin. Verulam Formation, Manitoulin Island, Ontario.

\section{F-O: Plaesiomys subcircularis (Roy, 1941)}

F-J: Specimen from Western University - dorsal, ventral, anterior, posterior, and lateral views. Verulam Formation, Lake Simcoe area, Ontario (new occurrence).

K-O: GSC 113498, holotype - dorsal, ventral, lateral, anterior, posterior, and lateral views showing small size relative to other congeneric species and bilobed cardinal process of the genera. GSC locality O-104526, Amadjuack Formation, Silliman's Fossil Mount, Baffin Island, Nunavut.

\section{P-S: Plaesiomys columbia (Wilson, 1926)}

P-S: Specimen from Wigington's collection at Western University - dorsal, ventral, anterior, posterior, and lateral views. Note the large size of these specimens in comparison to most other plaesiomyids and characteristic coarse ribs. Locality LZ 26, 245' (=75 m), Whittaker Formation, Mackenzie Mountains, Northwest Territories. 

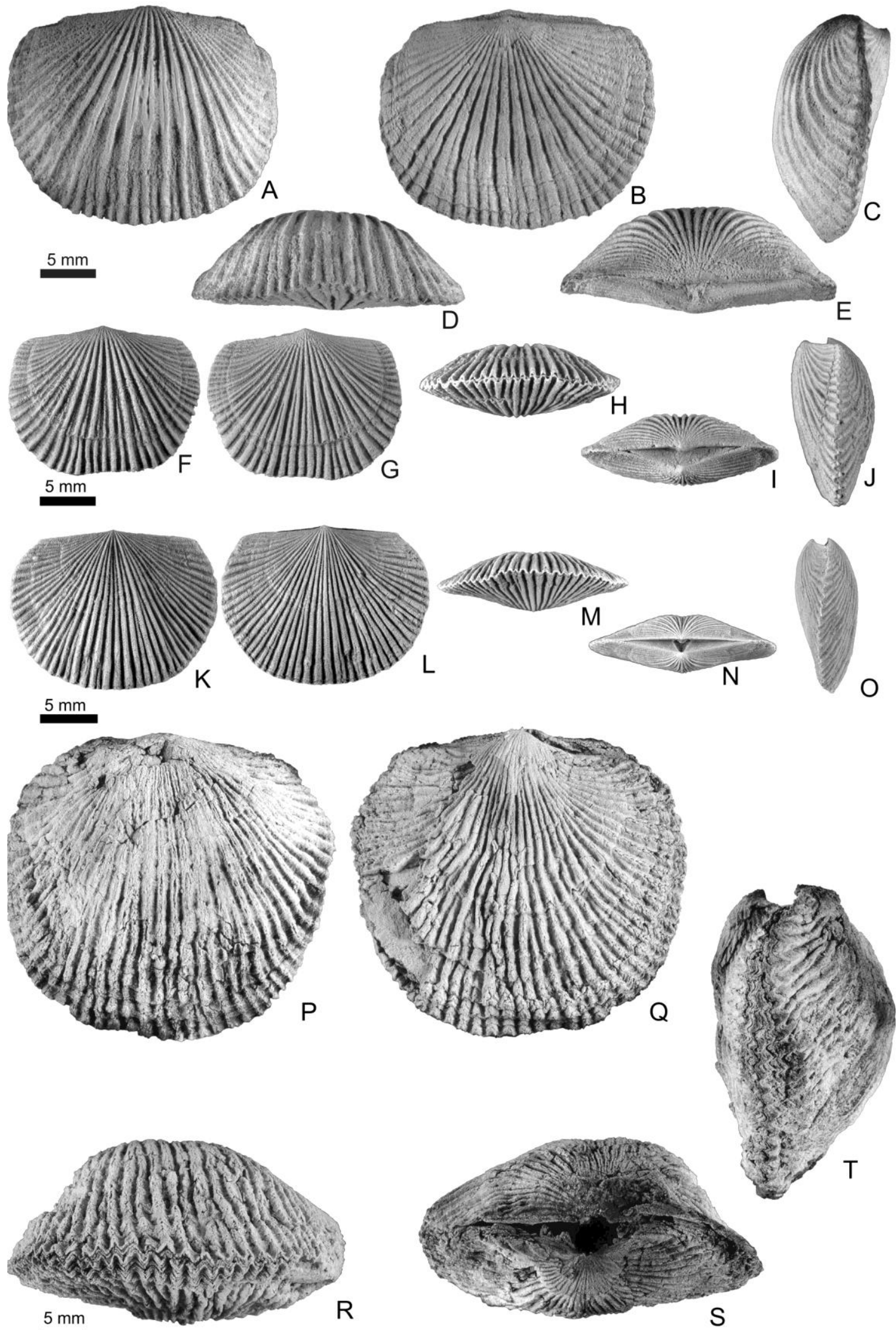

$\mathrm{R}$

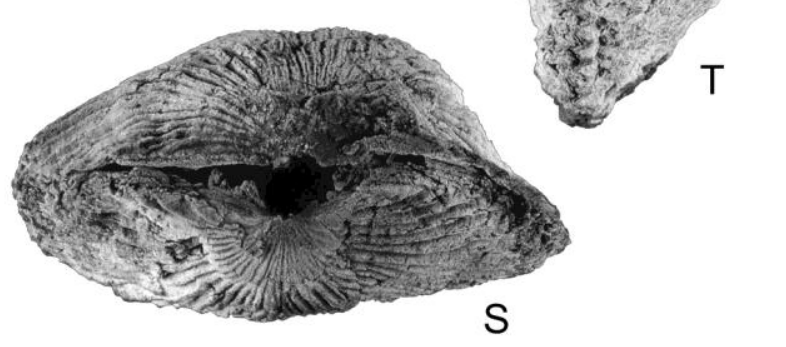




\section{Figure 4.3}

\section{A-E - Plaesiomys lenzi n. sp.}

A-E: GSC 131790 - dorsal, ventral, anterior, posterior, and lateral views showing fine ribbing pattern of the species; locality M1730-35' (=527-529 m), Whittaker Formation, Mackenzie Mountains, Northwest Territories.

\section{F-I Plaesiomys periosa n. sp.}

F-I: GSC 131793 - dorsal, ventral, anterior, posterior, and lateral views. Note much larger size than other species of the genus. Locality LZ-26, 245' (=75m), Whittaker Formation, Mackenzie Mountains, Northwest Territories.

\section{J-N Plaesiomys occidentalis (Okulitch, 1943)}

J-N: GSC 117745, hypotype - dorsal, ventral, lateral, anterior, and posterior views showing coarse and infrequently bifurcating/intercalating ribs. Gunn Member, Stony Mountain Formation, Stony Mountain, Manitoba. 

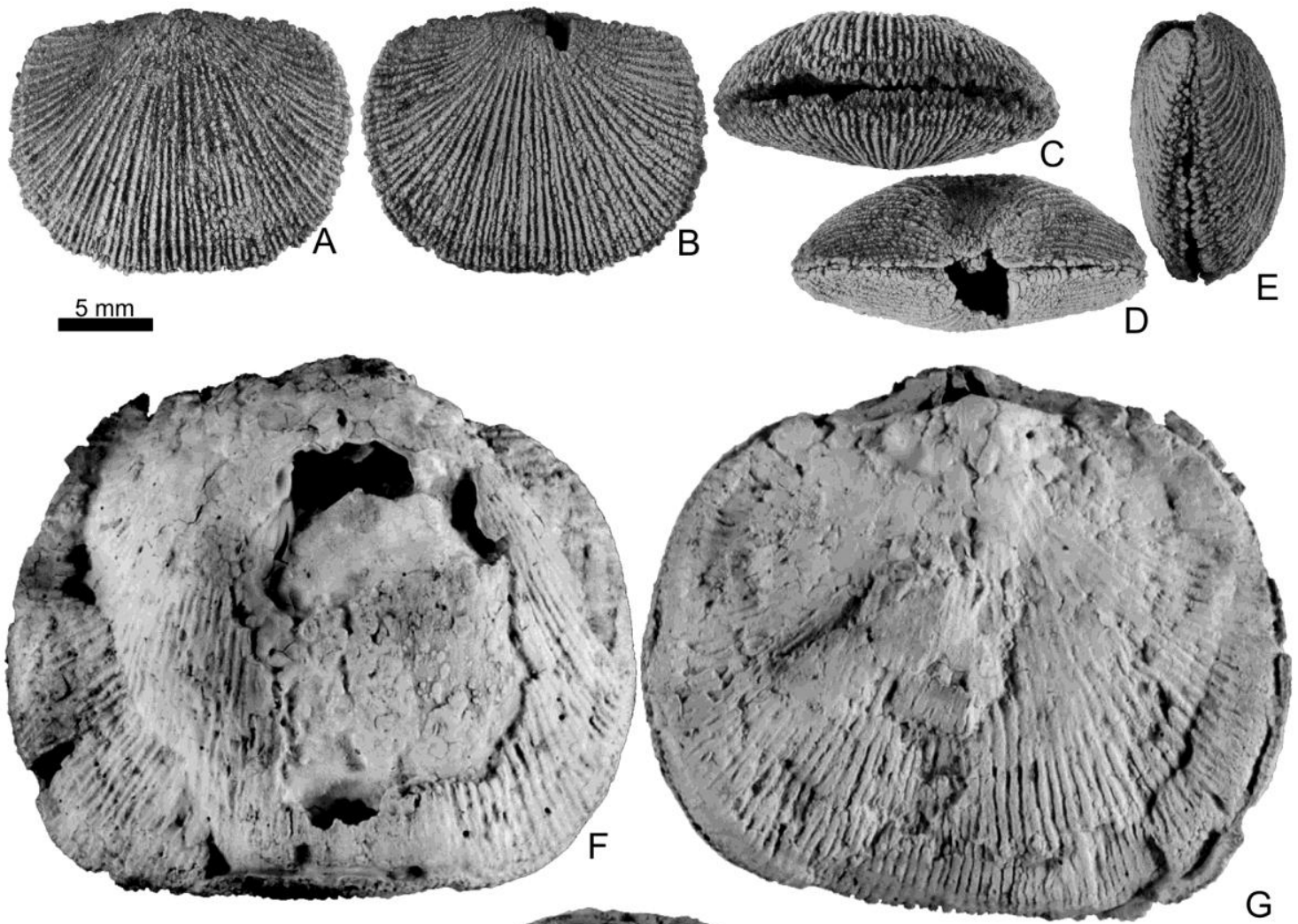

$10 \mathrm{~mm}$
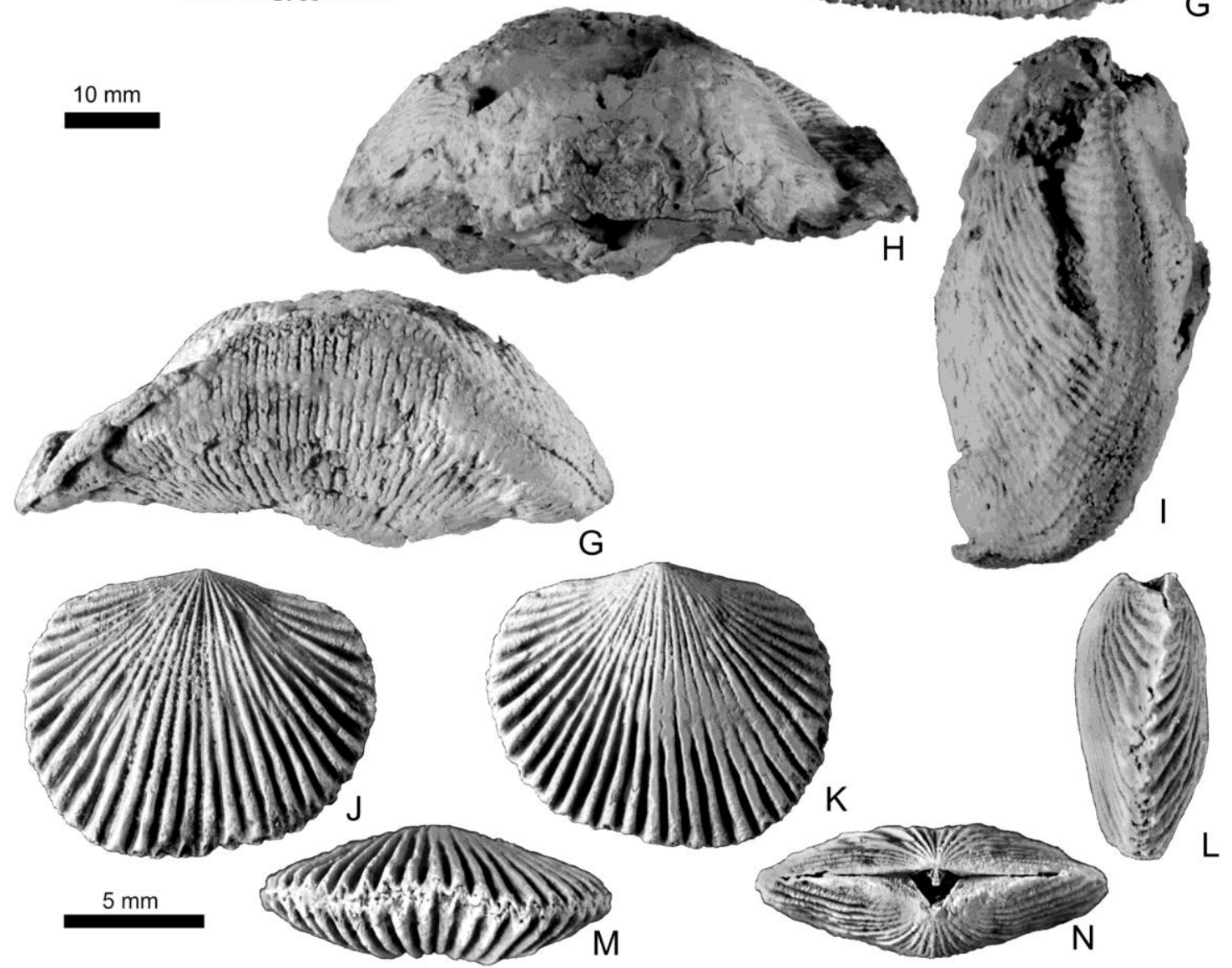
avivill)

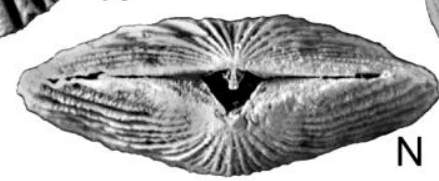


Figure 4.4

\section{A-E: Plaesiomys subquadrata (Hall, 1847)}

A-E: W2525 - dorsal, ventral, anterior, posterior, and lateral views. Liberty Formation, upper Katian (Richmondian) strata, Germantown, Ohio.

\section{F-J: Plaesiomys bellistriatus Wang, 1949}

F-J: FM-PE2204a - dorsal, ventral, anterior, posterior, and lateral views. Note the fine ribbing pattern and rugae near the commissure. Locality PE 2168, Richmond Group, Madison, Indiana.

K-O: Plaesiomys anticostiensis (Shaler, 1865)

K-O: MCZ 147679 - lectotype, dorsal, ventral, lateral, anterior, and posterior views. Likely from Junction Cliff, Grindstone Member, Ellis Bay Formation. 

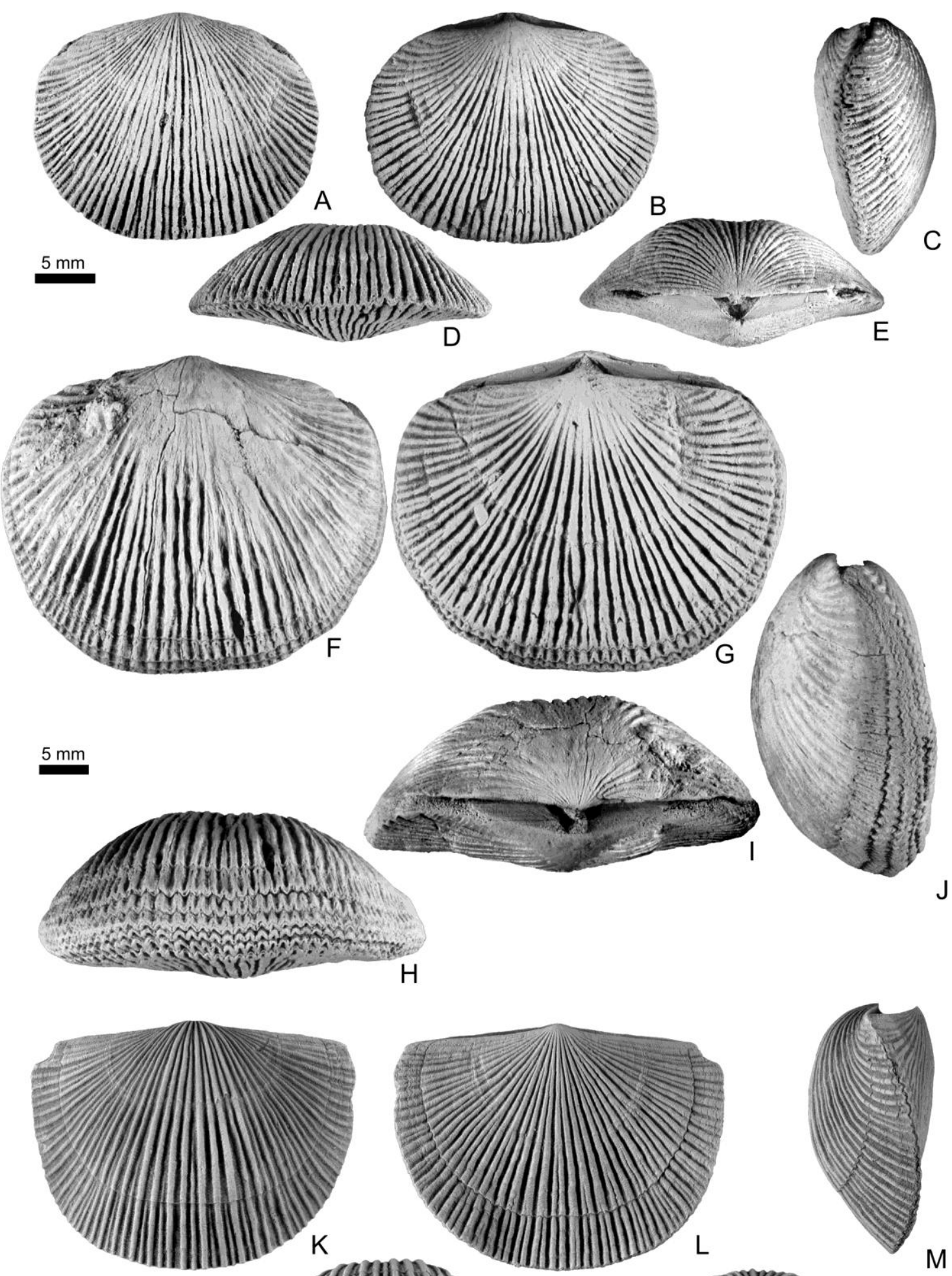

$5 \mathrm{~mm}$
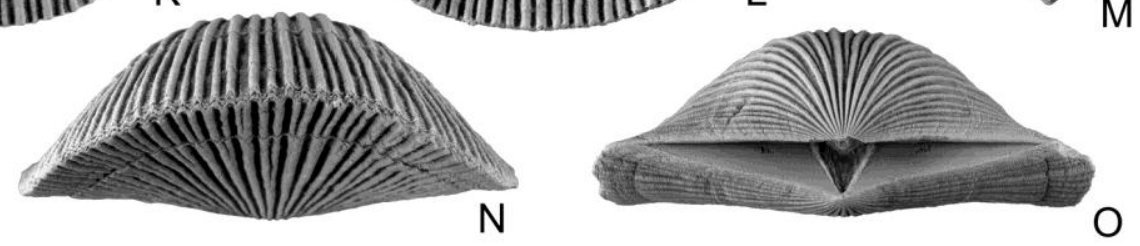


\subsubsection{Notes on the Field Museum collection}

The geological and stratigraphical settings of the localities listed above were discussed in detail in Chapter 2. It suffices here to provide some notes on the samples on loan from the Field Museum in Chicago, Illinois. This collection contained three specimens from Illinois (sample number P 6827). No stratigraphic information is available for the specimens, but the sample probably originated from the Brainard Shale greenish grey dolomite-rich shale that contains beds of argillaceous dolostone (Willman and Buschbach 1975; Witzke et al. 1997). This unit correlates with the Elkhorn Formation of Cincinnati, making the plaesiomyid fossils slightly younger than the specimens from the Cincinnati region, but still late Katian (Richmondian) (Willman and Buschbach 1975).

There are also three specimens of Austinella multicostella Alberstadt, 1973 from this collection (sample number PE 5523) labelled as being from the Bromide Formation of Oklahoma. The Bromide Formation specimens are Sandbian (Turinian, Blackriveran) in age (Amsden and Sweet 1983; Roseneau et al. 2012), making them the oldest representatives of plaesiomyids examined in this study. However, there are only three specimens, and only one of them is sufficiently preserved for examination of the biometric measurements used in this study; the others appear to be compressed, and partially damaged. As such, any discussion regarding the Oklahoma specimens is brief and generalized - meaningful analytical results would be impossible to obtain on a single specimen. More recent publications indicate that Dinorthis and Plaesiomys are unknown in the Bromide Formation, but Plaesiomys is known to occur in the younger Edenian Maysvillian (lower-middle Katian) Welling Formation (Amsden and Sweet 1983). Thus, it is possible that the Field Museum specimens actually came from these younger strata.

Thirteen of the plaesiomyid specimens are labelled as originating from the Lorraine Formation - now the Maysville Group (after Foerste 1905) and part of Holland and Patzkowsky's (1996) C4 sequence. However, their exact stratigraphic position within this group is unknown and they may have been mislabelled. Indeed, Malizia and Stigall (2011) report that no Plaesiomys subquadrata specimens have yet been found in strata 
older than the $\mathrm{C} 5$ sequence, suggesting that the species only became abundant after an ecological shift that occurred during early in the deposition of the $\mathrm{C} 4$ sequence. Furthermore, Holland and Patzkowsky (2007), in their ecological analysis of the Ordovician succession in the Cincinnati region, have documented Plaesiomys only from the $\mathrm{C} 5$ sequence. Thus, it seems reasonable to assume that they originated from between the upper C4 and the C5 sequence (late Katian, or Maysvillian to Richmondian in age).

Finally, it should be noted that the stratigraphic nomenclature of the Cincinnati region is currently in a state of flux. Attempts have been made to divide the traditional "layer cake" stratigraphy of Cincinnati into sequences in an attempt to define synchronous in a succession formerly thought to have consisted of diachronous lithostratigraphic units (Holland 1993, 1997, 2008 Holland and Patzkowsky 1996). Work has also begun on systematically correlating units that have been named regionally by the individual state geological surveys into cohesive, inclusive, synchronous units across the tri-state area through the use of fine-scale sequence stratigraphy (e.g. Brett et al. 2008, 2012). Once this work is complete, it may be necessary to update the collection information to include these new units.

\subsection{Methods}

Selection of specimens from each locality was based mainly on the quality of preservation and care was taken to select specimens at random in an attempt to avoid a bias in shell size.

Nine biometric measurements, where possible, were taken on each brachiopod specimen (Figure 4.5). These included:

length of dorsal valve (Ld): linear measurement from the apex to the most anterior point of the valve;

length of ventral valve ( $\mathbf{L v})$ : linear measurement from the apex to the most anterior point of the valve;

width $(\mathbf{W})$ : linear measurement of the shell width at its widest point; 

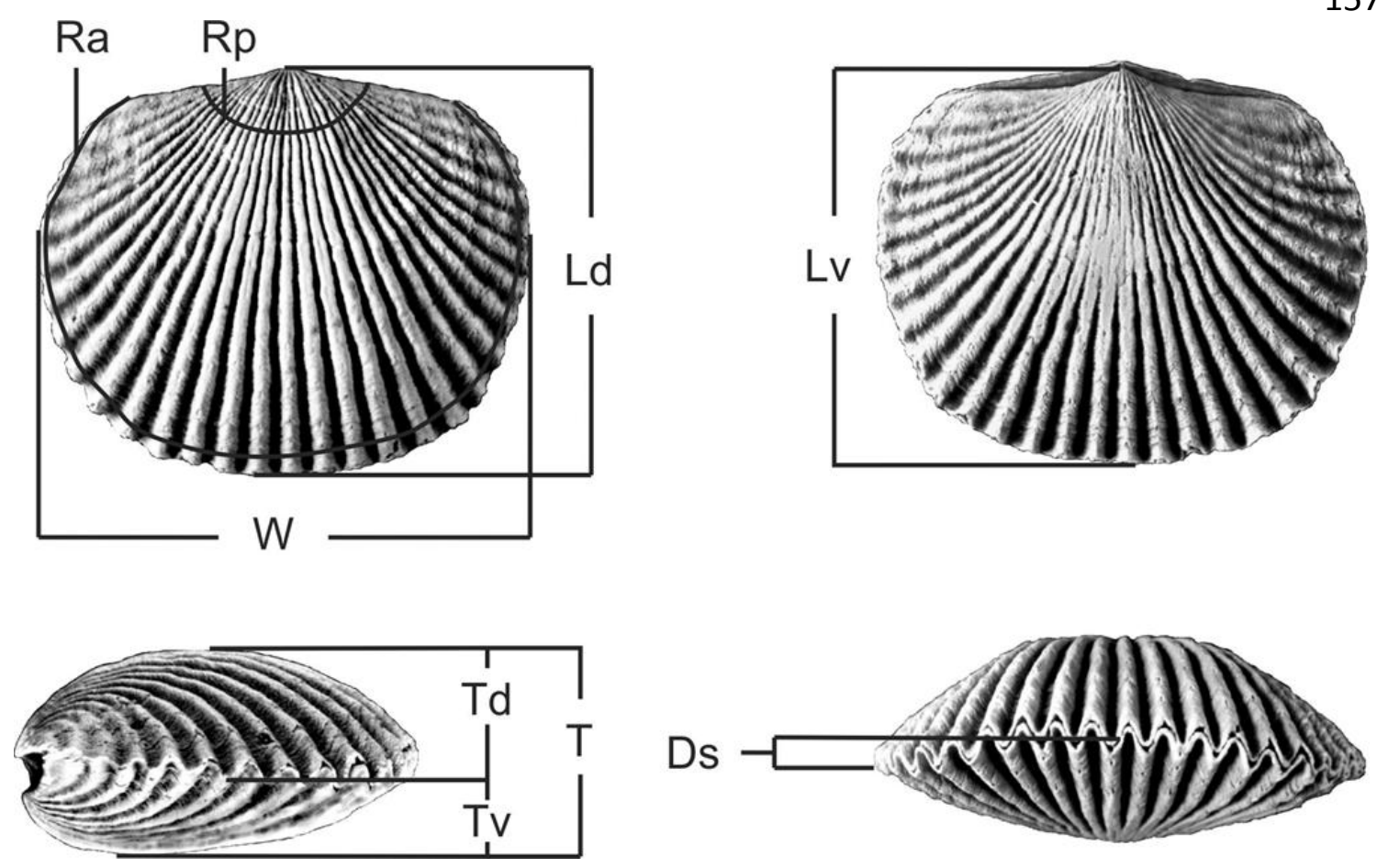

Figure 4.5 - Dimensions measured in this study for use in principal component analysis (PCA). Length, width, and depth were measured in millimeters. 
depth of dorsal valve (Td): linear distance from the deepest point of the valve perpendicularly to the commissural plane;

depth of ventral valve (Tv): linear distance from the deepest point of the valve perpendicularly to the commissural plane;

shell thickness (T): linear measurement between the highest points of the two valves;

depth of the sulcus (Ds): total depth of the sulcus at the anterior margin, measured perpendicularly to the commissural plane;

number of ribs at anterior margin (Ra): count of the number of ribs at the commissure, counted on the dorsal valve;

number of ribs in posterior part (Rp): count of the number of ribs in a $5 \mathrm{~mm}$ arc from the dorsal apex, counted on the dorsal valve.

From these measurements, the following four ratios were calculated, mostly as proxies of morphological characters commonly used to differentiate between plaesiomyid taxa.

ratio of length of ventral valve/length of dorsal valve (Lv/Ld)

rib bifurcation index (ratio of ribs at posterior/ribs at anterior)

dorsal convexity index (depth of dorsal valve/shell width)

globosity index (shell thickness/shell width)

In general, only complete specimens were included in the analysis in order to compare the same required measurements among the specimens and to conduct multivariate analysis of biometric characters. The remaining unmeasured specimens were still included in calculated mean values of individual biometric variables.

Each measurement was made using a set of digital vernier callipers to ensure accuracy. A total of 509 specimens were measured, among which 198 well-preserved specimens were selected for principle component analysis (Table 4.1). 
Table 4.1 - Number of plaesiomyid specimens per locality measured and used for analysis.

\begin{tabular}{|l|l|l|}
\hline Locality & $\begin{array}{l}\text { No. of Specimens } \\
\text { Measured }\end{array}$ & $\begin{array}{l}\text { No. of Specimens } \\
\text { Included in Analysis }\end{array}$ \\
\hline Lake Simcoe & 4 & 3 \\
\hline Manitoulin Island & 25 & 4 \\
\hline Baffin Island & 8 & 6 \\
\hline Mackenzie Mountains & 7 & 5 \\
\hline Stony Mountain & 260 & 57 \\
\hline Cincinnati & 36 & 27 \\
\hline Anticosti Island & 167 & 94 \\
\hline Illinois & 1 & 1 \\
\hline Oklahoma & 1 & 1 \\
\hline Total & 509 & 198 \\
\hline
\end{tabular}

Principal components analysis (PCA) is a quantitative method used to analyze a data set that includes multiple variables (Davis 2002; Harper and Owen 1999; Hammer and Harper 2006). It groups the number of variables into a smaller number (usually 2) of hypothetical variables (components), plotted in two or three dimensions on a graph. Each principal component represents maximum amount of variance generated from related variables within the data set (Hammer et al. 2001; Hammer and Harper 2006). Thus, PCA simplifies a complicated multivariate, multi-axis plot to a graph that can be presented in two dimensions with two axes. This allows comparison of groups that are related in terms of the original variables being measured - the direction and magnitude of difference in the variables between groups. A more detailed mathematical explanation can be found in Davis (2002) and Harper (1999).

Because not all measurements were in the same units, correlation analysis was used rather than variance-covariance. This allows the analysis to weigh the variables equally and to compare among the variables regardless of their units of measurement. In the PCA scattergram each sample is plotted as an $\mathrm{x}$ and y coordinate on a plane. Biplot lines show how the specimens were related to each other in terms of the variables being 
compared, even though the length of a biplot line does not necessarily reflect its weight in data ordination due to the multidimensional trajectories of the lines being flattened in two dimensions.

Principal component analysis can be performed using a variety of software. In this study, PAST (version 2.14, 2012; see Hammer and Harper 2012) was used because it is a statistical software package developed specifically for analysis of paleontological data (Hammer et al. 2001). It can be used for various types of quantitative analyses, such as univariate and multivariate statistics, calculation of biodiversity indices and faunal similarity indices, time-series analysis, and phylogenetic analysis. This software is freely available online, with accompanying documentation (http://folk.uio.no/ohammer/past/).

\subsection{Results}

In the PCA plot (Figure 4.6), three patterns can be recognized. Specimens that plotted in the left part of the scattergram are characterized by small shells with a moderate degree of rib multiplication. Shells near the top of the scattergram are typically larger with the least amount of rib multiplication. The remaining specimens at the bottom of the scattergram are generally large, and show frequent rib bifurcation. These characteristics were used to broadly group the specimens into three groups: A, B, and C.

Group A consists of samples from the Verulam Formation of Manitoulin Island (Plaesiomys browni) and near Lake Simcoe, Ontario (P. subcircularis), and the Amadjuack Formation on Baffin Island (P. subcircularis).

These specimens are smaller than those of groups B and C when mature shells are compared (Table 4.2). The specimens from Manitoulin Island (Plaesiomys browni) were the largest in this group, averaging a length of $18.23 \mathrm{~mm}$, width of $22.74 \mathrm{~mm}$, and total thickness of $8.26 \mathrm{~mm}$. The Lake Simcoe and Baffin Island specimens (both $P$. subcircularis) were significantly smaller - Lake Simcoe specimens averaged $12.37 \mathrm{~mm}$ in length, $15.48 \mathrm{~mm}$ in width, and $6.24 \mathrm{~mm}$ in total thickness while Baffin Island specimens measured a similar length of $13.40 \mathrm{~mm}$, width of $16.62 \mathrm{~mm}$, and total thickness of $5.26 \mathrm{~mm}$. 


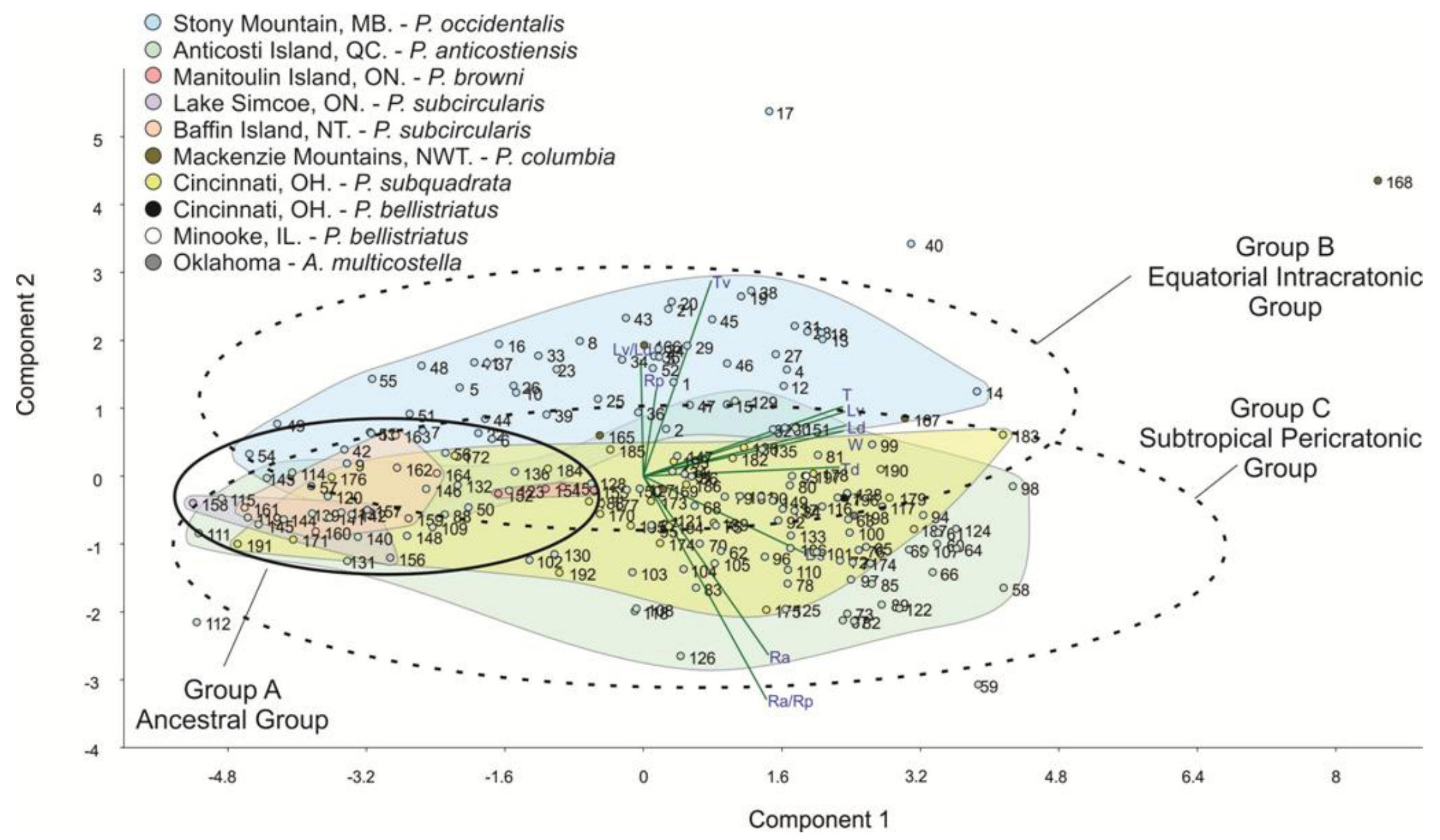

Figure 4.6 - Scattergram result of PCA. Each number corresponds to an individual specimen in the analysis. The samples fell into three main groups: The ancestral group, equatorial intracratonic group, and subtropical pericratonic group. 
Specimens of Group A all exhibit a similar ribbing style intermediate between groups B and C, showing some rib multiplication (see discussion on bifurcation index below). All forms showed a similar The Plaesiomys browni of Manitoulin Island averaged 24.25 ribs at the posterior and 35.00 at the anterior commissure. The Lake Simcoe specimens showed less rib multiplication overall, but given their smaller size than Manitoulin actually showed a greater degree of rib multiplication per length - averaging 23 ribs at the posterior and 34.33 ribs at the anterior. Baffin Island forms, although resembling the Lake Simcoe specimens in other dimensions, show slightly higher number of ribs, averaging 31.67 ribs at the posterior and 46 ribs at the anterior, but note that the ratio of ribs at anterior versus ribs at the posterior is similar (see discussion below).

Typically, these shells show a dorsibiconvex to somewhat convexo-plane profile, but the dorsal valve is typically shallower in depth than those of groups B and C. Manitoulin Island forms have the most convex dorsal valve averaging $6.13 \mathrm{~mm}$ in thickness in comparison to $2.04 \mathrm{~mm}$ thickness of the ventral valve. The other two forms have ventral valves of similar thickness, averaging 1.94 and $2.08 \mathrm{~mm}$ for the Lake Simcoe and Baffin Island specimens respectively, but have significantly thinner dorsal valves of $3.99 \mathrm{~mm}$ and $3.20 \mathrm{~mm}$. Sulcus depth ranged from an average of $0.84 \mathrm{~mm}$ in the Lake Simcoe specimens to $2.29 \mathrm{~mm}$ in the Manitoulin specimens.

Table 4.2 - Average measured values of specimens of Group A.

\begin{tabular}{|c|c|c|c|c|c|c|c|c|}
\hline Locality & $\begin{array}{c}\mathbf{L} \\
(\mathbf{m m})\end{array}$ & $\begin{array}{c}\mathbf{W} \\
(\mathbf{m m})\end{array}$ & $\mathbf{T}(\mathbf{m m})$ & $\begin{array}{c}\mathbf{T d} \\
(\mathbf{m m})\end{array}$ & $\begin{array}{c}\mathbf{T v} \\
(\mathbf{m m})\end{array}$ & $\begin{array}{c}\mathbf{D s} \\
(\mathbf{m m})\end{array}$ & $\mathbf{R a}$ & $\mathbf{R p}$ \\
\hline Manitoulin Island & 18.23 & 22.74 & 8.26 & 6.13 & 2.04 & 2.29 & $\begin{array}{c}35 . \\
00\end{array}$ & $\begin{array}{c}24 . \\
25\end{array}$ \\
\hline Lake Simcoe & 12.37 & 15.48 & 6.24 & 3.99 & 1.94 & 0.84 & $\begin{array}{c}34 . \\
33\end{array}$ & 23 \\
\hline Baffin Island & 13.40 & 16.62 & 5.26 & 3.20 & 2.08 & 1.03 & 46 & $\begin{array}{c}31 . \\
67\end{array}$ \\
\hline
\end{tabular}

Shells of group B are all Plaesiomys occidentalis from the Stony Mountain Formation of southern Manitoba. This species is much larger than the species of Group 
A, averaging a length of $20.20 \mathrm{~mm}$, width of $34.78 \mathrm{~mm}$, and thickness of $10.66 \mathrm{~mm}$. The dorsal thickness $(8.23 \mathrm{~mm})$ and ventral thickness $(3.87 \mathrm{~mm})$ makes this form more globose than the Baffin and Lake Simcoe specimens, but slightly less globose than the Plaesiomys browni from Manitoulin Island. P. occidentalis has the lowest degree of rib multiplication, averaging 28.94 ribs at the anterior and 32.84 ribs at the posterior (Table 4.3). Sulcus depth averaged $2.41 \mathrm{~mm}$.

Table 4.3 - Average measured values of specimens of Group B.

\begin{tabular}{|c|c|c|c|c|c|c|c|c|}
\hline Locality & $\begin{array}{c}\mathbf{L} \\
(\mathbf{m m})\end{array}$ & $\begin{array}{c}\mathbf{W} \\
(\mathbf{m m})\end{array}$ & $\begin{array}{c}\mathbf{T} \\
\mathbf{( m m}\end{array}$ & $\begin{array}{c}\mathbf{T d} \\
(\mathbf{m m})\end{array}$ & $\begin{array}{c}\mathbf{T v} \\
(\mathbf{m m})\end{array}$ & $\begin{array}{c}\mathbf{D s} \\
(\mathbf{m m})\end{array}$ & $\mathbf{R a}$ & $\mathbf{R p}$ \\
\hline Stony Mountain & 20.20 & 24.78 & 10.66 & 8.23 & 3.87 & 2.41 & 32.84 & 28.94 \\
\hline
\end{tabular}

Group C includes specimens of several species, including Plaesiomys subquadrata and $P$. bellistriatus from the Cincinnati type area and Illinois locality, A. multicostella from the Arbuckle Mountains, Oklahoma, and P. anticostiensis from Anticosti Island.

These shells have a shell size and convexity similar to those of Group B, and are significantly more globose than specimens of Group A. The largest is Plaesiomys bellistriatus of the Cincinnati-Kentucky-Indiana region with an average length of 26.31 $\mathrm{mm}$, width of $31.09 \mathrm{~mm}$, and total thickness of $14.89 \mathrm{~mm}$. The smallest groups are the $P$. subquadrata (same area) and P. anticostiensis (Anticosti Island), but even these were large compared to earlier forms. P subquadrata measured an average of $19.56 \mathrm{~mm}$ in length, $24.94 \mathrm{~mm}$ in width, and $10.23 \mathrm{~mm}$ in total thickness. P. anticostiensis averaged a similar $20.22 \mathrm{~mm}$ in length, $24.77 \mathrm{~mm}$ in width, and $10.82 \mathrm{~mm}$ in thickness.

Shells in Group C show the highest degree of rib multiplication among the studied groups. Most species in this group show an average number of ribs at the anterior commissure ranging from 59.67 to 78 , but the Austinella multicostella from Oklahoma have many more ribs than the other species -106.5 at the anterior margin. Plaesiomys subquadrata and $P$. anticostiensis had similar number of ribs at the anterior, but $P$. bellistriatus showed significantly more rib multiplication. P. subquadrata averaged 59.67 
ribs at the anterior and $P$. anticostiensis averaged 55.63. P. bellistriatus from the Cincinnati-Kentucky-Indiana region showed 67 ribs at the commissure and the specimens from Illinois showed 78.

Plaesiomys anticostiensis possessed the deepest sulcus of any of the species, with an average sulcus depth of $3.14 \mathrm{~mm}$, equivalent to $29 \%$ of the average total thickness, compared to approximately $10-20 \%$ for the other species.

Table 4.4 - Average measured values of specimens of Group C.

\begin{tabular}{|c|c|c|c|c|c|c|c|c|c|}
\hline \multicolumn{2}{|c|}{ Locality } & $\mathrm{L}$ & W & $\mathrm{T}$ & $\mathrm{Td}$ & $\mathrm{Tv}$ & Ds & $\mathrm{Ra}$ & $\mathrm{Rp}$ \\
\hline \multirow{2}{*}{$\begin{array}{l}\text { Ohio- } \\
\text { Kentucky- } \\
\text { Indiana }\end{array}$} & $\begin{array}{l}P . \\
\text { subquadrata }\end{array}$ & 19.56 & 24.94 & 10.23 & 7.26 & 2.88 & 1.74 & 59.67 & 30.25 \\
\hline & $\begin{array}{l}P . \\
\text { bellistratus }\end{array}$ & 26.31 & 31.09 & 14.89 & 12.03 & 3.41 & 1.44 & 67 & 31 \\
\hline \multicolumn{2}{|c|}{ Illinois } & 21.6 & 27.75 & 12.03 & 7.66 & 4.61 & 1.07 & 78 & 30 \\
\hline \multicolumn{2}{|c|}{ Oklahoma } & 22.51 & 26.81 & 11.21 & 7.06 & 3.99 & 1.86 & 106.5 & 43 \\
\hline \multicolumn{2}{|c|}{ Anticosti } & 20.22 & 24.77 & 10.82 & 8.74 & 2.33 & 3.14 & 55.63 & 28.11 \\
\hline
\end{tabular}

The remaining brachiopods are from the Mackenzie Mountains. Only five specimens were included for PCA because of a general lack of whole specimens for measurements. The specimens seem to plot as intermediate between Group B and Group $\mathrm{C}$, but they do not plot closely together in PCA and thus this is not a natural grouping. Among the shells from the Mackenzie Mountains, there is an unusually wide range of morphological variation. Plaesiomys periosa n. sp., for example, attains a length of 51.4 $\mathrm{mm}$, with a width of $59.5 \mathrm{~mm}$, and a thickness of $25 \mathrm{~mm}$, making it the largest Plaesiomys shell known.

\subsection{Discussion}

The three groups recognized in principal component analysis correspond to different settings in terms of time and depositional environment. Group A represents the small-shelled pioneer forms of plaesiomyids that first appeared in the early Katian 
(Chatfieldian) plaesiomyid forms but persisted until the Maysvillian in pericratonic settings (e.g. southern Baffin Island). Group B consists of the late Katian (Richmondian) Plaesiomys occidentalis from the Stony Mountain Formation of southern Manitoba paleogeographically located in the northwestern margin of the intracratonic Williston Basin that straddled the paleoequator (Cocks and Torsvik, 2011). Group C consists of the late Katian to Hirnantian (Richmondian to Gamachian) species from the subtropical pericratonic basins and continental-margin shelves of Laurentia.

From this data, two major trends of morphological change are recognized. The first is a temporal trend showing changing size and convexity over time, as shown by the shell globosity index (SGI) and dorsal convexity index (DCI). When Group A, is compared to the groups B and C, it is clear that earlier forms (Group A) were much smaller and less globose than later forms (groups B and C). Plaesiomys subcircularis from Lake Simcoe and Baffin Island (early to mid-Katian) is only slightly larger than half the size of the Late Katian species (Figure 4.7). The increase in plaesiomyid shell size seems to be part of an overall trend towards gigantism in the Late Ordovician shelly fauna of Laurentia, especially in the epicontinental sea settings (Jin, 2001).

The second trend can be considered as a paleogeographical gradient of morphology shown by an increase in the degree of rib bifurcation in pericratonic shelves in comparison to intracratonic seas. The predominant coarsely ribbed plaesiomyid shells in equatorial intracratonic basins (Group B) show very little rib bifurcation with an average bifurcation index of 1.14, while the finely ribbed specimens from the subtropical pericratonic shelves (Group C) show a far greater bifurcation index of 1.98 or greater. The early Katian forms, interestingly, have rib bifurcation index values between those of Group B and Group C, averaging 1.44 for the Manitoulin shells and 1.50 in the Lake Simcoe specimens (Figure 4.8).

The detailed spatio-temporal morphological changes will be discussed in the following sections. 


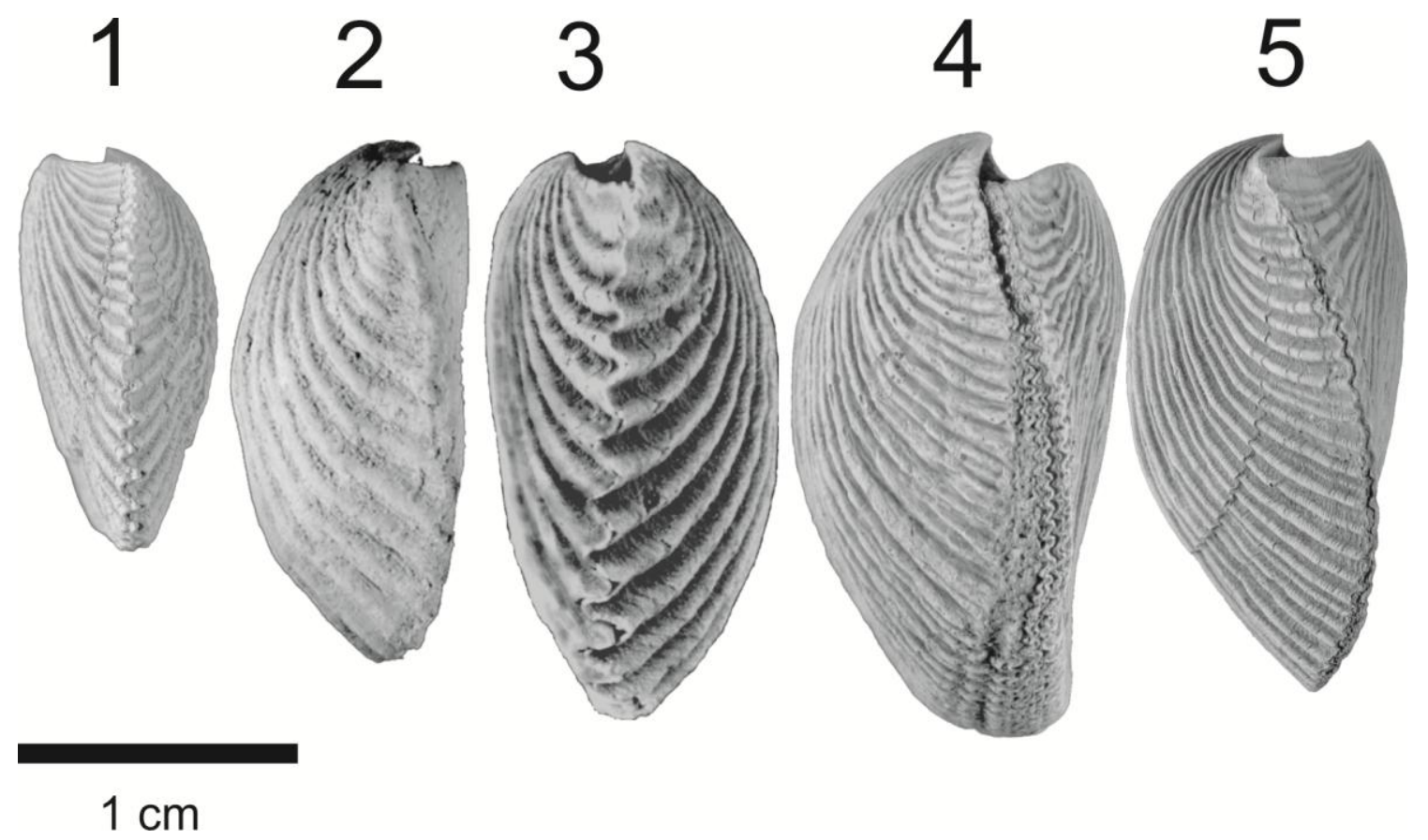

Figure 4.7 - Increasing globosity over time. 1 - P. subcircularis from Lake Simcoe (Chatfieldian), 2 - P. browni from Manitoulin Island (Chatfieldian), 3 - P. occidentalis from Stony Mountain (Richmondian), 4 - P. subquadrata from Cincinnati (Richmondian), and 5 - P. anticostiensis from Anticosti Island (Hirnantian). 

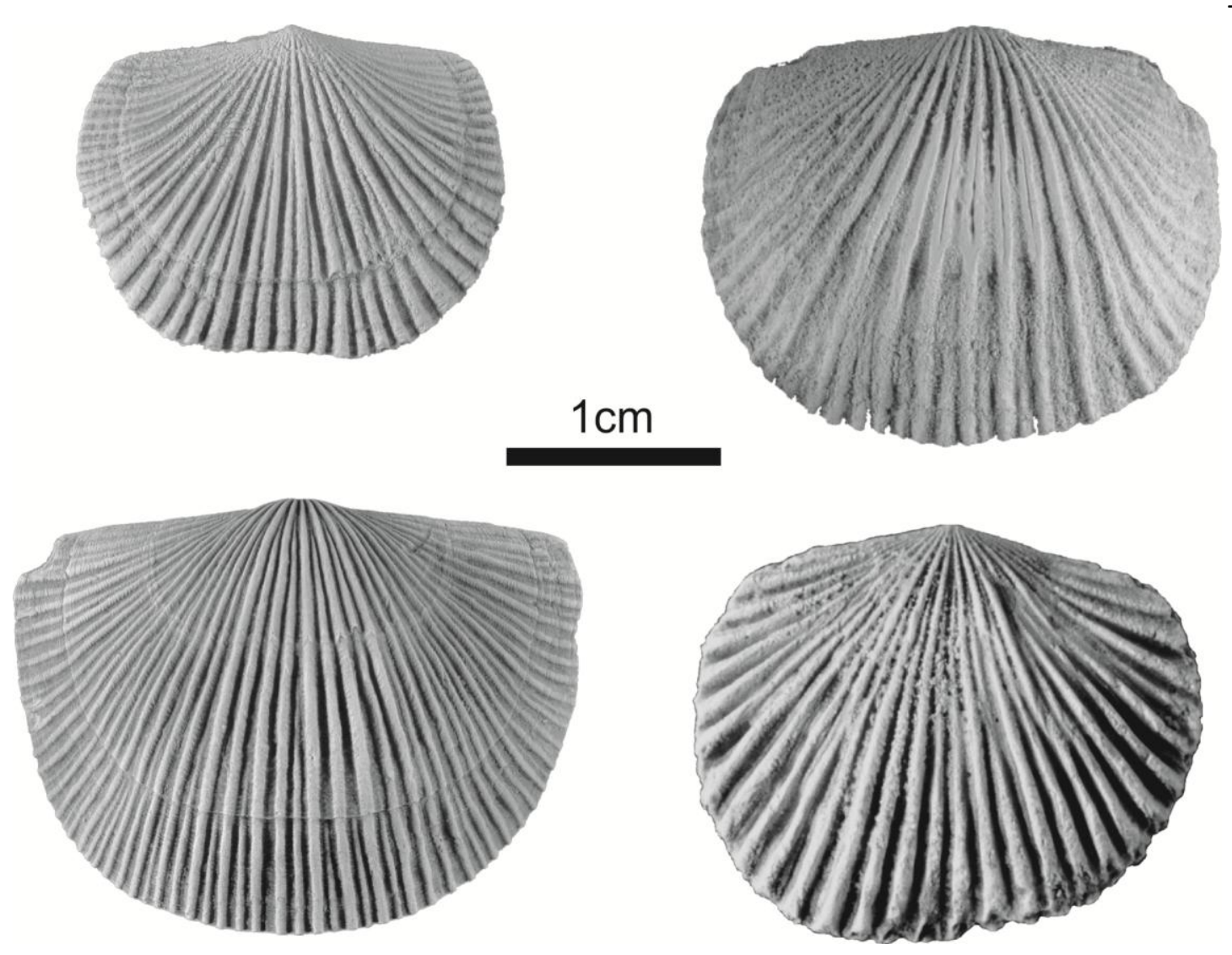

Figure 4.8 - Contrasting styles of ribbing in plaesiomyids: ribs that branch frequently towards the commissure (left: P. subcircularis - top and P. anticostiensis - bottom), ribs that branch only near the anterior commissure (top right: P. browni), and ribs that rarely branch (bottom right: P. occidentalis). 


\subsubsection{Dorsal convexity index, globosity index (DCI, SGI)}

During the early Katian (Chatfieldian) age, the pioneer species Plaesiomys subcircularis (from Lake Simcoe) had small, and relatively flat shells with an average shell globosity index (SGI) value of 0.41 (Figure 4.9). These forms possessed a relatively shallow dorsal valve, with an average dorsal convexity index value (DCI) of 0.26. By mid Katian (Edenian to Maysvillian) time, this morphology had become rare, known only from Baffin Island in Silliman's Fossil Mount (Amadjuack Formation) paleogeographically located on a pericratonic continental shelf.

However, even some early forms began to show greater globosity. Plaesiomys browni of the Verulam Formation on Manitoulin Island (early Katian, Chatfieldian) shows a significantly higher SGI of 0.27 indicating a greater thickness per unit width. These forms also show an accelerated deepening of the dorsal valve relative to the ventral valve, with a DCI of 0.36. P. browni is significant as it is of an intermediate form between the $P$. subcircularis of Lake Simcoe and Baffin Island, and the typically globose, strongly dorsibiconvex forms of the late Katian and Hirnantian (Richmondian and Gamachian). It shows a certain degree of similarity with the late Katian forms in shell globosity, but is still notably smaller.

By mid Katian (Maysvillian) time, globose and strongly dorsibiconvex forms became common across North America, both in tropical intracratonic seas (e.g. southern Manitoba) and subtropical pericratonic shelves (e.g. the Cincinnati type area). These forms are characterized by the common and widespread Plaesiomys subquadrata in pericratonic settings such as the American mid-continent, Oklahoma, Nevada, Utah, the Rocky Mountains, and Mackenzie Mountains (Hall 1847, Winchell and Schuchert 1893, Wang 1949; Howe 1966; Alberstadt 1973; Wigington 1977; Ross et al. 1979; Howe 1988; Jin and Norford 1996; Sheehan and Harris 1997; Jin et al. 2007). In the CincinnatiKentucky-Indiana tri-state area, these forms have an average SGI of 0.41 (maximum 0.51 ) and DCI of 0.29. The largest of these forms was Plaesiomys periosa of the Mackenzie Mountains (Richmondian), with the single complete specimen in this study reaching $51.39 \mathrm{~mm}$ in length and $59.54 \mathrm{~mm}$ in width (thickness was not measurable as the shell was compressed) - making it the largest Plaesiomys specimen documented thus far. 


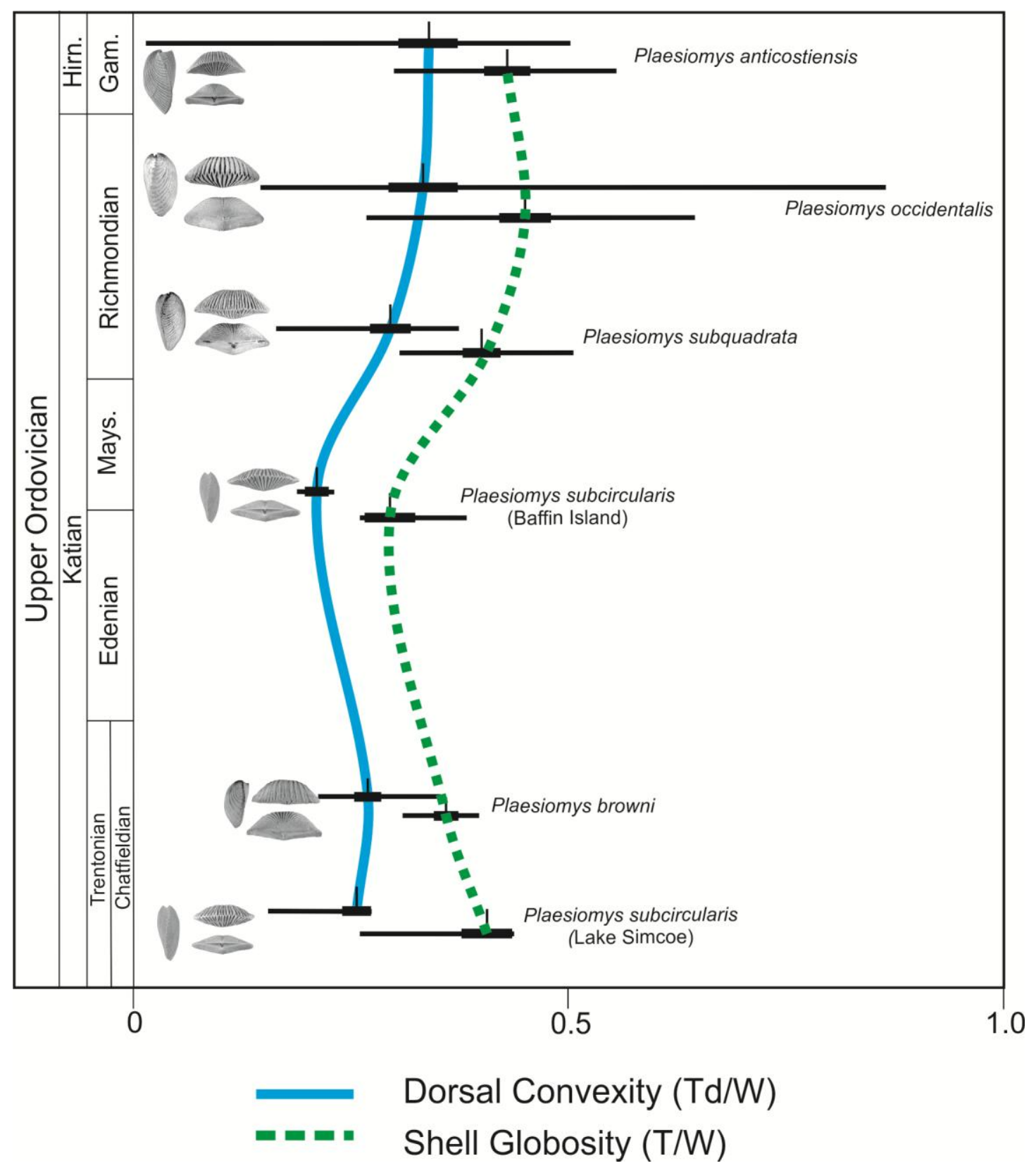

Figure 4.9 - Average dorsal convexity index and shell globosity index, showing mean, total range, and standard deviation. During the Richmondian, there is a deepening of the dorsal valve that led to the increase in globosity in plaesiomyid species. 
Intracratonic areas were represented almost entirely by Plaesiomys occidentalis in the Williston and Hudson Bay basins with an average DCI of 0.33 and SGI of 0.45.

This temporal change occurred in both the Late Ordovician equatorial intracratonic epicontinental seas and in the subtropical pericratonic shelves of Laurentia (Figure 4.9). Thus, this morphological feature is unlikely the result of phenotypical variations controlled by local ecological factors, but rather it is an evolutionary trend of continental and broader paleogeographical scale. Gigantism was common in many fossil groups of Maysvillian-Richmondian age, including brachiopods, gastropods, nautiloids, and trilobites (Rohr et al. 1992; Jin 2001; Rudkin et al. 2003; Young et al. 2008).

This increase in globosity during the Richmondian is mainly due to a more convex dorsal valve (as can be seen in Figure 4.9). The most likely physiological advantage of a more globose shell and more convex dorsal valve would have been to accommodate an enlarged lophophore, as the lophophores in brachiopods are attached to the dorsal valve. A larger shell would allow for a larger body cavity. Increased shell size and globosity would correspond mostly to an increase in the overall tissue volume of lophophores. By enlarging the lophophore, a brachiopod gains surface area for more efficient filter feeding allowing it to trap minute food particles, as well as more efficient respiration (gas exchange), to increase metabolic rates. Other selective pressures may have contributed to the increase in shell size and globosity, such as defense against relatively small-sized predators. From the ecosystem point of view, the invertebrate gigantism in the Late Ordovician may have been favoured by the abundance of available nutrients, as phytoplankton radiated during the Great Ordovician Biodiversification Event (GOBE) increasing species diversity and overall abundance. Thus phytoplankton blooms may have become more common during the Ordovician (Servais et al. 2008, 2009, 2010), reducing the effects of any nutrient limitations in the marine environment.

A secondary advantage with increased globosity would be increased stability. A larger and heavier shell would make the organism less vulnerable to movement on the sea floor by strong ocean currents. This may not have been a significant problem for brachiopods of the intracratonic seas located in the hurricane-free equatorial zone (Jin et al. 2012), but those in the subtropical pericratonic basins may have been exposed to 
stronger currents and storm events as shown by storm deposits in some localities (e.g. Anticosti Island - see Long 2007; Cincinnati - see Holland 1993, Jennete and Pryor 1993; Brett et al. 2012).

The accelerated, allometric increase in the convexity of dorsal valve in plaesiomyids may have been analogous to the morphology of many atrypides. The dorsally directed spiralia in atrypides show that the number of whorls of lophophores increases with increased depth/convexity of the dorsal valve. In plaesiomyids, there is no skeletal support for the lophophores and thus the morphology of their lophophores are unknown. The similarity in preferential increase in dorsal convexity, however, suggests that plaesiomyids probably had dorsally directed spiral-shaped lophophores.

\subsubsection{Rib Bifurcation index (RBI)}

In pericratonic settings, Plaesiomys subquadrata (late Katian, Richmondian) shows a bifurcation index averaging 1.97 (Figure 4.10). The Hirnantian species $P$. anticostiensis averaged a slightly higher bifurcation index average of 1.99. An extremely high high bifurcation index is found in P. bellistriatus, reaching a maximum of 2.6 in the few specimens examined in this study. All of these values are much higher than the average value of 1.14 scored for $P$. occidentalis from the paleoequatorial intracratonic basins. Earlier forms generally plot intermediate to these extreme cases, ranging from an average of 1.44 in P. browni to 1.50 in P. subcircularis (Figure 4.10). These statistics show that intracratonic forms with coarser ribs tend to show less multiplication than subtropical pericratonic forms with finer ribs.

It has long been suggested that, in fossils brachiopods, the rib crests and their corresponding peripheral crenulations on the inner shell surface housed setae, which are sensitive bristles around the margin of brachiopod shells (Rudwick 1970). More recently, it was found that various-sized perforations on the external surface of plaesiomyid shells, called epipunctae and aditicules, also housed setae, as shown by the finely phosphatized setae in Plaesiomys anticostiensis from the Velleda Member of the Ellis Bay Formation on Anticosti Island (Jin et al. 2007; Jin and Zhan 2008; Jin and Copper, 2010). In plaesiomyid shells, the aditicules (relatively large perforations) are aligned along the 


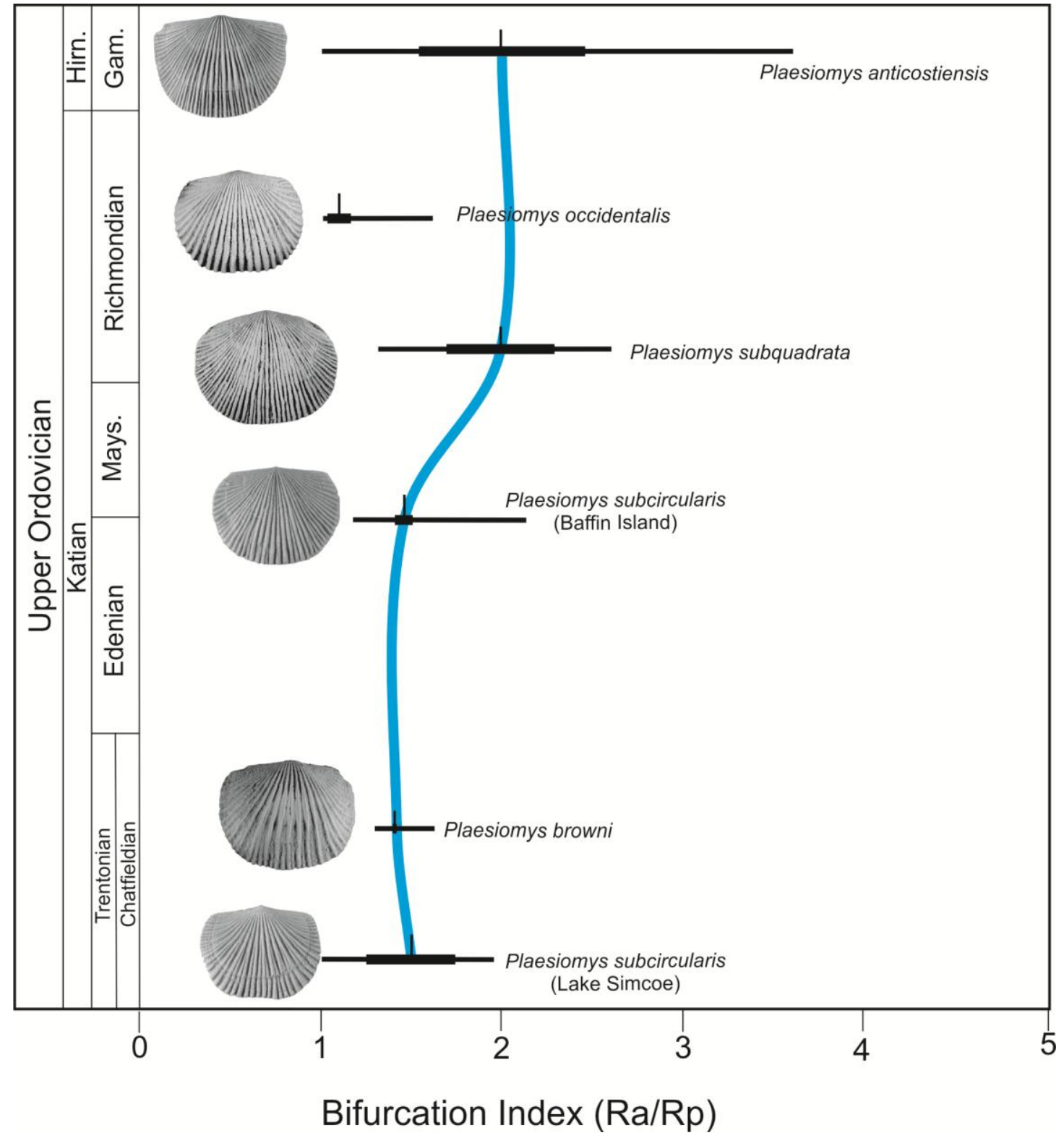

Figure 4.10 - Bifurcation index. Note the contrasting trend in pericratonic specimens during the late Katian (Richmondian), represented by the blue line, in comparison to intracratonic forms (represented by Plaesiomys occidentalis). 
crests of ribs, representing the position the setae would have occupied near the anterior commissure at successive growth stages. In addition to the long setae on rib crests, numerous smaller setae are present in the epipunctae along the anterior margin and the peripheral rim of the outer shell surface. Both the large and small setae are extensions of the mantle and sensitive to tactile stimuli. A higher RBI value implies that there were more numerous large setae near the anterior commissure of the shell, thus enhancing the sensitivity of the brachiopods to their surrounding environment.

This enhanced ability to detect changes in the external environment due to these adaptations of the mantle would have enabled plaesiomyids to better adjust to their environment. For example, when an approaching predator touched the setae, the brachiopod shell could quickly clamp shut before the predator was able to reach the commissure, thus serving as an early warning system for the brachiopod. A similar response would have also served the brachiopods when severe storms would generate suspended sediments or sediment-laden flows. Brachiopods are suspension filter feeders, and their lophophores are susceptible to clogging by fine silt and mud. Presumably, anincrease in the number of setae would lead to more efficient and effective response to sudden increase in suspended sediments in the sea water around them during storms. In addition, the dense setae around the shell margin may help prevent relatively coarse sediments from entering the mantle cavity to clog the lophophores (Kemežys 1967).

It remains debatable whether the development of a greater number of setae at the commissure, or fewer but larger setae, was related to any specific evolutionary pressure on plaesiomyids of the subtropical pericratonic seas in comparison to those of the equatorial intracratonic basins. One significant difference between the two environments is storm frequency. Evidence of storm beds in some localities on the pericratonic settings, such as Anticosti island (Long 2007) and the Cincinnati type area (Holland 1993; Jennete and Pryor 1993; Holland 2008; Brett et al. 2012), suggests that severe storms were much more frequent in subtropical environments, but rare or absent in the paleoequatorial zone (Jin et al. 2012). The relatively clear paleogeographical separation between Plaesiomys occidentalis (with relatively sparse and long setae) in the intracratonic basins and most common Plaesiomys (e.g. Plaesiomys subquadrata and P. anticostiensis) in subtropical 
pericratonic settings suggests that storm-generated sediment suspension and turbidity was a likely stressor for the morphological gradient of plaesiomyids in Laurentia.

The increase in the number of ribs at the shell anterior and in rib size may have enhanced shell strength. This has been interpreted as an evolutionary response to predation in two ways: to counter boring predation and to structurally strengthen the shell against durophages (shell cracking or peeling predators). Gastropod shells that developed a more elaborately ornamented exterior during the Mesozoic have been found to have fewer attacks by boring predators and durophages (Vermeij 1977), and it is reasonable to assume that this life strategy applied also to brachiopod shells. Laboratory tests of the mechanical strength of several modern brachiopod shells indicate that coarsely ribbed shells resisted breakage from compression better than finer-ribbed or non-ribbed shells (Alexander 1990). An analysis of the trends in ornamentation of fossil specimens indicates that the evolution of towards more coarsely ribbed shells corresponds to an interval of predatory escalation (Alexander 1990). 

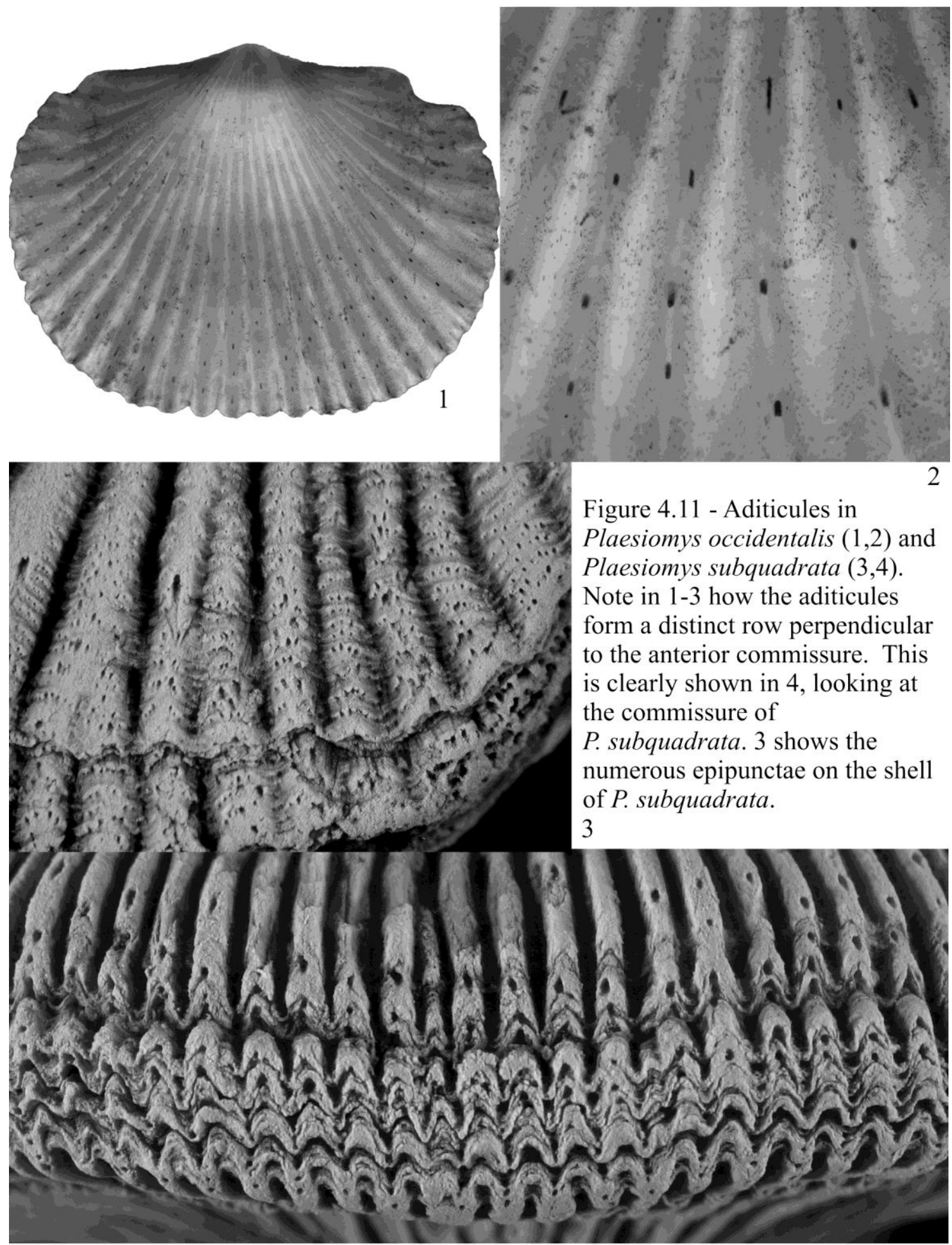
Sculpted shells of invertebrates, in comparison to smooth forms, provide a greater resistance to durophagous predators by increasing the effective diameter of the shell, distributing stress over a larger surface area, concentrating stress on the thickest parts of the shell, and causing injury to the jaw or claw of a predator (Palmer 1979). Coarse ribbing and crenulation of the shell in plaesiomyids probably did not result in much effective increase in the shell diameter, but would have enhanced the shell strength to resist predation.

In smaller-shelled ostracods, however, experimental study showed that ornamentation played no role in strengthening the shell (Kontrovitz et al. 1988). Apart from the generally much smaller shell, the ostracod shell structure is different from that of a brachiopod (generally prismatic in ostracods versus lamellar in brachiopods) and, therefore, the shells of these two different groups cannot be compared directly.

\subsubsection{Cardinal process: slender versus bulbous, bilobed versus trilobed}

The cardinal process is not quantifiable for this analysis because it is difficult to measure. Nonetheless, this character varies greatly among plaesiomyid species and shows two trends of change in time and space. There are three forms of cardinal process in plaesiomyids: slender-bilobed, bulbous-bilobed, and trilobed (Figure 4.12).

The slender bilobed type consists of a relatively thin shaft and a thin crest (myophore) that is crenulated and bilobed. This type of cardinal process is typical of two species groups in this study: early pioneer species (Plaesiomys subcircularis) and the Hirnantian form P. anticostiensis. In P. subquadrata, the cardinal process has a thicker shaft and an inflated, commonly bulbous, crenulated crest. Both bilobed forms are most common in pericratonic settings.

The trilobed form is typically found in specimens from intracratonic basins, such as Plaesiomys occidentalis and P. rockymontana from the Williston and Hudson Bay basins (see Macomber 1970; Jin et al. 1997; Jin and Zhan 2001). The crest of the cardinal process is strongly inflated and occupies nearly the entire notothyrial cavity, bearing three distinct and crenulated lobes, with the high medial lobe projecting ventro-posteriorly into the delthyrial cavity of the ventral valve. This type of cardinal process can also be found 


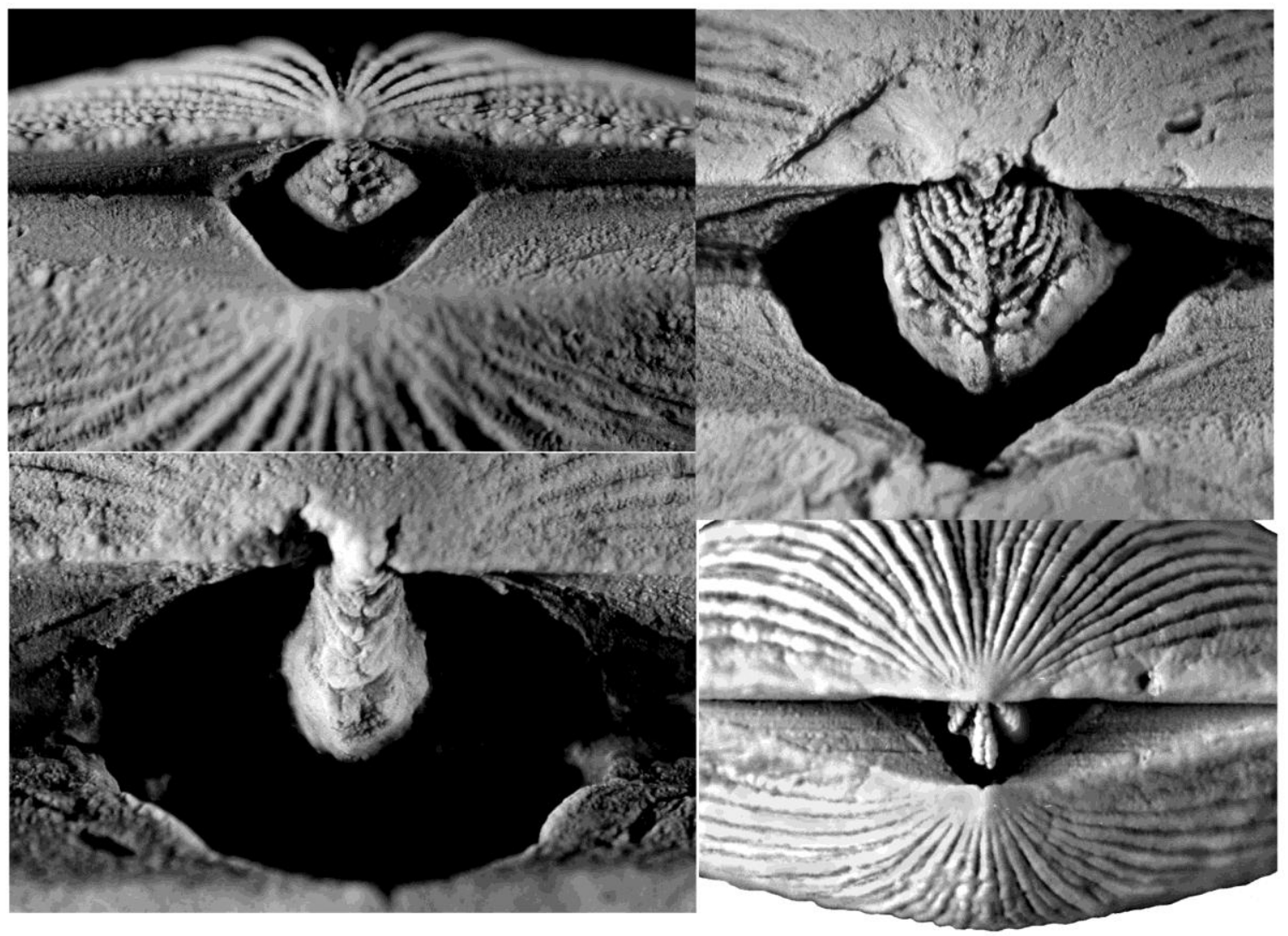

Figure 4.12 - Three styles of cardinal process in plaesiomyids: slender bilobed (left), enlarged bilobed (top right), and trilobed (bottom left). Bilobed cardinal processes are most common in species of subtropical pericratonic settings (e.g. Plaesiomys subcircularis - top left, $P$. anticostiensis - bottom right, and P. subquadrata - top right) while trilobed cardinal processes are most common in species of tropical intracratonic settings (e.g. P. occidentalis - top right). 
in species from pericratonic settings such as $P$. carletona from the upper Vauréal Formation of Anticosti Island (Jin and Zhan 2008), but there it is far less common than species with a bilobed cardinal process.

Two trends of morphological change can be observed in the evolution of the plaesiomyid cardinal process, the first being temporal, and the second paleogeographical, in nature.

From early to late Katian, the cardinal process evolved from the slender bilobed form in Plaesiomys subcircularis to the more inflated bilobed form (e.g. P. subquadrata) or more elaborate, trilobed form (e.g. P. carletona; P. occidentalis). Such enlargement of the cardinal process coincided temporally with an increase in shell globosity (Figure 4.9). This suggests that this trend is most likely a phenotypical adaptation to changing mode of life. As the plaesiomyids developed increasingly larger and more globose shells through the Katian, the muscles required to open and close the valves would have had to be stronger and larger. As the attachment site of the diductor muscles in the dorsal valve, an enlarged and more crenulated crest (myophore) or the addition of a projecting medial lobe in the cardinal process would provide a large surface area and a keeled attachment (analogous to the sternum of birds) for the muscle.

The phenotypical adaptation interpreted for the cardinal process is further supported by the recurrence of the slender bilobed cardinal process in Plaesiomys anticostiensis in Hirnantian strata of Anticosti Island. Despite its overall large size and convexity, comparable to Richmondian forms (e.g. P. subquadrata, P. carletona, $P$. occidentalis), P. anticostiensis possesses a relatively delicate cardinal process similar to that of pioneer species. Such a morphological regression may be related to a decrease in water temperature and increased oceanic circulation during the glacial interval of the Hirnantian. Generally, extravagant skeletal features in calcareous shells are less common in cool water than in warm water environments because it requires more metabolic energy to secrete and maintain shell substance in sea water below supersaturation with respect to calcium carbonate precipitation. In addition, with greater oceanic circulation and productivity in the ocean, the nutrient and oxygen contents would be higher and more stable than in intracratonic seas and, therefore, the plaesiomyids would have had greater 
access to nutrients than earlier forms, and may not have required the ability to open their valves widely to increase lophophore efficiency. Thus the development of an enlarged cardinal process would become unnecessary for $P$. anticostiensis. This interpretation is further supported by the predominance of $P$. carletona in the underlying upper Katian strata on Anticosti Island - this species occurs in the upper Vauréal Formation (deposited during a greenhouse episode) and it has a trilobed cardinal process (like $P$. occidentalis). Replacement of the $P$. carletona by $P$. anticostiensis within the same basin took place at the Katian-Hirnantian boundary. Although the smaller cardinal process was favored by natural selection, a larger lophophore would still have presumably had some benefit to the brachiopod, so it was retained by $P$, anticostiensis. It would not be advantageous to reduce the size of the lophophore, whereas a smaller cardinal process would provide metabolic savings.

The second trend is a paleogeographical gradient in the distribution of plaesiomyids - those with trilobed cardinal process predominantly in paleoequatorial intracratonic basins, in contrast to those with a bilobed cardinal process in subtropical pericratonic settings. This pattern, like the bifurcation index above, is probably related to the paleoecological constraints in different environments. The posteriorly projecting trilobed cardinal process allowed plaesiomyids to increase the gape of the valves, and to maximize the lophophore efficiency to filter feeding and gas exchange, especially in paleoequatorial intracratonic seas with poor water circulation (due to lack of severe storms) and unstable organic productivity.

\subsection{Conclusions}

The Plaesiomys lineage shows three main morphological trends over the Late Ordovician (Figure 4.13): 1) increased globosity over the Katian (Chatfieldian to Hirnantian); 2) development of fewer, coarser ribs in specimens from paleoequatorially located intracrotonic basins, in contrast to more numerous, finer ribs in specimens from the continental-margin shelves or basins (Figure 4.14) and 3) development of a larger cardinal process during the late Katian (Richmondian) and a divergence in forms, with subtropical pericratonic species retaining a bilobed cardinal process and equatorial 
intracratonic forms evolving a trilobed cardinal process. These temporal and spatial trends morphological gradients led to several paleoecological and evolutionary interpretations in this study:

1) Increased globosity allowed for an expansion of the lophophore and more efficient feeding and respiration. This is shown by the increased convexity of the dorsal valve, while the ventral valve remained only slightly convex. This is largely a temporal trend because the increase in dorsal globosity is observed in plaesiomyids from both equatorial intracratonic basins and subtropical pericratonic settings during the Katian and Hirnantian.

2) From the mid-Katian to Hirnantian (Richmondian to Gamachian), plaesiomyids with simple and coarse ribs were overwhelmingly dominant in equatorially located intracratonic seas, whereas those with finer and bifurcating ribs were confined largely to pericratonic settings in higher tropics. The increased ribbing led to the development of more numerous long setae on the rib crests around the shell margin to enhance sensory functions, or prevent the influx of sediments that would cause lophophore clogging, especially during storm disturbances.

3) The development of different types of cardinal process was related to the optimal balance among the size of the diductor muscles, the gape size of shell opening, lophophore efficiency for filter feeding and respiration, and metabolic energy required to secrete and maintain an optimum-sized cardinal process. Early plaesiomyids had a small and weakly convex shell, thus requiring a relatively small diductor muscle mass and slender cardinal process. Late Katian (Richmondian) forms had a larger shell, a more strongly convex dorsal valve, hence longer and stronger diductors to keep the shell wide open. Plaesiomyids in subtropical pericratonic environments developed an inflated bilobed cardinal process while tropical intracratonic forms developed a trilobed cardinal process to further increase muscle attachment surface area. Both of these adaptations would have allowed the shell to open to a wider gape to improve lophophore function. The Hirnantian Plaesiomys anticostiensis of Anticosti Island retained a slender bilobed cardinal process, and thus smaller diductor muscles, probably in response to a combination of ecological factors such as non-supersaturation of sea water with respect to 
calcium carbonate precipitation, improved circulation, and enhanced productivity during the cool-water Hirnantian, when the ecological stress on secreting calcareous shell substance increased, whereas that on lophophore efficiency decreased. 


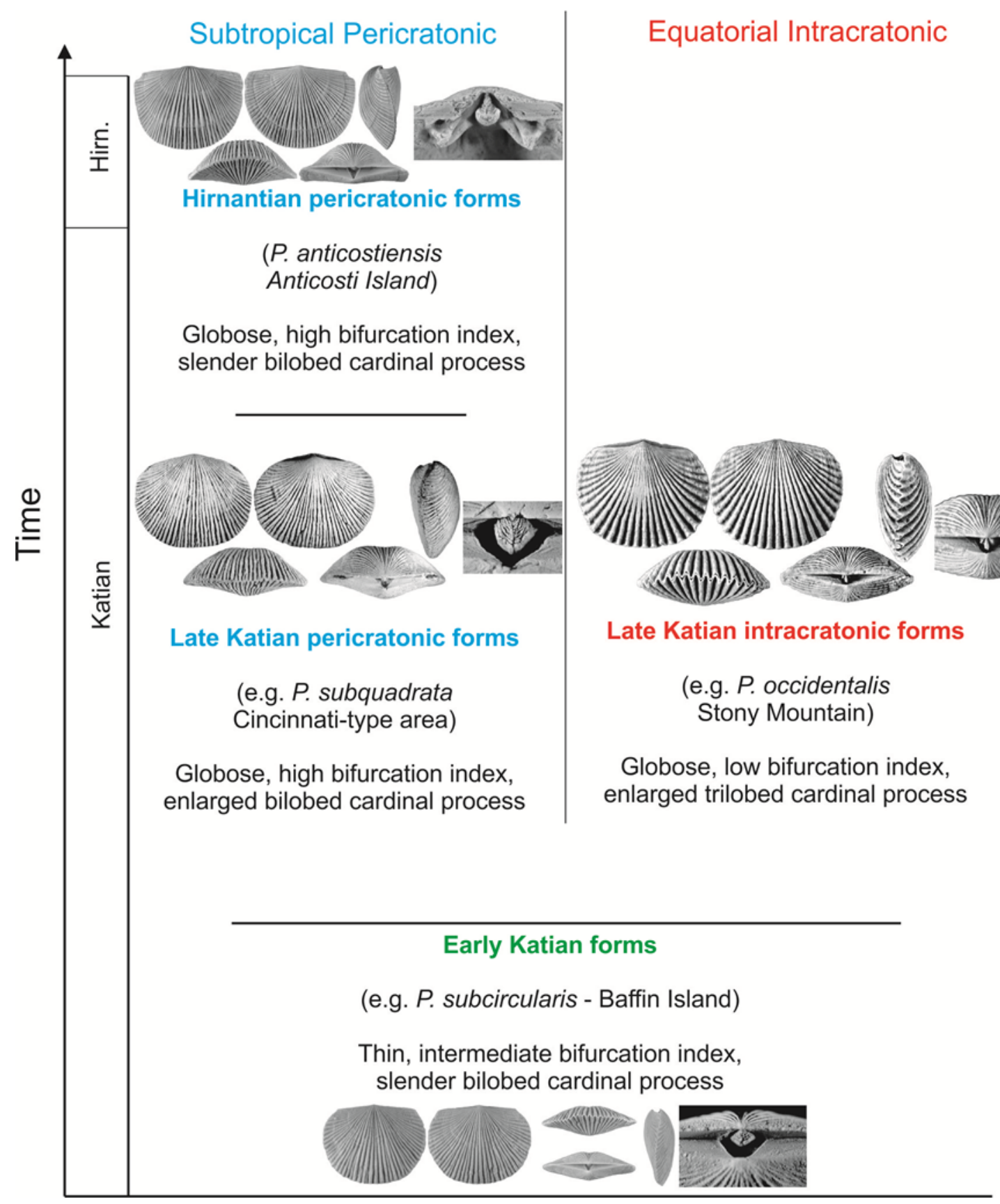

Figure 4.13 - Summarizes the morphological evolution of the plaesiomyid lineage over the Katian and Hirnantian. Note the three trends shown (changes in dorsal convexity and globosity, bifurcation index, and cardinal process), discussed within the text of section 4.5 Discussions. 


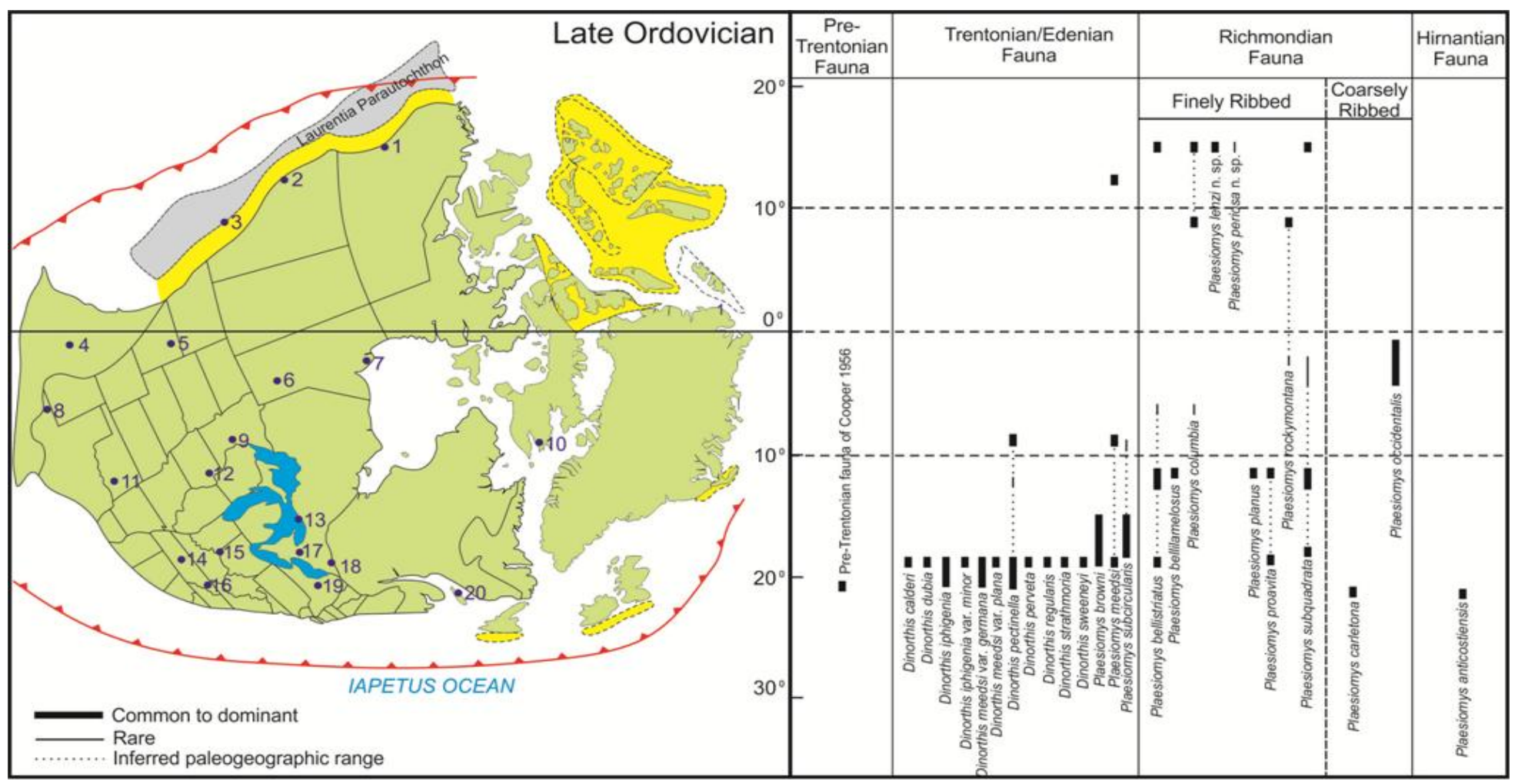

Figure 4.14 - Geographic distribution of plaesiomyids and diverging changes in bifurcation index in geographical context. Compiled mainly from the following references:1 Mackenzie Mountains (Wigington 1977), 2 Rocky Mountains (Jin and Norford 1997), 3

Southern Rocky Mountains (Wilson 1926), 4 Nevada (Roy et al. 1979), 5 Bighorn Mountains, Wyoming (Macomber 1970), 6 Stony Mountain, Manitoba (Jin and Zhan 2001), Hudson Bay lowlands, Manitoba (Jin et al. 1997), 8 Trans-Pecos, Texas (Howe 1966), Twin Cities, Minnesota (Rice 1987), 10 Silliman's Fossil Mount, Baffin Island (Bolton 2000), 11 Arbuckle Mountains, Oklahoma

(Alberstadt 1973), 12 Maquoketa, Iowa (Wang 1949), 13 Manitoulin Island (this paper), 14 Tennessee (Howe 1988), 15 Cincinnati tristate area (Davis 1985, Holland and Patzkowsky 2007), 16 Tennessee and Virginia (Cooper 1956), 17 Lake Simcoe (this paper), 18 Ottawa Valley (Wilson 1946), 19 Trenton New York (Titus 1982, 1986), 20 Anticosti Island (Jin and Zhan 2008). 


\section{References}

Alberstadt, L.P. 1973. Articulate Brachiopods of the Viola Formation (Ordovician) in the Arbuckle Mountains, Oklahoma. Oklahoma Geological Survey Bulletin 117. 90 pp.

Alexander 1990. Mechanical strength of shells of selected extant articulate brachiopods: implications for Paleozoic morphologic trends. Historical Biology, 3: 169-188.

Amsden, T.W. and Sweet, W.C. 1983. Upper Bromide Formation and Viola Group (Middle and Upper Ordovician) in Eastern Oklahoma. Oklahoma Geological Survey Bulletin 132. 75 pp.

Bayer, T.N. 1967. Benthonic community in the Maquoketa Formation (Ordovician) of Minnesota. Journal of Paleontology, 41: 417-422.

Benedetto, J.L. 1998. Braquiópodos Caradocianos en los bloques de la diamictita galigénica de La Formación Don Braulio (Ashgilliano), Sierra de Vilivum, Precordillea Argentina. Ameghiniana, 35: 243-254.

Benedetto, J.L. 2003. Braquiópodos del Caradoiano Temperano de La Formación La Pola, sierra de Villicum, Precordillera de San Juan (Argentina). Ameghiniana, 40: 33-52.

Bergström, S., Carnes, J.B. Hall, J.C., Kurapkate, and O'Neil, B.E. 1988. Conodont Biostratigraphy of Some Middle Ordovician in Eastern North American Marginal Sequences with Coeval Successions in Northern China and Oslo, Norway. In The Canadian Paleontology and Biostratigraphy Seminar - Proceddings of Meeting Sepetember 26-29, 1986. Bulletin Number 462, New York State Museum/Geological Association of Canada. Edited by E. Landing. p. 33-42.

Billings, E. 1866. Catalogues of the Silurian fossils of the island of Anticosti, with descriptions of some new genera and species. Geological Survey of Canada Paper, 71-19. 45 pp.

Bolton, T.E. 1972. Geological map and notes on the Ordovician and Silurian litho- and biostratigraphy, Anticosti Island, Quebec. Geological Survey of Canada Paper, 71-19. 45 pp.

Bolton, T.E. 1981. Ordovician and Silurian biostratigraphy, Anticosti Island, Québec. In IUGS Subcommission on Silurian Stratigraphy, Ordovician - Silurian Working Group, Field Meeting, Antiocsti - Gaspé, Québec, 1981, Vol. 2, Stratigraphy and Paleontology. Edited by P.J. Lespérance. Université de Montréal, Montréal, Québec. pp. 41-59.

Bolton, T.E. 2000. Ordovician megafauna, southern Baffin Island, Nunavut. In Geology and paleontology of the southeast Arctic Platform and southern Baffin Island, Nunavut Geological Survey of Canada Bulletin 557. Edited by A.D. McCracken and T.E. Bolton. Geological Survey of Canada, Ottawa. pp. 39-158.

Brett, C.E., Algeo, T.J., and McLaughlin, P.I. 2008. Chapter 9 - Use of Event Beds and Sedimentary Cycles in High-Resolution Stratigraphic Correlation of Lithologically Repetititve Successions: The Upper Ordovician Kope Formation of Northern Kentucky and Southern Ohio. In High-Resoltuion Approaches in Stratigraphic Paleontology, Topics in Geobiology, Vol. 21. Edited by P.J. Harries. Springer Netherlands. p. 315-350.

Brett, C.E., Schramm, T.J., Dattilo, B.F., and Marshall, N.T. 2012. Upper Ordovician Strata of 
Southern Ohio-Indiana: Shales, Shell Beds, Storms, Sediment Starvation, and Cycles 2012 GSA North-Central Section Meetin Fieldtrip 40S. 79 pp.

Cocks, L.R.M. and Torsvik, T.H. 2011. The Palaeozoic geography of Laurentia and western Laurussia: A stable craton with mobile margins. Earth Science Reviews, 106: 1-51.

Cooper, G.A. 1956. Chazyan and related brachiopods. Smithsonian Miscellaneous Collections, vol. $127,1245 \mathrm{pp}$.

Davis, R.A. 1985. Cincinnati fossils, an elementary guide to the Ordovician rocks and fossils of the Cincinnati, Ohio, region. Cincinnati Museum of Natural History Popular Publications Series, 10. $60 \mathrm{pp}$.

Davis, J.C. 2002. Statistics and Data Analysis in Geology. John Wiley and Sons, Chichester, United Kingdom. 638 pp.

Emmons, E. 1842. Geology of New York, part, comprising the survey of the second geological district. W.A. White and J. Visscher, Albany, New York. 57 pp., 17 pls.

Foerste, A.F. 1905. The classification of the Ordovician Rocks of Ohio and Indiana. Science (New Series), 22: 149-152.

Hall, J. 1847. Descriptions of the organic remains of the lower division of the New York System. New York State Geological Survey, Palaeontology of New York, Vol. 1, 338 pp.

Hall, J. and Clarke, J.M. 1892. An introduction to the study of the genera of Palaeozic Brachiopoda. New York State Geological Survey, Palaeontology of New York, 8(1): 1367, pls. 1-20.

Hammer, Ø., and Harper, D.A.T. 2006. Paleontological Data Analysis. Blackwell Publishing, Malden, MA. $351 \mathrm{pp}$.

Hammer, Ø., and Harper, D.A.T. 2012. PAST software package, v. 2.14. (http://nhm2.uio.no/norlex/past/download.html)

Hammer, Ø., Harper, D.A.T., and Ryan, P. 2001. PAST: Paleontological statistics software package for education and data analysis. Palaeontologia Electronica 4.

Harper, D.A.T. 1979. The environmental significance of some faunal changes in the Upper Ardmillan succession (upper Ordovician), Girvan, Scotland. The Caledonides of the British Isles - reviewed, Geological Society of London. p. 439-445.

Harper, D.A.T. and Owen, A.W. 1999. Quantitative and Morphometric Methods in Taxonomy. In Numerical Palaeobiology: Computer-Based Modelling and Analysis of Fossils and their Distributions. Edited by D.A.T. Harper. John Wiley and Sons, Chichester, United Kingdom. p. 1-40.

Hints, L. and Harper, D.A.T. 2003. Review of the Ordovician rhynchonelliformean Brachiopoda of the East Baltic: Their distribution and biofacies. Bulletin of the Geological Society of Denmark, 50: 29-43.

Holland, S.M. 1993. Sequence stratigraphy of a carbonate-clastic ramp: The Cincinnatian Series (Upper Ordovician) in its type area. Geological Society of America Bulletin, 105: 306322.

Holland, S.M. 1997. Using Time/Environment Analysis to Recognize Faunal Events in the 
Upper Ordovician of the Cincinnati Arch. In Paleontological Events: Stratigraphic, Ecological, and Evolutionary Implications. Edited by C.E. Brett and G.C. Baird. Columbia University Press, New York. p. 309-334.

Holland, S.M. 2008. The type Cincinnatian series: an overview. In Stratigraphic Renaissance in the Cincinnati Arch - Cincinnati Museum Venter Scientific Contributions Number 2. Edited by P. I. McLaughlin, C.E. Brett, S.M. Holland, and G.W. Storrs. McNaughton \& Gunn, Inc., United States. p. 174-184.

Holland, S.M and Patzkowsky, M.E. 1996. Sequence Stratigraphy and Long-Term Paleoceanographic Change in the Middle and Upper Ordovician of the Eastern United States. In Paleozoic Sequence Stratigraphy - Geological Society of America Special Paper 306. Edited by B.J. Witzke, G.A. Ludvigson, and J. Day. Geological Society of America, Boulder, Colorado. p. 117-130.

Holland, S.M. and Patzkowsky, M.E. 2007. Gradient ecology of a biotic invasion: Biofacies of the type Cincinnatian series (Upper Ordovician), Cincinnati, Ohio, region, USA. Palaios, 22: 392-407.

Howe. H.J. 1966. Orthacea from the Montora Group (Ordovician) of Trans-Pecos Texas. Journal of Paleontology, 40: 241-257.

Howe, H.J. 1988. Articulate brachiopods from the Richmondian of Tennessee. Journal of Paleontology, 62: 204-218.

Jennette, D.C. and Pryor, W.A. 1993. Cyclic alternation of proximal and distal storm facies: Kope and Fairview Formations (Upper Ordovician), Ohio and Kentucky. Journal of Sedimentary Petrology, 63: 183-203.

Jin, J. 2001. Evolution and extinction of the North American Hiscobeccus brachiopod Fauna during the Late Ordovician. Canadian Journal of Earth Sciences, 38: 143-151.

Jin, J. 2012. Cincinnetina, a new Late Ordovician dalmanellid brachiopod from the Cincinnati type area, USA: implications for the evolution and palaeogeography of the epicontinental fauna of Laurentia. Palaeontology, 55: 205-228.

Jin, J. and Chatterton, B.D.E. 1997. Latest Ordovician-Silurian articulate brachiopods and biostratigraphy of the Avalanche Lake area, southwestern District of Mackenzie, Canada. Palaeontographica Canadiana No. 13, Canadian Society of Petroleum Geologists and the Geological Association of Canada. McAra Printing, Calgary, Alberta. 167 pp.

Jin, J. and Copper, P. 2008. Response of brachiopod communities to environmental change during the Late Ordovician mass extinction interval, Anticosti Island, eastern Canada. Fossils and Strata, 54: 41-51.

Jin, J. and Copper, P. 2010. Microbially induced phophatization of intercrystalline tissue in the Late Ordovician brachiopod Plaesiomys, Anticosti Island, eastern Canada. Special papers in palaeontology, 84: 1-15.

Jin, J. and Norford, B.S. 1996. Upper Middle Ordovician fauna from the Advance Formation, northern Rocky Mountains, British Columbia. In Advance Formation: Stratigraphy and biostratigraphy of a new Ordovician formation in the Rocky Mountains, northeastern British Columbia. Geological Survey of Canada, Bulletin 491, p. 20-77. 
Jin, J. and Zhan, R. 2001. Late Ordovician articulate brachiopods from the Red River and Stony Mountain Formations, southern Manitoba. NRC Research Press, Ottawa. 117 pp.

Jin, J. and Zhan, R. 2008. Late Ordovician Orthide and Billingsellide Brachiopods from Anticosti Island, Eastern Canada: Diversity Change through Mass Extinction. NRC Research Press, Ottawa. 151 pp.

Jin, J., Caldwell, W.G.E., and Norford, B.S. 1997. Late Ordovician brachiopods and biostratigraphy of the Hudson Bay Lowlands, northern Manitoba and Ontario. Geological Survey of Canada, Bulletin 513, 115 pp.

Jin, J., Zhan, R., Copper, P., and Caldwell, W.G.E. 2007. Epipunctae and phosphatized setae in Late Ordovician plaesiomyid brachiopods from Anticosti Island, Eastern Canada. Journal of Paleontology, 81: 666-683.

Jin, J., Harper, D.A.T., Cocks, L.R.M., McCausland, P.J.A., Rasmussen, C.M.Ø. and Sheehan, P.M. 2012 (in press). Precisely locating the Ordovician equator in Laurentia. Geology.

Kemežys, K.J. 1967. A Note on Costellae in Orthid and Strophomenid Brachiopods. Geological Magazine 104: 435-442.

Kontovitz, M., Pani, E.A., and Bray H. 1998. Experimental Crushing of Some Podocopid Ostracode Valves: An Aspect of Taphonomy. Palaios, 13: 500-507.

Ladd, H.S. 1929. The stratigraphy and paleontology of the Maquoketa shale of Iowa, pat 1. Iowa Geological Survey Annual Report, 34: 309-448.

Liberty, B.A. 1969. Palaeozoic geology of the Lake Simcoe area, Ontario - Geological Survey of Canada Memoir 355. Geological Survey of Canada, Ottawa. p. 1-201.

Long, D.G.F. 2007. Tempestite frequency curves: a key to Late Ordovician and Early Silurian subsidence, sea-level change, and orbital forcing in the Anticosti foreland basin, Canada. Canadian Journal of Earth Sciences, 44: 413-431.

Ludvigsen, R. 1975. Ordovician Formations and Faunas, Southern Mackenzie Mountains. Canadian Journal of Earth Science, 12: 663-697.

Macomber, R.W. 1970. Articulate brachiopods from the upper Bighorn Formation (Late Ordovician) of Wyoming. Journal of Paleontology, 44: 416-450.

Malizia, R.W. and Stigall, A.L. 2011. Niche stability in Late Ordovician articulated brachiopod species before, during, and after the Richmondian Invasion. Palaeogeography, Palaeoclimatology, Plalaeoecology, 311: 154-170.

Norford, B.S. 1962. The Beaverfoot-Brisco Formation in the Stanford Range, British Columbia. Journal of the Alberta Society of Petroleum Geologists, 10:443-453.

Okulitch, V.J. 1943. The Stony Mountain Formation of Manitoba. Transactions of the Royal Society of Canada, 3rd series, 37: 1-74, 2 pls.

Palmer, R.A. 1979. Fish predation and the evolution of gastropod shell sculpture: experimental and geographic evidence. Evolution, 33: 697-713.

Paškevičius, J. 1994. Baltijos Respubliku geologija. Valstybinis leidybos centras, Vienius. 447 pp. 
Pickerill, R.K and Brenchley, P.J. 1979. Caradoc marine benthic communities of the South Berwyn Hills, North Wales. Palaeontology, 22: 229-264.

Popov, L.E., Nikitin, I.F., and Cocks, L.R.M. 2000. Late Ordovician brachiopods from the Otar Member of the Chu-Ili Range, south Kazakhstan. Palaeontology, 43: 833-870.

Rice, W.F. 1987. The systematics and biostratigraphy of the brachiopods of the Decorah Shale at St. Paul, Minnesota. Minnesota Geological Survey Report of Investigations, 35: 136231.

Rosenau, N.A., Herrmann, A.D., and Leslie, S.A. 2012. Conodont apatite $\delta^{18} \mathrm{O}$ values from a platform margin setting, Oklahoma, USA: Implications for initiation of Late Ordovician icehouse conditions. Palaeogeography, Palaeoclimatology, Palaeoecology, 315-316: 172180.

Ross, R.J., Jr. 1957. Ordovician fossils from wells in the Williston Basin, eastern Montana. United States Geological Survey, Bulletin 1021-M:439-506.

Ross, R.J. Jr., Nolan, T.B., and Harris, A.G. 1979. The Upper Ordovician and Silurian Hanson Creek Formation of Central Nevada. Shorter Contributions to Stratigraphy and Structural Geology, USGS Professional Paper 1126-A-J, C1-C-22.

Rohr, D.M., Blodgett, R.B., and Furnish, W.M. 1992. Maclurina manitobensis (Whiteaves) (Ordovician Gastropoda): The largest known Paleozoic gastropod. Journal of Paleontology, 66: 880-884.

Ross, R.J. Jr. 1979. The Upper Ordovician and Silurian Hanson Creek Formation of Central Nevada. Shorter Contributions to Stratigraphy and Structural Geology, USGS Professional Paper 1126-A-J, C1-C-22.

Roy, S.K. 1941. The Upper Ordovician fauna of Frobisher Bay, Baffin Island. Field Museum of Natural History, Geology, Memoirs 2:1-212.

Rudkin, D.M., Young, G.A., Elias, R.J., and Dobrzanski, E.P. 2003. The world's biggest trilobite - Isotelus rex new species from the Upper Ordovician of northern Manitoba, Canada. Journal of Paleontology, 77: 99-112.

Rudwick, M.J.S. 1970. Living and Fossil Brachiopods. Hutchinson University Library, London, U.K. 199 pp.

Schuchert, C. 1900. On the Lower Silurian (Trenton) fauna of Baffin Island. Proceedings of the U.S. National Museum, 22(1192): 143-177, pls. 12-14.

Schuchert. 1913. Class 2. Brachiopoda. 355-420. In Text-book of Palaeontology, Volume 1, 2nd edition. By K.A. von Zittel. Translated and edited by C.R. Eastman. Macmillan, London. p. 355-420.

Schwimmer, B.A., and M.R. Sandy, 1996. Phylum Brachiopoda. In Fossils of Ohio. Ohio Division of Geological Survey Bulletin 70. Edited by R.M. Feldman and M. Hackathorn. p. 210-241.

Servais, T., Lehnert, O., Li, J., Mullins, G.L., Munnecke, A., Nützel, A., and Vecoli, M. 2008. The Ordovician Biodiversity: revolution in the oceanic trophic chain. Lethaia, 41: 99-109.

Servais, T., Harper, D.A.T., Li, J., Munnecke, A., Owen, A.W., Sheehan, P.M. 2009. 
Understanding the Great Ordovician Biodiversification Event (GOBE): Influences of paleogeography, paleoclimate, or paleoecology? GSA Today, 19: 4-10.

Servais, T., Owen, A.W., Harper, D.A.T., Kröger, B.,Munnecke, A. 2010. The Great Ordovician Biodiversification Event (GOBE): The palaeoecological dimension. Palaeogeography, Palaeoclimatology, and Palaeoecology, 294: 99-119.

Shaler, N.S. 1865. List of the Brachiopoda from the island of Anticosti sent by the Museum of Comparative Zoology to different institutions for exchange for other specimens, with annotations. Bulletin of the Museum of Comparative Zoology at Harvard College, 1: 6170.

Sheehan, P.M. and Harris, M.T. 1997. Upper Ordovician-Silurian Macrofossil Biostratigraphy of the Eastern Great Basin, Utah and Nevada. USGS Professional Paper 1579, C1-115.

Titus, R. 1982. Fossil communities of the Middle Trenton Group (Ordovician) of New York state. Journal of Paleontology, 56: 477-485.

Titus, R. 1986. Fossil communities of the Upper Trenton Group (Ordovician) of New York state. Journal of Paleontology, 60: 805-824.

Twenhofel, W.H. 1928. Geology of Anticosti Island. Geological Survey of Canada, Memoir 154. Geological Survey of Canada, Ottawa. $481 \mathrm{pp}$.

Vermeij, G.J. 1977. The Mesozoic Marine Revolution: Evidence from snails, predators, and grazers. Paleobiology, 3: 245-258.

Wang, Y. 1949. Maquoketa Brachiopods of Iowa. Geological Society of America Memoir 42. $55 \mathrm{pp}$.

Wigington, R.J.S. 1977. The age and orthid fauna of the Lower Whittaker Formation, southern Mackenzie Mountains, Northwest Territories. MSc. Thesis, Department of Geology, University of Western Ontario, London, Ontario. 147 pp.

Willard, B. 1928. No. 6a - The Brachiopods of the Ottosee and Holston Formations of Tennessee and Virginia. Bulletin of the Harvard Museum of Comparative Zoology, 48: 255-292, pl. 1-3.

Willman, H.B. and Buschbach, T.C., 1975. Ordovician System. In Handbook of Illinois stratigraphy - Illinois Geological Survey Bulletin 95. Edited by H.B. Willman, E. Atherton, T.C. Buschbach, C. Collinson, J.C. Frye, M.E. Hopkins, J.A. Lineback, and J.A. Simon. Illinoise Geological Survey, Urbana, Illinois. pp. 47-87.

Wilson, A.E. 1926. An Upper Ordovician fauna from the Rocky Mountains, British Columbia. Canada Department of Mines, Geological Survey, Bulletin 44 (Geological Series No. 46), p. 1-34, pls. 1-8.

Wilson, A.E. 1946. Brachiopoda of the Ottawa Formation of the Ottawa-St. Lawrence lowland. Canada Department of Mines and Resources - Mines and Geology Branch, Geological Survey Bulletin, No. 8. 147 pp.

Winchell, N.H. and Schuchert, C. 1892. Preliminary descriptions of new brachiopoda from the Trenton and Hudson River groups of Minnesota. American Geologist, 9: 284-294.

Winchell, N.H. and Schuchert, C. 1893. The Lower Silurian Brachiopoda of Minnesota. The 
Geology of Minnesota, Minnesota Geological and Natural history Survey, Final Report, 3(1): 333-374 [entire volume dated 1895].

Witzke, B.J., Anderson, R.R., and Heathcote, R.C. 1997. Upper Ordovician Brainard Shale (Maquoketa Formation); Stop 4: Highway 20, Dubuque County. In Geology in the Dubuque area. Geological Society of Iowa Guidebook 63. p. 15-24.

Young, G.A., Elias, R.J., Wong, S., and Dobrzanski, E.P. 2008. Upper Ordovician Rocks and Fossils in Southern Manitoba, Canadian Paleontology Conference Field Trip Guidebook No. 13. Geological Association of Canada Publications, 97 pp. 


\section{Chapter 5 - Conclusions}

\subsection{Summary and Conclusions}

This thesis examined the evolution of the Ordovician plaesiomyid brachiopod lineage of Laurentia. The study was carried out in four steps: 1) a review of Late Ordovician biota, paleoecology, and paleogeography; 2) a broad survey of the geological and stratigraphical settings of plaesiomyid-bearing strata and localities dealt with in this thesis; 3 ) a taxonomic reassessment of some key plaesiomyid taxa used for multivariate analysis; and 4) a quantitative examination of the morphological changes in several species of the plaesiomyid lineage ranging from the early Katian (Chatfieldian) to Hirnantian, and the morphological gradients from paleoequatorial inland seas to mid- to high-tropical pericratonic shelves and platforms.

The oldest representatives of the plaesiomyid lineage are known in the Tennessee area, from rocks of Darriwilian age (Whiterockian; see Willard, 1928, Cooper 1956, and Bergström et al. 1988) while the youngest species became extinct in the Anticosti basin of eastern Canada, in the Ellis Bay Formation of the Hirnantian age. Thus, the range of this group spanned from the Great Ordovician Biodiversification Event (GOBE) to the Late Ordovician Mass Extinction.

During the GOBE, the elevated eustatic sea levels, high global temperatures, calcite seas, and abundant food supply in the water column allowed this lineage to diversify, reaching peak abundance by the late Katian (Richmondian) similar to many other brachiopod groups (Harper et al. 2004; Harper 2006), becoming abundant from paleosubtropical pericratonic shelves to paleoequatorial intracratonic basins of Laurentia.

The survival and extinction of the youngest plaesiomyid species during the glacial period, Plaesiomys anticostiensis (Shaler, 1865), may have been caused by two factors. This species was adapted to the cooling oceans during the Hirnantian glaciation, by developing a large mantle cavity to house the filter-feeding lophophores but a smaller musculature to conserve metabolic energy, so as to take advantage of the nutrient-rich and well-oxygenated environment at the continental margin, where greater upwelling may 
have allowed nutrients to better circulate throughout the water column (see below). This increased metabolic efficiency allowed it to survive when many other brachiopod lineages became extinct. Also, it was much less affected by the severe drop in sea level caused by glaciation on Gondwana (Haq and Schutter 2008) which caused the extinction of the epicontinental fauna (including such species as $P$. occidentalis).

Specimens from a total of seven localities were examined in this study. These can be broadly divided into three temporal divisions. The Lake Simcoe and Manitoulin Island, Ontario, localities (Verulam Formation) and the Baffin Island locality (Amadjuack Formation) are early Katian in age. The late Katian localities consist of the Mackenzie Mountains (Whittaker Formation), the Cincinnati-Kentucky-Indiana tri-state area (C-5 Sequence), and Stony Mountain, Manitoba (Stony Mountain Formation). Of the late Katian localities, the Mackenzie Mountains and tri-state area represent subtropical pericratonic shelves while the Stony Mountain locality was within the vast intracratonic seas during the Late Ordovician. The Anticosti Island locality (Ellis Bay Formation) is the youngest locality - Hirnantian in age.

The paleogeographic position of these localities had ecological consequences for the plaesiomyids that inhabited them. Localities within the intracratonic seas (e.g. Stony Mountain) would have been subject to fewer and less severe storm events, as shown by the absence of significant storm deposits. This environment would have been prone to low oxygen levels and unstable supplies of nutrients due to the lack of circulation in the shallow epicontinental seas. The subtropical pericratonic shelves (e.g. CincinnatiIndiana-Kentucky tri-state area, Anticosti Island), however, would have been exposed to more frequent storm events (as shown by the storm deposits - Holland 1993; Jennete and Pryor 1993; Long 2007; Brett et al. 2012, trace fossils, and non-amalgamated shell beds Jin et al. 2012), and more consistent nutrient supplies due to enhanced circulation at the continental-margin.

To conduct reliable and meaningful multivariate analysis based on biometric characters, the taxonomic positions of two species were reassessed. In this study, Dinorthis browni Wilson, 1946, and Dinorthis occidentalis (Okulitch, 1943) were reassigned to Plaesiomys. P. browni showed a distinct style multiplication, where ribs 
were added through both intercalation and bifurcation in the anterior third of the shell. Despite some relatively rare variants that show little rib multiplication, the ribbing pattern of the overall species population warrants its assignment to Plaesiomys.

Dinorthis occidentalis (Okulitch, 1943) was first assigned to Pionorthis, but this genus has been rendered obsolete by Jin and Zhan (2001) as the type specimen is actually a Mendacella. The generic assignment has been debated and treated by some as a Dinorthis (e.g. Macomber 1970, Jin and Zhan 2001). In this study, it is assigned to Plaesiomys based on its morphological similarity (especially rib multiplication) to the type species of Plaesiomys, P. subquadrata from the American Midcontinent. True Dinorthis of early Katian age have simple coarse costae that do not multiply. In contrast, P. occidentalis typically show some degree of rib multiplication in adult specimens much like other species of Plaesiomys.

Two new species, Plaesiomys lenzi and P. periosa, were recognized in this study. $P$. lenzi was a small, extremely finely ribbed species, similar to the more common $P$. bellistriatus except for a much smaller shell size. P. periosa, on the contrary, was extremely large - the largest Plaesiomys species described thus far. Both species are only known from Richmondian strata of the Whittaker Formation of the Mackenzie Mountains, Northwest Territories.

Through multivariate analysis of nine biometric characters, derived from measurements of 198 specimens (10 species) from seven localities, three main trends of morphological changes were identified in the Late Ordovician plaesiomyids of Laurentia. The first was increasing dorsal convexity and globosity (dorsal thickness/width and total thickness/width as proxies, respectively), as was manifest from early Katian (Chatfieldian) forms to the late Katian (Richmondian) specimens. The early Katian plaesiomyids are much smaller than the late Katian forms which show indications of gigantism in both paleoequatorial intracratonic and higher-tropical pericratonic settings. Thus, this is interpreted as true a temporal evolutionary trend in Late Ordovician plaesiomyids. Increased shell size and convexity would have allowed for a larger lophophore and enabled greater efficiency in filter feeding and gas exchange - an advantage in the highly stratified, oxygen and nutrient poor oceans of the Late 
Ordovician.

The second trend is a the tendency of paleoequatorial intracratonic forms to develop coarse ribs which only occasionally bifurcate/intercalate, while specimens from the subtropical pericratonic shelves and basins typically have much finer ribs that multiply at least once but commonly two or three times. This shows that the trend is a phenotypical change related to differing environments. This may be due to the different living environments in the intracratonic seas in comparison to the pericratonic margins. An increase in the number of ribs would have corresponded with an increase in the number of large setae, which may have been in response to unstable conditions at the continental margin in comparison to the relatively static intracratonic seas, allowing the brachiopod to better sense their surroundings. In brachiopods, setae serve a sensory function, and could have provided warning to the brachiopod about approaching predators or sediment flows which could have clogged the lophophore with sediment.

The third trend was shown by the variation in the shape and size of the cardinal process, which serves as an attachment site for the diductor muscle. From the early to late Katian (Chatfieldian to Richmondian), the cardinal process changed from being slender and platy to enlarged and bulbous. This was a result of the gigantism also shown in these specimens - a larger and more globose shell would require stronger muscles to open and close. These stronger muscles would have required a larger attachment point to be effective. As the diductor muscles attach to the myophore of the cardinal process, a larger cardinal process enabled enlargement of the diductors. This trend was seemingly reversed during the Hirnantian, with Plaesiomys anticostiensis of the Ellis Bay Formation of Anticosti Island developing a slender bilobed cardinal process similar to that in pioneer species in the early Katian. This can be explained as an evolutionary response to the icehouse climate during this interval - the cooler oceans would have meant a higher metabolic cost to biomineralization, favouring the development of smaller internal skeletal parts. However, these cooler oceans would have led to increased circulation and an abundance of nutrients in continental shelf environments, reducing the selection pressure on the size of lophophores and musculature.

Also, there was a broad pattern of plaesiomyids developing a bilobed cardinal 
process in subtropical pericratonic settings and a trilobed cardinal process in the equatorial intracratonic seas. The posteriorly projecting trilobed cardinal process would have enabled a wider gape at the anterior margin, perhaps compensating for the lower oxygen content and unstable food supply in the paleoequatorial intracratonic seas, where severe storms would be rare and circulations sluggish, unlike the higher-tropical continental shelves where storms were dominant with better circulation, and upwelling would continually replenish nutrients in the water column.

\subsection{Future Work}

This study examined some of most common plaesiomyid species from the early to Hirnantian. As explained in Chapter 4, little is known about the internal morphology of the early species of this lineage as documented by Hall (1847), Willard (1928), Cooper (1956), and Wilson (1926) from the Darriwilian to early Katian (Whiterockian to Chatfieldian). Additionally, there is a seemingly large number of species documented from these periods with very narrow temporal and geographic ranges, suggesting that the taxonomy of these early species may be in need of revision. In particular, well-preserved topotype specimens of the type species of Dinorthis, D. pectinella (Emmons, 1842), need to be found and examined in order to determine its detailed morphology, especially with regard to the presence or absence of epipunctae, and the nature (bilobed or trilobed) of its cardinal process. Such information will be critical for investigating the phylogeny of the plaesiomyid family.

Also, the study of the evolution of additional lineages during this interval is ongoing, with Sohrabi and Jin (2012) investigating evolutionary trends in the Rhynchotrema-Hiscobeccus lineage from the Middle Ordovician to Early Silurian. By examining additional brachiopod lineages, evolutionary trends may be revealed at the faunal and ecosystem level, further enhancing our knowledge of the Ordovician biotic radiation and mass extinction events. 


\section{References}

Bergström, S., Carnes, J.B. Hall, J.C., Kurapkate, and O'Neil, B.E. 1988. Conodont Biostratigraphy of Some Middle Ordovician in Eastern North American Marginal Sequences with Coeval Successions in Northern China and Oslo, Norway. In The Canadian Paleontology and Biostratigraphy Seminar - Proceddings of Meeting Sepetember 26-29, 1986. Bulletin Number 462, New York State Museum/Geological Association of Canada. Edited by E. Landing. p. 33-42.

Brett, C.E., Algeo, T.J., and McLaughlin, P.I. 2008. Chapter 9 - Use of Event Beds and Sedimentary Cycles in High-Resolution Stratigraphic Correlation of Lithologically Repetititve Successions: The Upper Ordovician Kope Formation of Northern Kentucky and Southern Ohio. In High-Resoltuion Approaches in Stratigraphic Paleontology, Topics in Geobiology, Vol. 21. Edited by P.J. Harries. Springer Netherlands. p. 315-350.

Cooper, G.A. 1956. Chazyan and related brachiopods. Smithsonian Miscellaneous Collections, vol. 127, 1245 pp.

Emmons, E. 1842. Geology of New York, part, comprising the survey of the second geological district. W.A. White and J. Visscher, Albany, New York. 57 pp., 17 pls.

Haq, B.U. and Schutter, S.R. 2008. A Chronology of Paleozoic Sea-Level Changes. Science, 322:64-68.

Harper, D.A.T. 2006. The Ordovician biodiversification: setting an agenda for marine life. Palaeogeography, Palaeoclimatology, Palaeoecology, 232:148-166.

Harper, D.A.T., Cocks, R.M., Popov, L.E., Sheehan, P.M., Bassett, G., Copper, P., Holmer, L.E., Jin, J., Jia-yu, R. 2004. Brachiopods. In The Great Ordovician Biodiversification Event. Edited by B.D. Webby, F. Paris, M.L. Droser, and I.G. Percival. Columbia University Press, New York. p. 157-178.

Holland, S.M. 1993. Sequence stratigraphy of a carbonate-clastic ramp: The Cincinnatian Series (Upper Ordovician) in its type area. Geological Society of America Bulletin, 105: 306-322.

Jennette, D.C. and Pryor, W.A. 1993. Cyclic alternation of proximal and distal storm facies: Kope and Fairview Formations (Upper Ordovician), Ohio and Kentucky. Journal of Sedimentary Petrology, 63: 183-203.

Jin, J. and Zhan, R. 2001. Late Ordovician articulate brachiopods from the Red River and Stony Mountain Formations, southern Manitoba. NRC Research Press, Ottawa. 117 pp.

Jin, J., Harper, D.A.T., Cocks, L.R.M., McCausland, P.J.A., Rasmussen, C.M.Ø. and Sheehan, P.M. 2012 (in press). Precisely locating the Ordovician equator in Laurentia. Geology.

Long, D.G.F. 2007. Tempestite frequency curves: a key to Late Ordovician and Early Silurian subsidence, sea-level change, and orbital forcing in the Anticosti foreland basin, Canada. Canadian Journal of Earth Sciences, 44: 413-43 
Macomber, R.W. 1970. Articulate brachiopods from the upper Bighorn Formation (Late Ordovician) of Wyoming. Journal of Paleontology, 44:416-450.

Okulitch, V.J. 1943. The Stony Mountain Formation of Manitoba. Transactions of the Royal Society of Canada, 3rd series, 37:1-74, 2 pls.

Shaler, N.S. 1865. List of the Brachiopoda from the island of Anticosti sent by the Museum of Comparative Zoology to different institutions for exchange for other specimens, with annotations. Bulletin of the Museum of Comparative Zoology at Harvard College, 1: 61-70.

Sohrabi, A and Jin, J. 2012. Evolution of the Rhynchotrema-Hiscobeccus brachiopod lineage: implications for the diversification of the Late Ordovician epicontinental brachiopod fauna of Laurentia. Lethaia, DOI: 10.1111/j.1502-3931.2012.00333.x.

Wang, Y. 1949. Maquoketa Brachiopoda of Iowa. Geological Society of America, Memoir $42.55 \mathrm{pp}$.

Wigington, R.J.S. 1977. The age and orthid fauna of the Lower Whittaker Formation, southern Mackenzie Mountains, Northwest Territories. MSc. Thesis, Department of Geology, University of Western Ontario, London, Ontario. 147 pp.

Willard, B. 1928. No. 6a-The Brachiopods of the Ottosee and Holston Formations of Tennessee and Virginia. Bulletin of the Harvard Museum of Comparative Zoology, 48:255-292, pl. 1-3.

Wilson, A.E. 1946. Brachiopoda of the Ottawa Formation of the Ottawa-St. Lawrence lowland. Canada Department of Mines and Resources - Mines and Geology Branch, Geological Survey Bulletin, No. 8. 147 pp. 


\section{Appendix 1: Cincinnati Specimens from the Field Museum, Chicago, Illinois}

The specimens from the Field Museum collections are as followed. Many of the species were incorrectly identified, and as such the correct identification has been suggested.

A total of 49 specimens were received from the Field Museum. 


\begin{tabular}{|c|c|c|c|c|c|c|}
\hline Code & $\begin{array}{l}\text { Number of } \\
\text { Specimens }\end{array}$ & Species & $\begin{array}{l}\text { Species as } \\
\text { Documented }\end{array}$ & Locality & Formation & Sequence \\
\hline $\begin{array}{l}\text { UC } \\
56428\end{array}$ & 8 & $\begin{array}{l}\text { P. subquadrata, Glyptorthis, } \\
\text { Hebertella,Diceromyonia/Paucicrura }\end{array}$ & $\begin{array}{l}\text { Plaesiomys } \\
\text { subquadrata }\end{array}$ & Madison, IN & & \\
\hline P 6827 & 3 & P. subquadrata, $P$. bellistratus & $\begin{array}{l}\text { Plaesiomys } \\
\text { subquadrata }\end{array}$ & Minooke, IL & & \\
\hline $\begin{array}{l}P \\
18306\end{array}$ & 1 & Hebertella & $\begin{array}{l}\text { Plaesiomys } \\
\text { subquadrata }\end{array}$ & Ohio & & \\
\hline $\begin{array}{l}\mathrm{PE} \\
2168\end{array}$ & 3 & $\begin{array}{l}\text { P. subquadrata, P. bellistratus, } \\
\text { Hebertella }\end{array}$ & $\begin{array}{l}\text { Plaesiomys } \\
\text { subquadrata }\end{array}$ & Madison, IN & Lorraine Fm. & \\
\hline $\begin{array}{l}P E \\
2204\end{array}$ & 10 & P. subquadrata, $P$. bellistratus & $\begin{array}{l}\text { Plaesiomys } \\
\text { subquadrata }\end{array}$ & Cincinnati, $\mathrm{OH}$ & Lorraine Fm. & \\
\hline $\begin{array}{l}\mathrm{PE} \\
5523\end{array}$ & 3 & A. multicostella & $\begin{array}{l}\text { Plaesiomys } \\
\text { subquadrata }\end{array}$ & Ardmore, OK & Richmond Gp. & C-5 \\
\hline $\begin{array}{l}\mathrm{PE} \\
5777\end{array}$ & 3 & P. subquadrata & $\begin{array}{l}\text { Plaesiomys } \\
\text { subquadrata }\end{array}$ & Clarksville, $\mathrm{OH}$ & Waynesville Fm. & C-5 \\
\hline $\begin{array}{l}\mathrm{PE} \\
5800\end{array}$ & 2 & P. subquadrata & $\begin{array}{l}\text { Plaesiomys } \\
\text { subquadrata }\end{array}$ & Oxford, $\mathrm{OH}$ & Liberty Fm. & C-5 \\
\hline $\begin{array}{l}\mathrm{PE} \\
5814\end{array}$ & 4 & P. subquadrata & $\begin{array}{l}\text { Plaesiomys } \\
\text { subquadrata }\end{array}$ & Oxford, $\mathrm{OH}$ & Richmond Gp. & C-5 \\
\hline $\begin{array}{l}\mathrm{PE} \\
16606\end{array}$ & 3 & P. subquadrata & $\begin{array}{l}\text { Plaesiomys } \\
\text { subquadrata }\end{array}$ & Clarksville, $\mathrm{OH}$ & Whitewater Fm. & C-5 \\
\hline $\begin{array}{l}\mathrm{PE} \\
25232\end{array}$ & 5 & P. subquadrata & $\begin{array}{l}\text { Plaesiomys } \\
\text { subquadrata }\end{array}$ & Germantown, $\mathrm{OH}$ & Liberty Fm. & C-5 \\
\hline $\begin{array}{l}\mathrm{PE} \\
25257\end{array}$ & 2 & P. subquadrata & $\begin{array}{l}\text { Plaesiomys } \\
\text { subquadrata }\end{array}$ & Clarksville, $\mathrm{OH}$ & Liberty Fm. & C-5 \\
\hline $\begin{array}{l}\mathrm{PE} \\
25750\end{array}$ & 1 & P. subquadrata, $P$. bellistratus & $\begin{array}{l}\text { Plaesiomys } \\
\text { subquadrata }\end{array}$ & Fairfield, IN & U. Dillboro Fm. & C-5 \\
\hline $\begin{array}{l}\mathrm{PE} \\
25904\end{array}$ & 1 & P. subquadrata & $\begin{array}{l}\text { Plaesiomys } \\
\text { subquadrata }\end{array}$ & Bentonville, $\mathrm{OH}$ & Bullfork Fm. & C-5 \\
\hline Total & 49 & & & & & \\
\hline
\end{tabular}




\section{Appendix 2: Measured Specimens}

Appendix 2 contains measurements of all specimens measured for the project. Abbreviations are the same as those in Chapter 4.

Table 1: Stony Mountain, Manitoba - Plaesiomys occidentalis (11 pages)

Table 2: Anticosti Island, Quebec - Plaesiomys anticostiensis (7 pages)

Table 3: Manitoulin Island, Ontario - Plaesiomys browni (2 pages)

Table 4: Lake Simcoe, Ontario, and Baffin Island, Nunavut - Plaesiomys subcircularis (1 page)

Table 5: Mackenzie Mountains, Northwest Territories - Plaesiomys columbia, P. periosa, $P$. lezi, and $P$. bellistriatus (2 pages)

Table 6: Ohio-Kentucky-Indiana tri-state area - Plaesiomys subquadrata, P. cf. P. bellistriatus, and P. bellistriatus (3 pages)

Table 7: Oklahoma - Austinella multicostella (1 page)

Notes:

Table 4 - Specimen 4 is the type specimen from Baffin Island (GSC 113498). 
Stony Mountain, Manitoba - Plaesiomys occidentalis Table 1

\begin{tabular}{|c|c|c|c|c|c|c|c|c|c|c|c|c|c|c|c|c|c|c|c|c|c|c|c|}
\hline$\xi$ & $\stackrel{m}{+}$ & 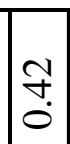 & $\stackrel{n}{\stackrel{n}{0}}$ & $\tilde{n}$ & & $\begin{array}{l}\vec{\Xi} \\
0\end{array}$ & సุ. & & 告 & $\tilde{n}$ & $\hat{n}$ & 守. & $\tilde{n}$ & ले & & $\stackrel{0}{+}$ & $\stackrel{n}{\stackrel{n}{\circ}}$ & & & & & & 㝘 \\
\hline$\sum^{z}$ & n? & సิ & 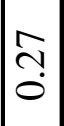 & 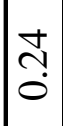 & & ஸे & $\frac{\infty}{\dot{0}}$ & & ?ָ & 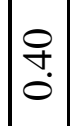 & ?̊ & @ি & ì & กิ & & 官 & $\ddot{\sigma}$ & & & & & ?n & ஸ़่ \\
\hline$\underset{1}{\stackrel{0}{3}}$ & ب & ڤ̆ & $\underset{8}{8}$ & o̊ & б. & $\underset{8}{8}$ & - & ठే. & 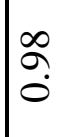 & ọ & ڤ̆ & $\underset{O}{\sigma}$ & @̊ & 8 & $\overline{0}$ & $\stackrel{8}{8}$ & ○े & $\underset{\sigma}{\sigma}$ & & & అִ & & - \\
\hline$\stackrel{\text { }}{\approx}$ & $\stackrel{N}{\sim}$ & $\stackrel{?}{n}$ & $\vec{\sim}$ & 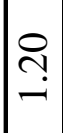 & 苞 & $\underline{0}$ & 旾 & $\underline{0}$ & 웅 & & $\underset{0}{8}$ & 今. & ণి & $\underset{8}{8}$ & $\stackrel{\infty}{\beth}$ & $\stackrel{0}{\beth}$ & $\vec{\sim}$ & & & & & & \\
\hline 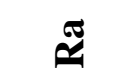 & $\hat{n}$ & ले & mे & 象 & خे & શે & $\tilde{n}$ & নे & ৯े & & ஜ & లి & m & $\stackrel{\circ}{\circ}$ & $\tilde{m}$ & m & $\nabla$ & & & & & & \\
\hline से & $\stackrel{\infty}{\sim}$ & ㄴ. & $\stackrel{\infty}{\sim}$ & p & $\stackrel{\infty}{\sim}$ & $\widehat{\sim}$ & $\stackrel{\sim}{\sim}$ & $\hat{\imath}$ & 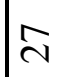 & & $\stackrel{\ominus}{\circ}$ & $\stackrel{\infty}{\sim}$ & $\widehat{\curvearrowright}$ & $\stackrel{\circ}{\circ}$ & $\stackrel{\infty}{\sim}$ & શิ & mे & & & & & & શે \\
\hline ค̊ ఏ & $\stackrel{+}{\sim}$ & $\overline{\widehat{c}}$ & $\stackrel{m}{r}$ & $\overline{\vec{i}}$ & $\stackrel{\infty}{\circ}$ & 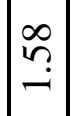 & $\tilde{\overbrace{}}$ & $\stackrel{n}{\stackrel{f}{\sim}}$ & $\stackrel{g}{\stackrel{f}{q}}$ & 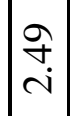 & 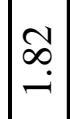 & nุ? & ヘ઼ & बे. & & $\begin{array}{l}0 \\
\infty \\
0 \\
\dot{0}\end{array}$ & 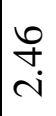 & & & & & & $\begin{array}{l}\hat{b} \\
\text { i. }\end{array}$ \\
\hline$\Rightarrow$ छ & $\begin{array}{l}\stackrel{\partial}{\infty} \\
\stackrel{\mathrm{N}}{ }\end{array}$ & $\begin{array}{c}\stackrel{a}{r} \\
\mathrm{i}\end{array}$ & $\begin{array}{l}2 \\
\infty \\
\dot{i}\end{array}$ & 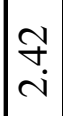 & $\frac{\mathrm{N}}{\mathrm{N}}$ & $\left|\begin{array}{c}\infty \\
0 \\
i \\
\sim\end{array}\right|$ & $\stackrel{\odot}{\infty}$ & $\vec{n}$ & $\frac{n}{2}$ & $\mid \begin{array}{l}\mathscr{0} \\
\dot{\theta} \\
\dot{r}\end{array}$ & $\left|\begin{array}{c}\tilde{f} \\
\sim \\
\sim\end{array}\right|$ & $\frac{m}{i}$ & 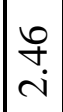 & $\begin{array}{c}\tilde{D} \\
\infty \\
-\end{array}$ & & $\stackrel{\infty}{\infty}$ & 尺̂n. & & & 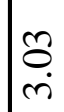 & & & On. \\
\hline 己 & $=$ & $\stackrel{m}{\stackrel{9}{\sigma}}$ & $\frac{\infty}{\pi}$ & $\underset{\infty}{\infty}$ & ri & $\begin{array}{l}0 \\
f \\
\dot{r}\end{array}$ & ก̃. & 于. & $\begin{array}{l}\text { Dे } \\
\text { in }\end{array}$ & $\begin{array}{l}\bar{\sigma} \\
\text { ci }\end{array}$ & 告 & $\stackrel{2}{\substack{n \\
r}}$ & 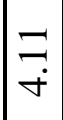 & $\left|\begin{array}{l}\infty \\
0 \\
0\end{array}\right|$ & & 色 & $\stackrel{\infty}{\infty}$ & & & & & ஓं & $\begin{array}{l}\infty \\
\infty \\
0\end{array}$ \\
\hline$-\widehat{\Xi}$ & ñ & $\begin{array}{l}0 \\
2 \\
0 \\
-1\end{array}$ & $\begin{array}{c}\hat{a} \\
\text { i } \\
-\end{array}$ & ป̃ & $\begin{array}{l}n \\
\infty \\
\dot{n}\end{array}$ & 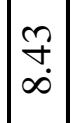 & 㫄 & $\underset{\infty}{\stackrel{\gamma}{+}}$ & $\begin{array}{l}\dot{n} \\
\infty \\
\infty\end{array}$ & $\begin{array}{l}n \\
0 \\
0 \\
-\end{array}$ & $\left|\begin{array}{c}2 \\
\infty \\
\infty\end{array}\right|$ & $\begin{array}{l}n \\
\sigma \\
=\end{array}$ & $\begin{array}{l}n \\
n \\
n\end{array}$ & ڤેa & & $\frac{2}{0}$ & m. & & & & & & ?̊ \\
\hline$\gtrless \widehat{\Xi}$ & = & $\begin{array}{l}\stackrel{m}{+} \\
\ddot{n}\end{array}$ & \begin{tabular}{l}
$n$ \\
\multirow{2}{0}{} \\
$i$
\end{tabular} & $\begin{array}{l}0 \\
\dot{m} \\
\dot{m}\end{array}$ & & م̂. & $\begin{array}{l}m \\
\ddot{\sigma} \\
\ddot{n}\end{array}$ & & $\begin{array}{l}\infty \\
\infty \\
\infty\end{array}$ & ๓n & $\begin{array}{l}n \\
\infty \\
\tilde{n}\end{array}$ & 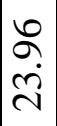 & \begin{tabular}{l}
$n$ \\
0 \\
\cline { 1 - 1 }
\end{tabular} & 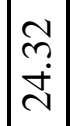 & ๙ิ & $\stackrel{2}{\beth}$ & i & $\begin{array}{l}\infty \\
0 \\
0 \\
-1\end{array}$ & $\stackrel{\infty}{\infty}$ & خे & $\hat{a}$ & $\frac{m}{m}$ & $\begin{array}{l}2 \\
\infty \\
\ddot{2}\end{array}$ \\
\hline 念 & 文 & 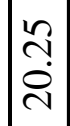 & 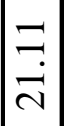 & 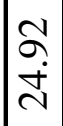 & $\begin{array}{l}6 \\
6 \\
2 \\
-1\end{array}$ & సิ & 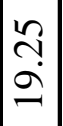 & $\begin{array}{l}n \\
\dot{J} \\
\end{array}$ & $\begin{array}{l}\hat{\sigma} \\
\dot{ \pm}\end{array}$ & $\begin{array}{l}\vec{\nabla} \\
\dot{\sigma}\end{array}$ & $\begin{array}{l}9 \\
\infty \\
\infty\end{array}$ & $\begin{array}{l}\infty \\
\infty \\
\infty \\
-1\end{array}$ & $\begin{array}{l}\infty \\
a \\
\\
1\end{array}$ & $\begin{array}{l}\infty \\
n \\
\\
=\end{array}$ & 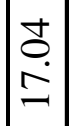 & $\begin{array}{l}\stackrel{\Xi}{\sim} \\
\dot{\Xi}\end{array}$ & त̄ & $\stackrel{n}{\sim}$ & & $\begin{array}{l}n \\
\infty \\
\infty\end{array}$ & $\begin{array}{l}\stackrel{0}{+} \\
\infty \\
\infty \\
\sim\end{array}$ & & ڤ̊̀ \\
\hline ర્తి & @̊ & 吕 & $\stackrel{\vec{\lambda}}{\vec{\lambda}}$ & $\begin{array}{l}n \\
\vdots \\
a\end{array}$ & $\begin{array}{l}n \\
n \\
n \\
n\end{array}$ & त̂ & $\begin{array}{l} \pm \\
0 \\
0 \\
=\end{array}$ & $\stackrel{m}{n}$ & & 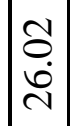 & $\begin{array}{l}n \\
\infty \\
\infty\end{array}$ & $\begin{array}{l}\stackrel{\infty}{+} \\
\infty \\
\infty\end{array}$ & $\vec{\sim}$ & $\begin{array}{l}\widetilde{\sigma} \\
\check{C} \\
\end{array}$ & $\begin{array}{l}\infty \\
\infty \\
0 \\
-1\end{array}$ & $\begin{array}{l}\mathrm{N} \\
\dot{\Xi} \\
\end{array}$ & $\stackrel{n}{\ddot{n}}$ & $\begin{array}{l}\sigma \\
\dot{ \pm}\end{array}$ & ڤે & & 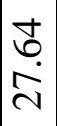 & $\begin{array}{l}0 \\
\dot{0} \\
\dot{2}\end{array}$ & 용 \\
\hline 咅 & - & $N$ & $m$ & $\forall$ & in & 6 & $r$ & $\infty$ & $a$ & $ㅇ$ & 二 & 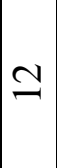 & $m$ & $\Xi$ & $n$ & 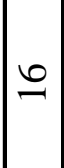 & 工 & $\infty$ & 9 & 尺 & $\vec{\sim}$ & ป & 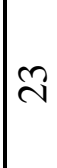 \\
\hline
\end{tabular}


Stony Mountain, Manitoba - Plaesiomys occidentalis Table 1 (continued)

\begin{tabular}{|c|c|c|c|c|c|c|c|c|c|c|c|c|c|c|c|c|c|c|c|c|c|c|c|}
\hline 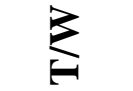 & & 守 & & & $\mid \begin{array}{l}0 \\
+ \\
0 \\
0\end{array}$ & & & $\left|\begin{array}{l}n \\
0 \\
0\end{array}\right|$ & & & & & $\begin{array}{l}\nexists \\
\dot{0} \\
0\end{array}$ & & & & & & & & & & $\underset{0}{\sharp}$ \\
\hline i & & & $\stackrel{+}{+}$ & ?̦ & $\begin{array}{l}\tilde{n} \\
0 \\
0\end{array}$ & $\tilde{n}$ & $\tilde{n}$ & $\begin{array}{l}\tilde{f} \\
\dot{0}\end{array}$ & & $\bar{n}$ & 움 & & શે & & & $\tilde{?}$ & $\ddot{n}$ & $\tilde{m}$ & & & 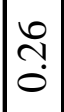 & & 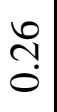 \\
\hline 롫 & & & & & 8 & & & $\mid \begin{array}{l}\overline{0} \\
-\end{array}$ & & & & & $\hat{a}$ & & & & & & & & & & \\
\hline$\overbrace{\mathscr{A}}^{2}$ & & & & ? & & $\exists$ & $\underset{\sim}{ \pm}$ & 8 & & & $\exists$ & $\vec{\sim}$ & 官 & & & & $\stackrel{\simeq}{\simeq}$ & & & & & & 고 \\
\hline$\stackrel{\pi}{\mathscr{*}}$ & & $\vec{n}$ & m & ले & & $\bar{m}$ & ৯ & ㄱ. & & & $\bar{n}$ & 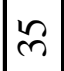 & $\stackrel{m}{\forall}$ & & & & $\hat{n}$ & & & & & & $\vec{m}$ \\
\hline a & & & & @) & $\bar{m}$ & $\infty$ & $\stackrel{\infty}{\sim}$ & ㅇ & & & $\stackrel{\infty}{\sim}$ & ๙े & $\bar{m}$ & & & & $m$ & ৯े & & $\stackrel{\infty}{\sim}$ & & & $\stackrel{\infty}{\sim}$ \\
\hline$\tilde{\varrho}$ & & 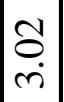 & & กั & \begin{tabular}{l}
0 \\
\multirow{2}{*}{} \\
¿
\end{tabular} & $\stackrel{n}{\hat{i}}$ & $\vec{n}$ & & $\begin{array}{c}\overline{0} \\
\dot{0}\end{array}$ & 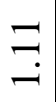 & & & $\left|\begin{array}{c}m \\
\stackrel{v}{v}\end{array}\right|$ & & $\begin{array}{c}0 \\
m \\
m \\
m\end{array}$ & $\frac{m}{i}$ & 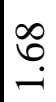 & 光 & $\begin{array}{l}8 \\
\stackrel{0}{0} \\
ن\end{array}$ & $\mid$ & à & ? & \\
\hline$\gtrsim \widehat{\Xi}$ & $\underset{\nabla}{\vec{\nabla}}$ & & & & $\begin{array}{l}\infty \\
\dot{\infty}\end{array}$ & & & $\left|\begin{array}{l}\infty \\
\infty \\
\dot{9}\end{array}\right|$ & & & & & $\left|\begin{array}{l}\infty \\
\vdots \\
\dot{n}\end{array}\right|$ & 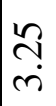 & $\hat{m}$ & & & & તุ & $\mid \begin{array}{l}- \\
\infty \\
i \\
\end{array}$ & & 旾 & $\underset{⿱}{\sim}$ \\
\hline 로 & & & ป̃ & مุ & $\begin{array}{l}0 \\
r \\
r\end{array}$ & $\hat{a}$ & $\begin{array}{l}\alpha \\
\alpha \\
\alpha\end{array}$ & $\stackrel{\Upsilon}{\Upsilon}$ & 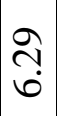 & $\begin{array}{l}\dot{a} \\
\sigma\end{array}$ & $\begin{array}{l}\infty \\
\stackrel{1}{\prime} \\
=\end{array}$ & $\stackrel{n}{r}$ & $\stackrel{ \pm}{a}$ & & & $\begin{array}{l}a \\
a \\
a\end{array}$ & 官 & $\begin{array}{l}m \\
\tilde{a}\end{array}$ & & & $\begin{array}{l}\infty \\
m \\
n \\
n\end{array}$ & & $\bar{a}$ \\
\hline - 犬 & & $\begin{array}{l}\stackrel{9}{a} \\
\dot{m}\end{array}$ & & & $\begin{array}{l}0 \\
\text { ำ } \\
=\end{array}$ & & & $\begin{array}{l}0 \\
0 \\
0 \\
0\end{array}$ & & & & & $\begin{array}{l}m \\
\ddot{n}\end{array}$ & & & & & & & & & & $\begin{array}{l}8 \\
\varnothing \\
0 \\
\end{array}$ \\
\hline$B \widehat{\Xi}$ & $\begin{array}{l} \pm \\
\dot{J} \\
\dot{\sim}\end{array}$ & $\mid \begin{array}{c}\infty \\
\sim \\
\infty \\
\infty \\
N\end{array}$ & $\begin{array}{l}\infty \\
\text { N } \\
\end{array}$ & ஓ̊. & $\begin{array}{l}0 \\
\stackrel{+}{+} \\
\stackrel{ \pm}{\sim}\end{array}$ & กิ & $\begin{array}{l}\vec{\nabla} \\
\infty \\
\stackrel{0}{\sim}\end{array}$ & 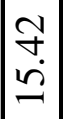 & & $\frac{\hat{n}}{\dot{m}}$ & $\begin{array}{l}\sim \\
\tilde{n} \\
\infty \\
\infty\end{array}$ & & $\begin{array}{l}\dot{0} \\
\dot{0} \\
\dot{n}\end{array}$ & $\frac{n}{\stackrel{d}{d}}$ & $\frac{n}{n}$ & $\mid \begin{array}{l}n \\
0 \\
\infty \\
\sim \\
\end{array}$ & $\stackrel{\infty}{\stackrel{\infty}{+}}$ & $\begin{array}{c}\stackrel{0}{+} \\
\dot{0} \\
\stackrel{0}{d}\end{array}$ & $\begin{array}{l}\hat{a} \\
\text { ஸे }\end{array}$ & $\begin{array}{l}\hat{\sigma} \\
\dot{a} \\
\end{array}$ & $\mid \begin{array}{c}n \\
\stackrel{n}{0} \\
\stackrel{i}{2}\end{array}$ & 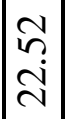 & 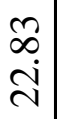 \\
\hline 点 & $\begin{array}{l}\infty \\
\infty \\
\infty\end{array}$ & & & & बें & & & $\begin{array}{l}m \\
\sim \\
\sim\end{array}$ & & & & & $\begin{array}{l}\nexists \\
\dot{v} \\
\grave{v}\end{array}$ & $\begin{array}{l}\nexists \\
\dot{\theta}\end{array}$ & $\begin{array}{l}\stackrel{P}{2} \\
\dot{\sim} \\
\end{array}$ & & & & $\begin{array}{l}o \\
\stackrel{n}{\sim} \\
\end{array}$ & $\begin{array}{l}\bar{n} \\
\stackrel{\sim}{2}\end{array}$ & & $\begin{array}{c}\mathcal{N} \\
\infty \\
-\infty\end{array}$ & \\
\hline છ્త & & $\begin{array}{l}n \\
\tilde{n} \\
\text { na }\end{array}$ & 今. & $\begin{array}{l}\infty \\
\infty \\
\infty\end{array}$ & হৃ. & 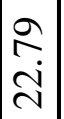 & $\begin{array}{l}\infty \\
\dot{+} \\
\dot{\sim}\end{array}$ & $\begin{array}{l}\Omega \\
\pm \\
\pm\end{array}$ & $\begin{array}{l}\varnothing \\
\infty \\
\\
\end{array}$ & \begin{tabular}{l}
0 \\
\multirow{2}{0}{} \\
N.
\end{tabular} & 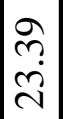 & $\begin{array}{l}0 \\
\dot{0} \\
\dot{n}\end{array}$ & $\begin{array}{l}\stackrel{0}{~} \\
\dot{ป}\end{array}$ & & & $\begin{array}{l}m \\
\ddot{n} \\
\dot{n}\end{array}$ & $\stackrel{m}{\stackrel{m}{\sim}}$ & $\begin{array}{l}n \\
\tilde{n} \\
\tilde{n}\end{array}$ & & & $\begin{array}{l}\dot{0} \\
\text { I } \\
\text { I }\end{array}$ & & 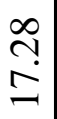 \\
\hline 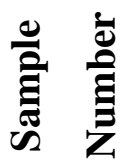 & $\stackrel{\Delta}{\sim}$ & an & 인 & 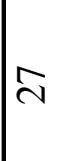 & $\stackrel{\infty}{\sim}$ & શે & 요 & $\bar{m}$ & ñ & $m$ & m & $n$ & $\begin{array}{l}0 \\
m\end{array}$ & $\hat{m}$ & $\stackrel{\infty}{\infty}$ & ले & 앙 & $F$ & ㄱ & $\mathscr{f}$ & $\stackrel{\wp}{f}$ & $\begin{array}{l}0 \\
+\end{array}$ & 于 \\
\hline
\end{tabular}


Stony Mountain, Manitoba - Plaesiomys occidentalis Table 1 (continued)

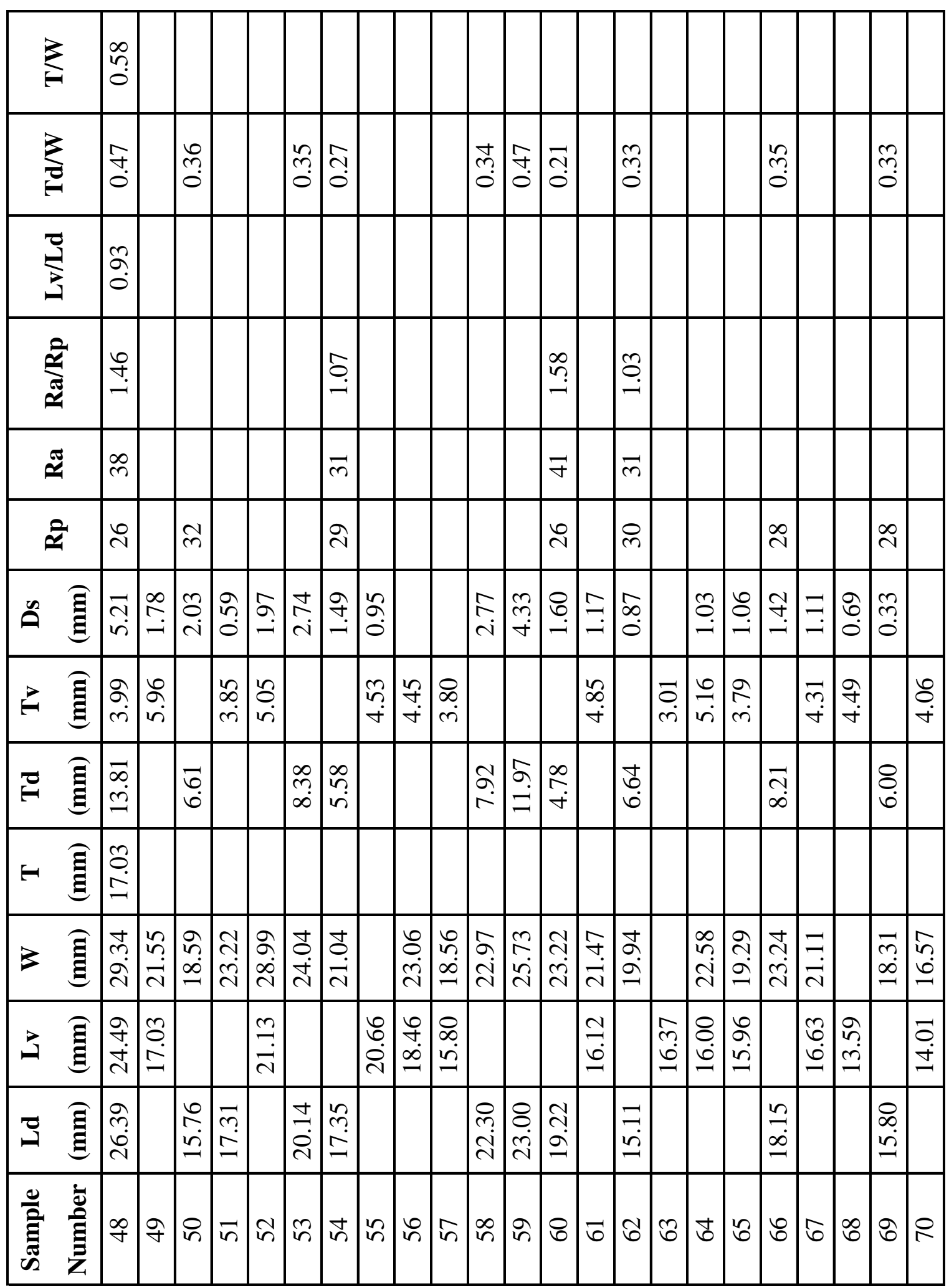


Stony Mountain, Manitoba - Plaesiomys occidentalis Table 1 (continued)

\begin{tabular}{|c|c|c|c|c|c|c|c|c|c|c|c|c|c|c|c|c|c|c|c|c|c|c|}
\hline 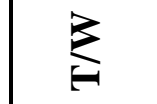 & & & & $\begin{array}{l}\tilde{f} \\
\dot{0}\end{array}$ & $\mid \begin{array}{l}0 \\
\stackrel{0}{0} \\
\dot{0}\end{array}$ & ñ & & & $\begin{array}{l}n \\
n \\
0\end{array}$ & $\left|\begin{array}{l}m \\
\stackrel{9}{0}\end{array}\right|$ & $\begin{array}{c}n \\
n \\
0\end{array}$ & $\begin{array}{l}q \\
+ \\
0\end{array}$ & ?ִ. & $\begin{array}{c}\infty \\
\stackrel{\infty}{0} \\
0\end{array}$ & 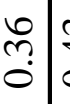 & 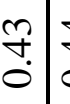 & $\frac{0}{8}$ & & & 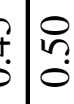 & 过 & $\stackrel{9}{\circ}$ \\
\hline$\sum^{3}$ & & & ले & 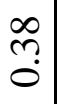 & $\mid$ & $\stackrel{q}{9}$ & & & 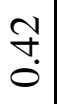 & $\left|\begin{array}{l}\overparen{T} \\
0\end{array}\right|$ & $\stackrel{m}{?}$ & $\begin{array}{lll}\infty & \\
& 0 & \\
0 & & \end{array}$ & $\begin{array}{l}0 \\
\text { ñ. } \\
0\end{array}$ & $\begin{array}{c}\dot{T} \\
m \\
\vdots\end{array}$ & & $\vec{m}$ & लै & & & $\begin{array}{l}l \\
\vdots\end{array}$ & m. & $\stackrel{+}{m}$ \\
\hline 㿣 & & & & $\begin{array}{l}a \\
0 \\
0\end{array}$ & - & 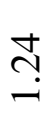 & & & ڤ. & $\hat{a}$ & $\stackrel{8}{-}$ & $\overrightarrow{0}$ & ôे & $\hat{\vdots}$ & $\begin{array}{l}\infty \\
\vdots \\
\vdots \\
\vdots\end{array}$ & $\underset{\sigma}{\sigma}$ & g. & & & $\begin{array}{c}0 \\
\vdots \\
\vdots\end{array}$ & $\hat{a}$ & @. \\
\hline 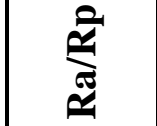 & & & & ô. & $\underset{-}{8}$ & ô. & & & 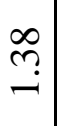 & $\stackrel{0}{0}$ & & & $\stackrel{m}{=}$ & $\underset{-}{8}$ & $\underset{-}{8}$ & $\stackrel{0}{.}$ & $\stackrel{\infty}{=}$ & & & . & $\stackrel{\overbrace{}}{\overbrace{}}$ & 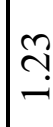 \\
\hline$\approx$ & & & & $\grave{\lambda}$ & $\grave{\lambda}$ & $\bar{m}$ & & 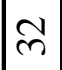 & లి & in & & & $\stackrel{m}{m}$ & 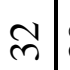 & ঃ্ল) & $\stackrel{\sim}{m}$ & $m$ & & $\stackrel{ल}{\curvearrowright}$ & 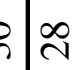 & $\hat{m}$ & 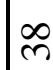 \\
\hline$\stackrel{2}{2}$ & & & & $\hat{\imath}$ & $\grave{\lambda}$ & $\grave{\lambda}$ & & & ㄴ. & ৯े & & & in & $\tilde{n}$ & లి & లి & $\underset{\sim}{\sim}$ & & $\stackrel{\alpha}{c}$ & 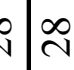 & in & $\bar{m}$ \\
\hline 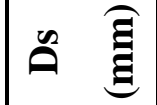 & $=$ & & $\left|\begin{array}{c}\infty \\
m \\
m\end{array}\right|$ & $\begin{array}{c}n \\
n \\
i\end{array}$ & 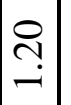 & $\overrightarrow{\vec{i}}$ & & $\underset{\dot{m}}{\stackrel{8}{ }}$ & $\begin{array}{c}\tilde{c} \\
\dot{m}\end{array}$ & 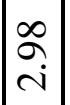 & $\underset{\overbrace{}}{\sim}$ & & iq & $\underset{-}{\vec{f}}$ & 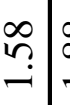 & $\begin{array}{l}\infty \\
\infty \\
-\end{array}$ & $\stackrel{9}{=}$. & $\begin{array}{l}\stackrel{+}{+} \\
\dot{\forall}\end{array}$ & & 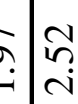 & $\stackrel{i}{i}$ & $\stackrel{\infty}{\infty}$ \\
\hline 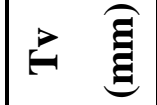 & $\left|\begin{array}{l}0 \\
n \\
i\end{array}\right|$ & $\begin{array}{l}\dot{\theta} \\
\dot{r}\end{array}$ & & $\frac{a}{i}$ & $\mid \begin{array}{l}0 \\
\dot{n} \\
\dot{m}\end{array}$ & $\underset{\oplus}{\stackrel{f}{m}}$ & & $\mid \begin{array}{c}n \\
\cdots \\
i n \\
\end{array}$ & \begin{tabular}{|}
$\vec{\oplus}$ \\
$\dot{\sim}$
\end{tabular} & $\left|\begin{array}{c}\mathcal{Y} \\
\stackrel{+}{+}\end{array}\right|$ & $\begin{array}{l}2 \\
i n\end{array}$ & $\begin{array}{l}\vec{i} \\
\vec{i}\end{array}$ & $\begin{array}{l}\stackrel{?}{\circ} \\
\stackrel{+}{+}\end{array}$ & $\begin{array}{l}\tilde{n} \\
\dot{m}\end{array}$ & 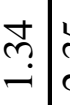 & $\begin{array}{c}m \\
\cdots \\
i\end{array}$ & $\begin{array}{l}\dot{\theta} \\
\dot{m}\end{array}$ & & & t. & $\bar{a}$ & $\frac{\partial}{m}$ \\
\hline 戸 $\widehat{\Xi}$ & & & $\left|\begin{array}{l}\mathbb{N} \\
\infty \\
\infty\end{array}\right|$ & $\stackrel{f}{\stackrel{f}{0}}$ & $\mid$ & ñ & & & $\underset{f}{\stackrel{f}{二}}$ & $\begin{array}{c}\hat{n} \\
\infty \\
\infty\end{array}$ & $\begin{array}{l}0 \\
\stackrel{2}{0} \\
0\end{array}$ & $\underset{\square}{+}$ & $\begin{array}{l}\vec{\infty} \\
\infty\end{array}$ & $\begin{array}{l}0 \\
\infty \\
\infty \\
\infty\end{array}$ & 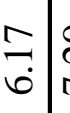 & 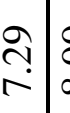 & $\sigma_{\infty}$ & $\begin{array}{l}\stackrel{0}{*} \\
= \\
=\end{array}$ & & $\begin{array}{l}6 \\
:\end{array}$ & $\stackrel{2}{a}$ & 茴 \\
\hline - $\widehat{\overparen{E}}$ & & & & $\mid \begin{array}{c}\hat{A} \\
\mathrm{i} \\
\mathrm{c}\end{array}$ & 苟 & $\begin{array}{l}8 \\
\dot{ \pm}\end{array}$ & & & $\mid \begin{array}{l}P \\
\dot{ \pm}\end{array}$ & $\mid \begin{array}{c}\tilde{n} \\
\tilde{n} \\
\\
\end{array}$ & $\begin{array}{l}1 \\
\check{2} \\
\vdots\end{array}$ & 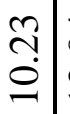 & $\begin{array}{l}\dot{I} \\
\text { i }\end{array}$ & $\begin{array}{l}\hat{\sigma} \\
\dot{j}\end{array}$ & 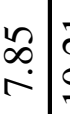 & $\begin{array}{l}\vec{\sim} \\
\stackrel{0}{0}\end{array}$ & $\stackrel{ \pm}{i}$ & & & ¿̊. & $\begin{array}{l}\text { ñ } \\
\text { ñ. }\end{array}$ & O̊ \\
\hline$>\widehat{\Xi}$ & & $\stackrel{?}{\underline{n}}$ & $\left|\begin{array}{l}0 \\
n \\
i \\
\text { in }\end{array}\right|$ & $\left|\begin{array}{l}\stackrel{2}{N} \\
\stackrel{N}{N}\end{array}\right|$ & $\mid$ & 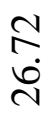 & $\begin{array}{l}0 \\
n \\
0 \\
n \\
n\end{array}$ & $\begin{array}{l}0 \\
n \\
\infty \\
\infty \\
\end{array}$ & 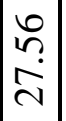 & $\left|\begin{array}{c}\tilde{f} \\
\stackrel{\infty}{d} \\
\dot{\sim}\end{array}\right|$ & $\begin{array}{c}\stackrel{N}{i} \\
\dot{m}\end{array}$ & $\begin{array}{l}n \\
n \\
n \\
n\end{array}$ & $\begin{array}{l}\infty \\
\text { i } \\
\text { i }\end{array}$ & 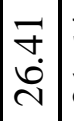 & 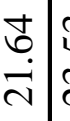 & $\begin{array}{l}n \\
n \\
n \\
n\end{array}$ & $\begin{array}{l}\stackrel{0}{n} \\
\stackrel{n}{n}\end{array}$ & & हैं) & $\begin{array}{l}\text { vis } \\
\dot{v}\end{array}$ & 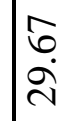 & 吕 \\
\hline ב嗃 & $\begin{array}{l}= \\
\vec{\sim}\end{array}$ & $\begin{array}{l}\vec{\forall} \\
\dot{\Xi}\end{array}$ & & $\mid \frac{\tilde{\sigma}}{\hat{N}}$ & 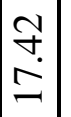 & $\begin{array}{l}\hat{\sigma} \\
\dot{0} \\
\text { i. }\end{array}$ & & $\mid \begin{array}{l}\tilde{N} \\
\tilde{n}\end{array}$ & $\left|\begin{array}{l}\hat{b} \\
\grave{i}\end{array}\right|$ & $\left|\begin{array}{l}\vec{\sim} \\
\vec{\lambda}\end{array}\right|$ & 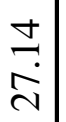 & $\mid \begin{array}{l}\vec{J} \\
\stackrel{d}{d}\end{array}$ & $\begin{array}{l}\stackrel{R}{2} \\
\dot{i}\end{array}$ & ते & $\begin{array}{l}\infty \\
0 \\
\vdots \\
\end{array}$ & 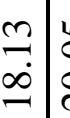 & $\begin{array}{l}2 \\
\dot{i} \\
\text { ¿े. }\end{array}$ & & 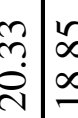 & $\begin{array}{l}6 \\
\dot{0} \\
\dot{0}\end{array}$ & $\begin{array}{l}\text { ले } \\
\text { ते }\end{array}$ & \begin{tabular}{l}
0 \\
\multirow{2}{*}{} \\
in
\end{tabular} \\
\hline Э & & & $\begin{array}{l}\tilde{N} \\
\tilde{丶} \\
\tilde{n}\end{array}$ & $\mid \begin{array}{l}\tilde{N} \\
\ddot{n}\end{array}$ & શે & $\frac{\vec{q}}{\dot{N}}$ & & & $\left|\begin{array}{l}\dot{\lambda} \\
\text { aे }\end{array}\right|$ & $\left|\begin{array}{l}\infty \\
\dot{\lambda} \\
\dot{\sim}\end{array}\right|$ & 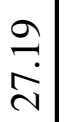 & $\left|\begin{array}{c}\infty \\
0 \\
i \\
\text { in }\end{array}\right|$ & $\begin{array}{l}\infty \\
\infty \\
\dot{i}\end{array}$ & $\left|\begin{array}{l}2 \\
\infty \\
\dot{\lambda}\end{array}\right|$ & $\begin{array}{lll}0 & & \\
\infty & & \end{array}$ & 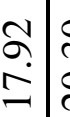 & 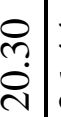 & 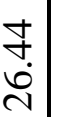 & ì & t) & $\begin{array}{l}\text { İ } \\
\dot{d}\end{array}$ & $\begin{array}{l}8 \\
\dot{\text { d}}\end{array}$ \\
\hline 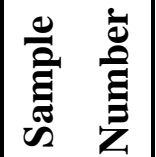 & $\bar{F}$ & $\mathbb{N}$ & $\cong$ & $\mid ম$ & $\because$ & $\div$ & $\approx$ & $\infty$ & 2 & $\infty$ & $\bar{\infty}$ & $\mid \begin{array}{l}\sim \\
\infty\end{array}$ & $\infty$ & $\mid \begin{array}{l}+ \\
\end{array}$ & $\infty$ & $\infty$ & $\infty$ & $\infty$ & $\infty$ & 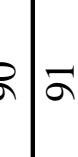 & $\sigma$ & $\alpha$ \\
\hline
\end{tabular}


Stony Mountain, Manitoba - Plaesiomys occidentalis Table 1 (continued)

\begin{tabular}{|c|c|c|c|c|c|c|c|c|c|c|c|c|c|c|c|c|c|c|c|c|c|c|c|}
\hline 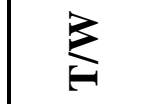 & $\mid \begin{array}{l}\stackrel{+}{*} \\
\dot{0}\end{array}$ & $\mid \begin{array}{l}f \\
0 \\
0\end{array}$ & $\left|\begin{array}{l}\infty \\
n \\
0 \\
0\end{array}\right|$ & $\stackrel{f}{\circ}$ & 角 & ñ? & 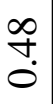 & $\mid \begin{array}{l}f \\
\stackrel{9}{0}\end{array}$ & & $\left|\begin{array}{l}q \\
\stackrel{f}{0} \\
0\end{array}\right|$ & กี & $\stackrel{?}{\leftrightarrow}$ & & $\begin{array}{l}\tilde{f} \\
\dot{0}\end{array}$ & & 守. & 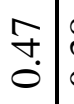 & $\begin{array}{c}\infty \\
\infty \\
0 \\
0 \\
0\end{array}$ & \begin{tabular}{c}
$n$ \\
\hdashline \\
0
\end{tabular} & & 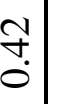 & & 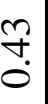 \\
\hline$\sum_{E}^{3}$ & $\stackrel{m}{m}$ & $\mid$ & $\left|\begin{array}{l}q \\
\stackrel{f}{0}\end{array}\right|$ & ڤ్. & $\stackrel{\infty}{+}$ & ?ֶ. & m़ & 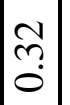 & & กิ & $\begin{array}{c}\infty \\
\stackrel{0}{0} \\
0\end{array}$ & $\bar{m}$ & & $\begin{array}{l}n \\
\tilde{a} \\
0\end{array}$ & & $\begin{array}{l}0 \\
\stackrel{0}{0} \\
0\end{array}$ & $\bar{m}$ & ָָ & $\frac{9}{0}$ & ñ? & 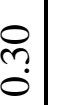 & & 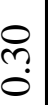 \\
\hline 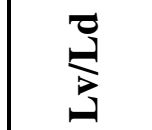 & ôे & $\hat{a}$ & $\hat{o}$ & ڤे. & ڤ̆ & & ڤे. & $\hat{\hat{o}}$ & $\hat{\grave{o}}$ & ڤे. & $\hat{\grave{o}}$ & & $\hat{\sigma}$ & ڤे. & & $\begin{array}{l}\infty \\
\stackrel{0}{\circ}\end{array}$ & ڤ̊ & 8 & $\hat{o}$ & बे. & ڤ. & $\hat{a}$ & ఏ. \\
\hline 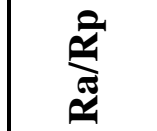 & $\Xi$ & $\stackrel{\text { Iิ }}{-}$ & $\stackrel{\vartheta}{-}$ & 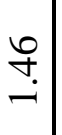 & & $\stackrel{\overbrace{}}{\stackrel{n}{=}}$ & $\stackrel{9}{=}$ & $\stackrel{m}{=}$ & & & 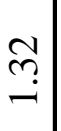 & $\stackrel{8}{-}$ & & $\stackrel{m}{=}$ & & $\stackrel{9}{\rightarrow}$ & ô. & & $\stackrel{m}{=}$ & $\cong$ & ô. & & $\exists$ \\
\hline$\approx$ & iి & 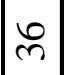 & $m$ & F & & $\underset{m}{\infty}$ & $\underset{m}{\infty}$ & mি & & & $\hat{n}$ & $\vec{m}$ & & $\vec{m}$ & & $\hat{n}$ & চ্ & $\hat{\imath}$ & ஜ & m & ৪্লি & ন & $\vec{m}$ \\
\hline से & 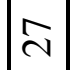 & in & mे & $\stackrel{\infty}{\sim}$ & in & $\vec{m}$ & $\tilde{n}$ & in & & & $\stackrel{\infty}{\sim}$ & $\vec{n}$ & & m. & & $\bar{m}$ & $\stackrel{\infty}{\sim}$ & $\widehat{\imath}$ & $\tilde{n}$ & $\widehat{\imath}$ & $\underset{\sim}{\infty}$ & & $\stackrel{\infty}{\sim}$ \\
\hline$\stackrel{\overbrace{}}{\hat{\Xi}}$ & $\mid \vec{\infty}$ & $\stackrel{\curvearrowright}{\curvearrowright}$ & $\stackrel{\sim}{\sim}$ & $\begin{array}{l}\bar{\infty} \\
i\end{array}$ & : & $\stackrel{8}{:}$ & $\stackrel{?}{?}$ & $\left|\begin{array}{l}n \\
m \\
m\end{array}\right|$ & & $\begin{array}{l}0 \\
0 \\
0\end{array}$ & $\stackrel{\infty}{i}$ & $\stackrel{g}{.}$ & $\stackrel{8}{\stackrel{0}{-}}$ & $\stackrel{\sim}{\stackrel{N}{-}}$ & $\left|\begin{array}{c}0 \\
\hdashline \\
i\end{array}\right|$ & 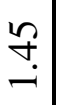 & $\left|\begin{array}{l}n \\
2 \\
m\end{array}\right|$ & $\stackrel{n}{n}$ & $\begin{array}{l}n \\
\infty \\
0 \\
0\end{array}$ & 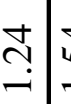 & ?n: & & $\stackrel{i}{i}$ \\
\hline$\geqslant \widehat{\underline{E}}$ & $\left|\begin{array}{l}0 \\
\infty \\
i\end{array}\right|$ & $\mid \begin{array}{l}\vec{\sigma} \\
\dot{m}\end{array}$ & $\overrightarrow{\widehat{i}}$ & $\stackrel{\infty}{\infty}$ & $\mid \begin{array}{l}\vec{n} \\
i \\
\end{array}$ & $\begin{array}{l}\hat{s} \\
\dot{+}\end{array}$ & $\begin{array}{l}\hat{\sigma} \\
\dot{m}\end{array}$ & $\left|\begin{array}{c}\tilde{\sigma} \\
\dot{+}\end{array}\right|$ & & $\left|\begin{array}{c}\tilde{r} \\
\dot{\sim}\end{array}\right|$ & $\begin{array}{l}8 \\
\dot{m}\end{array}$ & $\begin{array}{c}\hat{\infty} \\
i\end{array}$ & & $\left|\begin{array}{l}\infty \\
\infty \\
m\end{array}\right|$ & $\mid \begin{array}{c}\infty \\
\dot{m} \\
\end{array}$ & $\stackrel{m}{i}$ & $\mid \begin{array}{l}8 \\
\dot{0} \\
i\end{array}$ & $\frac{\sim}{m}$ & $\underset{\tilde{N}}{\tilde{N}}$ & $\stackrel{\tilde{q}}{+}$ & $\vec{n}$ & & $\begin{array}{l}\vec{c} \\
\infty \\
\dot{r}\end{array}$ \\
\hline 巨 $\widehat{\mathrm{g}}$ & $\left|\begin{array}{c}\infty \\
\infty \\
\infty\end{array}\right|$ & $\left|\begin{array}{c}\infty \\
\infty \\
\infty\end{array}\right|$ & $\begin{array}{l}\mathbb{G} \\
\stackrel{J}{J}\end{array}$ & $\begin{array}{l}2 \\
\infty \\
0\end{array}$ & 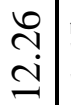 & $\mid$ & $\begin{array}{l}\underset{1}{\infty} \\
\infty\end{array}$ & 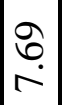 & & $\left|\begin{array}{l}R \\
\dot{m}\end{array}\right|$ & 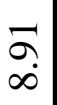 & $\begin{array}{l}\hat{b} \\
\dot{0}\end{array}$ & & $\begin{array}{l}\vec{N} \\
\stackrel{0}{\varrho}\end{array}$ & & $=$ & $\left|\begin{array}{c}\infty \\
\infty \\
0\end{array}\right|$ & $\begin{array}{c}\overrightarrow{0} \\
\dot{n} \\
\end{array}$ & $\begin{array}{l}\infty \\
\stackrel{\infty}{m} \\
\dot{m}\end{array}$ & $\begin{array}{l}0 \\
\text { ? } \\
\infty \\
\infty\end{array}$ & 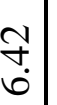 & & $\hat{\alpha}$ \\
\hline 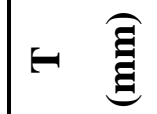 & $\begin{array}{l}\infty \\
\infty \\
= \\
=\end{array}$ & $\left|\begin{array}{c}\infty \\
\infty \\
= \\
=\end{array}\right|$ & $\begin{array}{l}\infty \\
0 \\
\dot{1} \\
\end{array}$ & $\begin{array}{l}\stackrel{n}{i} \\
i\end{array}$ & $\begin{array}{l}\infty \\
\infty \\
\dot{ \pm}\end{array}$ & $\begin{array}{l}\Omega \\
\hat{O} \\
0\end{array}$ & $\stackrel{n}{n}$ & $\mid \begin{array}{l}8 \\
\varrho \\
0\end{array}$ & & $\mid$\begin{tabular}{c}
$\infty$ \\
\multirow{1}{\infty}{} \\
$\infty$
\end{tabular} & $\begin{array}{l}\text { a } \\
\text { I }\end{array}$ & $\frac{2}{a}$ & & $\begin{array}{l}0 \\
\stackrel{2}{2}\end{array}$ & & $\stackrel{m}{m}$ & $\mid \begin{array}{c}\vec{N} \\
\ddot{n}\end{array}$ & $\underset{\infty}{ \pm}$ & $\vec{r}$ & $\begin{array}{l}n \\
\stackrel{n}{i} \\
c\end{array}$ & 8 & & $\stackrel{?}{?}$ \\
\hline$\geq \widehat{\overparen{E}}$ & $\left|\begin{array}{l}2 \\
\stackrel{2}{0} \\
\dot{0}\end{array}\right|$ & $\mid$ & $\begin{array}{l}\circ \\
\infty \\
\ddot{v}\end{array}$ & $\begin{array}{c} \pm \\
0 \\
\infty \\
i\end{array}$ & $\left|\begin{array}{l}n \\
\tilde{n} \\
n \\
n\end{array}\right|$ & $\mid$ & $\begin{array}{l}\stackrel{n}{a} \\
\stackrel{+}{\sim}\end{array}$ & $\mid$ & $\left|\begin{array}{l}n \\
\dot{d} \\
\end{array}\right|$ & $\mid$ & $\begin{array}{l}\vec{b} \\
\dot{n}\end{array}$ & $\begin{array}{l}\infty \\
\stackrel{\vec{\lambda}}{\vec{v}}\end{array}$ & $\mid \begin{array}{l}\vec{N} \\
\dot{d}\end{array}$ & $\mid$ & $\mid$ & $\begin{array}{l}\tilde{\infty} \\
\vdots \\
\vdots\end{array}$ & $\left|\begin{array}{c}\vec{d} \\
i \\
i\end{array}\right|$ & $\begin{array}{l}\stackrel{m}{\dot{v}} \\
\dot{v}\end{array}$ & 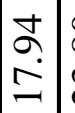 & 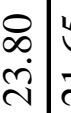 & & 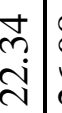 & 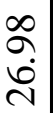 \\
\hline 己壭 & 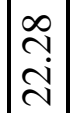 & $\left|\begin{array}{l}q \\
\stackrel{+}{\dot{d}}\end{array}\right|$ & $\begin{array}{l}n \\
i \\
i\end{array}$ & $\begin{array}{l}\overrightarrow{0} \\
\dot{v}\end{array}$ & $\begin{array}{l}\infty \\
\infty \\
i \\
\end{array} \mid$ & $\begin{array}{l}\hat{a} \\
\vdots \\
a\end{array}$ & $\begin{array}{l}\hat{\alpha} \\
\infty \\
-\end{array}$ & $\mid \begin{array}{l}\tilde{2} \\
\stackrel{2}{2} \\
\varrho\end{array}$ & \begin{tabular}{|c|}
$\hat{n}$ \\
$\infty$ \\
$\infty$
\end{tabular} & $\mid \begin{array}{c}\mathcal{Y} \\
\stackrel{\mathcal{Z}}{\mathrm{I}}\end{array}$ & 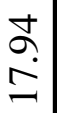 & $\begin{array}{l}\infty \\
n \\
0 \\
-0\end{array}$ & $\mid$\begin{tabular}{l}
$\infty$ \\
$\stackrel{+}{a}$ \\
\hdashline
\end{tabular} & $\begin{array}{l}\hat{n} \\
\stackrel{2}{i}\end{array}$ & $\mid$ & $\stackrel{\grave{m}}{2}$ & $\mid \begin{array}{l}\infty \\
\infty \\
\sim \\
\end{array}$ & 守 & $\begin{array}{c}1 \\
6 \\
\end{array}$ & $\begin{array}{l}\alpha \\
\infty \\
\infty\end{array}$ & $\begin{array}{l}1 \\
\delta \\
0 \\
-\end{array}$ & \begin{tabular}{|l|}
$\hat{0}$ \\
0 \\
- \\
\end{tabular} & $\begin{array}{l}\underset{q}{+} \\
\text { ì }\end{array}$ \\
\hline 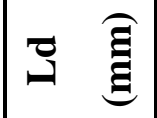 & $\mid \begin{array}{l}\mathcal{q} \\
\dot{i}\end{array}$ & $\left|\begin{array}{l}\simeq \\
\stackrel{\sim}{\sim}\end{array}\right|$ & $\begin{array}{l}\tilde{m} \\
\\
\end{array}$ & $\begin{array}{l}\bar{a} \\
\vec{\lambda}\end{array}$ & $\begin{array}{l}\& \\
\grave{\lambda} \\
\text { in }\end{array}$ & \begin{tabular}{|l|}
$\frac{n}{6}$ \\
-0
\end{tabular} & $\begin{array}{l}0 \\
\frac{0}{2}\end{array}$ & $\mid$ & $\begin{array}{l}\overrightarrow{0} \\
\ddot{0}\end{array}$ & 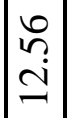 & 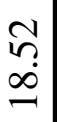 & 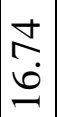 & $\mid \begin{array}{l}\dot{1} \\
\infty \\
\dot{d}\end{array}$ & $\begin{array}{l}8 \\
\dot{d} \\
\dot{d}\end{array} \mid$ & & \begin{tabular}{l}
$\infty$ \\
\multirow{2}{a}{} \\
2
\end{tabular} & $\left|\begin{array}{l}0 \\
0 \\
\dot{b} \\
\end{array}\right|$ & $\begin{array}{l}n \\
\\
\end{array}$ & $\begin{array}{l}\infty \\
0 \\
\dot{\Xi}\end{array}$ & $\stackrel{\simeq}{a}=$ & $\begin{array}{l}8 \\
\stackrel{0}{0} \\
-\end{array}$ & \begin{tabular}{l|}
$\sigma$ \\
$\infty$ \\
$\infty$ \\
\end{tabular} & $\begin{array}{l}\stackrel{n}{a} \\
\vec{i}\end{array}$ \\
\hline 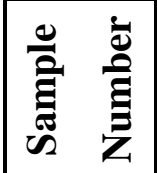 & $\alpha$ & 2 & |ః| & ấ & $\stackrel{\infty}{\circ}$ & হ & 8 & $\overline{0}$ & $\tilde{\sigma}$ & $\hat{\theta}$ & 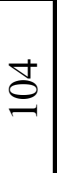 & $\stackrel{\varrho}{\varrho}$ & 。 & 5 & $\stackrel{\infty}{\varrho}$ & \& & $\stackrel{ }{=}$ & $\Xi$ & $\cong$ & $\stackrel{m}{=}$ & $\Xi$ & $\underline{=}$ & $\exists$ \\
\hline
\end{tabular}


Stony Mountain, Manitoba - Plaesiomys occidentalis Table 1 (continued)

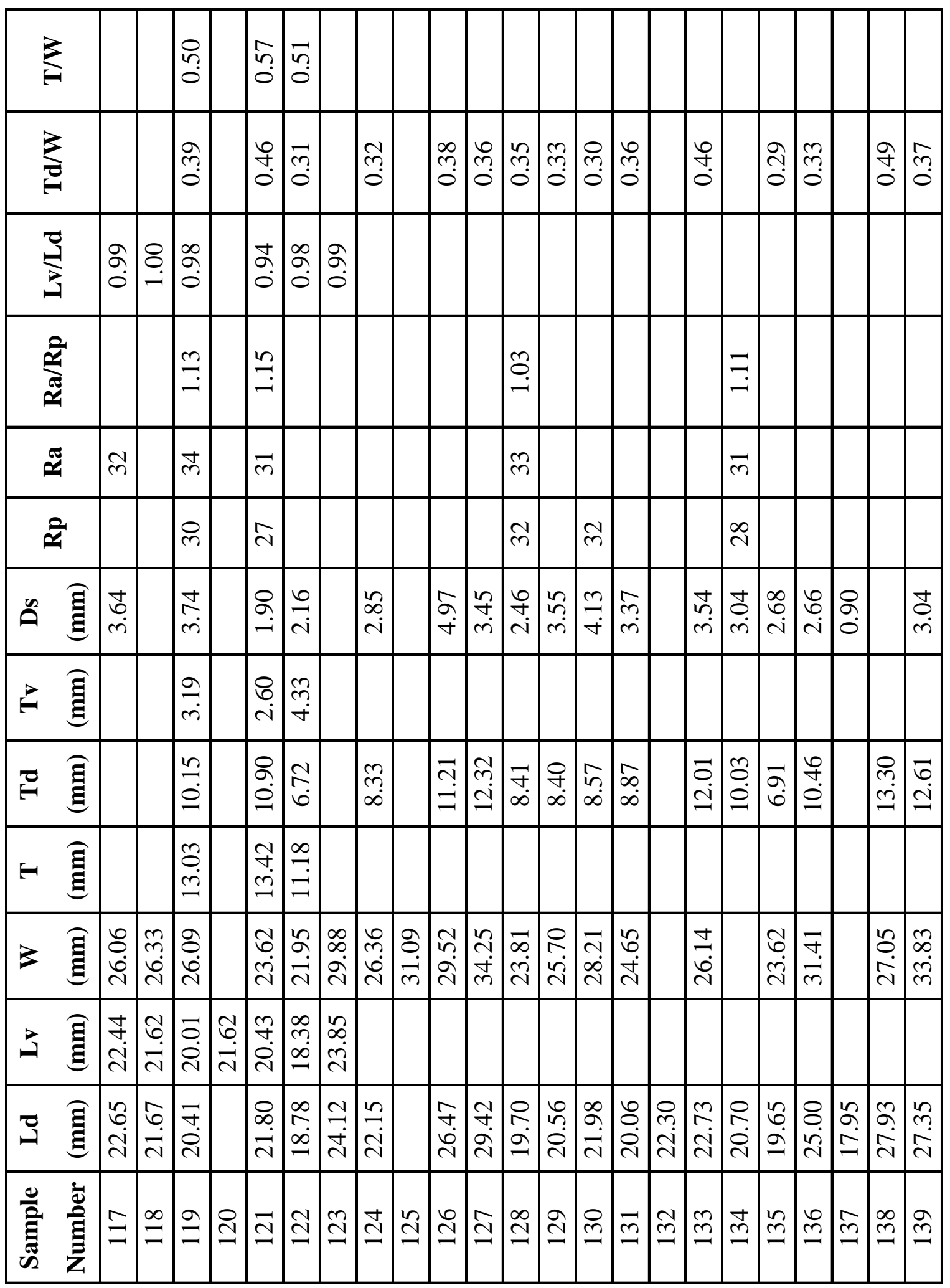


Stony Mountain, Manitoba - Plaesiomys occidentalis Table 1 (continued)

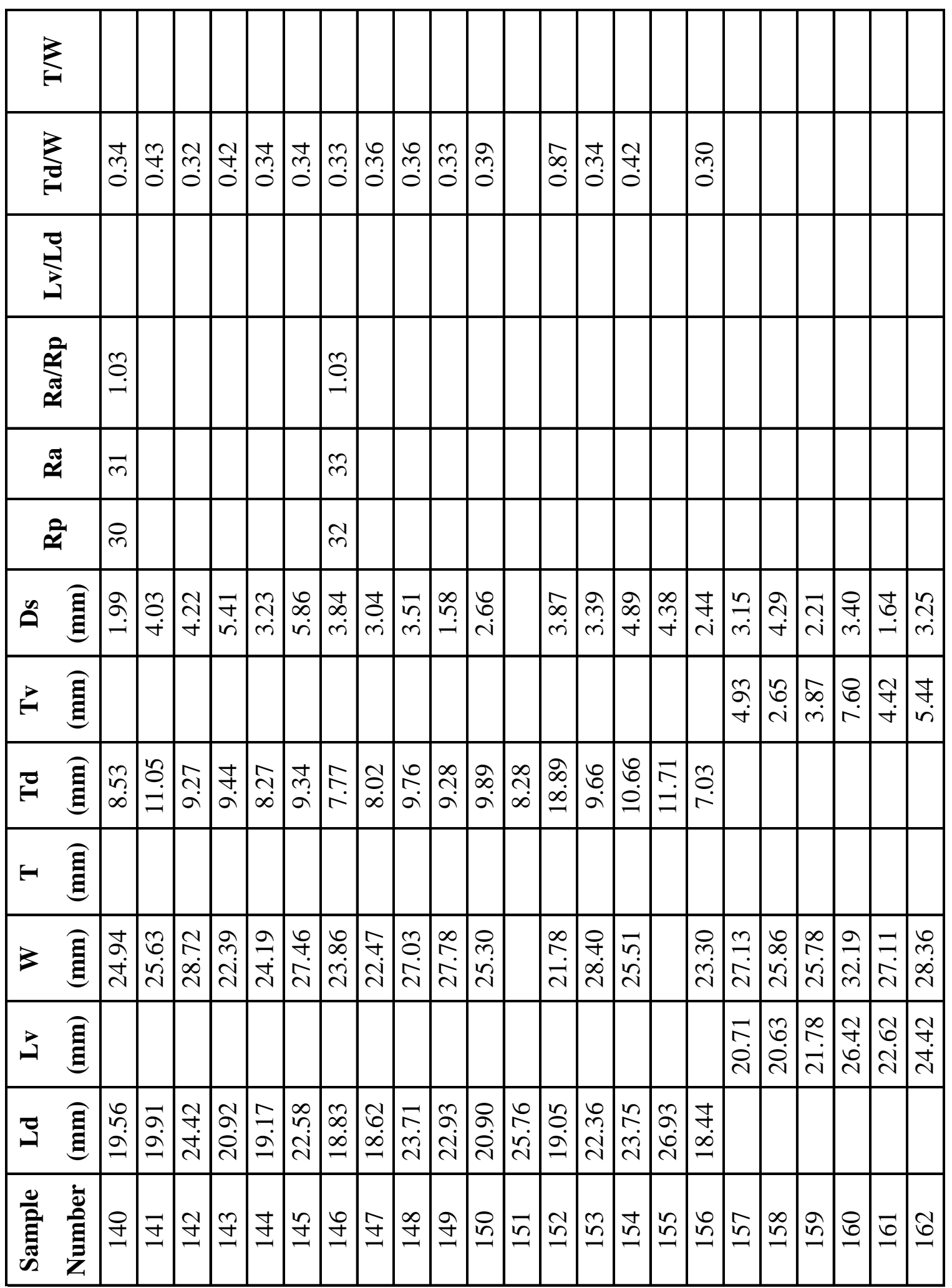


Stony Mountain, Manitoba - Plaesiomys occidentalis Table 1 (continued)

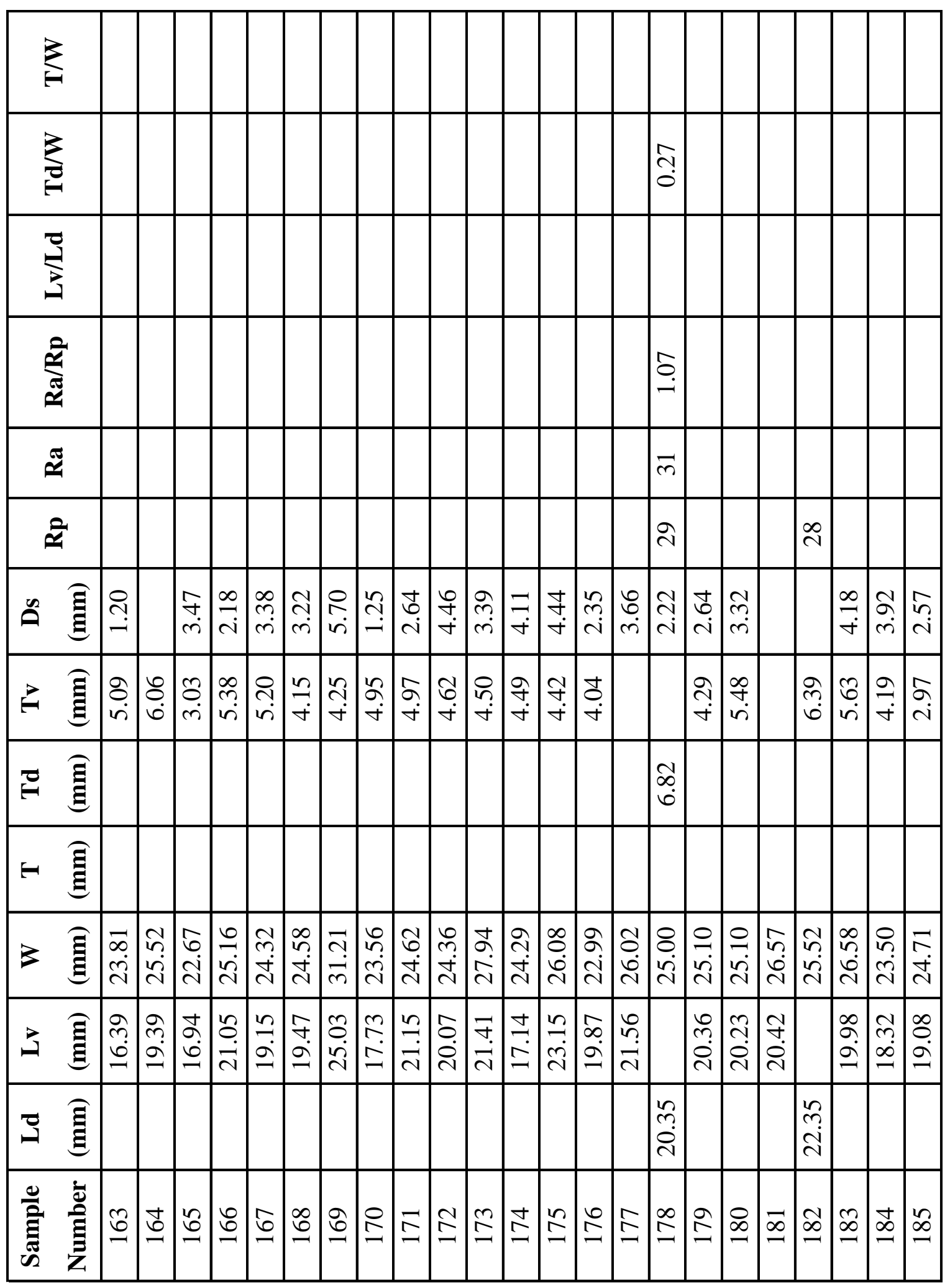


Stony Mountain, Manitoba - Plaesiomys occidentalis Table 1 (continued)

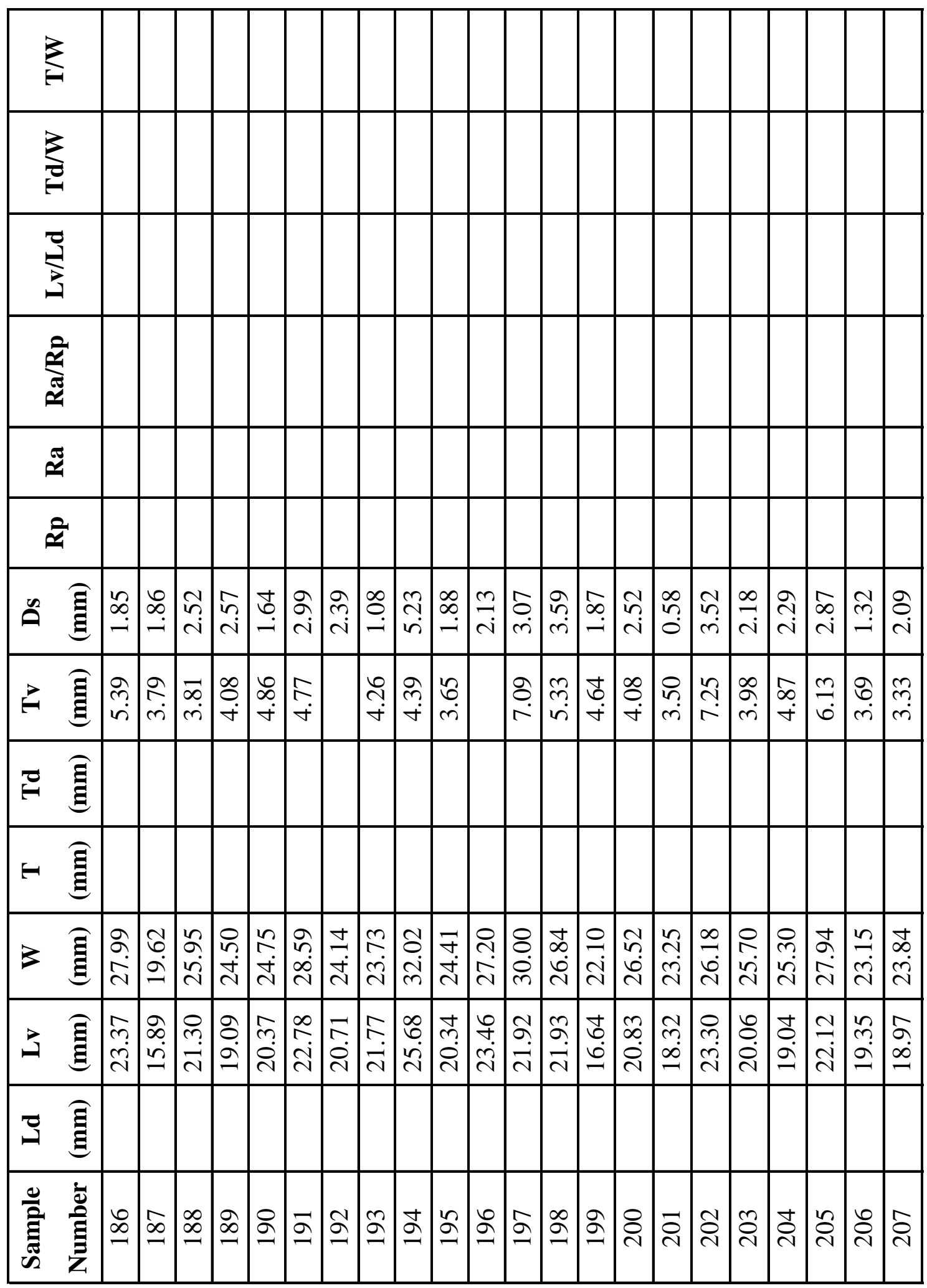


Stony Mountain, Manitoba - Plaesiomys occidentalis Table 1 (continued)

\begin{tabular}{|c|c|c|c|c|c|c|c|c|c|c|c|c|c|c|c|c|c|c|c|c|c|}
\hline$\xi$ & & & & & & & & & & & & & & & & $\stackrel{+}{n}$ & & & & & \\
\hline i & & & & & & & $\hat{n}$ & & & $\bar{n}$ & ?ै & & & $\frac{n}{0}$ & & $\stackrel{m}{m}$ & & $\overline{0}$ & & กै: & \\
\hline 冚 & & & & & & & & & & & & & & & - & $\begin{array}{l}\infty \\
\vdots \\
0\end{array}$ & & & & & \\
\hline$\stackrel{2}{\approx}$ & & & & & & & & & & & & & & & & $\underset{-}{\stackrel{\Delta}{ }}$ & & & & & \\
\hline$\stackrel{\mathscr{*}}{\approx}$ & & & & & & & & & & & & & & & & $\begin{array}{l}8 \\
8 \\
8 \\
\end{array}$ & & & & & \\
\hline से & & & & & & & & & & & & & & & & 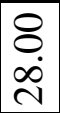 & & & & & \\
\hline 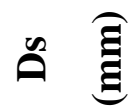 & $\begin{array}{l}n \\
\dot{n} \\
\dot{n}\end{array}$ & $\frac{0}{m}$ & $\begin{array}{l}0 \\
0 \\
i\end{array}$ & $\check{n}$ & กั & $\overline{6}$ & $\vec{\sim}$ & & & $\stackrel{\infty}{\sim}$ & (ָ) & $\stackrel{\infty}{\sim}$ & $\stackrel{ \pm}{\oplus}$ & 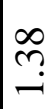 & $\begin{array}{l}6 \\
0 \\
i\end{array}$ & $\stackrel{g}{+}$ & 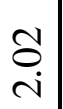 & & & ڤ̆ & $\begin{array}{l}\circ \\
\text { ุ̊ }\end{array}$ \\
\hline$\Rightarrow \widehat{\Xi}$ & $\begin{array}{l}\text { ते } \\
\text { in }\end{array}$ & $\begin{array}{l}6 \\
n \\
n \\
n\end{array}$ & $\begin{array}{l}\text { Oे } \\
\text { r. }\end{array}$ & ヘָ & $\frac{1}{2}$ & 감 & & $\begin{array}{l}\infty \\
\text { r } \\
\text { in }\end{array}$ & & & & r & $\hat{\sigma}$ & & $\stackrel{?}{\stackrel{9}{+}}$ & $\begin{array}{l}\tilde{b} \\
\dot{m}\end{array}$ & $\begin{array}{l}2 \\
\infty \\
\dot{m}\end{array}$ & & & & $\begin{array}{l}\stackrel{g}{+} \\
\dot{\nabla}\end{array}$ \\
\hline 已 હ્छ & & & & & & & $\begin{array}{l}\infty \\
0 \\
\sigma\end{array}$ & & $\stackrel{\infty}{\stackrel{\infty}{+}}$ & 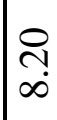 & $\frac{0}{\pi}$ & & & $\frac{7}{m}$ & $\begin{array}{l}0 \\
\infty \\
0 \\
0\end{array}$ & $\begin{array}{l}m \\
\dot{r}\end{array}$ & & $\begin{array}{l}8 \\
0 \\
\dot{r}\end{array} \mid$ & & $\frac{\infty}{\infty}$ & \\
\hline - $\widehat{\Xi}$ & & & & & & & & & & & & & & & & 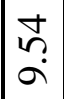 & & & & & \\
\hline$>\widehat{\Xi}$ & $\frac{a}{\stackrel{d}{d}}$ & $\frac{n}{n}$ & 웅 & $\stackrel{\infty}{\stackrel{\infty}{\sim}}$ & $\frac{n}{2}$ & $\begin{array}{l}8 \\
\text { ते } \\
\text { ते }\end{array}$ & $\begin{array}{l}\tilde{\sigma} \\
\hat{n}\end{array}$ & & & $\begin{array}{l}0 \\
\text { ஸे } \\
\stackrel{0}{0}\end{array}$ & in & $\hat{\bar{n}}$ & 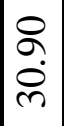 & $\frac{\sigma}{\sigma}$ & & $\begin{array}{l}n \\
n \\
-\end{array}$ & $\begin{array}{l}\stackrel{n}{\pi} \\
\stackrel{\sim}{*}\end{array}$ & $\begin{array}{l}\hat{a} \\
\hat{n}\end{array}$ & & $\begin{array}{l}\frac{v}{2} \\
\ddot{n}\end{array}$ & $\begin{array}{l}n \\
\tilde{n} \\
2\end{array}$ \\
\hline 主 & $\begin{array}{l}+ \\
\infty \\
\sigma\end{array}$ & $\begin{array}{l}n \\
n \\
n \\
n\end{array}$ & సิ & $\begin{array}{l}0 \\
\infty \\
\infty\end{array}$ & 궁 & $\begin{array}{l}\hat{2} \\
\infty \\
-\end{array}$ & & $\begin{array}{l}\tilde{\sigma} \\
\tilde{N}\end{array}$ & & & & 웅 & $\begin{array}{l}0 \\
n \\
0 \\
i \\
n\end{array}$ & & $\begin{array}{l}n \\
\infty \\
0 \\
-1\end{array}$ & $\begin{array}{l}\infty \\
0 \\
\dot{J}\end{array}$ & $\begin{array}{l}\hat{\infty} \\
0 \\
0\end{array}$ & & & & $\begin{array}{l}o \\
n \\
n \\
n\end{array}$ \\
\hline త્ઞ & & & & & & & $\stackrel{\infty}{\curvearrowright}$ & & กิ & ก̊ & $\begin{array}{l}\vec{\sim} \\
\infty \\
\infty\end{array}$ & & & حִ & 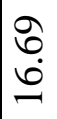 & $\begin{array}{l}n \\
0 \\
n\end{array}$ & & $\begin{array}{l}\hat{2} \\
\dot{2}\end{array}$ & $\begin{array}{l}\text { তे } \\
\check{a}\end{array}$ & $\begin{array}{c}\vec{N} \\
\text { ते }\end{array}$ & \\
\hline 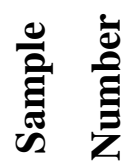 & 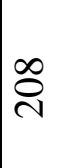 & 오 & $\stackrel{0}{\sim}$ & $\bar{\nabla}$ & $\frac{1}{n}$ & $\frac{m}{2}$ & $\stackrel{\nabla}{\curvearrowright}$ & $\frac{n}{2}$ & $\frac{0}{\sim}$ & $\bar{v}$ & $\frac{\infty}{\sim}$ & $\frac{\partial}{2}$ & సે & $\overrightarrow{\mathrm{N}}$ & ปี & 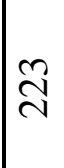 & $\stackrel{\searrow}{\triangle}$ & $\approx$ & 오 & $\widehat{\widehat{N}}$ & $\stackrel{\infty}{\sim}$ \\
\hline
\end{tabular}


Stony Mountain, Manitoba - Plaesiomys occidentalis Table 1 (continued)

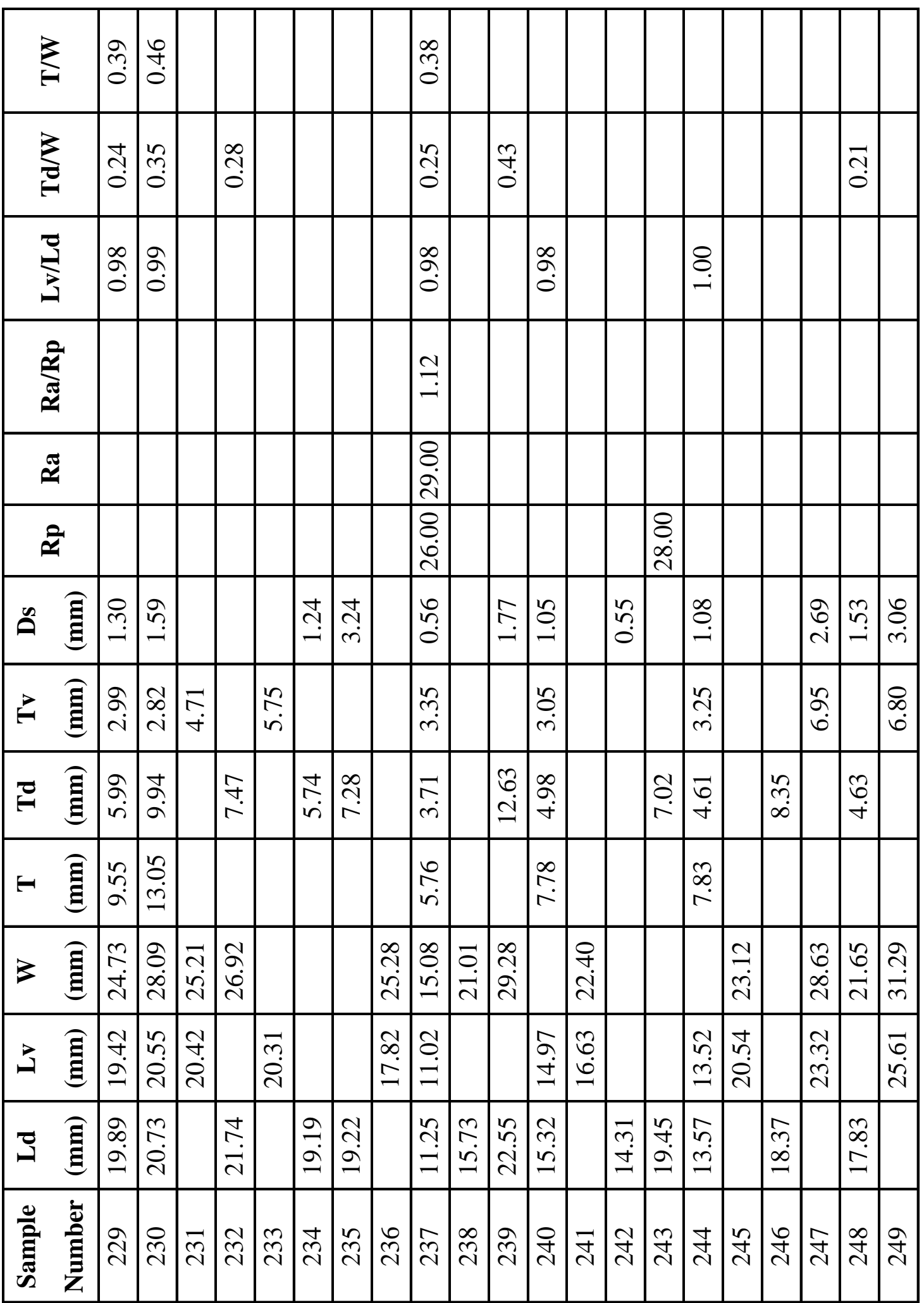


Stony Mountain, Manitoba - Plaesiomys occidentalis Table 1 (continued)

\begin{tabular}{|c|c|c|c|c|c|c|c|c|c|c|c|}
\hline 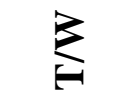 & & & & $\tilde{m}$ & تं. & $\stackrel{\tilde{f}}{\dot{\sigma}}$ & $\begin{array}{l}\vec{\gamma} \\
\dot{0}\end{array}$ & ñ & تे. & $\tilde{n}$ & تे. \\
\hline$\sum$ & $\tilde{n}$ & mे & & ڤุ & ஸे & $\stackrel{m}{m}$ & $\left|\begin{array}{l}\infty \\
1 \\
0\end{array}\right|$ & $\stackrel{ \pm}{0}$ & กิ & $\mid \begin{array}{l}0 \\
1 \\
0\end{array}$ & กิ \\
\hline$\stackrel{\text { }}{\stackrel{D}{3}}$ & & & & $\begin{array}{l}\infty \\
\vdots \\
0\end{array}$ & 文 & gे & $\hat{a}$ & $\dot{\sigma}$ & $\stackrel{8}{8}$ & ڤे & $\begin{array}{l}\infty \\
0 \\
0\end{array}$ \\
\hline$\stackrel{0}{\mathscr{n}}$ & & & & $\stackrel{\infty}{\sim}$ & - & શે & 色 & $\stackrel{8}{8}$ & $\stackrel{8}{8}$ & ֻُ & $\stackrel{\jmath}{\rightleftarrows}$ \\
\hline$\stackrel{乛}{\approx}$ & & & & $\begin{array}{l}8 \\
\text { mi } \\
\text { mi }\end{array}$ & $\begin{array}{l}8 \\
0 \\
0 \\
\text { n. }\end{array}$ & $\begin{array}{l}8 \\
8 \\
0 \\
m\end{array}$ & \begin{tabular}{|l|} 
\\
$\dot{0}$ \\
$m$ \\
$m$
\end{tabular} & $\begin{array}{l}8 \\
8 \\
0 \\
\text { N }\end{array}$ & $\begin{array}{l}8 \\
0 \\
n \\
m\end{array}$ & $\begin{array}{l} \\
0 \\
\text { ñ. } \\
\end{array}$ & 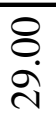 \\
\hline से & & & & 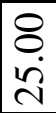 & 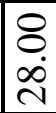 & 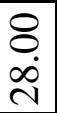 & \begin{tabular}{|l|}
8 \\
$\dot{d}$ \\
ñ
\end{tabular} & $\begin{array}{l}8 \\
8 \\
\text { ते }\end{array}$ & $\begin{array}{l}8 \\
8 \\
n \\
m\end{array}$ & 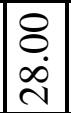 & $\begin{array}{l}8 \\
8 \\
\text { ஸे }\end{array}$ \\
\hline ค̊ ఏ & 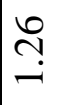 & $\begin{array}{l}n \\
\infty \\
\infty\end{array}$ & 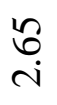 & ¿̊. & $\stackrel{N}{n}$ & $\vec{i}$ & $\underset{0}{\infty}$ & $\frac{m}{0}$ & ڤo & ヘ̊ & ஜn \\
\hline $\overrightarrow{\widehat{E}}$ & & & $\vec{i}$ & 弪 & $\begin{array}{l}\text { d } \\
\text { ì }\end{array}$ & $\underset{\dot{\sigma}}{\vec{\sigma}}$ & $\frac{n}{2}$ & శ̊ & $\begin{array}{l}n \\
\infty \\
i \\
i\end{array}$ & $\begin{array}{l}m \\
\vec{i}\end{array}$ & $\underset{\nabla}{\sim}$ \\
\hline 로 & กุ & $\frac{n}{\infty}$ & & ָู & $\begin{array}{l}\sigma \\
0 \\
\text { in }\end{array}$ & 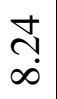 & $\mid \begin{array}{l}\infty \\
0 \\
0 \\
1\end{array}$ & $\stackrel{n}{n}$ & $\begin{array}{l}2 \\
\infty \\
\text { மे }\end{array}$ & $\begin{array}{l}\tilde{c} \\
\stackrel{n}{n}\end{array}$ & $\stackrel{n}{f}$ \\
\hline$-\widehat{\Xi}$ & & & & $\stackrel{\infty}{\circ}$ & $\stackrel{2}{2}$ & $\stackrel{\infty}{\mp}$ & $\stackrel{+}{r}$ & $\stackrel{\infty}{\stackrel{\gamma}{\gamma}}$ & $\frac{2}{\pi}$ & $\underset{\nabla}{\check{r}}$ & ले \\
\hline 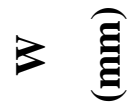 & 命 & $\begin{array}{l}\bar{\infty} \\
\stackrel{n}{c}\end{array}$ & $\begin{array}{l}\text { o } \\
\text { ปे } \\
\text { ते }\end{array}$ & $\frac{n}{\ddot{\sigma}}$ & $\frac{1}{2}$ & $\begin{array}{l}m \\
0 \\
\end{array}$ & $\begin{array}{l}n \\
\infty \\
1 \\
-1\end{array}$ & $\begin{array}{l}\simeq \\
\pm \\
\pm\end{array}$ & $\begin{array}{l}\infty \\
\\
\end{array}$ & $\begin{array}{l}\vec{\infty} \\
\dot{1}\end{array}$ & 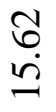 \\
\hline$\stackrel{\Xi}{\Xi}$ & & & $\begin{array}{l}0 \\
2 \\
2\end{array}$ & 它 & $\begin{array}{l}6 \\
\dot{0} \\
\pm\end{array}$ & $\stackrel{n}{n}$ & 光 & $\hat{a}$ & $\begin{array}{l}n \\
n \\
n\end{array}$ & $\begin{array}{l}m \\
\ddot{2}\end{array}$ & ָ̃ \\
\hline ర્త & 吾 & $\begin{array}{l}\infty \\
\infty \\
\infty \\
\dot{\sim}\end{array}$ & & Oִ & ğ & $\begin{array}{l}0 \\
a \\
a\end{array}$ & $\begin{array}{l}\stackrel{0}{r} \\
\dot{2}\end{array}$ & $\begin{array}{l}\infty \\
0 \\
\\
\end{array}$ & $\begin{array}{r}\ddot{\sigma} \\
\dot{\sigma}\end{array}$ & 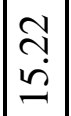 & $\begin{array}{l}\stackrel{g}{ \pm} \\
\stackrel{1}{ }\end{array}$ \\
\hline 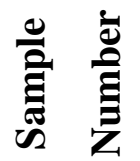 & $\stackrel{\circ}{2}$ & $\sqrt{n}$ & กิ & $\stackrel{m}{\sim}$ & 究 & $\stackrel{n}{n}$ & $\stackrel{\circ}{\sim}$ & $\sqrt{2}$ & $\stackrel{\infty}{\sim}$ & $\stackrel{2}{2}$ & 용 \\
\hline
\end{tabular}


Anticosti Island, Quebec - Plaesiomys anticostiensis Table 2

\begin{tabular}{|c|c|c|c|c|c|c|c|c|c|c|c|c|c|c|c|c|c|c|c|c|c|c|c|}
\hline$\xi$ & 華 & 0 & $\begin{array}{l}\infty \\
n \\
0\end{array}$ & $\stackrel{f}{\stackrel{f}{0}}$ & $\underset{0}{\nabla}$ & 官 & $\stackrel{\infty}{+}$ & ñ & $\stackrel{\sim}{\circ}$ & $\stackrel{f}{+}$ & 官 & $\stackrel{\stackrel{\sim}{\ddagger}}{\circ}$ & $\stackrel{\infty}{+} \underset{0}{0}$ & 寺 & $\stackrel{2}{\stackrel{2}{0}}$ & $\underset{⿱}{+}$ & $\mid \begin{array}{l}\stackrel{a}{+} \\
\dot{0}\end{array}$ & $\stackrel{f}{\tilde{\sigma}}$ & $\left|\begin{array}{l}\stackrel{q}{+} \\
\dot{0}\end{array}\right|$ & $\underset{\stackrel{+}{0}}{0}$ & 苟 & 寺 & $\stackrel{m}{\stackrel{f}{0}}$ \\
\hline$\sum^{z}$ & $\stackrel{\infty}{+}$ & ?ֶ. & 菑 & n̊. & mె? & $\stackrel{\infty}{n}$ & ले & m & $\stackrel{\infty}{\infty}$ & 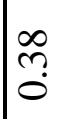 & $\tilde{n}$ & $\stackrel{\infty}{n}$ & ఫे & $\stackrel{\sim}{\stackrel{Y}{0}}$ & $\stackrel{0}{+}$ & ñ & {$\left[\begin{array}{l}\infty \\
n \\
0\end{array}\right.$} & $\tilde{n}$ & $\begin{array}{l}\stackrel{0}{+} \\
\dot{0}\end{array}$ & 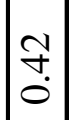 & กิ & ñ & ñ \\
\hline 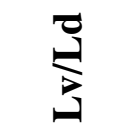 & ई̊ & @) & $\hat{a}$ & $\stackrel{\infty}{0}$ & $\hat{\sigma}$ & ڤ̊ & $\stackrel{0}{\circ}$ & $\stackrel{\infty}{\infty}$ & $\stackrel{n}{a}$ & ڤ̊ & $\stackrel{\infty}{0}$ & $\stackrel{+}{0}$ & $\stackrel{\infty}{0}$ & ô & $\hat{a}$ & ڤ̊ & $\stackrel{8}{-}$ & ळ. & $\left|\begin{array}{l}0 \\
\vdots \\
0\end{array}\right|$ & $\hat{a}$ & बे & ô & $\stackrel{\infty}{0}$ \\
\hline صै & $\begin{array}{l}n \\
\infty \\
i\end{array}$ & 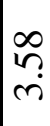 & $\stackrel{\nexists}{\stackrel{Z}{i}}$ & & $\bar{i}$ & $\begin{array}{l} \pm \\
\text { di }\end{array}$ & $\stackrel{m}{\sim}$ & \. & $\stackrel{n}{i}$ & $\stackrel{\infty}{\sim} \underset{\sim}{\sim}$ & $\stackrel{\circ}{\circ}$ & $\underset{i}{8}$ & $\stackrel{\infty}{\stackrel{i}{i}}$ & $\begin{array}{l}0 \\
0 \\
i\end{array}$ & $\stackrel{0}{i}$ & $\begin{array}{l}\tilde{b} \\
i\end{array}$ & $\begin{array}{l}\vec{b} \\
i\end{array}$ & $\mid \begin{array}{l}\infty \\
0 \\
i \\
\end{array}$ & $\begin{array}{l}\tilde{N} \\
\tilde{i}\end{array} \mid$ & $\stackrel{n}{r}$ & $\frac{n}{i}$ & $\stackrel{\Omega}{-}$ & 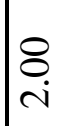 \\
\hline$\underset{\pi}{\simeq}$ & 吉 & $\infty$ & 6 & ชु & $i n$ & in & $\stackrel{2}{2}$ & t & $\nabla$ & $\widehat{\sigma}$ & $\bar{n}$ & ర & $\stackrel{\infty}{+}$ & 6 & 6 & 6 & 8 & in & 6 & ڤ & 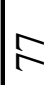 & in & $\stackrel{\infty}{+}$ \\
\hline$\stackrel{2}{a}$ & ำ & ন & $\bar{\lambda}$ & $\stackrel{\sim}{\sim}$ & तิ & $\stackrel{\infty}{\sim}$ & 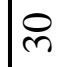 & ำ & ㅇ & ำ & ○ & $\approx$ & ป & $\tilde{m}$ & in & さ & $\tilde{N}$ & 궁 & $\stackrel{\infty}{\sim}$ & $\approx$ & $\stackrel{\infty}{\sim}$ & $\hat{\imath}$ & さ \\
\hline छ & $\begin{array}{l}0 \\
\text { in }\end{array}$ & $\begin{array}{l}n \\
n \\
n\end{array}$ & $\begin{array}{l}N \\
\infty \\
\dot{\sigma}\end{array}$ & $\begin{array}{l}\stackrel{一}{\Im} \\
\dot{+}\end{array}$ & $\begin{array}{l}0 \\
+ \\
\dot{1}\end{array}$ & $\underset{+}{\stackrel{\sigma}{+}}$ & $\begin{array}{l}\stackrel{\sim}{+} \\
+\end{array}$ & 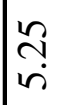 & ָָ & ڤે & $\stackrel{n}{r}$ & & बे & 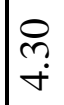 & 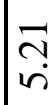 & $\begin{array}{l}n \\
\infty \\
+\end{array}$ & $\begin{array}{l}\tilde{N} \\
i\end{array}$ & $\begin{array}{l}n \\
n \\
n\end{array}$ & $\frac{ \pm}{ \pm}$ & 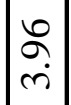 & $\begin{array}{l}\infty \\
m \\
m\end{array}$ & $\mid \begin{array}{c}\infty \\
0 \\
i \\
ن\end{array}$ & $\bar{\sigma}$ \\
\hline$\widehat{\mathrm{\Xi}}$ & $\underset{\sim}{\stackrel{m}{\sim}}$ & $\widetilde{O}$ & $\begin{array}{l}\infty \\
\infty \\
\dot{\sim}\end{array}$ & $\begin{array}{l}\infty \\
n \\
\sim \\
\sim\end{array}$ & $\stackrel{\widetilde{v}}{\sim}$ & ñ & $\stackrel{+}{m}$ & ָ̃ & $\stackrel{\infty}{\stackrel{\infty}{+}}$ & $\stackrel{\infty}{\stackrel{\infty}{0}}$ & 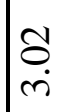 & 壳 & $\stackrel{\infty}{\sim}$ & $\hat{\varrho}$ & $\stackrel{\infty}{\sim}$ & $\stackrel{a}{2}$ & $\begin{array}{l}2 \\
i \\
i\end{array}$ & $\stackrel{n}{\sim}$ & $\frac{\bar{a}}{\mathrm{i}}$ & $\mid$\begin{tabular}{l}
$\infty$ \\
\hdashline \\
-
\end{tabular} & $\vec{F}$ & $\frac{ \pm}{i}$ & $\begin{array}{l}\hat{0} \\
\dot{\gamma}\end{array}$ \\
\hline$\widehat{\Xi}$ & ป̂. & $\bar{\infty}$ & $\stackrel{m}{\check{Z}}$ & 志 & $\frac{9}{\infty}$ & ?o & تِ & $\begin{array}{l}n \\
\infty \\
\infty \\
0\end{array}$ & ga & के & $\hat{\sigma}$ & $\stackrel{\text { I }}{\Xi}$ & $\stackrel{n}{n}$ & 吾 & $\begin{array}{l}\infty \\
\infty \\
\infty \\
0\end{array}$ & $\stackrel{m}{a}$ & $\mid \begin{array}{l}\infty \\
\infty \\
\sigma\end{array}$ & $\begin{array}{l}\Omega \\
\infty \\
\infty\end{array}$ & $\underset{z}{\Xi}$ & \begin{tabular}{l}
9 \\
\hdashline \\
$=$
\end{tabular} & $\hat{a}$ & $\begin{array}{l}\curvearrowleft \\
\infty \\
\infty\end{array} \mid$ & ก̊ \\
\hline छ & ڤે & ā & $\begin{array}{l}0 \\
\stackrel{2}{ \pm} \\
=\end{array}$ & \begin{tabular}{l}
\multirow{1}{*}{} \\
$\infty$ \\
$\dot{-}$
\end{tabular} & 守 & $\begin{array}{l}0 \\
\infty \\
\text { I }\end{array}$ & $\begin{array}{l}\stackrel{ }{+} \\
\dot{ \pm}\end{array}$ & $\begin{array}{l}\hat{0} \\
\dot{2}\end{array}$ & $\begin{array}{l}\infty \\
n \\
\stackrel{n}{n}\end{array}$ & $\begin{array}{l}\text { I } \\
\text { İ }\end{array}$ & Oِ & ก & ? & $\begin{array}{l}\text { 운 } \\
\text { i } \\
-1\end{array}$ & ปั & ָ̃ & 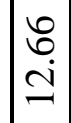 & $\stackrel{\substack{q \\
\hdashline}}{=}$ & $\left|\begin{array}{l}n \\
n \\
n \\
n\end{array}\right|$ & $\begin{array}{l}n \\
\stackrel{n}{q}\end{array}$ & o. & 吾 & $\underset{\infty}{\infty}$ \\
\hline$\widehat{\mathrm{\Xi}}$ & 文 & $\infty$ & $\begin{array}{l}\infty \\
n \\
n \\
n\end{array}$ & 文. & ĩ & 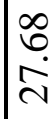 & O. & 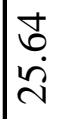 & $\begin{array}{l}0 \\
0 \\
\infty \\
\infty\end{array}$ & $\hat{a}$ & 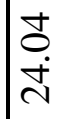 & 文 & $\begin{array}{l}\text { 寸 } \\
\text { ते }\end{array}$ & $\begin{array}{l}+ \\
0 \\
\infty \\
\text { ते }\end{array}$ & r̂? & ลิ & 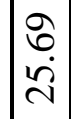 & $\stackrel{\grave{\sim}}{\stackrel{\sim}{\sim}}$ & 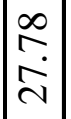 & $\begin{array}{l}\stackrel{\rho}{a} \\
\stackrel{\infty}{\sim}\end{array}$ & $\begin{array}{l}\infty \\
\infty \\
\dot{\jmath}\end{array}$ & 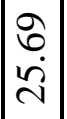 & กิ \\
\hline$\widehat{\Xi}$ & 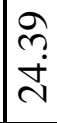 & 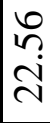 & $\vec{r}$ & $\begin{array}{l}0 \\
\vdots \\
\dot{d}\end{array}$ & 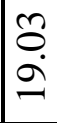 & $\frac{N}{i}$ & קे & $\frac{n}{\sim}$ & $\begin{array}{l}\bar{\sigma} \\
\text { ป }\end{array}$ & ণุ & $\begin{array}{l}n \\
0 \\
\infty\end{array}$ & $\begin{array}{l}\stackrel{n}{f} \\
\stackrel{2}{2}\end{array}$ & a & $\frac{\Omega}{\grave{\lambda}}$ & ?̊ & 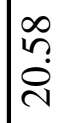 & $\begin{array}{l}\stackrel{\Omega}{\tilde{n}} \\
\text { ते }\end{array}$ & $\begin{array}{l} \pm \\
0 \\
0 \\
-\end{array}$ & $\begin{array}{l}\sigma_{\bar{\lambda}} \\
\dot{\lambda}\end{array}$ & $\begin{array}{l}\vec{\infty} \\
\dot{\sim}\end{array}$ & Õ. & \begin{tabular}{|l|}
$\infty$ \\
\\
\\
\end{tabular} & $\stackrel{a}{\tilde{n}}$ \\
\hline$\widehat{\mathrm{\Xi}}$ & 年 & $\overline{0}$ & 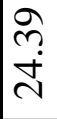 & $\begin{array}{l}\hat{\sigma} \\
\dot{d}\end{array}$ & $\begin{array}{l}\stackrel{0}{2} \\
\stackrel{2}{2}\end{array}$ & $\begin{array}{l}\text { ठ } \\
\text { ते }\end{array}$ & $\begin{array}{l}\infty \\
\infty \\
\dot{J}\end{array}$ & $\frac{a}{\dot{d}}$ & $\begin{array}{l}\curvearrowright \\
\infty \\
\dot{2}\end{array}$ & 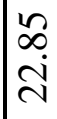 & $\begin{array}{l}m \\
\infty\end{array}$ & $\begin{array}{l}\hat{\infty} \\
\dot{J}\end{array}$ & $\stackrel{\infty}{\stackrel{\infty}{+}}$ & 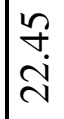 & $\frac{m}{2}$ & $\stackrel{\infty}{\stackrel{\infty}{\sim}}$ & $\begin{array}{l}\text { qे } \\
\text { ते }\end{array}$ & $\vec{\sim}$ & 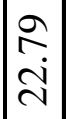 & $\begin{array}{l}n \\
\sim \\
\check{z} \\
\approx\end{array}$ & กิ & \begin{tabular}{|l|}
$\infty$ \\
$\infty$ \\
$\dot{\lambda}$ \\
\end{tabular} & $\hat{\infty}$ \\
\hline 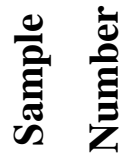 & - & $c$ & $m$ & $\nabla$ & in & 0 & N & $\infty$ & $a$ & $=$ & 二 & $\simeq$ & 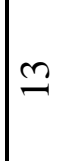 & $\Xi$ & n & $\underline{0}$ & 드. & $\infty$ & 2 & $\stackrel{ }{\text { ㄱ. }}$ & $\bar{\sim}$ & ה & $\pi$ \\
\hline
\end{tabular}


Anticosti Island, Quebec - Plaesiomys anticostiensis Table 2 (continued)

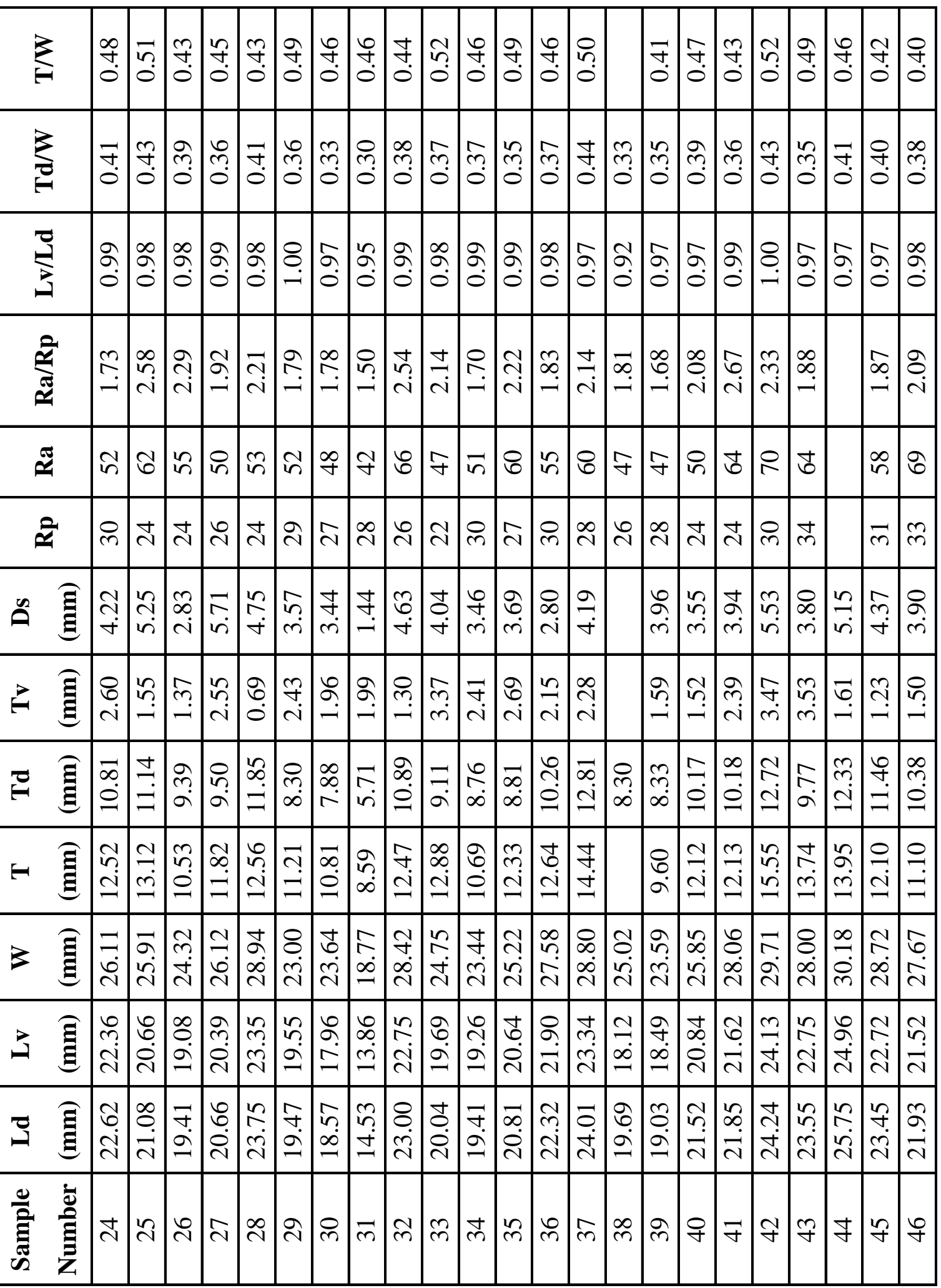


Anticosti Island, Quebec - Plaesiomys anticostiensis Table 2 (continued)

\begin{tabular}{|c|c|c|c|c|c|c|c|c|c|c|c|c|c|c|c|c|c|c|c|c|c|c|c|}
\hline 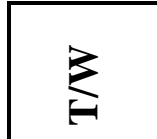 & $\mid \begin{array}{l}n \\
\tilde{o} \\
0\end{array}$ & $\begin{array}{l}F \\
0\end{array}$ & $\begin{array}{l}f \\
\dot{J} \\
0\end{array}$ & $\begin{array}{l}\vec{\nabla} \\
0\end{array}$ & & 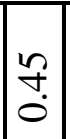 & 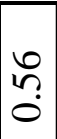 & i̊ & \begin{tabular}{l}
7 \\
\multirow{0}{*}{}
\end{tabular} & $\mid \begin{array}{l}0 \\
+ \\
0\end{array}$ & $\begin{array}{l}7 \\
0 \\
0\end{array}$ & $\stackrel{f}{\stackrel{1}{0}}$ & $\hat{n}$ & $\stackrel{m}{\grave{o}}$ & $\begin{array}{l}\infty \\
+ \\
0\end{array} \mid$ & 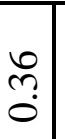 & $\bar{\sigma}$ & \begin{tabular}{l}
$\tilde{f}$ \\
\hdashline \\
\hdashline
\end{tabular} & \begin{tabular}{l}
$\infty$ \\
$n$ \\
\hdashline
\end{tabular} & $\begin{array}{l}n \\
n \\
n\end{array}$ & & $\begin{array}{l}\tilde{0} \\
\dot{0}\end{array}$ & \\
\hline$\sum_{E}^{z}$ & స़े & $\mid \begin{array}{c}\infty \\
m \\
0\end{array}$ & 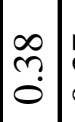 & $\tilde{n}$ & $\begin{array}{l}7 \\
\end{array}$ & $\vec{F}$ & $\overrightarrow{0}$ & $\mid \begin{array}{c}\infty \\
\tilde{n} \\
?\end{array}$ & $\left|\begin{array}{l}\infty \\
\\
0\end{array}\right|$ & $\mid \begin{array}{l}0 \\
\\
0\end{array}$ & 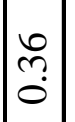 & त̂ & 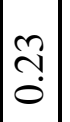 & $\begin{array}{l}n \\
0 \\
0\end{array}$ & $\begin{array}{c}m \\
\dddot{m}\end{array}$ & तి & $\frac{1}{0}$ & $\begin{array}{l}n \\
\ddot{o} \\
\vdots\end{array}$ & 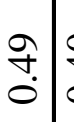 & $\stackrel{0}{+}$ & & $\begin{array}{l}\stackrel{0}{+} \\
0 \\
0\end{array}$ & \\
\hline 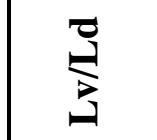 & $\underset{ن}{8}$ & $\begin{array}{l}\infty \\
\varrho \\
0\end{array}$ & 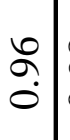 & $\begin{array}{l}\infty \\
\vdots \\
0\end{array}$ & 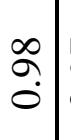 & $\hat{a}$ & $\begin{array}{l}\infty \\
2 \\
0 \\
0\end{array}$ & $\begin{array}{l}\infty \\
2 \\
0 \\
0\end{array}$ & $\stackrel{\partial}{\partial}$ & $\hat{a}$ & $\mid \begin{array}{l}\infty \\
2 \\
0 \\
0\end{array}$ & $\begin{array}{l}2 \\
\stackrel{0}{0}\end{array}$ & $\mid \begin{array}{l}\infty \\
\infty \\
0 \\
0\end{array}$ & $\stackrel{8}{-}$ & $\overrightarrow{0}$ & ڤે & ڤ̊. & $\stackrel{n}{\varrho}$ & $\hat{o}$ & $\begin{array}{l}0 \\
\vdots \\
\vdots\end{array}$ & \begin{tabular}{l}
$\infty$ \\
\multirow{2}{\infty}{} \\
$\vdots$
\end{tabular} & ڤ. & م. \\
\hline 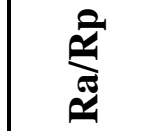 & $\stackrel{\infty}{\infty}$ & 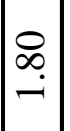 & $\begin{array}{l}\stackrel{2}{\infty} \\
\dot{-}\end{array}$ & $\begin{array}{c}J \\
i\end{array}$ & $\stackrel{n}{i}$ & $\left|\begin{array}{l}\hat{\sigma} \\
\text { ii }\end{array}\right|$ & $\overline{\hat{i}}$ & $\left|\begin{array}{l}m \\
\vec{i}\end{array}\right|$ & $\left|\begin{array}{c}1 \\
\infty \\
-\end{array}\right|$ & & 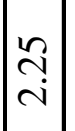 & $\stackrel{\substack{ \pm-}}{-}$ & $\vec{\exists}$ & $\stackrel{n}{n}$ & & $\stackrel{\overbrace{}}{-}$ & 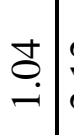 & 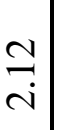 & & & & & $\stackrel{\partial}{i}$ \\
\hline$\approx$ & $n$ & in & $\bar{n}$ & $n$ & $\bullet$ & in & t & $\vec{n}$ & \& & & in & $\vec{n}$ & $\vec{n}$ & 于 & & $\hat{n}$ & $\hat{\imath}$ & 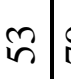 & $\stackrel{2}{2}$ & & 8 & & $\stackrel{\infty}{+}$ \\
\hline$\hat{\simeq}$ & శ্ল & ৪্ & $\widehat{\curvearrowright}$ & $\stackrel{\sim}{\sim}$ & $\underset{\sim}{\Delta}$ & নे & $\approx$ & $\underset{\sim}{\sim}$ & $\approx$ & ৪) & $\underset{\sim}{\Delta}$ & 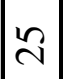 & $\approx$ & ৪্ & 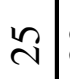 & $\stackrel{\infty}{\infty}$ & ¿ & 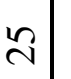 & & & & & $\ddot{\imath}$ \\
\hline คి & ñ & $\frac{\sim}{\sim}$ & $\begin{array}{c}0 \\
m \\
m \\
m\end{array} \mid$ & 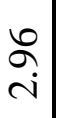 & & $\left|\begin{array}{l}2 \\
i \\
i\end{array}\right|$ & $\mid$ & $\mid \begin{array}{c}\sim \\
\dot{m}\end{array}$ & $\stackrel{\mathcal{Y}}{\stackrel{\sim}{-}}$ & $\frac{\partial}{\stackrel{\rho}{r}}$ & $\mid \begin{array}{l} \pm \\
\stackrel{े}{ }\end{array}$ & $\begin{array}{l}\infty \\
= \\
=\end{array}$ & $\mid \begin{array}{l}\infty \\
+ \\
0\end{array}$ & 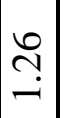 & $\begin{array}{l}n \\
\\
-1\end{array}$ & $\stackrel{0}{=}$ & ઼ָ & 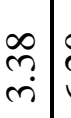 & તું & $\begin{array}{l}\stackrel{2}{2} \\
i\end{array}$ & 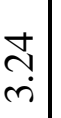 & 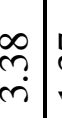 & $\hat{n}$ \\
\hline$\rightleftarrows \widehat{\mathrm{E}}$ & 守 & f. & $\stackrel{2}{\stackrel{2}{=}}$ & $\stackrel{+}{m}$ & & $\stackrel{\infty}{=}$ & $\left|\begin{array}{l}+ \\
\infty \\
\dot{m}\end{array}\right|$ & $\mid \begin{array}{l}0 \\
0 \\
0\end{array}$ & $\begin{array}{l}n \\
\vec{i} \\
\sim\end{array} \mid$ & $\mid \begin{array}{c}f \\
\dot{i}\end{array}$ & $\mid \begin{array}{c}0 \\
\stackrel{0}{-}\end{array}$ & $\overrightarrow{\vec{i}}$ & $\stackrel{n}{n}$ & $\stackrel{\wp}{-}$ & $\underset{m}{\stackrel{R}{r}}$ & $\begin{array}{l}\tilde{c} \\
i\end{array}$ & $\stackrel{9}{-}$ & $\begin{array}{l}\stackrel{O}{\dot{m}} \\
\dot{m}\end{array}$ & 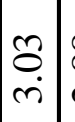 & $\begin{array}{l}\infty \\
\infty \\
i \\
i\end{array}$ & & $\begin{array}{l}\stackrel{2}{0} \\
i \\
c\end{array}$ & \\
\hline 戸 $\widehat{\mathrm{g}}$ & $\mid$\begin{tabular}{l}
$\infty$ \\
\hdashline \\
$i$
\end{tabular} & $\left|\begin{array}{l}\infty \\
\infty \\
\infty \\
\infty\end{array}\right|$ & 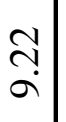 & $\stackrel{\infty}{\stackrel{\infty}{a}}$ & $\stackrel{\bar{m}}{=}$ & 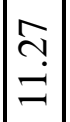 & $\begin{array}{l}\partial \\
\infty \\
0\end{array}$ & $\left|\begin{array}{l}\infty \\
\infty \\
\infty\end{array}\right|$ & $\begin{array}{c}\simeq \\
\vec{n}\end{array}$ & $\stackrel{0}{2}$ & $\left|\begin{array}{l}0 \\
0 \\
0\end{array}\right|$ & $\left|\begin{array}{l}0 \\
i \\
i\end{array}\right|$ & $\mid \begin{array}{l}\infty \\
\stackrel{i}{i} \\
\end{array}$ & $\mid \begin{array}{l}\infty \\
\stackrel{n}{i}\end{array}$ & $\stackrel{\text { ร. }}{\stackrel{2}{\sim}}$ & $\stackrel{ \pm}{\dot{m}}$ & 京 & $\begin{array}{l}+ \\
\infty \\
\vdots \\
\vdots\end{array}$ & $\begin{array}{l}8 \\
\dot{0} \\
\dot{ \pm}\end{array}$ & $\stackrel{f}{\stackrel{J}{二}}$ & & $\begin{array}{l}q \\
\stackrel{9}{a}\end{array}$ & \\
\hline$-\widehat{\widehat{\Xi}}$ & $\stackrel{n}{\sim}$ & 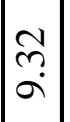 & $\begin{array}{l}0 \\
\stackrel{0}{0} \\
0\end{array}$ & $\begin{array}{l}\overrightarrow{0} \\
\Xi\end{array}$ & & $\left|\begin{array}{l}\stackrel{i}{\mathrm{i}} \\
\mathrm{i}\end{array}\right|$ & $\begin{array}{l}\infty \\
\infty \\
\dot{ \pm}\end{array}$ & $\mid$ & $\mid$ & 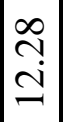 & $\mid \begin{array}{c}8 \\
i \\
i\end{array}$ & $\overrightarrow{\dot{\sigma}}$ & 导 & $\begin{array}{c}\vec{b} \\
\dot{v}\end{array}$ & $\begin{array}{l}\mathscr{2} \\
\hat{0}\end{array}$ & $\begin{array}{l}? \\
i\end{array}$ & $\underset{+}{F}$ & $\stackrel{g}{=}$ & 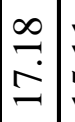 & $\bar{n}$ & & $\begin{array}{l}\underset{N}{\Xi} \\
\Xi\end{array}$ & \\
\hline$\geq \widehat{\widehat{g}}$ & ڤ్n. & $\left|\begin{array}{c}8 \\
\dot{\lambda} \\
\end{array}\right|$ & $\begin{array}{l}8 \\
\dot{j}\end{array}$ & $\begin{array}{l}\vec{\imath} \\
\dot{d}\end{array}$ & $\begin{array}{l}0 \\
+ \\
\dot{v} \\
\text { 1. }\end{array}$ & $\left|\begin{array}{c}\stackrel{\imath}{a} \\
\hat{\imath}\end{array}\right|$ & $\mid \begin{array}{l}\overrightarrow{6} \\
\dot{\theta} \\
\overrightarrow{1}\end{array}$ & $\mid \begin{array}{l}0 \\
0 \\
\\
\end{array}$ & $\begin{array}{l}- \\
0 \\
\infty \\
-\end{array}$ & $\left|\begin{array}{l}\overrightarrow{0} \\
\dot{0} \\
\dot{c}\end{array}\right|$ & $\left|\begin{array}{l}0 \\
\vdots \\
\grave{2}\end{array}\right|$ & $\begin{array}{l}\vec{\infty} \\
\dot{\Xi}\end{array}$ & $\mid \begin{array}{c}\infty \\
\stackrel{\infty}{=} \\
=\end{array}$ & $\mid \begin{array}{l}0 \\
0 \\
\dot{0}\end{array}$ & $\begin{array}{l}\hat{b} \\
\dot{i} \\
\text { an }\end{array}$ & $\begin{array}{l}8 \\
0 \\
0\end{array}$ & $\left|\begin{array}{l}n \\
m \\
\dot{ \pm}\end{array}\right|$ & 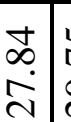 & 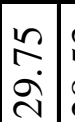 & 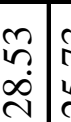 & 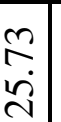 & $\begin{array}{l}0 \\
\stackrel{0}{ } \\
\end{array}$ & $\frac{\bar{c}}{\vec{N}}$ \\
\hline$\exists \widehat{\mathrm{E}}$ & 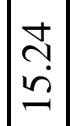 & $\begin{array}{l}\dot{1} \\
m \\
\infty \\
\end{array}$ & $\begin{array}{l}8 \\
\vdots \\
9\end{array}$ & $\begin{array}{l} \pm \\
\infty \\
\infty \\
\infty\end{array}$ & $\begin{array}{l}\because \\
\dot{v} \\
i\end{array}$ & $\left|\begin{array}{c}\stackrel{\hat{\imath}}{\mathrm{i}} \\
\mathrm{i}\end{array}\right|$ & \begin{tabular}{|l}
$\overrightarrow{0}$ \\
$\dot{v}$ \\
$\vec{i}$
\end{tabular} & 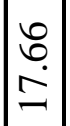 & \begin{tabular}{|l|}
$\vec{N}$ \\
$\dot{\Xi}$
\end{tabular} & 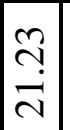 & $\left|\begin{array}{l}1 \\
\infty \\
\grave{N} \\
0\end{array}\right|$ & $\begin{array}{c}\stackrel{f}{f} \\
\infty \\
\infty\end{array}$ & $\left|\begin{array}{l}2 \\
\infty \\
\infty\end{array}\right|$ & 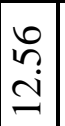 & 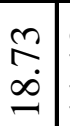 & $\stackrel{9}{\exists}$ & \begin{tabular}{l|} 
\\
0 \\
0 \\
\end{tabular} & 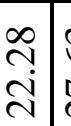 & 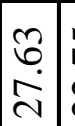 & 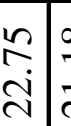 & $\begin{array}{l}\infty \\
\stackrel{\Delta}{\vec{\lambda}} \\
\vec{\sim}\end{array}$ & $\begin{array}{l}0 \\
2 \\
\vdots \\
2\end{array}$ & 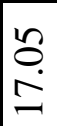 \\
\hline こ $\widehat{\Xi}$ & $\mid \begin{array}{l}\tilde{N} \\
\mathfrak{n} \\
\end{array}$ & $\begin{array}{l}\curvearrowright \\
\infty \\
\infty\end{array} \mid$ & $\begin{array}{l}\infty \\
\infty \\
\vdots \\
\vdots\end{array}$ & $\frac{n}{2}$ & $\begin{array}{l}0 \\
\dot{\lambda} \\
\dot{\lambda}\end{array}$ & $\left|\begin{array}{l}\delta \\
\bar{\lambda}\end{array}\right|$ & $\begin{array}{l}m \\
\vec{n} \\
\dot{n}\end{array}$ & $\mid \begin{array}{l}0 \\
0 \\
\infty \\
0\end{array}$ & $\vec{m}$ & $\overline{\bar{\lambda}}$ & $\begin{array}{l}\stackrel{\sim}{\sim} \\
\stackrel{\sim}{N} \\
\end{array}$ & $\mid \begin{array}{l}0 \\
\infty \\
\infty \\
\infty\end{array}$ & \begin{tabular}{|c|}
0 \\
0 \\
0 \\
0 \\
\end{tabular} & $\begin{array}{l}0 \\
\tilde{n} \\
\\
\end{array}$ & $\begin{array}{l}\tilde{N} \\
\infty \\
\infty\end{array}$ & તָ. & 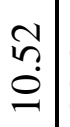 & $\begin{array}{l}\stackrel{\oplus}{\curvearrowright} \\
\grave{\lambda}\end{array}$ & $\begin{array}{l}\infty \\
\infty \\
\dot{\lambda}\end{array}$ & $\begin{array}{l}\infty \\
\stackrel{n}{n} \\
\end{array}$ & $\begin{array}{l}\stackrel{N}{\vec{d}} \\
\dot{\vec{v}}\end{array}$ & $\begin{array}{l}2 \\
\infty \\
\infty\end{array}$ & If \\
\hline 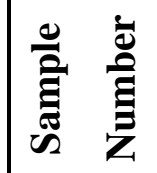 & & 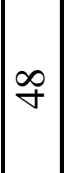 & 守 & in & $\bar{n}$ & in & $n$ & 伿 & in & {$\left[\begin{array}{l}0 \\
i n\end{array}\right.$} & in & {$\left[\begin{array}{l}\infty \\
n\end{array}\right.$} & in & 8 & 6 & $\sqrt{6}$ & 6 & J & 6 & 8 & $\widehat{6}$ & 0 & 8 \\
\hline
\end{tabular}


Anticosti Island, Quebec - Plaesiomys anticostiensis Table 2 (continued)

\begin{tabular}{|c|c|c|c|c|c|c|c|c|c|c|c|c|c|c|c|c|c|c|c|c|c|c|c|}
\hline$\xi$ & $\stackrel{\nabla}{\circ}$ & & $\stackrel{m}{+}$ & $\underset{0}{+}$ & & ?. & $\stackrel{m}{\tilde{\theta}}$ & 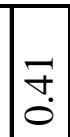 & $\stackrel{\infty}{+}$ & & & $\mid$\begin{tabular}{l}
0 \\
\multirow{+}{+}{} \\
0
\end{tabular} & & $\bar{n}$ & 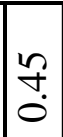 & & & $\left|\begin{array}{l}0 \\
+ \\
0\end{array}\right|$ & & $\underset{\bullet}{+}$ & & ก̊ & \\
\hline$\sum^{z}$ & mె & ले & $\stackrel{\infty}{n}$ & ?ִ & & $\frac{9}{0}$ & సָ & $\tilde{n}$ & $\stackrel{n}{\stackrel{n}{0}}$ & & & ำ & $\stackrel{n}{n}$ & $\begin{array}{l}\nexists \\
0 \\
0\end{array}$ & 永 & & & m & $\bar{n}$ & $\stackrel{0}{+}$ & & f̊. & ñ \\
\hline 곰 & $\hat{\sigma}$ & $\stackrel{\infty}{\infty}$ & & & ○. & 8 & बे & $\begin{array}{l}\infty \\
a \\
0\end{array}$ & $\stackrel{n}{a}$ & $\begin{array}{l}0 \\
\infty \\
0\end{array}$ & ó & ڤे & & $\begin{array}{l}\tilde{\sigma} \\
\hat{\sigma}\end{array}$ & $\hat{a}$ & $\begin{array}{l}\dot{J} \\
\dot{0}\end{array}$ & & $\begin{array}{l}0 \\
- \\
-\end{array}$ & $\left|\begin{array}{l}\Omega \\
0 \\
-\end{array}\right|$ & ڤ̊ & & 吕 & 文 \\
\hline$\overbrace{\mathscr{0}}^{\frac{0}{4}}$ & $\underset{2}{2}$ & & $\hat{\sigma}$ & & & $\stackrel{\sim}{\stackrel{f}{\tau}}$ & $\stackrel{\infty}{n}$ & $\begin{array}{l}0 \\
\infty \\
-\end{array}$ & $\stackrel{\sim}{\sim}$ & & & $\mid \begin{array}{l}6 \\
0 \\
-\end{array}$ & $\begin{array}{l}0 \\
\infty \\
- \\
-\end{array}$ & & 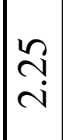 & & & & $\stackrel{\sim}{\stackrel{\sim}{\sim}}$ & $\begin{array}{l}\nexists \\
\dot{v} \\
\mathrm{i}\end{array}$ & & & \\
\hline$\stackrel{\mathscr{*}}{\approx}$ & 6 & & in & & & $\hat{n}$ & 尹 & 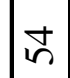 & 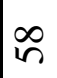 & & & $\stackrel{m}{\forall}$ & 6 & & $\stackrel{N}{N}$ & & & $\infty$ & $\hat{m}$ & $\overline{6}$ & & & \\
\hline 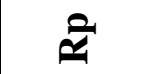 & లి & & $\widehat{\sim}$ & & & సి & $\tilde{N}$ & શે & $\stackrel{\sim}{2}$ & 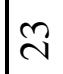 & $\bar{m}$ & $\stackrel{0}{\sim}$ & D & & ñ & & $\stackrel{\infty}{\sim}$ & & ○ & $\approx$ & & ㄱ. & \\
\hline อ̊ ఏ & $\vec{\sim}$ & $\begin{array}{l}\hat{\sigma} \\
i\end{array}$ & $\begin{array}{l}\infty \\
\infty \\
\sim\end{array}$ & in & & $\stackrel{\infty}{=}$ & $\mid \begin{array}{l}\infty \\
\infty \\
0\end{array}$ & $\stackrel{n}{n}$ & 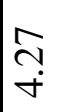 & & $\stackrel{m}{\stackrel{\sim}{+}}$ & $\mid \begin{array}{c}\infty \\
\sim \\
\sim \\
c\end{array}$ & $\begin{array}{l}0 \\
0 \\
0\end{array}$ & $\begin{array}{l}n \\
\text { nु. } \\
0\end{array}$ & $\begin{array}{l}0 \\
i \\
i\end{array}$ & $\stackrel{\infty}{\stackrel{n}{m}}$ & & $\left|\frac{m}{m}\right|$ & $\left|\begin{array}{l}\infty \\
\sim \\
\sim \\
\sim\end{array}\right|$ & $\frac{ \pm}{\Delta}$ & & $\underset{\overbrace{}}{\stackrel{一}{+}}$ & તָ \\
\hline$\Rightarrow$ छ & î & & $\stackrel{2}{\stackrel{0}{0}}$ & $\underset{\infty}{\infty}$ & & $\infty$ & $\stackrel{\infty}{\circ}$ & बे & $\stackrel{+}{\stackrel{0}{0}}$ & & $\bar{\sigma}$ & $\bar{n}$ & & $\left|\begin{array}{l}\infty \\
\hdashline \\
\sim i\end{array}\right|$ & in & $\left|\begin{array}{c}\infty \\
0 \\
\\
\text { in }\end{array}\right|$ & & $\left|\begin{array}{c}\infty \\
0 \\
ن \\
\text { in }\end{array}\right|$ & & $\underset{-}{\Delta}$ & & 二 & \\
\hline 리 & $\stackrel{1}{0}$ & $\infty$ & $\stackrel{\partial}{\infty}$ & $\begin{array}{l}\qquad 6 \\
\infty \\
\infty\end{array}$ & & $\begin{array}{l}\bar{\sigma} \\
\text { i }\end{array}$ & 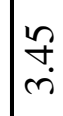 & 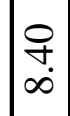 & $\frac{0}{2}$ & & $\underline{ }$ & $\begin{array}{l}0 \\
n \\
i n \\
i\end{array}$ & $\begin{array}{l}\overrightarrow{0} \\
0 \\
0\end{array}$ & \begin{tabular}{l}
\multirow{U}{0}{} \\
$\stackrel{1}{ }$
\end{tabular} & $\begin{array}{l}\infty \\
\stackrel{0}{0} \\
-\end{array}$ & & 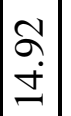 & $\left|\begin{array}{l}2 \\
0 \\
\infty\end{array}\right|$ & $\stackrel{尺}{\stackrel{\gamma}{*}}$ & $\begin{array}{l}\stackrel{0}{0} \\
\stackrel{0}{0}\end{array}$ & & $\begin{array}{l}0 \\
0 \\
\end{array}$ & $\begin{array}{l}2 \\
\infty \\
\pm\end{array}$ \\
\hline$-\widehat{\Xi}$ & $\frac{n}{2}$ & & $\stackrel{\infty}{\stackrel{\infty}{0}}$ & in & & $\stackrel{\infty}{\stackrel{\infty}{+}}$ & $\begin{array}{l}6 \\
6 \\
i\end{array}$ & $\begin{array}{l}\infty \\
\tilde{n} \\
0 \\
0\end{array}$ & $\begin{array}{l}\stackrel{g}{+} \\
\dot{m}\end{array}$ & & 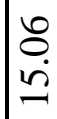 & $\begin{array}{c}0 \\
\searrow \\
\infty\end{array}$ & & $\begin{array}{l}\stackrel{ \pm}{ \pm} \\
\dot{\Xi}\end{array}$ & $\begin{array}{l}n \\
n \\
n\end{array}$ & & & $\begin{array}{l}\$ \\
\infty \\
\sigma\end{array}$ & & $\stackrel{\check{n}}{=}$ & & 足 & \\
\hline$\gtrless \widehat{\Xi}$ & $\frac{\text { वे }}{2}$ & ب̃ & $\begin{array}{l}g \\
\text { cे } \\
\text { ते }\end{array}$ & $\begin{array}{l}\infty \\
\stackrel{\infty}{r} \\
\ddot{v}\end{array}$ & & 守 & å & $\begin{array}{l}\bar{n} \\
\ddot{n}\end{array}$ & $\begin{array}{l}\stackrel{0}{+} \\
\infty \\
\infty \\
\sim\end{array}$ & & & å & $\mid \begin{array}{l}n \\
+ \\
\infty \\
\sim \\
\sim\end{array}$ & $\begin{array}{l}- \\
\infty \\
\infty \\
\sim\end{array}$ & ๙े & 금 & & $\begin{array}{l}n \\
\stackrel{f}{+} \\
\stackrel{\sim}{\sim}\end{array}$ & $\begin{array}{l}n \\
\\
\\
=\end{array}$ & 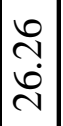 & & वे & $\begin{array}{l}n \\
n \\
\infty \\
\sim\end{array}$ \\
\hline 氞 & $\begin{array}{l}\infty \\
\tilde{n} \\
\tilde{n}\end{array}$ & ত্ & â & & กิ & $\stackrel{m}{m}$ & ปิ & $\bar{n}$ & $\begin{array}{l}\stackrel{\sim}{+} \\
\ddot{\sim}\end{array}$ & $\begin{array}{l}\hat{\sigma} \\
\dot{\sigma}\end{array}$ & $\begin{array}{l}\infty \\
0 \\
0 \\
0\end{array}$ & $\begin{array}{l}\infty \\
i \\
i \\
-1\end{array}$ & & $\begin{array}{l}\infty \\
\infty \\
\infty \\
\sim \\
\sim\end{array}$ & $\begin{array}{l}\tilde{y} \\
\dot{\sim} \\
\dot{\sim}\end{array}$ & $\begin{array}{l}0 \\
\stackrel{n}{\sim} \\
\end{array}$ & & $\begin{array}{l}- \\
\infty \\
\infty \\
-1\end{array}$ & 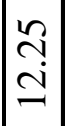 & 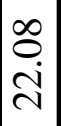 & & $\stackrel{\hat{n}}{\stackrel{2}{2}}$ & $\begin{array}{l}\bar{n} \\
\ddot{n}\end{array}$ \\
\hline ટ્ છ & $\frac{N}{\stackrel{\sim}{\sim}}$ & $\begin{array}{l}8 \\
\text { ¿̀ं }\end{array}$ & 옴 & 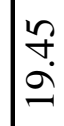 & ठै. & m & 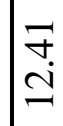 & $\begin{array}{l}\infty \\
0 \\
0\end{array}$ & $\begin{array}{l}n \\
\mathfrak{n} \\
\dot{d}\end{array}$ & $\begin{array}{l}\infty \\
\infty \\
\infty \\
-1\end{array}$ & 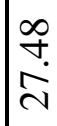 & $\begin{array}{l}\partial \\
\ddot{n} \\
\end{array}$ & 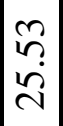 & 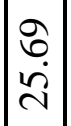 & $\begin{array}{l}\dot{J} \\
\dot{J}\end{array}$ & $\begin{array}{l}\stackrel{尺}{\grave{d}} \\
\stackrel{\mathrm{N}}{\mid}\end{array}$ & 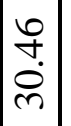 & $\begin{array}{l}n \\
n \\
\infty\end{array}$ & $\begin{array}{l}8 \\
\dot{1} \\
\end{array}$ & $\begin{array}{l}\hat{0} \\
\dot{\lambda}\end{array}$ & $\begin{array}{l}\circ \\
\\
\end{array}$ & $\begin{array}{l}\infty \\
\infty \\
\dot{J}\end{array}$ & $\begin{array}{l}\sigma \\
\tilde{\sigma}\end{array}$ \\
\hline 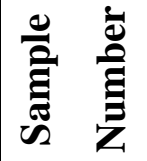 & $\stackrel{2}{R}$ & $\nabla$ & 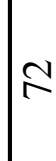 & $\stackrel{m}{r}$ & 文 & $\stackrel{n}{2}$ & 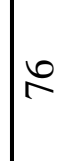 & 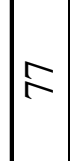 & $\infty$ & 9 & $\infty$ & $\infty$ & $\infty$ & $\infty$ & $\infty$ & $\infty$ & $\infty$ & $\infty$ & $\infty$ & ळ) & ஓ & $\bar{a}$ & ๙ૂ \\
\hline
\end{tabular}


Anticosti Island, Quebec - Plaesiomys anticostiensis Table 2 (continued)

\begin{tabular}{|c|c|c|c|c|c|c|c|c|c|c|c|c|c|c|c|c|c|c|c|c|c|c|}
\hline$\xi$ & 声 & 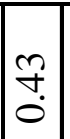 & & $\begin{array}{l}\stackrel{a}{0} \\
\dot{0}\end{array}$ & & $\begin{array}{l}n \\
n \\
n\end{array}$ & & & & & & & & & 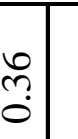 & & & & & & & \\
\hline$\stackrel{8}{e}$ & ?n & $\bar{m}$ & & $\begin{array}{l}0 \\
? \\
0 \\
0\end{array}$ & & $\hat{n}$ & & & & & & & & & $\hat{n}$ & & & & & & & \\
\hline 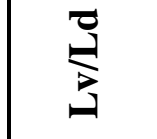 & $\hat{\grave{o}}$ & $\begin{array}{l}8 \\
- \\
-\end{array}$ & & $\stackrel{2}{\varrho}$ & & $\begin{array}{l}0 \\
\vdots \\
\vdots\end{array}$ & & & & & & & & & & & & & & & & \\
\hline 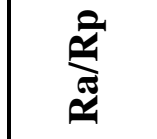 & $\begin{array}{l}8 \\
i \\
i\end{array}$ & & & & & & & & & & & & & & & & & & & & & \\
\hline$\approx$ & $\infty$ & & & & & in & & & & & & & & & & & & & & & & \\
\hline$\hat{\imath}$ & ㄱ. & & & & & & & & & & & & & & & & & & & & & \\
\hline 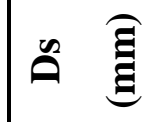 & $\stackrel{+}{i}$ & $\left|\begin{array}{c}\sigma \\
\dot{+}\end{array}\right|$ & & $\begin{array}{l}\vec{N} \\
i n\end{array}$ & $\begin{array}{c}\tilde{m} \\
\dot{m}\end{array}$ & $\begin{array}{l}\qquad \\
\infty \\
+ \\
+\end{array}$ & $\underset{+}{\vec{f}}$ & & & $\begin{array}{l}\stackrel{i}{n} \\
\ddot{n}\end{array}$ & & $\vec{I}$ & $\begin{array}{l}\infty \\
\dot{i} \\
i\end{array}$ & 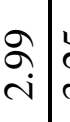 & $\begin{array}{l}\vec{c} \\
\vec{n} \\
\end{array}$ & 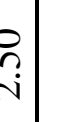 & & & ?. & $\hat{\imath}$ & & \\
\hline ¿ & $\stackrel{9}{-}$ & $\frac{\partial}{m}$ & & $\frac{\infty}{m}$ & & $\begin{array}{l}\sim \\
\infty \\
\dot{r}\end{array}$ & $\begin{array}{l}\hat{b} \\
i \\
i\end{array}$ & & $\bar{m}$ & $\stackrel{m}{m}$ & & & & $\begin{array}{l}2 \\
\infty \\
\\
\end{array}$ & $\delta$ & $\begin{array}{l}y \\
\dot{v} \\
\dot{y}\end{array}$ & $\begin{array}{l}\hat{y} \\
\mathrm{v}\end{array}$ & & 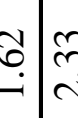 & $\left\{\begin{array}{c}\infty \\
\stackrel{\infty}{\sim}\end{array}\right.$ & तָ & \\
\hline 巨气 & $\mid \begin{array}{l}\vec{\vdots} \\
\infty\end{array}$ & $\stackrel{\grave{2}}{r}$ & $\begin{array}{l}n \\
2 \\
a\end{array}$ & $\begin{array}{c}\infty \\
0 \\
0\end{array}$ & 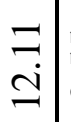 & $\begin{array}{l}n \\
n \\
n \\
a\end{array}$ & & $\begin{array}{l}\hat{6} \\
\stackrel{0}{0}\end{array}$ & & & $\underset{r}{\stackrel{q}{r}}$ & $\mid$ & & & $\begin{array}{l}\infty \\
0 \\
0\end{array}$ & & & 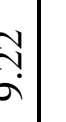 & & & & \\
\hline - $\widehat{\mathrm{g}}$ & $\begin{array}{l}n \\
0 \\
0\end{array}$ & 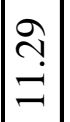 & & $\begin{array}{l}\infty \\
0 \\
\grave{2}\end{array}$ & & $\begin{array}{l}\stackrel{+}{n} \\
\stackrel{n}{2}\end{array}$ & & & & & & & & & $\begin{array}{l}\stackrel{2}{0} \\
0 \\
0\end{array}$ & & & & & & & \\
\hline 己 $\widehat{\mathrm{g}}$ & $\mid \begin{array}{l}m \\
\stackrel{2}{n} \\
\end{array}$ & $\mid \begin{array}{l}\overrightarrow{0} \\
\dot{\omega} \\
\dot{\nu}\end{array}$ & & 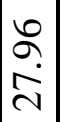 & & 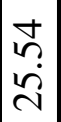 & & & 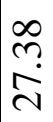 & $\mid \begin{array}{c}0 \\
0 \\
\dot{0} \\
\dot{m}\end{array}$ & & & 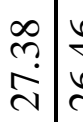 & 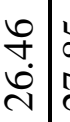 & $\begin{array}{l}n \\
\infty \\
\grave{\sim}\end{array}$ & & $\begin{array}{l}\dot{q} \\
\dot{a} \\
\vdots\end{array}$ & & 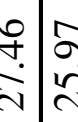 & $\begin{array}{l}\stackrel{\infty}{\infty} \\
\stackrel{+}{\sim}\end{array}$ & $\stackrel{n}{\stackrel{n}{d}}$ & के \\
\hline 觉 & $\begin{array}{l}\infty \\
\infty \\
= \\
\end{array}$ & $\left|\begin{array}{l}\sigma \\
\partial \\
\partial\end{array}\right|$ & & $\left|\begin{array}{l}\hat{N} \\
\stackrel{\sim}{i}\end{array}\right|$ & & $\begin{array}{l}\tilde{N} \\
\tilde{n} \\
\tilde{N}\end{array} \mid$ & $\stackrel{r}{\vec{v}}$ & & $\begin{array}{l}\dot{y} \\
\dot{\theta}\end{array}$ & 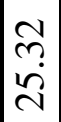 & & & 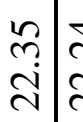 & $\begin{array}{l}\stackrel{+}{\Delta} \\
\text { त }\end{array}$ & $\frac{\pi}{7}$ & $\begin{array}{l}+ \\
\dot{v} \\
\dot{v}\end{array}$ & $\begin{array}{l}0 \\
: \\
\\
\end{array}$ & & 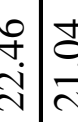 & $\begin{array}{l}0 \\
\dot{c} \\
\dot{n}\end{array}$ & $\begin{array}{l}0 \\
2 \\
0 \\
0\end{array}$ & $\underset{\vec{i}}{\vec{i}}$ \\
\hline ઉ & $\mid \begin{array}{l}\hat{m} \\
\dot{0} \\
-\end{array}$ & $\begin{array}{l}2 \\
2 \\
2\end{array}$ & $\left|\begin{array}{l}\hat{a} \\
\dot{d}\end{array}\right|$ & $\begin{array}{l}n \\
\tilde{n} \\
\tilde{n}\end{array} \mid$ & 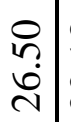 & $\begin{array}{l}\infty \\
\vec{i} \\
\vec{\Delta}\end{array} \mid$ & & $\begin{array}{l}8 \\
\ddot{n}\end{array} \mid$ & & & $\begin{array}{l}\vec{n} \\
\tilde{n}\end{array}$ & $\mid \begin{array}{l}\infty \\
2 \\
2\end{array}$ & & & $\begin{array}{l}\infty \\
\text { i } \\
\text { i }\end{array}$ & & 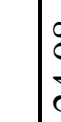 & \begin{tabular}{l}
0 \\
2 \\
$\dot{y}$ \\
\cline { 1 - 1 }
\end{tabular} & & & & \\
\hline 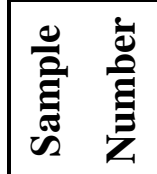 & $\sigma$ & I & $\approx$ & ๑ & ลิ & $\approx$ & ন & 8 & 으 & 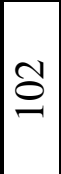 & లో & 总 & $\stackrel{2}{0}$ & 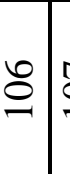 & ఏ) & $\stackrel{\infty}{0}$ & $\hat{b}$ & $\underline{\underline{Z}}$ & $E \cong$ & $\stackrel{\oplus}{=}$ & $\Xi$ & $\stackrel{n}{=}$ \\
\hline
\end{tabular}


Anticosti Island, Quebec - Plaesiomys anticostiensis Table 2 (continued)

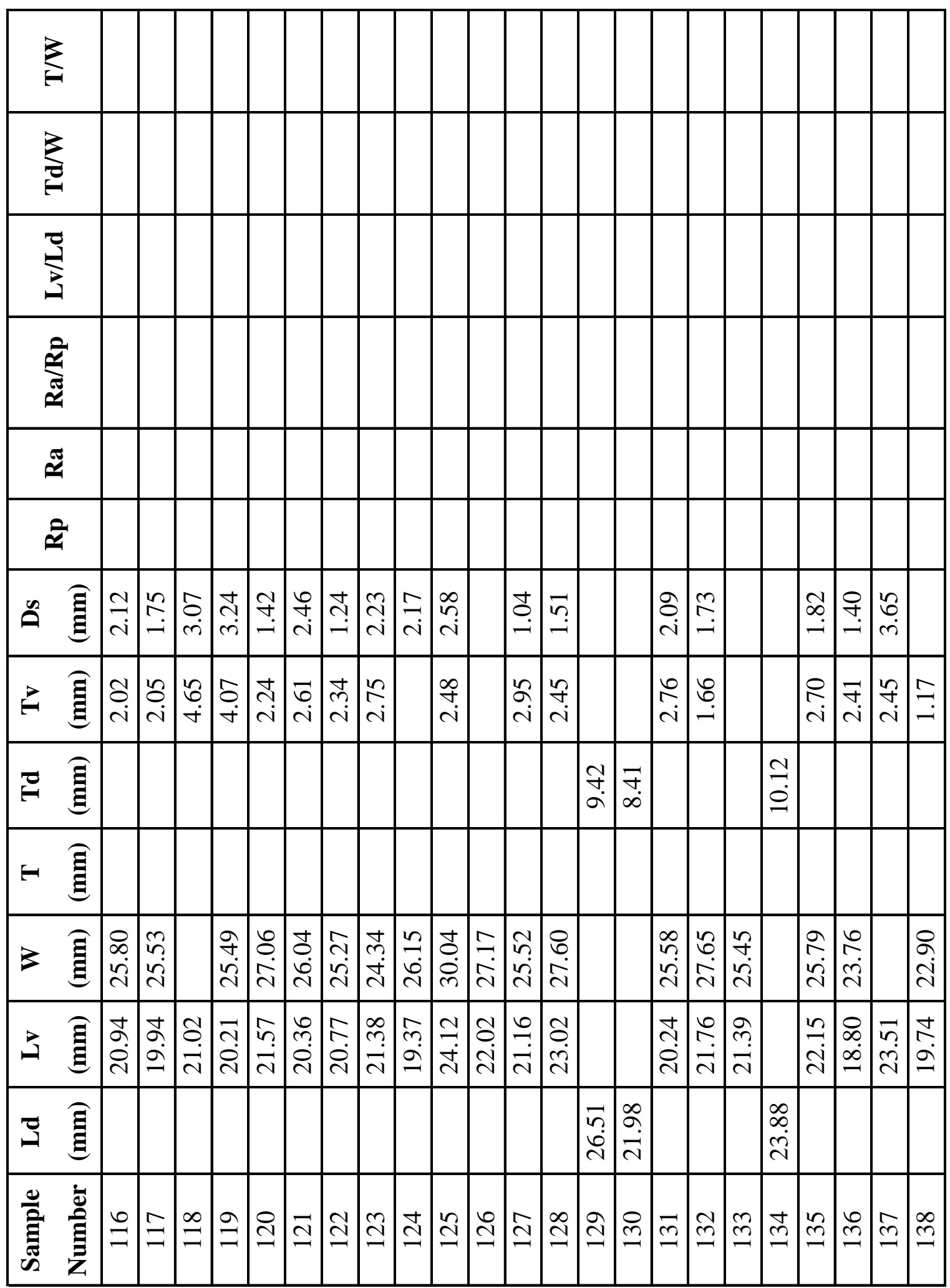


Anticosti Island, Quebec - Plaesiomys anticostiensis Table 2 (continued)

\begin{tabular}{|c|c|c|c|c|c|c|c|c|c|c|c|c|c|c|c|c|c|c|c|c|c|c|c|}
\hline 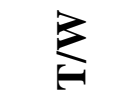 & & & & & $\stackrel{m}{+}$ & $\begin{array}{l}\infty \\
n \\
0\end{array}$ & $\stackrel{\partial}{\ominus}$ & $\tilde{n}$ & ñ & $\ddot{n}$ & $\stackrel{\sim}{+}$ & $\stackrel{n}{\stackrel{n}{0}}$ & İ & $\stackrel{0}{\stackrel{0}{0}}$ & 움 & $\stackrel{\nabla}{\dot{\nabla}}$ & $\ddot{n}$ & $\tilde{n}$ & $\tilde{n}$ & ñ. & $\stackrel{0}{+}$ & $\ddot{n}$ & ñ. \\
\hline ह & & & & & 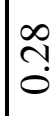 & กิ & $\tilde{n}$ & ñ & ֻัণ & $\frac{a}{0}$ & $\tilde{n}$ & $\stackrel{n}{m}$ & & กิ & 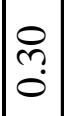 & సิ & 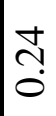 & ণ̊ & స్ & 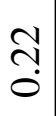 & $\stackrel{n}{n}$ & $\mid \frac{\infty}{0}$ & ָุ \\
\hline 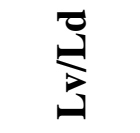 & & & & & o̊ & o̊ & $\stackrel{\infty}{\infty}$ & gे & ấ & o̊ & ô & $\mid \begin{array}{l}\infty \\
\vdots \\
0\end{array}$ & $\hat{a}$ & ڤ్ & $\mid$ & $\begin{array}{l}\infty \\
\vdots \\
0\end{array}$ & o̊ & ڤे & aे & $\begin{array}{l}0 \\
0 \\
0\end{array}$ & 8 & $\left|\begin{array}{l}n \\
\vdots \\
0\end{array}\right|$ & $\begin{array}{l}\dot{I} \\
\vdots \\
0\end{array}$ \\
\hline$\stackrel{\text { }}{\approx}$ & & & & & 年 & $\stackrel{n}{n}$ & ○ִ & $\hat{a}$ & $\stackrel{n}{n}$ & in & 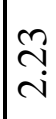 & {$\left[\begin{array}{l}n \\
\infty \\
-\end{array}\right.$} & i & io & 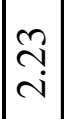 & $\stackrel{\stackrel{\rho}{+}}{i}$ & $\ddot{n}$ & $\stackrel{9}{2}$ & ñ & $\stackrel{\stackrel{\rho}{+}}{-}$ & ले & 吕 & $\stackrel{9}{\rightleftarrows}$ \\
\hline$\approx$ & & & & & in & in & $\sigma$ & in & \& & $\bar{n}$ & $\widehat{6}$ & $\tilde{6}$ & in & in & 8 & $\stackrel{N}{\curvearrowright}$ & 舟 & in & $\stackrel{\oplus}{+}$ & $\stackrel{\sim}{f}$ & ले & ল্ & $\stackrel{m}{\sigma}$ \\
\hline से & & & & & 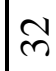 & $\hat{n}$ & $\infty$ & প & $\stackrel{\infty}{\sim}$ & mे & ల) & m & $\stackrel{\infty}{\sim}$ & $n$ & $\bar{m}$ & en & $\tilde{n}$ & $\stackrel{\infty}{\sim}$ & $\hat{\sim}$ & 요 & $\stackrel{\infty}{\sim}$ & $\approx$ & r) \\
\hline อ̊ ఏ & & Oे & & $\frac{\pi}{r}$ & 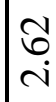 & ñ & $\begin{array}{l}n \\
\dot{b} \\
i\end{array}$ & a & $\bar{\sigma}$ & さ & $\begin{array}{l}\hat{b} \\
\text { iे }\end{array}$ & & $\begin{array}{l}\dot{U} \\
\dot{m}\end{array}$ & 我 & 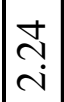 & $\begin{array}{l}\ddot{m} \\
\dot{m}\end{array}$ & 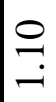 & $\stackrel{n}{f}$ & ? & $\underline{0}$ & 文 & $\begin{array}{l}\infty \\
\infty \\
0\end{array} \mid$ & ڤn \\
\hline $\overrightarrow{\mathrm{E}}$ & $\stackrel{n}{n}$ & ㄱ. & & ๙ุ & ๙ે & $\stackrel{0}{a}$ & $\underset{\dot{\sigma}}{\dot{\sigma}}$ & 尚 & $\stackrel{\infty}{\stackrel{\infty}{+}}$ & $\begin{array}{l}8 \\
0 \\
i\end{array}$ & $\begin{array}{l}0 \\
0 \\
i\end{array}$ & $\begin{array}{l}\dot{a} \\
\text { i }\end{array}$ & 于 & $\begin{array}{l}n \\
\infty \\
i\end{array}$ & $\begin{array}{l}\dot{\hat{~}} \\
\text { i }\end{array}$ & $\stackrel{9}{\dot{r}}$ & - & $\mid$\begin{tabular}{l}
0 \\
\multirow{7}{*}{} \\
i
\end{tabular} & $\mid \begin{array}{l}\nexists \\
\dot{v} \\
ن\end{array}$ & 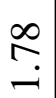 & ñ & $\begin{array}{l}n \\
n \\
\sim \\
n\end{array}$ & $\underset{\sim}{\stackrel{\gamma}{f}}$ \\
\hline ت $\widehat{\Xi}$ & & & & & قु & n & $\begin{array}{c}1 \\
\infty \\
\infty\end{array}$ & 遂 & ñ & ๙̊. & $\underset{\infty}{\stackrel{a}{+}}$ & 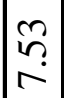 & 守 & $\begin{array}{l}0 \\
\text { in }\end{array}$ & $\begin{array}{l}\stackrel{a}{m} \\
\infty\end{array}$ & $\frac{0}{\infty}$ & $\begin{array}{l}\infty \\
\dot{m}\end{array}$ & $=$ & $\mid \begin{array}{c}0 \\
0 \\
\dot{m}\end{array}$ & $\bar{\sigma}$ & $\underset{\infty}{\infty}$ & $\begin{array}{l}n \\
\tilde{1} \\
2\end{array}$ & $\hat{v}$ \\
\hline$-\widehat{\Xi}$ & & & & & $\hat{\sigma}$ & $\begin{array}{l}8 \\
0 \\
0\end{array}$ & $\underline{\Xi}$ & 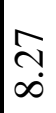 & $\begin{array}{l}0 \\
n \\
n \\
n\end{array}$ & $\underset{\nabla}{\sigma}$ & $\stackrel{\infty}{=}$ & $\begin{array}{l}\hat{\sigma} \\
0 \\
0\end{array}$ & $\stackrel{8}{0}$ & $\underset{\infty}{\infty}$ & 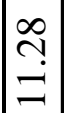 & $\begin{array}{l}\mathfrak{g} \\
\text { ב }\end{array}$ & $\underset{\forall}{\stackrel{+}{\sigma}}$ & $\begin{array}{l}2 \\
i n\end{array}$ & $\begin{array}{l}m \\
i \\
i\end{array}$ & $\begin{array}{l}\vec{b} \\
\dot{r}\end{array}$ & $\begin{array}{l}\stackrel{g}{+} \\
\dot{r}\end{array}$ & $\hat{\sigma}$ & $\begin{array}{l}\infty \\
\stackrel{\sigma}{0} \\
\dot{\tau}\end{array}$ \\
\hline 3 ఏ & & $\begin{array}{l}n \\
\text { ñ } \\
\text { ñ }\end{array}$ & $\begin{array}{l}\stackrel{2}{r} \\
\text { ri }\end{array}$ & ָ̃ & $\begin{array}{l}m \\
\ddot{n}\end{array}$ & $\begin{array}{l}\infty \\
\infty \\
\text { ñ }\end{array}$ & $\begin{array}{l}n \\
n \\
n\end{array}$ & ปู & I & 尺̂́ & $\begin{array}{l}8 \\
0 \\
0 \\
\text { i }\end{array}$ & $\left|\begin{array}{l}\overrightarrow{1} \\
\infty \\
\dot{\lambda}\end{array}\right|$ & 吉 & & 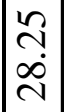 & $\begin{array}{l}\vec{\nabla} \\
\infty \\
\sim \\
\sim\end{array}$ & $\begin{array}{l}\infty \\
\infty \\
\infty\end{array}$ & ri & m & $\begin{array}{l}\vec{\nabla} \\
\text { I }\end{array}$ & $\begin{array}{l}\tilde{\sigma} \\
\dot{m} \\
\end{array}$ & 告 & $\begin{array}{l}n \\
\tilde{z} \\
\pm\end{array}$ \\
\hline 点 & $\begin{array}{l}\stackrel{a}{+} \\
\dot{\sigma}\end{array}$ & 每 & O̊ & $\underset{d}{d}$ & N̦ & 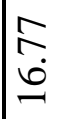 & $\begin{array}{l}\stackrel{n}{f} \\
\stackrel{a}{=}\end{array}$ & $\frac{1}{6}$ & $\frac{0}{2}$ & $\begin{array}{l}\text { I } \\
\pm\end{array}$ & ڤ̊̀ & $\begin{array}{l}\hat{a} \\
\infty \\
-\end{array}$ & $\stackrel{\infty}{a}$ & $\begin{array}{l}\infty \\
0 \\
\dot{ \pm}\end{array}$ & $\begin{array}{l}0 \\
\stackrel{ }{\lambda} \\
\end{array}$ & ন & $\stackrel{\nexists}{\rightleftharpoons}$ & $\begin{array}{l}m \\
\stackrel{n}{c}\end{array}$ & $\stackrel{8}{8}$ & $\begin{array}{l}\text { ă } \\
\text { ஸे }\end{array}$ & 尚 & $\begin{array}{l}n \\
= \\
=\end{array}$ & $\hat{n}$ \\
\hline ન્త ఏ & & & & & ? & $\stackrel{m}{\stackrel{m}{+}}$ & ڤ̆ & 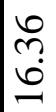 & $\stackrel{n}{\stackrel{n}{r}}$ & $\begin{array}{l}\sim \\
\check{2} \\
\end{array}$ & $\frac{n}{\sim}$ & $\begin{array}{l}\infty \\
\cdots \\
\varrho \\
=\end{array}$ & రై & $\begin{array}{l}\stackrel{\infty}{\stackrel{\Xi}{\Xi}} \\
\square\end{array}$ & $\begin{array}{l}\vec{\sigma} \\
\vec{\lambda}\end{array}$ & $\begin{array}{l}\vec{\nabla} \\
\text { } \\
\dot{y}\end{array}$ & 車 & $\begin{array}{l}0 \\
\stackrel{2}{1} \\
\end{array}$ & $\mid \begin{array}{l}0 \\
\stackrel{0}{*} \\
=\end{array}$ & $\begin{array}{l}\stackrel{0}{+} \\
\dot{2}\end{array}$ & 占 & $\begin{array}{l}\infty \\
\underset{\sim}{\beth} \\
\end{array}$ & $\stackrel{8}{8}$ \\
\hline 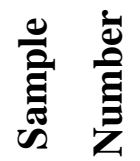 & ले & $\stackrel{゚}{ \pm}$ & $\Xi$ & 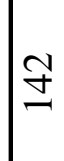 & $\stackrel{m}{\Xi}$ & 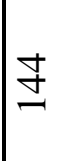 & $\stackrel{n}{ \pm}$ & $\underset{+}{ \pm}$ & Ð & $\stackrel{\infty}{ \pm}$ & 守 & 요 & $\bar{n}$ & in & $\stackrel{n}{n}$ & $\stackrel{\sim}{n}$ & $\stackrel{n}{n}$ & $\stackrel{6}{n}$ & $n$ & $\begin{array}{l}\infty \\
n \\
n\end{array}$ & 点 & 응 & $\bar{\sigma}$ \\
\hline
\end{tabular}


Anticosti Island, Quebec - Plaesiomys anticostiensis Table 2 (continued)

\begin{tabular}{|c|c|c|c|c|c|c|}
\hline$\xi$ & ñ & $\stackrel{n}{\mathfrak{o}}$ & $\begin{array}{l}\infty \\
m \\
0\end{array}$ & $\stackrel{7}{\dot{\theta}}$ & $\stackrel{f}{t}$ & $\stackrel{\sim}{+}$ \\
\hline$\sum^{3}$ & กิ & $\ddot{n}$ & $\stackrel{n}{0}$ & ? & $\stackrel{\infty}{N}$ & ฺุ. \\
\hline$\underset{3}{\stackrel{2}{3}}$ & $\hat{o}$ & $\stackrel{\infty}{0}$ & $\hat{a}$ & $\hat{a}$ & ấ & $\begin{array}{l}\infty \\
a \\
0\end{array}$ \\
\hline 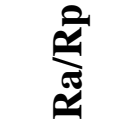 & $\stackrel{\infty}{n}$ & $\underset{\infty}{\infty}$ & 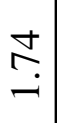 & $\stackrel{2}{7}$ & $\stackrel{\infty}{\infty}$ & $\begin{array}{l}\tilde{D} \\
- \\
-\end{array}$ \\
\hline$\underset{4}{\mathscr{4}}$ & in & 8 & $\tilde{\nabla}$ & in & ڤ & ชิ \\
\hline से & $m$ & $\stackrel{\sim}{n}$ & $\hat{\lambda}$ & $m$ & $\vec{m}$ & $\dot{m}$ \\
\hline ค̊ ఏ & ? & ñ & $\underset{0}{0}$ & $\frac{a}{m}$ & Dי & $\underset{r}{+}$ \\
\hline 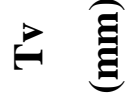 & $\begin{array}{l}n \\
\infty \\
i\end{array}$ & $\frac{0}{m}$ & $\stackrel{ \pm}{\Delta}$ & min. & 官 & ळे \\
\hline 들 & Oे & @ & $\begin{array}{l}a \\
\dot{\gamma}\end{array}$ & 市 & 年 & $\begin{array}{l}\vec{\infty} \\
-\end{array}$ \\
\hline$\Leftrightarrow$ छ & 囟 & 三 & & ָे & ○ & 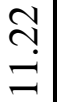 \\
\hline 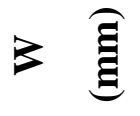 & $\begin{array}{l}\forall \\
\infty \\
\infty\end{array}$ & $\begin{array}{l}\infty \\
\stackrel{\infty}{d} \\
\dot{d}\end{array}$ & $\begin{array}{l}\infty \\
+ \\
\infty \\
-1\end{array}$ & ñ & ñ & 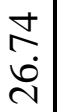 \\
\hline 刍 & 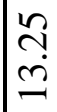 & $\begin{array}{l}\infty \\
\infty \\
\infty\end{array}$ & $\begin{array}{l}\stackrel{2}{m} \\
\text { m. }\end{array}$ & مo & 音 & ন্ \\
\hline ఠુ ఏ & $\begin{array}{l}\dot{\sigma} \\
\dot{\theta}\end{array}$ & 文 & $\begin{array}{l}\infty \\
\dot{\sigma}\end{array}$ & $\bar{a}$ & $\begin{array}{l}\infty \\
\infty \\
\infty\end{array}$ & $\begin{array}{l}\stackrel{\sim}{+} \\
\text { ป̀ }\end{array}$ \\
\hline 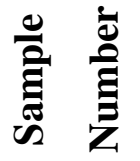 & ర్ర & $\underline{6}$ & $\underset{\sigma}{\sigma}$ & 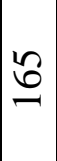 & 8 & 6 \\
\hline
\end{tabular}


Manitoulin Island, Ontario - Plaesiomys browni Table 3

\begin{tabular}{|c|c|c|c|c|c|c|c|c|c|c|c|c|c|c|c|c|c|c|c|c|c|c|}
\hline$\sum$ & & & 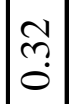 & ? & ले & 文 & 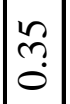 & 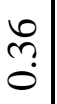 & $\begin{array}{l}m \\
m \\
0\end{array}$ & ?ִ & & & 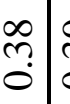 & \begin{tabular}{c|c} 
ले \\
ले
\end{tabular} & \begin{tabular}{lll}
$?$ \\
$?$ & 7 & \\
\hdashline
\end{tabular} & & & m. & $\bar{m}$ & & & ?] \\
\hline$\sum_{e}^{2}$ & ڤె. & & 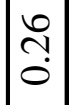 & in & 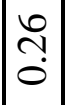 & $\bar{m}$ & 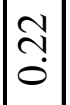 & 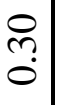 & ֶֻ. & 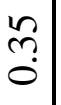 & în & तु & 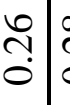 & 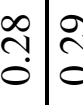 & $\bar{c}$ & & & ते & ָ̊. & & & \\
\hline 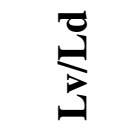 & & & $\mid \begin{array}{l}0 \\
0 \\
0\end{array}$ & $\hat{\sigma}$ & 文 & $\hat{a}$ & ڤ̊ & ڤ̊. & $\hat{\sigma}$ & ڤ̊ & ?ִ & & $\hat{\sigma}$ & 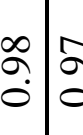 & 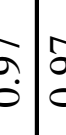 & के & $\hat{o}$ & $\hat{\sigma}$ & $\stackrel{n}{o}$ & & & \\
\hline 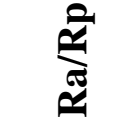 & & & $\stackrel{\mathcal{F}}{-}$ & & & ָे. & : & & & $\stackrel{?}{\rightarrow}$ & & & & & & & & & & & & \\
\hline $\mathscr{\approx}$ & 将 & & $\hat{n}$ & & & $\vec{m}$ & চ & & & 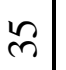 & & & & $\underset{c}{c}$ & & & & & & & & \\
\hline$\approx$ & & & $\stackrel{\sim}{~}$ & & & 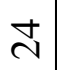 & $\approx$ & & & 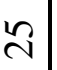 & & & & & & & & & & & & \\
\hline$\widehat{\theta} \widehat{\hat{g}}$ & $\begin{array}{l}\infty \\
i \\
i\end{array}$ & & $\stackrel{2}{m}$ & $\mid \begin{array}{l}n \\
\sim \\
i\end{array}$ & $\left|\begin{array}{c}\tilde{c} \\
\stackrel{i}{i}\end{array}\right|$ & $\begin{array}{l}\dot{H} \\
\dot{n}\end{array}$ & $\left|\begin{array}{c}\hat{b} \\
i\end{array}\right|$ & $\begin{array}{l}n \\
b \\
i \\
i\end{array} \mid$ & $\left|\begin{array}{c}\infty \\
\infty \\
i\end{array}\right|$ & $\stackrel{\infty}{\underset{n}{c}}$ & $\left|\begin{array}{c}\multirow{f}{f}{} \\
i\end{array}\right|$ & 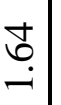 & \begin{tabular}{c|c}
$\infty$ \\
\\
\end{tabular} & 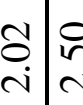 & 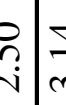 & & & 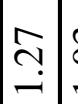 & ô. & & & \\
\hline$\rightleftarrows \widehat{\mathbb{g}}$ & & & 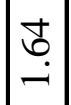 & $\stackrel{\mathscr{P}}{-}$ & 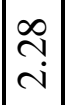 & مِ & $\left|\begin{array}{l}\infty \\
0 \\
i\end{array}\right|$ & $\stackrel{q}{\rightarrow}$ & 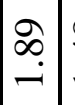 & $\stackrel{\infty}{\stackrel{\infty}{+}}$ & & $\overrightarrow{\widetilde{N}}$ & \begin{tabular}{c|c}
$n$ & \\
$i$ &
\end{tabular} & 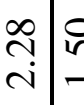 & حְ & & & $\stackrel{0}{0}$ & $\stackrel{\infty}{?}$ & & & \\
\hline 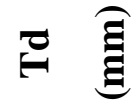 & $\frac{7}{6}$ & & $\mid \begin{array}{l}0 \\
\infty \\
i\end{array}$ & $\frac{m}{\pi}$ & $\left|\begin{array}{c}n \\
\infty \\
i\end{array}\right|$ & $\begin{array}{l}\infty \\
\infty \\
\dot{0}\end{array}$ & $\mid$\begin{tabular}{c} 
\pm \\
\hdashline$i$
\end{tabular} & 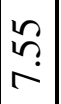 & $\left|\begin{array}{l}8 \\
\dot{1} \\
1\end{array}\right|$ & $\begin{array}{c}0 \\
b \\
\infty \\
\infty\end{array}$ & $\mid \begin{array}{l}0 \\
\stackrel{2}{i n} \\
\end{array}$ & 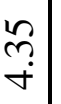 & $\begin{array}{ll}\hat{b} & \\
\dot{0} & \end{array}$ & \begin{tabular}{l|l}
$\delta$ & $\alpha$ \\
$i n$ & $\alpha$
\end{tabular} & 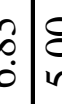 & & & $\mid$ & $\begin{array}{l}\text { aे } \\
\text { n. }\end{array}$ & & & $\mid \begin{array}{l}0 \\
\vdots \\
i\end{array}$ \\
\hline - & & & 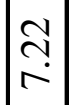 & $\left|\begin{array}{l}6 \\
\infty \\
\infty\end{array}\right|$ & $\mid \begin{array}{l}\infty \\
\infty \\
\sim \\
\sim\end{array}$ & $\begin{array}{l}\tilde{n} \\
i \\
\infty \\
\infty\end{array}$ & $\underset{\infty}{\stackrel{1}{\infty}}$ & $\begin{array}{l}\stackrel{2}{2} \\
\infty \\
\infty\end{array}$ & 皇 & $\begin{array}{c}0 \\
\vdots \\
\vdots \\
\vdots\end{array}$ & & $\begin{array}{l}0 \\
ٍ \\
0\end{array}$ & 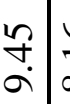 & 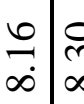 & $\begin{array}{lll}\vec{n} & \bar{\alpha} \\
\infty & 0 & 0\end{array}$ & & & $\stackrel{2}{\sim}$ & $\stackrel{\infty}{\sim}$ & & & \\
\hline$\geqslant \widehat{\mathrm{E}}$ & $\begin{array}{l}0 \\
0 \\
0 \\
\dot{m}\end{array}$ & $\mid \begin{array}{l}\overrightarrow{0} \\
\dot{2}\end{array}$ & 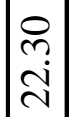 & $\left|\begin{array}{l}m \\
\stackrel{\sim}{\dot{d}}\end{array}\right|$ & 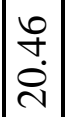 & 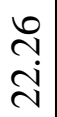 & 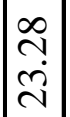 & $\begin{array}{l}n \\
\dot{a} \\
i\end{array}$ & $\mid \begin{array}{l}\stackrel{\vec{\lambda}}{\vec{\lambda}} \\
\mid\end{array}$ & 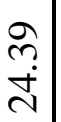 & $\left|\begin{array}{c}\infty \\
\hdashline \\
\vec{\lambda}\end{array}\right|$ & 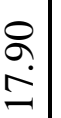 & 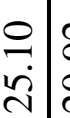 & 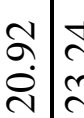 & 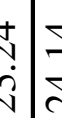 & $\mid \begin{array}{l}\infty \\
\stackrel{i}{\infty} \\
\dot{i}\end{array}$ & $\left|\begin{array}{l}\infty \\
\infty \\
i \\
i\end{array}\right|$ & $\left|\begin{array}{l}0 \\
\infty \\
\dot{i} \\
\dot{\nu}\end{array}\right|$ & 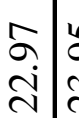 & $\begin{array}{l}n \\
\vdots \\
\vec{n}\end{array}$ & & 站 \\
\hline 忿 & & $\mid \begin{array}{l}20 \\
\dot{0} \\
0\end{array}$ & $\stackrel{ }{i}$ & $\mid \begin{array}{l}n \\
\tilde{n} \\
\infty \\
\infty\end{array}$ & 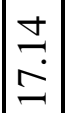 & $\begin{array}{l}\dot{1} \\
\infty \\
\infty\end{array}$ & $\begin{array}{l}= \\
\infty \\
\infty\end{array}$ & $\begin{array}{l}m \\
\stackrel{2}{2}\end{array}$ & 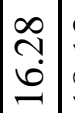 & $\begin{array}{c}m \\
\stackrel{0}{\infty} \\
-1\end{array}$ & 吕 & $\begin{array}{l}\vec{b} \\
\dot{\Xi}\end{array}$ & \begin{tabular}{l|l}
$\vec{T}$ & 0 \\
$\infty$ & 0 \\
0 & 0
\end{tabular} & 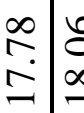 & 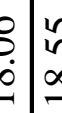 & $\frac{n}{8}$ & $\mid \begin{array}{l}\infty \\
\infty \\
\\
\end{array}$ & 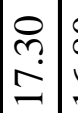 & $\begin{array}{l}0 \\
\infty \\
\dot{0}\end{array}$ & & & \\
\hline Ð & $\begin{array}{l}\hat{A} \\
\dot{\lambda}\end{array}$ & & $\mid \begin{array}{c}2 \\
\text { ले } \\
\infty\end{array}$ & $\mid \begin{array}{l}\infty \\
n \\
\infty \\
-1\end{array}$ & 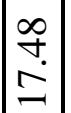 & $\frac{n}{9}$ & $\left|\begin{array}{l}\vec{D} \\
\infty \\
\infty\end{array}\right|$ & $\begin{array}{l}\hat{\sigma} \\
\stackrel{2}{2}\end{array}$ & $\left|\begin{array}{c}0 \\
\infty \\
0 \\
0\end{array}\right|$ & $\begin{array}{l}\stackrel{1}{\infty} \\
\dot{\infty} \\
\infty\end{array}$ & $\mid$\begin{tabular}{c}
\multirow{2}{*}{} \\
$\infty$ \\
$\infty$ \\
-1
\end{tabular} & $\begin{array}{l}\vec{b} \\
\dot{ \pm}\end{array}$ & \begin{tabular}{l|l}
$\tilde{N}$ & \\
$\Omega$ &
\end{tabular} & 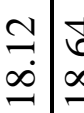 & 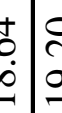 & 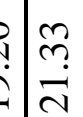 & $\mid$\begin{tabular}{l}
0 \\
\multirow{2}{2}{} \\
2
\end{tabular} & 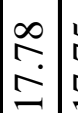 & $\begin{array}{l}n \\
\\
\end{array}$ & a & & 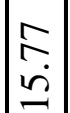 \\
\hline 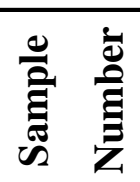 & 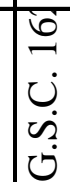 & $\begin{array}{l}\dot{\sigma} \\
ن \\
\dot{0} \\
ن \\
ن\end{array}$ & - & $N \mid$ & $m$ & $\nabla$ & $\ln$ & 6 & 1 & $\infty$ & a & 으 & $=5$ & $\simeq \cong$ & $\therefore=$ & 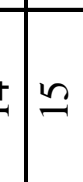 & 0 & 二 & $\infty$ & 9 & & $\vec{\sim}$ \\
\hline
\end{tabular}


Manitoulin Island, Ontario - Plaesiomys browni Table 3 (continued)

\begin{tabular}{|c|c|c|c|c|}
\hline 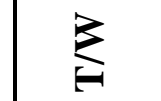 & & & & \\
\hline 粍 & & & & \\
\hline 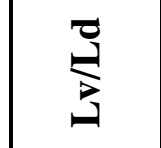 & $\left|\begin{array}{l}2 \\
\infty \\
0\end{array}\right|$ & ఫू & & \\
\hline 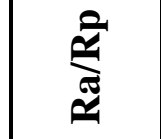 & & & & \\
\hline$\underset{\approx}{\approx}$ & & & & \\
\hline से & & & & \\
\hline 乞 $\widehat{\Xi}$ & & & & \\
\hline 己 & & & & \\
\hline 동 & & & & \\
\hline$-\widehat{\text { ह }}$ & & & & \\
\hline 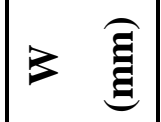 & \begin{tabular}{l}
0 \\
\multirow{2}{*}{} \\
2
\end{tabular} & 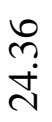 & $\begin{array}{l}8 \\
0 \\
\vdots \\
\end{array}$ & $\begin{array}{l}\infty \\
\dot{a} \\
\text { ì }\end{array}$ \\
\hline 臣 & \begin{tabular}{l|}
$\vec{\sigma}$ \\
$\dot{ \pm}$
\end{tabular} & $\stackrel{\substack{n\\
}}{-}$ & 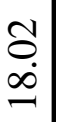 & 莳 \\
\hline త્વ & \begin{tabular}{l}
$\exists$ \\
\hdashline \\
0
\end{tabular} & 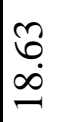 & & \\
\hline 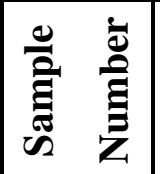 & ลี & $\ddot{\sim}$ & $\stackrel{\sim}{\Delta}$ & $\dddot{\sim}$ \\
\hline
\end{tabular}


- Plaesiomys subcircularis Table 4

\begin{tabular}{|c|c|c|c|c|}
\hline 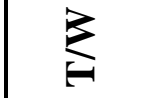 & 象 & $\hat{n}$ & $\stackrel{m}{+}$ & $\stackrel{f}{0}$ \\
\hline$\sum^{z}$ & ֻั & $\stackrel{⿱ 亠 凶}{0}$ & ஸ̊ & 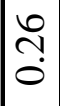 \\
\hline 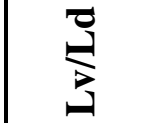 & gे & o̊ & $\begin{array}{l}\infty \\
0 \\
0\end{array}$ & $\frac{n}{a}$ \\
\hline 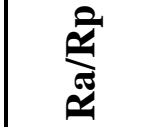 & $\bar{a}$ & & ñ & $\underset{8}{8}$ \\
\hline$\stackrel{\mathscr{T}}{\mathcal{2}}$ & 寸 & & $n$ & 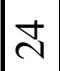 \\
\hline a & 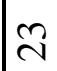 & & Nิ & $\stackrel{\sim}{\sim}$ \\
\hline $\mathscr{\rho}$ छ & $\frac{0}{0}$ & $\begin{array}{l}\infty \\
\infty \\
0\end{array}$ & $\stackrel{0}{0}$ & $\stackrel{0}{\stackrel{0}{0}}$ \\
\hline $\overrightarrow{\widehat{\Xi}}$ & $\mathscr{\infty}$ & $\stackrel{\infty}{\infty}$ & $\bar{n}$ & 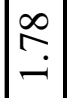 \\
\hline 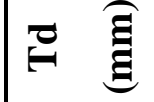 & 華 & $\begin{array}{l}\frac{0}{m} \\
\dot{m}\end{array}$ & $\begin{array}{c}n \\
\dot{r} \\
\dot{\sigma}\end{array}$ & $\frac{m}{m}$ \\
\hline 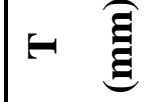 & $\begin{array}{l}6 \\
6 \\
0\end{array}$ & $\begin{array}{l}n \\
\infty \\
1 \\
1\end{array}$ & $\underset{\infty}{\infty}$ & $\hat{n}$ \\
\hline $\overrightarrow{\mathrm{E}}$ & ? & $\begin{array}{l}0 \\
a \\
\text { in }\end{array}$ & $\underset{\partial}{\sigma}$ & $\frac{m}{2}$ \\
\hline$\exists$ छ & $\begin{array}{l}n \\
\stackrel{n}{r} \\
\ddot{r}\end{array}$ & ๙̃ & $\begin{array}{l}0 \\
0 \\
\dot{n} \\
\end{array}$ & กै? \\
\hline ర્ఏ ఏ & $\begin{array}{l}6 \\
\dot{6} \\
\end{array}$ & $\stackrel{n}{\stackrel{n}{c}}$ & $\begin{array}{l}0 \\
m \\
m\end{array}$ & $\hat{\gamma}$ \\
\hline 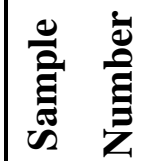 & 이 & $\bar{\sim}$ & $\stackrel{\infty}{\sim}$ & ฉิ \\
\hline
\end{tabular}

\begin{tabular}{|c|c|c|c|c|c|c|c|c|}
\hline$\xi$ & $\stackrel{\infty}{\sim}$ & 文 & ָे & ñ & ñ. & ñ. & ñ & $\stackrel{1}{0}$ \\
\hline$\sum^{3}$ & $\stackrel{n}{0}$ & $\frac{0}{0}$ & $\frac{\infty}{0}$ & $\frac{1}{0}$ & $\frac{9}{0}$ & กิ & $\frac{9}{0}$ & $\frac{a}{0}$ \\
\hline 艿 & ڤ్ & $\hat{a}$ & & 8 & ई़े & o̊ & ๙ু & Oֵ. \\
\hline 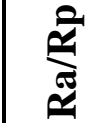 & ? & $\stackrel{\text { fo }}{\sim}$ & 무 & $\stackrel{\infty}{+}$ & $\stackrel{\infty}{n}$ & $\stackrel{n}{n}$ & & \\
\hline$\stackrel{\mathscr{*}}{\approx}$ & $\bar{n}$ & $\stackrel{\infty}{+}$ & F & q & $\infty$ & g) & & \\
\hline 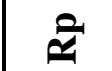 & m & $m$ & m & $m$ & 志 & $\tilde{n}$ & & \\
\hline$\stackrel{\Xi}{\Xi}$ & $\stackrel{\Omega}{2}$ & ñ & すே & $\stackrel{?}{\stackrel{0}{\tau}}$ & $\frac{9}{2}$ & - & g. & 웅. \\
\hline$\Rightarrow \Xi$ & $\hat{n}$ & $\infty$ & ? & ণ̃ & পి & â & $\underline{\sigma}$ & $\stackrel{m}{=}$ \\
\hline 로 & 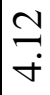 & in & ñ & के & $\ddot{m}$ & $\underset{\dot{\sigma}}{\infty}$ & $\begin{array}{l}n \\
\dot{n} \\
\dot{m}\end{array}$ & $\begin{array}{l}\text { No } \\
\infty \\
\text { di }\end{array}$ \\
\hline$\in \hat{\mathrm{g}}$ & $\begin{array}{l}8 \\
\text { in }\end{array}$ & 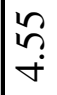 & $\frac{\infty}{m}$ & స్ & ఫै & ڤ̊ & $\begin{array}{l}\infty \\
0 \\
\text { in }\end{array}$ & $\stackrel{n}{a}$ \\
\hline$z \widehat{\Xi}$ & $\stackrel{\substack{0 \\
\infty}}{\infty}$ & กิ & $\begin{array}{l}\tilde{g} \\
\dot{n}\end{array}$ & $\underset{\infty}{ \pm}$ & $\stackrel{\infty}{=}$ & $\begin{array}{l}0 \\
\infty \\
\infty\end{array}$ & $\begin{array}{l}\stackrel{0}{i} \\
\text { in }\end{array}$ & $\begin{array}{l}n \\
\infty \\
\dot{J}\end{array}$ \\
\hline 今 & กั & $\begin{array}{l}6 \\
0 \\
1 \\
1\end{array}$ & E & ڤे & $\stackrel{m}{\stackrel{2}{ \pm}}$ & 寺 & $\underline{n}$ & 占 \\
\hline 오 & $\begin{array}{l}\text { రิ } \\
\pm \\
\pm\end{array}$ & $\begin{array}{l}\dot{y} \\
m \\
\ddot{2}\end{array}$ & $\stackrel{m}{m}$ & $\hat{a}$ & $\begin{array}{l}\infty \\
\dot{ \pm}\end{array}$ & సิ & $\begin{array}{l}m \\
\stackrel{2}{c} \\
\sim\end{array}$ & $\stackrel{テ}{\Xi}$ \\
\hline 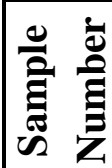 & - & $N$ & $m$ & $\checkmark$ & $n$ & 6 & $r$ & $\infty$ \\
\hline
\end{tabular}


Mackenzie Mountains, Northwest Territories - Plaesiomys columbia (top)

Plaesiomys periosa (bottom) Table 5

\begin{tabular}{|c|c|c|c|c|c|c|c|c|c|}
\hline$\sum$ & ñ & $\stackrel{\sim}{+}$ & ๗ે. & in & & & & & \\
\hline$\sum_{0}^{2}$ & 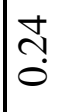 & $\begin{array}{l}n \\
n \\
0\end{array}$ & กิ & $\stackrel{0}{+}$ & $\stackrel{m}{m}$ & $\tilde{n}$ & & & \\
\hline 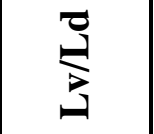 & $\hat{a}$ & $\hat{a}$ & ڤ̊ & aे & & & & & \\
\hline 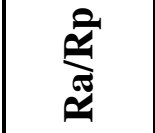 & ?n & $\bar{n}$ & ñ & $\underline{\sigma}$ & ?ֶ? & & & & \\
\hline$\underset{4}{\mathscr{4}}$ & $\stackrel{\mathcal{F}}{\leftarrow}$ & m & 寸 & กn & $\hat{n}$ & & & & \\
\hline$\hat{\sim}$ & $\bar{n}$ & $\stackrel{\leftrightarrow}{\sim}$ & $\stackrel{\infty}{\sim}$ & ñ & $\stackrel{\infty}{\sim}$ & & & & \\
\hline ค̊ $\hat{\Xi}$ & oे & 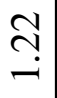 & $\frac{n}{r}$ & $\begin{array}{l}\text { ते } \\
\text { in }\end{array}$ & & & $\ddot{n}$ & $\begin{array}{l}\infty \\
\infty \\
0 \\
0\end{array}$ & $\infty$ \\
\hline $\overrightarrow{\underline{\Xi}}$ & $\stackrel{n}{\infty}$ & $\stackrel{\infty}{\underset{+}{+}}$ & $\stackrel{n}{n}$ & 尚 & & & $\begin{array}{l}\infty \\
\dot{+} \\
\dot{r}\end{array}$ & $\stackrel{N}{\stackrel{N}{n}}$ & $\stackrel{n}{\stackrel{n}{r}}$ \\
\hline 토 & さัષ & $\frac{1}{0}$ & $\begin{array}{c}N \\
n \\
\infty\end{array}$ & $\frac{n}{6}$ & $\begin{array}{l}n \\
\infty \\
\infty\end{array}$ & $\begin{array}{l}n \\
n \\
0\end{array}$ & & & \\
\hline- छ & $\frac{n}{a}$ & ํ. & $\begin{array}{l}0 \\
\stackrel{1}{c} \\
\end{array}$ & व̊ & & & & & \\
\hline$>$ छ & $\begin{array}{l}\hat{\sigma} \\
\ddot{1}\end{array}$ & $\begin{array}{l}\infty \\
\infty \\
0 \\
0 \\
\end{array}$ & $\begin{array}{l}g \\
\dot{\theta} \\
\dot{m}\end{array}$ & 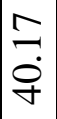 & ? & 穵 & $\begin{array}{l}0 \\
\stackrel{0}{\infty} \\
\infty \\
N\end{array}$ & $\frac{\Xi}{\stackrel{ \pm}{d}}$ & 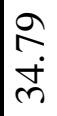 \\
\hline 念 & 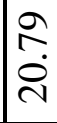 & $\begin{array}{l}\stackrel{0}{ } \\
\text { N̦} \\
\stackrel{\text { }}{ }\end{array}$ & $\begin{array}{l}90 \\
\text { ஸे }\end{array}$ & 吕 & & & 官 & $\begin{array}{l}n \\
\infty \\
\infty\end{array}$ & $\begin{array}{l}n \\
\infty \\
\end{array}$ \\
\hline ర્ఏ ఏ & $\frac{m}{\sim}$ & হি & $\begin{array}{l}\infty \\
\infty \\
\infty \\
\infty\end{array}$ & 文 & 导 & $\begin{array}{l}n \\
i \\
2\end{array}$ & & & \\
\hline 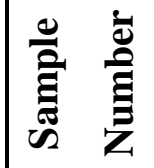 & - & $N$ & $n$ & $\nabla$ & in & 10 & $r$ & $\infty$ & $a$ \\
\hline
\end{tabular}

\begin{tabular}{|c|c|c|c|}
\hline$\xi$ & $\stackrel{\stackrel{f}{f}}{\circ}$ & & \\
\hline$\sum$ & กै & & \\
\hline$\underbrace{\stackrel{3}{3}}_{3}$ & ڤ̊ & & \\
\hline$\stackrel{2}{a}$ & & & \\
\hline 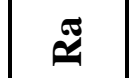 & & & \\
\hline$\stackrel{2}{a}$ & & & \\
\hline 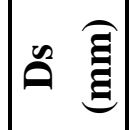 & $\begin{array}{l}\infty \\
\infty \\
\infty \\
\infty\end{array}$ & $\begin{array}{l}8 \\
\dot{0} \\
-1\end{array}$ & \\
\hline$>\widehat{\Xi}$ & $\frac{m}{n}$ & 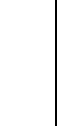 & $\stackrel{ \pm}{=}$ \\
\hline$=\widehat{\Xi}$ & $\begin{array}{l}\infty \\
\stackrel{\infty}{a} \\
\end{array}$ & $\begin{array}{l}\alpha \\
\infty \\
-\end{array}$ & \\
\hline 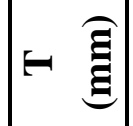 & $\begin{array}{l}n \\
\dot{d}\end{array}$ & & \\
\hline 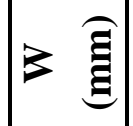 & 年 & & \\
\hline 百 & 旾 & & $\begin{array}{l}\infty \\
\dot{f}\end{array}$ \\
\hline ટ્ટ & ले & $\begin{array}{l}n \\
\\
\dot{q}\end{array}$ & \\
\hline 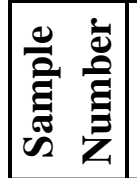 & - & $N$ & $m$ \\
\hline
\end{tabular}


Mackenzie Mountains, Northwest Territories - Plaesiomys lenzi (top)

Plaesiomys bellistriatus ? (bottom) Table 5

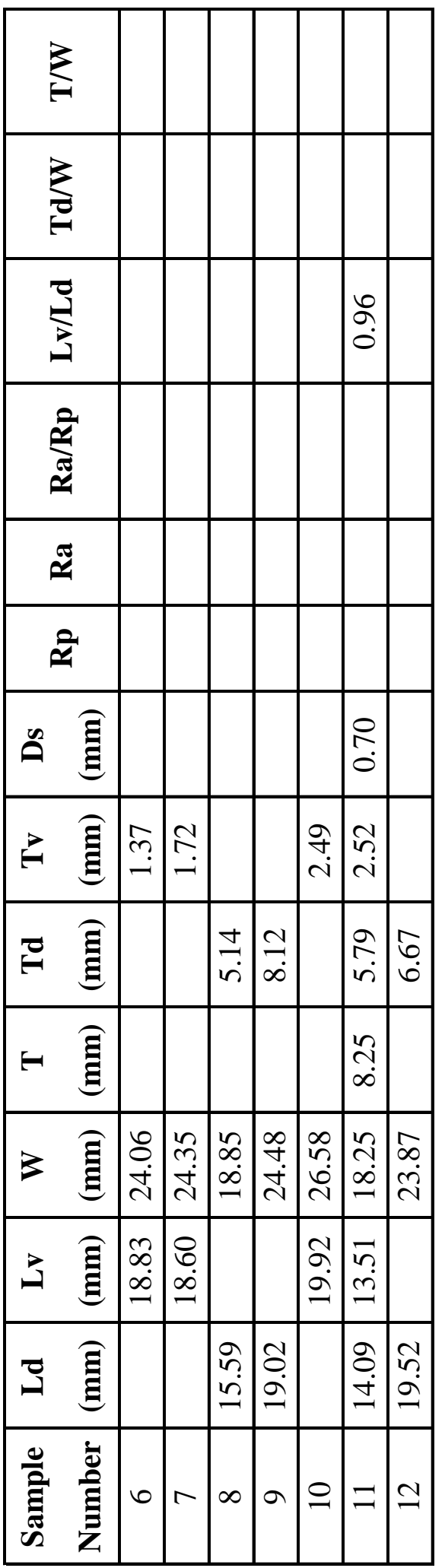

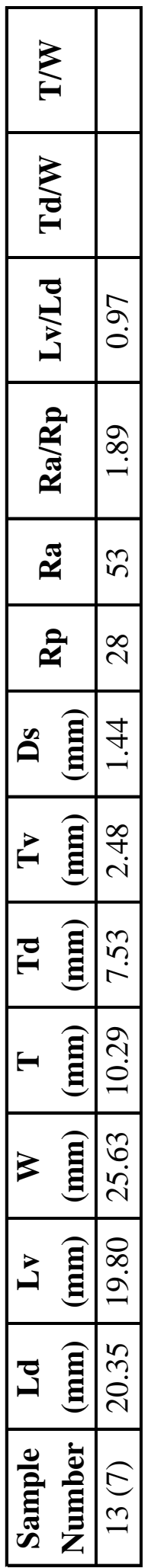


Ohio-Kentucky-Indiana tri-state area - Plaesiomys subquadrata Table 6

\begin{tabular}{|c|c|c|c|c|c|c|c|c|c|c|c|c|c|c|c|c|c|c|c|c|c|c|c|}
\hline$\xi$ & 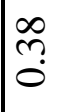 & & $\stackrel{+}{+}$ & ले & $\stackrel{\infty}{\infty}$ & ๗ે & $\stackrel{\infty}{\infty}$ & $\ddot{n}$ & $\stackrel{\overbrace{}}{\dot{\theta}}$ & ڤ̊ & $\stackrel{+}{\dot{Z}}$ & $\stackrel{\sim}{\stackrel{Y}{*}}$ & 吕 & ñ & ? & 官 & 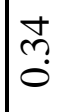 & $\begin{array}{l}n \\
\stackrel{f}{+} \\
0\end{array}$ & $\stackrel{\forall}{+}$ & ñ & $\stackrel{\forall}{\ominus}$ & ষ্ণ & $\stackrel{m}{+}$ \\
\hline$\sum$ & ?̊ & & $\stackrel{\overbrace{}}{0}$ & 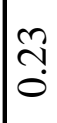 & $\stackrel{\overbrace{}}{0}$ & 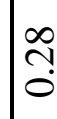 & ֻొ & $\frac{0}{0}$ & $\tilde{n}$ & సิ & mె? & กี & ñ & ñ. & $\tilde{\overbrace{}}$ & 吕 & ก̃ & $\begin{array}{c}0 \\
\tilde{n} \\
0\end{array} \mid$ & $\bar{m}$ & $\stackrel{0}{\sim}$ & $\stackrel{n}{\tilde{m}}$ & $\stackrel{m}{m}$ & ڤ̊ \\
\hline 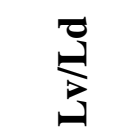 & o̊ & $\mid \begin{array}{l}\infty \\
0 \\
0\end{array}$ & $\underset{8}{8}$ & - & $\hat{\sigma}$ & ڤे & 文 & $\underset{-}{8}$ & $\hat{a}$ & $\stackrel{\infty}{\varrho}$ & $\stackrel{n}{\tilde{o}}$ & $\underset{\infty}{\infty}$ & 富 & $\hat{a}$ & @̊ & $\stackrel{\infty}{\infty}$ & ळ. & $\left|\begin{array}{l}n \\
\hat{o}\end{array}\right|$ & ○. & $\hat{\sigma}$ & \% & @̊ & ڤ̊ \\
\hline$\stackrel{\text { }}{2}$ & r & $\frac{n}{i}$ & 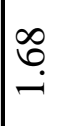 & - & $\hat{\sigma}$ & $\stackrel{+}{\sim}$ & $\begin{array}{l}\tilde{b} \\
\sim\end{array}$ & $\hat{n}$ & & & $\underline{\sigma}$ & $\begin{array}{l}8 \\
\text { i }\end{array}$ & $\stackrel{\infty}{\sim}$ & $\stackrel{\infty}{\stackrel{\infty}{\sim}}$ & & $\stackrel{0}{i}$ & $\hat{a}$ & & 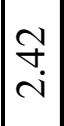 & $\stackrel{\infty}{+}$ & $\stackrel{\vec{b}}{-}$ & $\begin{array}{l}\infty \\
\infty \\
-\end{array}$ & $\stackrel{\circ}{i}$ \\
\hline$\stackrel{\mathscr{2}}{\mathscr{2}}$ & 8 & in & $\hat{n}$ & $\stackrel{n}{7}$ & 6 & ষ & $\bar{\gamma}$ & 于 & & & 8 & 6 & $\cong$ & in & & 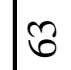 & $\nabla$ & & $\curvearrowleft$ & fo & $n$ & 8 & $\infty$ \\
\hline ฉิ & m & ○ & ป & $\widehat{\sim}$ & $\tilde{m}$ & $\stackrel{m}{m}$ & ㄱ & ○ & in & & D & $m$ & $\tilde{n}$ & $\approx$ & & en & o & & $\bar{m}$ & $\bar{n}$ & $m$ & 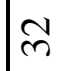 & in \\
\hline ค̊ ఏ & $\stackrel{\sigma}{\infty}$ & & $\stackrel{a}{n}$ & $\stackrel{\overbrace{}}{\stackrel{\Upsilon}{-}}$ & $\stackrel{n}{\infty}$ & $\begin{array}{l}\overline{0} \\
\text { i }\end{array}$ & $\stackrel{\sim}{\stackrel{\sim}{*}}$ & $\exists$ & $\begin{array}{l}\qquad r \\
\\
m\end{array}$ & $\frac{n}{2}$ & $\frac{N}{\sim}$ & $\stackrel{n}{\infty}$ & 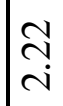 & $a$ & $\stackrel{?}{\stackrel{f}{-}}$ & ב & กֵ & $\underline{m}$ & $\begin{array}{c}0 \\
0 \\
ن\end{array}$ & $\begin{array}{l}\infty \\
\infty \\
\infty \\
-\end{array}$ & 节 & ب0 & $\stackrel{\infty}{\infty}$ \\
\hline$\Rightarrow$ छ & $\vec{\sim}$ & & $\frac{ \pm}{2}$ & $\ddot{a}$ & ri & $\sqrt{n}$ & $\hat{\sigma}$ & $\frac{ \pm}{2}$ & ホั & $\overline{\text { ज. }}$ & $\begin{array}{l}\infty \\
n \\
\sim \\
\sim\end{array}$ & $\begin{array}{l}\infty \\
n \\
\sim \\
\sim\end{array}$ & $\stackrel{N}{\stackrel{N}{r}}$ & r. & ri & ñ & ๙ุ & $\begin{array}{l}\infty \\
n \\
\forall\end{array}$ & $\begin{array}{l}\stackrel{R}{r} \\
\dot{r}\end{array}$ & ñ & $\begin{array}{l}0 \\
i \\
i\end{array}$ & ấ & ڤ. \\
\hline 토 & 常 & & ñ & $\stackrel{\stackrel{\sim}{f}}{\underset{f}{*}}$ & ĭ & $\begin{array}{l}\infty \\
n \\
0\end{array}$ & $\begin{array}{l}n \\
\infty \\
\infty\end{array}$ & $\frac{1}{2}$ & $\begin{array}{l}0 \\
\infty \\
\infty\end{array}$ & ñ & $\bar{r}$ & กิ & 官 & $\frac{1}{a}$ & ने & ñ & ป̂. & $\begin{array}{l}0 \\
\infty \\
\infty\end{array}$ & 它 & חִ & 吕. & $\underset{\infty}{\infty}$ & ?̊ \\
\hline - छ & $\begin{array}{l}0 \\
\infty \\
\infty\end{array}$ & & $\begin{array}{l}\infty \\
\infty \\
\dot{n}\end{array}$ & 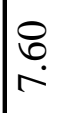 & $\stackrel{\infty}{\sigma}$ & ปุ & 끔 & $\bar{n}$ & In & ?n & $\bar{\sigma}$ & 声 & $\underset{\Xi}{O}$ & $\begin{array}{l}\infty \\
n \\
\\
\end{array}$ & 告 & $\begin{array}{c}0 \\
0 \\
1 \\
1\end{array}$ & $\begin{array}{l}\infty \\
\infty \\
\infty \\
\infty\end{array}$ & $\begin{array}{l}\bar{\sigma} \\
\dot{q}\end{array}$ & $\stackrel{m}{n}$ & $\begin{array}{l}\infty \\
\infty \\
\infty\end{array}$ & 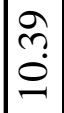 & ò & ָ̃ \\
\hline$\gtrless$ छ & $\begin{array}{l}\hat{0} \\
\dot{2}\end{array}$ & $\begin{array}{l}\infty \\
\sim \\
\sim \\
\end{array}$ & ra & ֻั & $\begin{array}{l}\bar{\infty} \\
\dot{J}\end{array}$ & $\begin{array}{l}\bar{a} \\
\text { nे }\end{array}$ & \begin{tabular}{l}
$n$ \\
\multirow{2}{N}{}
\end{tabular} & $\begin{array}{l}\infty \\
n \\
\end{array}$ & $\begin{array}{l}\hat{O} \\
\dot{J}\end{array}$ & $\begin{array}{l}0 \\
\hat{0}\end{array}$ & वั & $\begin{array}{l}0 \\
n \\
\infty \\
\infty\end{array}$ & $\begin{array}{l}\widetilde{\sigma} \\
\infty \\
\infty \\
\sim\end{array}$ & $\begin{array}{l}\stackrel{શ}{+} \\
\dot{J}\end{array}$ & $\begin{array}{l}\infty \\
\infty \\
\grave{\sim}\end{array}$ & 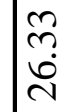 & 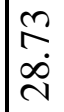 & $\begin{array}{l}\bar{r} \\
\grave{n} \\
0\end{array}$ & $\mid \begin{array}{l}\infty \\
\stackrel{\dot{d}}{m} \\
\end{array}$ & $\begin{array}{l}\stackrel{8}{+} \\
\stackrel{\sim}{\sim}\end{array}$ & $\begin{array}{l}\tilde{\sigma} \\
\dot{v}\end{array}$ & $\begin{array}{l}\infty \\
\infty \\
\dot{d}\end{array}$ & ĩ \\
\hline 点 & ñ & $\stackrel{\infty}{\infty}$ & 旾 & $\begin{array}{l}\infty \\
\vdots \\
\pm \\
+\end{array}$ & å & $\begin{array}{l}0 \\
\infty \\
\infty \\
0\end{array}$ & 응 & $\begin{array}{l}+ \\
\infty \\
\end{array}$ & ố & $\frac{\infty}{\tilde{d}}$ & 年 & רั & ลิ & $\frac{d}{d}$ & ì & 綮 & $\frac{\pi}{\stackrel{a}{2}}$ & बें & $\begin{array}{l}\infty \\
n \\
n \\
n \\
n\end{array}$ & $\frac{1}{6}$ & $\frac{m}{\infty}$ & ọ. & $\begin{array}{l}\hat{\sigma} \\
\text { ஸे }\end{array}$ \\
\hline 도 & $\underset{\infty}{\stackrel{2}{\infty}}$ & $\begin{array}{l}\sigma \\
\dot{0} \\
\infty\end{array}$ & $\begin{array}{l}\infty \\
\infty \\
0 \\
0\end{array}$ & J & จุ & $\begin{array}{l}0 \\
+ \\
\infty \\
0\end{array}$ & 守 & $\begin{array}{l}8 \\
\text { บุ }\end{array}$ & ñ & in & 웅 & $\begin{array}{l}\infty \\
\infty \\
\dot{\gamma}\end{array}$ & 苞 & ন্ঠ & $\begin{array}{l}8 \\
\text { ते }\end{array}$ & مू & 㐫 & $\begin{array}{l}\vec{\sim} \\
\text { ra }\end{array}$ & $\begin{array}{l}\hat{b} \\
\dot{0} \\
\sim\end{array}$ & $\begin{array}{l}\sigma \\
6 \\
0\end{array}$ & $\begin{array}{l}\infty \\
\infty \\
\infty \\
\infty\end{array}$ & $\hat{\sigma}$ & $\begin{array}{l}\text { in } \\
\text { ป }\end{array}$ \\
\hline 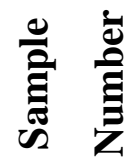 & - & $\sim$ & $m$ & $\nabla$ & $n$ & 6 & N & $\infty$ & a & 으 & $=$ & $\simeq$ & 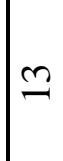 & 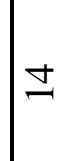 & 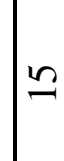 & $\underline{6}$ & 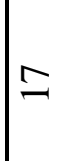 & $\infty$ & 9 & $\stackrel{\overbrace{}}{\circ}$ & $\vec{\sim}$ & ป & $\ddot{n}$ \\
\hline
\end{tabular}


Ohio-Kentucky-Indiana tri-state area - Plaesiomys subquadrata (continued - top)

Plaesiomys cf. P. bellistriatus (bottom) Table 6

\begin{tabular}{|c|c|c|c|c|c|c|c|c|}
\hline 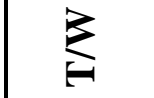 & के & $\stackrel{\stackrel{\sim}{+}}{\circ}$ & 官 & 文 & ñ & के & 里 & ले \\
\hline$\sum$ & 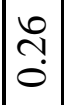 & $\begin{array}{l}m \\
\tilde{n} \\
0\end{array}$ & ?ִ & $\stackrel{\Xi}{\Xi}$ & 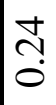 & ấ & ஸे & ஸ̃ \\
\hline$\underset{3}{\stackrel{2}{3}}$ & $\begin{array}{l}\infty \\
a \\
0\end{array}$ & ڤे & $\hat{0}$ & ô. & \% & 年 & $\hat{a}$ & $\mid \begin{array}{l}\infty \\
0 \\
0\end{array}$ \\
\hline ֻै & $\underline{a}$ & $\begin{array}{l}\hat{0} \\
i\end{array} \mid$ & i & $\stackrel{\sim}{\stackrel{f}{\sim}}$ & în & $\stackrel{+}{\infty}$ & 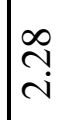 & $\mid \begin{array}{l} \pm \\
\text { i }\end{array}$ \\
\hline$\stackrel{\mathscr{*}}{\mathscr{4}}$ & in & ชิ & $\infty$ & $\hat{n}$ & สర & in & 6 & 于 \\
\hline से & 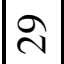 & in & m & $\stackrel{\sim}{\sim}$ & $\widehat{\curvearrowright}$ & $\approx$ & $\curvearrowright$ & $\approx$ \\
\hline 气̊ & ִֻ & $\infty$ & $\ddot{n}$ & mె & $\begin{array}{l}n \\
\infty \\
0\end{array}$ & $\underset{1}{\infty}$ & 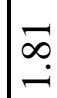 & 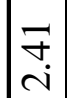 \\
\hline $\overrightarrow{\widehat{\Xi}}$ & $\begin{array}{l}0 \\
0 \\
i\end{array}$ & $\tilde{\sigma}$ & $\begin{array}{l}0 \\
0 \\
i\end{array}$ & 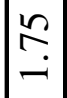 & 年 & ते & $\stackrel{\theta}{m}$ & $\begin{array}{l}\tilde{\infty} \\
\infty \\
\dot{i}\end{array}$ \\
\hline E & $\begin{array}{l}\infty \\
a \\
i\end{array}$ & $\mid \begin{array}{l}\sigma \\
\infty \\
\infty\end{array}$ & $\frac{m}{a}$ & $\begin{array}{l}\Xi \\
\check{c}\end{array}$ & $\begin{array}{l}n \\
\text { in }\end{array}$ & 早 & ஸे & ָ̃ \\
\hline$-\widehat{\Xi}$ & $\frac{a}{a}$ & \begin{tabular}{l}
0 \\
\multirow{2}{0}{} \\
0
\end{tabular} & $\begin{array}{l}\infty \\
\infty \\
\end{array}$ & $\underset{c}{\simeq}$ & io & $\begin{array}{l}0 \\
0 \\
0\end{array}$ & $\begin{array}{l}\infty \\
\infty \\
\infty\end{array}$ & $\begin{array}{l}\infty \\
\infty \\
0\end{array}$ \\
\hline ఏ & $\begin{array}{l}\stackrel{\rho}{+} \\
\dot{v} \\
\dot{\lambda}\end{array}$ & $\begin{array}{l}\text { ๙̃ } \\
\text { ป̂. }\end{array}$ & $\begin{array}{l}\overline{0} \\
\dot{0} \\
\text { ñ }\end{array}$ & $\begin{array}{l}\tilde{\sigma} \\
\dot{\theta}\end{array}$ & $\frac{\infty}{\sim}$ & $\begin{array}{l}2 \\
\check{n} \\
\end{array}$ & in & $\begin{array}{l}\text { mे } \\
\text { ñ } \\
\text { ñ }\end{array}$ \\
\hline 今 畐 & $\begin{array}{l}0 \\
2 \\
-1\end{array}$ & 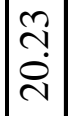 & $\begin{array}{l}\infty \\
\infty \\
\infty \\
\end{array}$ & $\frac{n}{a}$ & $\stackrel{\infty}{-}$ & 㝘 & $\begin{array}{l}0 \\
\infty \\
\infty\end{array}$ & $\stackrel{a}{\check{2}}$ \\
\hline ت્ఏ ఏ & $\begin{array}{l}\infty \\
\infty \\
\infty\end{array}$ & กิ & $\begin{array}{l}\bar{\sigma} \\
\dot{\sim}\end{array}$ & $\begin{array}{l}\infty \\
\ddot{0} \\
0\end{array}$ & 焉 & 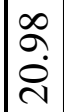 & a & 染 \\
\hline 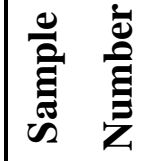 & $\stackrel{d}{d}$ & $\stackrel{n}{\sim}$ & 인 & $\widehat{N}$ & $\stackrel{\infty}{\sim}$ & নे & 요 & $\approx$ \\
\hline
\end{tabular}

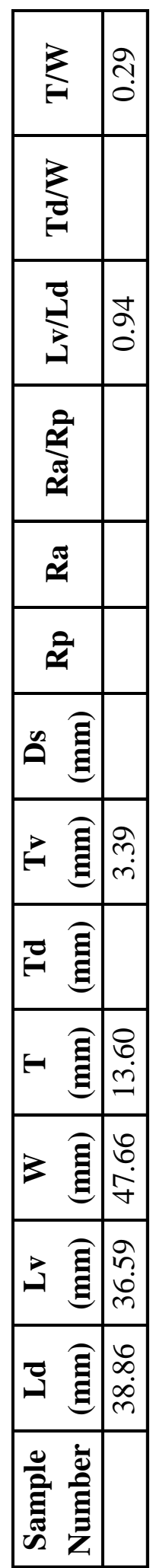


Ohio-Kentucky-Indiana tri-state area - Plaesiomys bellistriatus (top), Illinois - Plaesiomys

bellistriatus (middle), Oklahoma - Austinella multicostella (bottom) Table 6

\begin{tabular}{|c|c|c|}
\hline$\xi$ & 呇 & $\stackrel{f}{+}$ \\
\hline$\sum^{3}$ & $\stackrel{\sim}{ナ}$ & ñ? \\
\hline 莫 & $\hat{\sigma}$ & $\tilde{a}$ \\
\hline 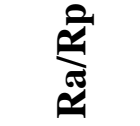 & & $\begin{array}{l}0 \\
\ddot{i}\end{array}$ \\
\hline$\stackrel{\mathscr{*}}{\mathscr{4}}$ & & 6 \\
\hline$\hat{\imath}$ & & $\bar{n}$ \\
\hline ค̊ ఏ & $\stackrel{\Xi}{\text { ñ }}$ & $\stackrel{+}{n}$ \\
\hline$\notin$ छ & $\underset{\dot{\sigma}}{\bar{\sigma}}$ & $\begin{array}{l}\infty \\
\infty \\
i\end{array}$ \\
\hline 토 & $\begin{array}{l}\hat{\gamma} \\
\dot{2}\end{array}$ & \begin{tabular}{c}
$\infty$ \\
\multirow{2}{0}{} \\
0
\end{tabular} \\
\hline - & 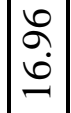 & $\begin{array}{l}- \\
\infty \\
\end{array}$ \\
\hline$\gtrless$ ఏ & $\mid \begin{array}{l}\tilde{\sigma} \\
\tilde{n} \\
\tilde{n}\end{array}$ & 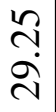 \\
\hline$\stackrel{\Xi}{\Xi}$ & 品 & $\begin{array}{l}\overline{0} \\
\dot{\lambda}\end{array}$ \\
\hline ర્త & 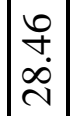 & $\begin{array}{l}o \\
\stackrel{0}{d} \\
\dot{d}\end{array}$ \\
\hline 尝 & $\tilde{m}$ & mे \\
\hline
\end{tabular}

\begin{tabular}{|c|c|}
\hline 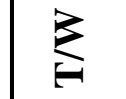 & $\stackrel{m}{+}$ \\
\hline$\sum^{3}$ & ֻ̊ \\
\hline 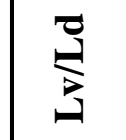 & ळ. \\
\hline$\stackrel{0}{\mathscr{a}}$ & $\begin{array}{l}8 \\
\text { i } \\
\text { i }\end{array}$ \\
\hline$\stackrel{\mathscr{2}}{\simeq}$ & $\infty$ \\
\hline a & 요 \\
\hline ค̊ & 웅. \\
\hline$\rightarrow \widehat{\Xi}$ & $\underset{\dot{\sigma}}{\dot{+}}$ \\
\hline 리 & r \\
\hline$-\widehat{\Xi}$ & $\begin{array}{l}0 \\
0 \\
1\end{array}$ \\
\hline$>\widehat{\Xi}$ & $\frac{n}{\sim}$ \\
\hline 忞 & 守 \\
\hline 로 & $\frac{8}{i}$ \\
\hline 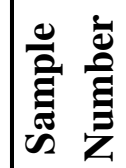 & $\ddot{n}$ \\
\hline
\end{tabular}

\begin{tabular}{|c|c|c|c|}
\hline$\xi$ & $\stackrel{\sim}{\stackrel{\circ}{0}}$ & & \\
\hline$\sum^{z}$ & సి & & \\
\hline 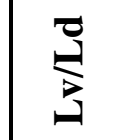 & $\stackrel{0}{-}$ & $\stackrel{\infty}{\stackrel{0}{0}}$ & \\
\hline$\underset{\mathscr{c}}{\mathscr{\alpha}}$ & $\begin{array}{l}\infty \\
0 \\
i \\
i\end{array}$ & & \\
\hline$\stackrel{\text { تี }}{*}$ & 응 & \& & \\
\hline a & $\stackrel{P}{+}$ & o & \\
\hline$\stackrel{\varrho}{\Xi}$ & $\stackrel{0}{\infty}$ & & \\
\hline 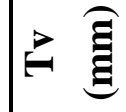 & $\begin{array}{l}\curvearrowright \\
\dot{\infty}\end{array}$ & & \\
\hline 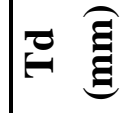 & ○. & & \\
\hline$-\widehat{\Xi}$ & 글 & & \\
\hline$<\widehat{\Xi}$ & $\begin{array}{l}\vec{\infty} \\
\dot{0} \\
\text { i }\end{array}$ & $\begin{array}{l}\text { oे } \\
\text { dे }\end{array}$ & 命 \\
\hline$\rightarrow$ 主 & $\begin{array}{l}\bar{n} \\
\text { ป }\end{array}$ & $\begin{array}{l}\text { ڤై } \\
\text { ¿ें }\end{array}$ & $\frac{n}{2}$ \\
\hline 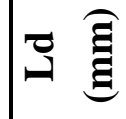 & $\begin{array}{l}a \\
\text { ते }\end{array}$ & $\frac{8}{\dot{d}}$ & $\begin{array}{l}\text { ते } \\
\text { ते }\end{array}$ \\
\hline 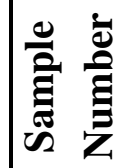 & $\neg$ & $\sim$ & $m$ \\
\hline
\end{tabular}




\section{Appendix 3: Principal Component Analysis Input}

Appendix 3 contains measurements of all specimens used for principal component analysis input. Abbreviations are the same as those in Chapter 4.

Table 1: Stony Mountain, Manitoba - Plaesiomys occidentalis (3 pages)

Table 2: Anticosti Island, Quebec - Plaesiomys anticostiensis (5 pages)

Table 3: Manitoulin Island, Ontario - Plaesiomys browni (1 page)

Table 4: Lake Simcoe, Ontario, and Baffin Island, Nunavut - Plaesiomys subcircularis (1 page)

Table 5: Mackenzie Mountains, Northwest Territories - Plaesiomys columbia, (1 page)

Table 6: Ohio-Kentucky-Indiana tri-state area - Plaesiomys subquadrata, and $P$. bellistriatus; Illinois - P. bellistriatus (2 pages)

Table 7: Oklahoma - Austinella multicostella (1 page)

Notes:

Table 4 - Specimen 4 is the type specimen from Baffin Island (GSC 113498). 
Stony Mountain, Manitoba - Plaesiomys occidentalis Table 1

\begin{tabular}{|c|c|c|c|c|c|c|c|c|c|c|c|c|c|c|c|c|c|c|c|c|c|c|c|}
\hline 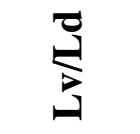 & 8 & बे & 8 & 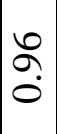 & 8 & 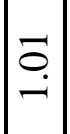 & $\begin{array}{l}\infty \\
\vdots \\
0 \\
0\end{array}$ & Oִ & 文 & 8 & 8 & ڤ̊ & $\hat{a}$ & $\begin{array}{l}\tilde{a} \\
\dot{0}\end{array}$ & $\begin{array}{l}+ \\
0 \\
0\end{array}$ & - & $\stackrel{\Xi}{\stackrel{\Xi}{-}}$ & बे & $\hat{a}$ & ڤे & $\hat{a}$ & $\begin{array}{l}\infty \\
\vdots \\
0\end{array}$ & $\overline{0}$ \\
\hline בิ & กֶ? & in & $\stackrel{\bar{n}}{-}$ & 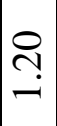 & - & $\stackrel{n}{n}$ & 官 & 官 & $\stackrel{0}{\sim}$ & $\underset{8}{8}$ & $\stackrel{0}{=}$ & ָุ & $\hat{n}$ & 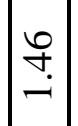 & ث. & 8 & ọ & $\stackrel{\infty}{n}$ & $\stackrel{0}{\circ}$ & $\stackrel{m}{=}$ & $\stackrel{8}{\circ}$ & $\stackrel{8}{-}$ & - \\
\hline$\underset{\sim}{\mathscr{a}}$ & $\bar{m}$ & ले & mे & D & নे & $n$ & શิ & i্ & $\stackrel{+}{\text { m }}$ & 요 & กิ & $F$ & $\stackrel{m}{\forall}$ & $\infty$ & શे & શे & $\bar{m}$ & Oి & ㅇ. & $\dot{m}$ & $\tilde{n}$ & ల্ & $\approx$ \\
\hline జ & $\stackrel{\infty}{\sim}$ & $\stackrel{\sim}{\sim}$ & $\stackrel{\infty}{\sim}$ & 尺) & $\widehat{\sim}$ & $\stackrel{\sim}{\circ}$ & $\hat{\sim}$ & $\stackrel{\infty}{\sim}$ & $\widehat{\curvearrowright}$ & ㅇ. & নे & $m$ & $\bar{n}$ & ¿ & $\widehat{\imath}$ & શે & নे & ¿ & Әे & 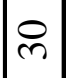 & $\approx$ & 尺্লি & అి \\
\hline$\stackrel{\mathscr{\Xi}}{\mathrm{\Xi}}$ & กั & $\bar{a}$ & $\stackrel{2}{2}$ & $\bar{a}$ & $\stackrel{\infty}{n}$ & $\stackrel{\overbrace{}}{\sim}$ & $\stackrel{q}{\stackrel{q}{q}}$ & 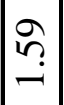 & กิ & gి & $\begin{array}{l}0 \\
\infty \\
0 \\
0\end{array}$ & $\mid \begin{array}{l}0 \\
⿱ \\
+ \\
i\end{array}$ & $\mid \begin{array}{l}\tilde{f} \\
\dot{\sim}\end{array}$ & $\begin{array}{l}\vec{v} \\
\dot{v}\end{array}$ & $\begin{array}{c}n \\
n \\
\sim \\
\sim\end{array}$ & 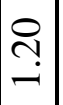 & $=$ & $\begin{array}{l}\sigma \\
\text { r. } \\
\text { r. }\end{array}$ & 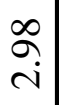 & $\left|\begin{array}{l}n \\
\stackrel{i}{v}\end{array}\right|$ & $\underset{\sim}{-}$ & 文 & $\stackrel{\infty}{\infty}$ \\
\hline $\overrightarrow{\widehat{\Xi}}$ & $\begin{array}{l}2 \\
\infty \\
\text { i }\end{array}$ & $\frac{2}{i}$ & $\begin{array}{l}2 \\
\infty \\
\text { ì }\end{array}$ & 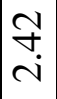 & $\begin{array}{l}\infty \\
0 \\
i\end{array}$ & 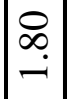 & $\frac{n}{i}$ & $\stackrel{m}{i}$ & ì & $\left|\begin{array}{c}\infty \\
\infty \\
-\end{array}\right|$ & $\stackrel{\infty}{\infty}$ & in & $\left|\begin{array}{l}\infty \\
\infty \\
\dot{n}\end{array}\right|$ & $\begin{array}{l}\text { gे } \\
\dot{m}\end{array}$ & $\frac{a}{i}$ & \begin{tabular}{|c|} 
\\
$\dot{\theta}$ \\
$\dot{r}$
\end{tabular} & $\begin{array}{l}\nexists \\
\dot{v} \\
\dot{r}\end{array}$ & $\vec{\sim}$ & 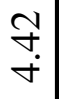 & 年 & $\left|\begin{array}{l}n \\
\dot{b} \\
\dot{r}\end{array}\right|$ & $\stackrel{\sim}{m}$ & $\stackrel{\sim}{\sim}$ \\
\hline$\widehat{\mathrm{\Xi}}$ & $=$ & $\stackrel{m}{\stackrel{n}{r}}$ & $\frac{\infty}{\pi}$ & 市 & $\begin{array}{l}\stackrel{8}{+} \\
\text { ir }\end{array}$ & $\begin{array}{l}\sim \\
\sim \\
\forall\end{array}$ & \begin{tabular}{|l}
+ \\
in
\end{tabular} & $\stackrel{n}{n}$ & $\underset{+}{F}$ & $\left|\begin{array}{l}\infty \\
0 \\
0\end{array}\right|$ & $\begin{array}{l}9 \\
\dot{n}\end{array}$ & $\begin{array}{l}\infty \\
\infty \\
\\
\end{array}$ & $\stackrel{ \pm}{a}$ & $\begin{array}{l}\infty \\
\dot{\theta} \\
\ddot{-}\end{array}$ & 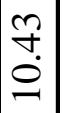 & 号 & 旾 & $\stackrel{\nexists}{\Xi}$ & $\hat{n}$ & $\vec{r}$ & $\mid \begin{array}{l}0 \\
\infty \\
\infty \\
\infty\end{array}$ & $\frac{7}{6}$ & ปิ \\
\hline$\widehat{\mathfrak{\Xi}}$ & ? & 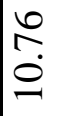 & $\begin{array}{l}0 \\
0 \\
1\end{array}$ & $\begin{array}{l}\text { Ñ } \\
\text { ป̃ }\end{array}$ & $\stackrel{m}{+}$ & 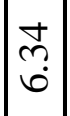 & $\mid \begin{array}{l}n \\
\infty \\
\infty\end{array}$ & $\mid \begin{array}{l}0 \\
6 \\
\\
=\end{array}$ & $\begin{array}{l}n \\
n \\
n\end{array}$ & बें & $\frac{9}{6}$ & $\begin{array}{c}m \\
\dot{\theta} \\
2\end{array}$ & $\begin{array}{l}m \\
\ddot{n} \\
\ddot{n}\end{array}$ & $\begin{array}{l}0 \\
0 \\
\end{array}$ & 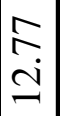 & \begin{tabular}{l}
\multirow{2}{*}{} \\
å
\end{tabular} & $\begin{array}{l}0 \\
\vdots \\
\dot{\Xi}\end{array}$ & $\begin{array}{l}\stackrel{P}{7} \\
\pm \\
\Xi\end{array}$ & $\begin{array}{l}n \\
n \\
\sim \\
\sim\end{array}$ & $\begin{array}{l} \pm \\
\dot{d} \\
\end{array}$ & 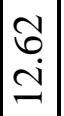 & $\mid$ & 끔 \\
\hline$\widehat{\mathrm{\Xi}}$ & चْ & $\begin{array}{l}m \\
\stackrel{n}{7} \\
\stackrel{\sim}{7}\end{array}$ & $\frac{m}{\stackrel{m}{0}}$ & $\begin{array}{l}0 \\
\dot{m} \\
\dot{m}\end{array}$ & i̊ & $\begin{array}{l}\tilde{\sigma} \\
\tilde{\gamma} \\
\text { }\end{array}$ & $\begin{array}{l}\infty \\
\infty \\
\infty \\
-\end{array}$ & 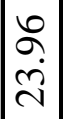 & $\begin{array}{l}n \\
0 \\
1\end{array}$ & $\begin{array}{l}\sim \\
\tilde{\sim} \\
\dot{\sim}\end{array}$ & $\stackrel{I}{\beth}$ & $\begin{array}{c}\stackrel{0}{i} \\
\infty \\
i \\
i\end{array}$ & $\begin{array}{l}\dot{0} \\
\dot{m} \\
\end{array}$ & ڤે & 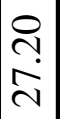 & 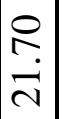 & $\begin{array}{l}\mathcal{N} \\
\stackrel{2}{0} \\
\stackrel{2}{*}\end{array}$ & $\begin{array}{c}0 \\
n \\
\\
\end{array}$ & $\begin{array}{c}m \\
\stackrel{+}{+} \\
\infty \\
\sim\end{array}$ & 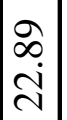 & $\begin{array}{l}\overrightarrow{7} \\
\dot{0} \\
\text { i }\end{array}$ & $\mid \begin{array}{l}\text { ते } \\
\text { ते }\end{array}$ & ñ \\
\hline$\widehat{\mathrm{\Xi}}$ & 文 & în & $\vec{z}$ & 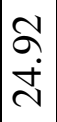 & స్ & ấ & $\begin{array}{l}\hat{\sigma} \\
\dot{ \pm}\end{array}$ & $\begin{array}{l}\infty \\
\infty \\
\infty \\
-\infty\end{array}$ & $\begin{array}{l}\infty \\
\stackrel{1}{1} \\
\end{array}$ & $\begin{array}{l}\infty \\
n \\
n \\
=\end{array}$ & \begin{tabular}{l}
\multirow{J}{*}{} \\
$\dot{\Xi}$
\end{tabular} & $\begin{array}{l}\vec{N} \\
\text { ते }\end{array}$ & $\begin{array}{l}\dot{J} \\
\dot{v} \\
\text { ते }\end{array}$ & $\mid \begin{array}{l}a \\
\dot{J} \\
\dot{J}\end{array}$ & à & 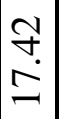 & 畠 & $\begin{array}{l}\text { ல̂ } \\
\text { ì }\end{array}$ & $\begin{array}{c}\vec{N} \\
\text { ते }\end{array}$ & 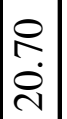 & సે & $\mid \begin{array}{l}\infty \\
0 \\
\\
-\end{array}$ & $\frac{m}{\infty}$ \\
\hline$\widehat{\mathrm{\Xi}}$ & 年 & ñ & $\stackrel{ }{\stackrel{\lambda}{\lambda}}$ & $\begin{array}{l}n \\
a \\
n\end{array}$ & ป̂ & $\begin{array}{l}\Delta \\
0 \\
0 \\
-1\end{array}$ & $\begin{array}{l}\mathscr{a} \\
\dot{ \pm}\end{array}$ & $\begin{array}{l}\mathscr{m} \\
\stackrel{0}{\infty} \\
-\end{array}$ & $\vec{r}$ & $\begin{array}{l}\mathcal{\sigma} \\
0 \\
- \\
-\end{array}$ & $\begin{array}{l}\stackrel{N}{\Xi} \\
\dot{J}\end{array}$ & $\frac{n}{\ddot{n}}$ & 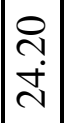 & 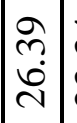 & $\begin{array}{l}\dot{\nabla} \\
\tilde{n} \\
\tilde{n}\end{array}$ & సે & $\mid \begin{array}{l}q \\
\dot{a} \\
\vec{v}\end{array}$ & त̂̀ & 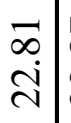 & 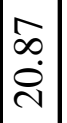 & $\mid \begin{array}{l}n \\
\infty \\
0 \\
0\end{array}$ & $\begin{array}{l}0 \\
\stackrel{\infty}{\infty} \\
=\end{array}$ & วิ \\
\hline 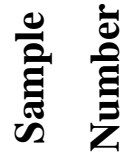 & - & $\sim$ & $m$ & $\nabla$ & 6 & $r$ & $a$ & $\cong$ & $m$ & \pm & $\underline{0}$ & $=$ & $\begin{array}{l}0 \\
m\end{array}$ & $\stackrel{\infty}{+}$ & 志 & $\stackrel{n}{r}$ & 2 & $\pi$ & $\infty$ & $\infty$ & $\infty$ & $\infty$ & $\infty$ \\
\hline
\end{tabular}


Stony Mountain, Manitoba - Plaesiomys occidentalis Table 1 (continued)

\begin{tabular}{|c|c|c|c|c|c|c|c|c|c|c|c|c|c|c|c|c|c|c|c|c|c|c|c|c|}
\hline 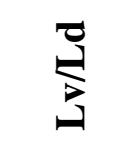 & & $\stackrel{\infty}{a}$ & $\mid \begin{array}{l}\infty \\
\vdots \\
0\end{array}$ & $\hat{\sigma}$ & $\stackrel{\infty}{0}$ & ڤे & $\hat{\sigma}$ & $\hat{\sigma}$ & $\dot{0}$ & रे & & $\begin{array}{l}a \\
\dot{\sigma}\end{array}$ & $\hat{a}$ & $\hat{a}$ & ळे & $\dot{a}$ & $\begin{array}{l}\infty \\
0 \\
0\end{array}$ & ○े & 8 & $\hat{a}$ & à & $\begin{array}{l}0 \\
2 \\
0\end{array}$ & $\begin{array}{l}\hat{\sigma} \\
\grave{0}\end{array} \mid$ & 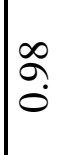 \\
\hline है & $\stackrel{\infty}{\longrightarrow}$ & 웅 & 8 & $\stackrel{\overbrace{}}{\sim}$ & $\stackrel{\overbrace{}}{\stackrel{n}{n}}$ & ב & ํㅗ & $\stackrel{n}{0}$ & & $\begin{array}{c}o \\
+ \\
+\end{array}$ & & $\stackrel{a}{\rightleftharpoons}$ & 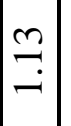 & r̃ & 8 & $\stackrel{m}{=}$ & $\stackrel{9}{\beth}$ & $\underline{0}$ & 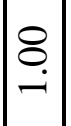 & $\stackrel{m}{=}$ & $\stackrel{0}{\beth}$ & 임 & $\exists$ & $\stackrel{m}{=}$ \\
\hline$\stackrel{\mathscr{*}}{\approx}$ & $m$ & లి & $\stackrel{\infty}{\sim}$ & $\hat{n}$ & $\underset{m}{\infty}$ & లి & m & $m$ & $\therefore=$ & $\vec{f}$ & $\begin{array}{c}\infty \\
m\end{array}$ & $\stackrel{\infty}{\infty}$ & m & $\hat{n}$ & $\bar{m}$ & m & $\bar{n}$ & in & $\widehat{\sim}$ & i & ñ & 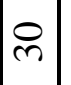 & $\bar{n}$ & $\dot{m}$ \\
\hline$\stackrel{2}{4}$ & $\stackrel{\infty}{\sim}$ & $\stackrel{\infty}{\sim}$ & $\stackrel{\infty}{\sim}$ & ㅇ & $\bar{m}$ & $\widehat{\nu}$ & ㅇ & mे & $\delta \propto$ & $\stackrel{\infty}{v}$ & $\bar{m}$ & ก) & లి & $\stackrel{\infty}{\sim}$ & $\bar{m}$ & i্ & $\vec{m}$ & $\stackrel{\infty}{\sim}$ & तิ & ñ & $\hat{\sim}$ & $\stackrel{\infty}{\sim}$ & $\stackrel{\infty}{\sim}$ & లి \\
\hline ค̊ & $\stackrel{m}{=}$ & $\hat{a}$ & กn & $\frac{\sim}{\sim}$ & $\stackrel{\infty}{\infty}$ & $\bar{\infty}$. & $\stackrel{\Re}{\sim}$ & ñ & & \begin{tabular}{l|l}
$\infty$ & \\
$\dot{v}$ &
\end{tabular} & | & $\begin{array}{l}\hat{\sigma} \\
-\end{array}$ & $\begin{array}{l}n \\
m \\
m\end{array} \mid$ & $\left|\begin{array}{c}\infty \\
+ \\
\sim \\
ن\end{array}\right|$ & 8 & กิ & $\stackrel{r}{\stackrel{r}{\sim}}$ & $\begin{array}{l}n \\
\check{n} \\
\dot{m}\end{array}$ & $\bar{n}$ & $\mid \begin{array}{l}n \\
\infty \\
0 \\
0\end{array}$ & $\stackrel{\Xi}{\beth}$ & $\stackrel{\sim}{n}$ & $\stackrel{+}{\sim}$ & $\stackrel{+}{\stackrel{+}{r}}$ \\
\hline $\overrightarrow{\mathrm{E}}$ & $\dot{\partial}$ & $\frac{\Xi}{i}$ & ஓ & $\bar{a}$ & $\stackrel{\theta}{\dot{m}}$ & $\begin{array}{l}\infty \\
\infty \\
i\end{array}$ & ळे & $\vec{a}$ & & 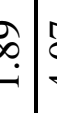 & $\begin{array}{l}\hat{0} \\
\dot{f}\end{array}$ & $\begin{array}{c}\hat{0} \\
\dot{n}\end{array}$ & $\left|\begin{array}{c}\sigma \\
\delta \\
\dot{\gamma}\end{array}\right|$ & $\left|\begin{array}{c}8 \\
\dot{m}\end{array}\right|$ & $\begin{array}{l}\infty \\
\infty \\
i\end{array}$ & $\begin{array}{l}\infty \\
\infty \\
\dot{r} \\
\dot{n}\end{array}$ & $\frac{m}{i}$ & $\begin{array}{l}8 \\
\dot{0} \\
\dot{r}\end{array}$ & $\stackrel{\sim}{\stackrel{\sim}{r}}$ & 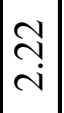 & 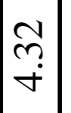 & $\vec{n}$ & $\left|\begin{array}{c}\sigma \\
\infty \\
\dot{r}\end{array}\right|$ & $\stackrel{\theta}{\dot{m}}$ \\
\hline 얔 & $\begin{array}{l}\grave{\sigma} \\
\infty\end{array}$ & $\begin{array}{l}6 \\
6 \\
\infty\end{array}$ & $\frac{6}{6}$ & $\frac{a}{a}$ & 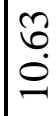 & $\begin{array}{l}\infty \\
\infty \\
\infty\end{array}$ & $\begin{array}{l}\infty \\
\infty \\
\infty\end{array}$ & $\begin{array}{l}\text { ర } \\
\text { ป }\end{array}$ & $\begin{array}{l}\mathrm{j} \\
\mathrm{j} \\
\mathrm{j}\end{array}$ & 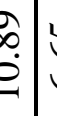 & $\begin{array}{l}6 \\
6 \\
6\end{array}$ & $\begin{array}{l}\mathfrak{N} \\
\infty\end{array}$ & Oे. & 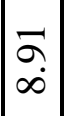 & $\begin{array}{l}6 \\
6 \\
0\end{array}$ & ำ & $=$ & $\mid \begin{array}{l}\infty \\
\sigma \\
a\end{array}$ & \begin{tabular}{|c|}
$\overline{0}$ \\
$\dot{r}$
\end{tabular} \mid & $\begin{array}{c}\infty \\
\stackrel{\infty}{+} \\
\dot{r}\end{array}$ & $\left|\begin{array}{l}0 \\
n \\
\infty \\
\infty\end{array}\right|$ & 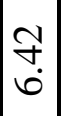 & $\hat{a}$ & $\frac{n}{0}$ \\
\hline$-\widehat{\Xi}$ & $\frac{\Xi}{d}$ & à & ๙ุ & $\begin{array}{l}n \\
n \\
n \\
n\end{array}$ & $\begin{array}{l}0 \\
0 \\
\dot{J}\end{array}$ & 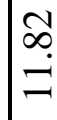 & $\begin{array}{l}\text { N } \\
\text { ¿ }\end{array}$ & $\begin{array}{l}\infty \\
0 \\
\\
-\end{array}$ & 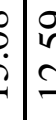 & 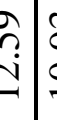 & $\begin{array}{l}0 \\
\vdots \\
0\end{array}$ & ñ & 呑 & 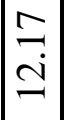 & $\frac{1}{a}$ & $\begin{array}{l}0 \\
\dot{2} \\
2\end{array}$ & $\begin{array}{l}m \\
\tilde{n} \\
\sigma\end{array}$ & $\begin{array}{l}\vec{\sim} \\
\ddot{n}\end{array}$ & $\underset{\infty}{ \pm}$ & $\vec{r}$ & $\begin{array}{l}n \\
n \\
\sim \\
c\end{array}$ & ○! & 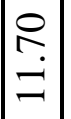 & $\begin{array}{l}0 \\
\ddot{2}\end{array}$ \\
\hline$>\widehat{\Xi}$ & 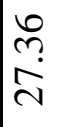 & 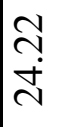 & â & $\begin{array}{l}6 \\
\text { ते }\end{array}$ & ڤ̊ & $\begin{array}{l}\text { शे } \\
\text { वें }\end{array}$ & $\begin{array}{l}n \\
n \\
n \\
n\end{array}$ & $\begin{array}{l}\infty \\
\infty \\
\\
\end{array}$ & 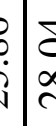 & 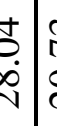 & 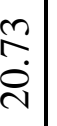 & $\begin{array}{l}n \\
\stackrel{n}{\sim}\end{array}$ & $\begin{array}{l}0 \\
0 \\
\dot{d} \\
\end{array}$ & $\begin{array}{l}\bar{b} \\
\dot{2}\end{array}$ & $\stackrel{\infty}{\check{a}}$ & $\mid \begin{array}{l}\infty \\
a \\
\infty \\
\sim \\
\end{array}$ & $\mid \begin{array}{l}\infty \\
\infty \\
0\end{array}$ & $\begin{array}{l} \pm \\
0 \\
i \\
i \\
n\end{array}$ & $\underset{\dot{v}}{\stackrel{m}{v}}$ & 紊 & $\begin{array}{l}\infty \\
\infty \\
\dot{\gamma} \\
\curvearrowright\end{array}$ & 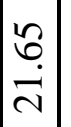 & $\begin{array}{l}\infty \\
a \\
0 \\
0 \\
\end{array} \mid$ & $\begin{array}{l}8 \\
0 \\
0 \\
0\end{array}$ \\
\hline 氞 & $\begin{array}{l}n \\
0 \\
0 \\
0\end{array}$ & $\begin{array}{l}n \\
\infty \\
\infty \\
-\end{array}$ & 年 & 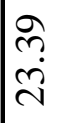 & $\begin{array}{l}0 \\
\stackrel{0}{+} \\
\text { ते }\end{array}$ & 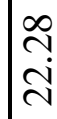 & ণ্ণি & $\begin{array}{l}\approx \\
\text { i }\end{array}$ & i & \begin{tabular}{l|l}
$\vec{b}$ & $:$ \\
$\dot{v}$ &
\end{tabular} & $\hat{a}$ & $\hat{\sigma}$ & $\begin{array}{l}2 \\
\tilde{a} \\
a\end{array}$ & 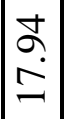 & $\begin{array}{l}\infty \\
n \\
0 \\
0\end{array}$ & $\begin{array}{l}\hat{n} \\
\text { तn } \\
\text { na }\end{array}$ & aे & $\mid \begin{array}{l} \pm \\
\infty \\
i \\
\end{array}$ & 守 & $\left|\begin{array}{l}\tilde{\sigma} \\
\dot{v}\end{array}\right|$ & $\begin{array}{l}\tilde{\sigma} \\
\infty \\
\infty\end{array}$ & $\begin{array}{l}\sqrt{0} \\
0 \\
0 \\
-1\end{array}$ & $\begin{array}{l}a \\
\dot{v} \\
\text { ḋ }\end{array} \mid$ & 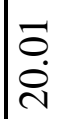 \\
\hline త્తి & în. & à & $\begin{array}{l}0 \\
0 \\
0 \\
-1\end{array}$ & $\begin{array}{l}\text { J } \\
\dot{+}\end{array}$ & $\begin{array}{l}8 \\
\stackrel{+}{+}\end{array}$ & $\begin{array}{l}\text { テे } \\
\text { ป̀ }\end{array}$ & $\stackrel{\text { I }}{\stackrel{\sim}{N}}$ & $\begin{array}{l}\tilde{n} \\
\tilde{n}\end{array}$ & $\begin{array}{l}\overline{0} \\
\vdots \\
\vdots \\
\vdots\end{array}$ & $\begin{array}{c}S \\
\text { S. }\end{array}$ & $\frac{n}{6}$ & $\begin{array}{c}0 \\
\stackrel{0}{a}\end{array}$ & $\begin{array}{l}\infty \\
\hat{a} \\
2\end{array}$ & $\begin{array}{c}n \\
n \\
\infty \\
=\end{array}$ & $\frac{+}{0}$ & $\begin{array}{l}8 \\
\ddot{0} \\
\text { in }\end{array}$ & $\begin{array}{l}\infty \\
a \\
2 \\
-\end{array}$ & $\begin{array}{l}m \\
\infty \\
\dot{0} \\
\end{array}$ & $\begin{array}{l}n \\
n \\
\\
\end{array}$ & $\begin{array}{ll}\infty \\
\stackrel{0}{0} \\
\stackrel{+}{ \pm} \\
\end{array}$ & $\stackrel{\sim}{a}$ & $\mid \begin{array}{l}0 \\
0 \\
0 \\
-1\end{array}$ & $\begin{array}{l}m \\
\sim \\
\sim \\
\sim\end{array} \mid$ & 户ั \\
\hline 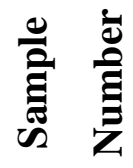 & $\infty$ & శ̊ & $\bar{a}$ & ๙ু & ă & す & ๙ூ & 2 & 10 & $\hat{\lambda}$ & ริ & $\stackrel{8}{\varnothing}$ & $\overline{0}$ & $\stackrel{+}{0}$ & $\stackrel{2}{0}$ & 응 & 8 & $\stackrel{0}{=}$ & $\Xi$ & $\cong$ & $\stackrel{?}{=}$ & \pm & 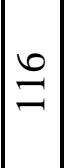 & $\stackrel{2}{=}$ \\
\hline
\end{tabular}


Stony Mountain, Manitoba - Plaesiomys occidentalis Table 1 (continued)

\begin{tabular}{|c|c|c|c|c|c|c|c|c|c|c|c|}
\hline 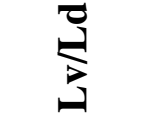 & $\mid \begin{array}{l}0 \\
\vdots \\
0\end{array}$ & $\begin{array}{l}\infty \\
\vdots \\
0\end{array}$ & $\mid$ & $\begin{array}{l}\infty \\
\vdots \\
\vdots \\
0\end{array}$ & $\stackrel{2}{\infty}$ & ڤे. & $\hat{a}$ & $\hat{\sigma}$ & 8 & ळे & $\stackrel{\infty}{0}$ \\
\hline 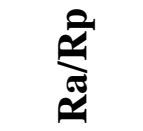 & $\stackrel{n}{=}$ & 吾 & $\stackrel{\sim}{=}$ & 文 & s. & సิ & $\stackrel{\rho}{-}$ & $\stackrel{8}{8}$ & : & $\stackrel{\vartheta}{\rightarrow}$ & $\cong$ \\
\hline$\approx$ & $\bar{m}$ & $\stackrel{\mathrm{\lambda}}{ }$ & ते & $\approx$ & 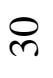 & 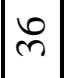 & $m$ & $\stackrel{i}{\circ}$ & $\approx$ & $\approx$ & 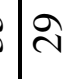 \\
\hline$\approx$ & $\hat{\imath}$ & $\infty$ & $\stackrel{\bullet}{\sim}$ & 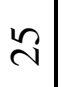 & $\stackrel{\infty}{\sim}$ & $\stackrel{\infty}{\sim}$ & $\pi$ & $\stackrel{v}{i}$ & $\ddot{n}$ & $\stackrel{\infty}{\sim}$ & $\stackrel{\sim}{*}$ \\
\hline 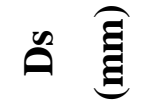 & @ & $\begin{array}{l}\stackrel{q}{+} \\
\dot{0}\end{array}$ & ?ִ & $\begin{array}{l}8 \\
i\end{array}$ & $\stackrel{2}{-}$ & $=\bar{a}$ & $\stackrel{\circ}{\circ}$ & $\stackrel{\overbrace{}}{0}$ & $\stackrel{?}{n}$ & i̊n & ?ִ \\
\hline$\notin \widehat{\mathrm{E}}$ & $\left|\begin{array}{l}\stackrel{8}{0} \\
i\end{array}\right|$ & $\begin{array}{l}\tilde{r} \\
\dot{m}\end{array}$ & $\mid$ & $\begin{array}{c}0 \\
\infty \\
0 \\
0\end{array}$ & $\begin{array}{l}\mathbb{U} \\
\text { i }\end{array}$ & $\mid \begin{array}{l}\vec{j} \\
\dot{r}\end{array}$ & $\stackrel{n}{i}$ & @ & $\begin{array}{l}\mathscr{\infty} \\
\infty \\
i\end{array}$ & $\stackrel{m}{i}$ & f \\
\hline E & $\begin{array}{l}8 \\
\vdots \\
0\end{array}$ & $\begin{array}{c}n \\
\dot{n}\end{array}$ & \begin{tabular}{|l}
$\vec{r}$ \\
$\dot{m}$
\end{tabular} & ત્રુ & 官 & $\left|\begin{array}{c}\multirow{2}{N}{} \\
\infty \\
\infty\end{array}\right|$ & $\begin{array}{l}\infty \\
0 \\
i\end{array}$ & î & $\begin{array}{l}\stackrel{\partial}{\infty} \\
\dot{m}\end{array}$ & $\begin{array}{l}\tilde{N} \\
i n\end{array}$ & $\stackrel{n}{+}$ \\
\hline$\widehat{\widehat{\Xi}}$ & $\mid \begin{array}{c}\tilde{y} \\
\dot{m} \\
\end{array}$ & $\begin{array}{l}\vec{n} \\
n \\
a\end{array}$ & $\mid \begin{array}{l}0 \\
\stackrel{2}{n} \\
\text {. }\end{array}$ & 文 & $\stackrel{\Re}{2}$ & 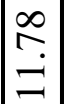 & $\stackrel{\substack{n\\
}}{2}$ & 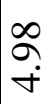 & $\stackrel{\cong}{\rightleftharpoons}$ & 咅 & ठ઼े \\
\hline$\widehat{\mathrm{\Xi}}$ & $\left|\begin{array}{l}\tilde{\sigma} \\
\tilde{i} \\
\tilde{N}\end{array}\right|$ & 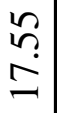 & $\mid \begin{array}{l}\infty \\
0 \\
\ddot{n} \\
-1\end{array}$ & $\begin{array}{l}\hat{b} \\
\vec{i} \\
\vec{d}\end{array}$ & $\frac{1}{a}$ & $\begin{array}{l}0 \\
0 \\
\ddot{i}\end{array} \mid$ & 足 & $\stackrel{\sim}{\stackrel{I}{ \pm}}$ & 文 & $\begin{array}{l}\infty \\
\infty \\
\varrho \\
0\end{array}$ & $\begin{array}{l}\tilde{\sigma} \\
\stackrel{\sigma}{2}\end{array}$ \\
\hline 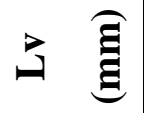 & $\mid \begin{array}{l}\stackrel{f}{\leftrightarrow} \\
\stackrel{\sim}{\sim}\end{array}$ & $\begin{array}{l}\infty \\
0 \\
\dot{ \pm}\end{array}$ & $\mid \begin{array}{l}0 \\
0 \\
= \\
=\end{array}$ & $\begin{array}{l}\hat{\sigma} \\
\dot{0}\end{array}$ & $\mid \begin{array}{l}6 \\
0 \\
\dot{I}\end{array}$ & $\mid \begin{array}{l}n \\
n \\
2 \\
2\end{array}$ & 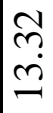 & $\hat{a}$ & $\begin{array}{l}n \\
n \\
n\end{array}$ & $\frac{m}{2}$ & ऽ \\
\hline ฮ & $\left|\begin{array}{c}0 \\
\infty \\
\vec{\lambda}\end{array}\right|$ & $\left|\begin{array}{l}n \\
0 \\
0 \\
a\end{array}\right|$ & 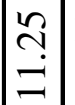 & $\begin{array}{l}0 \\
\vdots \\
\\
\end{array}$ & 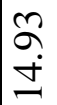 & $\begin{array}{l}0 \\
2 \\
2\end{array}$ & $\stackrel{?}{\stackrel{m}{2}}$ & 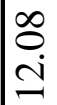 & $\stackrel{f}{\stackrel{f}{9}}$ & 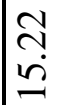 & 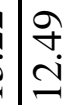 \\
\hline 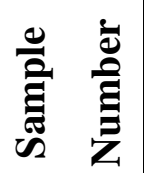 & $\bar{\Xi}$ & & & & $\stackrel{+}{n}$ & & 党 & 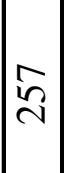 & 2 & ते & \\
\hline
\end{tabular}


Anticosti Island, Quebec - Plaesiomys anticostiensis Table 2

\begin{tabular}{|c|c|c|c|c|c|c|c|c|c|c|c|c|c|c|c|c|c|c|c|c|c|c|c|}
\hline 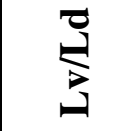 & & $\mid \begin{array}{l}\infty \\
0 \\
0\end{array}$ & $\hat{o}$ & $\int_{0}^{\infty}$ & $\hat{\alpha}$ & $\stackrel{2}{\circ}$ & ڤ̊. & $\stackrel{\infty}{\infty}$ & $\stackrel{\varkappa}{o}$ & o̊ & $\stackrel{\infty}{\infty}$ & 离 & $\mid \begin{array}{l}\infty \\
0 \\
0 \\
0\end{array}$ & $\left|\begin{array}{l}\infty \\
0 \\
0\end{array}\right|$ & $\hat{\sigma}$ & ڤ̊ & $\stackrel{8}{8}$ & ڤे & ڤ̊. & $\hat{a}$ & ڤે. & $\mid$\begin{tabular}{l}
$\infty$ \\
\hdashline \\
0
\end{tabular} & $\begin{array}{l}\infty \\
2 \\
0\end{array}$ \\
\hline 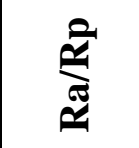 & $\mid \begin{array}{l}\infty \\
\infty \\
i\end{array}$ & $\mid \begin{array}{l}\infty \\
\ddot{n} \\
\end{array}$ & $\underset{i}{\stackrel{8}{i}}$ & 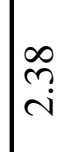 & $\overrightarrow{\vec{i}}$ & $\underset{i}{\stackrel{t}{i}}$ & rn & & $\hat{n}$ & $\stackrel{\infty}{\sim}$ & $\stackrel{2}{\Im}$ & $\begin{array}{l}8 \\
i \\
i\end{array}$ & $\stackrel{\infty}{\vec{i}}$ & $\mid \begin{array}{l}0 \\
0 \\
i\end{array}$ & 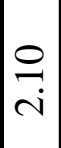 & $\begin{array}{l}\hat{6} \\
i \\
i\end{array}$ & $\begin{array}{l}\vec{b} \\
i \\
\text { i }\end{array}$ & $\left|\begin{array}{c}\infty \\
0 \\
i\end{array}\right|$ & $\mid \begin{array}{c}\tilde{\imath} \\
\hat{\sim}\end{array}$ & $\stackrel{n}{=}$ & $\stackrel{n}{i}$ & $\tilde{-}$ & $\begin{array}{c}8 \\
\text { i }\end{array}$ \\
\hline $\mathscr{\approx}$ & 浮 & $\infty$ & 8 & $\sqrt{6}$ & in & in & 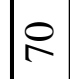 & t & $\nabla$ & 6 & $\bar{n}$ & t & $\stackrel{\infty}{q}$ & 6 & 6 & 6 & 8 & in & 6 & in & $\curvearrowright$ & in & 悉 \\
\hline से & $\stackrel{\sim}{\sim}$ & đ & $\widehat{\imath}$ & i & $\widehat{\lambda}$ & $\infty_{i}^{\infty}$ & ¿ & $\stackrel{\sim}{\sim}$ & లి & $\stackrel{\sim}{\circ}$ & $\stackrel{\sim}{\sim}$ & $\tilde{\tilde{c}}$ & $\widetilde{\sim}$ & $m$ & m & $\mid \stackrel{ \pm}{\sim}$ & $\tilde{\imath}$ & $\stackrel{\sim}{\sim}$ & $\stackrel{\infty}{\sim}$ & $\approx$ & $\stackrel{\infty}{\sim}$ & $\hat{\imath}$ & 㐫 \\
\hline 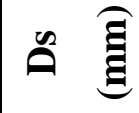 & in & 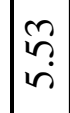 & $\mid \begin{array}{c}\tilde{D} \\
\dot{\gamma} \\
\dot{\gamma}\end{array}$ & $\underset{+}{\stackrel{f}{2}}$ & $\begin{array}{l}\stackrel{0}{+} \\
\dot{m}\end{array}$ & $\underset{f}{\stackrel{f}{f}}$ & $\begin{array}{l}\stackrel{f}{f} \\
+\end{array}$ & $\begin{array}{l}\varkappa \\
i \\
i n\end{array}$ & $\begin{array}{l}\tilde{N} \\
\text { in }\end{array}$ & & 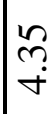 & $\mid \begin{array}{l}\infty \\
\stackrel{+}{+}\end{array}$ & & 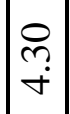 & $\begin{array}{l}\overrightarrow{\vec{v}} \\
\text { in }\end{array}$ & 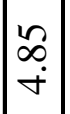 & $\begin{array}{l}\hat{y} \\
i n\end{array}$ & 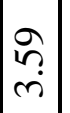 & $\frac{ \pm}{\dot{m}}$ & 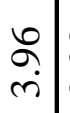 & $\begin{array}{c}\infty \\
m \\
m \\
m\end{array} \mid$ & $\mid$ & $\left|\begin{array}{l}\bar{\sigma} \\
\dot{\gamma}\end{array}\right|$ \\
\hline 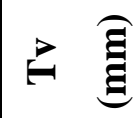 & $\stackrel{\mathscr{f}}{\stackrel{\sim}{c}}$ & $\begin{array}{l}\sigma \\
\dot{\rho} \\
\dot{r}\end{array}$ & $\begin{array}{l}\infty \\
i \\
i\end{array}$ & $\mid \begin{array}{l}\infty \\
\\
\sim\end{array}$ & 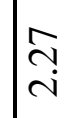 & 命 & $\stackrel{ \pm}{i}$ & $\underset{\hat{n}}{\hat{n}}$ & $\stackrel{\infty}{\stackrel{\infty}{\sim}}$ & $\stackrel{\infty}{\stackrel{\infty}{0}}$ & $\underset{\sim}{\stackrel{\sigma}{r}}$ & $\underset{Z}{\beth}$ & $\stackrel{\infty}{\stackrel{\infty}{i}}$ & $\tilde{\varrho}$ & $\stackrel{\infty}{\stackrel{\infty}{-}}$ & $\begin{array}{l}\stackrel{\vec{\lambda}}{\mathrm{i}} \\
\mid\end{array}$ & $\stackrel{2}{i}$ & $\left|\begin{array}{l}\tilde{n} \\
\sim \\
i\end{array}\right|$ & $\stackrel{\vec{i}}{\mathrm{i}}$ & $\mid$ & $\vec{m}$ & $\vec{\Delta}$ & $\left|\begin{array}{c}0 \\
\dot{r}\end{array}\right|$ \\
\hline 도 & 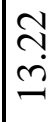 & 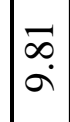 & $\stackrel{?}{=}$ & $\stackrel{\text { D }}{=}$ & 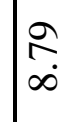 & ? & 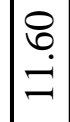 & 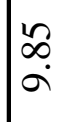 & ஓे & 官 & $\stackrel{5}{6}$ & 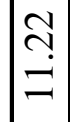 & ñ & $\stackrel{+}{\stackrel{2}{\Xi}}$ & $\mid \begin{array}{l}\infty \\
\infty \\
0 \\
0\end{array}$ & $\stackrel{n}{a}$ & $\begin{array}{l}\hat{\infty} \\
\sigma \\
\sigma\end{array}$ & $\begin{array}{l}\sigma \\
\infty \\
\infty\end{array} \mid$ & $\begin{array}{l}\beth \\
= \\
=\end{array}$ & $\stackrel{શ}{=}$ & $\stackrel{2}{r}$ & $\left|\begin{array}{l}n \\
a \\
\infty\end{array}\right|$ & $\mid$ \\
\hline$-\widehat{\Xi}$ & $\begin{array}{l}\sigma \\
\dot{\Xi}\end{array}$ & $\vec{a}$ & $\begin{array}{l}0 \\
\pm \\
\pm\end{array}$ & $\begin{array}{l}\sim \\
\infty \\
\end{array}$ & 守 & $\begin{array}{l}\infty \\
\infty \\
\end{array}$ & $\begin{array}{l}\stackrel{q}{+} \\
\dot{\Xi}\end{array}$ & $\begin{array}{l}\hat{0} \\
\dot{a}\end{array}$ & $\begin{array}{l}\infty \\
\sim \\
n \\
n\end{array}$ & 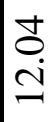 & $\stackrel{0}{\circ}$ & $\begin{array}{l}i n \\
i \\
\end{array}$ & 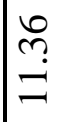 & $\mid \begin{array}{l}\stackrel{q}{a} \\
\text { i }\end{array}$ & $\begin{array}{l}\vec{J} \\
\dot{I}\end{array}$ & 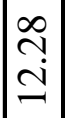 & $\begin{array}{l}0 \\
0 \\
i \\
\text { I }\end{array}$ & 宇 & $\begin{array}{l}\tilde{n} \\
\tilde{n}\end{array}$ & $\frac{n}{m}$ & $\stackrel{m}{\dot{g}}$ & $\stackrel{m}{\stackrel{m}{=}}$ & $\mid \begin{array}{l}\infty \\
\doteq \\
=\end{array}$ \\
\hline $3 \widehat{\mathrm{E}}$ & 文 & $\left|\begin{array}{l}+ \\
\infty \\
\grave{\sim} \\
\end{array}\right|$ & 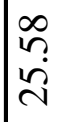 & ì & ה્ & 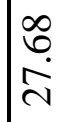 & $\mid \begin{array}{l}0 \\
0 \\
\dot{m}\end{array}$ & $\begin{array}{l}\dot{b} \\
\dot{a} \\
\dot{i}\end{array}$ & $\begin{array}{l}8 \\
0 \\
\infty \\
i\end{array}$ & $\begin{array}{l}\hat{\alpha} \\
\infty \\
\hat{\sim}\end{array}$ & $\begin{array}{l}\dot{d} \\
\dot{d}\end{array}$ & $\begin{array}{l}\text { ते } \\
\overrightarrow{\hat{\lambda}}\end{array}$ & 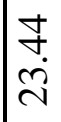 & 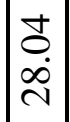 & 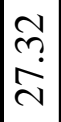 & $\left|\begin{array}{l}\hat{a} \\
\grave{\lambda}\end{array}\right|$ & $\begin{array}{l}a \\
b \\
\dot{a}\end{array}$ & $\mid \begin{array}{r}\hat{N} \\
\dot{N}\end{array}$ & 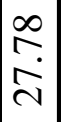 & & $\begin{array}{l}\infty \\
\dot{\sim}\end{array}$ & $\begin{array}{l}0 \\
0 \\
i \\
i\end{array}$ & $\mid$ \\
\hline 至 & ले & 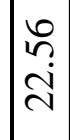 & $\vec{\sim}$ & \& & 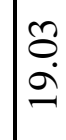 & 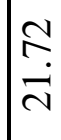 & $\begin{array}{l}2 \\
\dot{2} \\
2\end{array}$ & $\stackrel{\overbrace{}}{\stackrel{N}{N}}$ & $\begin{array}{l}\bar{b} \\
\text { i } \\
\text { in }\end{array}$ & 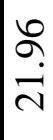 & $\begin{array}{l}0 \\
\infty \\
\infty \\
-\end{array}$ & 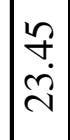 & $\stackrel{0}{9}$ & $\begin{array}{l}\alpha \\
\grave{\lambda}\end{array}$ & 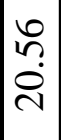 & $\mid \begin{array}{c}\infty \\
\\
\grave{n} \\
\end{array}$ & 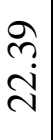 & $\begin{array}{l}0 \\
0 \\
9\end{array}$ & নे & $\begin{array}{l}\vec{\infty} \\
\vec{\lambda} \\
\end{array}$ & 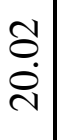 & $\mid \begin{array}{c}\infty \\
\stackrel{n}{\lambda} \\
\sim\end{array}$ & ले \\
\hline Э & $\begin{array}{l}\infty \\
\stackrel{\infty}{n} \\
\stackrel{N}{N}\end{array}$ & $\begin{array}{l}\tilde{\vdots} \\
\dot{\sim}\end{array}$ & ले & f̊ & $\stackrel{2}{2}$ & $\begin{array}{l}\text { d } \\
\text { ì }\end{array}$ & $\begin{array}{l}\infty \\
\infty \\
\dot{\sim}\end{array}$ & 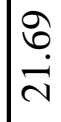 & $\begin{array}{l}\infty \\
\infty \\
\end{array}$ & $\begin{array}{l}n \\
\infty \\
i \\
i\end{array}$ & $\stackrel{m}{\infty}$ & $\begin{array}{l}\widehat{\infty} \\
\dot{\sim} \\
\dot{\sim}\end{array}$ & $\stackrel{\infty}{\stackrel{0}{\circ}} \stackrel{0}{2}$ & 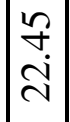 & $\stackrel{m}{\stackrel{\vec{v}}{\sim}}$ & $\left|\begin{array}{l}\infty \\
\stackrel{\sim}{\sim} \\
\stackrel{\sim}{N}\end{array}\right|$ & $\begin{array}{l}\stackrel{a}{+} \\
\text { ì }\end{array}$ & $\mid \begin{array}{l}\vec{N} \\
\stackrel{2}{-}\end{array}$ & $\begin{array}{l}\hat{\widehat{A}} \\
\mathrm{i}\end{array}$ & $\begin{array}{l}n \\
n \\
i \\
\end{array}$ & 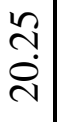 & $\mid \begin{array}{l}\infty \\
\infty \\
\infty \\
\dot{N}\end{array}$ & $\mid \begin{array}{c}\infty \\
\dot{\alpha} \\
\dot{N}\end{array}$ \\
\hline 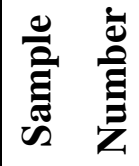 & & $N$ & $m$ & $\nabla$ & in & 6 & $r$ & $\infty$ & a & 으 & $=$ & $\simeq$ & 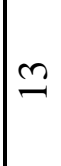 & \pm & 19 & 0 & $\Xi$ & $\stackrel{\infty}{=}$ & 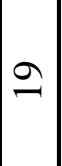 & ì & $\vec{\sim}$ & तิ & i \\
\hline
\end{tabular}


Anticosti Island, Quebec - Plaesiomys anticostiensis Table 2 (continued)

\begin{tabular}{|c|c|c|c|c|c|c|c|c|c|c|c|c|c|c|c|c|c|c|c|c|c|c|c|}
\hline 吝 & హे. & $\sigma_{0}^{\infty}$ & a & aे & o̊ & : & s. & ô & aे & $\stackrel{\infty}{0}$ & ठे & हे & o & $\mid \begin{array}{l}\hat{0} \\
0\end{array}$ & $\hat{a}$ & $\mid \begin{array}{c}\hat{\sigma} \\
\hat{0}\end{array}$ & $\begin{array}{l}\text { oे } \\
\dot{0}\end{array}$ & 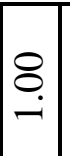 & ș. & $\hat{a}$ & 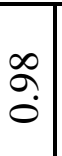 & $\stackrel{8}{-}$ & 文 \\
\hline 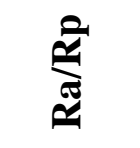 & $\stackrel{m}{=}$ & in & ते & 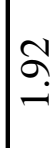 & $\overrightarrow{\widetilde{N}}$ & ? & $\stackrel{\infty}{\sim}$ & ? & in & $\frac{\Delta}{i}$ & $\stackrel{R}{\stackrel{2}{*}}$ & त̂ & $\stackrel{\infty}{\infty}$ & $\stackrel{ \pm}{i}$ & $\mid$\begin{tabular}{l}
$\infty$ \\
0 \\
\hdashline \\
-1 \\
\end{tabular} & $\begin{array}{c}\infty \\
0 \\
i\end{array}$ & $\begin{array}{l}\hat{b} \\
i\end{array}$ & ले & $\mid \begin{array}{l}\infty \\
\infty \\
- \\
-\end{array}$ & $\mid$ & $\begin{array}{l}8 \\
i\end{array}$ & $\begin{array}{l}m \\
\infty \\
-\infty \\
-\end{array}$ & $\mid \begin{array}{l}\infty \\
\infty \\
-\infty \\
\end{array}$ \\
\hline$\approx$ & in & $\sigma$ & $n$ & in & $n$ & in & $\stackrel{\infty}{+}$ & $\mathcal{F}$ & 8 & チ & $\bar{n}$ & 8 & $n$ & 8 & F & in & t & in & t & $\infty$ & gे & $\therefore$ & 部 \\
\hline حิ & পি & I & $\stackrel{\sim}{\sim}$ & $\approx$ & $\stackrel{\Xi}{\sim}$ & ৯े & $\widehat{\imath}$ & $i \stackrel{\infty}{\sim}$ & $\approx$ & $\widetilde{\sim}$ & pি & $\hat{\imath}$ & pr & $\stackrel{\infty}{\sim}$ & $\infty$ & $\stackrel{\sim}{\sim}$ & $\stackrel{\Xi}{\sim}$ & & $m$ & $\bar{m}$ & $m$ & m. & $\dot{m}$ \\
\hline คิ & 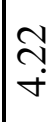 & in & $\begin{array}{l}\infty \\
\infty \\
i\end{array}$ & in & 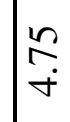 & in & $\begin{array}{l}\mathbb{Z} \\
\dot{m}\end{array}$ & $\stackrel{+}{-}$ & $\begin{array}{l}0 \\
+ \\
+\end{array}$ & $\mid \begin{array}{l}+ \\
\dot{+}\end{array}$ & c. & $\begin{array}{l}0 \\
0 \\
\text { r }\end{array}$ & $\begin{array}{l}\infty \\
i \\
i\end{array}$ & $\stackrel{\vartheta}{\overrightarrow{+}}$ & ڤ্. & $\left|\begin{array}{l}n \\
n \\
n\end{array}\right|$ & $\begin{array}{l}\vec{m} \\
\dot{m}\end{array}$ & $\left|\begin{array}{l}n \\
n \\
n\end{array}\right|$ & $\begin{array}{l}\infty \\
\infty \\
\dot{r}\end{array}$ & $\stackrel{m}{+}$ & $\begin{array}{l}\& \\
\dot{m}\end{array}$ & n़े & $\frac{?}{m}$ \\
\hline 已 & $\begin{array}{l}8 \\
i \\
i\end{array}$ & $\stackrel{n}{n}$ & $\hat{n}$ & $\begin{array}{l}n \\
n \\
i\end{array}$ & oे & $\stackrel{\substack{f \\
i}}{i}$ & $\stackrel{\circ}{\circ}$ & aे & @ & $\hat{m}$ & i & d & $\stackrel{n}{i}$ & 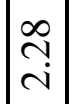 & : & $\underset{n}{n}$ & ले & $\mid \begin{array}{c}\hat{f} \\
\stackrel{\rho}{c}\end{array}$ & $\begin{array}{l}n \\
n \\
n \\
n\end{array}$ & 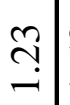 & 華 & 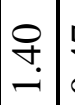 & శึ. \\
\hline こ & $\begin{array}{l}\infty \\
\stackrel{\infty}{0} \\
\varrho\end{array}$ & $\Xi$ & बें & no & 占 & i & $\begin{array}{l}\infty \\
\infty \\
r\end{array}$ & in & 官 & $=$ & $\begin{array}{l}\stackrel{2}{2} \\
\infty \\
\infty\end{array}$ & $\begin{array}{l}\vec{\infty} \\
\infty \\
\infty\end{array}$ & 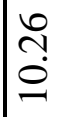 & 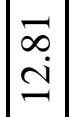 & $\left|\begin{array}{c}m \\
\infty \\
\infty\end{array}\right|$ & $\stackrel{1}{0}$ & $\frac{\infty}{0}$ & 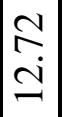 & $\stackrel{\curvearrowright}{\curvearrowright}$ & $\begin{array}{l}0 \\
\stackrel{1}{0} \\
= \\
=\end{array}$ & \begin{tabular}{l}
$\infty$ \\
\multirow{2}{0}{} \\
0
\end{tabular} & $\left|\begin{array}{l}\infty \\
\hdashline \\
i \\
\mid\end{array}\right|$ & $\left|\begin{array}{c}3 \\
\infty \\
\infty\end{array}\right|$ \\
\hline$-\widehat{\mathrm{E}}$ & $\begin{array}{l}\sim \\
\tilde{c} \\
c\end{array}$ & $\stackrel{\sim}{\stackrel{1}{2}}$ & ñ & $\stackrel{\substack{\infty \\
\infty}}{=}$ & $\begin{array}{l}0 \\
\stackrel{n}{1} \\
\end{array}$ & $\stackrel{ }{=}$ & $\begin{array}{l}\infty \\
\infty \\
0\end{array}$ & $\infty_{\infty}^{n}$ & 今 & $\begin{array}{l}\infty \\
\infty \\
1 \\
\end{array}$ & : & $\stackrel{m}{\tilde{c}}$ & $\begin{array}{l}\text { I } \\
\text { i } \\
\text { I }\end{array}$ & $\begin{array}{l}\forall \\
\dot{\Xi} \\
\dot{\Xi}\end{array}$ & 官. & $\begin{array}{c}\sim \\
\check{c} \\
\beth\end{array}$ & $\frac{n}{a}$ & $\left|\begin{array}{l}n \\
n \\
n \\
n\end{array}\right|$ & $\begin{array}{l} \pm \\
\dot{\sim} \\
\dot{\sim}\end{array}$ & 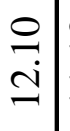 & $\begin{array}{l}0 \\
\beth \\
\beth\end{array}$ & 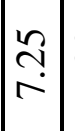 & $\tilde{c}$ \\
\hline 高 & $=$ & $\vec{\sigma}$ & 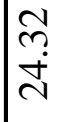 & ר. & $\mid \begin{array}{l}\text { in } \\
\text { in } \\
\end{array}$ & $\begin{array}{l}8 \\
\ddot{\lambda} \\
\text {. }\end{array}$ & $\begin{array}{l}+ \\
\text { ते } \\
\text { ते }\end{array}$ & 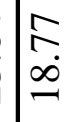 & 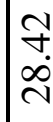 & $\stackrel{r}{\stackrel{n}{d}}$ & 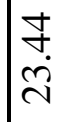 & 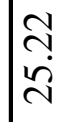 & $\begin{array}{l}\infty \\
\stackrel{n}{\sim} \\
\stackrel{\sim}{N}\end{array}$ & $\left|\begin{array}{l}0 \\
\infty \\
\infty \\
\infty \\
i\end{array}\right|$ & 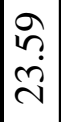 & $\left|\begin{array}{l}n \\
\infty \\
a \\
\end{array}\right|$ & $\begin{array}{l}\stackrel{b}{ } \\
\dot{d} \\
i\end{array}$ & $\begin{array}{l}\vec{i} \\
\overrightarrow{2}\end{array}$ & $\begin{array}{c}8 \\
8 \\
\dot{i} \\
i\end{array}$ & 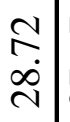 & $\begin{array}{l}\hat{b} \\
\vec{\sim}\end{array}$ & 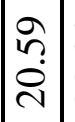 & $\left|\begin{array}{l}8 \\
\dot{\lambda} \\
\end{array}\right|$ \\
\hline 己 & ro & : & $\stackrel{\infty}{\circ}$ & ले & $\begin{array}{l}\tilde{n} \\
\tilde{n} \\
\tilde{n}\end{array}$ & $\begin{array}{l}n \\
2 \\
2\end{array}$ & 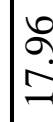 & $\begin{array}{l}\infty \\
\infty \\
\ddot{2}\end{array}$ & 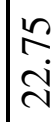 & $\begin{array}{l}0 \\
0 \\
0\end{array}$ & 華 & 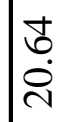 & $\frac{\&}{\dot{\lambda}}$ & $\mid \begin{array}{l}\vec{m} \\
m \\
\vec{n}\end{array}$ & $\left|\begin{array}{l}q \\
\sigma \\
0 \\
0\end{array}\right|$ & $\left|\begin{array}{l} \pm \\
\infty \\
\stackrel{\sim}{\sim}\end{array}\right|$ & $\begin{array}{l}\tilde{b} \\
\vec{\sim}\end{array}$ & $\frac{m}{\stackrel{d}{\sim}}$ & $\begin{array}{l}\curvearrowleft \\
\stackrel{\sim}{i} \\
\end{array} \mid$ & $\begin{array}{l}\hat{N} \\
\vec{i} \\
\end{array} \mid$ & 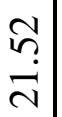 & 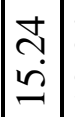 & \begin{tabular}{|l|} 
\\
m. \\
$\infty$ \\
$\infty$
\end{tabular} \\
\hline 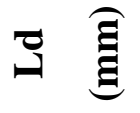 & 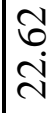 & 竞. & $\overrightarrow{8}$ & $\begin{array}{l}8 \\
0 \\
\stackrel{2}{0}\end{array}$ & $\stackrel{n}{\stackrel{n}{n}}$ & $\stackrel{\overbrace{}}{\stackrel{+}{\circ}}$ & in & $\mid \begin{array}{l}n \\
\stackrel{n}{ \pm}\end{array}$ & $\begin{array}{l}8 \\
\text { ते } \\
\text { ते }\end{array}$ & 苍 & 音 & 㐫 & 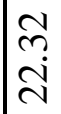 & $\mid \begin{array}{l}\overrightarrow{0} \\
\dot{+} \\
\end{array}$ & $\begin{array}{l}\tilde{0} \\
0 \\
0\end{array}$ & $\left|\begin{array}{l}n \\
\tilde{n} \\
\sim\end{array}\right|$ & $\begin{array}{l}n \\
\infty \\
\dot{v}\end{array}$ & $\mid \begin{array}{l}\stackrel{\sim}{\sim} \\
\stackrel{d}{\sim}\end{array}$ & $\begin{array}{l}n \\
\tilde{n} \\
\tilde{n}\end{array}$ & $\mid$ & $\begin{array}{c}\tilde{\lambda} \\
\dot{\sim}\end{array}$ & 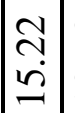 & $\begin{array}{r}\tilde{\imath} \\
\dot{\infty}\end{array} \mid$ \\
\hline 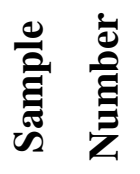 & 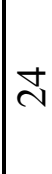 & a & $\underset{\sim}{\sim}$ & $\bar{\lambda}$ & $\stackrel{\sim}{\sim}$ & बे & ల్లి & $\bar{m}$ & $\tilde{m}$ & $m$ & লি & $\stackrel{m}{m}$ & in & $\hat{m}$ & ले & q & $\bar{F}$ & $\mathcal{F}$ & $\mathscr{F}$ & f & +o & F & + \\
\hline
\end{tabular}


Anticosti Island, Quebec - Plaesiomys anticostiensis Table 2 (continued)

\begin{tabular}{|c|c|c|c|c|c|c|c|c|c|c|c|c|c|c|c|c|c|c|c|c|c|c|c|}
\hline$\stackrel{\text { }}{\stackrel{D}{3}}$ & ڤ. & ô. & $\hat{a}$ & $\stackrel{\infty}{0}$ & 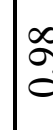 & हे & o & $\hat{\jmath}$ & $\begin{array}{l}\infty \\
\infty \\
0\end{array}$ & $£$ & ई & 3 & $\hat{\sigma}$ & $\hat{a}$ & $\hat{\varrho}$ & $\stackrel{8}{-}$ & â. & $\left|\begin{array}{l}\infty \\
\hdashline \\
0\end{array}\right|$ & an & ڤे & $\hat{\sigma}$ & ڤ̊ & $\hat{o}$ \\
\hline 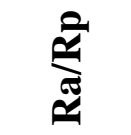 & $\stackrel{\infty}{-}$ & $\frac{\mathcal{A}}{\sim}$ & $\hat{\sigma}$ & $\overline{\widehat{\lambda}}$ & $\frac{m}{n}$ & م. & $\stackrel{2}{n}$ & $\stackrel{\text { I }}{-}$ & $\underset{\nabla}{\nabla}$ & in & $\stackrel{\overbrace{}}{\text { กิ }}$ & $\stackrel{t}{0}$ & $\stackrel{\overbrace{}}{i}$ & $\stackrel{\circ}{i}$ & $\hat{\Omega}$ & $\stackrel{f}{f}$ & $\stackrel{\infty}{\stackrel{\infty}{\rightarrow}}$ & $\mid \begin{array}{l}\infty \\
\infty \\
-\end{array}$ & $\left|\begin{array}{c}1 \\
\\
\end{array}\right|$ & $\mid \begin{array}{l}n \\
\stackrel{6}{-} \\
-\end{array}$ & in & $\stackrel{+}{\stackrel{+}{i}}$ & i \\
\hline$\dddot{\sharp}$ & $\bar{n}$ & $\approx n$ & in & t & $\bar{n}$ & 우 & 莦 & $\bar{m}$ & $\vec{m}$ & ช & $\hat{m}$ & $\hat{\imath}$ & $\tilde{n}$ & $\widetilde{6}$ & in & $\hat{m}$ & 扵 & in & $\infty$ & $\mathscr{\gamma}$ & $\sqrt{1}$ & $\overline{6}$ & in \\
\hline$\hat{\approx}$ & $\grave{\lambda}$ & $\stackrel{\sim}{\sim}$ & ते & $\tilde{N}$ & $\stackrel{J}{\sim}$ & $\widehat{\approx}$ & $\stackrel{J}{\sim}$ & $\approx$ & तี & 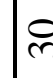 & i & $\stackrel{\odot}{~}$ & 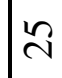 & i & $\hat{\imath}$ & i & $\approx$ & $\grave{\lambda}$ & $\approx$ & $\stackrel{\sim}{\sim}$ & $\approx$ & $\approx$ & i \\
\hline$\stackrel{\infty}{\hat{\Xi}}$ & लि & $\stackrel{\circ}{i}$ & $\stackrel{\circ}{i}$ & ڤ & $\frac{\tau}{c}$ & รั & के & $\stackrel{\infty}{=}$ & $\stackrel{\infty}{\stackrel{\infty}{0}}$ & ָ̊ & $\stackrel{0}{=}$ & ?ุ & 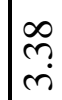 & $\stackrel{\vec{\sim}}{+}$ & $\left|\begin{array}{l}\hat{\infty} \\
i \\
i\end{array}\right|$ & $\stackrel{\infty}{=}$ & $\mid \begin{array}{l}\infty \\
\infty \\
0 \\
0\end{array}$ & $\left|\begin{array}{c}n \\
i \\
\end{array}\right|$ & 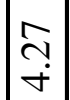 & $\left|\begin{array}{l}\infty \\
\sim \\
i\end{array}\right|$ & is & $\underset{i}{\Delta}$ & $\stackrel{i}{i}$ \\
\hline $\overrightarrow{\widehat{E}}$ & $\stackrel{2}{=}$ & $\stackrel{m}{m}$ & $\stackrel{\infty}{=}$ & $\begin{array}{l}\dot{D} \\
\infty \\
\dot{c}\end{array}$ & छூ & $\frac{n}{\mathrm{a}}$ & ț & $\underset{i}{\bar{i}}$ & กี & $\delta$ & ô & $\$$ & 它 & $\begin{array}{l}0 \\
0 \\
i\end{array}$ & $\left|\begin{array}{l}2 \\
\vdots \\
0\end{array}\right|$ & $\stackrel{\infty}{\infty}$ & 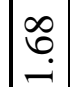 & 官 & $\mid \begin{array}{c} \pm \\
0\end{array}$ & 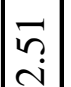 & in & Oִ & @ \\
\hline 巨્⿷ & त̂ & $\frac{\infty}{a}$ & 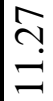 & 离 & $\begin{array}{l}n \\
\infty \\
\infty \\
\infty\end{array}$ & $\frac{7}{i n}$ & $\begin{array}{l}0 \\
\infty \\
0 \\
0\end{array}$ & i & $\stackrel{\infty}{\stackrel{\infty}{i}}$ & $\begin{array}{l}\infty \\
n \\
n\end{array}$ & $\frac{\Delta}{m}$ & $\stackrel{\infty}{\sim}$ & $\begin{array}{l}\dot{0} \\
\infty \\
\sigma\end{array}$ & $\stackrel{1}{0}$ & $\left|\begin{array}{l}2 \\
\infty \\
\infty\end{array}\right|$ & $\begin{array}{l}\vec{b} \\
\text { i }\end{array}$ & rag & $\left|\begin{array}{c}0 \\
+ \\
\infty \\
\infty\end{array}\right|$ & $\mid \begin{array}{l}0 \\
\stackrel{i}{i} \\
i\end{array}$ & $\mid \begin{array}{l}0 \\
m \\
i\end{array}$ & $\stackrel{\infty}{\stackrel{\infty}{0}}$ & $\begin{array}{l}0 \\
\dot{0} \\
0\end{array}$ & ${ }_{\infty}^{\sigma}$ \\
\hline$-\widehat{\mathrm{E}}$ & 6. & 官 & ते & $\begin{array}{l}\infty \\
\infty \\
\dot{I}\end{array}$ & $\begin{array}{l}n \\
n \\
a\end{array}$ & • & $\begin{array}{l}8 \\
\text { i }\end{array}$ & $\vec{g}$ & $\stackrel{\circ}{+}$ & $\begin{array}{l}5 \\
\text { in }\end{array}$ & $\stackrel{?}{\text { in }}$ & $\underset{\forall}{F}$ & बे & $\frac{n}{c}$ & $\mid \begin{array}{l}\infty \\
1 \\
\vdots \\
0\end{array}$ & 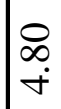 & $\begin{array}{l}n \\
6 \\
n\end{array}$ & $\begin{array}{l}\infty \\
\cdots \\
0 \\
0\end{array}$ & $\begin{array}{l}\stackrel{r}{q} \\
\dot{q}\end{array}$ & $\mid \begin{array}{c}0 \\
\dot{q} \\
\infty \\
\infty\end{array}$ & 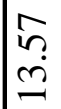 & $\stackrel{n}{=}$ & $\frac{n}{0}$ \\
\hline $3 \widehat{\mathrm{E}}$ & $\begin{array}{l}8 \\
\dot{j} \\
\dot{j}\end{array}$ & 중 & 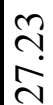 & 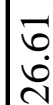 & 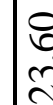 & $\begin{array}{l}\sigma \\
\infty \\
\infty\end{array}$ & 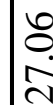 & 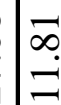 & $\stackrel{\infty}{=}$ & $\begin{array}{l}\infty \\
\infty \\
0 \\
0\end{array}$ & : & $\stackrel{m}{m}$ & $\begin{array}{l}+ \\
\infty \\
\mid \begin{array} { l } { + } \\
{ \infty } \\
{ }\end{array}$
\end{tabular}$} &{\text { 离 }} &{\left|\begin{array}{l}0 \\
\dot{2} \\
\tilde{i}\end{array}\right|} &{\text { 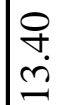 }} &{\underline{\sigma}} &{\left|\begin{array}{c}\overrightarrow{1} \\
\tilde{a} \\
\end{array}\right|} &{\left|\begin{array}{c}q \\
\dot{d} \\
\dot{d} \\
i\end{array}\right|} &{\mid} &{\begin{array}{l}\hat{\alpha} \\
\hat{\partial}\end{array}} &{\text { 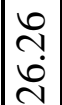 }} &{\stackrel{m}{\stackrel{m}{a}}} \\
{\hline \text { ב }} &{\stackrel{8}{\circ}} &{\begin{array}{l}1 \\
\infty \\
\infty \\
\infty\end{array}} &{\text { 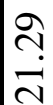 }} &{\begin{array}{l}\overline{0} \\
\text { i }\end{array}} &{\begin{array}{l}0 \\
\multicolumn{2}{c}{} \\
\multicolumn{1}{c}{}\end{array}} &{\stackrel{\tilde{I}}{\mathcal{I}}} &{\begin{array}{l}\infty \\
\infty \\
\vdots \\
\vdots\end{array}} &{\int_{\infty}^{7}} &{\begin{array}{l}\varkappa \\
\infty \\
\infty\end{array}} &{\text { in }} &{\stackrel{\vartheta}{=}} &{\text { Oे }} &{\text { 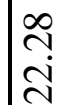 }} &{\begin{array}{l}\infty \\
\cdots \\
\\
\end{array}} &{\text { 㑒 }} &{\stackrel{m}{\stackrel{\rho}{2}}} &{\text { ָָ }} &{\mid \begin{array}{l}\bar{a} \\
\dot{a}\end{array}} &{\left|\begin{array}{c}\tilde{y} \\
\dot{v} \\
\end{array}\right|} &{\left|\begin{array}{c}\infty \\
\\
a \\
a\end{array}\right|} &{\begin{array}{l}\hat{\sim} \\
\dot{\sim}\end{array}} &{\mid \begin{array}{l}\infty \\
0 \\
\vec{i} \\
\mathbf{n}\end{array}} &{\text { 㐫 }} \\
{\hline \text { ఏ }} &{\mid \begin{array}{l}n \\
\infty \\
\infty \\
a\end{array}} &{\frac{n}{9}} &{\frac{\sigma}{\vec{\alpha}}} &{\frac{m}{\tilde{n}}} &{\begin{array}{l} \pm \\
\infty \\
\infty\end{array}} &{\vec{m}} &{\frac{\pi}{\pi}} &{\begin{array}{l}\infty \\
\infty \\
\infty\end{array}} &{\begin{array}{l}0 \\
\stackrel{0}{0}\end{array}} &{\text { in }} &{\text { ָָ }} &{\text { ?ֶ. }} &{\text { ले }} &{\text { 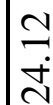 }} &{\left|\begin{array}{l}\tilde{r} \\
\dot{0} \\
0\end{array}\right|} &{\stackrel{m}{\stackrel{\rho}{2}}} &{\begin{array}{l}\vec{t} \\
\stackrel{i}{I}\end{array}} &{\left|\begin{array}{l}0 \\
0 \\
0 \\
0\end{array}\right|} &{\left|\begin{array}{l}n \\
n \\
\dot{a} \\
\end{array}\right|} &{\left|\begin{array}{l}2 \\
\partial \\
0 \\
0\end{array}\right|} &{\text { à }} &{\begin{array}{l}\hat{0} \\
\dot{a} \\
\dot{a}\end{array}} &{\text { ले }} \\
{\hline \text { 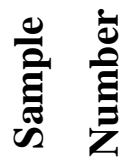 }} &{\text { I }} &{\text { in }} &{\text { in }} &{\text { nี }} &{\text { in }} &{n} &{\text { in }} &{i \infty} &{\text { in }} &{\text { 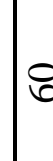 }} &{\widehat{\sigma}} &{0} &{\text { to }} &{R} &{\mathbb{N}} &{\text { 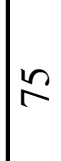 }} &{\text { 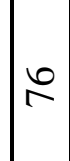 }} &{\approx} &{\stackrel{\infty}{\sim}} &{|\vec{\infty}|} &{\Phi_{\infty}^{\ddagger}} &{\infty} &{\text { ma }} \\
$\hline$\end{array}$


Anticosti Island, Quebec - Plaesiomys anticostiensis Table 2 (continued)

\begin{tabular}{|c|c|c|c|c|c|c|c|c|c|c|c|c|c|c|c|c|c|c|c|c|c|c|c|c|}
\hline$\stackrel{\text { }}{\stackrel{D}{3}}$ & ڤ. & ڤ̊. & $\mid \begin{array}{l}\infty \\
0 \\
0\end{array}$ & ळे & $\hat{o}$ & ڤ. & 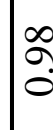 & 齐 & o & & & $\overbrace{}^{\infty}$ & $\begin{array}{l}\infty \\
\vdots \\
0\end{array}$ & 离 & ईे & gे & ڤ̊ & $\stackrel{8}{8}$ & $\stackrel{n}{2}$ & 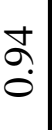 & $\hat{a}$ & 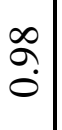 & $\hat{a}$ & $\begin{array}{l}2 \\
\hat{o}\end{array}$ \\
\hline 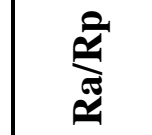 & $\stackrel{2}{\stackrel{2}{2}}$ & $\stackrel{n}{-}$ & $\stackrel{8}{\circ}$ & $\underline{\underline{S}}$ & $\stackrel{n}{n}$ & ñ & הి & $\infty$ & 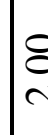 & & & $\begin{array}{c}\text { ch } \\
\text { in }\end{array}$ & $\begin{array}{l}q \\
i \\
i\end{array}$ & $\vec{m}$ & $\stackrel{\vartheta}{-}$ & ñ? & $\stackrel{q}{q}$ & ले & 点 & $\stackrel{9}{=}$ & 文 & $\begin{array}{l}\infty \\
\stackrel{\infty}{-} \\
-\end{array}$ & $\stackrel{+}{\stackrel{-}{2}}$ & $\stackrel{શ}{i}$ \\
\hline$\dddot{\sharp}$ & in & in & $\widehat{6}$ & in & 寸 & $\bar{n}$ & $\widehat{6}$ & 8 & v & is & ริ & 8 & 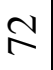 & o & in & $\stackrel{\vartheta}{f}$ & $\stackrel{\sim}{f}$ & ले & মি & $\stackrel{\vartheta}{\forall}$ & in & 8 & જ & in \\
\hline$\approx$ & $\approx$ & $\hat{n}$ & 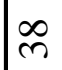 & i্ & $\stackrel{\infty}{\sim}$ & mি & లి & $\vec{c}$ & $a^{\infty}$ & 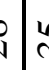 & $\hat{n}$ & $\vec{m}$ & లి & 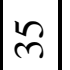 & $\stackrel{\infty}{\sim}$ & $\widehat{\imath}$ & i্লি & $\stackrel{\infty}{\sim}$ & $\approx$ & లి & $m$ & $\approx$ & $\hat{\imath}$ & $m$ \\
\hline คิ & $\begin{array}{l}\text { So } \\
\text { i }\end{array}$ & in & $\begin{array}{l}\hat{0} \\
i \\
i\end{array}$ & $\stackrel{2}{2}$ & $\bar{a}$ & $\stackrel{ \pm}{2}$ & $\stackrel{8}{\circ}$ & $\delta$ & ç & 5 & & 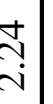 & $\stackrel{q}{r}$ & $\stackrel{0}{\stackrel{0}{\prime}}$ & $\stackrel{?}{\stackrel{f}{+}}$ & ?ִ & - & $\begin{array}{l}\infty \\
n \\
0 \\
0\end{array}$ & {$\left[\begin{array}{c}\tilde{\infty} \\
\infty \\
0 \\
0\end{array}\right.$} & ?. & ?ִ & $\tilde{n}$ & o. & $\frac{\partial}{m}$ \\
\hline 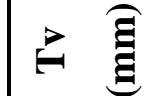 & $\delta$ & $\underset{i}{i}$ & $\underset{\dot{\theta}}{+}$ & حָ & $\stackrel{\infty}{+}$ & $\begin{array}{l}\stackrel{0}{0} \\
\text { i }\end{array}$ & $\begin{array}{l}: \\
i \\
i\end{array}$ & $\begin{array}{l}5 \\
9\end{array}$ & 8 & & $\begin{array}{l}6 \\
\text { i }\end{array}$ & $\begin{array}{l}\text { S. } \\
\text { S }\end{array}$ & $\begin{array}{l}\stackrel{\partial}{+} \\
\dot{t}\end{array}$ & $\mid$ & io & $\underset{i}{\stackrel{J}{i}}$ & $\mid$\begin{tabular}{l}
$\infty$ \\
\multirow{2}{-}{} \\
-1
\end{tabular} & $\begin{array}{l}n \\
\\
\end{array}$ & $\left|\begin{array}{c}n \\
i \\
i\end{array}\right|$ & 字 & $\left|\begin{array}{l}n \\
\infty \\
i\end{array}\right|$ & $\begin{array}{c}0 \\
\stackrel{0}{m}\end{array}$ & 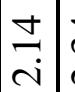 & ì \\
\hline 戸 $\widehat{\underline{\mathrm{g}}}$ & రి & nn & $\underset{\infty}{\infty}$ & 8 & ñ & ڤ̀ & $\begin{array}{l}q \\
\infty \\
\infty\end{array}$ & $\int_{2}^{2}$ & 7 & 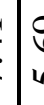 & of & 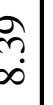 & $\stackrel{0}{\infty}$ & $\left|\begin{array}{l}\infty \\
\stackrel{n}{\infty}\end{array}\right|$ & $=$ & $\begin{array}{l}\stackrel{8}{\circ} \\
\dot{m}\end{array}$ & $\vec{\partial}$ & $\begin{array}{l}\infty \\
0 \\
\dot{r} \\
\dot{m}\end{array}$ & $\left|\begin{array}{r}2 \\
i \\
i\end{array}\right|$ & $\begin{array}{c}\hat{\imath} \\
\vec{n}\end{array}$ & $\stackrel{\hat{\sigma}}{\dot{+}}$ & 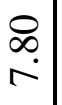 & $\stackrel{\vartheta}{\overrightarrow{+}}$ & $\begin{array}{c}\Delta \\
\stackrel{a}{a}\end{array}$ \\
\hline$-\widehat{\mathrm{E}}$ & $\hat{\sigma}$ & Oे. & $\bar{\sigma}$ & 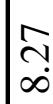 & $\begin{array}{l}0 \\
\text { in }\end{array}$ & f. & $\stackrel{\infty}{=}$ & 0 & s & & ?. & . & b. & $\mid \begin{array}{l}+ \\
\stackrel{f}{+}\end{array}$ & î & $\stackrel{m}{i}$ & $\mid \begin{array}{c}0 \\
\dot{b} \\
i\end{array}$ & $\begin{array}{l}m \\
\stackrel{q}{n} \\
\dot{n}\end{array}$ & $\mid \begin{array}{l}\hat{\sigma} \\
\dot{+}\end{array}$ & 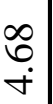 & $\left|\begin{array}{l}\mathscr{1} \\
\infty \\
0 \\
0\end{array}\right|$ & $\begin{array}{l}\Xi \\
\Xi\end{array}$ & बे & ָे \\
\hline ß & $\stackrel{m}{m}$ & $\begin{array}{l}\infty \\
\curvearrowright \\
\end{array}$ & 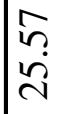 & $\begin{array}{l}\stackrel{+}{\mathrm{N}} \\
\text { ते }\end{array}$ & 卓 & ì & 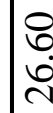 & $\left\{\begin{array}{l}\alpha \\
\alpha \\
c\end{array}\right.$ & శa & 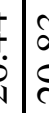 & לִ & $\begin{array}{c}n \\
\infty \\
c \\
c\end{array}$ & $\begin{array}{l}\vec{F} \\
\infty \\
\stackrel{N}{N}\end{array}$ & $\mid \begin{array}{l}\infty \\
\infty \\
n \\
n\end{array}$ & 究 & 尚 & 竎 & $\begin{array}{l}\tilde{\sigma} \\
\dot{\sigma} \\
\end{array}$ & 童 & $\begin{array}{l}n \\
n \\
\pm \\
\pm\end{array}$ & $\begin{array}{l}0 \\
0 \\
\infty \\
0 \\
-1\end{array}$ & $\begin{array}{l}\infty \\
\stackrel{d}{d}\end{array}$ & $\mid \begin{array}{l}\infty \\
+ \\
\infty \\
\infty \\
\end{array}$ & ָे. \\
\hline 己 & $\begin{array}{l}\tilde{N} \\
\infty \\
\infty\end{array}$ & م. & $\stackrel{n}{\stackrel{n}{a}}$ & $\stackrel{1}{0}$ & $\begin{array}{l}\stackrel{2}{i} \\
i\end{array}$ & $\vec{F}$ & ڤे & $\begin{array}{l}0 \\
\infty \\
\alpha\end{array}$ & $\begin{array}{l}\alpha \\
0 \\
0\end{array}$ & g & : & $\begin{array}{l}0 \\
\dot{2} \\
\vec{i}\end{array}$ & 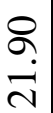 & $\begin{array}{l}\exists \\
\exists\end{array}$ & $\stackrel{m}{c}$ & : & $\mid \begin{array}{l}\tilde{\alpha} \\
\hat{c}\end{array}$ & $\begin{array}{l}2 \\
0 \\
0\end{array}$ & ? & $\begin{array}{l}\hat{n} \\
0 \\
0\end{array}$ & 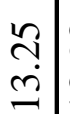 & $\begin{array}{l}\infty \\
\infty \\
\infty \\
\infty\end{array}$ & ले & $\begin{array}{l}0 \\
\stackrel{2}{8} \\
\dot{i}\end{array}$ \\
\hline Ð & 告 & $\stackrel{?}{\stackrel{?}{\leftrightarrows}}$ & 齐 & 吕 & $\begin{array}{l}\stackrel{n}{+} \\
\stackrel{2}{2}\end{array}$ & $\begin{array}{c}2 \\
\\
a\end{array}$ & $\frac{i}{2}$ & $\mid \begin{array}{l}\infty \\
\tilde{a} \\
0\end{array}$ & 5 & 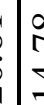 & $\begin{array}{l}\stackrel{0}{+} \\
\dot{t}\end{array}$ & $\begin{array}{l}6 \\
\dot{2} \\
\end{array}$ & $\begin{array}{l}\vec{F} \\
\vec{i} \\
\end{array}$ & $\mid$ & î & $\stackrel{?}{\stackrel{0}{=}}$ & $\left|\begin{array}{c}q \\
+ \\
\end{array}\right|$ & $\begin{array}{l}\hat{6} \\
\dot{0}\end{array}$ & 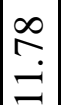 & |. & \begin{tabular}{|l}
$\vec{b}$ \\
$\dot{g}$ \\
$\dot{a}$
\end{tabular} \mid & 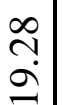 & $\left|\begin{array}{c}- \\
\infty \\
\dot{a}\end{array}\right|$ & $\overrightarrow{\bar{a}}$ \\
\hline 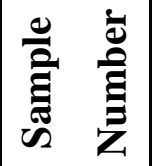 & & \pm & I & I & 守 & \& & g & ș & in & 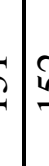 & I & $\tilde{n}$ & in & {$\left[\begin{array}{l}n \\
n\end{array}\right.$} & ஜ̊ & $\hat{n}$ & {$\left[\begin{array}{l}\infty \\
n\end{array}\right.$} & हn & $\mathbb{8}$ & $\underline{6}$ & $\widetilde{\sigma}$ & (6) & to & $\underline{6}$ \\
\hline
\end{tabular}


Anticosti Island, Quebec - Plaesiomys anticostiensis Table 2 (continued)

\begin{tabular}{|c|c|c|}
\hline 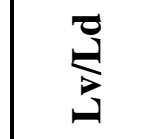 & $\stackrel{2}{0}$ & $\stackrel{\infty}{2}$ \\
\hline$\stackrel{\text { qิ }}{\approx}$ & $\stackrel{\infty}{-}$ & \\
\hline$\approx$ & in & $\sigma$ \\
\hline$\approx$ & $\bar{m}$ & mি \\
\hline 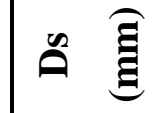 & i & 吾 \\
\hline 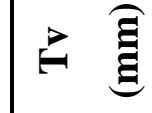 & $\begin{array}{l}\infty \\
\dot{m} \\
\dot{m}\end{array}$ & बे \\
\hline 己 & م. & $\stackrel{\infty}{\infty}$ \\
\hline - $\widehat{\mathrm{g}}$ & $\stackrel{0}{\infty}$ & $\stackrel{\stackrel{N}{\Xi}}{=}$ \\
\hline$=\widehat{\widehat{\Xi}}$ & $\begin{array}{l}n \\
\approx \\
\approx\end{array}$ & 络 \\
\hline ¿ & ב. & $\overline{\bar{\lambda}}$ \\
\hline Ð & $\begin{array}{l}\infty \\
\infty \\
\infty \\
\infty\end{array}$ & $\stackrel{\text { I}}{\stackrel{\mathrm{A}}{\mathrm{i}}}$ \\
\hline 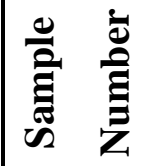 & $\stackrel{0}{\circ}$ & $\sqrt{6}$ \\
\hline
\end{tabular}


Manitoulin Island, Ontario - Plaesiomys browni Table 3

\begin{tabular}{|c|c|c|c|c|}
\hline 疍 & 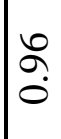 & 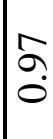 & 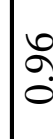 & 8 \\
\hline 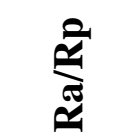 & $\stackrel{\mathcal{f}}{-}$ & సે & to & f \\
\hline$\approx$ & $\hat{m}$ & $\bar{m}$ & r. & 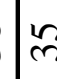 \\
\hline$\approx$ & $\underset{\imath}{ }$ & $\underset{\sim}{ \pm}$ & $\approx$ & 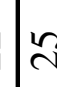 \\
\hline$\widehat{n} \widehat{\underline{E}}$ & $\stackrel{\sim}{\approx}$ & $\frac{7}{\dot{m}}$ & ia & $\infty$ \\
\hline ᄅ & 苞 & ర్ర & $\begin{array}{l}\infty \\
0 \\
i\end{array}$ & $\stackrel{\infty}{+}$ \\
\hline 르잌 & $\begin{array}{l}\infty \\
\infty \\
i\end{array}$ & $\begin{array}{l}0 \\
\infty \\
\infty \\
0\end{array}$ & $\frac{7}{n}$ & 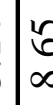 \\
\hline - & 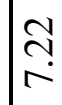 & है & $\frac{2}{\infty}$ & $\begin{array}{l}\square \\
0 \\
0\end{array}$ \\
\hline $3 \widehat{\widehat{E}}$ & $\begin{array}{l}0 \\
\tilde{n} \\
\text { in }\end{array}$ & 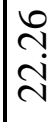 & $\begin{array}{l}\infty \\
\cdots \\
\pi\end{array}$ & $\mid \begin{array}{l}7 \\
\bar{y} \\
\dot{y}\end{array}$ \\
\hline 己 & $\stackrel{ }{\stackrel{1}{.}}$ & $\begin{array}{l}\text { s. } \\
\infty\end{array}$ & $\bar{\alpha}$ & $\frac{\sqrt{x}}{\alpha}$ \\
\hline 戸 & $\begin{array}{l}\hat{2} \\
\infty \\
\infty \\
-\infty\end{array}$ & $\frac{a}{9}$ & $\mid \begin{array}{l}\not \\
\alpha\end{array}$ & $\mid \begin{array}{l}\alpha \\
\alpha \\
\alpha\end{array}$ \\
\hline 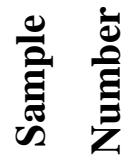 & - & | & in & $1 \alpha$ \\
\hline
\end{tabular}


- Plaesiomys subcircularis Table 4

\begin{tabular}{|c|c|c|c|}
\hline 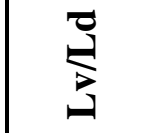 & बे & å & $\stackrel{n}{a}$ \\
\hline 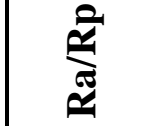 & $\bar{\sigma}$ & ñ & 8 \\
\hline$\underset{\mathscr{C}}{\mathscr{2}}$ & 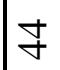 & $\stackrel{n}{m}$ & $\stackrel{さ}{\sim}$ \\
\hline 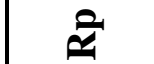 & $\pi$ & $\approx$ & $\stackrel{\sim}{\sim}$ \\
\hline 气 & $\frac{0}{0}$ & o. & $\begin{array}{l}\stackrel{0}{0} \\
0\end{array}$ \\
\hline 욬 & 艿 & $\bar{r}$ & $\underset{\sim}{\infty}$ \\
\hline$\bigoplus$ छ & $\stackrel{\sim}{\mathfrak{r}}$ & $\stackrel{n}{\sim}$ & $\frac{m}{m}$ \\
\hline$\Leftrightarrow \widehat{\Xi}$ & $\begin{array}{l}6 \\
6 \\
6\end{array}$ & مי & ñ \\
\hline 鸹 & $\begin{array}{l}0 \\
n \\
\\
\end{array}$ & 守 & $\begin{array}{l}m \\
\\
\sim\end{array}$ \\
\hline 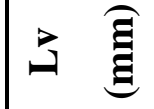 & $\begin{array}{l}n \\
\stackrel{n}{r} \\
\ddot{z}\end{array}$ & 官 & ๗̃a \\
\hline 모 ఏ & $\begin{array}{l}6 \\
\ddot{6} \\
-1\end{array}$ & $\begin{array}{l}0 \\
m \\
m \\
-1\end{array}$ & $\hat{\sigma}$ \\
\hline 龸 & 이 & $\stackrel{\infty}{\sim}$ & Әे \\
\hline
\end{tabular}

\begin{tabular}{|c|c|c|c|c|c|c|}
\hline 芦 & ळे & $\mid \begin{array}{l}n \\
\vdots \\
0\end{array}$ & $\begin{array}{l}\infty \\
0 \\
0\end{array}$ & 8 & बे & @̊ \\
\hline 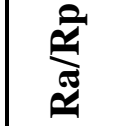 & ?̊ & $\stackrel{\sim}{\stackrel{n}{*}}$ & 구 & $\stackrel{\infty}{+}$ & $\stackrel{\infty}{n}$ & nn \\
\hline$\stackrel{\mathscr{*}}{\mathscr{4}}$ & $\bar{n}$ & $\underset{+}{+\infty}$ & 寸 & g̊ & $\underset{m}{\infty}$ & g) \\
\hline 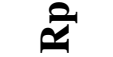 & $\dot{m}$ & $m$ & m & $m$ & ন & $\tilde{n}$ \\
\hline$\stackrel{\infty}{\mathrm{\Xi}}$ & g. & 古 & Jे & $\stackrel{8}{\stackrel{9}{+}}$ & $\frac{2}{0}$ & 它 \\
\hline 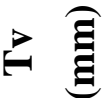 & กิ & $\underset{-\infty}{\infty}$ & ? & ì & ळ̊ & $\hat{a}$ \\
\hline 로 & $\stackrel{\sim}{\beth}$ & in & $\stackrel{n}{n}$ & gे & $m$ & $\underset{+}{\infty}$ \\
\hline$\in \widehat{\mathrm{\Xi}}$ & $\begin{array}{l}8 \\
0 \\
1\end{array}$ & $\mid \begin{array}{l}n \\
n \\
q \\
q\end{array}$ & $\begin{array}{l}\infty \\
\stackrel{\infty}{r} \\
\dot{m}\end{array}$ & ণิ & ت & ڤ̊ \\
\hline$>\widehat{\Xi}$ & $\begin{array}{l}\hat{N} \\
\infty \\
-\end{array}$ & ヘ̂̃ & $\begin{array}{l}m \\
\tilde{\sigma}\end{array}$ & $\underset{\square}{ \pm}$ & $\frac{\infty}{1}$ & $\begin{array}{l}0 \\
0 \\
0 \\
0\end{array}$ \\
\hline 主 & $\begin{array}{l}\tilde{v} \\
\tilde{\Xi} \\
\dot{Z}\end{array}$ & $\begin{array}{l}0 \\
0 \\
i \\
\end{array}$ & $\underline{0}$ & $\begin{array}{l}n \\
\tilde{m}\end{array}$ & $\stackrel{m}{\stackrel{2}{ \pm}}$ & 竎 \\
\hline త્ઞ & $\begin{array}{l}\tilde{\sigma} \\
\dot{J}\end{array}$ & $\begin{array}{l}\tilde{m} \\
m \\
m\end{array}$ & $\stackrel{m}{n}$ & ấ & $\begin{array}{l}\infty \\
\infty \\
\dot{J}\end{array}$ & ڤે \\
\hline 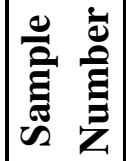 & - & $N$ & $m$ & $\nabla$ & $n$ & 6 \\
\hline
\end{tabular}


Mackenzie Mountains, Northwest Territories - Plaesiomys columbia Table 5

\begin{tabular}{|c|c|c|c|c|c|}
\hline 疍 & 3 & $\hat{a}$ & \& & & $\hat{\alpha}$ \\
\hline 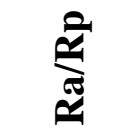 & $\stackrel{\overbrace{}}{\overbrace{}}$ & $\bar{m}$ & $\stackrel{n}{n}$ & م. & $\stackrel{\infty}{\infty}$ \\
\hline$\approx$ & ㄱ & ল্ & 活 & in & $n$ \\
\hline 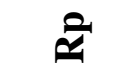 & $\bar{m}$ & i & $\stackrel{\infty}{\sim}$ & $\tilde{n}$ & $\stackrel{\infty}{\sim}$ \\
\hline$\stackrel{n}{\hat{\theta}}$ & g. & $\stackrel{\text { }}{\sim}$ & $\stackrel{n}{n}$ & $\begin{array}{l}\text { ते } \\
\text { in }\end{array}$ & 守 \\
\hline$\gtrless \widehat{\mathrm{E}}$ & ه & $\stackrel{\infty}{\stackrel{+}{+}}$ & in & ర్ర & 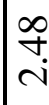 \\
\hline こ & 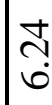 & م્ & $\begin{array}{l}\tilde{n} \\
\infty \\
\infty\end{array}$ & $\frac{n}{6}$ & $\stackrel{n}{n}$ \\
\hline - & $\frac{\pi}{6}$ & 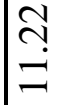 & 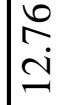 & $\frac{\dot{a}}{2}$ & సิ \\
\hline $3 \widehat{\mathrm{g}}$ & \begin{tabular}{l}
5 \\
\hdashline \\
\end{tabular} & $\mid \begin{array}{l}\infty \\
\infty \\
0 \\
0 \\
\end{array}$ & $\underset{\dot{m}}{\stackrel{g}{c}}$ & $\frac{5}{9}$ & $\begin{array}{l}6 \\
\qquad \\
\end{array}$ \\
\hline ב臣 & 尽 & 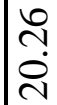 & $\begin{array}{l}a \\
\text { a }\end{array}$ & 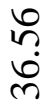 & $\begin{array}{l}\infty \\
\infty \\
0\end{array}$ \\
\hline ఏ & $\stackrel{f}{\stackrel{\sim}{*}}$ & î & $\begin{array}{l}\infty \\
\infty \\
\infty \\
\infty\end{array}$ & 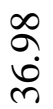 & 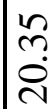 \\
\hline 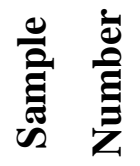 & - & $N$ & $m$ & $\nabla$ & 1 \\
\hline
\end{tabular}


Ohio-Kentucky-Indiana tri-state area - Plaesiomys subquadrata Table 6

\begin{tabular}{|c|c|c|c|c|c|c|c|c|c|c|c|c|c|c|c|c|c|c|c|c|c|c|c|c|}
\hline 疍 & ڤ & 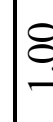 & 8 & $\begin{array}{l}8 \\
\delta \\
c\end{array}$ & & & 齐 & : & $\stackrel{n}{0}$ & o. & ț & $\mid \hat{a}$ & 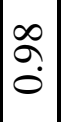 & 2 & $\begin{array}{l}\text { ڤ̊ } \\
\text { o. }\end{array}$ & ô. & 总 & $\begin{array}{l}\circ \\
\vdots \\
\vdots\end{array}$ & $\begin{array}{l}\text { å. } \\
\vdots\end{array}$ & $\begin{array}{l}\infty \\
\vdots \\
0\end{array}$ & $\begin{array}{l}2 \\
\vdots\end{array}$ & 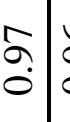 & & : \\
\hline 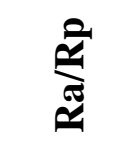 & $\stackrel{0}{\stackrel{2}{*}}$ & $\underset{c}{\infty}$ & 6 & 15 & & $\begin{array}{c}\Delta \\
\text { N } \\
\end{array}$ & $\begin{array}{c}2 \\
\text { in } \\
\text { i }\end{array}$ & $\stackrel{m}{?}$ & $\stackrel{5}{6}$ & 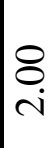 & $\stackrel{\infty}{i}$ & $\stackrel{\infty}{\stackrel{\infty}{r}}$ & $\left(\begin{array}{l}0 \\
i \\
i\end{array}\right.$ & - & $\stackrel{\substack{t \\
i}}{\stackrel{1}{i}}$ & $\stackrel{\infty}{\stackrel{\infty}{\sim}}$ & $\stackrel{\overrightarrow{0}}{-}$ & $\begin{array}{l}\infty \\
\infty \\
-\end{array}$ & $\stackrel{?}{i}$ & $\hat{g}$ & 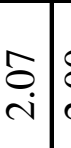 & $\underset{i}{8}$ & & i্ \\
\hline$\approx$ & 8 & $\tilde{c}$ & 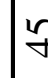 & 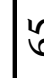 & ? & 寸 & $\nabla$ & F & 8 & 8 & $\cong$ & $i n$ & 6 & $\nabla$ & $\stackrel{2}{\curvearrowleft}$ & 安 & $\tilde{n}$ & 8 & $\bar{\infty}$ & in & $\widehat{\sigma}$ & $\infty$ & $n$ & 6 \\
\hline चे & $\stackrel{ }{m}$ & तิ & $\hat{\tau}$ & वृ & & $n$ & $\hat{\imath}$ & i & 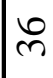 & $m$ & $\approx$ & $\tilde{m}$ & D & 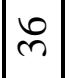 & $\bar{m}$ & $\vec{m}$ & $m$ & $\approx$ & 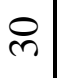 & $\grave{\lambda}$ & i & ষ্টে & i & $\hat{\imath}$ \\
\hline$\widehat{\ominus} \widehat{\Xi}$ & م & ले & $£$ & 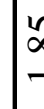 & & $\vec{s}_{i}$ & $\begin{array}{c}\stackrel{ \pm}{\sim} \\
\dot{n}\end{array}$ & $\exists$ & $\stackrel{\sim}{\sim}$ & $\stackrel{\infty}{\infty}$ & 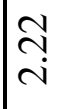 & 目 & $\exists$ & ñ & $\begin{array}{l}8 \\
i \\
i\end{array}$ & $\mid \begin{array}{c}\infty \\
\infty \\
- \\
-\end{array}$ & $\begin{array}{l}\text { t. } \\
\text { o. }\end{array}$ & : & $\begin{array}{l}\infty \\
\infty \\
-\end{array}$ & 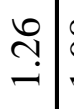 & 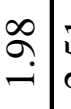 & \begin{tabular}{c|c}
$\tilde{n}$ & \\
&
\end{tabular} & & 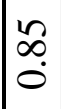 \\
\hline $\overrightarrow{\mathrm{E}}$ & $\overrightarrow{\mathrm{N}}$ & $\frac{\pi}{4}$ & $\frac{\sigma}{c}$ & $\mid \begin{array}{l}1 \\
7\end{array}$ & & ה. & â. & $\stackrel{A}{A}$ & 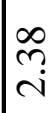 & $\begin{array}{l}\infty \\
i \\
i\end{array}$ & 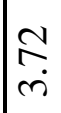 & $\left|\begin{array}{c}0 \\
\dot{n} \\
\dot{r}\end{array}\right|$ & $\left|\begin{array}{l}\tilde{n} \\
i \\
i\end{array}\right|$ & $\begin{array}{l}\hat{\sigma} \\
\hat{i}\end{array} \mid$ & $\stackrel{q}{+}$ & 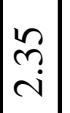 & $\begin{array}{l}0 \\
\stackrel{0}{i} \\
i\end{array}$ & $\left|\begin{array}{l}n \\
\hat{i} \\
i\end{array}\right|$ & $\begin{array}{l}\text { ठ্ } \\
\dot{r}\end{array}$ & $\left.\mid \begin{array}{l}0 \\
0 \\
i\end{array}\right)$ & $\hat{\varrho}$ & $\begin{array}{lll}0 & \\
: & \\
i & i\end{array}$ & & $\mid \begin{array}{l}\text { sq } \\
\text { in }\end{array}$ \\
\hline こ $\widehat{E}$ & 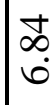 & in & $\vartheta$ & 5 & & $\stackrel{\circ}{?}$ & $\begin{array}{c}\infty \\
\infty \\
\infty\end{array}$ & $\stackrel{i}{i}$ & $\vec{N}$ & $\hat{\curvearrowright}$ & 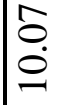 & $\stackrel{?}{a}$ & $\vec{n}$ & त̂̃ & $\begin{array}{l}0 \\
+ \\
0 \\
0\end{array}$ & ? & $\underset{\substack{q \\
r}}{.}$ & $\underset{\infty}{+}$ & $\begin{array}{c}0 \\
\vdots \\
\sigma\end{array}$ & $\begin{array}{l}\infty \\
2 \\
i\end{array}$ & 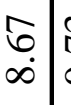 & $\stackrel{2}{a}$ & & $\begin{array}{l}\text { त̂ } \\
\text { in }\end{array}$ \\
\hline$-\widehat{\mathrm{E}}$ & $\begin{array}{l}\infty \\
\infty \\
\infty\end{array}$ & $\infty$ & s & $\int_{0}^{\alpha}$ & & vִ & $\begin{array}{l}\hat{n} \\
0 \\
0\end{array}$ & m. & $\hat{a}$ & $\stackrel{9}{=}$ & $\begin{array}{l}\tilde{\sigma} \\
\dot{\Xi} \\
\dot{\Xi}\end{array}$ & $\left|\begin{array}{l}\infty \\
\stackrel{n}{a} \\
\end{array}\right|$ & 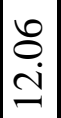 & $\left|\begin{array}{l}\infty \\
\infty \\
\infty \\
\sigma\end{array}\right|$ & $\begin{array}{l}m \\
\ddot{n}\end{array}$ & $\left|\begin{array}{l}\infty \\
\infty \\
\infty\end{array}\right|$ & $\begin{array}{l}\hat{m} \\
\stackrel{0}{0}\end{array}$ & $\begin{array}{l}2 \\
\hat{\sigma} \\
0\end{array}$ & $\begin{array}{l}\tilde{N} \\
\ddot{2}\end{array}$ & $\frac{9}{a}$ & $\begin{array}{ll}0 \\
\vdots \\
0\end{array}$ & \begin{tabular}{l|l}
$\vec{\infty}$ & \\
$\dot{I}$ &
\end{tabular} & & aे. \\
\hline ¿ $\widehat{\underline{\Xi}}$ & $\begin{array}{l}\hat{0} \\
\text { ते }\end{array}$ & 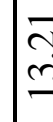 & Э & $\begin{array}{l}\bar{\alpha} \\
\bar{c}\end{array}$ & & 5 & 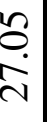 & 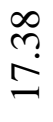 & $\frac{2}{\grave{\lambda}}$ & $\begin{array}{l}n \\
n \\
\infty \\
i\end{array}$ & 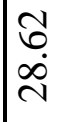 & $\left|\begin{array}{l}\stackrel{\curvearrowright}{\sim} \\
\dot{\sim}\end{array}\right|$ & 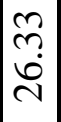 & $\left|\begin{array}{c}n \\
\dot{d} \\
\dot{d}\end{array}\right|$ & $\begin{array}{l}\infty \\
\stackrel{+}{\dot{m}}\end{array}$ & $\mid \begin{array}{l}q \\
\stackrel{+}{\sim} \\
\dot{\sim}\end{array}$ & $\begin{array}{l}\hat{b} \\
\dot{i} \\
\end{array}$ & $\mid \begin{array}{l}\infty \\
\infty \\
\dot{\sim} \\
\dot{N}\end{array}$ & $\begin{array}{l}\mathbb{N} \\
\hat{D} \\
\dot{m}\end{array}$ & $\begin{array}{l}\stackrel{+}{+} \\
\text { ते }\end{array}$ & & $\begin{array}{l}\text { ड़ } \\
\text { cे }\end{array}$ & & $\begin{array}{l}\infty \\
\vec{i} \\
\end{array}$ \\
\hline 省 & ñ & $\begin{array}{l}\infty \\
\infty \\
0\end{array}$ & $\begin{array}{l}\infty \\
\& \\
j \\
\end{array}$ & $\hat{0}$ & & $\begin{array}{l}0 \\
\vdots \\
0 \\
0 \\
0\end{array}$ & $\begin{array}{l}0 \\
\dot{0} \\
\stackrel{2}{2}\end{array}$ & 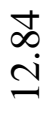 & $\stackrel{2}{\stackrel{2}{6}}$ & 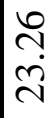 & ì & $\left|\begin{array}{c}\hat{\sigma} \\
\dot{\lambda} \\
\vec{v}\end{array}\right|$ & $\mid$ & $\left|\begin{array}{c}\stackrel{N}{\sim} \\
\dot{\sim}\end{array}\right|$ & $\begin{array}{l}\infty \\
n \\
n \\
n\end{array}$ & $\frac{1}{6}$ & $\begin{array}{c}m \\
\infty \\
\infty\end{array}$ & $\mid \begin{array}{l}0 \\
0 \\
0\end{array}$ & $\begin{array}{l}a \\
\dot{\lambda} \\
\text { iे }\end{array}$ & $\begin{array}{l}\stackrel{0}{2} \\
\stackrel{1}{=}\end{array}$ & 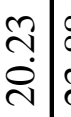 & $\begin{array}{lll}\infty & \\
\infty & \\
\dot{\lambda} & & \end{array}$ & & $\stackrel{\infty}{\rightarrow}$ \\
\hline ت્తి & 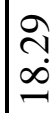 & $\underline{\underline{\infty}}$ & J & ¿ & & $\begin{array}{l}0 \\
\dot{0} \\
0\end{array}$ & 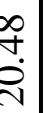 & $\begin{array}{l}8 \\
\text { i } \\
\text { in }\end{array}$ & $\stackrel{?}{\stackrel{2}{I}}$ & $\begin{array}{l}\infty \\
\infty \\
\ddot{\lambda}\end{array}$ & $\stackrel{\stackrel{m}{m}}{\stackrel{\sim}{N}}$ & $\mid \begin{array}{c}\stackrel{+}{\vec{\lambda}} \\
\dot{\vec{\lambda}}\end{array}$ & $\mid$ & $\left|\begin{array}{l}\infty \\
\infty \\
\dot{\vec{\lambda}}\end{array}\right|$ & $\begin{array}{l}\hat{b} \\
\dot{i} \\
\end{array}$ & 完 & $\begin{array}{l}\infty \\
\infty \\
\infty \\
\infty\end{array}$ & $\begin{array}{l}\Omega \\
\Omega \\
\Omega\end{array}$ & $\begin{array}{l}\stackrel{2}{n} \\
\stackrel{\sim}{2}\end{array}$ & $\frac{\infty}{\infty}$ & $\begin{array}{l}n \\
n \\
\vdots \\
\end{array}$ & \begin{tabular}{l|l}
$\vec{b}$ & \\
$\dot{d}$ &
\end{tabular} & & $\mid \begin{array}{c}\tilde{D} \\
\stackrel{\infty}{=} \\
\end{array}$ \\
\hline 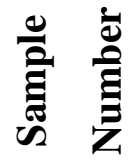 & - & $n$ & $\nabla$ & 4 & & 0 & - & $\infty$ & $=$ & 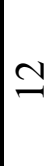 & $\because$ & \pm & 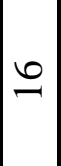 & $\Xi$ & $\stackrel{2}{2}$ & ì & $\bar{\lambda}$ & $\mathbb{N}$ & $\tilde{\lambda}$ & 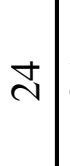 & v & तlt & $\hat{v}$ & 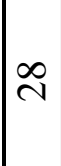 \\
\hline
\end{tabular}


Ohio-Kentucky-Indiana tri-state area - Plaesiomys subquadrata Table 6

(continued - Top), P. bellistriatus (middle); Illinois $P$. bellistriatus (bottom)

\begin{tabular}{|c|c|c|c|}
\hline 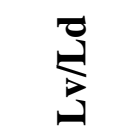 & o̊ & $\hat{a}$ & $\underset{\infty}{\infty}$ \\
\hline$\stackrel{2}{\mathscr{A}}$ & $\stackrel{+}{\infty}$ & $\begin{array}{c}\infty \\
\sim \\
\sim\end{array}$ & $\frac{ \pm}{i}$ \\
\hline$\underset{\mathscr{*}}{\mathscr{*}}$ & in & రి & 守 \\
\hline qu & ñ & নे & ㄱ. \\
\hline ค̊ ఏ & $\stackrel{\infty}{=}$ & $\stackrel{\infty}{\infty}$ & $\begin{array}{l}\vec{\nabla} \\
\text { i }\end{array}$ \\
\hline$\Rightarrow$ छ & શે & $\frac{a}{m}$ & $\begin{array}{l}\infty \\
\infty \\
i\end{array}$ \\
\hline 토 & & $\underset{\substack{\infty \\
ٍ}}{ }$ & $\underset{N}{N}$ \\
\hline$\Leftrightarrow$ ఏ & $\stackrel{9}{0}$ & $\begin{array}{l}\infty \\
\infty \\
\sigma\end{array}$ & $\begin{array}{l}\infty \\
\infty\end{array}$ \\
\hline$\gtrless \widehat{\Xi \Xi}$ & $\begin{array}{l}\sigma \\
\text { ñ }\end{array}$ & 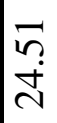 & \begin{tabular}{l}
\multirow{2}{n}{} \\
$\tilde{n}$ \\
$\sim$
\end{tabular} \\
\hline 氞 & 官 & $\begin{array}{l}0 \\
\infty \\
\infty\end{array}$ & $\frac{a}{2}$ \\
\hline ન્తి છ & o̊ & $\underline{a}$ & 告 \\
\hline 莺 & શે & in & mె \\
\hline
\end{tabular}

\begin{tabular}{|c|c|}
\hline 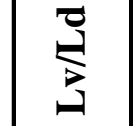 & ô \\
\hline 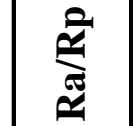 & $\frac{6}{2}$ \\
\hline$\underset{\sim}{*}$ & 6 \\
\hline बे & $\bar{m}$ \\
\hline 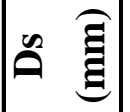 & $\stackrel{+}{n}$ \\
\hline$\rightarrow \widehat{\Xi}$ & $\begin{array}{l}\infty \\
\text { i } \\
\text { i }\end{array}$ \\
\hline 들 & $\begin{array}{l}\infty \\
\\
0\end{array}$ \\
\hline$-\widehat{\Xi}$ & $\begin{array}{l}\infty \\
\text { I } \\
\mathcal{1}\end{array}$ \\
\hline $3 \widehat{\Xi \Xi}$ & กิ \\
\hline$\gg \longdiv { \Xi }$ & $\begin{array}{l}\overline{0} \\
\ddot{\gamma}\end{array}$ \\
\hline ટ્తి & $\stackrel{0}{\stackrel{0}{\sim}}$ \\
\hline 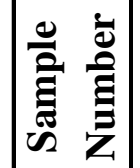 & m \\
\hline
\end{tabular}

\begin{tabular}{|c|c|}
\hline 芦 & aे \\
\hline$\overbrace{\mathscr{n}}^{2}$ & $\begin{array}{l}8 \\
i \\
i\end{array}$ \\
\hline$\underset{\sim}{\approx}$ & $\infty$ \\
\hline$\stackrel{2}{\alpha}$ & ల \\
\hline$\stackrel{\varrho}{\Xi}$ & 웅 \\
\hline$\rightarrow \widehat{\Xi}$ & $\underset{\sigma}{\sigma}$ \\
\hline 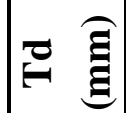 & ب \\
\hline$-\widehat{\Xi}$ & $\begin{array}{l}0 \\
0 \\
1\end{array}$ \\
\hline$B \widehat{\Xi}$ & $\frac{n}{i}$ \\
\hline 念 & 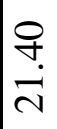 \\
\hline ఫ્ఏ & $\frac{0}{i}$ \\
\hline 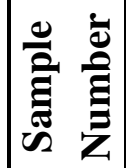 & $\ddot{n}$ \\
\hline
\end{tabular}


Oklahama - Austinella multicostella Table 7

\begin{tabular}{|c|c|}
\hline$\stackrel{\Xi}{\stackrel{\Xi}{3}}$ & $\bar{c}$ \\
\hline 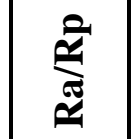 & \\
\hline$\tilde{~}$ & \\
\hline$\hat{\simeq}$ & 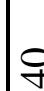 \\
\hline$\stackrel{\underline{\Xi}}{0}$ & \& \\
\hline$\geq \widehat{\mathrm{g}}$ & $\begin{array}{l}\infty \\
\dot{\rho} \\
\dot{\rho}\end{array}$ \\
\hline$\approx \widehat{\Xi}$ & $\underset{\sim}{\stackrel{2}{2}}$ \\
\hline$-\widehat{\mathrm{g}}$ & $\underset{ }{=}$ \\
\hline$>\widehat{\mathrm{g}}$ & $\left|\begin{array}{l}\vec{\infty} \\
\dot{b} \\
\end{array}\right|$ \\
\hline $\begin{array}{ll}\mathrm{g} \\
\mathrm{g}\end{array}$ & $\left|\begin{array}{c}\vec{n} \\
\grave{n}\end{array}\right|$ \\
\hline$\Xi \widehat{\underline{\mathrm{g}}}$ & $\left|\begin{array}{l}\stackrel{2}{\vec{i}} \\
\vec{i}\end{array}\right|$ \\
\hline 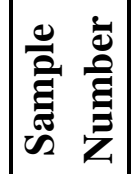 & 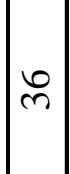 \\
\hline
\end{tabular}




\title{
Curriculum Vitae
}

\author{
Name \\ Colin David Sproat \\ Education \\ B.Sc. - Brandon University, 2005-2010 \\ M.Sc. - University of Western Ontario, 2010-2013
}

\begin{abstract}
Awards
Graduate

- Western Graduate Research Scholarship - 2011, 2012

- Charles Southworth Memorial Prize in Paleontology - 2011

- NSERC Canadian Graduate Scholarship - 2010

- Christopher Riley Memorial Graduate Scholarship - 2010

Undergraduate
\end{abstract}

- NSERC Undergraduate Student Research Award - 2008, 2009, 2010

- Honours List at Brandon University - 2006, 2007, 2008, 2009, 2010

- Silver Medal in Geology at Brandon University - 2010

- Louis Riel Scholarship - 2006, 2007, 2009

- John Malcolm Brodie Memorial Scholarship - 2009

- Isabelle Douglas Estate Scholarship - 2009

- Manitoba Telecom Services Scholarship for Aboriginal Students - 2009, 2006

- NSERC Undergraduate Student Research Award - 2009, 2008

- Christopher Riley Memorial Scholarship in 3rd Year Geology - 2008

- Department of Geology Research Award - 2008

- Louis Riel Scholarship - 2007, 2006

- Robert James Lang Memorial Scholarship in Geology - 2007

- Christopher Riley Memorial Scholarship in 1st Year Geology - 2006

- Brandon University Board of Governors Entrance Scholarship - 2005 


\section{Conference Presentations}

Sohrabi, A., Sproat, C.D., and Jin, J. 2012. Latitudinal gradients and development of endemism in Late Ordovician brachiopods of Laurentia: examples from the Hiscobeccus-Rhynchotrema and Dinorthis-Plaesiomys lineages. Canadian Paleontology Conference 2012.

Sproat, C.D., Jin, J., and Li, R.-y. 2012. The Late Ordovician plaesiomyid brachiopod lineage: Evolution and extinction towards the Ordovician-Silurian boundary. IGCP 591 Annual meeting and 1st Foerste Symposium.

Sproat, C.D., Jin, J., and Li, R.-y. 2011. Comparisons of the morphology of plaesiomyids across Laurentia during the Ordovician. Canadian Paleontology Conference 2011.

Sproat, C.D. and Greenwood, D.R. 2010. The Early Eocene McAbee Macroflora, British Columbia. Canadian Paleontology Conference 2010.

Li, R.-y. and Sproat, C. 2009. Internal structure and lifestyle of Triplesia anticostiensis (Early Silurian) from Anticosti Island, Eastern Canada. 6th International Brachiopod Congress.

Sproat, C. and Li, R.-y. 2008. Triplesia from Anticosti Island: internal structure and paleoecology. Canadian Paleontology Conference 2008. 